FERNANDO HENRIQUE MARTINS PORTELINHA

\title{
AVALIAÇÃO EXPERIMENTAL DA INFLUÊNCIA DO AVANÇO DO UMEDECIMENTO NO COMPORTAMENTO DE MUROS DE SOLOS FINOS REFORÇADOS COM GEOTÊXTEIS NÃO TECIDOS
}

\begin{abstract}
Tese apresentada à Escola de Engenharia de São Carlos da Universidade de São Paulo, como parte dos requisitos para a obtenção do Título de Doutor em Ciências, Programa de Pós-graduação em Geotecnia.
\end{abstract}

Orientador: Prof. Dr. Benedito de Souza Bueno Universidade de São Paulo Co-orientador: Prof. Dr. Jorge Gabriel Zornberg Universidade do Texas em Austin 
AUTORIZO A REPRODUÇÃO E DIVULGAÇÃO TOTAL OU PARCIAL DESTE TRABALHO, POR QUALQUER MEIO CONVENCIONAL OU ELETRÔNICO, PARA FINS DE ESTUDO E PESQUISA, DESDE QUE CITADA A FONTE.

Ficha catalográfica preparada pela Seção de Tratamento da Informação do Serviço de Biblioteca - EESC/USP

\begin{tabular}{|c|c|}
\hline \multirow[t]{3}{*}{ P843a } & $\begin{array}{l}\text { Portelinha, Fernando Henrique Martins } \\
\text { Avaliação experimental da influência do avanço do } \\
\text { umedecimento no comportamento de muros de solos finos } \\
\text { reforçados com geotêxteis não tecidos / Fernando Henrique } \\
\text { Martins Portelinha ; orientador Benedito de Souza Bueno. } \\
\text {-- São Carlos, 2012. }\end{array}$ \\
\hline & $\begin{array}{l}\text { Tese (Doutorado - Programa de Pós-Graduação e Área de } \\
\text { Concentração em Geotecnia) -- Escola de Engenharia de São } \\
\text { Carlos da Universidade de São Paulo, } 2012 \text {. }\end{array}$ \\
\hline & $\begin{array}{l}\text { 1. Geotêxteis não tecidos. 2. Solos finos. 3. Muros } \\
\text { reforçados. 4. Umedecimento. 5. Barreira capilar. } 6 . \\
\text { Sucção. I. Título. }\end{array}$ \\
\hline
\end{tabular}


FOLHA DE JULGAMENTO

Candidato: Engenheiro FERNANDO HENRIQUE MARTINS PORTELINHA.

Título da Tese: "Avaliação experimental da influência do avanço do umedecimento no comportamento de muros de solos finos reforçados com geotêxteis não tecidos".

Data da defesa: 28/09/2012

\section{Comissão Julgadora:}

Resultado:

Prof. Titular Orencio Monje Vilar (Orientador substituto)

APROVADO

(Escola de Engenharia de São Carlos/EESC)

Prof. Dr. Ennio Marques Palmeira

APTONADO

(Universidade de Brasília/UnB)

Prof. Dr. Eder Carlos Guedes dos Santos

APRO VAPO

(Universidade de Pernambuco)

Dr. Carlos Vinicius dos Santos Benjamim

(Ober/Consultoria)

ABROVADO

Prof. Associado Fernando Antonio Medeiros Marinho

APRovare

(Escola Politécnica/USP)

Coordenador do Programa de Pós-Graduação em Geotecnia:

Prof. Titular Osni José Pejon

Presidente da Comissão de Pós-Graduação:

Prof. Titular Denis Vinicius Coury 

À minha família

Dedico 

A estrada sinuosa sobe o tempo todo?

Sim, até o final.

A viagem vai levar o dia todo?

Da manhã até a noite, meu amigo!

Christina Rossetti (1830-1894) 



\section{AGRADECIMENTOS}

Ao Departamento de Geotecnia da Escola de Engenharia de São Carlos pelo suporte técnico, instalações e pelo conhecimento técnico repassado pelo corpo docente.

Ao meu orientador, Prof. Benedito de Souza Bueno, pela orientação, dedicação e conhecimento necessário para o desenvolvimento desse trabalho. Agradeço também pelas lições profissionais transmitidas durante nosso convívio.

À minha noiva, Natália de Souza Correia, não somente pela paciência, apoio e carinho, mas também por participar ativamente nas discussões técnicas quanto ao tema e auxiliar no preparo desse documento.

À minha família, pelo intenso apoio e compreensão durante essa importante etapa profissional.

Ao Prof. Dr. Jorge Gabriel Zornberg, pela co-orientação, por me receber na Universidade do Texas em Austin e pelas sugestões nas análises dos dados experimentais que, certamente, ajudaram a enriquecer este trabalho.

Ao professor Orêncio Monje Vilar, pelas sugestões, discussões e orientações, principalmente na etapa final do desenvolvimento deste trabalho.

Aos professores do Departamento de Geotecnia, por todo o conhecimento transmitido, pelas lições profissionais e pela agradável convivência ao longo de todos esses anos.

A todos os funcionários do Departamento de Geotecnia da EESC-USP, pelo apoio constante.

A todos os integrantes do Laboratório de Geossintéticos da EESC/USP, pela ajuda constante e sugestões imprescindíveis na execução dos protótipos.

Aos colegas de pós-graduação, pela amizade e convivência agradável ao longo dessa importante etapa da minha vida e por compartilhar conhecimentos técnicos adquiridos.

Aos colegas de laboratório da Universidade do Texas em Austin, pelas discussões técnicas em torno dos dados experimentais dos protótipos, que, certamente, foram essenciais para as análises apresentadas nesse trabalho. 
À Geosoluções Engenharia Geotécnica e Ambiental, em especial aos engenheiros Victor Pimentel e Vinícius Rocha, por disponibilizar a obra Bairro Novo na cidade de Campinas e auxiliar na instrumentação do muro reforçado, resultando num capítulo muito importante desse trabalho.

À Ober Geossintéticos, Maccaferri do Brasil Ltda., Formatto Coberturas especiais Ltda. e Sansuy Ltda., por fornecerem os materiais utilizados na pesquisa.

Ao Conselho Nacional de Desenvolvimento Científico e Tecnológico (CNPq), pela bolsa de estudos concedida para o desenvolvimento dessa pesquisa.

À Coordenação de Aperfeiçoamento de Pessoal de Nível Superior (CAPES), pela bolsa de estágio no exterior.

À Fundação de Amparo à Pesquisa do Estado de São Paulo (FAPESP), pelo apoio financeiro dado ao projeto temático no qual esta pesquisa está inserida.

A todos aqueles que participaram direta ou indiretamente no desenvolvimento do trabalho e no crescimento profissional e pessoal do autor. 


\section{RESUMO}

PORTELINHA, F. H. M. Avaliação experimental da influência do avanço do umedecimento no comportamento de muros de solos finos reforçados com geotêxteis não tecidos. 2012. 149 f.. Tese (Doutorado) - Escola de Engenharia de São Carlos, Universidade de São Paulo, São Carlos, 2012.

O presente trabalho consiste na avaliação experimental da influência do avanço da frente de umedecimento no comportamento de protótipos de muros de um solo fino reforçado com geotêxteis não tecidos. $\mathrm{O}$ desempenho dos protótipos foi analisado nas condições de eventos de chuvas de intensidade e duração variáveis, bem como na condição de precipitação intermitente com intensidade próxima e inferior à condutividade hidráulica do solo. Para efeito comparativo, avaliou-se o comportamento de um protótipo na condição de umidade de compactação constante. Durante a infiltração, observou-se a formação de barreira capilar sobre o geotêxtil e a eficiência de drenagem proporcionada pelos reforços, não permitindo o desenvolvimento de pressões da água positivas mesmo sob a condição de carregamento rápido. Após quebra da barreira, os valores de grau de saturação mantiveram-se em torno de $90 \%$ e as pressões da água ficaram próximas de zero ou negativas. Com relação ao comportamento dos protótipos, evidências mostraram que a formação de barreiras capilares nas interfaces solo-geotêxteis não influenciou negativamente no desempenho dos protótipos. Diante do umedecimento, as deformações e deslocamentos máximos aumentaram exponencialmente com o grau de saturação do solo. Ainda, estes parâmetros relacionaram-se com a sucção matricial de forma semelhante à tendência estabelecida na curva retenção de água do solo. Tais relações foram estritamente associadas às alterações da rigidez média do solo devido ao avanço da infiltração e as alterações na sucção do solo. Na condição umidade constante, constatou-se que o maciço poderia se manter estável mesmo com a ausência dos reforços devido à elevada rigidez proporcionada pela sucção do solo. De modo geral, os deslocamentos e deformações foram relativamente pequenos sob a ação da variável umedecimento. A associação desta com os incrementos de tensões geraram deformações adicionais, embora estas ainda não possam ser consideradas excessivas. Os resultados de uma estrutura real corroboraram o comportamento verificado em laboratório. De modo geral, os níveis de deformações foram bastante semelhantes e a presença de água não prejudicou o desempenho da estrutura. Curiosamente, geotêxteis não tecidos de baixa resistência e rigidez à tração foram tão eficazes na estabilidade quanto geotêxteis tecidos de maior rigidez e resistência. Portanto, a eficiência de estruturas de solos finos reforçados com geotêxteis não tecidos foi constatada, mostrando estas possíveis de compor estruturas permanentes.

Palavras-chave: geotêxteis não tecidos, solos finos, muros reforçados, umedecimento, barreira capilar, sucção. 



\begin{abstract}
PORTELINHA, F. H. M. Experimental evaluation of the wetting advancement effect on the performance of nonwoven geotextile reinforced soil walls with fine soil. 2012. $149 \mathrm{f}$.. Thesis Sao Carlos Engineering School, University of Sao Paulo, Sao Carlos, 2012.

The effect of the wetting front advancement on the performance of nonwoven geotextile reinforced soil walls constructed with poorly draining soils was evaluated by laboratory full scale models. The tested models performances were monitored under rainfall conditions with different intensities and duration, as well as under intermittent precipitation with reduced intensity of precipitation (lower than the soil permeability). For comparison purposes, an evaluation of a full scale model was conducted with constant soil water content (compaction water content). As regards infiltration, capillary barrier formation have been observed on the interface soil-geotextile during infiltration process; besides, the drainage function of reinforcements after the breakthrough of water, in which water pressures development have not been allowed to occur even after rapid loading. After breakthrough of water, the degree of saturation was maintained around $90 \%$ and water pressures were negatives and close to zero. Besides, there are evidences that capillary barriers did not affect the model performance. As a result of wetting advancement, reinforcement strains and internal displacements have increased exponentially with the average of degree saturation of soil. Additionally, these parameters have shown to be correlated to the matric suction of soil with the same trend of the water retention curve. These relationships are essentially resulted from the soil stiffness alterations due to the wetting advancement and suction reduction. Under water content of compaction, reinforcement tensile forces were approximately zero, as a result of the relatively high stiffness of the unsaturated soil caused by the matric suction. Generally, displacements and reinforcement strains were small under wetting conditions and increased when stress increments were applied. However, these strains levels obtained cannot be considered excessive. A validation of laboratory results was observed in an instrumented geotextile reinforced soil wall, in addition to the comparison between woven and nonwoven geotextile sections, in which similar performances were found. Strains levels registered in field were consistent to the laboratory and the nonwoven geotextile wall was not affected by the wetting occurrence. Therefore, the efficiency of nonwoven geotextiles reinforced walls under wetting conditions is assured with no positive water pressures and relatively low levels of degree of saturation, being able to constitute permanent reinforced walls.
\end{abstract}

Keywords: Nonwoven geotextile. Fine Soils. Reinforced walls. Wetting. Capillary barriers. Suction. 



\section{SUMÁRIO}

\section{CAPÍTULO 1 - INTRODUÇÃO E OBJETIVOS}

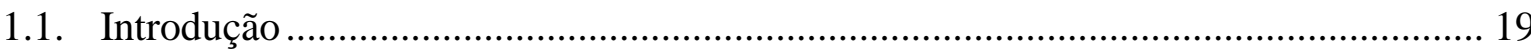

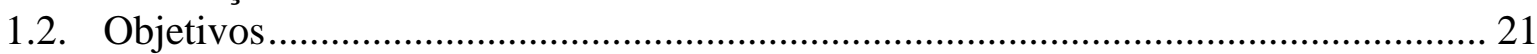

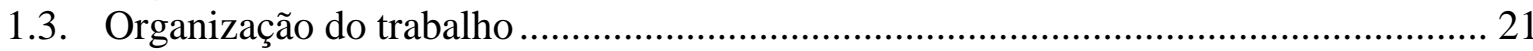

\section{CAPÍTULO 2 - REVISÃO DE LITERATURA - PARTE I: COMPORTAMENTO DE ESTRUTURAS DE SOLO REFORÇADO COM GEOTÊXTEIS NÃO TECIDOS}

2.1. Estruturas de solo reforçado com geossintéticos

2.2. Especificações técnicas para solos de estruturas reforçadas....................................... 27

2.3. Considerações sobre a influência do umedecimento no comportamento de solos finos

2.4. Problemas associados ao uso de solos finos coesivos em estruturas com reforços impermeáveis ....

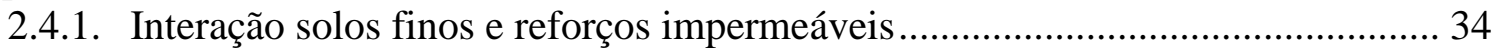

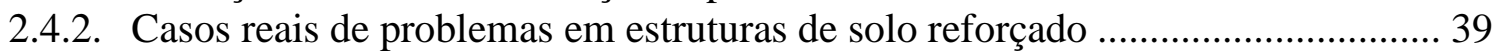

2.5. Estruturas de solos finos coesivos com reforços permeáveis ..................................... 49

2.5.1. Interação solos coesivos - reforços permeáveis................................................. 49

2.5.2. Efeito do confinamento nas propriedades mecânicas de geotêxteis não tecidos. 56

2.5.3. Relatos de estruturas de solos finos reforçadas com geotêxteis não tecidos ........ 58

2.6. Projetos de muros de solos finos reforçados com geotêxteis não tecidos ................. 69

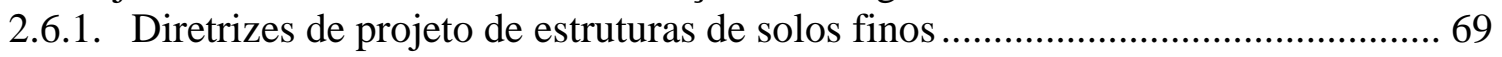

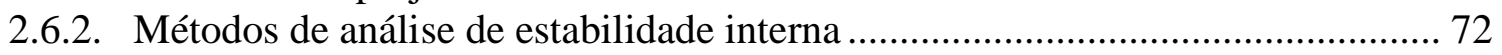

2.6.3. Projeto de drenagem interna utilizando geotêxteis não tecidos .......................... 79

\section{CAPÍTULO 3 - REVISÃO DE LITERATURA - PARTE II: COMPORTAMENTO HIDRÁULICO DE ESTRUTURAS DE SOLO REFORÇADO COM GEOTÊXTEIS NÃO TECIDOS}

3.1. Características hidráulicas de solos e geotêxteis não tecidos não saturados ............... 85

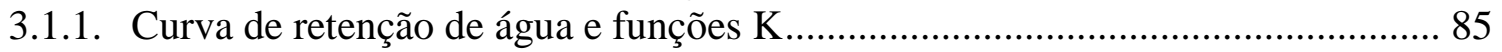

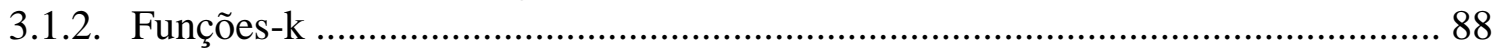

3.1.3. Infiltração em estruturas reforçadas com geotêxteis ......................................... 89

3.1.4. Comportamento hidráulico de interface solo-geotêxtil nas condições de

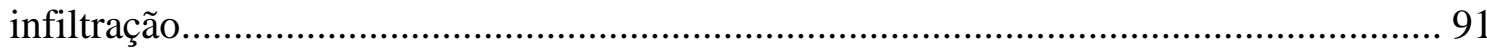

\section{CAPÍTULO 4 - MATERIAIS E MÉTODOS}

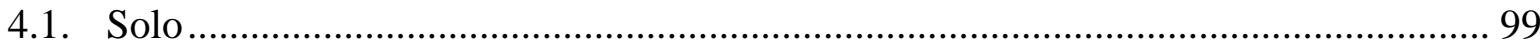

4.1.1. Resistência ao cisalhamento do solo ............................................................ 101

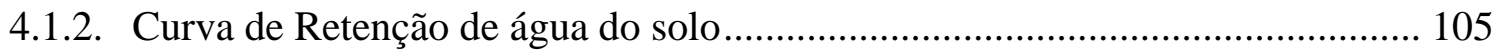

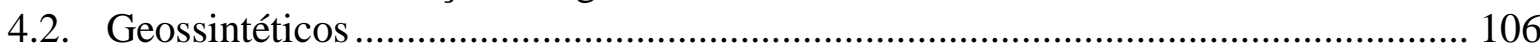

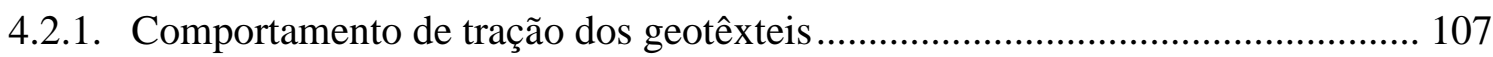

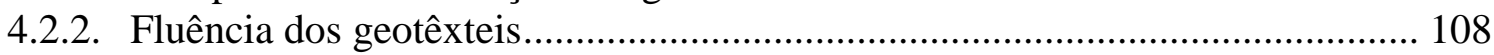

4.2.3. Comportamento hidráulico dos geotêxteis ..................................................... 109

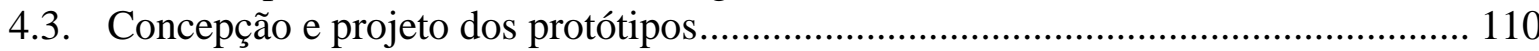

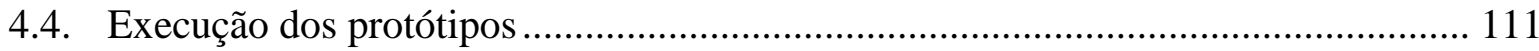

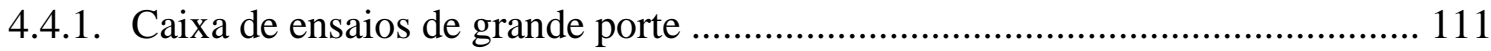

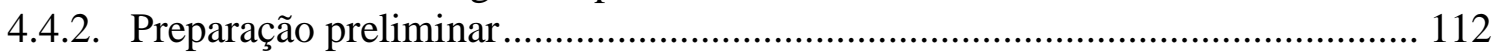

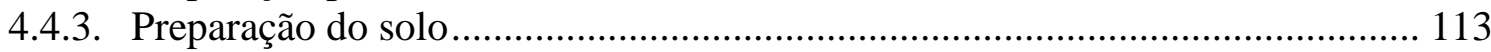

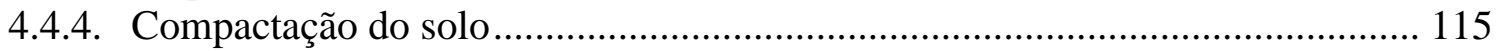




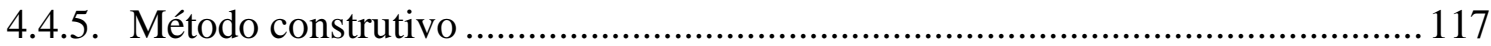

4.5. Sistema de simulação de lâmina de chuva ................................................................. 121

4.6. Sistema de aplicação de tensões verticais ............................................................. 124

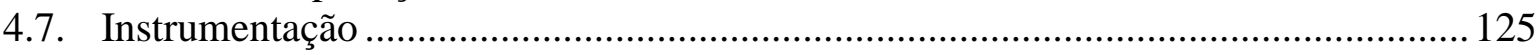

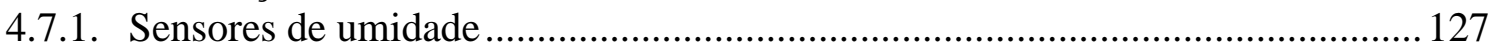

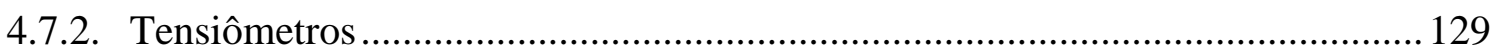

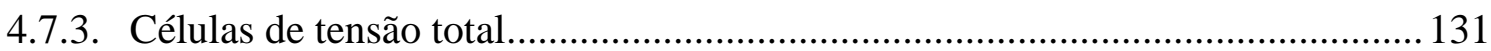

4.7.4. Medidas de deslocamentos horizontais internos - Sistema Tell-tales ................ 133

4.7.5. Medidas de deslocamentos horizontais de face ............................................. 134

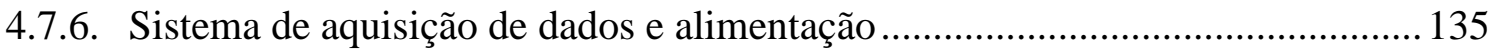

4.8. Método de cálculo das deformações nos geotêxteis ................................................. 136

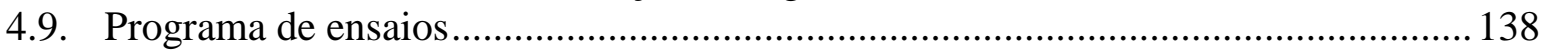

CAPÍTULO 5 - COMPORTAMENTO DE UM PROTÓTIPO REFORCADO COM GEOTÊXTIL NÃO TECIDO SOB A CONDIÇÃO DE UMIDADE CONSTANTE DE COMPACTAÇÃO

5.1. Monitoramento da saturação e sucção matricial do solo ....................................... 143

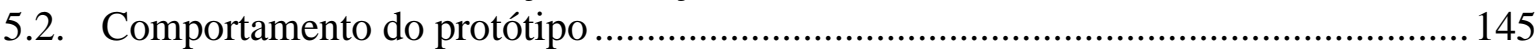

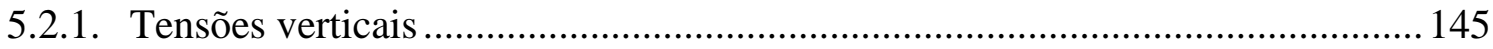

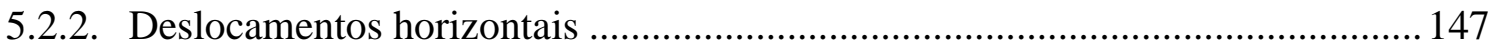

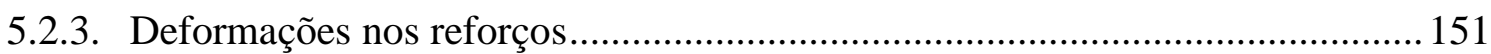

5.2.4. Relações entre parâmetros do solo não saturado e o comportamento do

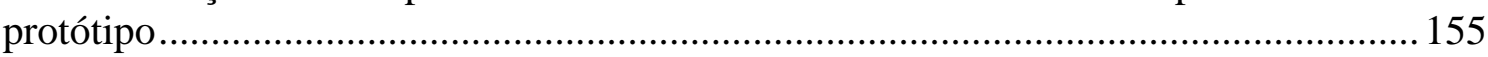

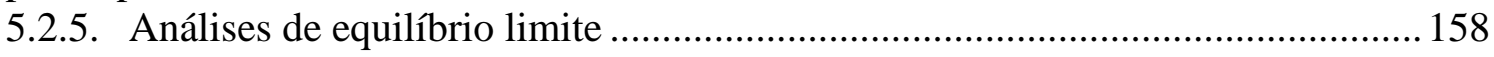

CAPÍTULO 6 - INFLUÊNCIA DO AVANÇO DO UMEDECIMENTO NO COMPORTAMENTO DE UM PROTÓTIPO DE MURO REFORÇDO COM GEOTEXXTL NÃO TECIDO

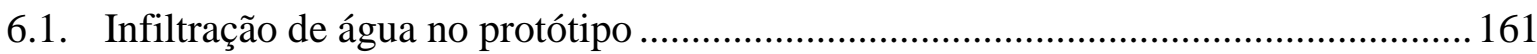

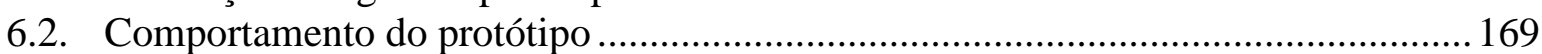

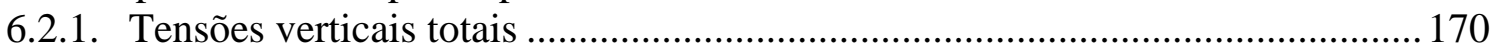

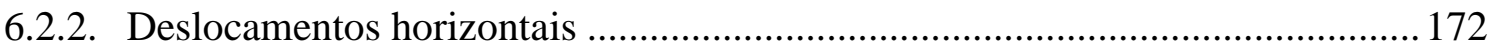

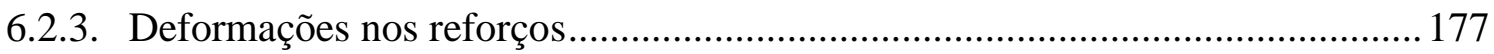

6.3. Relações entre os parâmetros de avanço de umedecimento e o comportamento dos

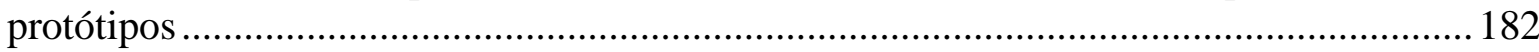

6.4. Efeito do avanço do umedecimento em análises de equilíbrio limite ...................... 188

\section{CAPÍTULO 7 - AVALIAÇÃO DO COMPORTAMENTO HIDRÁULICO DE INTERFACE SOLO-GEOTEXXTIL NÃO TECIDO EM UM PROTÓTIPO DE MURO REFORÇADO}

7.1. Comportamento hidráulico de interface durante o processo de infiltração................. 193

7.2. Constatações quanto ao efeito hidráulico da interface no comportamento do

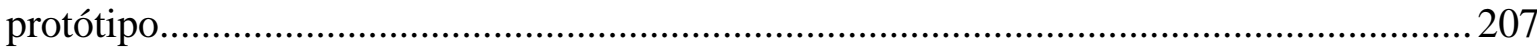

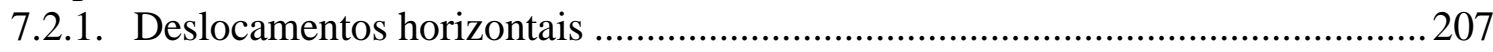

7.2.2. Deformação nos reforços .......................................................................... 211

CAPÍTULO 8 - AVALIAÇÃO DO ACRÉSCIMO DE TENSÕES NO COMPORTAMENTO DE UM MURO DE SOLO REFORÇADO COM GEOTÊXTEIS NÃO TECIDOS SOB CONDIÇÕES DE UMEDECIMENTO

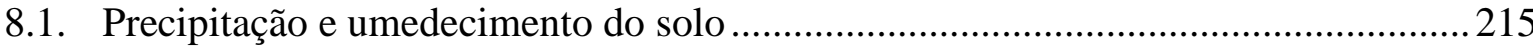

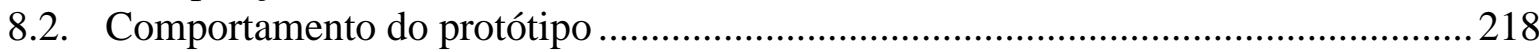




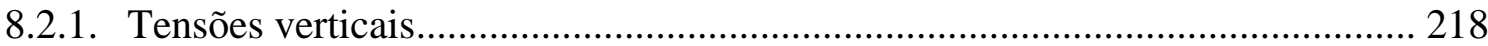

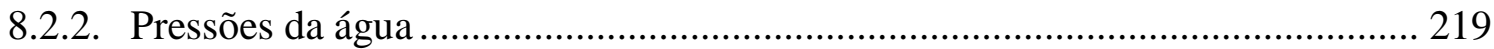

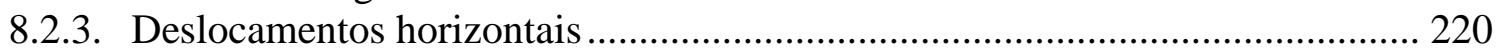

8.2.4. Deformação nos reforços ........................................................................ 223

\section{CAPÍTULO 9 - ANÁLISES DE FORÇAS MOBILIZADAS NOS REFORÇOS DOS PROTÓTIPOS}

9.1. Estimativa do parâmetro de coesão do solo

229

9.2. Comparação entre forças reais calculadas e forças estimadas .................................. 230

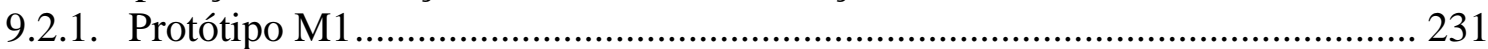

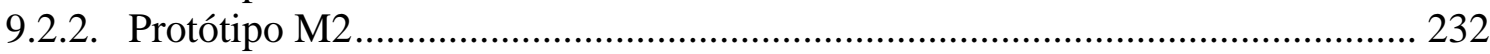

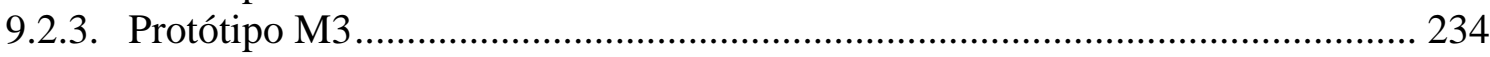

\section{CAPÍTULO 10 - COMPARAÇÕES ENTRE OS COMPORTAMENTOS DOS PROTÓTIPOS}

10.1. Comparações dos avanços do umedecimento e dos efeitos no comportamento dos protótipos

10.2. Comparações entre os efeitos das alterações do grau de saturação do solo devido às condições de umedecimento

10.3. Comparações das alterações nas superfícies de rupturas reais durante o avanço do umedecimento

CAPÍTULO 11 - AVALIAÇ̃̃O DO COMPORTAMENTO DE MUROS DE SOLOS FINOS REFORCADOS COM GEOTÊXTEIS: INVESTIGAÇÃO DE CAMPO

11.1. Informações quanto ao muro instrumentado em campo ...................................... 247

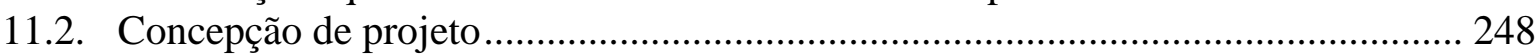

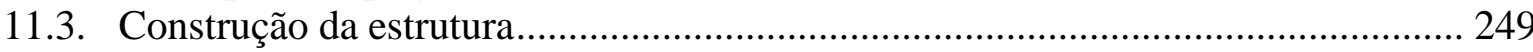

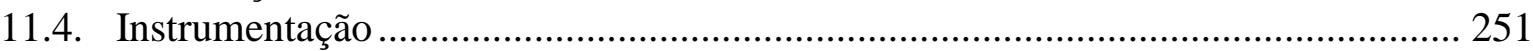

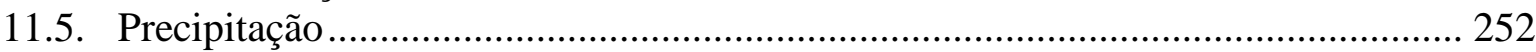

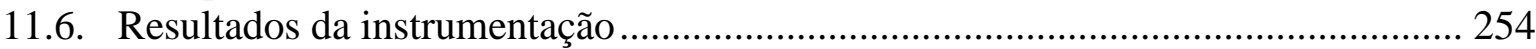

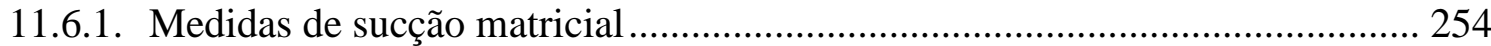

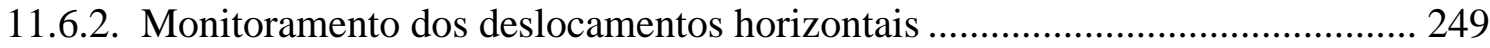

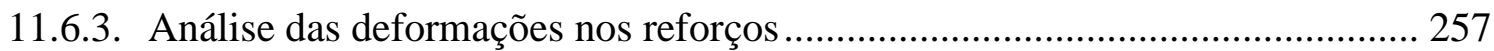

11.6.4. Aspectos gerais e comparações com laboratório .............................................. 262

\section{CAPÍTULO 12 - CONCLUSÕES}

12.1. Implicações em projetos de muros reforçados com geotêxteis não tecidos............. 267

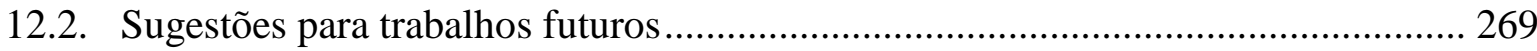

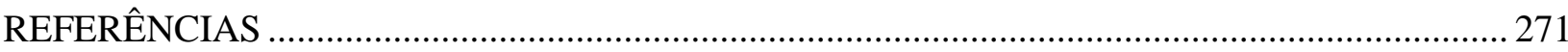

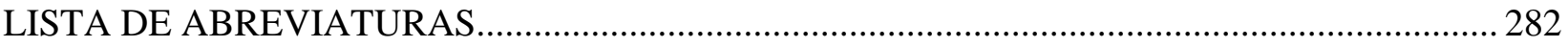

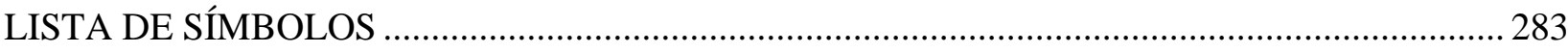

APÊNDICE A: Tabela dos resultados do controle de compactação dos protótipos .......................... 285

APÊNDICE B: Perfis de infiltração durante os ensaios nos protótipos ............................................. 286

APÊNDICE C: Ajustes sigmoidais e distribuições de deformações nos reforços ............................ 295 



\section{CAPÍTULO 1}

\section{INTRODUÇÃO E OBJETIVOS}

\subsection{Introdução}

Na prática da engenharia, existe sempre a tendência de buscar soluções competitivas no aspecto técnico-econômico dos projetos. No contexto dos muros de contenção, o uso da técnica de reforço de solos com geossintéticos tem sido uma solução amplamente utilizada devido à sua versatilidade, fácil emprego e, principalmente, baixo custo em comparação às soluções convencionais, tais como os muros de gravidade de concreto e os muros de flexão.

Existe atualmente no mercado, uma variedade de opções de reforços com funções de estabilização de maciços de terra. Na aplicação em muros de contenção em solo reforçado, os reforços mais utilizados são aqueles considerados mais rígidos e resistentes como as geogrelhas e os geotêxteis tecidos. Na década de 70, quando se iniciou a aplicação de reforços poliméricos na estabilização de maciços terrosos, função anteriormente designada aos reforços metálicos, utilizou-se muito os reforços em geotêxteis não tecidos por terem sido um dos primeiros geossintéticos aplicados na engenharia geotécnica. Nesse período, muitos trabalhos foram publicados na literatura ressaltando a aplicabilidade desses materiais como elementos de reforço. Posteriormente, começou-se a utilizar as geogrelhas e os geotêxteis tecidos por resultarem em estruturas menos deformáveis. De fato, os geotêxteis não tecidos consistem em reforços mais flexíveis em relação aos existentes no mercado; porém, apresentam uma característica bastante peculiar que é a elevada capacidade drenante. Existem também os geocompostos poliméricos que podem apresentar tanto características permeáveis como também elevada rigidez, mas sendo em sua maioria, de custo mais elevados.

$\mathrm{Na}$ época em que a técnica de solo reforçado passou a ser intensamente utilizada, o meio técnico passou a normatizar os procedimentos e métodos de cálculo, o que levou a uma série de restrições quanto ao tipo de solo a ser utilizado. As recomendações normativas como as da AASHTO (2002), FHWA (1998) e BS 8006 (1995) convencionaram a utilização de materiais granulares em estruturas de solo reforçado, uma vez que solos de graduação fina e baixa capacidade de drenagem são passíveis do desenvolvimento de pressões da água devido à uma eventual infiltração de água no sistema reforçado, ou, até mesmo, ao processo de compactação. No entanto, como jazidas com materiais competentes nem sempre são facilmente disponíveis, a possibilidade da utilização de solos locais na construção deste tipo de estrutura torna-se atraente, pois proporciona economias significativas, uma vez que a extração e o transporte de materiais apropriados podem aumentar o custo total da obra. Entretanto, estes solos finos podem apresentar baixa permeabilidade e rigidez, principalmente quando umedecidos. 
No caso do uso de solos finos, geralmente de rigidezes inferiores aos solos grossos, reforços mais rígidos são necessários. No entanto, o problema principal da possibilidade de desenvolvimento de pressões da água na zona reforçada persiste. Notou-se, no entanto, a partir da década de 80 , que os geotêxteis não tecidos, embora flexíveis, poderiam cumprir não somente a função de reforço, mas, associadamente, a função de drenagem interna de estruturas de solo reforçado. Dentre as vantagens da função de drenagem nestas estruturas estão a rápida dissipação de pressões da água na interface solo-reforço e a aceleração do adensamento do solo em situações em que o solo é saturado. Adicionalmente, os reforços não tecidos apresentam melhoria na rigidez e na resistência à tração devido ao confinamento e a impregnação de partículas de solo em sua estrutura interna. Com base nestas afirmações, geotêxteis não tecidos em estruturas de solos finos apresentam um grande potencial para compor estruturas permanentes com desempenho satisfatório, mesmo sob as condições de avanço de umedecimento.

A eficiência de geotêxteis não tecidos na função de drenagem é bastante conhecida atualmente, muito embora poucos trabalhos têm mostrado claramente o efeito da infiltração de água da chuva no comportamento de estruturas de solos finos reforçados. É bastante conhecido também que, os problemas de deslocamentos excessivos e rupturas são, na maioria das vezes, implicações do uso de solos finos e do avanço de umedecimento no interior da zona reforçada, o que prejudica não somente a resistência e a rigidez do solo, mas também a interação deste com o reforço. Por outro lado, necessita-se ainda conhecer o processo de infiltração na interface solo e geotêxtil não tecido e os efeitos deste no comportamento destas estruturas em escalas reais.

Sabe-se ainda que, solos de natureza tropical (mesmo finos) apresentam bom comportamento em termos de resistência e rigidez, além de serem materiais menos plásticos em comparação aos solos formados sob as condições de clima temperado. De fato, o uso desses solos no Brasil tem resultado em estruturas de solo reforçado que exibem bom comportamento ao longo do tempo. A confirmação do bom comportamento de estruturas construídas com solos finos e geotêxteis não tecidos sob ações de umedecimento pode trazer vantagens econômicas para projetistas de muros reforçados.

Neste contexto, esta pesquisa busca avaliar o comportamento de estruturas de solos finos reforçados com geotêxteis não tecidos sob condições de umedecimento, almejando-se identificar o comportamento hidráulico de interface e seus efeitos. O monitoramento simultâneo do avanço da frente de umedecimento e do comportamento hidráulico e mecânico de estruturas de solo reforçado podem gerar informações para futuras considerações em projetos ou, até mesmo, para possíveis modificações em métodos que venham a considerar não somente o efeito da água, mas também, da drenagem interna imposta por estes reforços. Este tipo de análise pode também consistir em uma comprovação de que determinados tipos de solos brasileiros podem vir a ser seguramente reforçados com geotêxteis não tecidos, mesmo sob condições críticas de umedecimento. 


\subsection{Objetivos}

Este trabalho tem por objetivo avaliar experimentalmente a influência do avanço da frente de umedecimento no comportamento de protótipos de muros de solos finos reforçados com geotêxteis não tecidos ensaiados em laboratório. Adicionalmente, foi acompanhado o desempenho de uma estrutura real construída em campo, em que o comportamento de seções de geotêxtil tecido e não tecido são comparados. Para tanto, foi utilizado de avaliações em protótipos de laboratório, que permitem que condições de ensaio sejam impostas e controladas, o que seria dificultado em condições de campo. Nesta perspectiva, a investigação contempla os seguintes tópicos:

a) avaliar a infiltração da água proveniente de eventos simulados de chuva em protótipos de muros de solo reforçado com geotêxteis não tecidos;

b) avaliar o comportamento de protótipos de solo reforçado com geotêxteis não tecidos sob as condições de umedecimento impostas, procurando estabelecer relações entre os parâmetros representativos do umedecimento do solo e os deslocamentos da estrutura e deformações nos reforços;

c) evidenciar o comportamento hidráulico da interface solo fino-geotêxtil não tecido em muros de solo reforçado, verificando desde a formação de barreiras capilares até a drenagem da água ao longo do reforço;

d) avaliar o comportamento de um protótipo de muro reforçado com geotêxtil não tecido na condição de umidade de compactação (sem o umedecimento) e após avanço do umedecimento com sobrecarga constante, e também verificar o efeito do incremento de sobrecargas em um protótipo umedecido;

e) verificar o comportamento de uma estrutura real de muro reforçado com geotêxteis tecidos e não tecidos, bem como validar o comportamento dos protótipos com base no comportamento da estrutura de campo.

\subsection{Organização do trabalho}

A tese foi organizada de modo a fornecer informações quanto ao comportamento de muros de geotêxteis não tecidos que, posteriormente, foram utilizadas para o entendimento das verificações constatadas neste trabalho.

O Capítulo 2, Parte I da revisão bibliográfica, tem caráter comparativo, em que se relatam, inicialmente, o comportamento de interface de solos finos e reforços impermeáveis e alguns casos de insucessos destes tipos de estruturas. Posteriormente, são relatados o comportamento de interface de solos finos e reforços permeáveis e suas vantagens. A Parte II da revisão bibliográfica (Capítulo 3) é dedicada à infiltração de água em muros de solo reforçado e solos finos não 
saturados, relatando teorias a respeito da formação de barreiras capilares na interface sologeotêxteis.

No Capítulo 4, são descritos os procedimentos de construção dos protótipos avaliados nesta pesquisa, bem como o sistema de simulação de eventos de chuva e instrumentação utilizados.

No Capítulo 5, avaliam-se os resultados do desempenho de um protótipo de solo reforçado com geotêxteis não tecidos sob a condição não saturada, em que a umidade de compactação foi mantida durante o ensaio. Já o Capítulo 6 apresenta os resultados da avaliação do efeito de eventos de chuva no comportamento de um dos protótipos, estabelecendo relações entre o avanço do umedecimento e os parâmetros representantes deste comportamento.

No Capítulo 7, avalia-se o comportamento hidráulico de interface em um protótipo, dedicando-se às constatações de barreiras capilares e drenagem interna oferecida pelas linhas de reforços. Busca-se também verificar o efeito dos fenômenos na interface no comportamento da estrutura reforçada.

No Capítulo 8, os resultados de um protótipo buscaram avaliar não só o efeito do umedecimento sob as condições críticas de precipitação, mas também sob a condição de incrementos de sobrecargas. Já o Capítulo 9 é dedicado às análises das forças mobilizadas pelos reforços nas condições de resistência ao cisalhamento do solo impostas pelas condições de saturação avaliadas nos protótipos, comparados a alguns métodos de previsão de forças mobilizadas. No capitulo 10, todos os protótipos tiveram seus resultados comparados.

O capítulo 11 relata o resultado da instrumentação de um muro reforçado com geotêxteis, cujo comportamento é comparado às constatações verificadas em laboratório.

Por fim, as conclusões gerais do trabalho são apresentadas no Capítulo 12, nas quais implicações de projeto e sugestões para pesquisas futuras são também apresentadas. 


\section{REVISÃO DE LITERATURA - PARTE I}

\section{COMPORTAMENTO DE ESTRUTURAS DE SOLO REFORÇADO COM GEOTÊXTEIS NÃO TECIDOS}

Neste capítulo discorre-se inicialmente sobre os problemas que afetam o comportamento de muros de solos finos coesivos reforçados com geossintéticos impermeáveis. Mostra-se, posteriormente, que tais problemas podem ser solucionados, ou amenizados, com a utilização de geossintéticos permeáveis, tais como os geotêxteis não tecidos e geocompostos, que podem apresentar funções simultâneas de reforço e drenagem. Finalmente, revisam-se os princípios de funcionamento, diretrizes e métodos de projetos encontrados na literatura, enfatizando muros de solos finos coesivos reforçados com geotêxteis não tecidos.

\subsection{Estruturas de solo reforçado com geossintéticos}

A tecnologia atual de estruturas de solo reforçado foi desenvolvida por Henry Vidal, na França, em meados de 1960. Desde então, muitos muros reforçados com barras e fitas metálicas foram construídos em todo mundo, representando a técnica chamada "Terra armada". No início da década de 70, iniciou-se a utilização de geossintéticos como elementos de reforço, que tem se difundido rapidamente como soluções em muros de contenções e estabilidade de taludes, uma vez que se apresentam como materiais viáveis economicamente e tecnicamente. Dentre as vantagens da utilização de reforços geossintéticos estão: facilidade de instalação; menor custo; facilidade de armazenagem; facilidade de transporte; melhor interação com o solo; estruturas resultantes mais flexíveis; e, muitas vezes, pela multifuncionalidade, neste caso, manifestada pela capacidade que alguns geossintéticos possuem de cumprirem diversas funções em uma única aplicação. Por exemplo, os geotêxteis não tecidos podem cumprir as funções de filtro e dreno. Ainda, geotêxteis tecidos podem cumprir funções de separação e reforço em estruturas de pavimentos.

A técnica de reforço de solos consiste na inserção de elementos de reforços (fitas metálicas, fibras, geogrelhas, fitas e mantas poliméricas) para restringir deformações e evitar a ruptura por cisalhamento do solo, por conta da mobilização das tensões pela capacidade de resistência a tração do reforço, como ilustra a Figura 2.1. Como o processo de interação permite que as tensões transferidas pelo solo sejam completamente mobilizadas pelos reforços, torna-se dispensável a utilização de uma parede estrutural. Recomenda-se, no entanto, a execução de faceamento sem função estrutural, para prevenir erosão, degradação e vandalismo. Existem hoje 
técnicas onde a função da face passa a ser também de caráter executivo, como a técnica de muro de solo reforçado com face em blocos segmentais.

a)

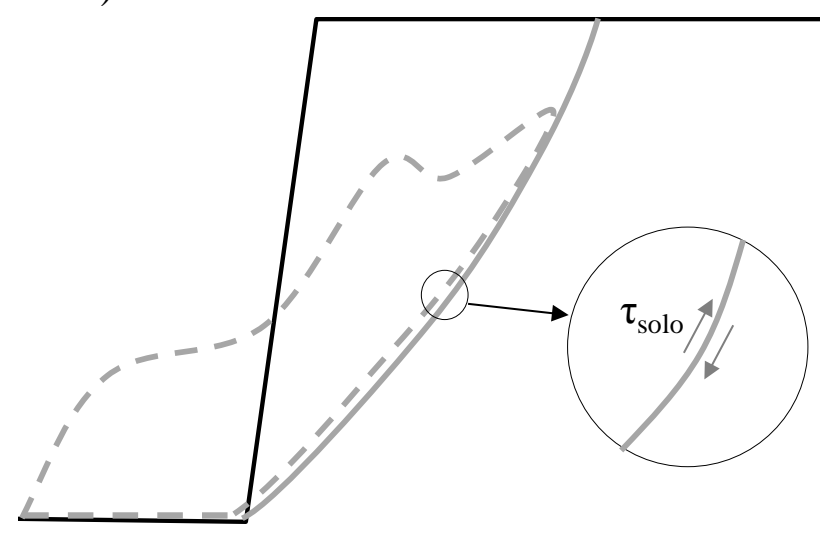

b)

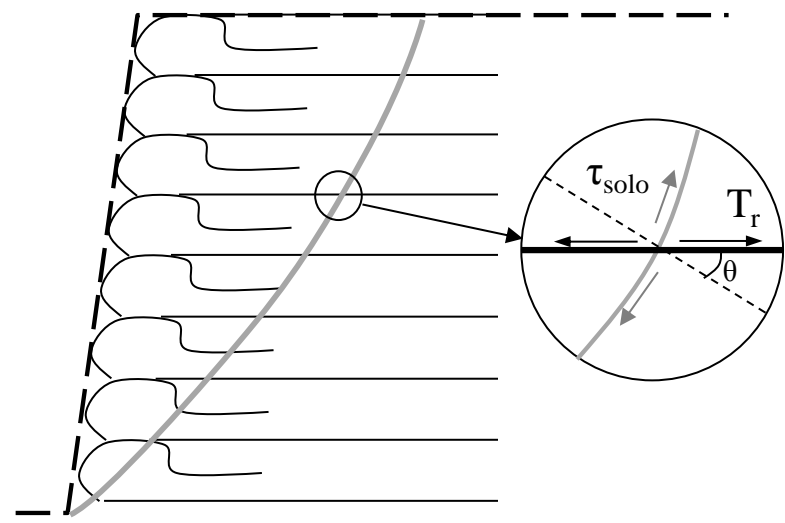

Figura 2.1. Princípio de funcionamento de estruturas de solo reforçado (adaptado de JONES, 2000).

A estabilidade de estruturas de solo reforçado com face envelopada pode ser afetada por forças externas à zona reforçada (estabilidade externa), e/ou pela insuficiência da resistência à tração do reforço e da interação na interface solo-reforço (estabilidade interna). Podem-se definir basicamente seis possíveis modos de ruptura deste tipo de estrutura: deslizamento da base, tombamento, ruptura da fundação, ruptura global, ruptura devido ao arrancamento do reforço e ruptura do reforço, como ilustra a Figura 2.2. A ruptura por tombamento é de difícil ocorrência em muros de geotêxteis não tecidos por se tratar de estruturas flexíveis.
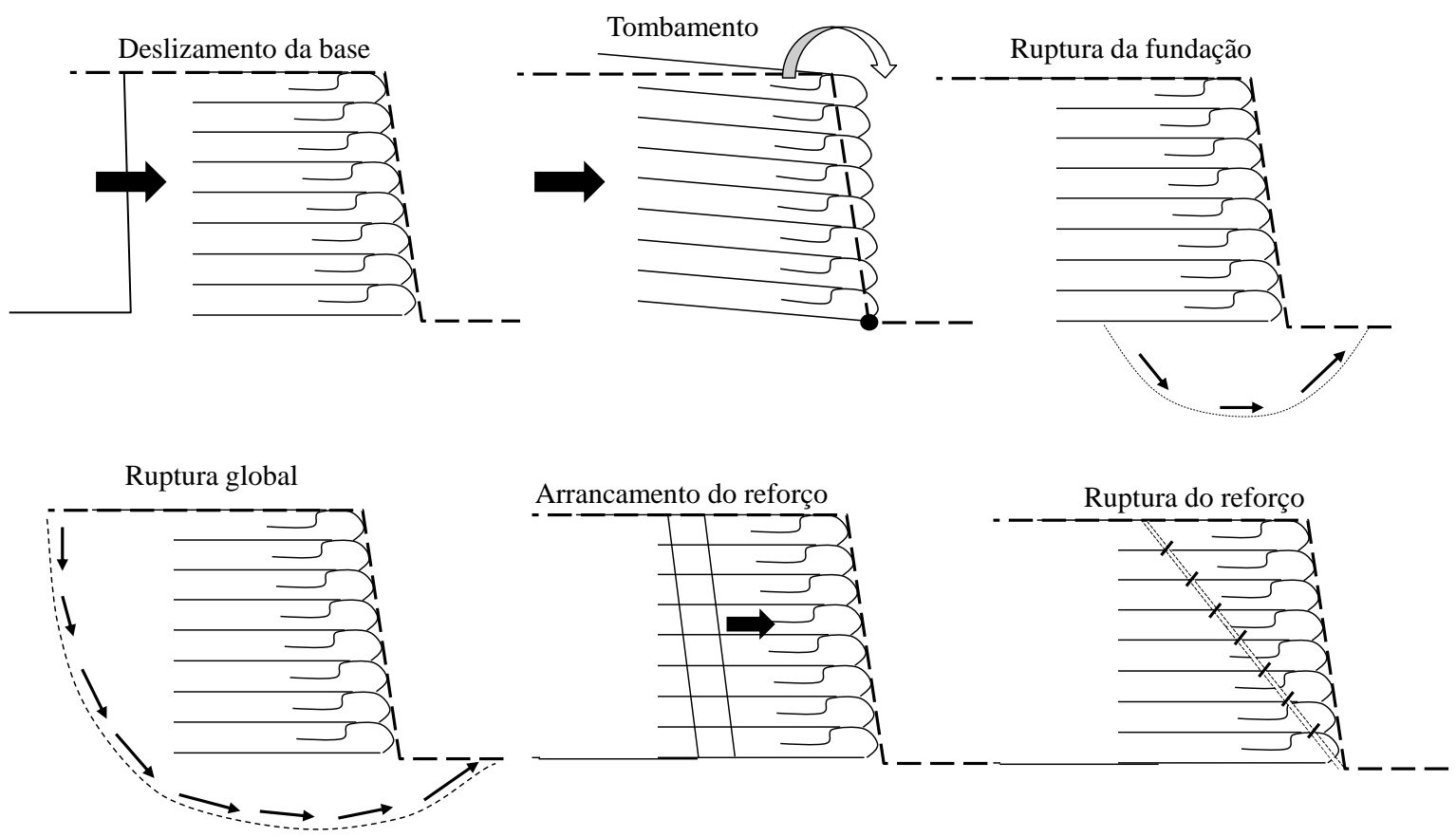

Figura 2.2. Modos de ruptura de um muro reforçado envelopado. 
Para um desempenho satisfatório, a técnica deve satisfazer a duas necessidades básicas: os deslocamentos da estrutura devem ser suficientes para mobilizar a resistência à tração do reforço e a resistência ao cisalhamento do solo; e os movimentos da estrutura, deslocamentos horizontais e recalques, devem ser limitados de forma a garantir os requisitos de utilização. Assim, o reforço do solo cumprirá com sua função somente se a magnitude de deformação do solo, requerida para ser mobilizada pelo reforço, for aceitável. Para reforços com elevados valores de rigidez, a mobilização se procede com baixos níveis de deformação do solo. Já em reforços mais flexíveis, tais como os geotêxteis não tecidos, significantes deformações podem ser requeridas até que a força de mobilização no reforço seja desenvolvida. Consequentemente, quando materiais extensíveis são usados, a magnitude de deformação e as forças de mobilização aceitáveis passam a compor critérios de projeto em substituição da tensão de ruptura, uma vez que estas promoverão deslocamentos consideráveis na estrutura (MITCHELL; VILLET, 1987). Essa compatibilidade de deformações é representada na Figura 2.3.

As tensões horizontais no solo tendem a diminuir com a deformação, partindo da condição em repouso $\left(K_{o}\right)$ para a condição ativa $\left(K_{a}\right)$. Inicialmente nenhuma tensão é transferida no reforço até que num determinado nível de deformação do solo (Figura 2.3), em que as tensões passam a ser transferidas para o reforço e o equilíbrio se estabeleça devido à mobilização de tensões do sistema. Este equilíbrio pode ser observado pelo ponto de cruzamento das curvas de força transmitida pelo solo e a curva de tração disponível do reforço com a deformação. Este ponto é chamado de "ponto de equilíbrio de deformações". Com uso de inclusões mais rígidas o equilíbrio ocorre em menores níveis de deformação, e assim, as tensões no solo e no reforço são mais elevadas. Os solos compactados de natureza argilosa podem apresentar curvas de forma plástica, e, neste caso, a curva da força requerida pode ser assintótica, como ilustrado na Figura 2.3b. Assim, embora as deformações variem para diferentes reforços, a força requerida nos reforço será constante. Portanto, o tipo de solo a ser utilizado em estruturas de solo reforçado tem um papel preponderante na escolha do reforço que irá suprir as tensões e deformações de projeto.

a)

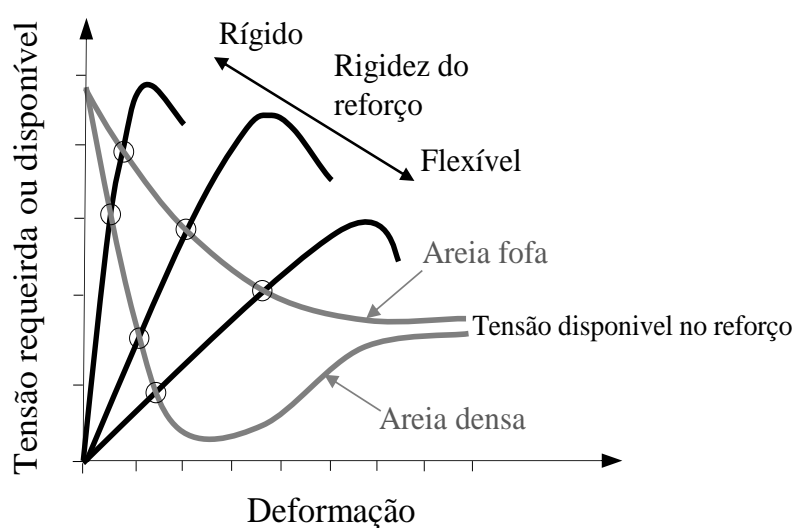

b)

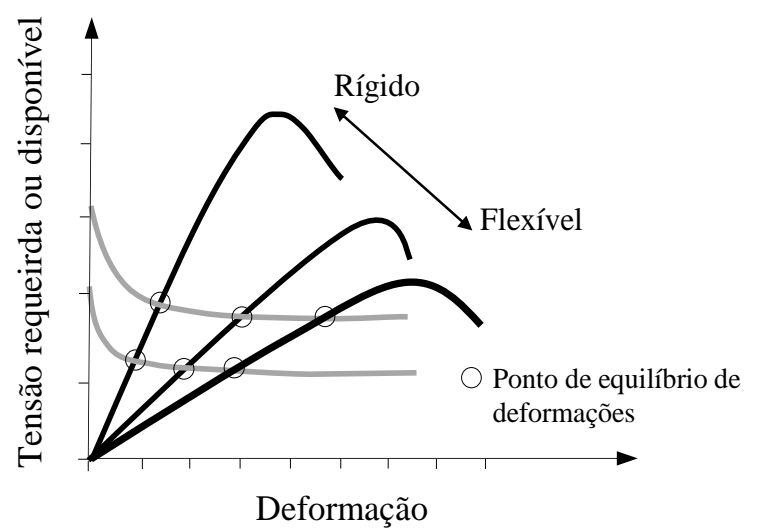

Figura 2.3. Compatibilidade de tensões e deformações entre solos e reforços de diferentes valores de rigidez: (a) solo arenoso; (b) solo argiloso (adaptado de JONES, 2000). 
Uma avaliação da influência do tipo de solo no comportamento de estruturas de solo reforçado foi realizado por Helwany et al. (1999). Os autores utilizaram análises de elementos finitos para avaliar o efeito de 16 diferentes tipos de solo e três diferentes tipos de reforços nas deformações, deslocamentos e fatores de segurança de muros de solo reforçado. A análise foi inicialmente validada utilizando dados de uma estrutura experimental de $6 \mathrm{~m}$ de altura construída em Denver, nos Estados Unidos, possibilitando que as análises paramétricas fossem posteriormente realizadas. Os parâmetros dos solos utilizados nas análises foram determinados via ensaios triaxiais e são apresentados na Tabela 2.1.

Tabela 2.1.Parâmetros dos solos utilizados na análises de Helwany et al. (1999)

\begin{tabular}{|c|c|c|c|c|c|c|}
\hline $\begin{array}{l}\text { Classificação } \\
\text { SUCS }\end{array}$ & $\begin{array}{c}\mathrm{N}^{0} . \\
\text { do solo }\end{array}$ & $\begin{array}{l}\text { GC } \\
(\%)\end{array}$ & $\begin{array}{c}\gamma_{\mathrm{m}} \\
\left(\mathrm{kN} / \mathrm{m}^{3}\right)\end{array}$ & $\begin{array}{l}\phi \\
\left({ }^{0}\right)\end{array}$ & $\begin{array}{c}\text { Coesão } \\
(\mathbf{k P a})\end{array}$ & $\begin{array}{c}\text { Rigidez } \\
(\mathbf{k P a})\end{array}$ \\
\hline \multirow{4}{*}{$\begin{array}{c}\text { GW, GP, SW, } \\
\text { SP }\end{array}$} & 1 & 105 & 23,6 & 42 & 0 & 600 \\
\hline & 2 & 100 & 22,8 & 39 & 0 & 450 \\
\hline & 3 & 95 & 22,1 & 36 & 0 & 300 \\
\hline & 4 & 90 & 21,3 & 33 & 0 & 200 \\
\hline \multirow{4}{*}{ SM } & 5 & 100 & 21,3 & 36 & 0 & 600 \\
\hline & 6 & 95 & 20,5 & 34 & 0 & 450 \\
\hline & 7 & 90 & 19,7 & 32 & 0 & 330 \\
\hline & 8 & 85 & 18,9 & 30 & 0 & 150 \\
\hline \multirow{4}{*}{ SM-SC } & 9 & 100 & 21,3 & 33 & 24 & 400 \\
\hline & 10 & 95 & 20,5 & 33 & 19 & 200 \\
\hline & 11 & 90 & 19,7 & 33 & 14 & 150 \\
\hline & 12 & 85 & 18,9 & 33 & 10 & 100 \\
\hline \multirow{4}{*}{ CL } & 13 & 100 & 21,3 & 30 & 19 & 150 \\
\hline & 14 & 95 & 20,5 & 30 & 14 & 120 \\
\hline & 15 & 90 & 19,7 & 30 & 10 & 90 \\
\hline & 16 & 85 & 18,9 & 30 & 5 & 60 \\
\hline
\end{tabular}

Os gráficos das análises paramétricas de Helwany et al. (1999) apresentados na Figura 2.4 mostram que as propriedades mecânicas do solo possuem um efeito preponderante no comportamento de estruturas de solos reforçado. Ainda, efeito considerável da rigidez do reforço só pode ser observado em solos de baixa rigidez.

Os solos que apresentaram maiores deformações são os solos classificados como SM-SC e $\mathrm{CL}$, solos finos que podem ter as propriedades ainda mais prejudicadas quando umedecidos. Em estruturas reais de solo reforçado, o efeito da saturação do solo pode vir a diminuir a rigidez deste com o tempo, resultando em deformações adicionais nos reforços e deslocamentos da estrutura. Portanto, a mobilização das tensões nos reforços depende da interação solo-reforço e da compatibilidade de deformações e rigidez de ambos os materiais. Solo mais rígidos absorvem maiores parcelas de tensão, proporcionando menor força de mobilização no reforço e, consequentemente, menor nível de deformação. No caso de solos menos rígidos, reforços mais rígidos devem ser utilizados para que deformações maiores não aconteçam até a mobilização, como acontece no caso do uso de reforços mais flexíveis. Muitas vezes o reforço apresenta rigidez 
considerável, mas devido à falta de resistência atritiva e/ou adesiva na interface, as tensões podem não ser mobilizadas. Para esse tipo de avaliação ensaios de resistência de interface, tais como cisalhamento de interface e arrancamento dos reforços, passam a ser de suma importância.
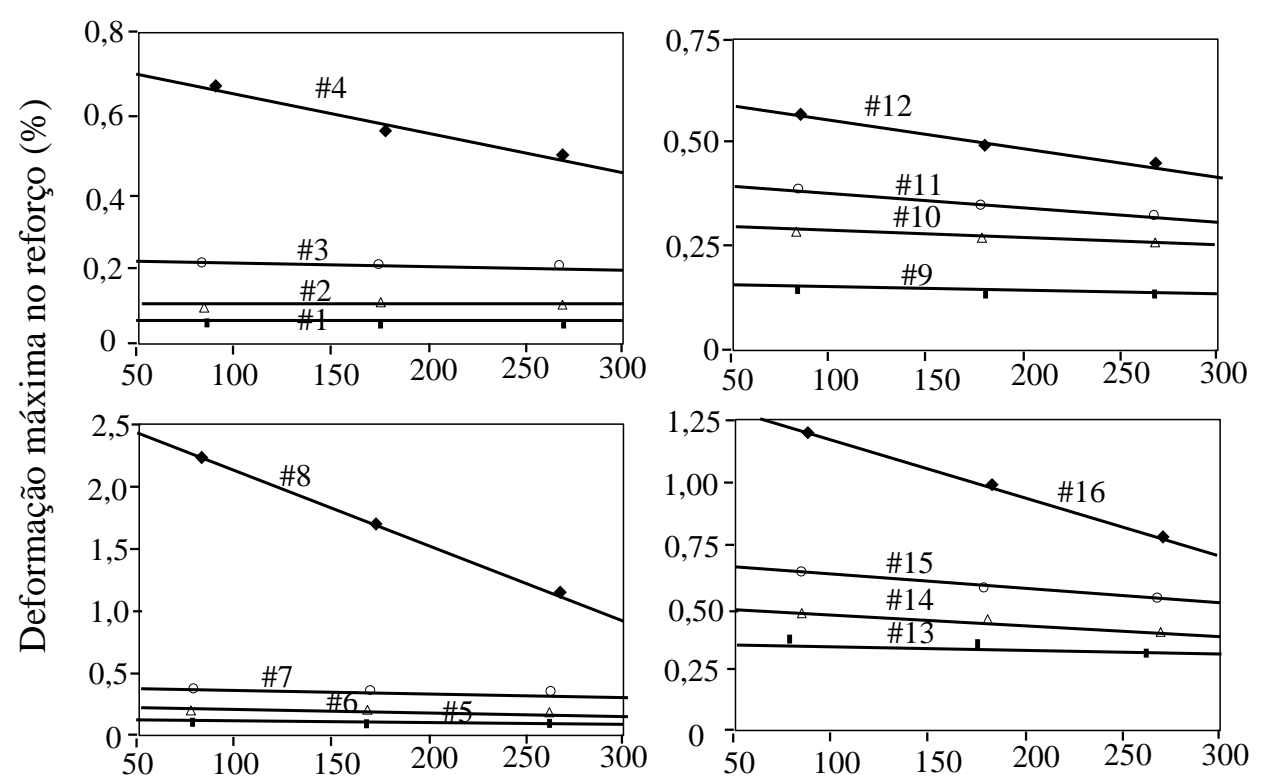

Rigidez do geossintético $(\mathrm{kN} / \mathrm{m})$

Figura 2.4. Deformações em uma estrutura de 6 metros com diferentes valores de rigidez dos solos e geossintéticos (HELWANY; REARDON; WU, 1999).

\subsection{Especificações técnicas para solos de estruturas reforçadas}

Atualmente, uma das práticas que torna a técnica de solo reforçado competitiva em relação às outras técnicas existentes no mercado é a utilização do solo existente no local da obra como material de aterro, o que reduz custos relacionados à extração e transporte de material. Existem relatos de que o uso de solos granulares tem sido um dos aspectos que mais encarece o custo total de estruturas de solo reforçado, chegando a compor $40 \%$ do custo total (ZORNBERG; KANG, 2005).

O problema é que especificações técnicas como a BS 8006 (1995), NCMA (1998), FHWA (1998) e AASHTO (2002), recomendam uma restrita faixa granulométrica de solos granulares, baseadas no fato de que o uso de solos de baixa condutividade hidráulica podem vir a favorecer o desenvolvimento de pressões da água na estrutura, aumentado a força de tração requerida no reforço e prejudicando a resistência na interface solo-reforço. Koerner e Soong (2001) levantaram diferentes casos de deformações excessivas e rupturas de muros reforçados, onde grande parte desses problemas foi associada ao uso de solos finos.

As especificações para a construção de obras públicas de solo reforçado nos Estados Unidos são regulamentadas pela Federal Highway Administration (FHWA, 1998) e American 
Association of State Highway and Transportation Officials (AASHTO, 2002). As restrições recomendadas pela FHWA e AASHTO são exatamente as mesmas e não toleram materiais de aterros de estruturas reforçadas com mais de $15 \%$ de materiais finos (\% passante na peneira \#200 - abertura de 0,075 mm). Tais normas recomendam também que o índice de plasticidade para o material de aterro seja menor que $6 \%$ para muros reforçados, $20 \%$ para taludes reforçados e, livres de matéria orgânica.

Embora as recomendações da FHWA (1998) e AASHTO (2002) sejam fortemente restritivas, as recomendações da National Concrete Masonry Association (NCMA, 1998) são mais amplas. Solos com até 35\% de material passante na peneira \#200 são aceitáveis (NCMA, 1998). Solos mais finos podem também ser utilizados, uma vez que sejam consideradas as seguintes implementações do projeto: instalação de sistemas internos de drenagem; utilização de solos com baixo a moderado potencial de expansão, e desconsideração da parcela coesiva de resistência ao cisalhamento nas análises de estabilidade. Por outro lado, Koerner (1998) recomenda que os solos não possuam partículas passando na peneira \#200, garantindo que a areia fina seja a menor graduação permitida. Na Figura 2.5 apresentam-se as recomendações de faixas granulométricas para estruturas de solo reforçado, estabelecidas pela NCMA (1998), FHWA (1998) e Koerner (1998).

A Norma Britânica BS 8006 (1995) baseia suas recomendações não somente em faixas granulométricas, mas também em critérios mecânicos, químicos e eletroquímicos. O critério mecânico requer que os materiais de aterros permanentes tenham resistência atritiva ou atritiva e coesiva. Quanto aos solos puramente coesivos, as especificações não recomendam a sua utilização em estruturas com altura maior que $1,5 \mathrm{~m}$. Quanto às restrições granulométricas, não é recomendado o uso de solo com mais de $10 \%$ de materiais finos, e restrições quanto à plasticidade não são estabelecidas.

Diferentes critérios de projetos de muros de solo reforçado incluindo normas da Austrália, Brasil, Canadá, Alemanha, Hong Kong, Itália, Japão, Reino Unido e Estados Unidos foram compilados no artigo de Zornberg e Leshchinsky (2003), abordando não somente especificações para seleção do material de aterro, mas também métodos de cálculo, seleção dos parâmetros de resistência do solo e reforço, resistência de interface, etc. (Tabela 2.2).

As restrições técnicas estabelecidas resultam numa faixa muito estreita de solos que podem ser utilizados em estruturas reforçadas. De fato, solos que se enquadram nas faixas granulométricas estabelecidas são raramente encontrados no local da obra. No caso do Brasil, onde não existem restrições para obras públicas federais, o uso de solo fino é bastante corriqueiro e o resultado final é satisfatório, o que está, muitas vezes, associado, ao uso de solos tropicais (VILAR; BUENO, 2008). 


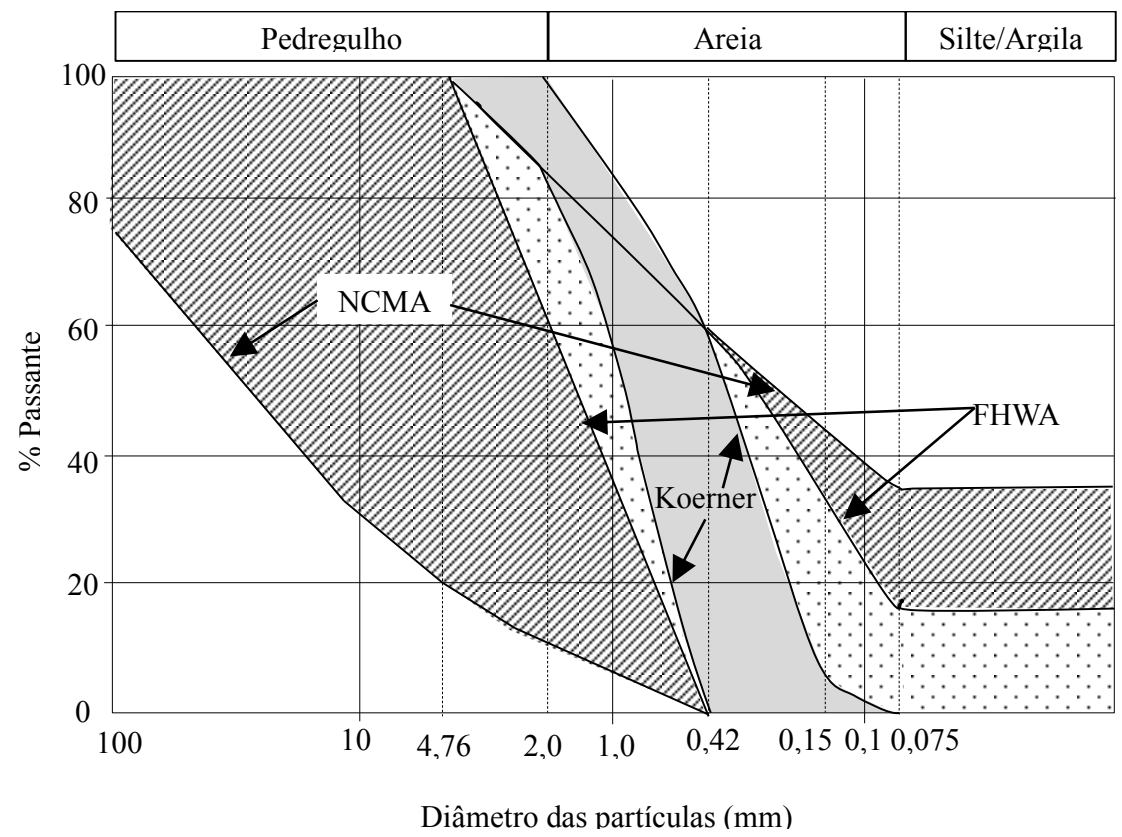

Figura 2.5. Limites granulométricos recomendados pela NCMA (1998), FHWA (1998) e KOERNER (1998) (KOERNER; SOONG 2001). 
Tabela 2.2. Resumos das especificações de solos para muros reforçados com geossintéticos em diferentes países (ZORNBERG; LESHCHINSKY, 2003).

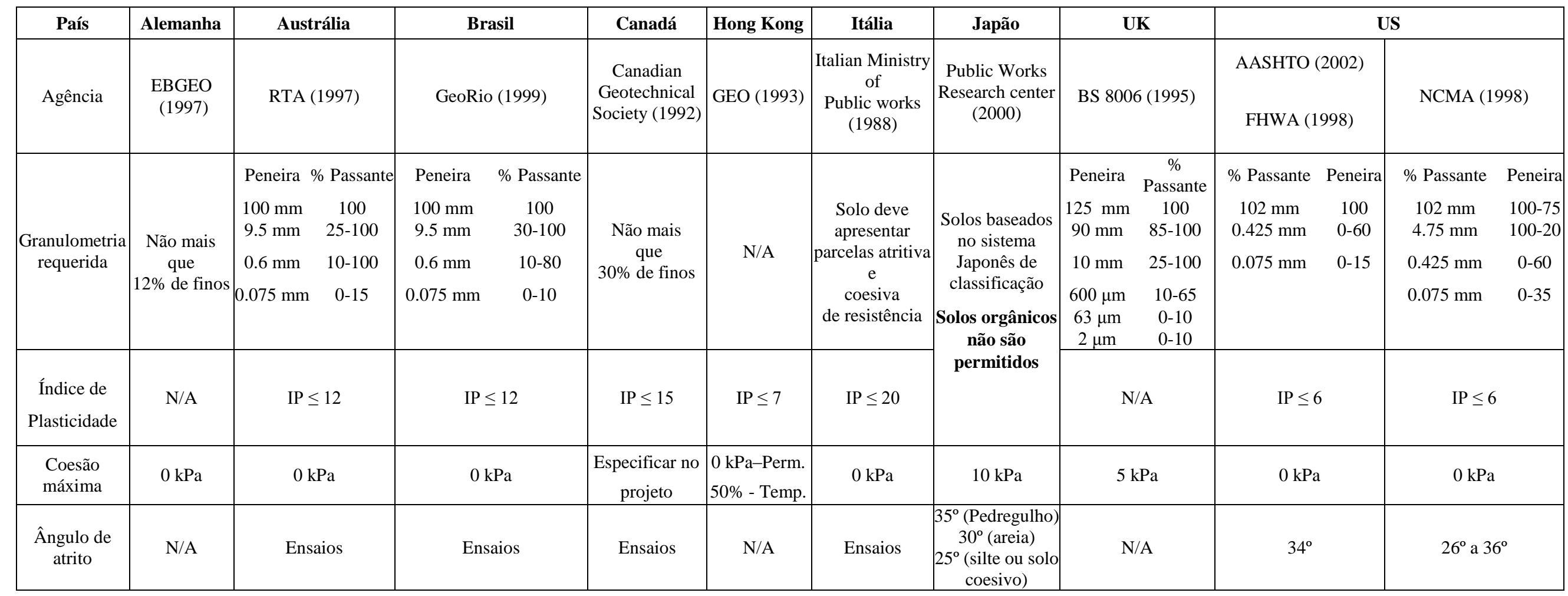




\subsection{Considerações sobre a influência do umedecimento no comportamento de solos finos}

Solos finos coesivos em condição não saturada apresentam grande parcela de resistência associada à sucção matricial $\left(\mathrm{u}_{\mathrm{a}}-\mathrm{u}_{\mathrm{w}}\right)$ devido à ação intergranular que mantém as partículas do solo fortemente unidas e promove um aumento na rigidez do solo. No entanto, o umedecimento pode vir a reduzir a sucção matricial e, consequentemente, diminuir essa força intergranular. A relação entre o teor de umidade e a sucção matricial do solo é frequentemente representada pela curva de retenção de água, que tem sido uma ferramenta bastante utilizada para o entendimento do comportamento do solo não saturado (FREDLUND; XING, 1994). Na Figura 2.6 são plotados exemplos de curvas de retenção de água de três diferentes tipos de solos.

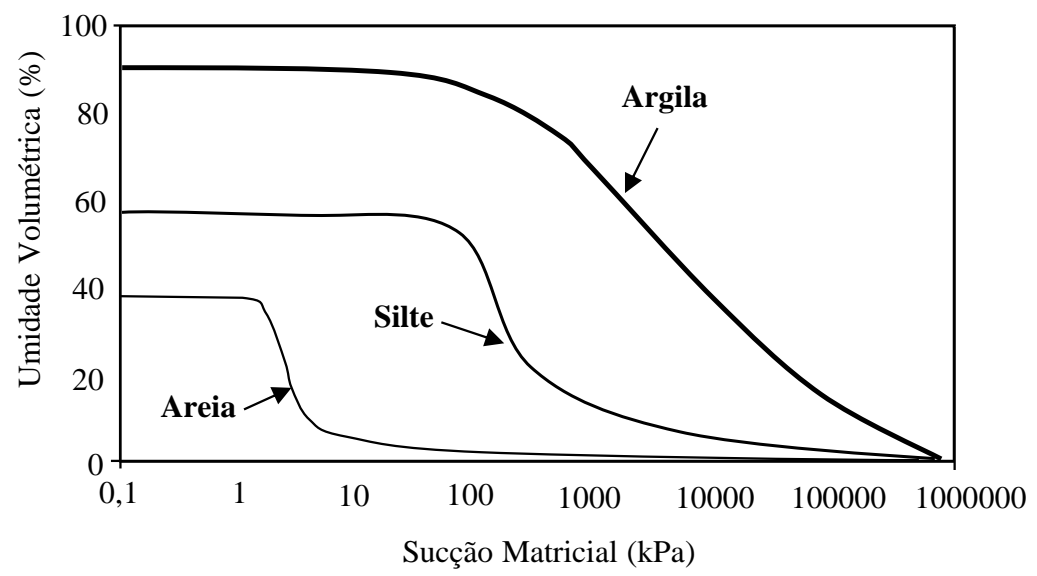

Figura 2.6. Curvas de retenção de água para três diferentes tipos de solo (FREDLUND; XING, 1994).

Fredlund et al. (1978) propôs uma extensão da equação de resistência de solos saturados, que considera o efeito da sucção matricial:

$$
\tau=c^{\prime}+\left(\sigma-u_{a}\right) \tan \phi^{\prime}+\left(u_{a}-u_{w}\right) \tan \phi^{b}
$$

onde:

$\tau$ : resistência ao cisalhamento;

c': coesão efetiva;

$\phi$ : ângulo de atrito interno efetivo;

$\sigma:$ tensão normal ao plano de ruptura;

$\mathrm{u}_{\mathrm{a}}$ : pressão de ar nos vazios do solo;

$\mathrm{u}_{\mathrm{w}}$ : pressão de água nos vazios do solo;

$\phi^{\mathrm{b}}$ : ângulo que indica a taxa de aumento da resistência ao cisalhamento com a sucção. 
Na Figura 2.7 é representada graficamente a expressão de Fredlund et al. (1978).

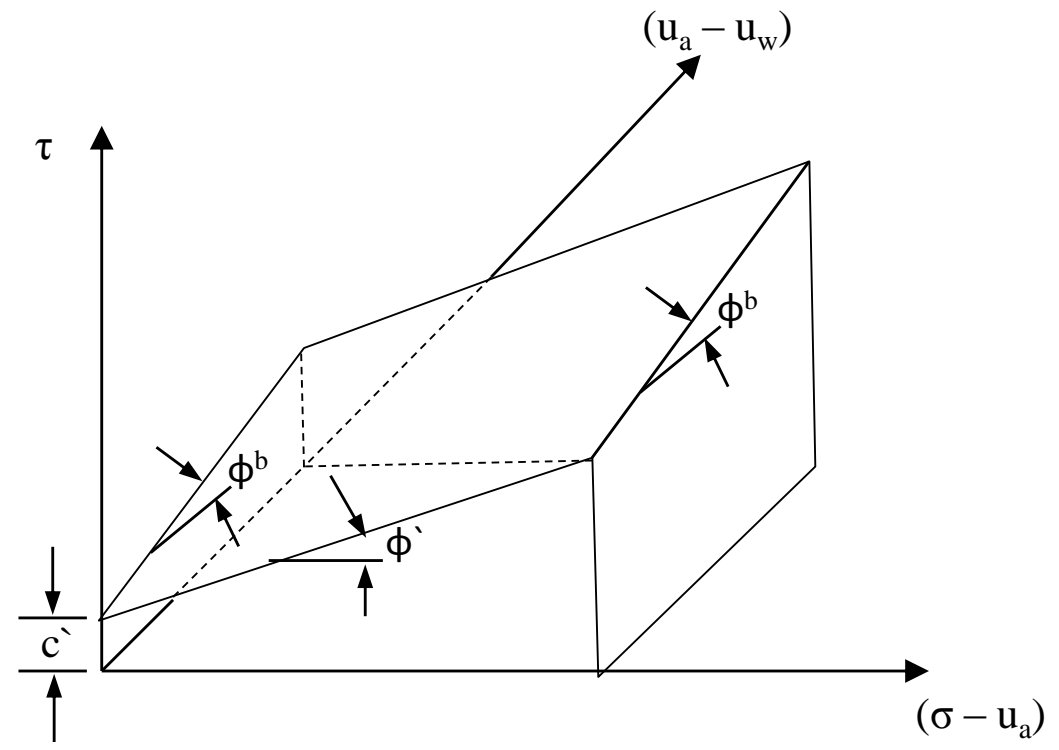

Figura 2.7. Representação gráfica da expressão de Fredlund et al. (1978).

Com base na Figura 2.7 pode-se notar que o modelo proposto por Fredlund et al. (1978) assume o ângulo de atrito interno constante com a variação da sucção matricial, e a resistência ao cisalhamento cresce linearmente com a sucção matricial. Portanto, todo acréscimo de resistência ao cisalhamento do solo reflete em acréscimo de coesão. Assim, a coesão do solo pode ser quantificada conforme a Equação 2.2:

$$
c=c^{\prime}+\left(u_{a}-u_{w}\right) \operatorname{tg} \phi^{b}
$$

O efeito da sucção matricial na coesão do solo é dependente do parâmetro $\phi^{\mathrm{b}}$, que consiste no coeficiente angular da reta e relaciona a resistência ao cisalhamento do solo com a sucção. Em solos argilosos, o parâmetro $\phi^{\mathrm{b}}$ é maior do que em solos arenosos. Este parâmetro mostra que o avanço de infiltração pode promover o aumento da pressão de água $\left(\mathrm{u}_{\mathrm{w}}\right)$ no sistema ar-águasólidos diminuindo a coesão e, consequentemente, a resistência ao cisalhamento do solo.

Melinda et al. (2004) constatou por meio de ensaios de cisalhamento direto que a infiltração não promove necessariamente a saturação completa do perfil de solo e que as pressões na água podem permanecer negativas mesmo após infiltração da água, embora com baixos valores de sucção. Os ensaios de cisalhamento direto com sucção controlada mostraram que a redução na resistência é considerável, como apresentado na Figura 2.8, sendo essa promovida pela redução na parcela de coesão, assim como representado pelo modelo de Fredlund et al. (1978). Outros trabalhos mostram ainda a independência do ângulo de atrito com a sucção, tais como Escario e Juca (1989) e Vanapalli (1996). 


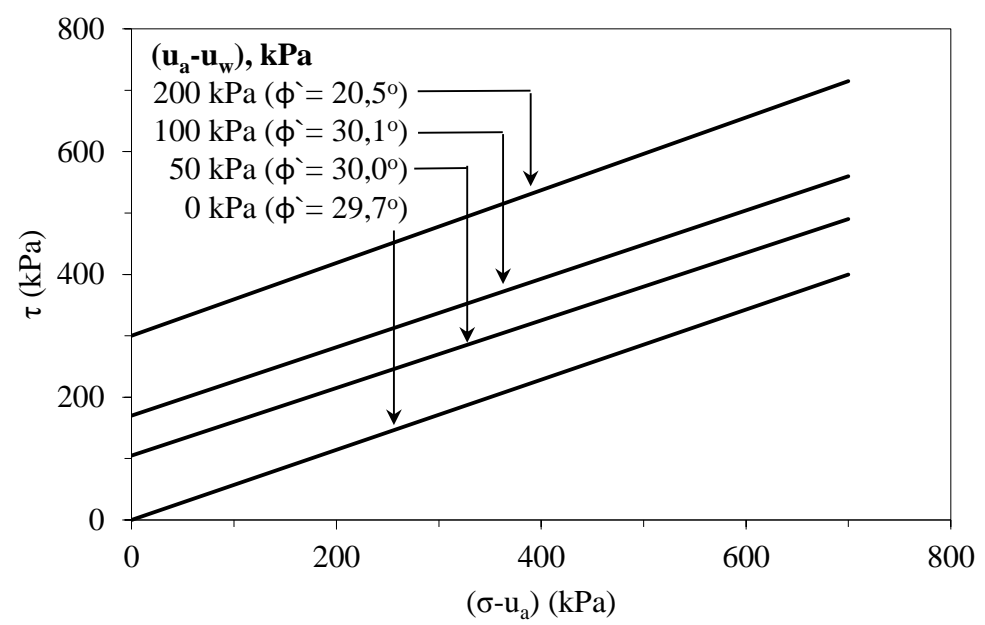

Figura 2.8. Envoltórias de resistência de ensaios de cisalhamento direto com sucção controlada de um solo fino compactado (MELINDA et al., 2004).

Um caso real que descreve a influência do umedecimento em obras geotécnicas é o aterro de solo siltoso com taludes de 1,5H:1,0V, e altura variando de 2 a 10 metros, construído em Notch Hill na Inglaterra. $\mathrm{O}$ aterro foi construído para suportar uma ferrovia, que após muitos anos sofreu ruptura em ambos os taludes das laterais que o compunha. Ensaios triaxiais do solo local e monitoramento da pressão da água no interior do aterro foram avaliados e concluiu-se que os aumentos do teor de umidade no interior do maciço e na fundação do aterro ocasionaram a ruptura (KRAHN et al., 1989). Os aterros permaneceram inicialmente estáveis devido à sucção do solo, que foi diminuindo devido à infiltração de água. Depois de algum tempo, o solo perdeu grande parte da parcela coesiva, reduzindo sua resistência ao cisalhamento que não foi suficiente para manter a estabilidade de estrutura. Leituras de piezômetros mostraram que por muito tempo as pressões da água negativas foram relativamente elevadas, mas no momento da ruptura estes valores diminuíram consideravelmente. A Figura 2.9 apresenta as medidas de sucção do solo ao longo da altura do aterro.

a)

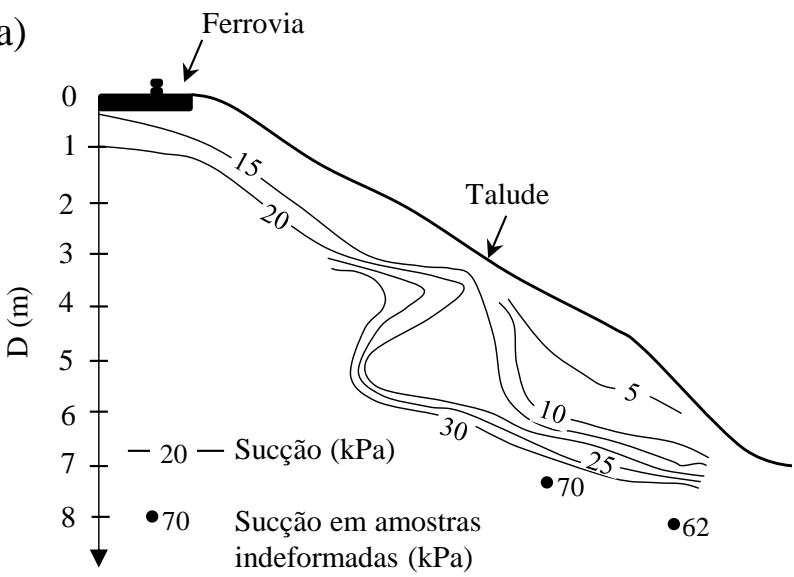

b)

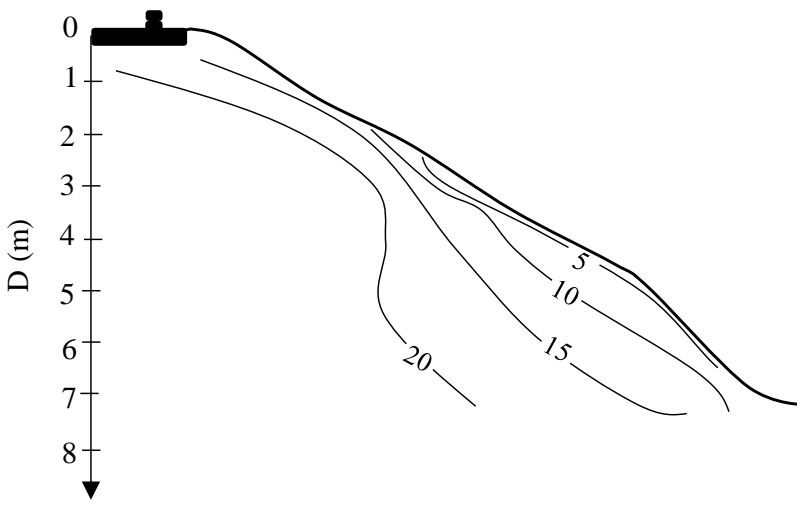

Figura 2.9. Medidas de sucção do solo ao longo da altura do aterro de Notch Hill, Inglaterra: (a) durante a vida útil; (b) no momento da ruptura (KRAHN; FREDLUND; KLASSEN, 1989). 
Outra grande preocupação na utilização de solos finos em estruturas geotécnicas é que, geralmente, devido à baixa condutividade hidráulica, pressões da água positivas podem vir a se desenvolver no interior de maciço e demandam muito tempo para serem dissipadas. Essas pressões internas promovem a diminuição das tensões efetivas, e consequentemente da resistência ao cisalhamento do solo, assim como prejudicam a interação solo-reforço. Desse modo, dependendo da maneira em que as pressões da água são desenvolvidas, estas podem vir a influenciar na estabilidade a curto prazo.

A estabilidade a curto prazo pode ser afetada pelo excesso de pressões da água desenvolvidas durante a construção. Isso pode ocorrer devido ao aumento do teor de umidade pela infiltração da água e/ou rápida construção da estrutura em tempo insuficiente para a dissipação das pressões da água. Como os solos argilosos podem apresentar baixíssima condutividade hidráulica, problemas de deformação excessiva ou ruptura da estrutura podem ocorrer durante ou logo após a construção (BURWASH; FROST, 1991; LEONARDS; FROST, BRAY, 1994). Qualquer outro evento de carregamento aplicado bruscamente a estrutura, principalmente em períodos pós-chuva, pode prejudicar a estabilidade a curto prazo devido ao desenvolvimento de pressões da água positivas. Tal fenômeno pode ser previsto por meio de ensaios triaxiais, buscando as condições de drenagem do solo e de carregamento no campo (CHRISTOPHER et al., 1998).

A estabilidade a longo prazo pode ser prejudicada pela infiltração da água após longos e/ou intensos períodos de chuva (pós-construção), elevação do lençol freático ou formação de zonas de fluxo no interior da estrutura. O acúmulo de água infiltrada com o tempo e a dificuldade de dissipação são fatores que favorecem o desenvolvimento de pressões da água positivas.

Outras considerações com relação à utilização de solos finos que podem prejudicar o desempenho e construção de estruturas de solo reforçado são (ZORNBERG; MITCHELL, 1994):

- movimentos pós-construção podem ocorrer sob tensões constantes devidos ao elevado potencial de fluência de solos finos;

- muitos solos finos podem apresentar elevado potencial de expansão, o que pode gerar tensões internas adicionais quando em contato com água;

- solos finos coesivos são mais difíceis de serem compactados.

\subsection{Problemas associados ao uso de solos finos coesivos em estruturas com reforços impermeáveis}

\subsubsection{Interação solos finos e reforços impermeáveis}

Desde que materiais finos começaram a ser utilizados como materiais de aterro em muros e taludes reforçados, muitos trabalhos passaram a avaliar a interação entre estes tipos de solos e diferentes tipos de reforços (INGOLD 1981; FABIAN; FOURIE, 1986; CHRISTOPHER; BERG, 
1990; GILBERT; OLDHAM; COFFING, 1992; ZORNBERG; MITCHELL, 1994; FARRAG; MORVANT, 2004; ABU-FARSAKH; CORONEL; TAO, 2007; PATHAK; ALFARO, 2010).

Assim como as diferenças de comportamento de resistência ao cisalhamento entre solos granulares e solos argilosos, o comportamento de interface solo-geossintéticos também possui peculiaridades de acordo com o tipo de solo que irá interagir. Resultados de ensaios de arrancamento em geogrelhas inseridas em diferentes tipos de solo, obtidos por Chang et al. (1995), mostram que as discrepâncias encontradas entre solos granulares em comparação aos solos finos se devem principalmente ao tamanho dos grãos que preenchem os vazios das geogrelhas. De acordo com Chang et al. (1995), a resistência ao arrancamento das grelhas aumenta com o confinamento, mas as taxas de crescimento são diferentes dependendo do tipo de solo. O efeito do confinamento é muito menor em solos mais finos, com ambas as parcelas adesiva e atritiva menores quando comparadas com a interface em solos granular, como mostra a Figura 2.10. Por outro lado, resultados apresentados por Bergado et al. (1987) mostraram taxas semelhantes de aumento na resistência ao cisalhamento de interface com o aumento da tensão de confinamento, tanto em solo areno argiloso como em solo argiloso intemperizado. No entanto, a parcela de adesão da interface em solo areno argiloso foi consideravelmente maior, enquanto às parcelas de atrito foram semelhantes (Figura 2.10).

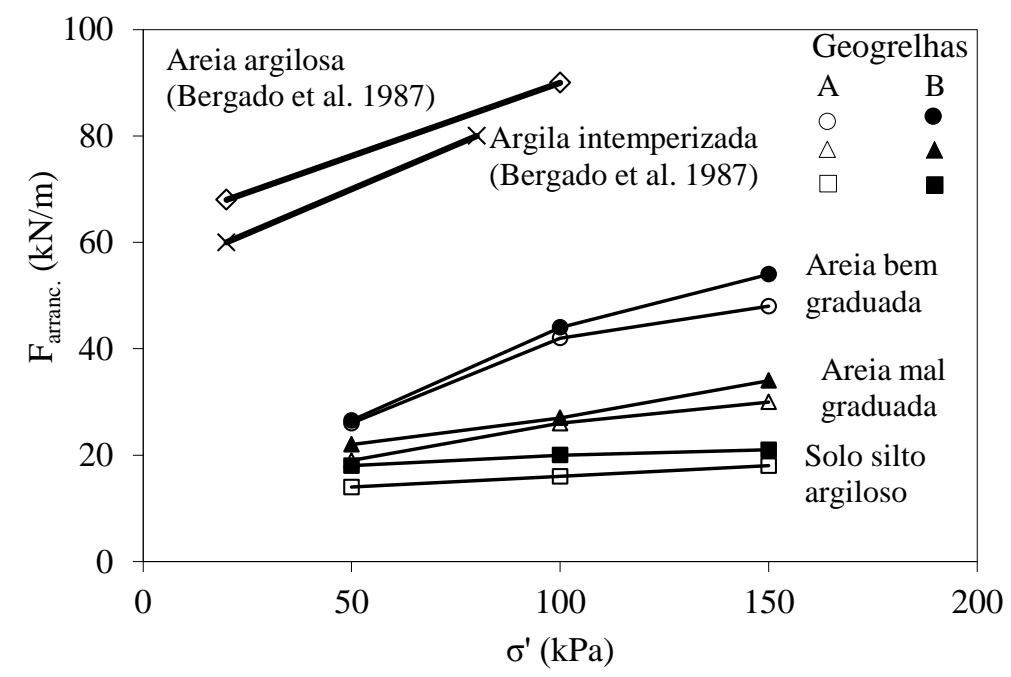

Figura 2.10. Resistência ao arrancamento em função da tensão confinante, para diferentes tipos de solos (modificado de CHANG; SUN; HUNG, 1995).

A diferenciação no comportamento de interface entre os solos finos relatados por Chan et al. (1995) e Bergado et al. (1987) é bastante comum na literatura técnica, uma vez que a resistência de interface é tão afetada pela mineralogia e porcentagem de argila como na resistência ao cisalhamento do solo. Por este motivo, os solos de Bangkoc apresentados por Bergado et al. (1987) apresentaram melhores comportamentos do que os solos ilustrados por Chang et al. (1995). 
Em solos granulares, a resistência ao arrancamento de geogrelhas é dependente de três mecanismos de interação: atrito, intertravamento das partículas de solo nos vazios da grelha e resistência passiva desenvolvida na junção dos elementos transversais (COLLIOS et al., 1980; INGOLD, 1984; TEIXEIRA; BUENO; ZORNBERG, 2007). Portanto, pode-se dizer que a interação solo granular - geogrelha é influenciada pela geometria e rigidez das geogrelhas. Em solos coesivos, tais mecanismos de interação podem ser prejudicados uma vez que a resistência atritiva e a capacidade de carga do sistema solo-membros transversais são geralmente menores quando comparados a solos granulares.

Amorim Jr (1992) avaliou a resistência de interface de diferentes geogrelhas em uma argila CL e outra argila $\mathrm{CH}$. Foram utilizadas geogrelhas biaxiais com mesmo espaçamento entre os elementos longitudinais e transversais $(28 \times 3 \mathrm{~mm})$, com valores de resistência 17,5 (SS2) e 34 (SS35) kN/m, e geogrelhas uniaxiais com espaçamentos longitudinais e transversais semelhantes (130x15 mm), porém maiores que das geogrelhas biaxiais, mas de diferentes resistências últimas, 80 (SR2) e 110 (SR110) kN/m. Resultados típicos são sintetizados na Figura 2.11.
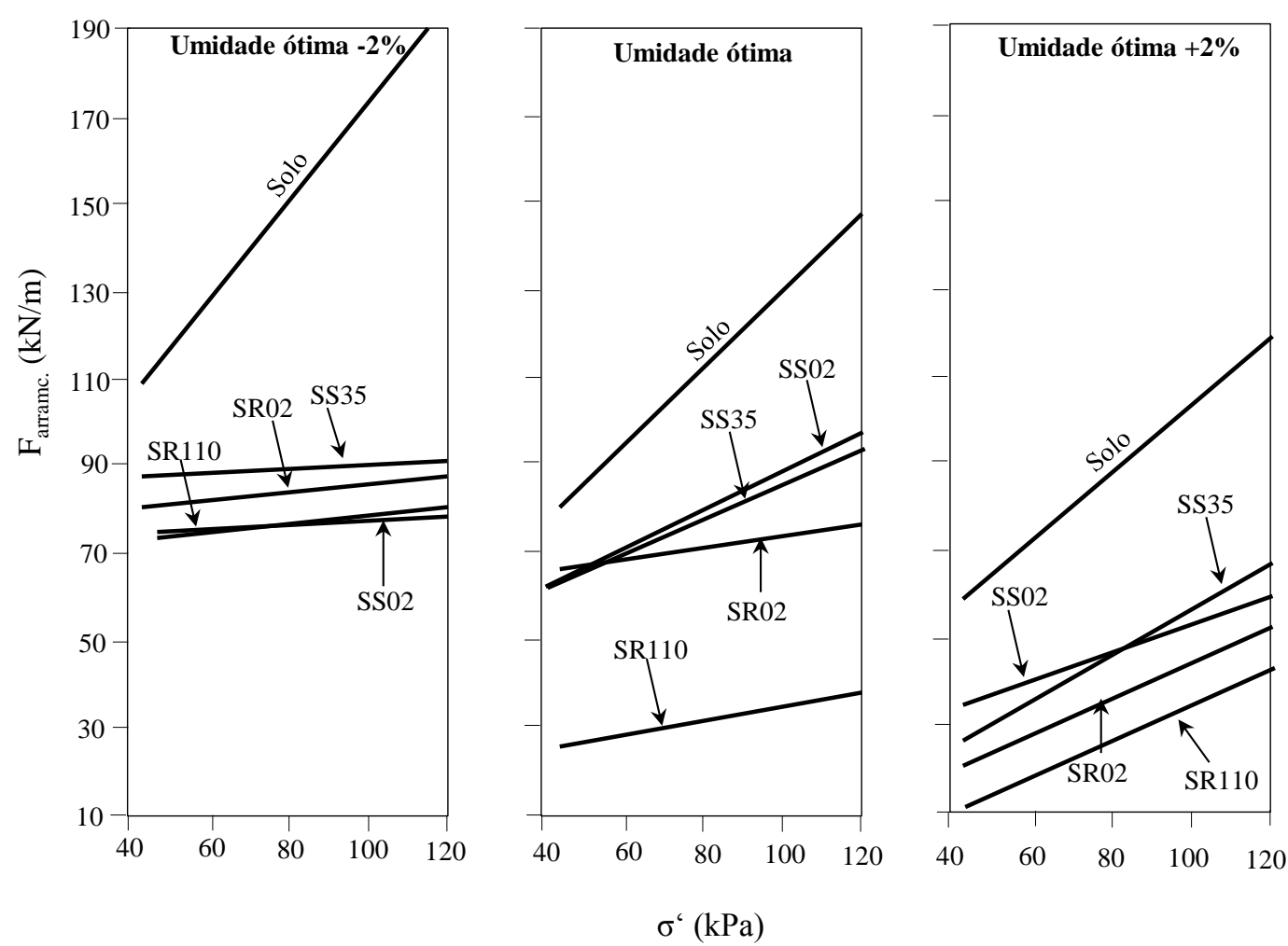

Figura 2.11. Ensaios de arrancamento de diferentes geogrelhas em solos argilosos CL sob três condições de umidade (Amorim Jr, 1992).

Resultados de ensaios de arrancamento mostraram que, de modo geral, a rigidez não influenciou significativamente na resistência de interface em solos argilosos. Por outro lado, as geogrelhas biaxiais apresentaram resistências de interface levemente maiores que as uniaxiais, mesmo com valores inferiores de rigidez, mostrando que a redução dos espaçamentos entre 
membros transversais e longitudinais podem vir a ser um fator de influência positiva em solos finos. Já o teor de umidade foi o fator de maior influência na resistência de interface para ambas as grelhas, como verificado na Figura 2.11. Conclusões semelhantes foram obtidas por Brand e Duffy (1987) em ensaios de arrancamento de quatro diferentes tipos de geogrelhas em um solo argiloso expansivo compactado em teor de umidade $10 \%$ abaixo da ótima.

O mesmo raciocínio quanto aos mecanismos que governam a interação solo-reforços pode ser utilizado para comparar o comportamento de interface entre solos finos-geogrelhas e solos finos-geotêxteis tecidos (também considerados reforços impermeáveis). Os reforços tecidos apresentam geometrias bastante diferentes das geogrelhas, em que a resistência de interface é totalmente mobilizada pela parcela atritiva e adesiva, sem influência da resistência passiva dos elementos transversais que compõe as geogrelhas. Portanto, a resistência de interface de solos granulares e geogrelhas são consideravelmente maiores do que com geotêxteis tecidos. Já para solos finos coesivos, esse contraste de interação passa a ser amenizado, ou eliminado, visto que a resistência passiva de solos argilosos sob a condição de carregamento pontual (elementos transversais) é relativamente menor, e a área de contato aumentada pela geometria dos geotêxteis tecidos pode compensar e aproximar os valores de resistência de interface. Uma comparação entre ensaios de arrancamento de dois diferentes tipos de reforços geossintéticos (geogrelha e geotêxteis tecidos) em solo argiloso foi conduzido em laboratório e campo por Abu-Farsakh et al. (2006). Os autores obtiveram boa concordância entre os parâmetros obtidos em laboratório e campo e concluíram que não existiram mudanças significativas na resistência de interface ao arrancar geogrelhas ou geotêxteis tecidos para o solo argiloso estudado. Nestes casos, a rigidez dos reforços não promoveram maiores alterações. Nos resultados obtidos por Teixeira et al. (2007), a presença dos membros transversais das geogrelhas contribuiu com $20 \%$ da resistência ao arrancamento em um solo areno argiloso.

A discrepância de comportamento de interface entre solos granulares e solos coesivos pode ser ainda maior nas condições críticas de saturação e velocidade de aplicação do carregamento. $\mathrm{O}$ fato é que a elevada condutividade hidráulica de solos granulares permite que as pressões da água desenvolvidas durante o arrancamento sejam dissipadas rapidamente, o que não ocorre na interface com solos finos de baixa condutividade hidráulica. Um trabalho realizado por Ingold (1981) permitiu avaliar o parâmetro de adesão de interface através de ensaios de cisalhamento direto e arrancamento do reforço em condições não consolidadas e não drenadas (UU). Os ensaios foram conduzidos com solo argiloso (Kaolin), moldados de modo a obter o peso específico de $18,7 \mathrm{kN} / \mathrm{m}^{3}$ e umidade de $35 \%$, referente à saturação teórica. A Figura 2.12 apresenta o comportamento de interface solo argiloso-geogrelha nas condições do ensaio. Resultados mostraram que a resistência ao arrancamento da geogrelha nas condições críticas pode representar aproximadamente $20 \%$ da resistência ao cisalhamento do solo, efeito não tão pronunciado nos ensaios de cisalhamento direto de interface (Figura 2.12b). Conclui-se, portanto, 
que a resistência de interface com solos finos pode ser bastante prejudicada nas condições críticas de carregamento e umidade, principalmente em ensaios de arrancamento.

a)

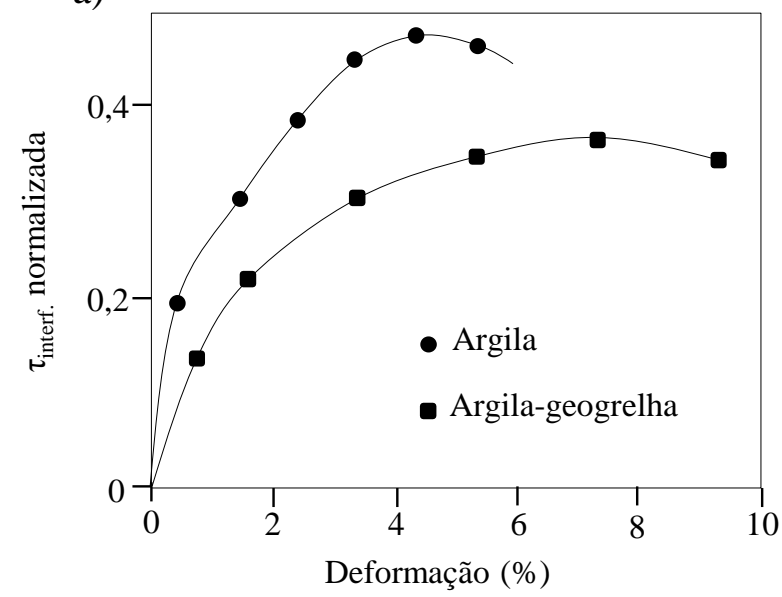

b)

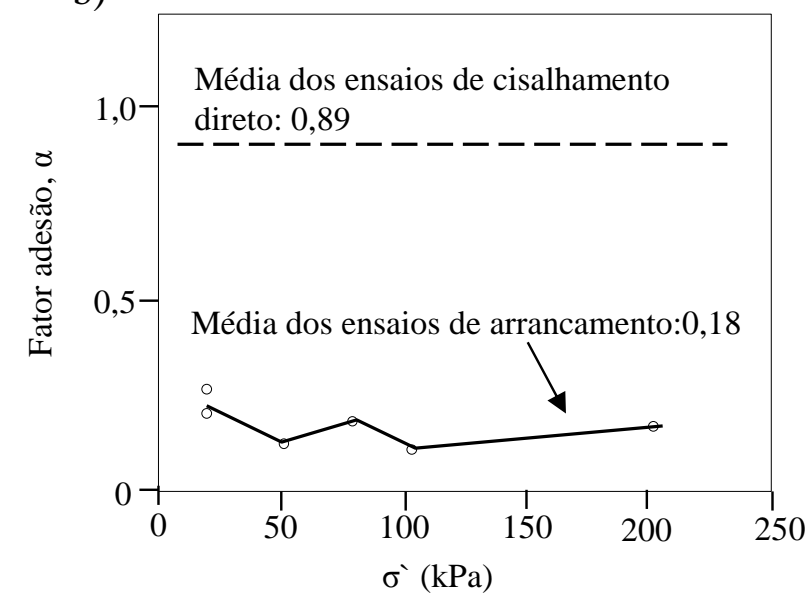

Figura 2.12. Comportamento de interface solo argiloso-geogrelha nas condições UU de ensaios: (a) Ensaios de cisalhamento direto de interface; (b) fatores de adesão de interface dos ensaios de cisalhamento direto e ensaios de arrancamento (INGOLD, 1981).

O efeito do teor de umidade e velocidade de carregamento foram também reconhecidos nos ensaios de arrancamento de geotêxteis tecidos em solos argilosos do tipo CH e CL conduzidos por Gilbert et al. (1992). Neste trabalho foi avaliada a influência da velocidade de ensaio, simulando condições drenada $(0,004 \mathrm{~cm} / \mathrm{min})$ e não drenada $(0,635 \mathrm{~cm} / \mathrm{min})$, bem como a influência do teor de umidade, inundação e confinamento. Os autores concluíram que não houve diferença significativa no atrito de interface entre solos argilosos e geotêxteis avaliados, sendo que as forças de arrancamento aumentaram com a velocidade de ensaio. $\mathrm{O}$ efeito da inundação e os teores de umidades avaliados provocaram uma considerável diminuição na resistência de arrancamento. Observou-se que o efeito do teor de umidade é mais significativo em ensaios com maiores tensões confinantes, como pode ser observado na Figura 2.13. Tal comportamento foi atribuído à perda das tensões capilares no contato e a sucção do solo e, principalmente, ao desenvolvimento de pressões da água positivas no momento do arrancamento. Acredita-se que maiores tensões confinantes proporcionam maiores valores pressões da água durante o arrancamento, assim como é geralmente observado em ensaios triaxiais de solos muito finos.

Pressões da água positivas foram registradas por Farrag e Morvant (2004) em ensaios de arrancamento de geogrelhas em condições não drenadas em solo silto argiloso na umidade ótima de compactação (18\%) e com adição de água até 40\%. Resultados mostraram redução de até 50\% no valor da força de arrancamento e desenvolvimento de pressão da água durante o ensaio, e a mesma taxa de redução foi verificada por Chen e Wu (2010). Resultados típicos dos ensaios realizados por Farrag e Morvant (2004) são apresentados na Figura 2.14. 


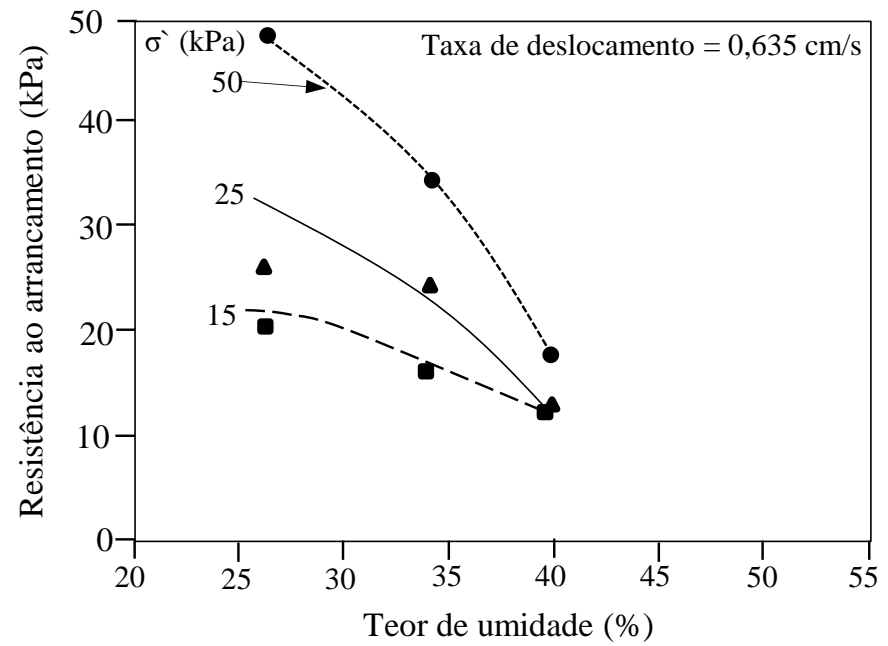

Figura 2.13. Efeito do teor de umidade em ensaios de arrancamento de geotêxteis tecidos em solos argilosos (GILBERT; OLDHAM;C OFFING, 1992).
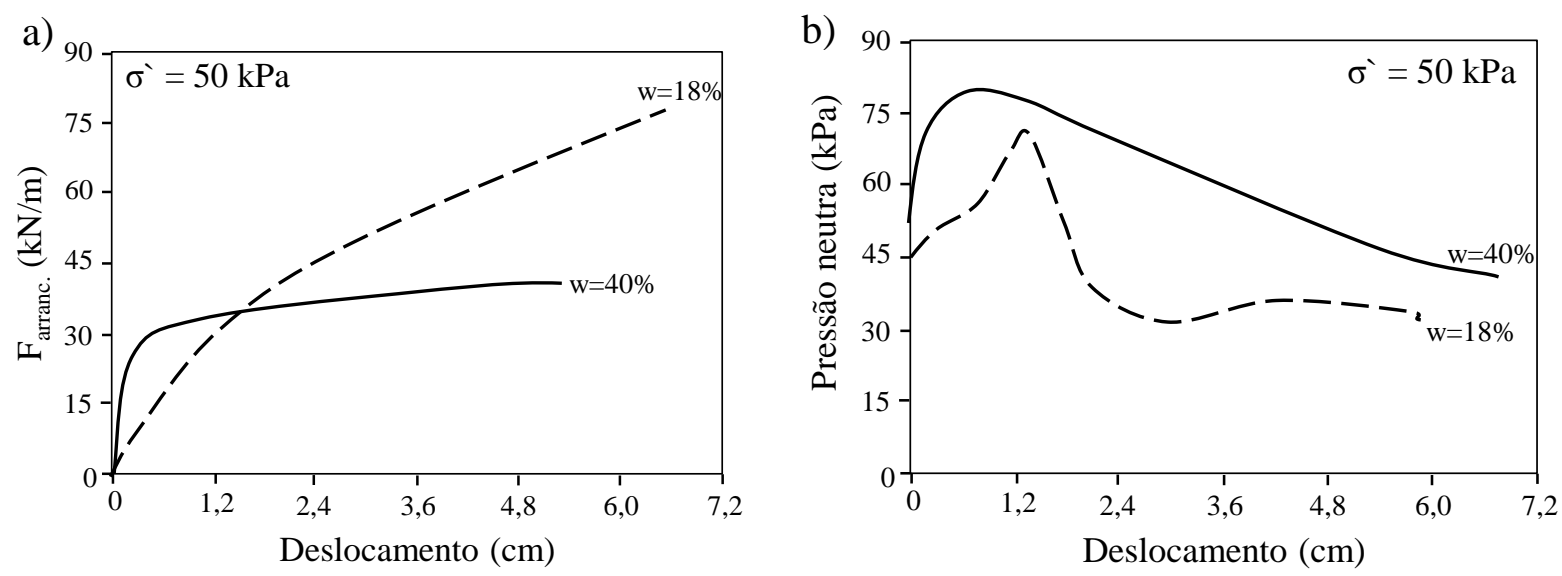

Figura 2.14. Ensaios de arrancamento de geogrelha em solo silto argiloso nas umidades de $18 \%$ (ótima) e 40\%: (a) curvas força de arrancamento versus deslocamento; (b) curvas pressão da água versus deslocamento (FARRAG e MORVANT, 2004).

\subsubsection{Casos reais de problemas em estruturas de solo reforçado}

Dentre os casos de rupturas ou deformações excessivas de estruturas de solo reforçado relatados na literatura, a grande maioria está associada à infiltração da água no interior do corpo do aterro de solos de finos (BODEN; IRWIN; POCOCK, 1978; MURRAY; BODEN, 1979; SCOTT et al., 1987; DELMAS et al., 1988; NAKAMURA et al., 1988; SEGO; SCOTT; RICHARDS, 1990; BERGADO et al., 1991; BURWASH; FROST, 1991; YOO; JUNG, 2006). Geralmente, mudança da sucção matricial do solo e o desenvolvimento de pressões da água positivas podem vir a aumentar o empuxo de terra na estrutura e, consequentemente, a força e a posição de tração requerida nos reforços, além de reduzir o atrito e adesão entre solo e reforço (LI; JIE; CHEW, 2002).

Um levantamento de muros reforçados que apresentaram comportamentos inadequados durante a vida da estrutura foi realizado por Koerner e Soong (2001). O objetivo dos autores foi 
extrair potenciais aspectos que influenciaram no comportamento das estruturas e fazer destes, lições para projeto de muros reforçados. As Tabelas 2.3 e 2.4 resumem as características de cada uma das estruturas relatadas, bem como as causas de cada problema. A grande maioria dos problemas está associada à baixa permeabilidade dos solos de aterro e por esse motivo, as normas de estruturas de solo reforçado recomendam uma faixa restrita de curvas granulométrica dos solos àqueles que permitem a livre drenagem da água dentro do aterro reforçado. Este trabalho evidenciou que, na maioria dos casos de problemas e rupturas, períodos de chuva alteraram as características do solo, prejudicando o comportamento da estrutura, mesmo aquelas que foram devidamente projetadas. Nestas ocasiões, o uso de reforços mais rígidos e resistentes, não necessariamente soluciona o problema, já que pode haver o acúmulo de pressões da água na zona reforçada. Ainda, cabe observar que, no contexto do umedecimento do solo, poucos foram os problemas com reforços não tecidos, sendo a maioria com geogrelhas. De fato, alguns trabalhos tem mostrado o potencial do uso de reforços permeáveis nesse tipo de estrutura (ZORNBERG; MITCHELL, 1994), o que pode estar associado com as constatações verificadas pelos autores. Koerner e Soong (2001) recomendam, caso solos finos sejam selecionados para compor o projeto de estruturas reforçadas, a utilização de elementos de drenagem atrás e na fundação da estrutura, de modo que a água seja coletada, transportada e descarregada para fora do interior do aterro. Adicionalmente, os autores recomendam a utilização de barreiras de avanço de umidade no topo da estrutura, podendo essas ser geomembranas ou GCLs, de modo a prevenir a infiltração da agua para a zona reforçada. Dentre outras causas estão à má execução pelo contratante e projetos deficientemente elaborados e especificados.

Um caso de ruptura de um muro reforçado com geogrelha é relatado por Yoo e Jung (2006), três meses a após o término da construção. A Figura 2.15 ilustra a obra e o detalhe da ruptura do muro. A estrutura consistia em um muro íngreme de 7,4 metros de altura na província de Chung-Nam, na Coréia. A seção de projeto desta estrutura é ilustrada na Figura 2.16. Em 2003, a estrutura entrou em colapso movimentando mais $1200 \mathrm{~m}^{3}$ de solo, tornando esta a maior ruptura já ocorrida na Coréia. O solo utilizado na execução do muro consiste em um solo residual de granito com $30 \%$ de material passante na peneira \#200, classificado como SC. O reforço utilizado consistiu em geogrelhas com resistência à tração na ruptura de $60 \mathrm{kN} / \mathrm{m}$. Os autores realizaram análises numéricas da infiltração de água e pressões da água no interior do maciço com o tempo, bem como análise de equilíbrio limite da estrutura, com intuito de entender o motivo da ruptura da estrutura. No projeto foram utilizados de parâmetros de resistência de ensaios triaxiais CU, cuja coesão foi de $13 \mathrm{kPa}$ e o ângulo de atrito de $22^{\circ}$. Para as análises, utilizaram-se dos mesmos parâmetros utilizados no projeto, além do parâmetro $\phi^{\mathrm{b}}$ do solo não saturado de $15^{\circ}$, o que possibilitou a avaliação do efeito da infiltração de água na estrutura. Ensaios de permeabilidade saturada do solo resultaram em coeficiente de condutividade hidráulica de 5,0 x $10^{-7} \mathrm{~m} / \mathrm{s}$. 


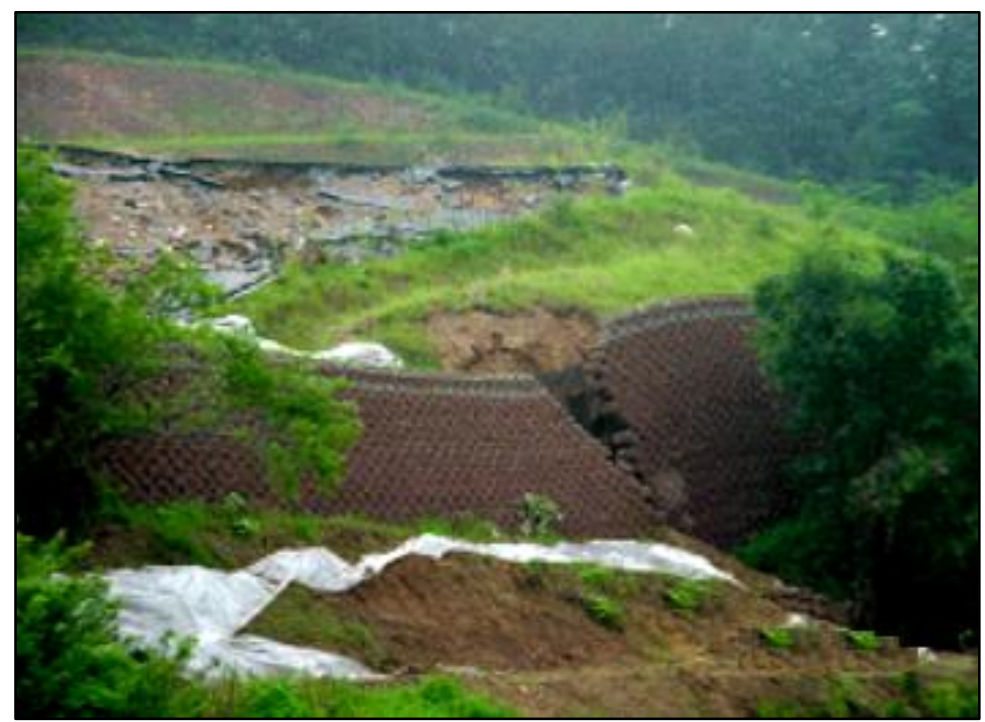

Figura 2.15. Ruptura do muro reforçado com geogrelha em Chung-Nam, na Coréia (YOO; JUNG, 2006).

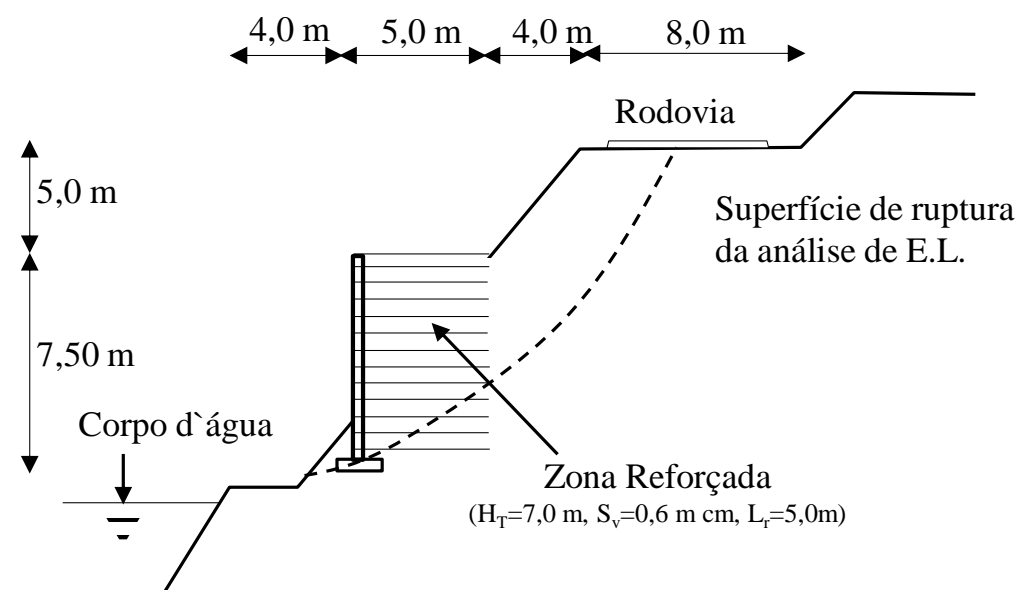

Figura 2.16. Geometria do muro reforçado em Chung-Nam (Coréia) e a superfície de ruptura obtida pela análise de equilíbrio limite (YOO; JUNG, 2006).

Yoo e Jung (2006) relatam ainda que durante o mês de Junho e Julho de 2003 foram registradas chuvas de $155 \mathrm{~mm} / \mathrm{dia}$, resultando num total de $580 \mathrm{~mm}$ no final do mês de Julho. Com isso, as análises numérica de infiltração de água registraram que após 20 dias o solo na zona reforçada se apresentava na condição saturada com pressões da água próximas de 0 (Figura 2.17a). As análises de estabilidade da Figura 2.17b mostram que depois de 40 dias fatores de segurança menores que 1 foram obtidos, exatamente na condição em que as pressões da água foram próxima de zero ao longo da altura do talude. Portanto, essa é uma lição típica de negligências nas análises de estabilidade da estrutura que não consideraram a condição crítica de umedecimento, bem como na omissão de sistemas de drenagem efetivos. 
Tabela 2.3. Casos de muros reforçados com problemas de deformações excessivas (KOERNER; SOONG, 2001)

\begin{tabular}{|c|c|c|c|c|c|c|c|c|c|}
\hline No. & Face & Reforço & Ano & Serviço & Causa & Problema & Solo de aterro & Tempo & Referência \\
\hline $\mathrm{S} 1$ & Envelopada & GG & 1984 & 3 anos & Projeto & Rotação do muro & Argila (ML-CL) & Frio & Burwash e Frost (1991) \\
\hline S2 & Envelopada & GG & 1990 & - & Projeto & $\begin{array}{c}\text { Embarrigamento na base } \\
\text { (sobrecarga) }\end{array}$ & Cascalho arenoso & $\mathrm{n} / \mathrm{a}$ & Christopher (1993) \\
\hline S3 & $\mathrm{BS}$ & GG & 1990 & - & Projeto & Embarrigamento na base & Areia & Desconhecido & Bathurst e Simac (1994) \\
\hline S4 & BS & GG & 1994 & DC & Projeto & $\begin{array}{l}\text { Embarrigamento no topo } \\
\text { (má drenagem) }\end{array}$ & $\mathrm{n} / \mathrm{a}$ & $\mathrm{n} / \mathrm{a}$ & Sandri (1997) \\
\hline S5 & BS & GG & 1994 & DC & Contratante & Embarrigamento no topo & $\mathrm{n} / \mathrm{a}$ & $\mathrm{n} / \mathrm{a}$ & Sandri (1997) \\
\hline S6 & BS & GG & 1994 & DC & Contratante & Alinhamento ruim & $\mathrm{n} / \mathrm{a}$ & $\mathrm{n} / \mathrm{a}$ & Sandri (1997) \\
\hline S7 & BS & GG & 1994 & DC & Contratante & Má colocação dos blocos & $\mathrm{n} / \mathrm{a}$ & $\mathrm{n} / \mathrm{a}$ & Sandri (1997) \\
\hline S8 & $\mathrm{BS}$ & GG & 1994 & DC & Contratante & Fundação muito rasa & $\mathrm{n} / \mathrm{a}$ & $\mathrm{n} / \mathrm{a}$ & Sandri (1997) \\
\hline S9 & BS & GT & 1994 & 2 anos & Contratante & $\begin{array}{l}\text { Embarrigamento no meio } \\
\text { (espaçamento errado) }\end{array}$ & Argila (CL) & Desconhecido & Gassner e James (1998) \\
\hline S10 & BS & GG & 1995 & 6 meses & Projeto & Deformação generalizada & Argila & Desconhecido & Koerner e Soong (2001) \\
\hline S11 & BPM & GG & 1995 & 4 anos & Projeto & Embarrigamento no topo & Silte argiloso & Chuvoso & Koerner e Soong (2001) \\
\hline $\mathrm{S} 12$ & $\mathrm{BS}$ & GG & 1998 & 8 meses & Projeto & Embarrigamento no topo & Argila siltosa & Chuvoso & Koerner e Soong (2001) \\
\hline
\end{tabular}

Tabela 2.4. Casos de rupturas de muros reforçados (KOERNER; SOONG, 2001)

\begin{tabular}{|c|c|c|c|c|c|c|c|c|c|}
\hline No & Face & Reforço & Ano & Serviço & Causa & Motivo & Solo de aterro & Clima & Referência \\
\hline F1 & Madeira & GT & 1987 & 3 meses & Contratante & Má conexão & não compactado & $\mathrm{n} / \mathrm{a}$ & Richardson e Behr (1998) \\
\hline $\mathrm{F} 2$ & BS & GG & 1990 & 6 meses & Contratante & GG-omitida & Argila & $\mathrm{n} / \mathrm{a}$ & Leonards et al. (1994) \\
\hline F3 & BS & GG & 1992 & 2 meses & Projeto & Global/combinado & Areia & Chuva forte & Berg e Meyers (1997) \\
\hline $\mathrm{F} 4$ & Envelopada & GG & 1992 & - & Projeto & Hidrostático & Argila Siltosa & Chuva forte & Huang (1994) \\
\hline F5 & Envelopada & GG & 1992 & - & Projeto & Hidrostático & Argila Siltosa & Chuva forte & Huang (1994) \\
\hline F6 & BPM & GG & 1992 & - & Projeto & $\begin{array}{c}\text { Hidrostático } \\
\text { (ruptura da grelha) }\end{array}$ & Argila Siltosa & Chuva forte & Huang (1994) \\
\hline F7 & $\mathrm{BS}$ & GT & 1993 & 3 anos & Projeto & Hidrostático & Argila Siltosa & Chuva forte & Gassner e James (1998) \\
\hline F8 & BS & GT & 1994 & 2 anos & Contratante & GT-omitido & Argila & Chuva forte & Gassner e James (1998) \\
\hline F9 & BS & GG & 1994 & - & Projeto & Hidrostático & Não drenante & Chuvoso & Sandri (1997) \\
\hline F10 & BS & GG & 1996 & 12 meses & Projeto & Hidrostático & Argila & Chuva forte & Koerner e Soong (2001) \\
\hline F11 & BS & GG & 1997 & 12 meses & Projeto & Hidrostático & Argila & Chuvoso & Koerner e Soong (2001) \\
\hline F12 & $\mathrm{BS}$ & GG & 1998 & 18 meses & Projeto & Hidrostático & Argila (ML-SP) & Chuvoso & Koerner e Soong (2001) \\
\hline F13 & BS & GG & 1998 & 8 meses & Projeto & Hidrostático & Argila Siltosa & Períodos de chuva & Koerner e Soong (2001) \\
\hline F14 & $\mathrm{BS}$ & GG & 1998 & 12 meses & Projeto & Hidrostático & Silte argiloso & Períodos de chuva & Koerner e Soong (2001) \\
\hline
\end{tabular}

Notas: BS - Blocos segmentados; BPM - Blocos pré-moldados; GG - Geogrelhas; DC - Durante construção; n/a - não aplicável ao problema. 
a)

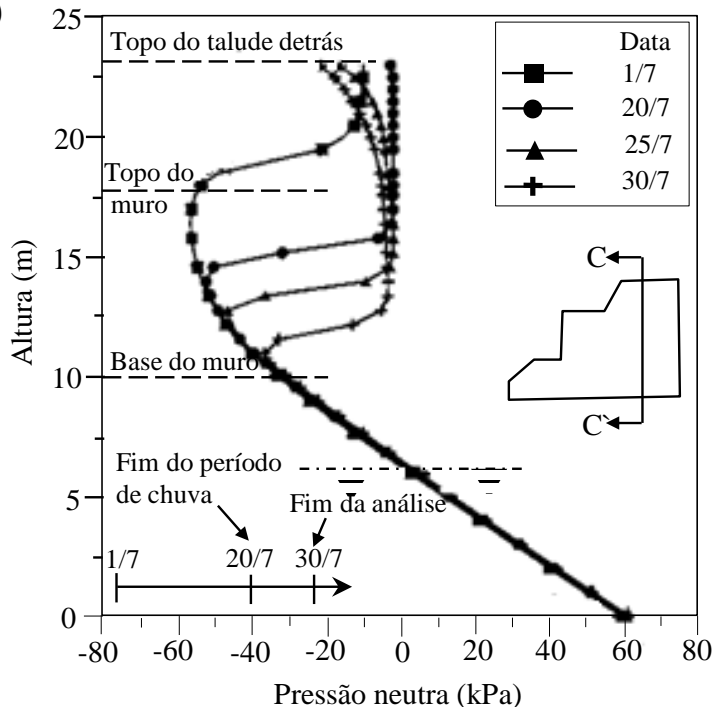

b)

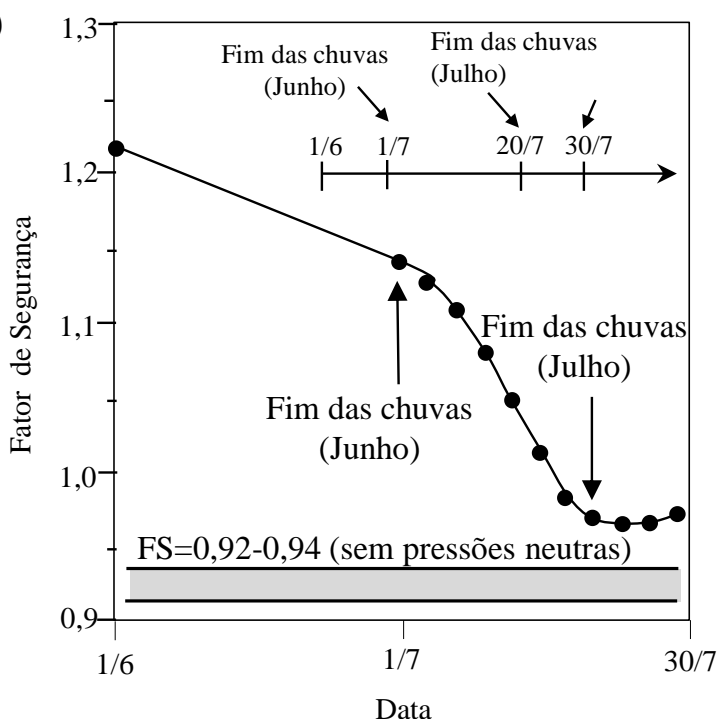

Figura 2.17. Análises de infiltração de água e estabilidade da estrutura do muro em Chung-Nam - Coréia: (a) variação da pressão da água; (b) resultados das análises de equilíbrio limite (YOO; JUNG, 2006).

Outros casos semelhantes que englobam rupturas e deformações excessivas de muros de solos finos reforçados com geossintéticos são relatados por Scarborough (2005). O artigo reporta dois casos históricos de ruptura de muros de solos locais finos reforçados com geogrelhas. $\mathrm{O}$ primeiro muro relatado totalizou $9,1 \mathrm{~m}$ de altura e foi construído no estado de Virgínia, nos Estados Unidos, com solo argiloso ( $82 \%$ passante na peneira $\# 200, \mathrm{w}_{\mathrm{L}}=51 \%$ e $\left.\mathrm{w}_{\mathrm{P}}=25 \%\right)$ e teve a ruptura ocorrida devido ao arrancamento do reforço, como ilustrado na Figura 2.18. O segundo muro foi construído no estado do Tennesse, nos Estados Unidos, com 8,5 metros de altura, também com solo argiloso $\left(\mathrm{w}_{\mathrm{L}}=62 \%\right.$ e IP=19\%). Este apresentou deformações na ordem de 150 $\mathrm{mm}$ e posterior ruptura. Segundo os autores, a causa da ruptura foi uma negligência da drenagem do muro, fazendo com que as pressões da água se acumulassem no interior da zona reforçada, bem como a má compactação das camadas superiores.

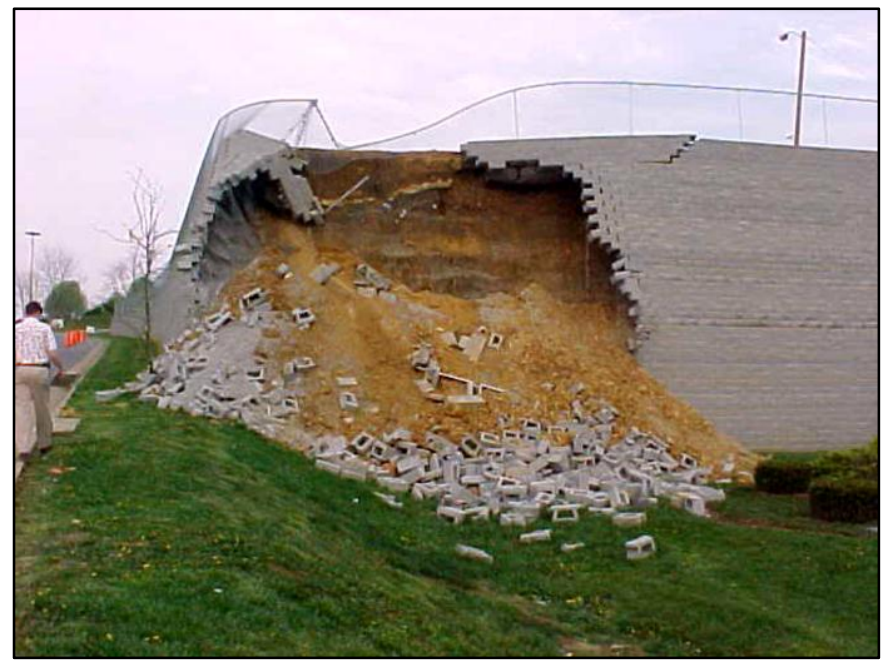

Figura 2.18. Ruptura do muro de solo argiloso reforçado com geogrelhas no estado de Virginia - Estados Unidos (SCARBOROUGH, 2005). 
Um aterro experimental de um solo fino reforçado com diferentes tipos de geogrelhas foi executado em Devon (Alberta, Canadá) em 1986. A altura total do muro é de 12 metros com taludes $1 \mathrm{~V}: 1 \mathrm{H}$ em ambas as laterais. Este aterro foi instrumentado com intuito de entender o comportamento de solo coesivo reforçado, e contemplou medidas de deformações nos reforços via strain gages, movimentos verticais e horizontais por meio de inclinômetros e monitoramento das pressões da água utilizando piezômetros. O material do aterro consistiu num solo silto argiloso. Relatos de construção e leituras da instrumentação foram reportado por Sego et al. (1990) e, posteriormente, por Liu et al. (1994). Na Figura 2.19 mostram-se resultados de deslocamentos horizontais, verticais, pressões da água e deformações da geogrelha a 2 metros da base da estrutura. Observam-se maiores deformações e deslocamentos ocorreram durante a construção, logo após a colocação de 6 metros de solo compactado. Chuvas ocorreram durante o período construtivo favorecendo o desenvolvimento das pressões da água positivas. A associação dos esforços de compactação, aumento do carregamento devido à colocação de camadas adicionais, e a infiltração da água foram os fatores que proporcionaram maiores solicitações de tração nas geogrelhas. No entanto, nenhum aumento nos deslocamentos e deformações ocorreu após construção, muito embora as pressões da água tenham permanecido elevadas nesse período.

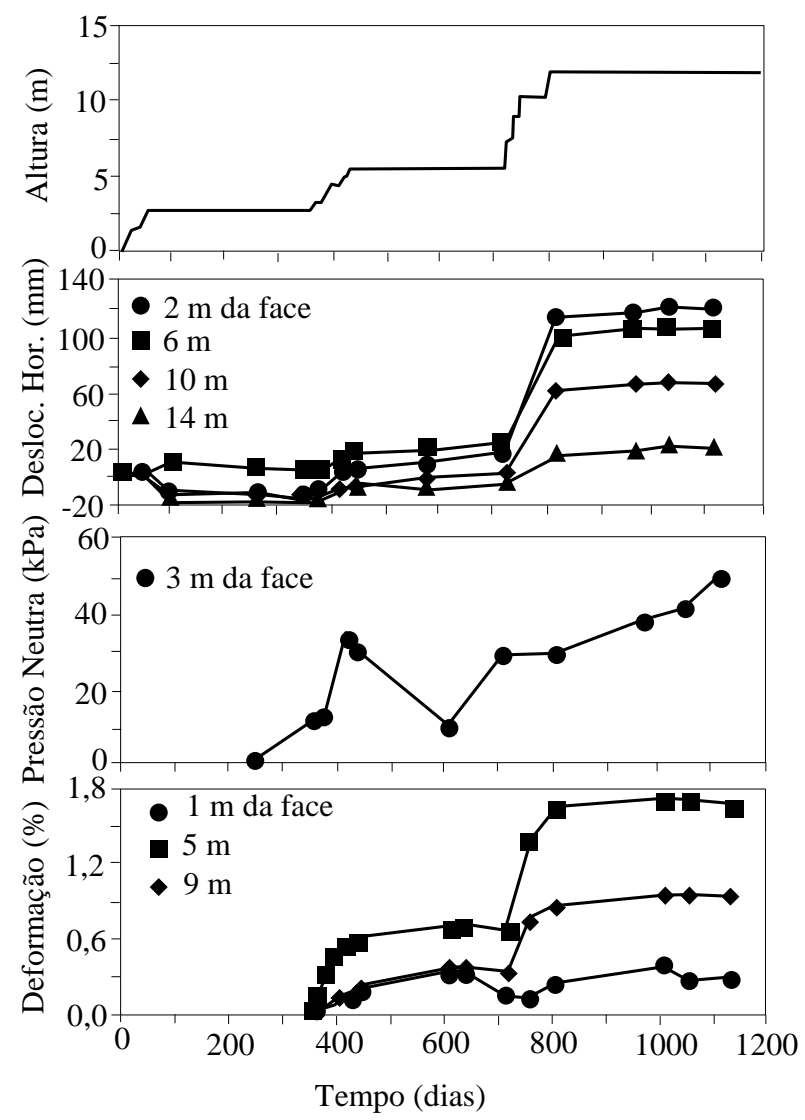

Figura 2.19. Resultados típicos da instrumentação do aterro experimental em Devon, Canadá - 2 metros da base do muro (SEGO; SCOTT; RICHARDS, 1990). 
Esse é um exemplo típico de uns dos problemas comuns durante a construção de estruturas em solos finos, em que o rápido aumento do carregamento devido à execução das camadas superiores e a drenagem lenta da água devido à baixa condutividade hidráulica do solo favorecem o desenvolvimento de pressões da água. Normalmente, isso acontece quando chuvas ocorridas durante a construção umedecem camadas já compactadas. A colocação de uma camada adicional, sobreposta à camada umedecida, pode provocar deslocamentos consideráveis.

Em 1984, um muro de 9 metros de solo argiloso reforçado com geogrelhas foi construído em Calgary (Alberta, Canadá). Geogrelhas foram utilizadas para reforçar um aterro de argila de baixa plasticidade compactada na umidade ótima de 14,5\%. Durante 12 meses após a construção, o muro se comportou satisfatoriamente, até quando sinais de recalques da estrutura foram evidenciados em 1985. As condições de serviço da estrutura foram gradativamente se deteriorando durante os quatro meses após a constatação dos recalques. Em 1986, medidas de deslocamento constataram a rotação da face em relação à base. Depois de 17 meses, o deslocamento máximo da face era de $310 \mathrm{~mm}$, como pode ser observado na Figura 2.20. Em 1987, recalques do estacionamento observados no topo do muro alcançaram valores de $900 \mathrm{~mm}$. Depois deste período, ações de estabilização foram providenciadas. Amostras foram extraídas do interior do muro após 30 dias da construção, permitindo evidenciar aumentos no teor de umidade de 5,5 a 7,0\% acima da umidade de compactação. Segundo os autores, eventos de chuvas ocorreram durante o período construtivo. Adicionalmente, chuvas de $40 \mathrm{~mm}$ em 24 horas foram registradas antes de evidenciarem-se os primeiros sinais de distorção da estrutura. Após análises de laboratório e da estabilidade da estrutura, concluiu-se que a infiltração de água no interior do maciço foi o principal responsável pelas deformações excessivas (BURWASH; FROST, 1991).

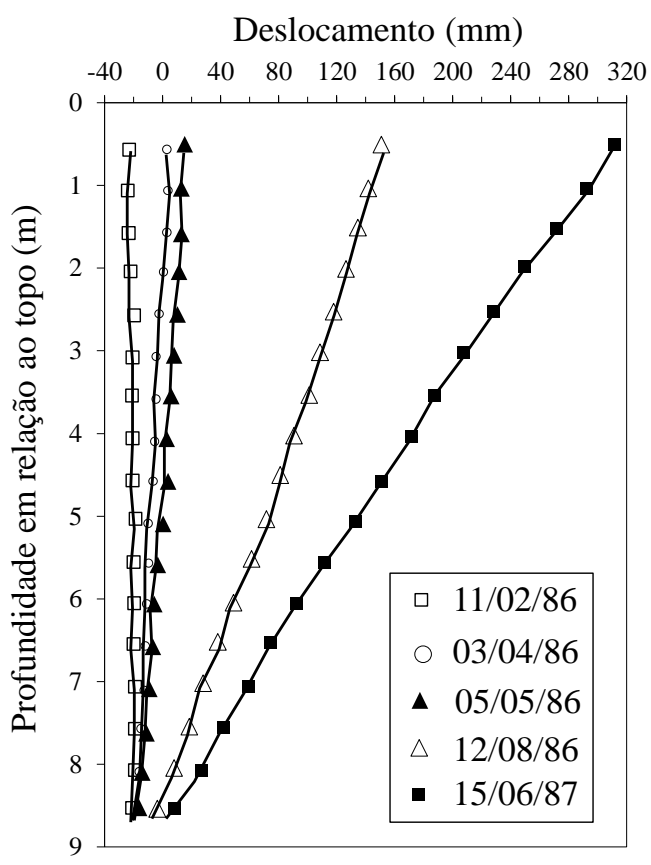

Figura 2.20. Deslocamentos de face da estrutura executada em Alberta, Canadá (BURWASH; FROST, 1991). 
Boden et al. (1978) relatam a construção e instrumentação de um muro reforçado experimental construído pelo Louisiana Transportation Research Center (LTRC) com 6 metros de altura e três camadas de diferentes tipos de solo, cada uma ocupando um terço da altura. $\mathrm{O}$ solo argiloso, localizado no nível mais baixo, o granular usado na porção central e um solo coesivo com menor teor de umidade foram implantados na parte superior do muro, como ilustra a Figura 2.21. Foram utilizados dois tipos de reforços impermeáveis: geossintéticos e fitas metálicas. Os autores relatam excessos de pressões da água na camada argilo-arenosa inferior, logo após a construção e seis meses depois, a uma distância de 3 metros da face muro, como apresenta a Figura 2.22. Os maiores valores de pressão da água foram registrados a 5 metros da face e insignificantes a 1 metro. Após 142 dias, as pressões da água passaram a decrescer até valores próximos à zero, no $315^{\circ}$ dia.

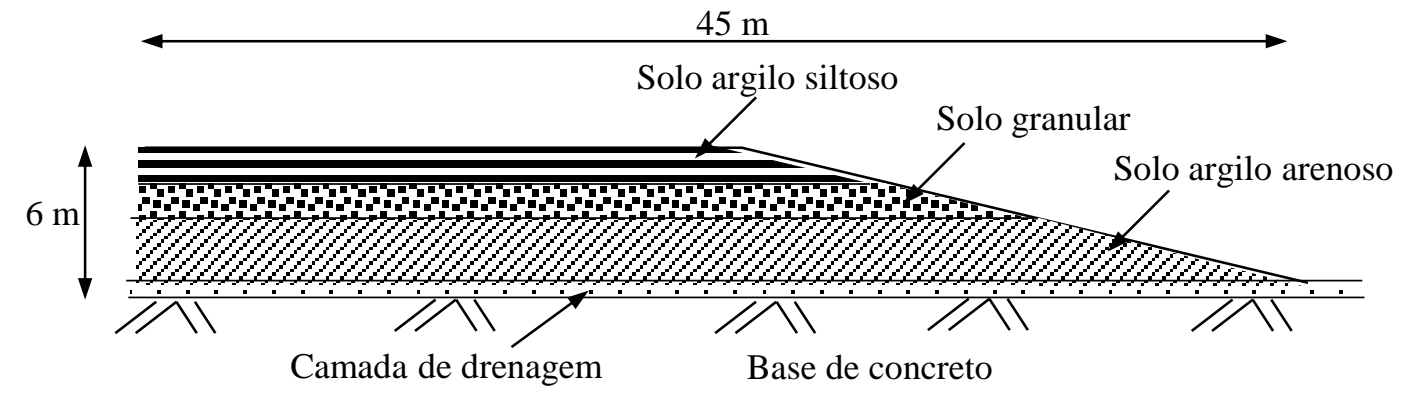

Figura 2.21. Aterro experimental construído pelo TRRL (BODEN; IRWIN; POCOCK, 1978, apud MITCHELL; ZORNBERG, 1995).

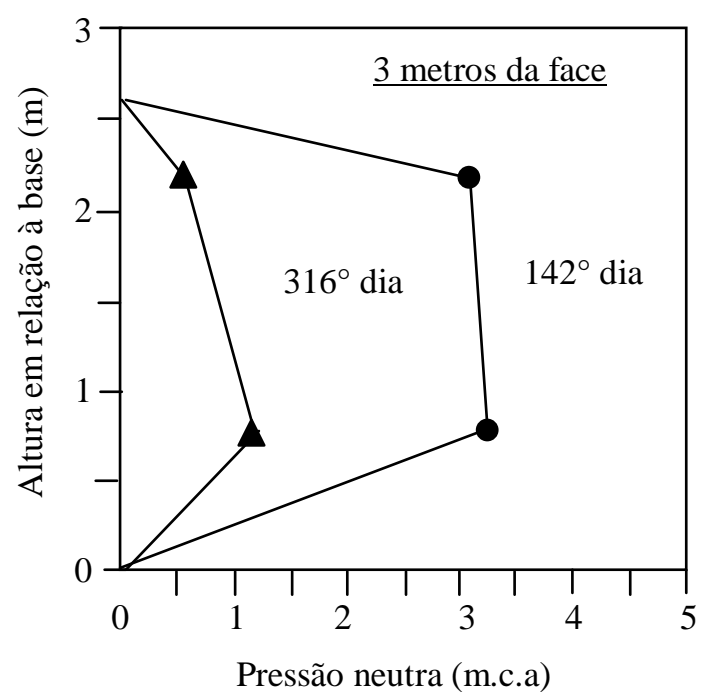

Figura 2.22. Distribuição das pressões da água na parte inferior do muro em solo argiloso desenvolvido pelo TRRL (MURRAY; BODEN, 1979, apud MITCHELL; ZORNBERG, 1995).

Outro trabalho elaborado pelo LTRC publicado por Farrag e Morvant (2004), foi a construção de uma estrutura experimental de solo reforçado com geossintéticos de 6,0 metros de 
altura e 50 metros de comprimento com face em blocos de concreto e solo argilo siltoso. Basicamente, foram avaliados reforços de geotêxtil tecido e geogrelhas, conforme representado na seção transversal da Figura 2.23. A estrutura foi construída durante seis meses (Fevereiro a Julho de 1998), e a instrumentação foi monitorada durante quatro anos (Fevereiro de 1998 a 2002).

O muro foi intencionalmente projetado com baixo fator de segurança de modo a observar maiores deformações e tensões nos reforços. O baixo fator de segurança causou elevados níveis de deformações e recalques. No entanto, a flexibilidade dos reforços geossintéticos foi suficiente para suportar as deformações sem ruptura ou arrancamento dos reforços. Ainda, as forças máximas nos reforços foram muito menores do que os valores previstos pela teoria de Rankine. Pressões da água também foram monitoradas por meio de piezômetros ao longo de todo o período de ensaio. Na Figura 2.24 são apresentadas as leituras das pressões da água, onde se verifica que estas foram relativamente constantes para os três primeiros meses de construção e aumentaram repentinamente durante o último mês de construção. Tal fato foi motivado pelo lento processo de construção nos primeiros meses, que permitiu a dissipação parcial das pressões da água durante esse período e a aceleração da construção nos últimos meses, causando o aumento das tensões em curto espaço de tempo, o que favoreceu o desenvolvimento das pressões da água. Depois do término da construção, as pressões da água foram decrescendo até alcançar o valor mínimo, em menos de um ano.

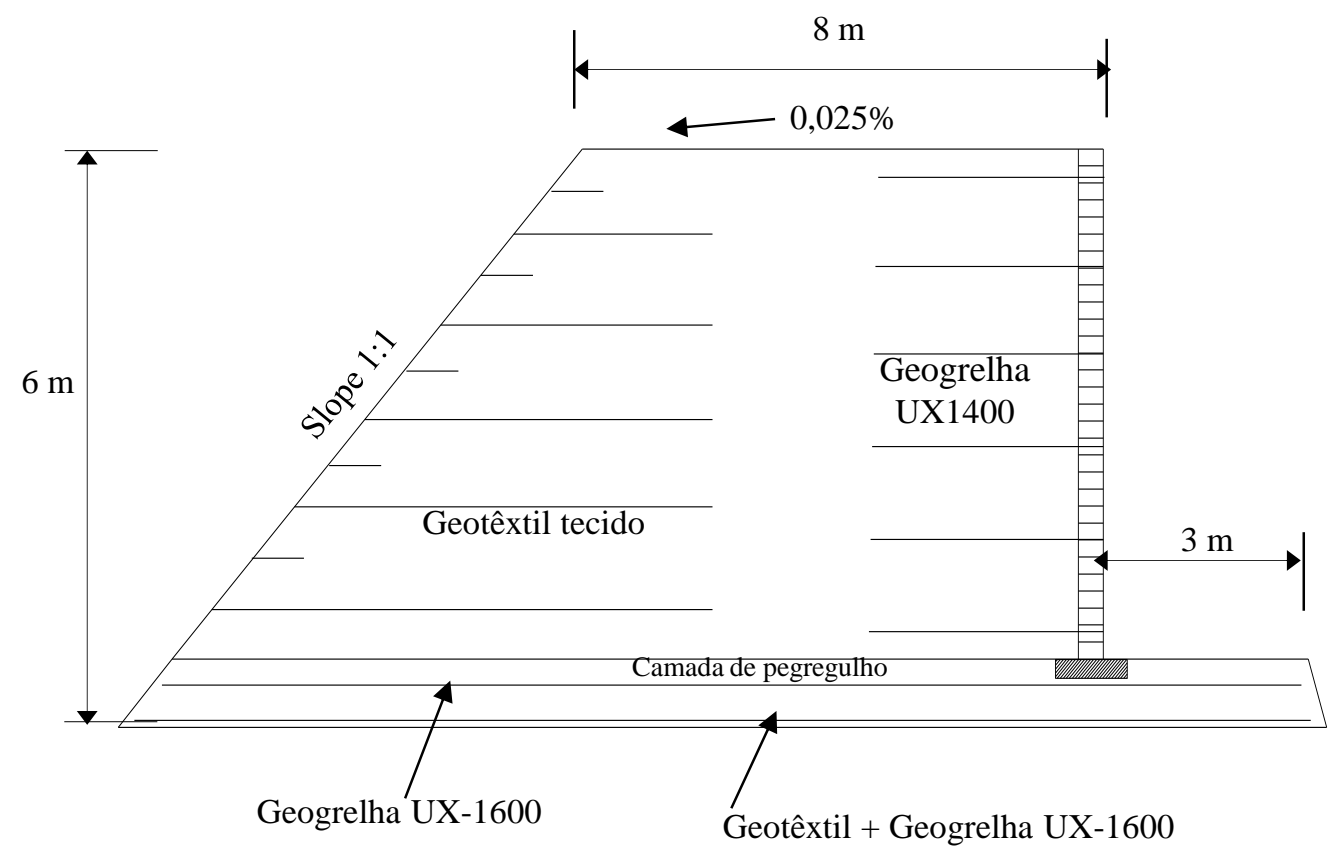

Figura 2.23. Estrutura construída pelo LRTC em 1998: (a) seção transversal típica; (b) elevação e vista superior das seções avaliadas (FARRAG; MORVANT, 2004). 


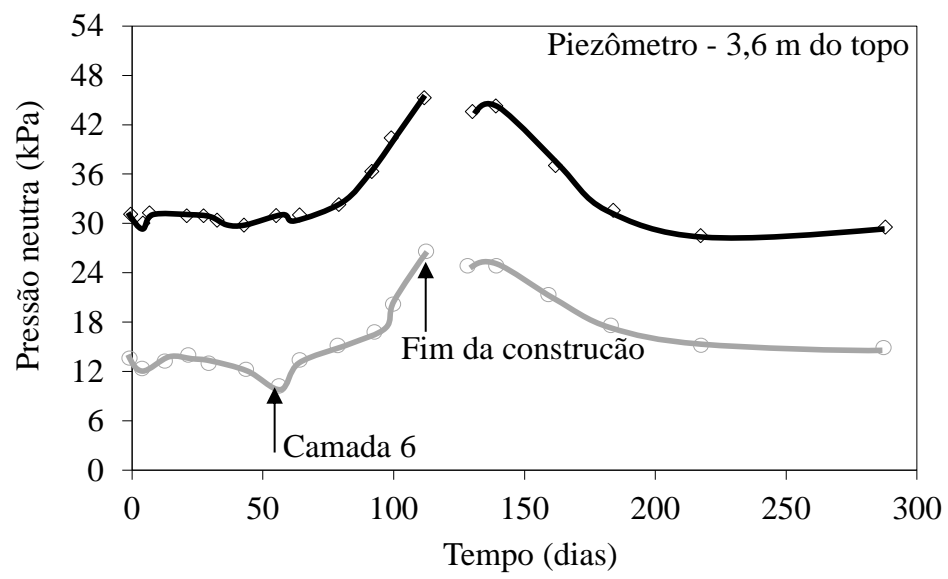

Figura 2.24. Pressões da água desenvolvidas durante a construção da estrutura do LTRC (FARRAG; MORVANT, 2004).

A velocidade de construção não é uma preocupação no caso de estruturas construídas com solos granulares, cuja condição drenada é mantida quaisquer que sejam as taxas de aumento da altura da estrutura com o tempo. No entanto, essa taxa pode vir a ser influenciada significativamente com o uso de solos finos. De modo a reduzir tal efeito, reforços permeáveis podem vir a ser utilizados de modo a auxiliar na velocidade de dissipação destes excessos de pressões da água. Outra solução é tomar conhecimento das máximas pressões da água a serem suportadas pelo sistema solo-reforço e monitorar essas pressões com devida instrumentação. Caso as pressões da água se aproximem do valor limite de projeto, deve-se interromper a construção até que as pressões internas se dissipem. Uma vez que as pressões da água decrescerem a um valor razoável, retoma-se a construção. Nota-se, que cuidados no controle do teor de umidade de compactação foram tomados de modo a não permitir o umedecimento excessivo. Este é um aspecto importante que tem sido o motivo de muitos casos de rupturas e deformações excessivas.

Um caso de muro reforçado que demonstra o efeito do umedecimento no comportamento da estrutura foi relatado por Won et al. (1994). Essa estrutura foi construída com a finalidade de suportar uma rampa de acesso de encontro de duas rodovias em Sydney na Austrália, cuja altura máxima alcançou 8 metros. Este muro consiste em um solo argilo xistoso reforçado com fitas poliméricas de poliéster de alta densidade "Paraweb". O material de aterro foi compactado no teor ótimo de compactação em fundação competente. A estrutura foi instrumentada de modo a obter medidas de tensão nos reforços, tensões no solo, deslocamentos internos e deslocamentos de face. Inicialmente, os deslocamentos de face alcançaram valores de $100 \mathrm{~mm}$, embora os deslocamentos internos máximos fossem de $50 \mathrm{~mm}$. As tensões nos reforços eram significantemente baixas comparadas aos valores previstos em projeto, até que passaram a aumentar com o tempo. A explicação foi embasada no fato do solo ter sido compactado no ramo seco da curva de compactação, ou seja, valores iniciais elevados de sucção matricial, que foram sendo dissipadas com o tempo devido ao avanço de águas da chuva. Os autores modelaram os valores de sucção de 
modo a ser representado em termos de coesão e verificaram a influência do umedecimento no parâmetro de coesão do solo, como ilustra a Figura 2.25.

a)

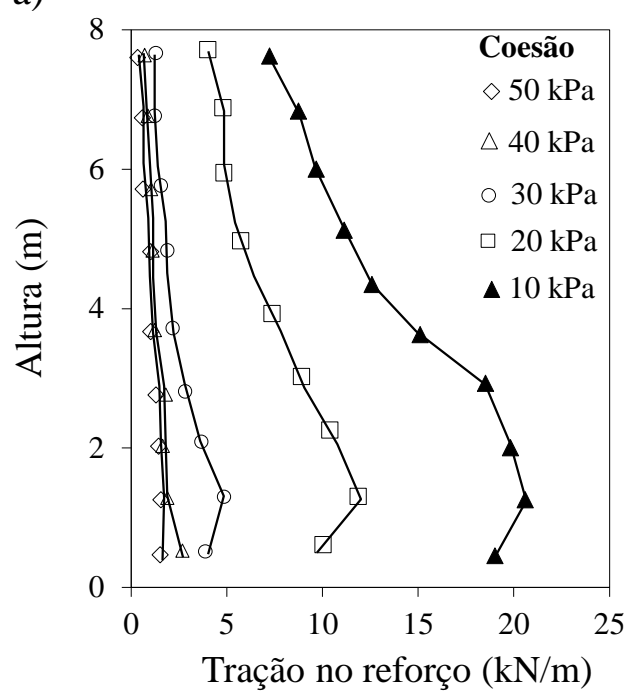

b)

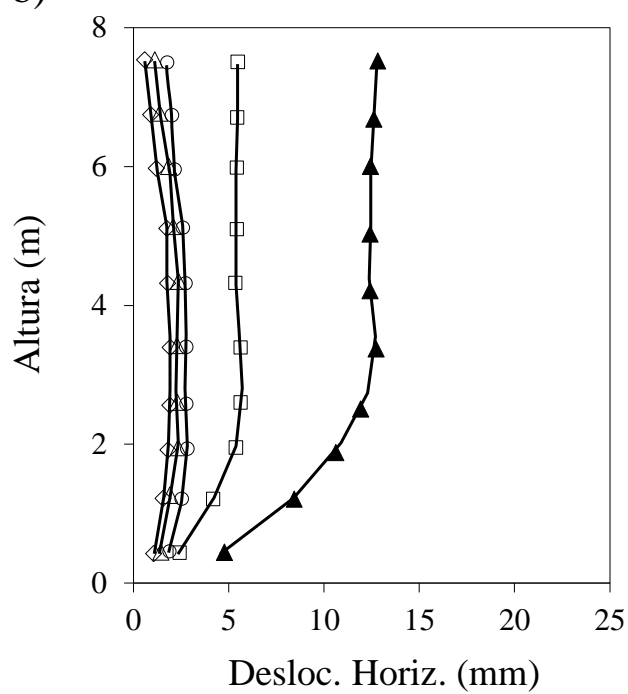

Figura 2.25. Muro reforçado construído em Sydney, Austrália: (a) tensões nos reforços e (b) deslocamentos horizontais devido à perda da coesão do solo (WON; HAUSSMANN; JANKULOVSKI, 1994).

Os casos de obras mostrados neste tópico mostram claramente que os efeitos do avanço de umidade podem realmente prejudicar o comportamento de estruturas de solos finos reforçados com geossintéticos impermeáveis. As pressões da água podem vir a serem desenvolvidas devido à diferentes fatores: processo de compactação e infiltração de água em solo de baixa condutividade hidráulica. Além disso, o efeito do umedecimento na redução da rigidez do solo e interface soloreforço, bem como o regime de carregamento aplicado durante e pós-construção, devem ser devidamente previstos em projetos. Ainda, o monitoramento das pressões da água desse tipo de estrutura consiste numa prática segura para o controle deste parâmetro ao longo do tempo.

\subsection{Estruturas de solos finos coesivos com reforços permeáveis}

Uma das soluções existentes na literatura para possibilitar a utilização de solos finos locais em estruturas de solo reforçados, é a utilização de reforços permeáveis que forneceriam drenagem interna da estrutura, evitando o excesso de pressões da água positivas, além de favorecer no processo de compactação. Tal técnica pode ainda vir a favorecer o comportamento da interação solo-reforço devido à dissipação da água na interface.

\subsubsection{Interação solos coesivos - reforços permeáveis}

Dentre os reforços considerados permeáveis estão os geotêxteis não tecidos e os geocompostos (geogrelha + geotêxtil não tecido). O objetivo desse tópico é demonstrar que, 
embora geotêxteis não tecidos sejam considerados materiais de rigidez muito baixa, e por esse motivo, muitas vezes, sejam excluídos na fase de escolha do reforço da estrutura, estes se apresentam como uma opção favorável em ocasiões em que a drenagem interna não é alcançada pelo próprio material do aterro, ou seja, quando solos de baixa permeabilidade são utilizados. Muitas pesquisas têm relatado a eficiência das funções de drenagem interna e reforço de geotêxteis não tecidos, ou geocompostos, no favorecimento do processo de interação solo-reforço (INGOLD; MILLER, 1982; FABIAN; FOURIE, 1986; FOURIE; FABIAN, 1987; LAFLEUR; DUCHAME, 1987; FABIAN, 1990; GILBERT et al., 1992; LING; WU; TATSUOKA, 1992; LING et al., 1993; ZORNBERG; MITCHELL, 1994; ZORNBERG; KANG, 2005; O'KELLY; NAUGHTON, 2008; GHIONNA et al., 2010; CLANCY; NAUGHTON, 2010).

Embora os mecanismos que regem a resistência de interface de geogrelhas sejam os mesmos, independente do tipo de solo, em solos granulares, o atrito e a resistência passiva são mais predominantes quando comparados aos solos finos. Adicionalmente, a capacidade de solos granulares de drenar água com maior facilidade contribui positivamente no comportamento mecânico de interface. No caso de reforços planares como os geotêxteis, a rugosidade e a interpenetração do solo nos vazios dos reforços consistem nos principais mecanismos de interação. Os geotêxteis não tecidos são reforços planares com larga quantidade de vazios, o que permite a impregnação do solo nestes vazios. Este fenômeno, juntamente com a rugosidade dos geotêxteis não tecidos, favorece o processo de interação. Adicionalmente, a característica singular de drenar água pelo interior da sua estrutura faz deste material uma excelente opção no reforço de solos finos de baixa capacidade de drenagem.

Uma comparação de eficiência de interface por meio de ensaios de cisalhamento entre diferentes geossintéticos e diferentes solos foi realizada por Eigenbrod e Locker (1987). Os ensaios foram conduzidos com geotêxteis tecidos, não tecidos e geomembranas em argila $\mathrm{MH}$ $\mathrm{CH}$, argila CL e dois tipos de areia. Resultados obtidos mostraram que, em solos granulares, os geotêxteis não tecidos mobilizaram mais de $90 \%$ da resistência das areias, enquanto os geotêxteis tecidos mobilizaram entre $76 \%$ e $86 \%$ e as geomembranas em torno de $56 \%$ a $70 \%$. Já em solos argilosos, os geotêxteis não tecidos mobilizaram entre $62 \%$ a $78 \%$ das resistências das argilas, e os geotêxteis tecidos entre $61 \%$ e $63 \%$.

Conclusões semelhantes foram obtidas por LaFleur et al. (1987) por meio de ensaios de cisalhamento direto em argila de elevada plasticidade. A eficiência de interface em geotêxtil não tecido foi maior do que $100 \%$, ou seja, a resistência ao cisalhamento na interface foi maior que a do solo. Por outro lado, o geotêxtil tecido mobilizou 50 a $60 \%$ da resistência do solo. No entanto, o deslocamento para a mobilização do reforço foi maior em geotêxteis não tecidos finos do que em geotêxteis tecidos, conforme é apresentado na Figura 2.26. A eficiência dos geotêxteis tecidos é prejudicada pela superfície lisa deste tipo de reforço, além de não permitirem a impregnação do solo em sua estrutura. Observa-se, na Figura 2.26, que a resistência de cisalhamento de interface em geotêxteis não tecidos é também dependente da espessura do material. Os autores relatam que 
tal dependência esta associada à capacidade de geotêxteis não tecidos mais grossos de serem impregnados por maior quantidade de partículas de solo em seu arranjo.

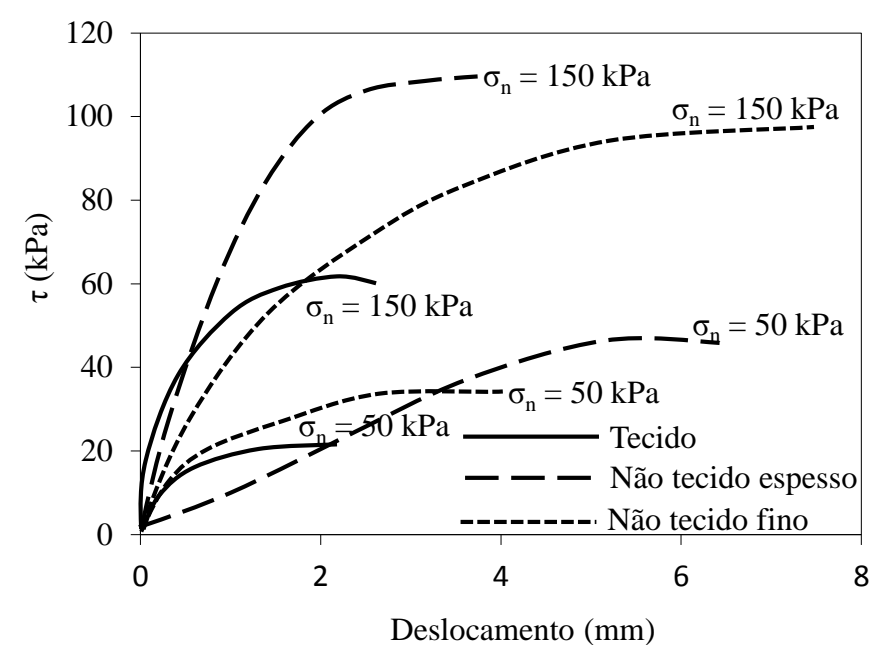

Figura 2.26. Resultados de cisalhamento direto de interface de três diferentes tipos de geotêxteis em solo argiloso (LAFLEUR et al. 1987).

A capacidade de drenagem de reforços não tecidos é uma das principais propriedades na escolha deste material como reforço de solos finos. Durante a vida útil da estrutura, carregamentos consideráveis e repentinos podem vir a ocorrer durante e após a construção, sendo estas condições ideais para o desenvolvimento de pressões da água. Portanto, em condições críticas de carregamento e saturação do solo, a função de drenagem passa a compor a função primordial no comportamento da estrutura.

Fourie e Fabian (1987) avaliaram efeito da dissipação da pressão da água dos geotêxteis não tecidos em condições drenadas e não drenadas em ensaios de arrancamento e cisalhamento de interface, estabelecendo a influência dessas condições em outros tipos de reforços impermeáveis avaliados. Ensaios foram realizados usando argila siltosa CL, geotêxtil não tecido, geotêxtil tecido e georrede. Ambos os ensaios foram conduzidos nas condições drenada $(0,033 \mathrm{~mm} / \mathrm{min}$.) e não drenada $(0,9 \mathrm{~mm} / \mathrm{min}$.). Os resultados mostraram que a resistência de interface com argilas pode ser aumentada com o uso do material permeável em ambas as condições drenada e não drenada. Os principais fatores que afetaram a resistência de interface foram a rigidez, a rugosidade e a transmissividade dos geotêxteis. Foi verificado ainda que a resistência de interface dos geotêxteis não tecidos é proporcional às tensões confinantes e a transmissividade. Na condição não drenada, a eficiência de contato foi maior para o geotêxtil não tecido (Figura 2.27a), enquanto na condição drenada, a resistência de arrancamento foi maior para os geotêxteis tecidos (Figura 2.27b). Os autores relatam que o comportamento drenado de arrancamento dos geotêxtil não tecidos foi influenciado pela relaxação, o que não ocorreu em ensaios de cisalhamento direto. Tal comportamento reduziu a resistência à tração do material, resultando em menores valores de resistência ao arrancamento em comparação ao observado nos ensaios não drenados. 
(a)

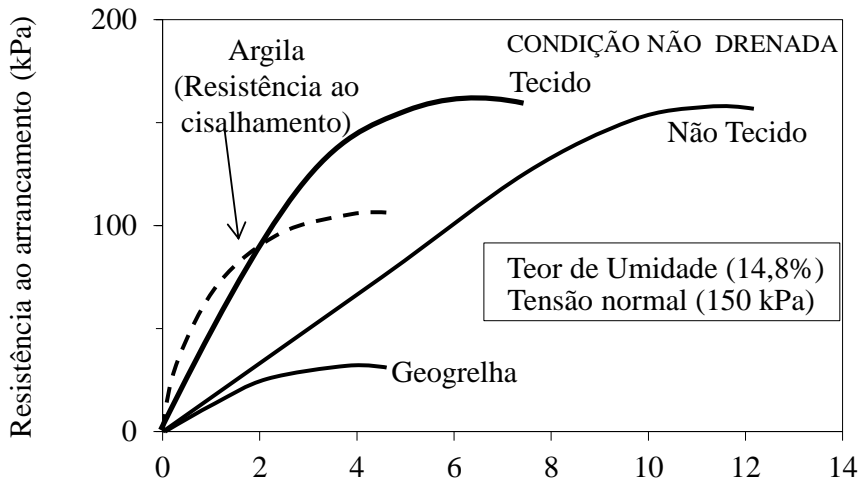

(b)

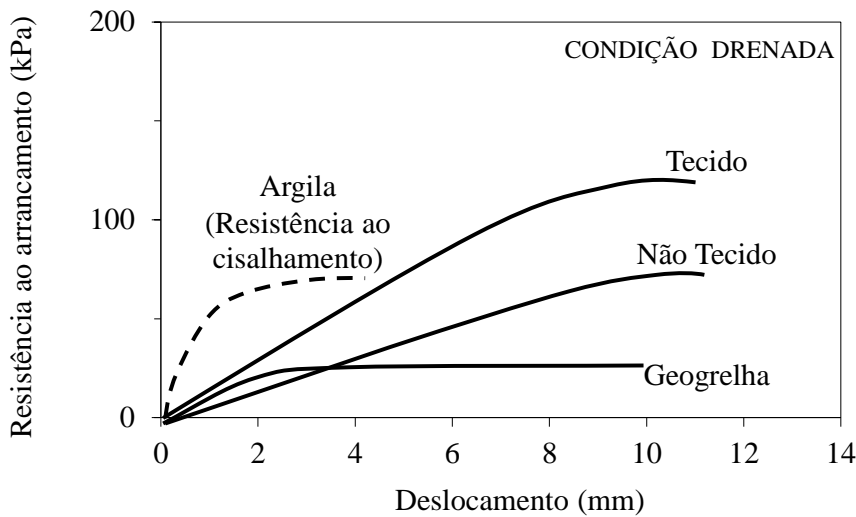

Figura 2.27. Ensaios arrancamento em argila: (a) condição não drenada; (b) condição drenada (FOURIE; FABIAN, 1987).

As questões relacionadas à utilização de reforços de diferentes permeabilidades nas condições não drenadas em solos argilosos saturados foram avaliadas por meio de ensaios triaxiais por Ingold e Miller (1982), Fabian e Fourie (1986), Patias (2005) e Noorzad e Mirmoradi (2010). No trabalho de Ingold e Miller (1982), o possível efeito do carregamento rápido (condição não drenada) foi investigado em uma série de ensaios triaxiais de amostras de duas argilas reforçadas com folha de alumínio e disco plástico poroso. O uso do reforço impermeável de folha de alumínio prejudicou a resistência ao cisalhamento do solo na condição não drenada devido à redução da tensão principal menor causada pelo desenvolvimento e, posteriormente, migração radial das pressões da água para o centro da amostra. A redução da resistência também foi verificada em amostras reforçadas com plástico poroso. No entanto, isso só foi observado em amostras com maiores espaçamentos entre os reforços. Com a redução do espaçamento e, consequentemente, a redução da distância de drenagem, as pressões da água foram parcialmente dissipadas e as tensões principais menores aumentaram, e desta forma, a tensão desviatória aumentou. A Figura 2.28 apresenta a influência do coeficiente $\mu$ (diâmetro da amostra/espaçamento entre reforços) na resistência de uma argila saturada nas condições lentas e rápidas de carregamento. 


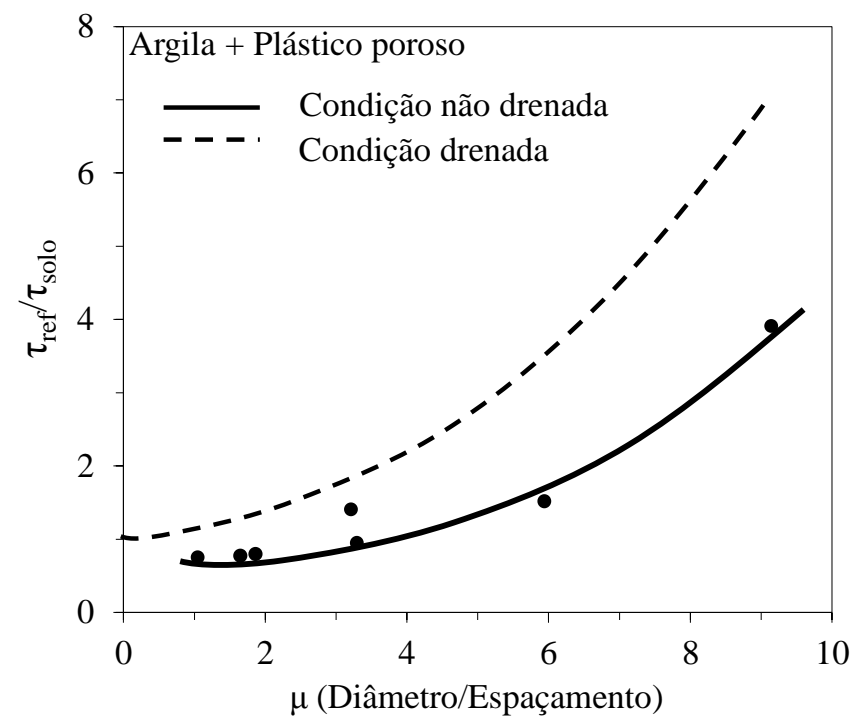

Figura 2.28. Influência do espaçamento de reforços permeáveis na resistência de uma argila saturada em condições de carregamento rápido de ensaios triaxiais (INGOLD; MILLER, 1982).

Fabian e Fourie (1986) obtiveram conclusões bastante semelhantes às de Ingold e Miller (1982), onde se constatou que reduções no parâmetro A de Skempton com uso de reforços permeáveis e a restrição das deformações laterais do solo são os principais fatores que influenciaram positivamente no comportamento tensão-deformação das amostras. Observou-se também que a variação no teor de umidade influenciou mais significativamente em amostras com reforços impermeáveis do que em amostras com reforços permeáveis. Um aspecto interessante é que os valores da eficiência de resistência $\left(\tau_{\text {solo reforçado }} / \tau_{\text {solo }}\right)$ aumentaram proporcionalmente com os teores de umidade, que, segundo os autores, foi devido à diminuição mais significativa da resistência do solo (sem reforço) e menos significativa em amostras reforçadas. Cabe observar que quanto mais permeável o reforço, maior é a eficiência de resistência. A Figura 2.29 ilustra a influência da permeabilidade dos reforços e o teor de umidade do solo na resistência não drenada.

A partir da década de 90, as vantagens da utilização de reforços permeáveis em solos finos já eram bastante conhecidas e muitas obras já haviam sido construídas. Porém, muros de alturas elevadas ou sobrecargas consideráveis não eram corriqueiramente executados devido à limitação da resistência à tração e rigidez de geotêxteis não tecidos. Foi nessa época que aplicações de reforços geocompostos drenantes começaram a ser estudadas, tais como geogrelhas com geotêxteis não tecidos, e geotêxteis tecidos com geotêxteis não tecidos (PERRIER et al., 1986), embora alguns relatos já haviam sido publicados na década de 80. Dentre os trabalhos que avaliaram o efeito da capacidade drenante de geocompostos (nas funções de reforço e drenagem) no processo de consolidação e mobilização das tensões na interface com solos argilosos estão os trabalhos de Ling e Tatsuoka (1994), Kempton et al. (2000), Zornberg e Kang (2005) e O'Kelly e Naughton (2008). Ling e Tatsuoka (1994) mostraram por meio de ensaios de interface em células cúbicas de grande porte que, em condições não drenadas de carregamento, tanto o geotêxtil não tecido como o geocomposto proporcionaram uma melhor mobilização das tensões e menores 
pressões da água no solo saturado do que em amostras reforçadas com geogrelhas, melhorando assim o confinamento da amostra e, consequentemente, a rigidez e resistência, como verificado na Figura 2.30.

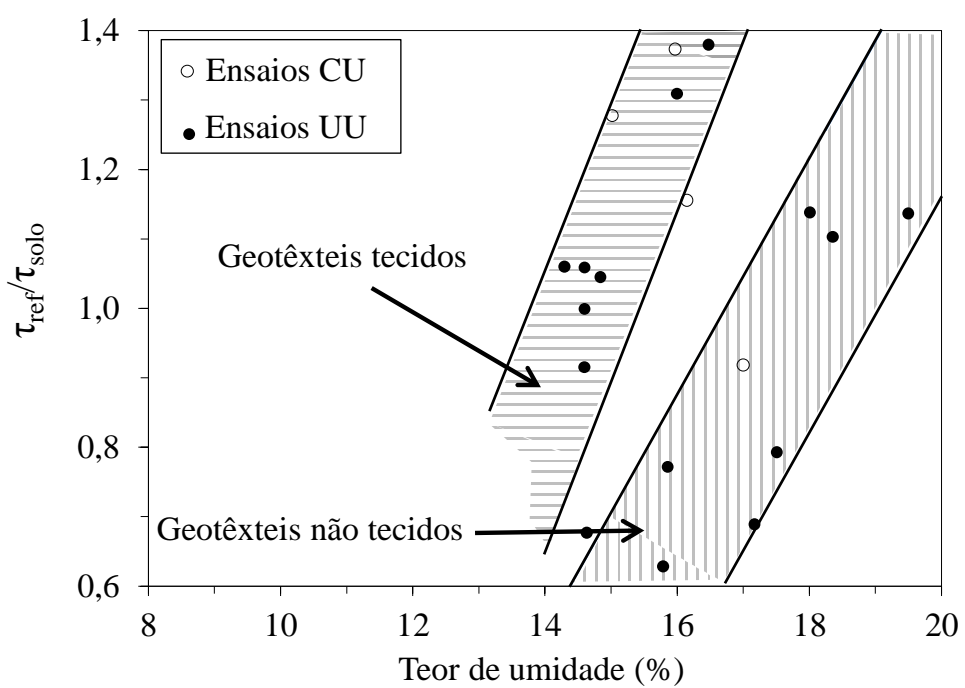

Figura 2.29. Influência da permeabilidade dos reforços e o teor de umidade do solo na resistência não drenada (FABIAN; FOURIE, 1986).

$\mathrm{Na}$ condição drenada, amostras reforçadas com geogrelhas mostraram maiores resistências. Nota-se na Figura 2.30, o desenvolvimento de maiores pressões da água nas amostras reforçadas (mesmo com reforços permeáveis) do que em amostras não reforçadas. Os autores atribuíram este comportamento ao aumento da tensão desviatória devido à restrição lateral e o enrijecimento das amostras reforçadas.

No mesmo contexto, os trabalhos de O'Kelly e Naughton (2008) e Zornberg e Kang (2005) avaliaram a resistência de interface geocomposto-solos finos com teores de umidade acima da ótima. O geocomposto Paradrain ${ }^{\mathrm{TM}}$ refere-se a uma geogrelha cujos membros longitudinais são fabricados com materiais permeáveis de modo a possibilitar a dissipação da pressão da água ao longo do reforço. O'Kelly e Naughton (2008) conduziram ensaios de cisalhamento direto consolidados-não drenados na interface solo argiloso-geocomposto e na interface solo argilosogeogrelha convencional de mesmas características de rigidez e resistência. Zornberg e Kang (2005) utilizaram esse geocomposto na análise de resistência de interface por meio de ensaios de arrancamento em solo siltoso. Os resultados obtidos por O'Kelly e Naughton (2008) mostraram que a resistência mobilizada pelo geocomposto foi de 120 a $130 \%$ da resistência do solo, enquanto à resistência mobilizada pela geogrelha convencional alcançou valores em torno de $80 \%$ da resistência do solo. Resultados bastante semelhantes foram observados nos ensaios de arrancamento, em que a resistência última de arrancamento da interface solo siltoso-geocomposto foi $25 \%$ maior que a interface solo-geogrelha, com tensão confinante de $41 \mathrm{kPa}$ (ZORNBERG; KANG, 2005). 


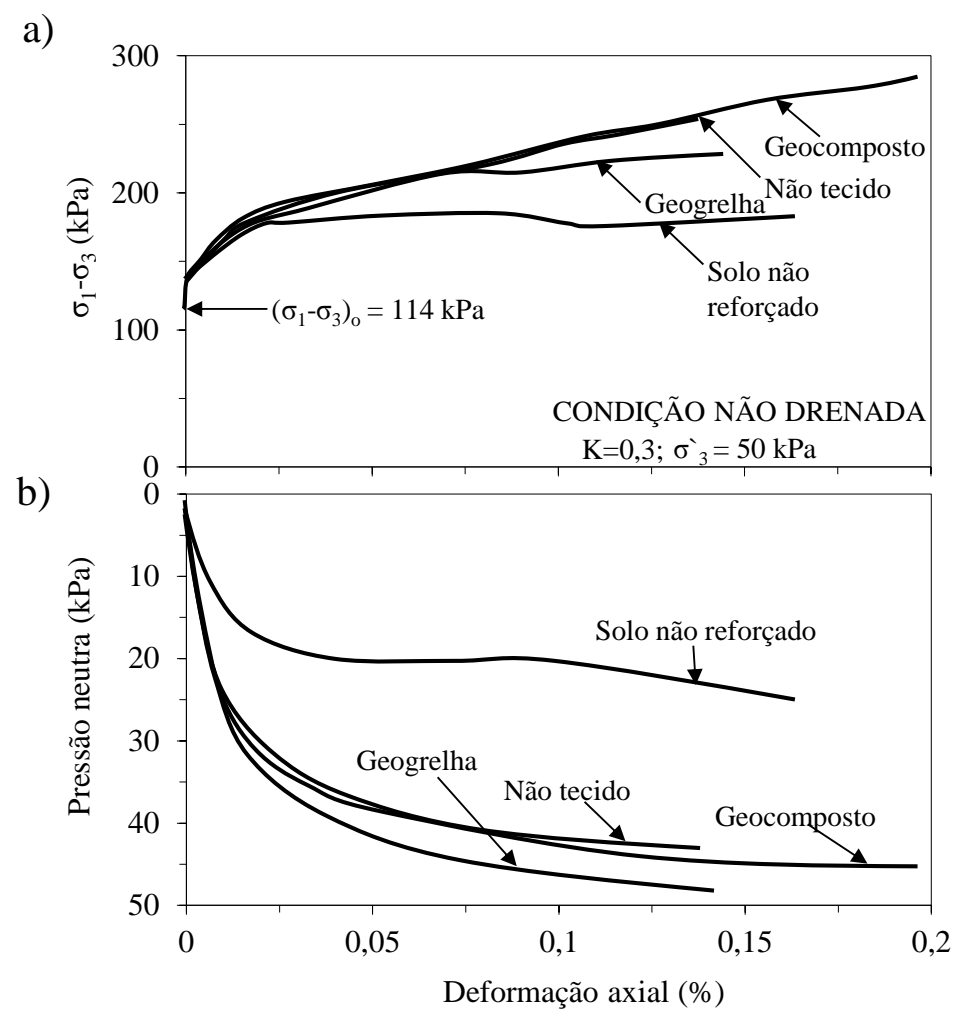

Figura 2.30. Amostras ensaiadas na condição não drenada: (a) curvas tensão versus deformação; (b) excesso de pressão da água (LING; TATSUOKA, 1994).

Ensaios com leituras de pressões da água durante o arrancamento do geocomposto Paragrid $^{\circledR}$ em solo argilo-arenoso realizados por Ghionna et al. (2010) mostraram concordância com os resultados obtidos por Zornberg e Kang (2005). A justificativa para este comportamento são os significantes valores de pressões da água durante o arrancamento da geogrelha convencional, enquanto pressões nulas ou negativas foram registradas como uso do geocomposto. Ressalta-se, que o efeito da transmissividade influencia na eficiência de interface de solos finosgeogrelhas. Os resultados do trabalho de Ghionna et al. (2010) são apresentados na Figura 2.31.
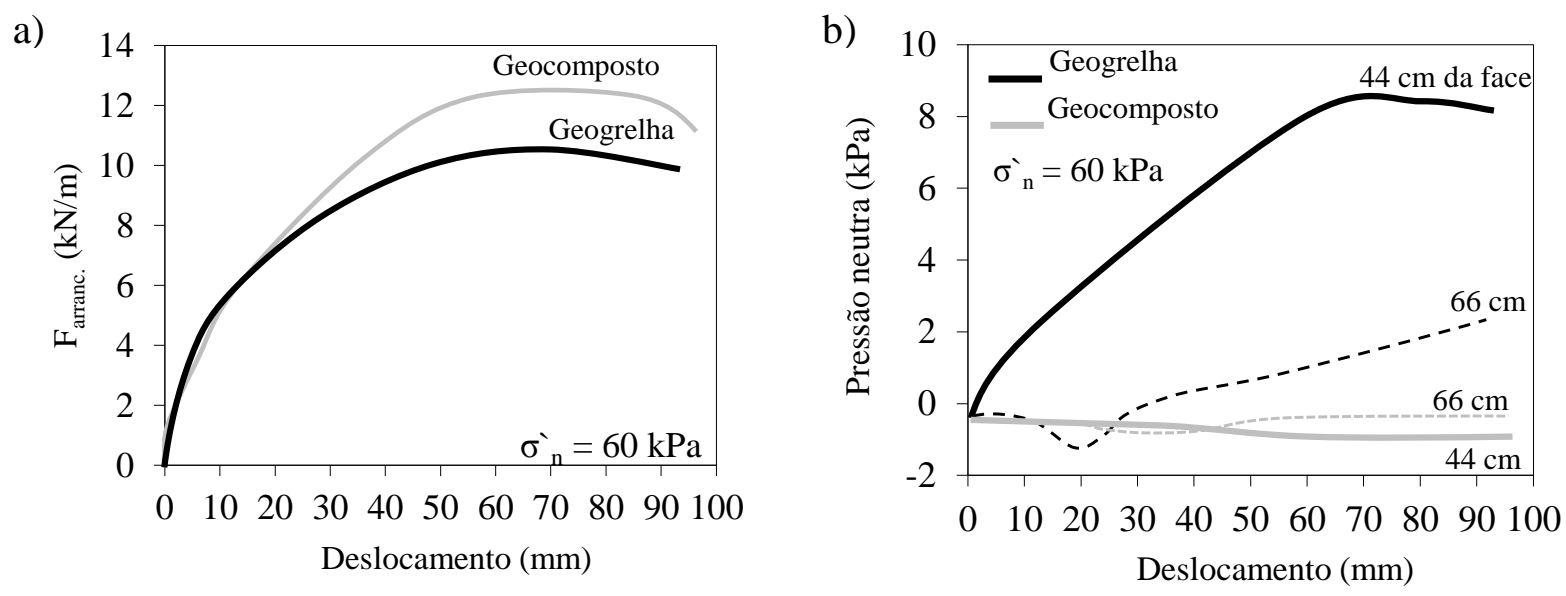

Figura 2.31. Resultados do trabalho de Ghionna et al. (2010): (a) curvas força de arrancamento versus deslocamento; (b) pressão da água versus deslocamento de geocomposto e geogrelha convencional em solo argilo arenoso (GHIONNA et al., 2010). 


\subsubsection{Efeito do confinamento nas propriedades mecânicas de geotêxteis não tecidos}

O comportamento de resistência e deformabilidade à tração de geotêxteis não tecidos são significativamente afetados pelo efeito do confinamento do solo. O confinamento dificulta o processo de reorientação das fibras têxteis na direção do esforço aplicado, devido à interpenetração do solo na estrutura interna dos geotêxteis não tecidos (MCGOWN et al., 1981; MCGOWN et al., 1982; ANDRAWES et al., 1984; NISHIGATA; YAMAOKA, 1989; LING; WU; TATSUOKA, 1992; GOMES, 1992; MENDES; PALMEIRA, 2008; FRANÇA; BUENO, 2011). Quaisquer que sejam os procedimentos utilizados, os resultados são semelhantes e demonstram acréscimos significativos na rigidez e na resistência dos geotêxteis não tecidos confinados em relação à condição não confinada. Por esse motivo, a experiência da utilização de reforços não tecidos em estruturas de solo reforçado tem mostrado que os níveis de deformação nos reforços e deslocamentos das estruturas não competem com as previsões de projeto que se baseia nas características de deformabilidade do reforço na condição não confinada.

McGown e Andrawes (1982) mostraram que a rigidez inicial dos geotêxteis não tecidos é significativamente modificada sob as condições de confinamento (Figura 2.32a). Segundo os autores, o confinamento do solo modifica os vazios na estrutura do geotêxteis, sendo que a uniformidade dessas mudanças depende da natureza do material confinante. Desde aquela época, os autores já recomendavam que as propriedades mecânicas de reforços utilizadas em projetos de estrutura de solo reforçado, principalmente os geotêxteis não tecidos, fossem determinadas em condições confinadas, uma vez que o confinamento governa as propriedades de tração. Segundo os autores, ensaios de tração não confinada são apropriados para o controle de qualidade dos materiais por demandarem menor tempo de ensaio, no entanto, não deveriam ser utilizados como parâmetros de projeto.
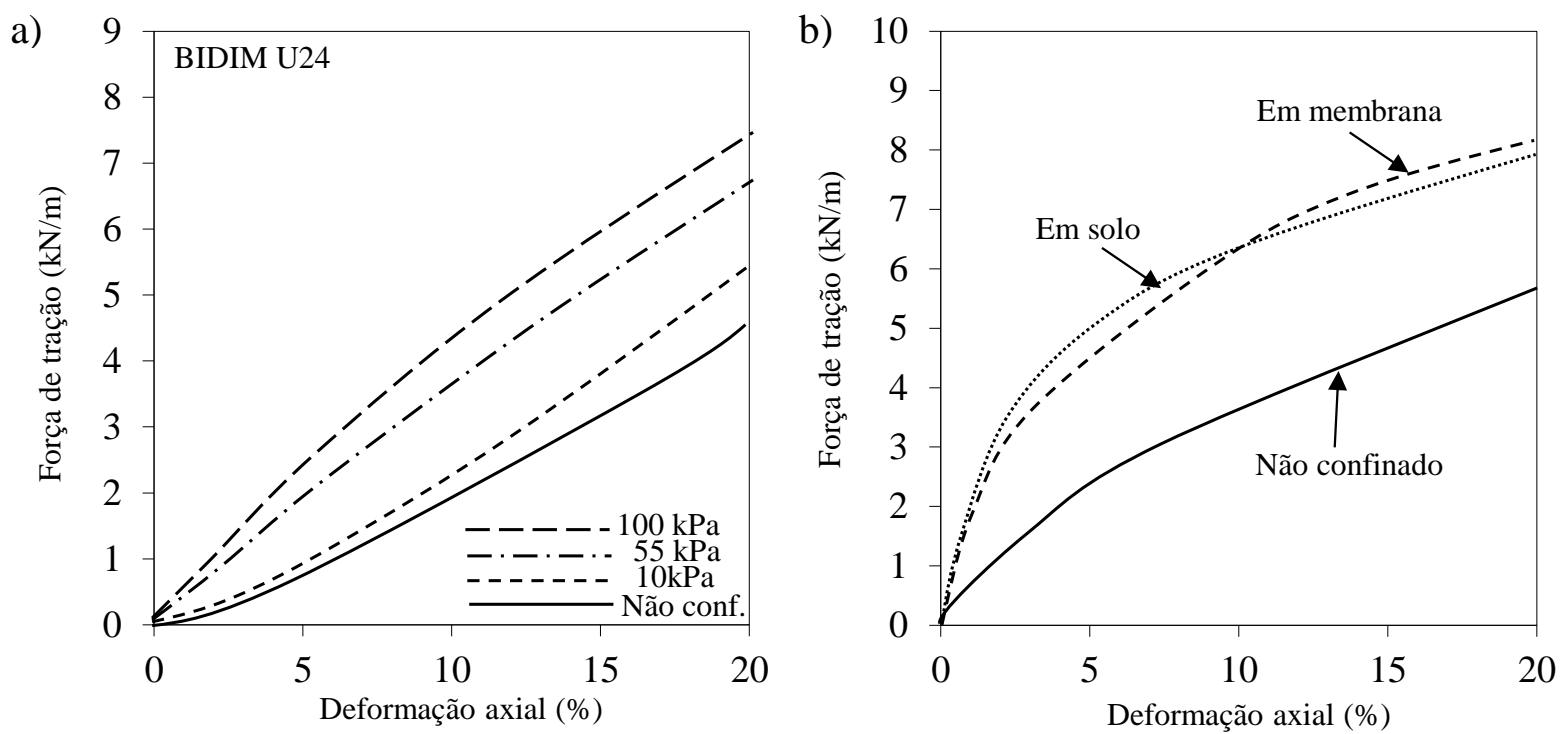

Figura 2.32. Resultados de tração confinada de geotêxteis não tecidos: (a) efeito do nível do confinamento (MCGOWN; ANDRAWES, 1982); (b) efeito da superfície de confinamento (LING et al., 1993). 
Ling et al. (1993) desenvolveram um equipamento para comparar ensaios de tração de geossintéticos sob diferentes condições de confinamento: não confinados, confinados em solo e confinados em geomembrana. Os valores de rigidez dos geotêxteis não tecidos agulhados e tricotados (Bidim U24) foram influenciados pelo confinamento, assim como observado por McGown e Andrawes (1982). No entanto, não foram observadas diferenças significativas nos valores de tração entre geotêxteis confinados em membrana e em solo (Figura 2.32b).

Por outro lado, ensaios de tração confinada em solos de diferentes granulometrias realizados por Gomes (1992) mostraram que a interpenetração das partículas mais finas de solo na matriz do geotêxtil não tecido favorece a ação do confinamento, enquanto para o tecido, o efeito do confinamento é o mesmo para todos os solos. Resultados do efeito da impregnação considerando o nível de impregnação, determinado pela relação entre a massa de solo impregnada e a massa das fibras do geotêxtil, foram apresentados por Mendes e Palmeira (2008). Os autores mostram que a impregnação contribui na rigidez dos não tecidos, podendo aumentar com da taxa de impregnação e do confinamento.

Do mesmo modo que as características de tração dos geotêxteis não tecidos são melhoradas pelo efeito do confinamento e impregnação do solo, o comportamento de fluência destes materiais também é alterado. Muitos trabalhos tem mostrado a redução da fluência dos geotêxteis tecidos sob o confinamento (HOLTZ; TOBIN; BURKE, 1982; MCGOWN et al., 1982; SAWICKI; SWIDZINSKI, 1999; KAMIJI, 2006; BUENO, 2010; FRANÇA; BUENO, 2011). Ensaios realizados por Kamiji (2006) mostram o efeito do confinamento nos resultados de fluência de geotêxteis não tecidos, cuja fluência foi drasticamente diminuída. Nos resultados apresentados por Holtz et al. (1982), em que a fluência triaxial confinada em areia foi avaliada, observou-se que a fluência dos geotêxteis não tecidos confinados foi semelhante à de tecido confinados. Já McGown et al. (1982) mostram reduções de até $60 \%$ na fluência do não tecido confinado com relação aos ensaios sem confinamento, como apresenta a Figura 2.33.

a)

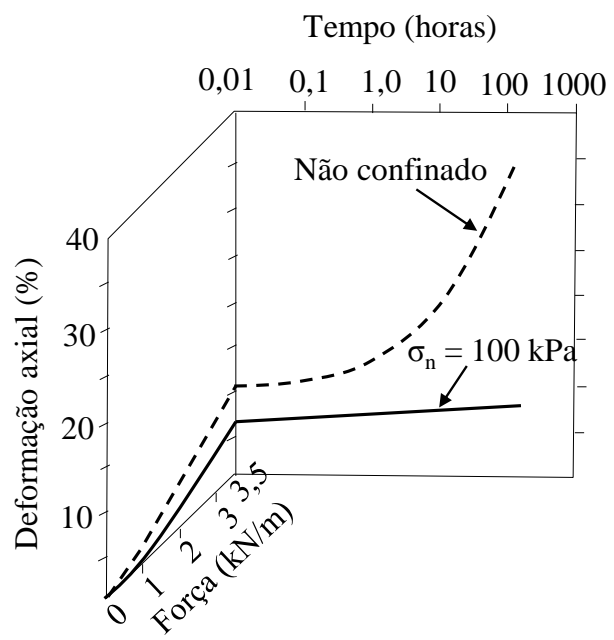

b)

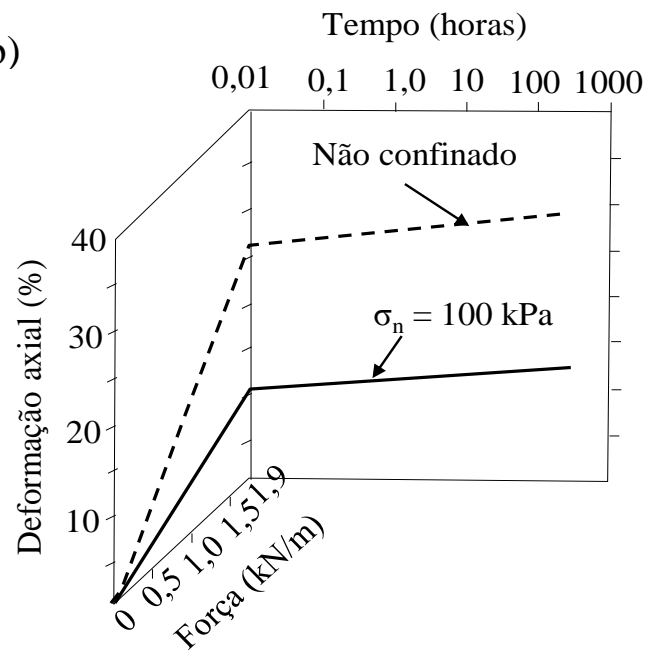

Figura 2.33. Comparação entre ensaios de fluência confinada e não confinada de: (a) geotêxtil não tecido resinado; (b) não tecido agulhado (MCGOWN et al., 1982). 


\subsubsection{Relatos de estruturas de solos finos reforçados com geotêxteis não tecidos}

O muro pioneiro de solo reforçado com geotêxtil não tecido foi construído em 1971 pela French Highway Administration na rodovia A15 em Rouen, França, onde os geotêxteis foram utilizados para reforçar solos finos coesivos e melhorar a drenagem interna na zona reforçada. A proposta desse muro foi melhorar as possibilidades construtivas e o comportamento geral de um aterro feito com solo fino local, suscetível aos efeitos da água, e geotêxteis (GOURC; MATICHARD, 1992). O material de aterro consistiu em uma argila compactada com teor de umidade 3\% acima da ótima. Este muro foi executado com faceamento vertical, utilizando a técnica de envelopamento de solo e um talude natural como escoramento temporário da face durante a construção.

Após o término da construção, o talude natural de escoramento foi retirado e um talude de $4 \mathrm{~m}$ de altura foi instalado no topo da estrutura de modo a gerar a sobrecarga. A Figura 2.34 ilustra o muro pioneiro e a seção instrumentada. O comportamento foi monitorado durante 8 meses por meio de instrumentação, conforme mostrado na seção transversal da Figura 2.34b. Poucos dias depois da retirada do talude de escoramento, as leituras da instrumentação mostraram deslocamentos de face de $25 \mathrm{~mm}$ no topo e $6 \mathrm{~mm}$ na base do muro. Depois do carregamento, estes deslocamentos aumentaram para $45 \mathrm{~mm}$ no topo e $26 \mathrm{~mm}$ na base. Os strain gages instalados nas mantas geotêxteis mostraram deformações máximas de 1,5 a $2 \%$ nos reforços próximos da base.

a)

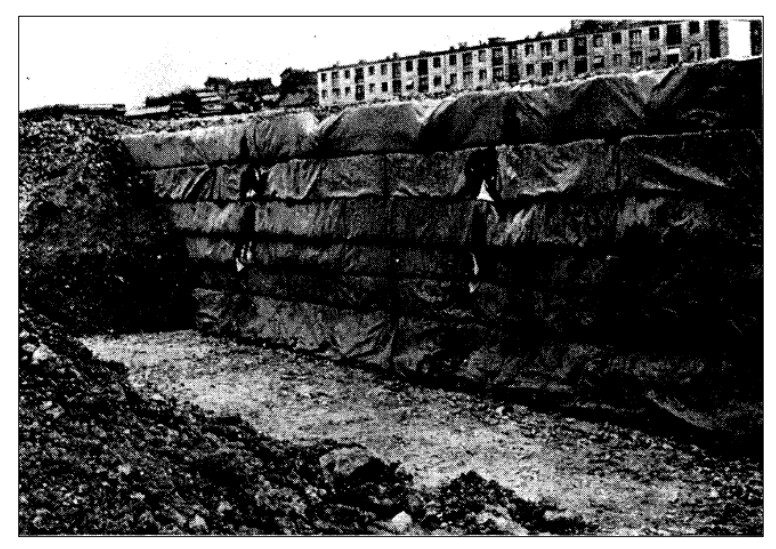

b)

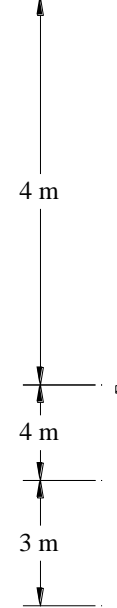

Figura 2.34. Primeira estrutura de geotêxteis não tecidos construídos em Rouen, França: (a) fotografia pósretirada do escoramento temporário; (b) seção instrumentada (GOURC; MATICHARD, 1992).

Outro muro reforçado com geotêxtil não tecido foi construído sob condições climáticas bastante severas em Prapoutel, próximo a Grenoble, nos Alpes Franceses. Esta estrutura teve por finalidade a ampliação de um acesso e estacionamento de automóveis, cuja solução foi selecionada por motivos econômicos. Esse foi um dos primeiros relatos do uso de formas móveis como técnica construtiva, que, segundo os autores, não favoreceu a uma boa compactação nas 
proximidades da face, proporcionando consideráveis deformações na estrutura. Os espaçamentos entre reforços de 1,20 m especificados em projeto foi mencionado como um dos agravantes das deformações na estrutura. Esta é, portanto, uma estrutura que exemplifica o potencial da técnica para muros reforçados com geotêxteis não tecidos. O material de aterro consistiu num solo local que foi compactado no teor de umidade próximo do limite de liquidez, sendo que análises mostraram que as propriedades mecânicas foram consideravelmente menores do que aquelas prevista em projetos. Nove anos após a construção, a estrutura apresentava-se em perfeito estado. Um único aspecto considerado falho nesta estrutura foi a aparência da face, levando ao desenvolvimento de novas técnicas de faceamento (GOURC; MATICHARD, 1992).

Estruturas experimentais foram executadas na Rouen Roadworks Research Centre (CER), na França, com o intuito de estudar novas técnicas construtivas, incluindo a função simultanea de reforço e drenagem de geotêxteis não tecidos. Foram testadas novas técnicas de execução, bem como a eficiência da dissipação de pressões da água por reforços permeáveis. A estrutura consistiu em muros com seções de geotêxteis tecidos e geocompostos (geogrelha com geotêxtil não tecido) reforçando um solo siltoso, com altura total de 5,6 m. Perrier et al. (1986) mostraram resultados encorajadores com relação a função drenante dos reforços. Na Figura 2.35, são apresentadas as pressões da água registradas ao longo do tempo em diferentes pontos instrumentados. De modo geral, pressões da água positivas foram verificadas em regiões sem os reforços e com reforços tecidos, e negativas nas proximidades dos reforços geocompostos.

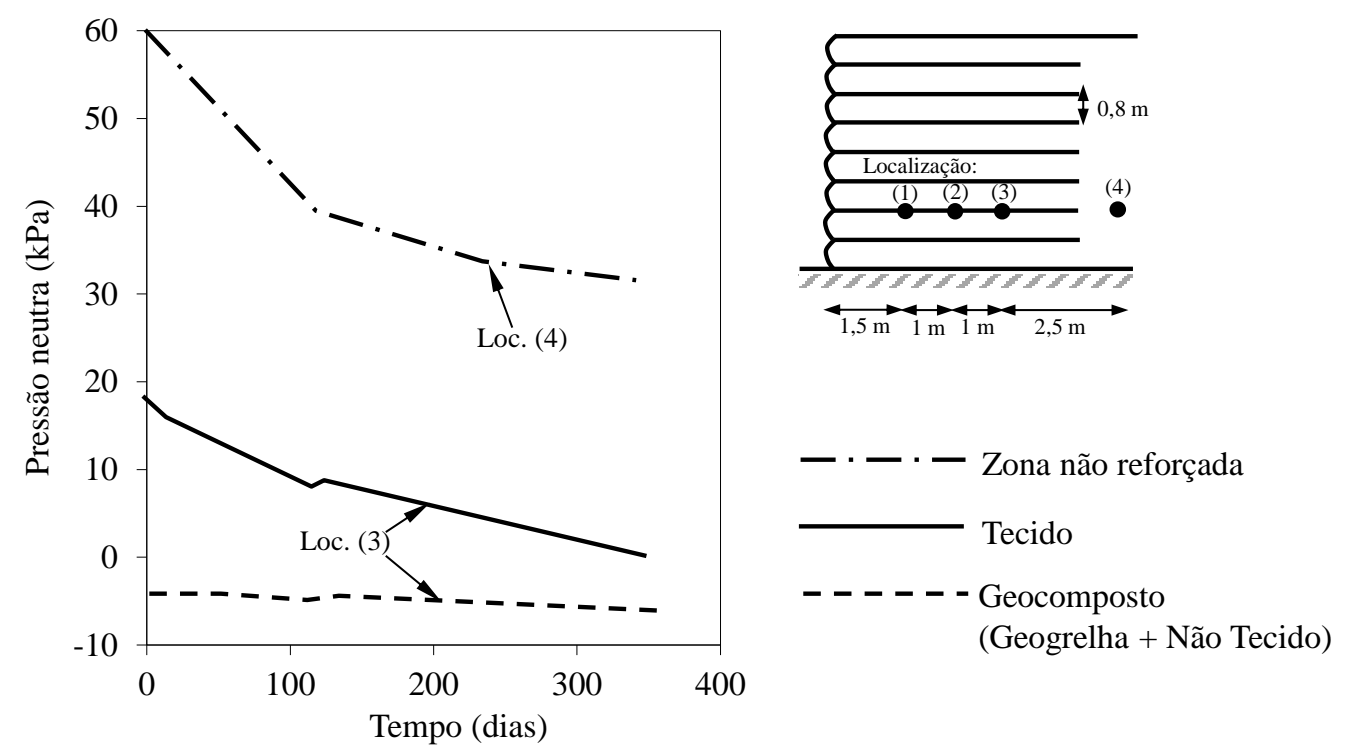

Figura 2.35. Pressões da água no muro de Rouen, França, em seções com geotêxteis tecidos e geocompostos (geogrelha com geotêxteis não tecidos) (PERRIER et al., 1986).

Reforços permeáveis foram também utilizados no controle das pressões da água durante a construção e para acelerar o adensamento pós-construtivo de um aterro na Pensilvânia, Estados Unidos (WAYNE et al., 1996). Problemas desenvolvidos numa seção da rodovia estadual SR54, 
devido ao colapso de um túnel abandonado, foram reparados com construção de um aterro reforçado de 15 metros de altura. Para a solução se tornar econômica, optou-se pela utilização do solo local argilo arenoso e geotêxtil não tecido. Estimou-se, na época, uma economia de $\$ 200.000,00$ em relação à solução em solos granulares, cuja reposição de solo custaria $\$ 19,60 / \mathrm{m}^{3}$, enquanto para o solo local, o custo seria de $\$ 4,00 / \mathrm{m}^{3}$. Foi especificado em projeto que o uso de camadas reforçadas de $30 \mathrm{~cm}$ (isto é, distância de drenagem de $15 \mathrm{~cm}$ ), resultaria na dissipação completa das pressões da água em 4 dias, enquanto em regiões não reforçadas, somente $25 \%$ das pressões da água seriam dissipadas. Tais previsões foram confirmadas pelos piezômetros instalados na estrutura, como indica a Figura 2.36, os quais registraram o desenvolvimento e, posteriormente, a dissipação destas pressões da água.

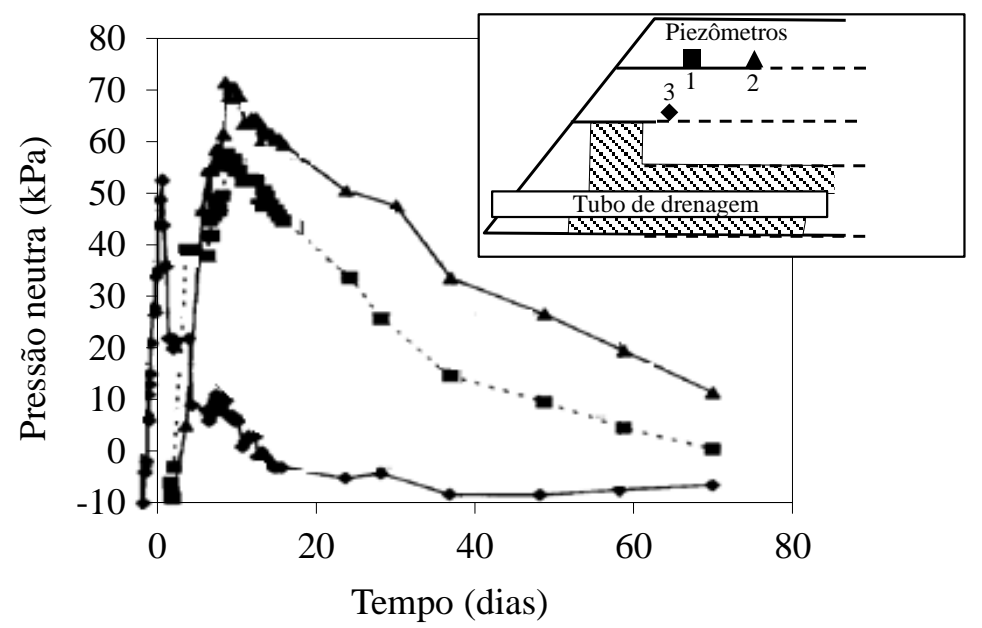

Figura 2.36. Pressões da água monitoradas no talude reforçado na rodovia SR54, Pensilvânia, EUA (WAYNE et al., 1996).

O efeito das propriedades hidráulicas de geotêxteis tecidos na estabilidade e deformação de dois aterros argilosos reforçados foi avaliado por Tatsuoka e Yamauchi (1986). Análises foram baseadas no monitoramento de duas estruturas, sendo a primeira (Aterro I) durante um período de três anos (Setembro de 1982 - Outubro de 1985), e a segunda (Aterro II) durante 1,5 anos (Março de 1984 - Outubro de 1985). Os aterros foram construídos com taludes íngremes e alturas totais de $5 \mathrm{~m}$, com argila de cinza vulcânica, cujo teor de umidade natural é entre 100 e 120\%, correspondente a um grau de saturação de $80 \%$. Reforços de geotêxtil não tecido foram designados a cumprir três funções: melhoria na compactação, drenagem e reforço. As estruturas ficaram sujeitas aos eventos naturais de chuva e, adicionalmente, um volume de água de $70 \mathrm{~m}^{3}$ foi abastecido no topo de modo a atingir uma condição crítica. A Figura 2.37 apresenta as leituras da instrumentação do Aterro II.

Observa-se que a função de drenagem dos reforços não tecidos foi eficiente, uma vez que pressões da água negativas foram praticamente preservadas na zona reforçada, enquanto pressões positivas elevadas foram verificadas na zona não reforçada (Figura 2.37a). Os autores 
recomendam que os reforços de geotêxteis não tecidos em estruturas de solo argiloso não sejam muitos curtos e o espaçamento entre os reforços não seja muito grande, de modo a suprir eficientemente a função de drenagem interna. Pode-se notar também que os deslocamentos cresceram proporcionalmente às chuvas acumuladas e pressões da água registradas no primeiro ano de ensaio. No segundo ano, a taxa de aumento diminuiu, o que os autores atribuíram ao colapso do solo devido ao umedecimento da estrutura (Figura 2.37).

Deformações na estrutura aumentaram em taxas consideráveis quando as pressões da água negativas passaram a decrescer em direção à zero, o que foi comparado ao comportamento viscoelasto-plástico do solo, onde a deformação aumenta consideravelmente somente quando um valor máximo de pressão da água é alcançado (tensão de cedência). A partir deste ponto, deformações por fluência predominam continuamente. Os autores relatam a importância da preservação de pressões da água negativas, uma vez que as deformações alcançaram valores consideráveis somente após a perda dessas tensões intergranulares, além de pressões da água positivas estarem possivelmente atuando, principalmente em seções com maiores espaçamentos entre os reforços. Isso pode ser observado comparando ambos os taludes reforçados apresentados na Figura 2.38, em que diferentes espaçamentos entre os reforços geraram comportamentos bastante diferenciados.

a)

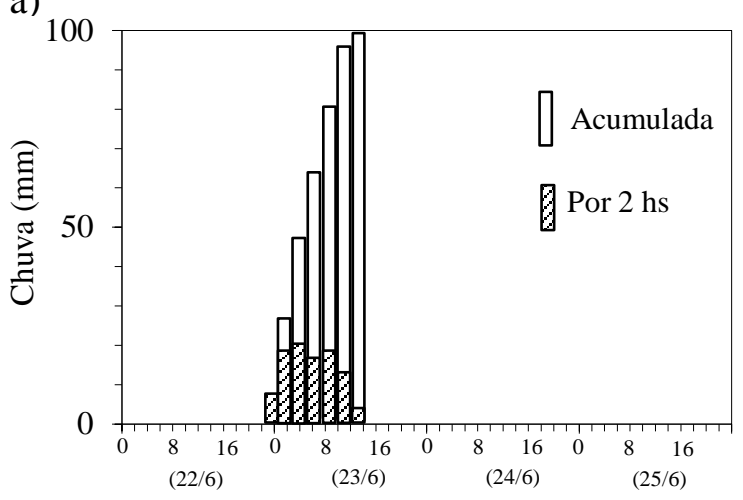

b)

Tempo (horas)
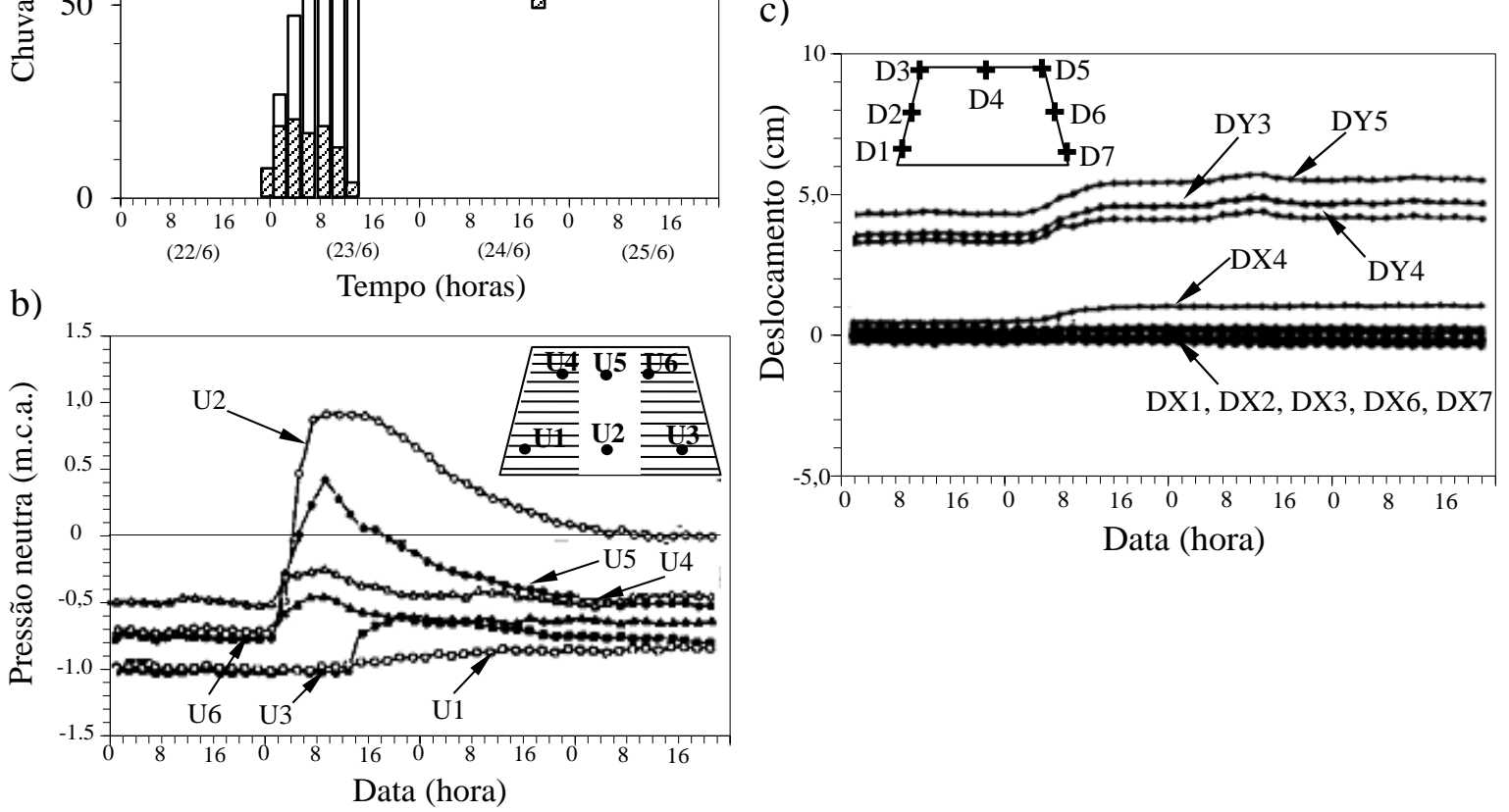

Figura 2.37. Leituras da instrumentação do Aterro II registradas durante 4 dias: (a) eventos de chuva; (b) pressões da água; (c) deslocamentos verticais e horizontais (TATSUOKA; YAMAUCHI, 1986). 


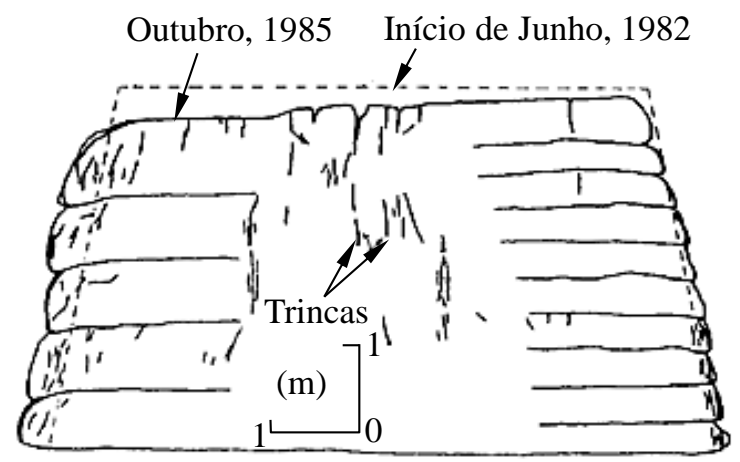

Figura 2.38. Seção transversal do Aterro I no término do ensaio (TATSUOKA; YAMAUCHI, 1986).

Considerando as condições críticas impostas por Tatsuoka e Yamauchi (1986), os autores concluíram que as estruturas avaliadas alcançaram valores de deformações e deslocamentos toleráveis e podem ser aplicadas seguramente, desde que um espaçamento máximo e comprimento mínimo dos reforços fossem devidamente respeitados, com base nas condições de drenagem requeridas para a preservação das pressões da água iniciais.

Outro relato de um aterro reforçado que utilizou a mesma argila de cinza vulcânica misturada com um silte arenoso, também encontrado no local da obra, foi relatado por Naemura e Miki (1996). A estrutura consiste em um aterro rodoviário de $7 \mathrm{~m}$ de altura, construído com geogrelhas biaxiais e geotêxteis não tecidos instalados alternadamente (geogrelhas espaçadas em $60 \mathrm{~cm}$ e geotêxteis em $120 \mathrm{~cm}$ ), de modo a suprir tanto as tensões transferidas pelo solo, como a drenagem interna da estrutura em um dos lados do aterro. A outra seção foi avaliada utilizando o mesmo solo, porém somente geotêxteis não tecidos espaçados a $30 \mathrm{~cm}$. Todos os reforços foram instalados com declividade de $4 \%$ na direção do faceamento. A seção típica instrumentada é apresentada na Figura 2.39.

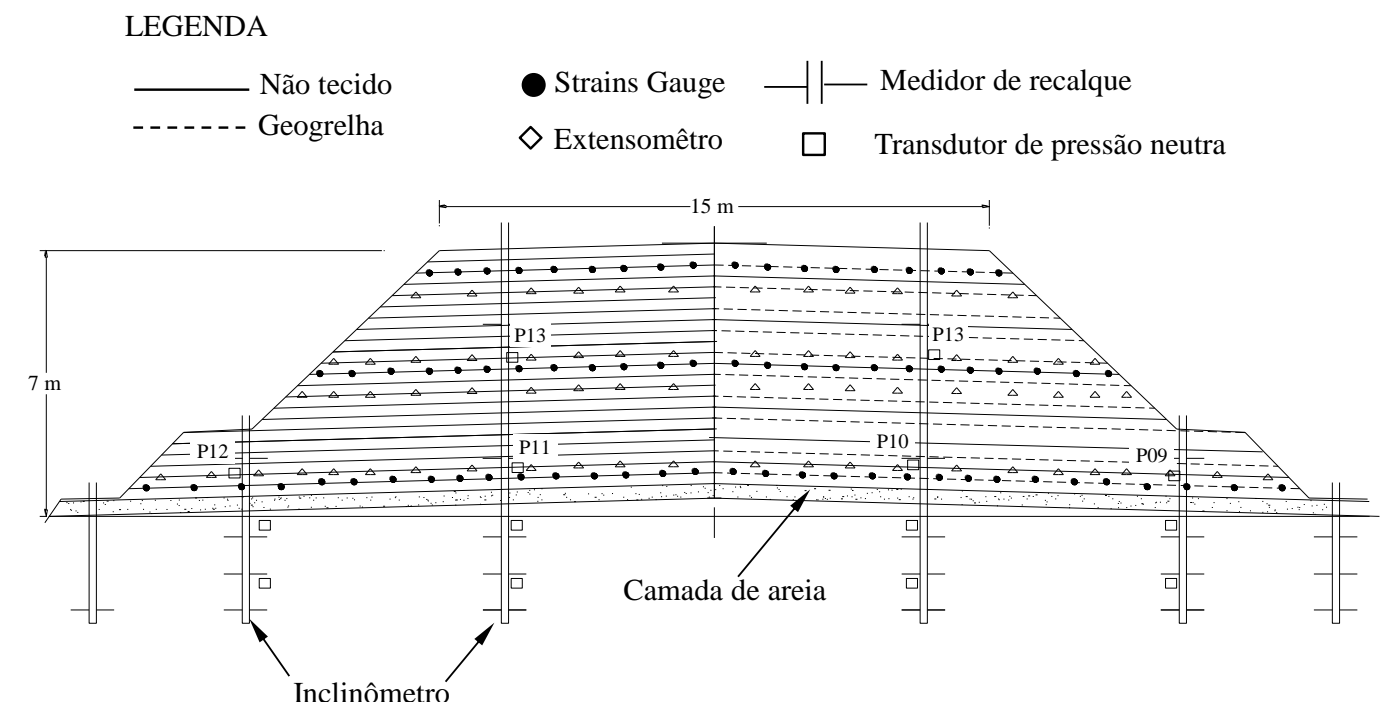

Figura 2.39. Seção típica instrumentada do aterro reforçado em Akita, Japão (NAEMURA; MIKI, 1996). 
Resultados da instrumentação mostraram o excesso de pressões da água próximas do centro do aterro sendo rapidamente dissipado na direção da face pelos geotêxteis não tecidos. Os maiores valores de pressões da água foram medidos durante a construção no talude em que os geotêxteis foram instalados com maiores espaçamentos (Figura 2.40). Nota-se ainda, que a dissipação ocorreu mais rapidamente na seção reforçada somente com geotêxteis, enfatizando o efeito positivo da diminuição da altura de drenagem anteriormente recomendada por Tatsuoka e Yamauchi (1986). A rápida consolidação do solo devido à dissipação das pressões da água na estrutura de geotêxteis fez com que as deformações nos geotêxteis (máxima de 0,5\%) fossem menores do que aquelas medidas na estrutura de geogrelhas (deformação máxima de $2 \%$ ).

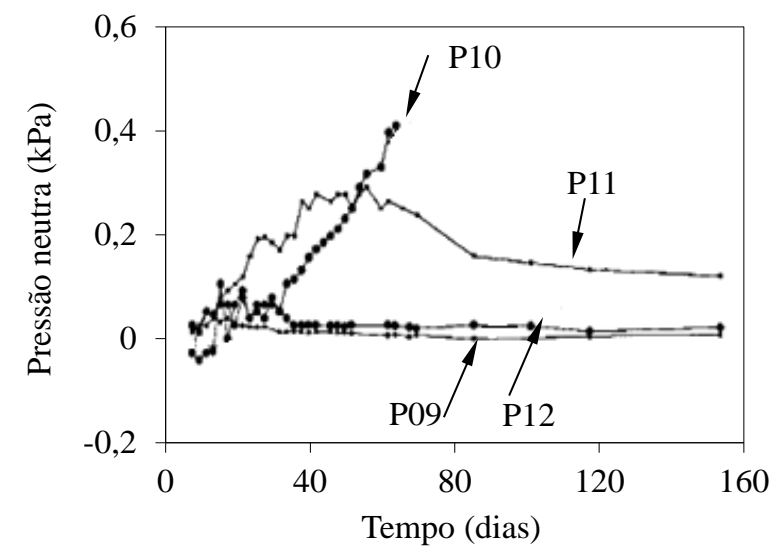

Figura 2.40. Leituras das pressões da água medidas na segunda camada de reforços (NAEMURA; MIKI 1996).

No Brasil, o sucesso do uso de solos finos em estruturas reforçadas com geotêxteis não tecidos é bastante evidente (CARVALHO; PEDROSA; WOLLE, 1986; EHRLICH; VIANNA; FUSARO, 1994; RIBEIRO; JUNIOR; PIRES, 1999; BENJAMIM; BUENO; ZORNBERG, 2007). Atualmente, a utilização de solos finos locais é bastante comum e o comportamento resultante é bastante satisfatório. Muitos autores atribuem o bom comportamento destas estruturas ao comportamento peculiar de solos tropicais finos brasileiros (EHRLICH; VIDAL; CARVALHO, 1997), bem como a não saturação completa destes ao longo da vida útil da estrutura por razões climáticas (EHRLICH; VIANNA; FUSARO, 1994).

A primeira estrutura de solo reforçado construída no Brasil foi um muro reforçado com geotêxteis, com 10 metros de altura e inclinação da face de $1 \mathrm{H} / 2 \mathrm{~V}$, construído em 1984 para a recuperação de um aterro rodoviário. A obra consiste na recomposição do deslizamento de um talude de $30 \mathrm{~m}$ de altura de uma seção da rodovia que liga Taubaté à Campos do Jordão (SP-123), em São Paulo (Carvalho et al., 1986). Construiu-se ao longo dessa encosta, o aterro de recomposição em três etapas, sendo que a segunda foi construída em solo reforçado. De acordo com Carvalho et al. (1986), a estrutura foi executada em camadas compactadas de uma areia siltoargilosa, mantas de geotêxteis dispostas a cada $60 \mathrm{~cm}$ e com comprimentos dos reforços iguais a 
7,0 m. Foram utilizados dois tipos de geotêxteis, sendo metade do comprimento do talude com um geotêxtil tecido de polipropileno e a outra metade com um geotêxtil não tecido de poliéster, com gramaturas de $167 \mathrm{~g} / \mathrm{m}^{2}$ e $300 \mathrm{~g} / \mathrm{m}^{2}$, respectivamente. Ambos os geotêxteis apresentaram resistência à tração não confinada de $22 \mathrm{kN} / \mathrm{m}$ e diferentes valores de rigidez. O muro pioneiro durante o processo de construção é mostrado na Figura 2.41, e a seção transversal típica e vista frontal são mostrados na Figura 2.42.

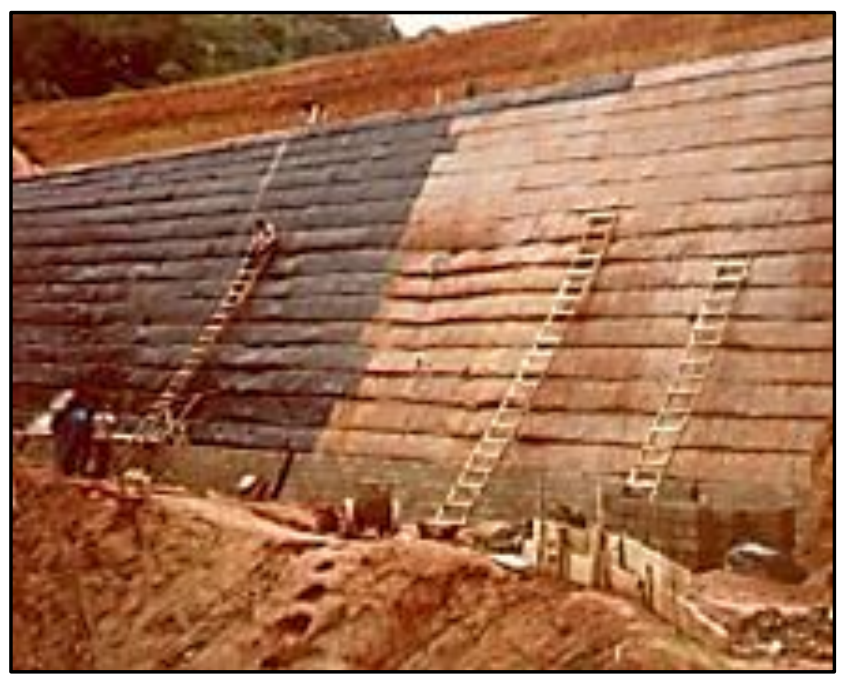

Figura 2.41. Muro pioneiro construído com solos locais finos e geotêxteis não tecidos (CARVALHO et al., 1986 apud BENJAMIM, 2006).

a)

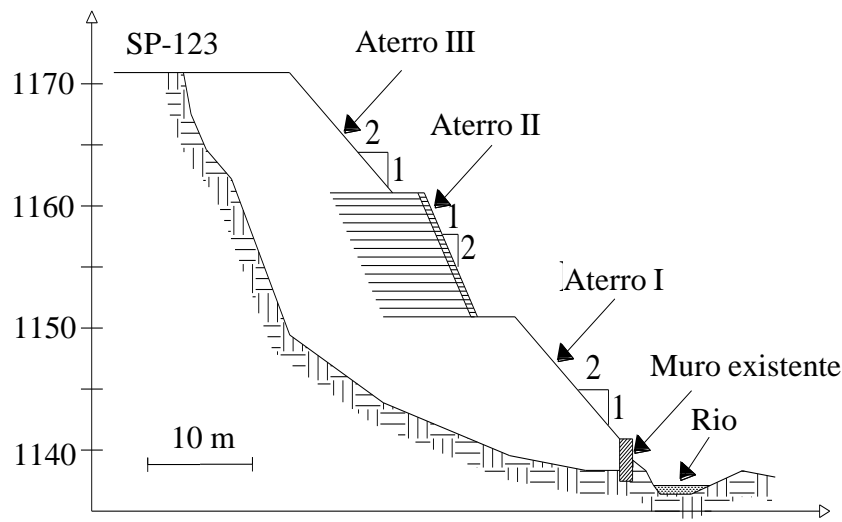

b)

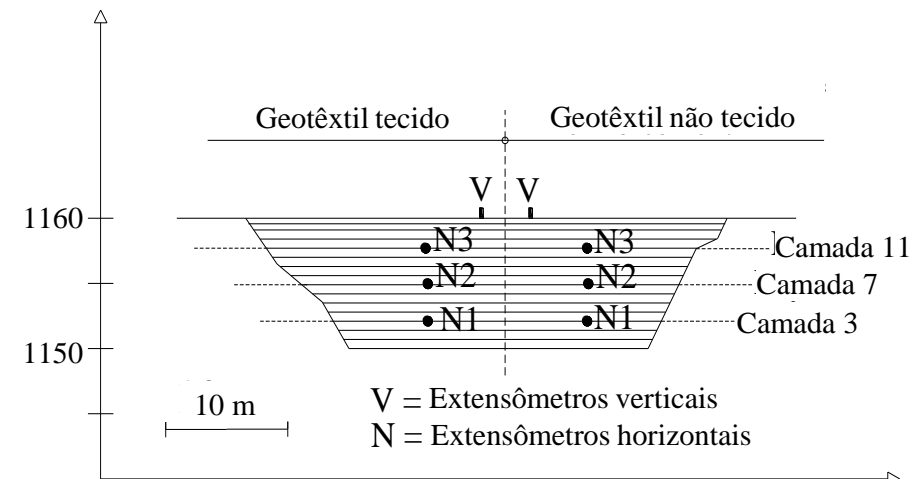

Figura 2.42. Muro pioneiro de geossintético no Brasil: (a) seção transversal típica; (b) vista frontal (CARVALHO et al., 1996). 
O solo utilizado na construção do muro reforçado consistia em uma areia silto argilosa (solo residual de granito), com 50\% de material passante na peneira $\# 200, \mathrm{~W}_{\mathrm{L}}=44 \%$ e $\mathrm{IP}=14 \%$, peso específico aparente máximo de $16,7 \mathrm{kN} / \mathrm{m}^{3}$, e teor ótimo de umidade de $16,8 \%$ (Proctor normal). Por razão desconhecida, o teor de umidade de compactação adotado foi de $18 \%$.

De maneira a acompanhar o comportamento da estrutura, uma vez que se tratava se uma técnica nunca utilizada no Brasil, a estrutura foi instrumentada e avaliada durante e após o período de construção. Detalhes da instrumentação podem ser observados nos artigos de Carvalho e Wolle (1985) e Ehrlich et al. (1997). A instrumentação foi distribuída em três camadas reforçadas, sendo estas a $3^{\mathrm{a}}, 7^{\mathrm{a}}$ e $11^{\mathrm{a}}$ camadas, de baixo para cima. Leituras da instrumentação foram acompanhadas durante dois anos. Células de tensão total foram instaladas na $3^{\mathrm{a}}$ e $11^{\mathrm{a}}$ camada, registrando leituras de tensões horizontais e verticais. Deslocamentos internos da estrutura foram monitoradas por extensômetros instalados a 1 m, 3 m e 6 m em relação à face em todas as camadas instrumentadas. Os piezômetros foram instalados somente na $3^{\text {a }}$ camada na seção reforçada com geotêxteis não tecidos. Extensômetros magnéticos verticais foram também dispostos em todas as camadas instrumentadas.

Os resultados da instrumentação mostraram um significante aumento dos deslocamentos horizontais ocorrendo durante a fase de construção. Um importante aspecto a ser observado é que o período de construção consistiu no mais úmido em 1984. Pode-se supor que, os maiores deslocamentos horizontais registrados na seção reforçada com geotêxteis tecidos em relação à seção de geotêxteis não tecidos são resultantes de um possível umedecimento da estrutura na fase construtiva. Pelo fato dos geotêxteis tecidos consistirem em reforços mais rígidos em relação aos não tecidos, esperava-se que estes deformassem menos, o que não foi evidenciado. Já a relação entre deslocamentos internos máximos e altura do muro nas condições de serviço da estrutura, ou seja, pós-construção, foram relatados como $1,2 \%$ e $0,6 \%$, para reforços tecido e não tecidos, respectivamente. Portanto, relativamente pequenas magnitudes de deslocamentos internos da estrutura foram constatadas (máximo de $10 \mathrm{~cm}$ ), sendo estes maiores para os geotêxteis tecidos. Ainda, nenhum deslocamento dependente do tempo foi evidenciado, o que exclui deformações excessivas por fluência dos reforços. Durante dois anos, os piezômetros registraram leituras negativas ou baixos valores de leituras positivas na seção de geotêxteis não tecidos, mostrando que pressões da água significantes não foram registradas. Porém, como as leituras variaram de negativas para positivas, não se pode descartar a presença da água no interior da estrutura.

Ribeiro et al. (1999) relata a construção e resultados da instrumentação de um muro de contenção de uma encosta na cidade de Presidente Epitácio, em São Paulo. O aterro com 7,0 m de altura e 4,8 m de base consiste em um maciço de solo areno argiloso reforçado com geotêxtil não tecido de poliéster, com gramatura de $300 \mathrm{~g} / \mathrm{m}^{2}$. O espaçamento vertical adotado entre as camadas de reforço foi de $30 \mathrm{~cm}$ nas camadas reforçadas inferiores e $60 \mathrm{~cm}$ nas superiores. Sobre o aterro de solo reforçado, fez-se necessário ainda, um aterro de solo compactado, com altura de 5,4 m. Curiosamente, a estrutura permaneceu alagada durante as condições de serviço, uma vez que 
consistiu na estabilização de uma encosta de um açude artificial. A presente estrutura permanece em serviço até os dias atuais. Ilustrações da estrutura durante a construção e nas condições de serviço são mostradas na Figura 2.43.

(a)

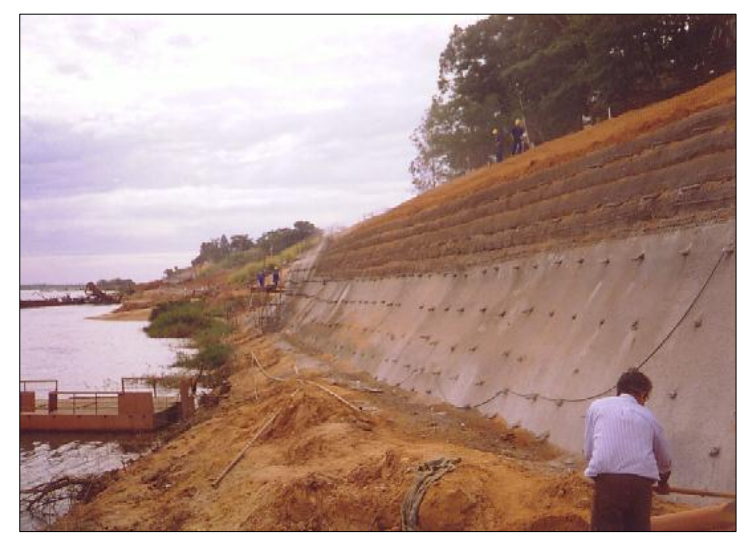

(b)

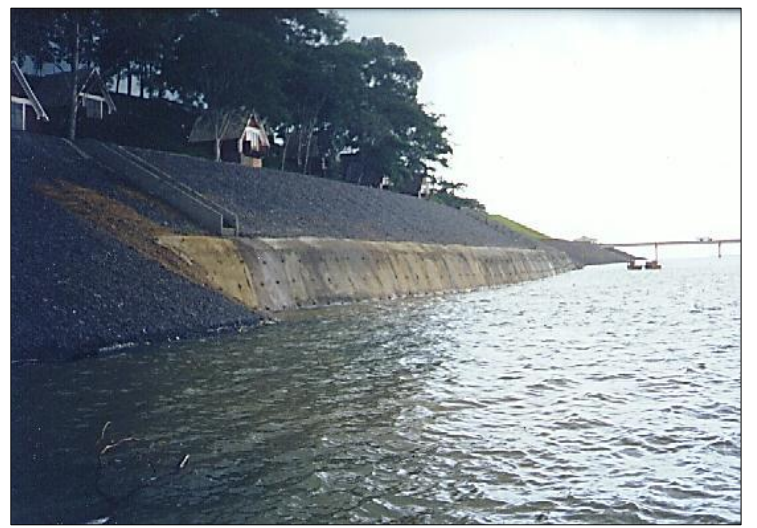

Figura 2.43. Muro de contenção de Presidente Epitácio - SP: (a) durante a construção; (b) nas condições de serviço (fonte desconhecida).

Os instrumentos foram instalados em duas camadas instrumentadas (1/3 e $2 / 3$ da altura), com o intuito de monitorar os deslocamentos horizontais e verticais decorrentes da construção e os registrados 160 dias após o término da obra. A Figura 2.44 apresenta os resultados da instrumentação para 1/3 da altura da estrutura. Os deslocamentos medidos no aterro reforçado foram relativamente pequenos ( $23 \mathrm{~mm}$ horizontal e $45 \mathrm{~mm}$ vertical), sendo que os extensômetros instalados a $2 / 3$ da altura foram os que apresentaram os maiores deslocamentos. Maiores deslocamentos também foram observados nas proximidades da face e menores adentrando o maciço. Durante um período de paralisação da construção, verificou-se a continuidade da ocorrência de deslocamentos horizontais em todos os extensômetros. Os deslocamentos verticais não foram expressivos e ocorreram principalmente durante a construção do aterro reforçado e do sobrejacente. Atualmente, a estrutura permanece sem nenhum problema no desempenho.

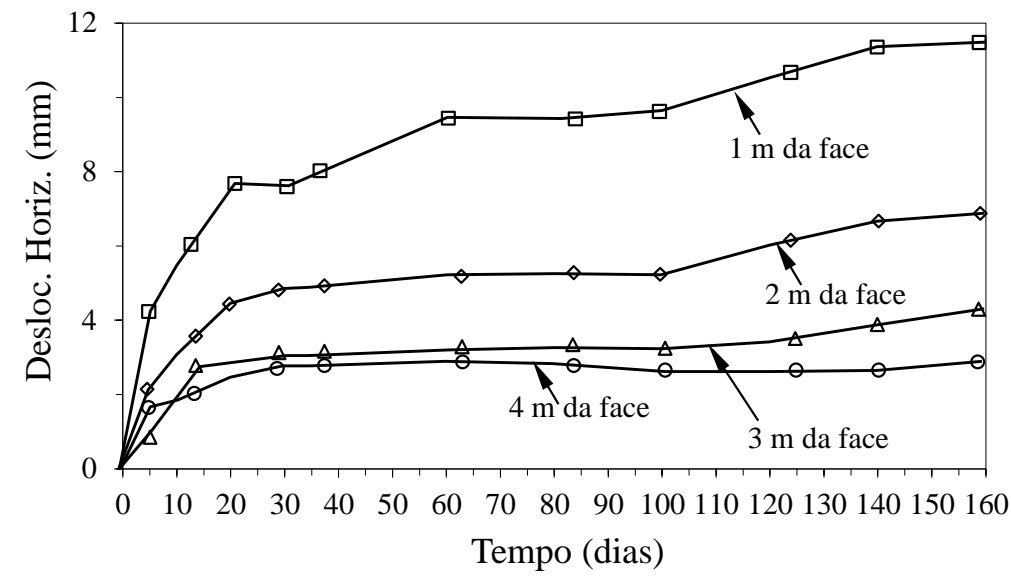

Figura 2.44. Resultados das leituras dos extensômetros para medidas de deslocamentos horizontais (RIBEIRO; JUNIOR; PIRES, 1999). 
O trabalho de Ehrlich et al. (1994) descreve parte de um programa de recuperação de uma via de acesso urbano na cidade de Petrópolis, Rio de Janeiro, onde ocorreram deslizamentos das encostas que envolviam a via de acesso. A ação restauradora foi a construção de dois muros com uma argila arenosa intemperizada reforçada com geotêxteis não tecidos $(1 \mathrm{H} / 8 \mathrm{~V})$ de gramatura 300 $\mathrm{g} / \mathrm{m}^{2}$, espaçados a cada $30 \mathrm{~cm}$. A seção reforçada tem 2,8 metros de largura e foram utilizados blocos de concreto para proteger a face do talude contra danos mecânicos e evitar a ação de raios UV. Além disso, envolvendo a massa do solo argiloso foi prevista uma camada de material drenante de forma a garantir a dissipação das pressões da água, tanto geradas por compactação como por infiltração de água de chuva ou ascensão de lençol freático. A Figura 2.45 ilustra a seção de projeto e a distribuição da instrumentação.

Para a verificação do comportamento durante e após a construção, lançou-se da utilização de placas magnéticas para a detecção dos deslocamentos verticais e barras de aço, de diversos comprimentos, dobradas e costuradas na extremidade das mantas de geotêxtil, para a determinação dos deslocamentos horizontais. A verificação da eficiência do material drenante que envolve a massa de solo reforçado na dissipação das pressões da água foi realizada com a utilização de piezômetros pneumáticos.

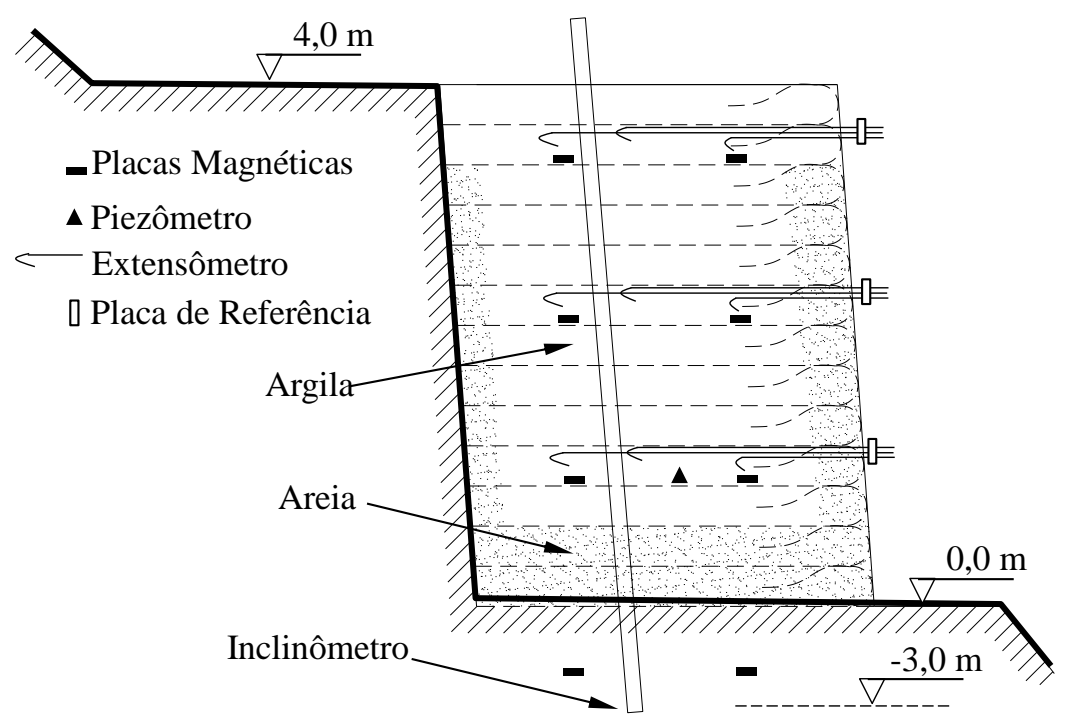

Figura 2.45. Seção transversal de projeto e instrumentação do muro reforçado em Petrópolis - RJ (EHRLICH; VIANNA; FUSARO, 1994).

A Figura 2.46 apresenta os movimentos horizontais medidos a $0,60 \mathrm{~m} \mathrm{e} 1,60 \mathrm{~m}$ da face. Os movimentos horizontais foram muito pequenos (inferiores a $1 \mathrm{~cm}$ ) e as placas magnéticas de recalque não acusaram quaisquer movimentos verticais expressivos. Com relação às leituras dos piezômetros, não se mediram pressões da água positivas durante o período de leituras, verificando-se a não saturação do solo ao longo das análises. Segundo os autores, as análises de estabilidade global, utilizando os métodos das cunhas, demonstraram que a massa de solo argiloso 
compactada poderia manter-se estável sem a presença dos reforços, apresentando um coeficiente de segurança de 3,9 .

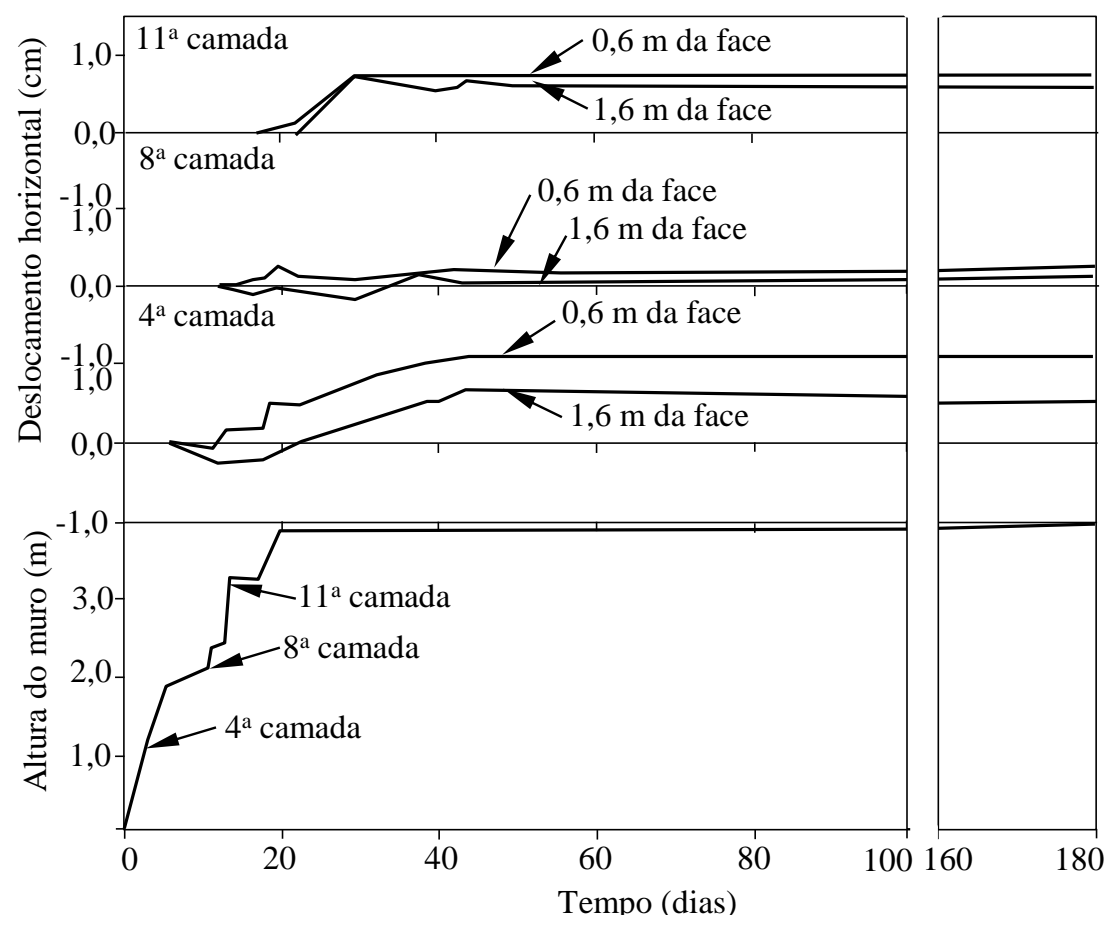

Figura 2.46. Movimentos horizontais do muro reforçado em Petrópolis - RJ (EHRLICH; VIANNA; FUSARO, 1994).

Com base nos casos relatados neste tópico, pode-se evidenciar que, mesmo em condições críticas de umedecimento, estruturas de solos finos reforçados com geotêxteis não tecidos podem se comportar satisfatoriamente, desde que a capacidade de drenagem do reforço seja devidamente considerada em projeto, juntamente com a resistência à tração. Poucos são os casos de insucessos desses tipos de estruturas, podendo-se referenciar os relatos de Gassner e James (1998) e Richardson e Behr (1998), sendo ainda este último atribuído à má compactação do solo do aterro. Portanto, é evidente que a técnica pode vir a ser uma alternativa economicamente e tecnicamente viável em casos onde a drenagem seja devidamente considerada em projeto. Tal potencial pode ser atribuído aos seguintes aspectos:

- funções simultâneas de reforço e drenagem de geotêxteis não tecidos;

- excelente interação com solos argilosos devido ao arranjo das partículas que permitem a penetração destas no interior da manta;

- melhoria do comportamento de geotêxteis não tecidos nas condições de trabalho, ou seja, sob condições confinadas;

- comportamento não saturado de solos finos, onde a sucção matricial passa a contribuir significativamente na resistência ao cisalhamento do solo, e;

- espaçamentos máximos entre reforços obedecidos, garantindo distância de drenagem suficiente para balancear a taxa de infiltração e a taxa de dissipação. 


\subsection{Projetos de muros de solos finos reforçados com geotêxteis não tecidos}

Este tópico descreve aspectos de projetos de estruturas de solos finos reforçados, na tentativa de direcionar informações para aplicações em reforços de geotêxteis não tecidos, bem como para o uso solos finos. Serão abordadas as características relevantes do solo e do reforço a serem considerados em projetos, assim como métodos para a previsão do tempo de dissipação das pressões da água e estabilidade nas condições de drenagem impostas. Finalmente, relata-se a respeito dos métodos de projeto atualmente utilizados.

\subsubsection{Diretrizes de projeto de estruturas de solos finos}

Para um comportamento satisfatório das estruturas de solos finos reforçados, devem-se considerar as condições de saturação e a possível geração de pressões da água. Assim, os critérios de projetos adotados para estruturas de solos granulares diferem das de solos argilosos, devido às diferenças nas características hidráulicas dos solos. Análises em termos de tensões totais, que incluem a influência da pressão da água, são usualmente adotadas em análises de reforços impermeáveis. Neste caso, direciona-se para a utilização de reforços com elevada resistência à tração para compensar a baixa resistência ao cisalhamento do solo. No caso de reforços permeáveis, CHRISTOPHER et al. (1998) propõem diretrizes de projeto para estruturas de solos finos. Tais diretrizes baseiam-se no fato de que a configuração dos reforços seja suficiente para conduzir a água para fora do maciço, sem desenvolver pressões da água ao longo da interface solo-reforço. As recomendações estabelecidas consideram três possíveis condições adversas de avanço de umedecimento no interior da estrutura, que resultam no desenvolvimento de pressões da água positivas: (1) processo de compactação e construção; (2) infiltração da água da chuva; e (3) formação de zonas de fluxo no interior de estrutura. Estas condições adversas são ilustradas na Figura 2.47.

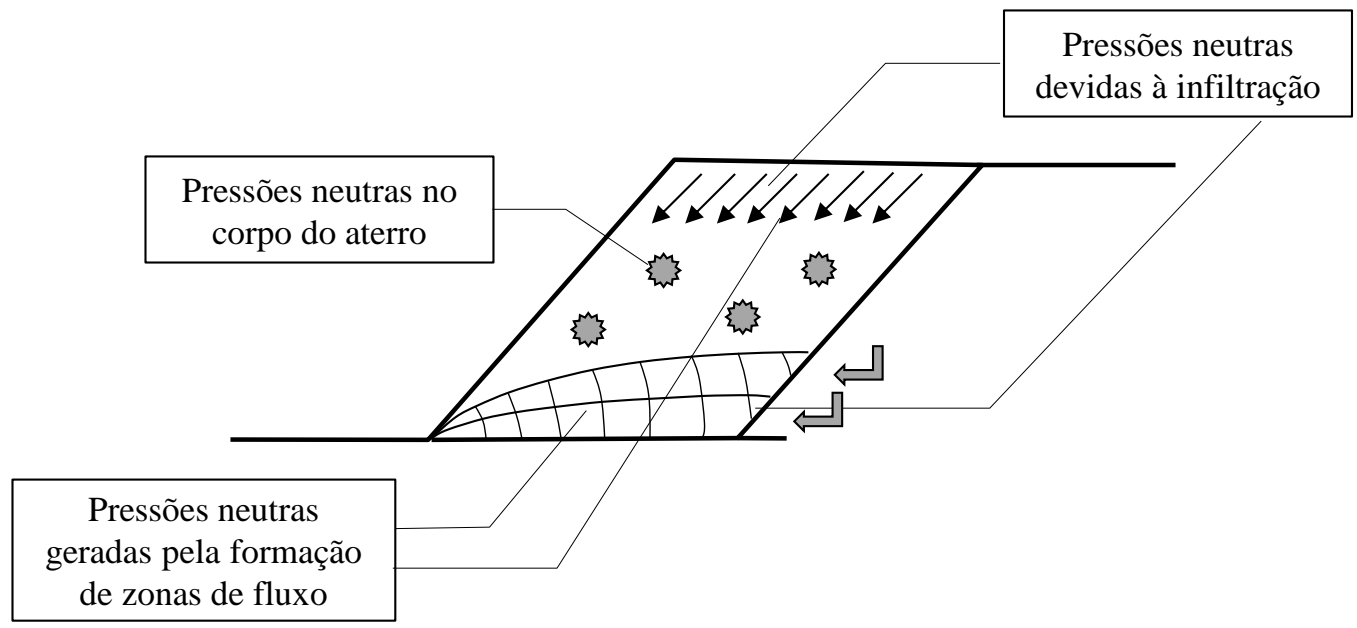

Figura 2.47. Possíveis condições de avanço de umedecimento em estruturas de solo reforçado (ZORNBERG; MITCHELL, 1994). 
Embora existam fortes evidências de que os geossintéticos podem dissipar o excesso de pressão da água na interface solo-reforço, pressões da água podem ser desenvolvidas no interior das camadas de solo entre as inclusões de geossintéticos. Desse modo, a proposta dos autores inclui duas análises distintas para cada condição adversa anteriormente estabelecida. A primeira ignora a contribuição de drenagem provida pelos reforços, cuja análise é realizada em termos de tensões totais considerando que a estabilidade é dada, principalmente, pelos reforços, com uma contribuição mínima da resistência ao cisalhamento do solo. Devido à natureza conservativa dessa consideração, sugere-se a utilização de baixos fatores de segurança, em torno de 1,1 . Normalmente, ensaios não drenados UU e CU são considerados dependendo da condição estabelecida em projeto. Para a situação em que as pressões da água são decorrentes do processo construtivo, análises deverão ser idealizadas considerando as pressões da água desenvolvidas a curto prazo e ensaios triaxiais UU devem ser utilizados. Na condição em que a resistência do solo é prejudicada pela infiltração de água, considera-se a condição dos ensaios CU, em amostras saturadas. Já o efeito das zonas de fluxo formadas no interior da estrutura deve-se considerar não somente uma condição CU de ensaios triaxiais em amostras saturadas, mas também as forças de percolação devido ao fluxo de água.

$\mathrm{Na}$ segunda concepção, recomendam-se análises em termos de tensões efetivas, levando em consideração a drenagem total da água do aterro pelos reforços permeáveis. A drenagem total do aterro reforçado é assumida como uma condição de longo prazo e, avalia-se a estabilidade da estrutura durante sua vida útil, em que as pressões da água geradas durante e após construção já tenham sido dissipadas. Neste caso, enfatiza-se que a transmissividade dos reforços deve ser tal que não haja geração de pressão da água na interface solo-reforço. A resistência ao cisalhamento do solo deve ser baseada no seu comportamento em ensaios triaxiais adensados não drenados (CU), executado com amostras saturadas, com medidas de pressão da água, ou em ensaios triaxiais drenados (CD). O fator de segurança de projeto usado nesta análise (longo prazo) é o mesmo usado para solos granulares, 1,3 a 1,5.

No caso em que infiltração de água superficial possa vir a reduzir a resistência ao cisalhamento dos solos, análises são feitas em termos de tensões totais, levando em conta o efeito da drenagem lateral provida pelos reforços permeáveis, impedindo que a água superficial avance para o interior do maciço de solo. Uma análise em termos de tensões totais é considerada neste caso, no lugar de tensões efetivas, de forma a levar em conta os benefícios atribuídos aos efeitos das pressões da água negativas desenvolvidas. A resistência ao cisalhamento total é definida a partir de ensaios executados com amostras não saturadas. Cabe salientar, que a transmissividade e a distribuição das inclusões de reforço devem ser adequadamente selecionados, para que o geossintético tenha capacidade de drenar todo o fluxo de água para fora do aterro reforçado. Adicionalmente, sistemas externos de controle da água superficial e subterrânea podem ser incorporados nos projetos. Um resumo das diretrizes gerais estabelecidas por Christopher et al. 
(1998) para projetos de estruturas de solos finos reforçados com materiais permeáveis é apresentado na Tabela 2.5 .

Tabela 2.5. Resumo das análises de estruturas de solo reforçado com aterro de baixa capacidade de drenagem (CHRISTOPHER et al., 1998)

\begin{tabular}{|c|c|c|c|}
\hline Condição & Características & $\begin{array}{c}\text { Análise 1: } \\
\text { Ignorando a Drenagem } \\
\text { Lateral } \\
\end{array}$ & $\begin{array}{c}\text { Análise 2: } \\
\text { Considerando } \\
\text { Drenagem Total }\end{array}$ \\
\hline \multirow{6}{*}{$\begin{array}{l}\text { 1. Geração de pressões } \\
\text { da água no corpo do } \\
\text { aterro reforçado }\end{array}$} & Tipo de análise & Tensões totais & Tensões efetivas \\
\hline & Caso & $\begin{array}{l}\text { Geração de pressões da } \\
\text { água a curto prazo }\end{array}$ & $\begin{array}{l}\text { Drenagem em longo } \\
\text { prazo devido aos } \\
\text { reforços permeáveis }\end{array}$ \\
\hline & Critérios de projeto & $\mathrm{FS}=1,1$ & $\mathrm{FS}=1,3$ a 1,5 \\
\hline & Transmissividade do reforço & Ignorada na análise & $\begin{array}{l}\text { Conduz fluxo } \\
\text { acelerando o } \\
\text { adensamento do solo }\end{array}$ \\
\hline & \multirow{2}{*}{$\begin{array}{l}\text { Resistência ao cisalhamento } \\
\text { do solo }\end{array}$} & $\phi$ e c - Ensaios UU & $\begin{array}{c}\phi \text { e c - Ensaios CU e } \\
\text { CD }\end{array}$ \\
\hline & & Amostra na condição local & $\begin{array}{c}\text { Amostra na condição } \\
\text { saturada }\end{array}$ \\
\hline \multirow{6}{*}{$\begin{array}{l}\text { 2. Água superficial } \\
\text { avançando para o } \\
\text { interior do aterro } \\
\text { reforçado }\end{array}$} & Tipo de análise & Tensões totais & Tensões efetivas \\
\hline & Caso & $\begin{array}{l}\text { Perda de resistência } \\
\text { devido à saturação }\end{array}$ & $\begin{array}{c}\text { Condição não saturada } \\
\text { devido à drenagem } \\
\text { interna }\end{array}$ \\
\hline & Critérios de projeto & $\mathrm{FS}=1,1$ & $\mathrm{FS}=1,3$ a 1,5 \\
\hline & Transmissividade do reforço & Ignorada na análise & $\begin{array}{c}\text { Avanço da água } \\
\text { superficial impedido }\end{array}$ \\
\hline & \multirow{2}{*}{$\begin{array}{l}\text { Resistência ao cisalhamento } \\
\text { do solo }\end{array}$} & $\phi$ e c - Ensaios CU & $\begin{array}{c}\phi \text { e c - Ensaios CU e } \\
\text { CD }\end{array}$ \\
\hline & & $\begin{array}{c}\text { Amostra na condição } \\
\text { saturada }\end{array}$ & $\begin{array}{l}\text { Amostra na condição } \\
\text { de umidade elevada }\end{array}$ \\
\hline \multirow{5}{*}{$\begin{array}{l}\text { 3. Zonas de fluxo } \\
\text { estabelecidas no corpo } \\
\text { do aterro reforçado }\end{array}$} & Tipo de análise & Tensões totais & Tensões efetivas \\
\hline & Caso & $\begin{array}{l}\text { Desenvolvimento de } \\
\text { forças de percolação }\end{array}$ & $\begin{array}{l}\text { Solo saturado sem } \\
\text { forças de percolação }\end{array}$ \\
\hline & Critérios de projeto & $\mathrm{FS}=1,1$ & $\mathrm{FS}=1,3$ a 1,5 \\
\hline & Transmissividade do reforço & Ignorada na análise & $\begin{array}{l}\text { Conduz fluxo total de } \\
\text { água dentro do aterro }\end{array}$ \\
\hline & $\begin{array}{l}\text { Resistência ao cisalhamento } \\
\text { do solo }\end{array}$ & $\begin{array}{l}\text { ф e c - Ensaios CU } \\
\text { condição saturada }\end{array}$ & $\begin{array}{c}\text { ф e c - Ensaios CU e } \\
\text { CD } \\
\text { condição saturada }\end{array}$ \\
\hline
\end{tabular}

Em estruturas de solos finos coesivos reforçados, as propriedades mecânicas e hidráulicas do reforço devem ser caracterizadas antes de sua aplicação e suprir com as seguintes funções: resistência à tração, resistência ao arrancamento, drenagem e filtração. Essas quatro características devem ser cuidadosamente avaliadas e quantificadas. As avaliações incluem, no mínimo, as seguintes considerações (CHRISTOPHER et al., 1998):

- a resistência à tração do geossintético será tipicamente maior para reforços de solo finos do que para solos de granulares. Atenção deve ser dada na determinação de 
resistência de projeto a longo prazo considerando o potencial de fluência do solo e do reforço.

- a resistência ao arrancamento, que requer especial consideração devido ao potencial de desenvolvimento de pressões da água na interface solo-reforço e o potencial de fluência dos solos coesivos. Ainda, os comportamentos de arrancamento em condições drenadas e não drenadas podem vir a ser avaliados e considerados em projeto.

- as características de transmissividade devem ser consideradas para diferentes condições indicadas na Tabela 2.5. Isto é, fluxos totais induzidos por consolidação ou percolação devem ser considerados sem induzir pressões da água dentro do reforço. Existem boas evidências que valores de transmissividade equivalentes para aqueles de geotêxteis não tecidos agulhados são adequados para livre drenagem de solos coesivos e dissipação de pressões da água ao longo da interface. Os geossintéticos devem ter espessura suficiente para restringir o avanço da frente de umedecimento.

- os requisitos de filtração necessários para minimizar a colmatação do geossintético devem também ser avaliados. Diretrizes de projeto de filtração foram desenvolvidas por Holtz et al. (1997) e Koerner (1994).

\subsubsection{Métodos de análise de estabilidade interna}

A grande diferença entre as estruturas de contenção em solo reforçado e outras estruturas está no fato de que a primeira necessita equilibrar não somente as forças que agem externamente ao bloco de gravidade, como também manter a estrutura estável internamente para que a funcionalidade seja garantida. Portanto, a estabilidade externa à zona reforçada e interna (na zona reforçada) são as preocupações nas análises de estabilidade de projetos. A análise de estabilidade externa é bastante conhecida no meio técnico e consiste em manter a estrutura equilibrada de forças que podem promover o deslizamento do bloco de gravidade, bem como os momentos que podem promover o tombamento. Ainda, a capacidade de carga da fundação deve ser analisada. Uma vez que as verificações de estabilidade externa são bastante gerais, o foco deste tópico será dado aos métodos de estabilidade interna utilizados em projetos de muros reforçados com geossintéticos.

\subsubsection{Métodos de equilíbrio limite}

Os métodos de projetos mais utilizados atualmente em muros de solo reforçado consistem naqueles baseados nos estados de tensões de Rankine ou Coulomb, que levam em consideração o estado de plastificação do solo, para a determinação das forças de tração atuantes, bem como fatores de segurança contra a ruptura, normalmente chamados de métodos das tensões de serviço 
(STEWARD; WILLIAMSON; MOHNEY, 1977; BROMS, 1978; COLLIN, 1986; BONAPARTE; HOLTZ; GIROUD, 1987; MITCHELL; VILET, 1987). A maioria destes métodos utilizam análises conceitualmente simples de forças horizontais desestabilizantes resultante dos empuxos laterais de terra, como mostra a Figura 2.48, e forças horizontais estabilizantes proporcionadas pelos reforços. Estes podem variar em algumas considerações com relação às distribuições de tensões, superfícies de ruptura e fatores de segurança. Porém basicamente existem dois fatores de segurança independentes, calculados para cada camada reforçada: fatores de segurança à ruptura dos reforços (Equação 2.3), e fatores de segurança ao arrancamento do reforço (Equação 2.4).

$$
\begin{aligned}
& F S_{\text {rup. }}=\frac{T_{a d m}}{k_{a} \gamma z S_{v} S_{h}} \\
& F S_{\text {arr. }}=\frac{2 \sigma_{v} L_{e} \tan \delta}{k_{a} \gamma z S_{v} S_{h}}
\end{aligned}
$$

onde:

$\mathrm{T}_{\mathrm{adm}}$ : tensão admissível obtida pela redução na tensão última obtida do ensaio de tração, devido à fatores que podem vir a afetar a resistência do reforços nas condições de trabalho: danos de instalação, fluência, degradação química, degradação biológica, e outros fatores que podem vir a ser relevantes em projetos mais específicos;

$\mathrm{K}_{\mathrm{a}}$ : coeficiente de empuxo ativo do solo;

$\gamma$ : peso específico do solo;

z: altura do solo acima do nível do reforço;

$\mathrm{S}_{\mathrm{v}}$ : espaçamento vertical entre reforços;

$\mathrm{S}_{\mathrm{h}}$ : espaçamento horizontal entre camadas de reforços ( $\mathrm{Sh}=1$ para inclusões planares);

$\sigma_{\mathrm{v}}$ : tensão vertical;

$\mathrm{L}_{\mathrm{e}}$ : comprimento do reforço na zona passiva; e

$\delta$ : ângulo de atrito de interface solo reforço.

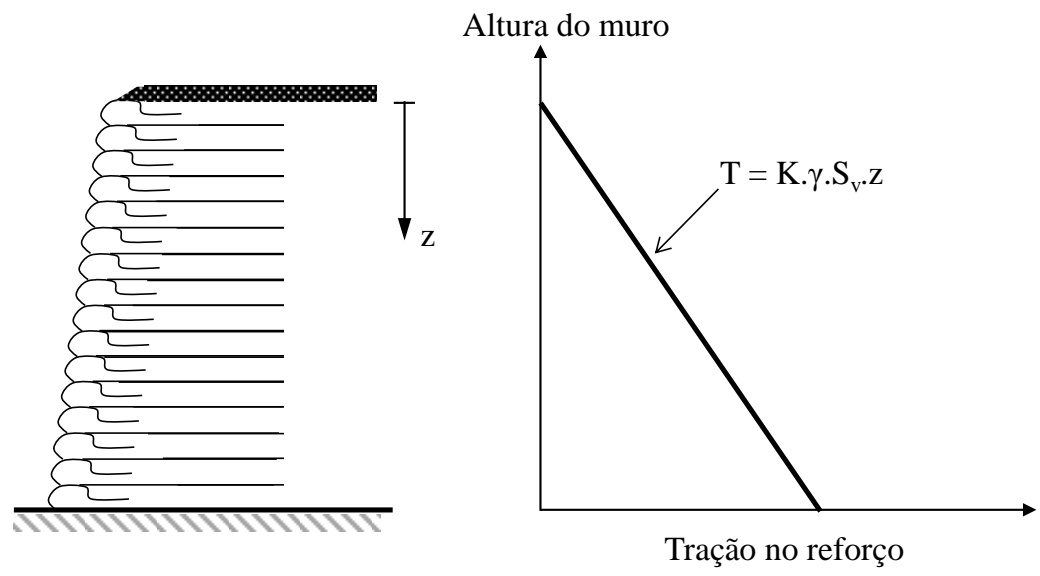

Figura 2.48. Distribuição da tensão máxima no reforço com a profundidade, assumida nos métodos de tensões de trabalho. 
Embora estes métodos normalmente apresentem superfícies planares de ruptura, determinadas pela teoria do estado de tensões do solo de Rankine ou Coulomb sem considerar a presença dos reforços na estrutura, Juran et al. (1990) demonstrou que a presença do reforço altera as deformações e as tensões na massa de solo, consequentemente causando alterações na superfície de ruptura com relação àquela determinada na massa não reforçada.

Outra modalidade de métodos de equilíbrio limite são também baseadas na resistência última do reforço e no estado de plastificação do solo. No entanto, neste caso, fatores de segurança globais são calculados com base no equilíbrio de forças e/ou momentos ao longo de uma assumida superfície de ruptura, assim como análises convencionais de estabilidade de talude, porém considerando as forças de tração do reforço (MURRAY, 1982; MILLIGAN; LA ROCHELLE, 1984; SCHNEIDER; HOLTZ, 1986; SCHMERTMAMM et al., 1987; LESHCHINSKY; BOEDEKER, 1989, WRIGHT; DUNCAN, 1991). A inclinação do reforço e superfícies de ruptura também pode ser levada em considerações neste tipo de análise. Leshchinsky e Boedeker (1989) descreveram um método de equilíbrio limite que usa uma superfície espiral logarítmica e consideram a inclinação da força de tração do reforço paralela à linha de ruptura, representado na Figura 2.49. Schmertmann et al. (1987) desenvolveram um método usando modelos de ruptura em cunha, onde superfícies linear e bilinear de ruptura são adotadas.

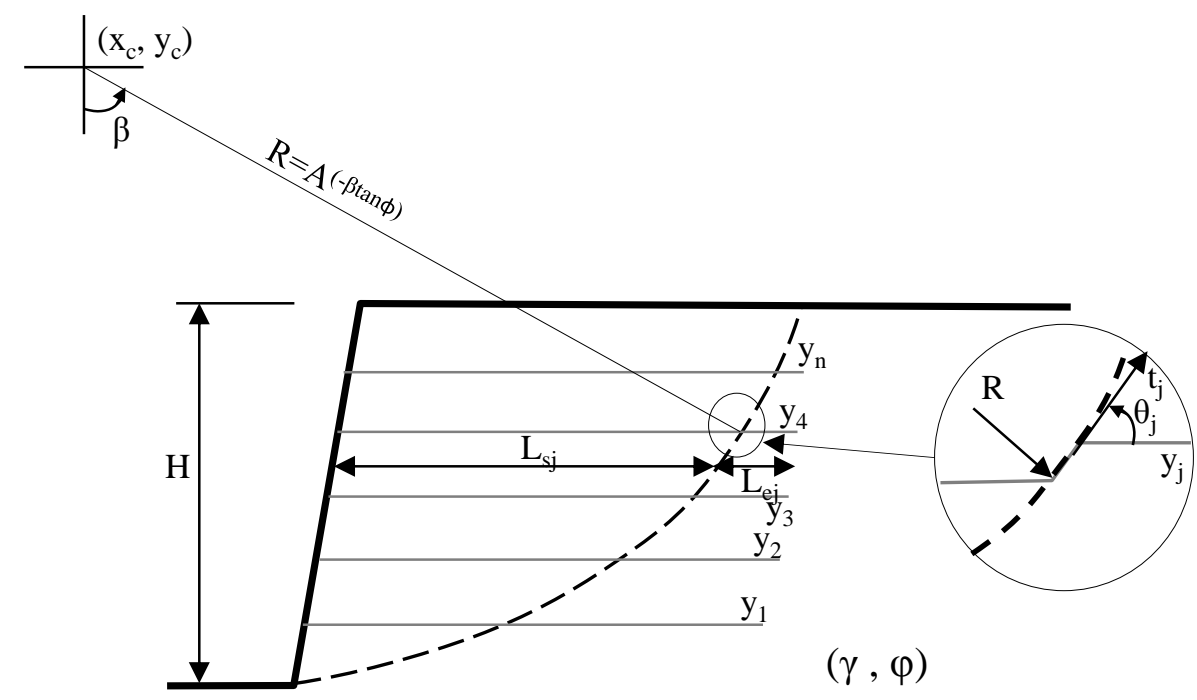

Figura 2.49. Definições e convenções na estabilidade externa (LESHCHINSKY; BOEDEKER, 1989).

Gourc et al. (1986) assumem que reforços extensíveis seriam sujeitos à uma rotação em relação à superfície de ruptura devido ao processo construtivo em que o reforço passaria a atuar tangencialmente à superfície de ruptura. Esta suposição facilita as análises de estabilidade pelo fato das forças de tração disponível nos reforços ser sobrepostas a uma coesão aparente na resistência ao cisalhamento do solo mobilizado ao longo da superfície potencial de ruptura. Murray (1982), Jewell et al. (1984), Hird (1986) e Schneider e Holtz (1986) simplesmente negligenciam a deformação local e consideram rotação zero em relação à superfície de ruptura 
$(\beta=0)$. Leshchinsky e Volk (1985) sugeriram que, para a eficiência máxima, a orientação do reforço deveria coincidir com a direção do deslocamento do solo na superfície de ruptura.

O trabalho de Clayborn e Wu (1993) comparou diferentes métodos de análises de equilíbrio limite. Foram comparados métodos das tensões de serviço de Steward et al. (1977), Broms (1878), Collin (1986) e Bonaparte et al. (1987), baseados nas teorias de empuxos laterais de terra de Rankine, e métodos de equilíbrio limite de Leshchinsky e Perry (1987) e Schmertmann et al. (1987). Constatou-se que, entre estes métodos, houve uma grande disparidade de valores de força de tração nos reforços e fatores de segurança. Ressalta-se que não existe base suficiente para afirmar qual dos métodos é mais apropriado em projetos de estruturas de solos reforçado. No entanto, o método de Steward et al. (1977) é recomendado para estruturas de solo reforçado com geotêxteis não tecidos com alturas limitadas a $4 \mathrm{~m}$, uma vez que este foi intensamente utilizado em estruturas reais e devido ao caráter conservativo deste método. Eventualmente, este método poderá resultar em espaçamentos relativamente grandes, o que poderá prejudicar o conservadorismo do método. Como para este tipo de estrutura é estritamente recomendado espaçamentos entre 30 e $60 \mathrm{~cm}$, este não é um problema na aplicação do método.

De modo geral, estes métodos de equilíbrio limite não incluem análises tensãodeformação para avaliar o comportamento, nem modelos realísticos que descrevem o verdadeiro mecanismo de interação solo-geossintético. De fato, para estruturas flexíveis, como as estruturas reforçadas com geotêxteis, análises deveriam ser baseadas no estado limite de utilização e não no estado limite último (CLAYBOURN; WU, 1993).

\subsubsection{2 . Métodos das tensões de serviço}

Uma das concepções para a previsão de tensões e deformações nos reforços são os métodos das tensões de trabalho mais recentes desenvolvidos por Allen et al. (2003), Miyata e Bathurst (2008), Ehrlich e Mitchell (1994). Estes consistem em métodos empíricos baseados em comportamentos de estruturas reais e modelos instrumentados. O método de Ehrlich e Mitchell (1994) pode ser aplicado para todos os tipos de sistemas reforçados, onde são consideradas as propriedades de rigidez do solo e do reforço, bem como tensões provenientes do processo de compactação. Do mesmo modo, o método $k$-stiffness (ALLEN et al., 2003) considera a influência das propriedades de rigidez dos diferentes materiais que compõe o sistema na tensão de tração transferida ao reforço. No entanto, tal método foi desenvolvido inicialmente para solos granulares utilizados em 11 muros de laboratório construídos em fundações rígidas, sendo que, posteriormente Miyata e Bathurst (2008) complementaram o método k-stiffness para obter previsões de tensões em estruturas com solos coesivos e atritivos utilizando dados de nove muros reais de solos finos de faces verticais. Essa nova aproximação acrescenta a influência da coesão de solos argilosos aos valores de tração máxima nos reforços. Valores de previsão de tensões de tração atuantes pelo método empírico $k$-stiffness modificado são obtidos pela seguinte formulação (Equação 2.5): 


$$
T_{\max }=\frac{1}{2} K \gamma(H+S) S_{v} D_{\text {tmax }} \Phi_{g} \Phi_{\text {local }} \Phi_{f s} \Phi_{f b} \Phi_{c}
$$

onde,

$\mathrm{S}_{\mathrm{v}}$ é a área tributária (assumida equivalente ao espaçamento vertical médio de reforço em cada camada quando as análises são feitas por unidade de comprimento do muro);

$\mathrm{K}$ é o coeficiente de empuxo em repouso para o aterro reforçado, podendo ser calculado pela formulação de Jaky;

H é a altura vertical da face do muro;

$\mathrm{S}$ é a sobrecarga média do solo;

$\mathrm{D}_{\text {tmax }}$ é o fator de distribuição empregado para estimar $\mathrm{T}_{\max }$ para cada camada, sendo uma função da profundidade abaixo do topo da estrutura relativo à $T_{\operatorname{maxmax}}$ (valor máximo de $\mathrm{T}_{\max }$ para toda a estrutura), e;

$\Phi_{\mathrm{g}}, \Phi_{\text {local }}, \Phi_{\mathrm{fs}}, \Phi_{\mathrm{fb}}$ são fatores de influência que consideram os efeitos da rigidez global e local dos reforços, rigidez da face e inclinação da face (ALLEN et al., 2003).

$\Phi_{c}$ é o fator coesão que visa considerar a influência deste parâmetro na força de tração máxima, que é dado por:

$$
\Phi_{c}=1-\lambda \frac{c}{\gamma H}
$$

em que,

c é a coesão do solo e $\lambda$ é o coeficiente de coesão $\lambda=6,5$.

A distribuição das forças máximas normalizadas $\left(\mathrm{D}_{\mathrm{tmax}}\right)$ ao longo da altura normalizada da estrutura estabelecida pelo método é apresentada na Figura 2.50.

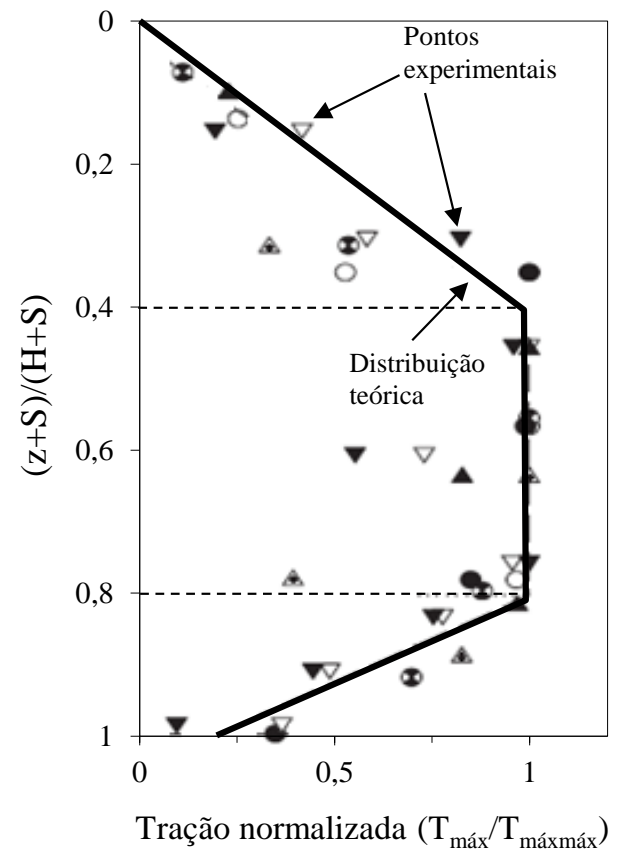

Figura 2.50. Distribuição de $D_{\text {tmax }}$ ao longo da altura normalizada para uma estrutura de solo reforçado com geossintético com c- $\varphi$ solos (MIYATA; BATHURST, 2008). 
Os valores previstos de força de tração máxima pelo método $k$-stiffness modificado apresentaram boa concordância com os dados reais; porém, quando comparados com os métodos convencionais de tensões de serviço, as forças de tração máximas são muito menores.

Outro método existente na literatura é o método das tensões de serviço de Erhlich e Mitchell (1994). Este consiste em um método para a verificação da estabilidade interna de muros em solo reforçado desenvolvido e avaliado com base em cinco muros de solo reforçado construídos com diferentes tipos de reforços. As características peculiares deste método, em comparação com os métodos convencionalmente utilizados, são que estes podem ser aplicados em diferentes sistemas de solos reforçado, em que diferentes propriedades de rigidez do solo e reforços podem ser consideradas, e as tensões de compactação do material de aterro são também consideradas nas análises. Segundo os autores, as tensões aplicadas durante a compactação promovem acúmulo de deformações e tensões mobilizadas fazendo que as tensões de serviço pósconstrução sejam pouco significantes. As determinações das tensões máximas utilizando este método são facilitadas pelo uso de ábacos desenvolvidos pelos autores.

\subsubsection{Método de compatibilidade de deformações}

Outro grupo de métodos de projetos são aqueles direcionados à compatibilidade de deformações do sistema solo-reforço (GOURC; RATEL; DELMAS, 1986; JEWELL; MILLIGAN, 1989; JURAN; HALIS; FARRAG, 1990), que consideram que em condições de serviço, a inclinação do reforço, a rotação da superfície de ruptura devido à presença do reforço e o deslocamento relativo na interface solo-reforço são parâmetros essenciais a serem considerados nas análises de estabilidade em diferentes níveis de deformações. Gourc et al. (1986) usaram o conceito de uma membrana ancorada, ilustrado na Figura 2.51, para analisar a influência da geometria ou a inclinação de um reforço na superfície de ruptura de modo a alcançar estimativas de tensões nos reforços em diferentes níveis de deformações. Os autores propuseram um método de compatibilidade de deslocamentos baseados nas seguintes suposições:

1. durante a construção, a zona ativa se movimenta ao longo da superfície de ruptura como um corpo rígido (rotação ou translação);

2. a resposta do reforço durante a construção é similar àquelas em uma membrana ancorada;

3. a deformabilidade de cada membrana geotêxtil satisfaz a compatibilidade de deformação durante a construção, com deslocamento cisalhante do solo ao longo da linha de ruptura;

4. a força de tração gerada na membrana geotêxtil elástica na superfície de ruptura é retida pelas porções do reforço na zona ativa e resistente que agem como ancoras; 
5. o método t-z, que é convencionalmente usado para projetos de estacas atritivas, tem sido adaptado para prever, por meio de compatibilidade de deslocamentos, o deslocamento do ponto de ancoragem induzido pela força de tração gerada;

6. avaliação da deformação local $\beta$ do reforço na superfície potencial de ruptura é baseada no conceito de módulo de reação lateral de uma fundação elástica. No entanto, valores relevantes de módulos de reação são de difícil obtenção. Para simplificação, Gourc et al. (1986) consideram dois casos limites assumindo que pequenos deslocamentos da membrana geotêxtil permanecem horizontais, enquanto para grandes deslocamentos o reforço torna-se tangencial à superfície de ruptura.

7. a posição da superfície potencial de ruptura é obtida usando a teoria de limite equilíbrio de Coulomb para a definição da ruptura translacional, e a estabilidade convencional pelo método das fatias para ruptura rotacional. As forças de tração são calculadas para proporcionar uma força resistente adicional ou momentos de modo a manter o equilíbrio da zona ativa com um fator de segurança aceitável.

a)

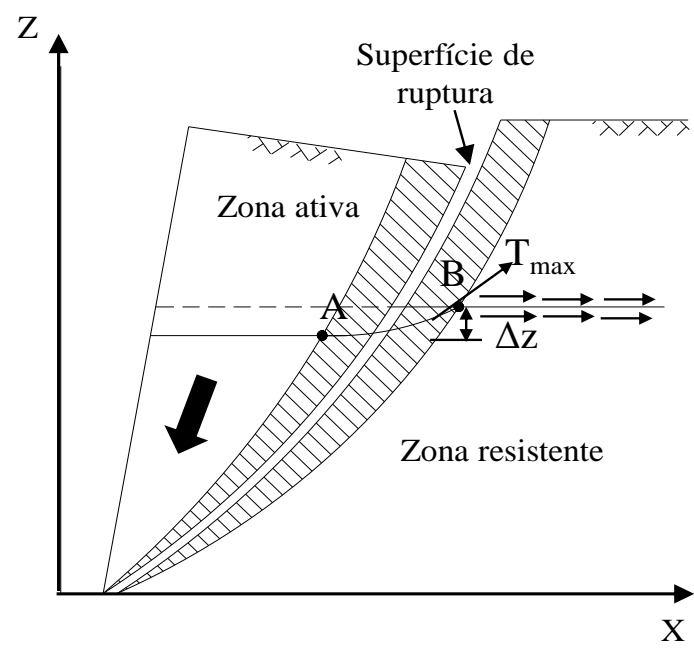

b)

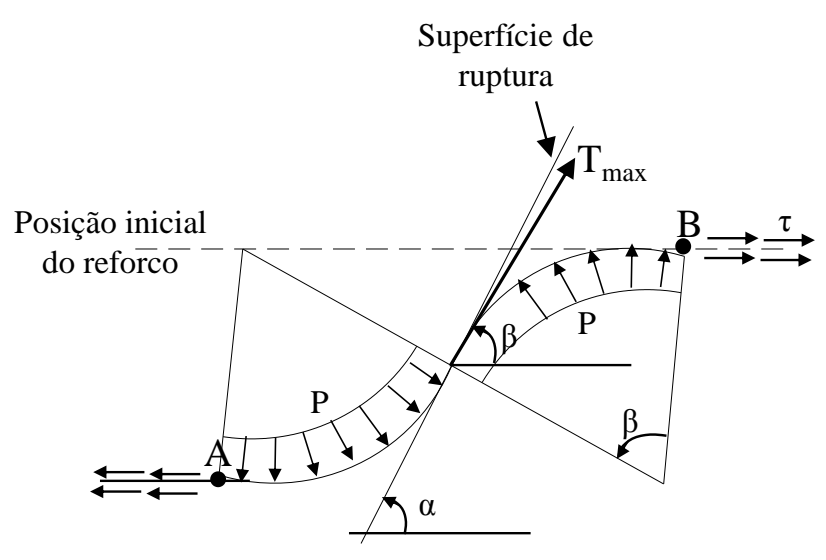

Figura 2.51. Conceito de membrana ancorada em reforços geotêxteis (GOURC; RATEL; DELMAS, 1986).

Juran et al. (1990) complementou essa aproximação analítica usando considerações em torno da relação constitutiva do solo, reforço, relação tensão x deformação, interação solo/reforço, trajetória de deformações e efeitos da construção nas deformações iniciais. Esta aproximação é direcionada a reforços extensíveis, em que um modelo de transferência de carga que associa uma deformação elasto-plástica rígida do solo, resposta perfeitamente elasto-plástica dos reforços, e uma perfeita aderência de interface é usada para calcular a força de tração transmitida nos reforços durante a construção. O sistema de transferência de carga permite uma avaliação da extensibilidade do reforço e da dilatância do solo na geração das forças de tração. A Figura 2.52 ilustra uma analogia do comportamento do geotêxtil. Este modelo foi bem avaliado por meio de 
simulações numéricas de compressão triaxial e ensaios de cisalhamento direto por muitos pesquisadores (LONG; GUEGAN; LEGEAY, 1972; JEWELL, 1980; GRAY; OHASHI, 1983; GRAY; REFAI, 1986), em amostras de areia reforçadas com diferentes tipos de inclusões.

a)

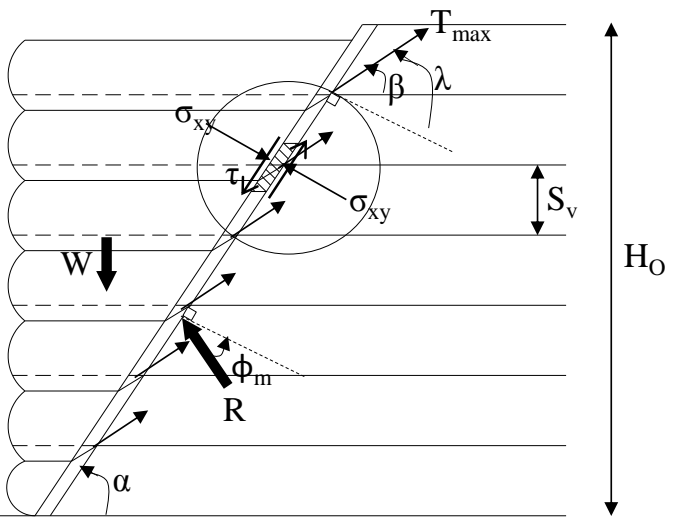

b)

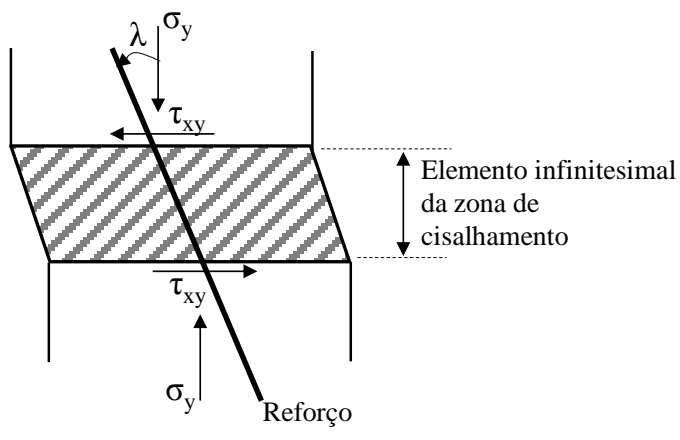

Figura 2.52. Analogia esquemática do comportamento do geotêxtil em muros de solo reforçados (JURAN; HALIS; FARRAG, 1990).

Este modelo analítico tem maior vantagem com relação às análises de equilíbrio limite pelo fato de que o modelo de transferência de cargas permite a avaliação dos efeitos da extensibilidade do reforço e da dilatância do solo nas forças de tração. No entanto, as condições de contorno, assim como equilíbrio de tensões em cada ponto ao longo da superfície de ruptura, não são inclusos na formulação (JURAN; HALIS; FARRAG, 1990). Assim, torna-se bastante difícil computar este modelo de análise, fazendo com que não seja corriqueiramente utilizado em projetos convencionais de estruturas reforçadas.

\subsubsection{Métodos numéricos}

Diversas análises numéricas também foram apresentadas na literatura baseada em métodos de elementos finitos (BLIVET; JOUVE; MAILLOT, 1986; COLLIN, 1986; CHALATURNYK; CHAN; SCOTT, 1988; CHEW; SCHMERTMANN; MITCHELL, 1990; HELWANY, 1992; KARPURAPU; BATHURST, 1992; YOGARAJAH; ANDRAWES, 1994; ROJAGOPAL; BATHURST, 1994; HO; ROWE, 1996; LING et al., 2000; YOO et al., 2006) e diferenças finitas (LESHCHINSKY; VULOVA, 2002; HATAMI; BATHURST, 2005; HATAMI; BATHURST, 2006).

\subsubsection{Projeto de drenagem interna utilizando geotêxteis não tecidos}

\subsubsection{Capacidade de fluxo de água no plano de geotêxteis}

Em muros de solos finos reforçados com geotêxteis não tecidos em que se busca a melhoria da drenagem interna adicionalmente à função de reforço, duas análises devem ser 
consideradas: análises de estabilidade e análises do comportamento hidráulico. As análises de estabilidade já foram devidamente discorridas nos tópicos anteriores. As análises quanto à drenagem do sistema solo-geotêxtil não são corriqueiras e não existem metodologias direcionadas.

Ao que se refere à contribuição do comportamento hidráulico de geotêxteis não tecidos na drenagem interna de estruturas de solo reforçado, a transmissividade do reforço passa a ser um parâmetro de fundamental importância. Existem métodos padronizados para a determinação da transmissividade de geossintéticos (ASTM D4716, 2008, NBR 15225, 2005), que forçam o fluxo de água sob carga hidráulica constante no plano do geossintético confinado por dois pratos rígidos. No entanto, este, muitas vezes, não reproduz a verdadeira condição do material no campo, principalmente a respeito do confinamento do geossintético no solo, que vem a ser uma importante variável no comportamento drenante de geotêxteis não tecidos.

Um sistema de ensaio capaz de medir a transmissividade sob carga constante e diferentes tensões de confinamento em solo, membrana e placa rígida foi descrito por Ling et al. (1993). A Figura 2.53 apresenta a influência da tensão normal e da condição de confinamento na condutividade hidráulica no plano de geotêxteis não tecidos. Como esperado, a condutividade depende da tensão normal efetiva e da interface que confina o material. Neste caso, os menores valores de condutividade hidráulica foram obtidos na interface do reforço confinado com solo, que está associado à penetração das partículas na estrutura do material. Portanto, ensaios que utilizam placas rígidas superestimam o valor de condutividade hidráulica ao longo do plano dos geotêxteis.

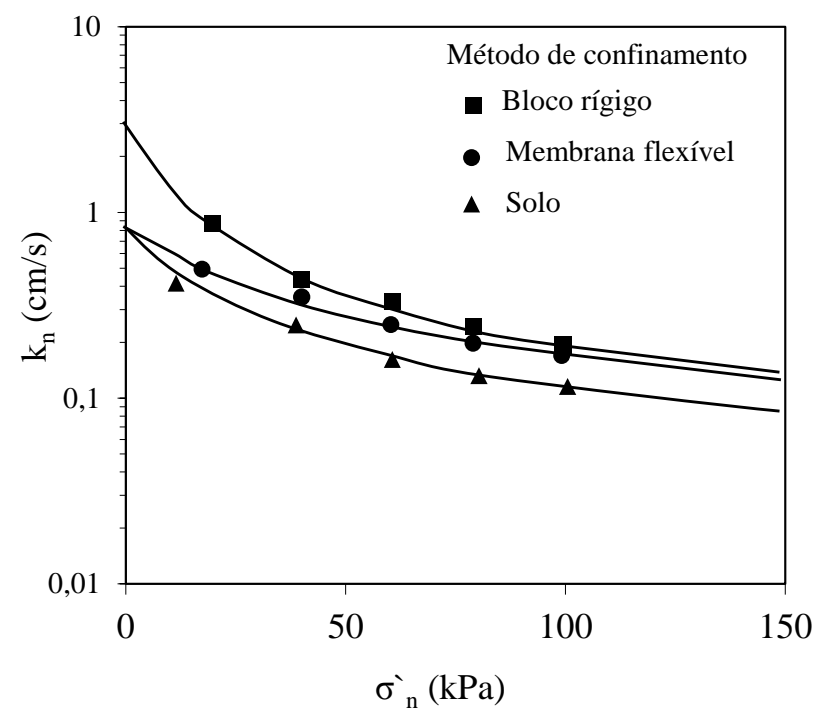

Figura 2.53. Relação entre coeficiente de permeabilidade no plano de geotêxteis não tecidos e diferentes tensões e condições de confinamento (adaptado de LING et al., 1993).

Ling et al. (1993) também investigaram a condutividade hidráulica ao longo do plano de geotêxtil não tecido comparado com um geocomposto (tecido com não tecido) sob condições típicas de operação, ou seja, sob confinamento. As análises permitiram a elaboração de uma formulação que permite incluir o efeito do confinamento na transmissividade destes materiais. A 
condutividade hidráulica dos geotêxteis confinados $(0,8$ a $0,1 \mathrm{~cm} / \mathrm{s})$ foi significantemente maior que a obtida para o geocomposto $(0,1$ e $0,01 \mathrm{~cm} / \mathrm{s})$, e o efeito do confinamento chegou às reduções na ordem de 10 vezes, com relação aos ensaios não confinados. Ainda, condutividades determinada em amostras extraídas de um aterro experimental foram menores quando comparadas com amostras virgens, sendo esta diferença ainda maior para maiores tensões de confinamento. Tal comportamento foi atribuído à penetração e retenção das partículas nos geotêxteis, que proporcionou reduções na porosidade. Os resultados deste estudo são apresentados na Figura 2.54.

Verifica-se, portanto, a influência da penetração das partículas de solo na condutividade. No caso de não ser possível a obtenção destes parâmetros sob o confinamento com o solo a ser utilizado, recomenda-se a adoção dos parâmetros dos ensaios padronizados, porém, a redução deste deve ser efetuada, uma vez que a condição de confinamento em bloco rígido superestima o valor de condutividade. A magnitude desta redução não foi ainda devidamente estudada e merece a atenção dos pesquisadores. Baseados nos ensaios relatados por Ling et al. (1993) este fator de redução seria da ordem de 3 vezes.

a)

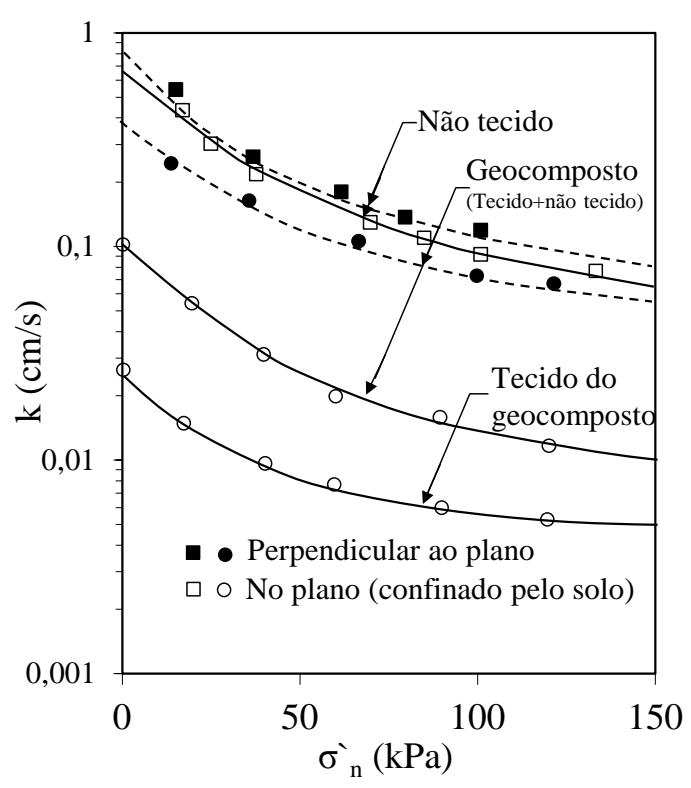

b)

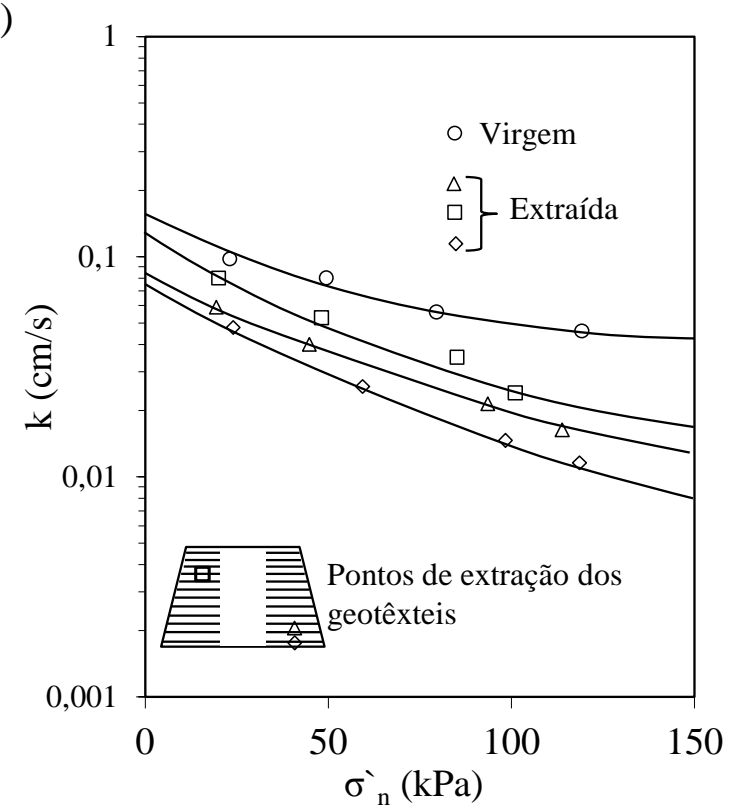

Figura 2.54. Relação entre coeficiente de permeabilidade e condições de confinamento: (a) condutividade hidráulica ao longo do plano de geotêxteis; (b) comparação entre amostras extraídas no campo e amostras virgens (LING et al., 1993).

Outro aspecto importante é o equilíbrio hidráulico do dreno a longo prazo devido à colmatação pelas partículas do solo. Uma consideração preliminar da capacidade drenante a longo prazo poderia ser realizada utilizando o mesmo fator de redução que levam em consideração a colmatação física de drenos a longo prazo, ou uma extensão do critério de resistência a colmatação de filtros geotêxteis elaborados por Christopher e Fisher (1992). 


\subsubsection{Análises da dissipação das pressões da água}

A distribuição das pressões da água em estruturas de solos reforçado é de difícil previsão, uma vez que o solo apresenta-se normalmente em condições não saturadas. Porém, considerar a condição crítica de que o solo apresenta-se totalmente saturado pode vir a ser uma aproximação segura nas análises da distribuição e velocidade de dissipação das pressões da água no interior do maciço. Este consideração conservadora nos direciona aos métodos teóricos tradicionais, como a teoria de adensamento de Terzaghi, que possibilita estimar a transmissividade requerida dos geotêxteis e a velocidade de dissipação das pressões da água pós-construção.

Tan et al. (2001) verificou que as pressões da água positivas desenvolvidas nas configurações que não usaram reforços impermeáveis foram dissipadas duas vezes mais lentamente quando comparadas ao ensaio com o geotêxtil embutido. Ainda, os níveis de pressões da água e a velocidade de dissipação destes ao longo dos reforços foram consistentes com os valores previstos pela teoria de adensamento unidimensional de Terzaghi, como mostra a Figura 2.55. Pesquisas mais recentes, como a de Raisinghani e Viswanadham (2010), chegaram a conclusões bastante semelhantes.
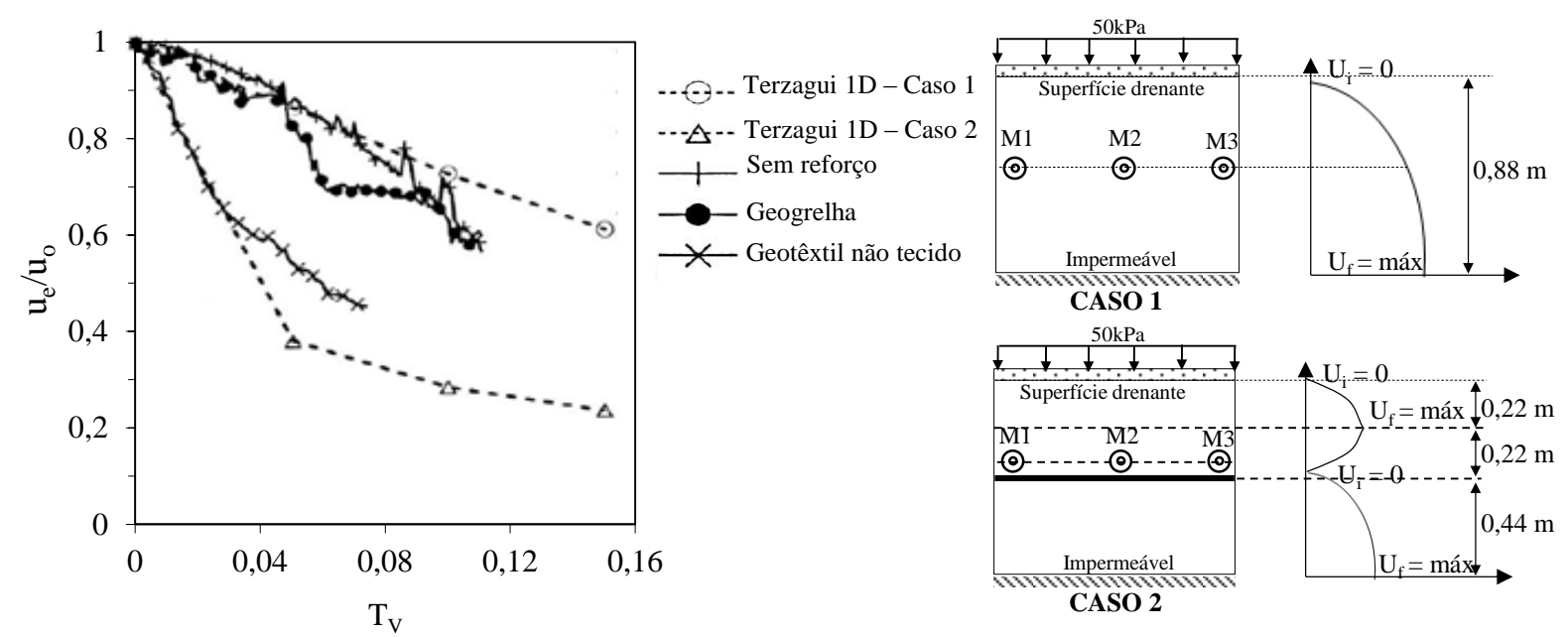

Figura 2.55. Dissipação das pressões da água em diferentes condições de drenagem (TAN et al., 2001).

Auriault et al. (1977) apresentaram um tratamento teórico para o adensamento de camadas saturadas localizada entre camadas de reforços permeáveis. A geometria considerada neste estudo é uma camada localizada entre dois geotêxteis não tecidos. A teoria de adensamento unidimensional de Terzaghi foi considerada, e o sistema de equações diferenciais parciais que modela o problema foi resolvido analiticamente. As taxas calculadas de consolidação foram consideradas assumindo dois casos diferentes: espessura constante de drenagem do geotêxtil; e a compressibilidade do geotêxtil. Exemplos numéricos mostraram que um geotêxtil não tecido típico (transmissividade de $6,6 \times 10^{-6} \mathrm{~m}^{2} / \mathrm{s}$ ), instalados com 2 metros de espaçamento vertical, trabalharia como um dreno perfeito para um solo argiloso. A mesma metodologia foi utilizada por Giroud (1983) e conclusões muito semelhantes foram observadas, mostrando que a taxa de 
construção, comprimento do geotêxtil, e a condutividade hidráulica e coeficientes de consolidação do solo são os fatores que controlam o adensamento de camadas reforçadas com geotêxteis não tecidos. Portanto, o critério para a seleção de geotêxteis na drenagem interna de estruturas reforçadas pode ser implementado para aplicações práticas de projeto utilizando de conceitos tradicionais da mecânica dos solos.

\subsubsection{Efeito da drenagem lateral na estabilidade}

O efeito da drenagem interna na estabilidade de estruturas de solos finos reforçados favorece em dois aspectos: promover um aumento na resistência do solo ao longo da superfície de ruptura; e, melhorias na resistência ao arrancamento com o tempo. No entanto, a maioria dos casos relatados não considera o aumento da estabilidade com o tempo proporcionado pelos reforços permeáveis.

Poucos são os casos que levam em conta o efeito do aumento da estabilidade com o tempo em materiais argilosos devido à aceleração do adensamento do solo com uso de reforços permeáveis, como a análise descrita por Yamanouchi et al. (1982) de um aterro de $32 \mathrm{~m}$ usando uma técnica especial chamada de multiple strip-sandwich, que usa cal e filtros de geotêxteis. Embora as análises de estabilidade não incorporem nenhuma resistência à tração às camadas de filtro, a resistência de solos coesivos foi considerada maior devida ao adensamento do solo. Camadas de cal viva de $50 \mathrm{~mm}$ de espessura, entre duas mantas de geotêxteis não tecidos, foram localizadas em camadas horizontais de solo argiloso. A ação combinada da hidratação da cal e absorção da água proporcionou a retirada da água e, consequentemente, o adensamento do solo e o aumento da resistência ao cisalhamento. A estabilidade foi calculada utilizando métodos das fatias, considerando a superfície circular de ruptura, e levando em consideração o aumento da resistência não drenada do solo coesivo com o tempo e com o progresso do adensamento. $\mathrm{O}$ ganho de resistência com o tempo foi estimado usando a média de grau de adensamento proporcionado pela drenagem de água. Depois de completar a construção do aterro, orifícios foram escavados de modo a acessar a efetividade do método aplicado. Inclinômetros indicaram nenhum movimento horizontal significativo no aterro mesmo após eventos de chuvas intensas.

Outro caso que relata o ganho de resistência em aterros argilosos devido à consolidação proporcionada por reforços não tecidos foi relatado por Yunoki e Nagao (1988) para um talude de 20 metros de altura construídos no Japão, utilizando solos argilosos. Geotêxteis não tecidos foram utilizados tanto para reforço como para acelerar a consolidação do solo. Os autores empregaram o método das fatias e superfícies circulares para análises de estabilidade do talude, onde verificaram o ganho de resistência devido à consolidação.

Baseadas nas constatações observadas até o momento, a Figura 2.56 mostra a possível distribuição das pressões da água ao longo da superfície de cisalhamento nas proximidades de um dos reforços drenos, em dois diferentes tempos após a construção. A dissipação do excesso das pressões da água causa um aumento nas tensões efetivas ao longo da superfície potencial de 
deslizamento que resulta no aumento da resistência ao cisalhamento do solo e, consequentemente, maiores fatores de segurança como tempo. A dissipação das pressões da água ao longo do reforço $\left(\mathrm{u}_{\mathrm{f}}\right)$ aumenta também as tensões efetivas ao longo do comprimento de ancoragem dos reforços, aumentando a resistência ao arrancamento.

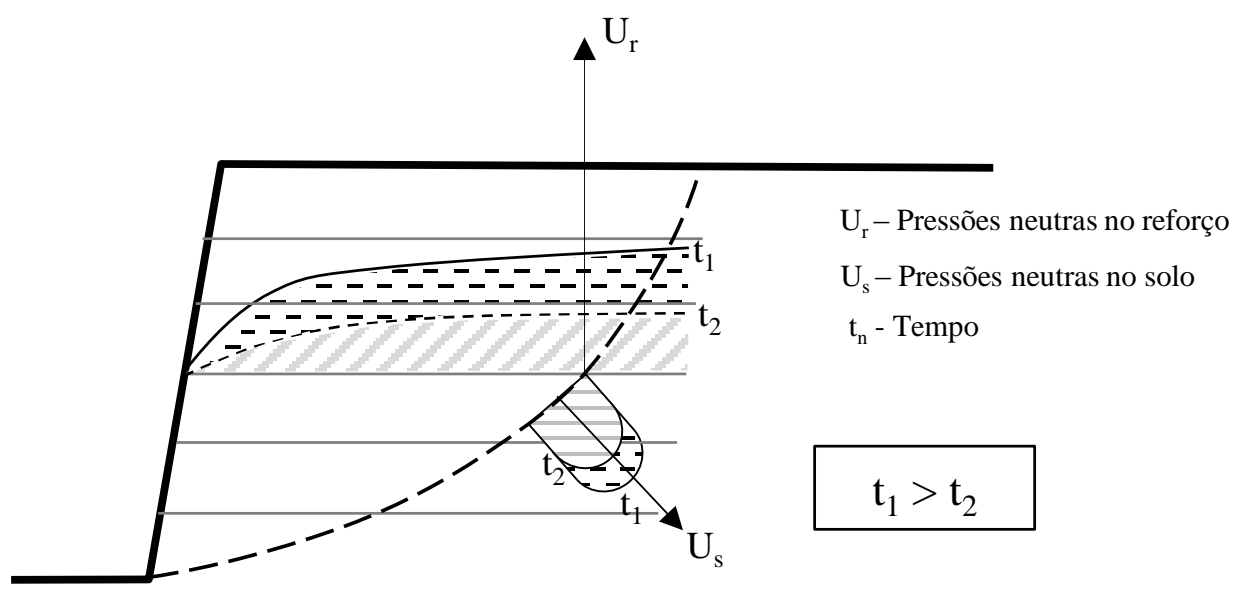

Figura 2.56. Efeito das pressões da água na estabilidade de uma estrutura reforçada com materiais permeáveis (adaptado de ZORNBERG; MITCHELL, 1994). 
CAPÍtULO 3

\section{REVISÃO DE LITERATURA - PARTE II}

\section{COMPORTAMENTO HIDRÁULICO DE ESTRUTURAS DE SOLO REFORÇADO COM GEOTÊXTEIS NÃO TECIDOS}

Conforme relatado, a infiltração de água consiste na principal preocupação de estruturas de solos finos reforçados, por prejudicar não somente a resistência e a deformabilidade do solo, mas também a interface solo-reforço. Portanto, torna-se importante conhecer o comportamento hidráulico destas estruturas nas reais condições de saturação do solo do aterro. Geralmente, as condições não saturadas ou parcialmente saturadas são mais comuns, devido aos ciclos de umedecimento e secagem impostos pelas condições climáticas no campo. Neste tópico, serão apresentadas as variáveis comumente usadas para quantificar os aspectos hidráulicos de solos e de interfaces solo-geotêxteis nas condições não saturadas.

\subsection{Características hidráulicas de solos e geotêxteis não tecidos não saturados}

\subsubsection{Curva de retenção de água e funções $K$}

As características hidráulicas dos solos e geotêxteis são significativamente influenciadas pela quantidade relativa de água e ar nos vazios da estrutura. As propriedades índices que indicam estas quantidades são o teor de umidade gravimétrico $(\mathrm{w})$, que é a massa de água $\left(\mathrm{M}_{\mathrm{w}}\right)$ dividida pela massa de sólidos $\left(\mathrm{M}_{\mathrm{s}}\right)$, e o teor de umidade volumétrico $(\theta)$, sendo o volume de água $\left(\mathrm{V}_{\mathrm{w}}\right)$ dividido pelo volume total $\left(\mathrm{V}_{\mathrm{T}}\right)$. $\mathrm{O}$ teor de umidade volumétrico é tipicamente utilizado para quantificar mudanças no armazenamento de água nos vazios de solo, embora esse seja limitado quando utilizado na avaliação de materiais rígidos como solos compactados ou sobre consolidados, uma vez que o volume total $\left(\mathrm{V}_{\mathrm{T}}\right)$ pode sofrer mudanças devido ao fluxo de água. Nestas situações, o teor de umidade gravimétrico e o índice de vazios podem ser utilizados juntamente, uma vez que a massa de sólidos não se altera com o fluxo de água nos vazios do solo.

Em solos não saturados, a água é aprisionada nos vazios pela combinação de pressões de absorção e capilaridade (OLSON; LANGFELDER, 1965). As pressões capilares, que compõem grande porção das pressões aprisionadoras, são definidas como a diferença entre a pressão de ar e a pressão de água nos poros, que implica em meniscos individuais entre as partículas do solo, promovendo uma atração interpartículas chamada de sucção matricial $(\psi)$. A magnitude destas forças intergranulares é dependente da quantidade de água aprisionada, ou seja, do teor de umidade do solo. Essa diferença entre a pressão de ar e pressão de água nos vazios do solo 
consiste na sucção matricial do solo. Esta diferença de pressão entre diferentes meios implica em um menisco convexo ar/água entre as partículas dos solos ou fibras geossintéticas (HENRY; PATTON, 1998). Consequentemente, a pressão de ar é maior do que a pressão de água, resultando numa pressão da água negativa quando o ar encontra-se sob a pressão atmosférica. Uma analogia bastante usual que ilustra a influência dos tamanhos dos poros na sucção matricial pode ser observada na ascensão capilar em uma pipeta. Neste caso, a sucção matricial ( $\psi)$ é dada pela Equação 3.1:

$$
\psi=P_{a}-P_{w}=h_{c} \rho_{w} g=\frac{2 \sigma_{a w} \cos \gamma}{R}
$$

onde $\mathrm{P}_{\mathrm{a}}$ é a pressão de ar nos poros, $\mathrm{P}_{\mathrm{w}}$ é a pressão de água nos poros, $\mathrm{h}_{\mathrm{c}}$ é a altura de ascenção capilar na pipeta de raio $\mathrm{R}, \rho_{\mathrm{w}}$ é a densidade da água, g é a aceleração da gravidade, $\sigma_{\mathrm{aw}}$ é a tensão superficial entre a água e o ar, and $\gamma$ é o ângulo de contato de umedecimento (tipicamente $10^{\circ}$ para minerais de quartzo). A Equação 3.1 assume que o ar está sob pressão atmosférica $\left(\mathrm{P}_{\mathrm{a}}=0\right)$, e indica que a sucção é inversamente proporcional ao raio dos poros, sendo que todas as outras variáveis são constantes. Portanto, fazendo uma analogia dos vazios do solo com o raio da pipeta, pode-se afirmar que para o mesmo teor de umidade volumétrico, um solo fino terá maiores valores de sucção em comparação à solos granulares ou geotêxteis não tecidos. Contudo, pode-se dizer que a relação entre o teor de umidade e a sucção está totalmente relacionada à distribuição do tamanho dos poros.

A relação entre o teor de umidade e a sucção matricial é corriqueiramente definida pela curva de retenção de água do material geotécnico, exemplificados na Figura 3.1a. Os comportamentos descritos pelas curvas de retenção de água dos solos e de geotêxteis não tecidos consistem no principal fator de influência na infiltração e fluxo de água no solo. Cabe observar que a forma da curva de retenção do solo é dependente de diferentes aspectos tais como: granulometria, tamanho dos vazios do solo, mineralogia, densidade e estrutura do solo (OLSON; LANGFELDER, 1965; TINJUM; BENSON; BLOTZ, 1997; MILLER et al., 2002). A curva de retenção de água dos solos pode mostrar diferentes formas quando determinadas por procedimentos de umedecimento e secagem de amostras, devido ao fenômeno de histerese (POULOVASILIS, 1962; TOPP; MILLER, 1966). No entanto, em geotêxteis não tecidos, o processo de umedecimento e secagem pode influenciar mais significativamente na forma da curva. As curvas de retenção típicas dos processos de umedecimento e secagem de geotêxteis são apresentadas na Figura 3.1b. 
a)

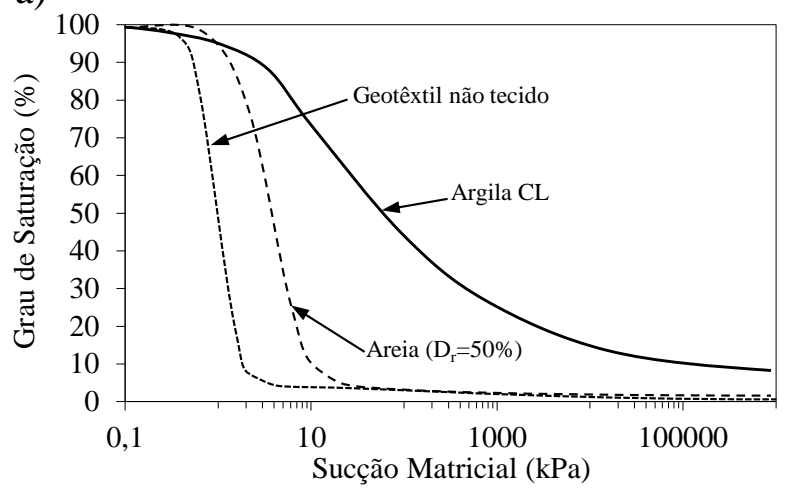

$\mathrm{b}$

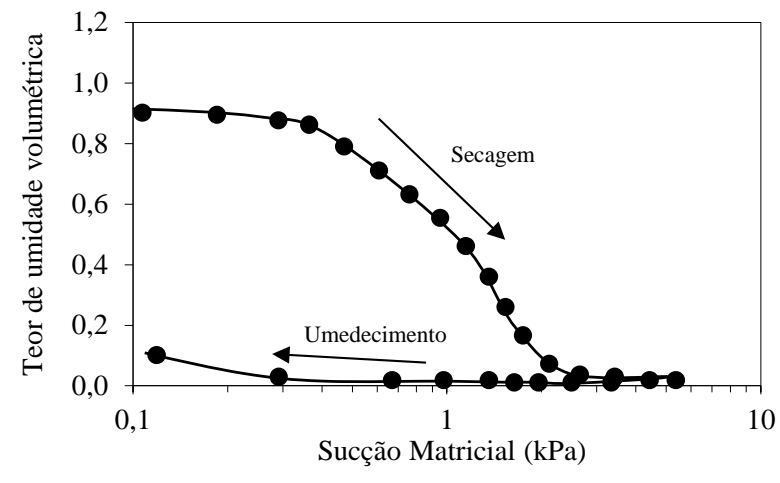

Figura 3.1. Relação entre o teor de umidade e a sucção matricial: (a) curva de retenção de água típica de solos e geotêxtil não tecido (MCCARTNEY; KUHN; ZORNBERG, 2005); (b) típico comportamento nos processos de secagem e umedecimento dos geotêxteis (BOUAZZA et al., 2006).

Diferentes métodos têm sido utilizados para determinação de pontos experimentais da curva de retenção de água de solos e geotêxteis, podendo ser estes por coluna de pressão (STORMONT; HENRY; EVANS, 1997; KLUTE, 1986; MCCARTNEY; KUHN; ZORNBERG, 2005; BOUAZZA et al., 2006), panelas de pressão (ASTM D6836, 2003); KNIGHT; KOTHA, 2001) e outros (WAN; BENSON, 2004). Os dados experimentais são tipicamente ajustados com funções hiperbólicas e polinomiais, tais como as reportadas por Brooks e Corey (1964), van Genuchten (1980) e Fredlund e Xing (1994). O modelo de van Genuchten (1980) consiste no mais utilizado atualmente em análises numéricas e é determinado pela Equação 3.2:

$$
\theta=\theta_{r}+\left(\theta_{s}-\theta_{r}\right)\left[1+(\alpha \psi)^{N}\right]^{-\left(1-\frac{1}{N}\right)}
$$

onde $\theta_{\mathrm{r}}$ é o teor de umidade residual, $\theta_{\mathrm{s}}$ é teor de umidade na saturação (porosidade), e $\mathrm{N}$ e $\alpha$ $\left(\mathrm{kPa}^{-1}\right)$ são parâmetros de ajuste. Estas funções podem também ser utilizadas para ajuste de dados experimentais de curva de retenção de água de geotêxteis comparados a materiais granulares (BOUAZZA et al., 2006).

A umidade armazenada nos vazios do solo depende da sua curva de retenção de água. A capacidade de armazenamento de água por unidade de área pode ser estimada multiplicando-se o teor de umidade volumétrica, para uma dada sucção, pela espessura da camada de solo. O limite máximo de armazenamento é a porosidade (n), enquanto o limite mínimo é o teor de umidade residual. Outro valor de armazenamento bastante utilizado é a "capacidade de campo", que consiste no teor de umidade do solo mantido durante infiltração devido ao efeito da gravidade (HILLEL, 1980). Quando água é adicionada ao solo na capacidade de campo, a drenagem ocorre. A capacidade de campo pode ser obtida por ensaios de condutividade hidráulica, embora o teor de umidade correspondente à sucção de $33 \mathrm{kPa}$ é geralmente utilizado em análises de infiltração (NACHABE, 1998). 


\subsubsection{Funções-k}

A condutividade hidráulica de solos e geossintéticos não saturados é totalmente associada à forma da curva de retenção de água. Ao contrário da permeabilidade de solos saturados, esta diminui com a diminuição da umidade do solo. Esta diminuição é quantificada pela função de condutividade hidráulica dos solos $\mathrm{k}(\theta)$, também chamadas funções-K, que consideram as variações na vazão e no gradiente hidráulico devido ao decréscimo do teor de umidade (ou aumento da sucção). Funções típicas de condutividade hidráulica de solos e geotêxteis são ilustradas na Figura 3.2.

Nota-se que, próximo da saturação, materiais com maiores vazios (areia e geotêxteis não tecidos) apresentam valores de condutividade hidráulica maiores que os solos mais finos. No entanto, o material granular passa a ser menos permeável do que os solos finos sob maiores valores de sucção (maior que $10 \mathrm{kPa}$ ). Isso pode ser explicado pela forma da curva de retenção de água de cada material. Materiais mais finos podem reter mais água sob elevadas sucções, disponibilizando mais caminhos para o fluxo de água. A areia e o geotêxtil não tecido apresentam a saturação residual para sucções maiores que $10 \mathrm{kPa}$. Então, poucos caminhos são disponíveis para o fluxo de água.

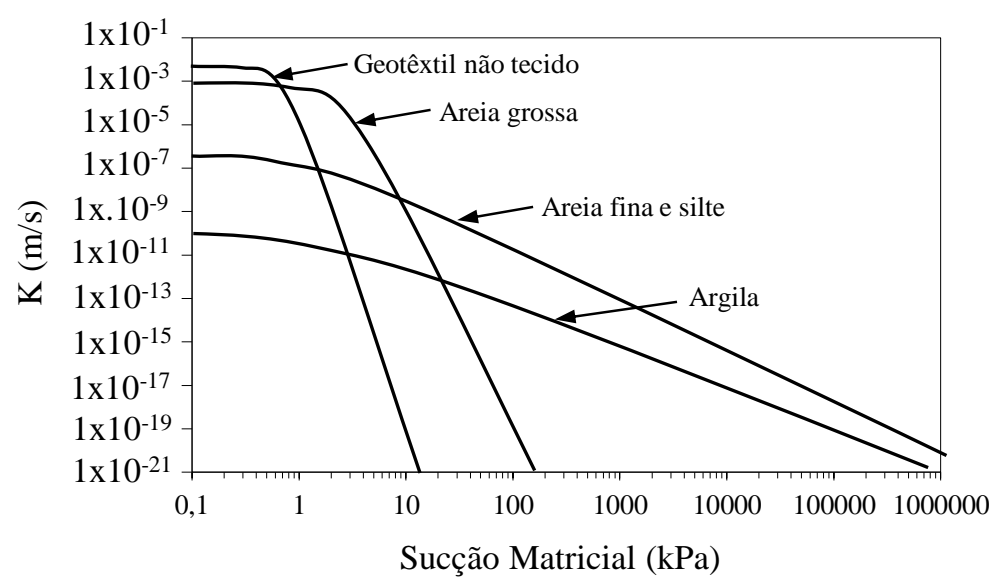

Figura 3.2. Funções típicas de condutividade hidráulica não saturada para diferentes materiais (ZORNBERG; BOUAZZA; MCCARTNEY, 2010).

A condutividade hidráulica de solo com níveis elevadíssimos de sucção é muito difícil de ser mensurada e pode ser igual a zero para valores de sucção abaixo da saturação residual. Alguns trabalhos tentaram medir valores de condutividade hidráulica sob elevados valores de sucção. Uma tentativa experimental realizada por Conca e Wright (1992) resultou em valores abaixo de $10^{-12} \mathrm{~m} / \mathrm{s}$. No caso de solos argilosos, elevadíssimos valores de sucção podem vir a promover a dessecação do solo e trincá-lo. Neste caso, o fluxo de água nos vazios originais dos solos são insignificantes comparados com o fluxo de água através das trincas. Por tais motivos, a condutividade não saturada é determinada por meio das funções-k. 
$\mathrm{Na}$ determinação das funções-k em materiais geotécnicos não saturados, a condutividade hidráulica na condição saturada ( $\psi=0$ e $\phi=n$ ) é o parâmetro fundamental (MITCHELL; HOOPER; CAMPANELLA, 1965; OLSON; DANIEL, 1981), sendo este o único valor obtido experimentalmente, enquanto métodos semi-empíricos são utilizados para a previsão do resto da função. Diversas são as funções de condutividade hidráulica dos solos não saturados existentes na literatura (CHILDS; COLLIS-GEORGE, 1950; BURDINE, 1953; GARDNER, 1958; MILLINGTON; QUIRK, 1961; BROOKS; COREY, 1964; MUALEM, 1976; VAN GENUCHTEN, 1980). O modelo de previsão da função-k mais comumente utilizado é obtido pela substituição do modelo de Mualem (1976) no modelo de van Genuchten (1980) para ajuste de curva de retenção de água, conforme segue na Equação 3.3:

$$
k(\theta)=k_{s} \sqrt{\frac{\theta-\theta_{r}}{\theta_{s}-\theta_{r}}\left[1-\left(1-\left(\frac{\theta-\theta_{r}}{\theta_{s}-\theta_{r}}\right)^{1-N_{V G}}\right)^{\frac{1}{1-N_{V G}}}\right]^{2}}
$$

onde NVG consiste no parâmetro de ajuste dos pontos experimentais da curva de retenção de água proposto por van Genuchten (1980).

Existem ainda modelos estatísticos baseados na distribuição dos tamanhos dos poros, com intuito de prever a condutividade hidráulica com base na curva de retenção de água dos solos (CHILDS; COLLIS-GEORGE, 1950; BURDINE, 1953; MILLINGTON; QUIRK, 1961). Estas aproximações consideram que o solo consiste em séries interconectadas de poros com tamanhos caracterizados pela forma da curva de retenção da água.

\subsubsection{Infiltração em estruturas reforçadas com geotêxteis}

\subsubsection{Fluxo de água em meios não saturados}

O fluxo de água em meios não saturados é mais complexo do que em meios saturados, o que é atribuído as variações na permeabilidade com a sucção do solo durante um evento de fluxo de água. Consequentemente, quantidades relativas de ar e água nos poros influenciam significativamente no comportamento hidráulico dos solos.

Um sistema unidimensional (1-D), representando uma camada de solo de espessura $\mathrm{L}_{\mathrm{p}}$, com fluxo de água passando no sentido vertical orientado para baixo, é apresentado na Figura 3.3. A referência é dada na base da camada de solo, com $\mathrm{z}_{\mathrm{p}}$ sendo a altura referente a base do sistema. Como $\mathrm{z}_{\mathrm{p}}$ é orientado pra cima, uma velocidade de descarga positiva $v_{\mathrm{p}}$ é designada pra cima. 


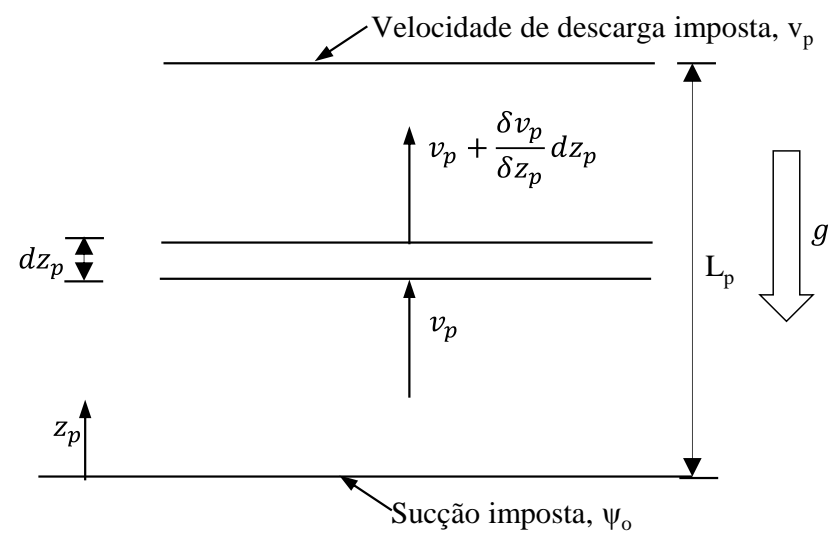

Figura 3.3. Esquema de infiltração em camada de solo não saturada (McCARTNEY, 2007).

O gradiente hidráulico (i) da lei de Darcy reflete a mudança na carga hidráulica sob um comprimento diferencial $\partial \mathrm{z}_{\mathrm{p}}$. Neste caso, a lei de Darcy pode ser expressa pela Equação 3.4:

$$
Q=-K\left(\frac{\partial h}{\partial z_{p}}\right) A
$$

onde: k é o coeficiente de permeabilidade de Darcy, i é o gradiente hidráulico, A é a área da seção perpendicular a direção do fluxo e h é a carga hidráulica total. Ainda, uma forma modificada da equação de Bernoulli pode ser utilizada para definir as diferentes componentes de h:

$$
h=z_{p}+\frac{1}{2 g}\left(\frac{v_{p}}{n}\right)^{2}+\frac{P_{o}}{\rho_{w} g}+\frac{P_{w}}{\rho_{w} g}
$$

onde $v_{\mathrm{p}}$ refere-se como a velocidade de escoamento igual a $\mathrm{Q} / \mathrm{A}, \mathrm{n}$ é a porosidade, $\mathrm{P}_{\mathrm{o}}$ é a pressão na água devido ao gradiente osmótico, e $\mathrm{P}_{\mathrm{w}}$ é a pressão devido ao peso da água. $\mathrm{O}$ termo $v_{\mathrm{p}} / \mathrm{n}$ refere-se a velocidade de escoamento, e reflete o aumento local na velocidade de descarga como fluxo de água envolta das partículas. Na Equação 3.5, os quatro termos a direita correspondem à carga energética potencial (ou carga de elevação ou altimétrica), carga cinética, carga de pressão osmótica e carga de pressão da água. A velocidade de escoamento é pequena para os solos (tipicamente menor que $10^{-7} \mathrm{~m} / \mathrm{s}$ para solos finos), direcionando a uma contribuição insignificante da energia cinética na carga hidráulica total. A pressão osmótica consiste na tendência da concentração de eletrólitos na água intersticial de alcançar um equilíbrio termodinâmico. Como se assume que a concentração de eletrólitos não altera significantemente com as mudanças do teor de umidade, considera-se que a pressão osmótica não contribui para o gradiente hidráulico. Assumindo que a pressão de ar é igual a zero e negligenciando-se as contribuições da pressão osmótica e da velocidade de escoamento, a carga hidráulica total pode ser simplificada pela Equação 3.6:

$$
h=z_{p}-\frac{\psi}{\rho_{w} g}=h_{e}+h_{p}
$$


onde $\mathrm{h}$ é a carga hidráulica total em unidade de comprimento, $\mathrm{h}_{\mathrm{e}}=\mathrm{z}_{\mathrm{p}}$ é a carga de elevação, e $\mathrm{h}_{\mathrm{p}}=-\psi / \rho_{\mathrm{wg}}$ é a carga de sucção. O gradiente da carga hidráulica em termos de $\mathrm{z}_{\mathrm{p}}$ é dado pela Equação 3.7:

$$
\frac{\partial h}{\partial z_{p}}=1-\frac{1}{\rho_{w}} \frac{\partial \psi}{\partial z_{m}}
$$

Portanto, a velocidade de descarga pode ser calculada usando a equação acima e a lei de Darcy, como segue na Equação 3.8:

$$
v_{p}=-k(\psi)\left(1-\frac{1}{\rho_{w} g} \frac{\partial \psi}{\partial z_{p}}\right)
$$

O princípio da continuidade no controle de volume pode ser expresso pela Equação 3.9:

$$
\frac{\partial \theta(\psi)}{\partial t}=-\frac{\partial v}{\partial z}
$$

Nesta equação, o lado esquerdo representa as mudanças na armazenagem de água no controle de volume com o tempo, enquanto o lado direito representado as mudanças na vazão com a distância. A substituição da Equação 3.8 na Equação 3.9 resulta na equação governante para fluxo unidimensional em meios porosos não saturados, também chamada de equação de Richards:

$$
\frac{\partial \theta(\psi)}{\partial \psi} \frac{\partial \psi}{\partial t}=\frac{\partial}{\partial z}\left[k(\psi)\left(1-\frac{1}{\rho_{w} g} \frac{\partial \psi}{\partial z}\right)\right]
$$

A equação de Richards consiste em uma equação parabólica não linear que pode ser resolvida usando diferenças finitas ou elementos finitos. A verificação da equação de Richards ilustra que a sucção é a variável primária nas análises de fluxo em solos não saturados. Soluções numéricas para esta equação pode ser um desafio, uma vez que as funções constitutivas $\theta(\psi)$ e $\mathrm{K}(\psi)$ são não lineares, e podem ter derivações indefinidas ou zero. Mais importante, as funções constitutivas $\theta(\psi)$ e $\mathrm{K}(\psi)$ precisam ser obtidas experimentalmente. No caso de geossintéticos, recentes pesquisas tem sido direcionadas à obtenção experimental de $\theta(\psi)$ ( curva de retenção de água) e $\mathrm{k}(\psi)$ ( funções-K), assim como mencionado nos tópicos anteriores.

\subsubsection{Comportamento hidráulico de interface solo-geotêxtil nas condições de infiltração}

Conforme relatado, a condutividade hidráulica de geotêxteis não tecidos em condições não saturadas pode vir a ser menor que diferentes tipos de solos sob elevados valores de sucção. Neste caso, existe a possibilidade da formação de uma barreira hidráulica na interface solo-geotêxtil, conhecida como barreira capilar. 
Uma barreira capilar se desenvolve na interface de um solo fino não saturado com um meio poroso não saturado com tamanhos de vazios relativamente grandes, tais como solos granulares (areia ou pedregulho), ou geossintéticos porosos (geotêxteis não tecidos) (ZORNBERG; BOUAZZA; MCCARTNEY, 2010). Este fenômeno foi primeiramente observado por Kisch (1959) e posteriormente avaliado na interface de solos com geotêxteis não tecidos por diversos outros pesquisadores (STORMONT, 1995; STORMONT; MORRIS, 1998; IRYO; ROWE, 2004; BOUAZZA et al., 2006; ZORNBERG; BOUAZZA; MCCARTNEY, 2010). Na prática, barreiras capilares foram observadas em aplicações geotécnicas em diferentes perfis acamados de solos (RASMUSSON; ERIKSSON, 1987; NICHOLSON, et al., 1989; BARBOUR, 1990; YANFUL, 1993; SHACKELFORD; CHANG; CHIU, 1994; WOYSHNER; YANFUL, 1995), bem como no sistema de cobertura final de resíduos em Rocky Mountain Arsenal em Denver, Colorado, Estados Unidos, relatado por Zornberg e McCartney (2003).

De acordo com Zornberg et al. (2010), o entendimento do comportamento de barreiras capilares pode ser obtido pela avaliação do fluxo e armazenagem de água nos poros dos materiais (solos ou geossintéticos) em condições não saturadas. Como um material pode dessaturar, a condutividade hidráulica não permanece constante, podendo ainda, ser reduzida com a diminuição do grau de saturação. A condutividade hidráulica de materiais geotécnicos não saturados com grandes vazios (pedregulhos e geotêxteis não tecidos) decresce rapidamente quando comparados aos solos mais finos. Esta característica direciona à uma situação em que a condutividade hidráulica dos pedregulhos ou geotêxteis não tecidos não saturados seja significantemente menor do que solos finos, em magnitudes menores do que na condutividade hidráulica de geocompostos bentoníticos saturados (GCLS). Tal fato pode ser observado nas funções-k, previamente ilustradas na Figura 3.2.

A barreira capilar ocorre na interface entre materiais finos, que irão proporcionar pequenos vazios interpartículas, e materiais mais grossos, ou aqueles com maiores vazios. A Equação 3.1, que faz uma analogia entre o menisco formado em pipetas de diferentes diâmetros e os tamanhos dos poros nos valores de sucção de um material geotécnico, mostra que pequenos poros resultam em elevados valores de sucção, e a água pode mover-se para os maiores vazios do material poroso da interface somente quando uma diminuição significativa no valor de sucção seja desenvolvida no sistema. Em outras palavras, a energia da água nos poros deve ser suficientemente elevada para permitir esta diminuição e promover a quebra para o interior dos poros maiores. Macroscopicamente, a barreira capilar previne uma determinada quantidade de água de infiltrar do solo para o material granular ou geotêxtil não tecido até que uma sucção crítica próxima de zero (saturação) seja alcançada. Neste ponto, a água e capaz de migrar dos poros menores do geotêxtil para os maiores, o que pode ser chamado de "quebra da capilaridade".

O efeito do desenvolvimento da barreira capilar em sistemas com geossintéticos tem sido recentemente avaliado, e o principal impacto deste efeito em uma camada de solo não saturado é medido pela quantidade de água que não irá infiltrar na camada formadora da barreira hidráulica 
até que uma condição crítica de armazenamento de água seja alcançada (BOUAZZA et al., 2006). Assim, o efeito de uma barreira capilar é observado pelo aumento da armazenagem de água nos níveis em que o fluxo ocorreria normalmente sob o efeito da gravidade (STORMONT; MORRIS, 1998; KHIRE; BENSON; BOSSCHER, 2000). A Figura 3.4 apresenta resultados de ensaios de coluna de infiltração de água em sistema solo/geotêxtil não tecido desenvolvido por McCartney e Zornberg (2010), em que a barreira capilar proporcionou a acúmulo de água (armazenagem) na interface da qual a barreira capilar se desenvolveu.

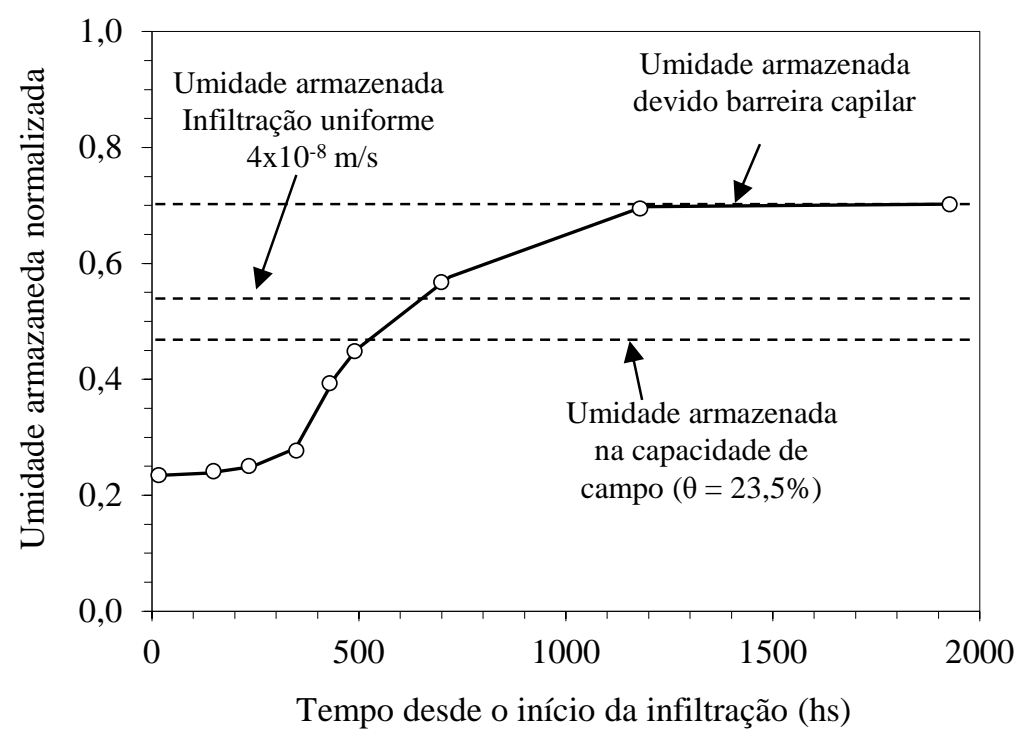

Figura 3.4. Aumento no armazenamento de água normalizado com o tempo desde o início da infiltração, devido à formação de barreira capilar (MCCARTNEY; ZORNBERG, 2010).

Normalmente, esta armazenagem de água no arranjo dos solos é observada pelo teor de umidade volumétrica ao longo do perfil avaliado. Avaliações da variação no teor de umidade com o tempo, em diferentes alturas em ensaios de coluna de infiltração foram conduzidos por Zornberg e McCartney (2007) onde o efeito da barreira capilar é apresentado na Figura 3.5. Neste tipo de ensaio a água é abastecida no topo da superfície do solo numa taxa constante de infiltração, e esta infiltração transiente através da coluna de solo argiloso com altura total de $750 \mathrm{~mm}$, foi monitorada visualmente e utilizando sensores TDR embutidos no solo. Sensores foram inseridos em diferentes alturas, inclusive nas proximidades do geocomposto avaliado como barreira capilar.

Verifica-se na Figura 3.5, que três fases distintas de fluxo de água podem ser identificadas para uma infiltração constante de $4 \times 10^{-8} \mathrm{~m} / \mathrm{s}$ (aproximadamente 100 vezes menor do que a condutividade hidráulica saturada do solo). Inicialmente, o perfil inteiro permanecia relativamente seco, com o teor de umidade volumétrica de compactação de 15\%. Embora a taxa de infiltração abastecida no topo do perfil fosse constante, a frente de umedecimento move-se através do perfil do solo num regime transiente, alcançando o ponto em que o sensor TDR foi instalado, registrando um aumento até o valor de $24 \%$. Uma vez que a frente de umedecimento alcançou a 
base do perfil (550 hs), ou seja, na interface com o geotêxtil não tecido, este não infiltra imediatamente para o geotêxtil. Ao contrário, a água passa a acumular no topo do geotêxtil devido à barreira capilar desenvolvida na interface.

a)
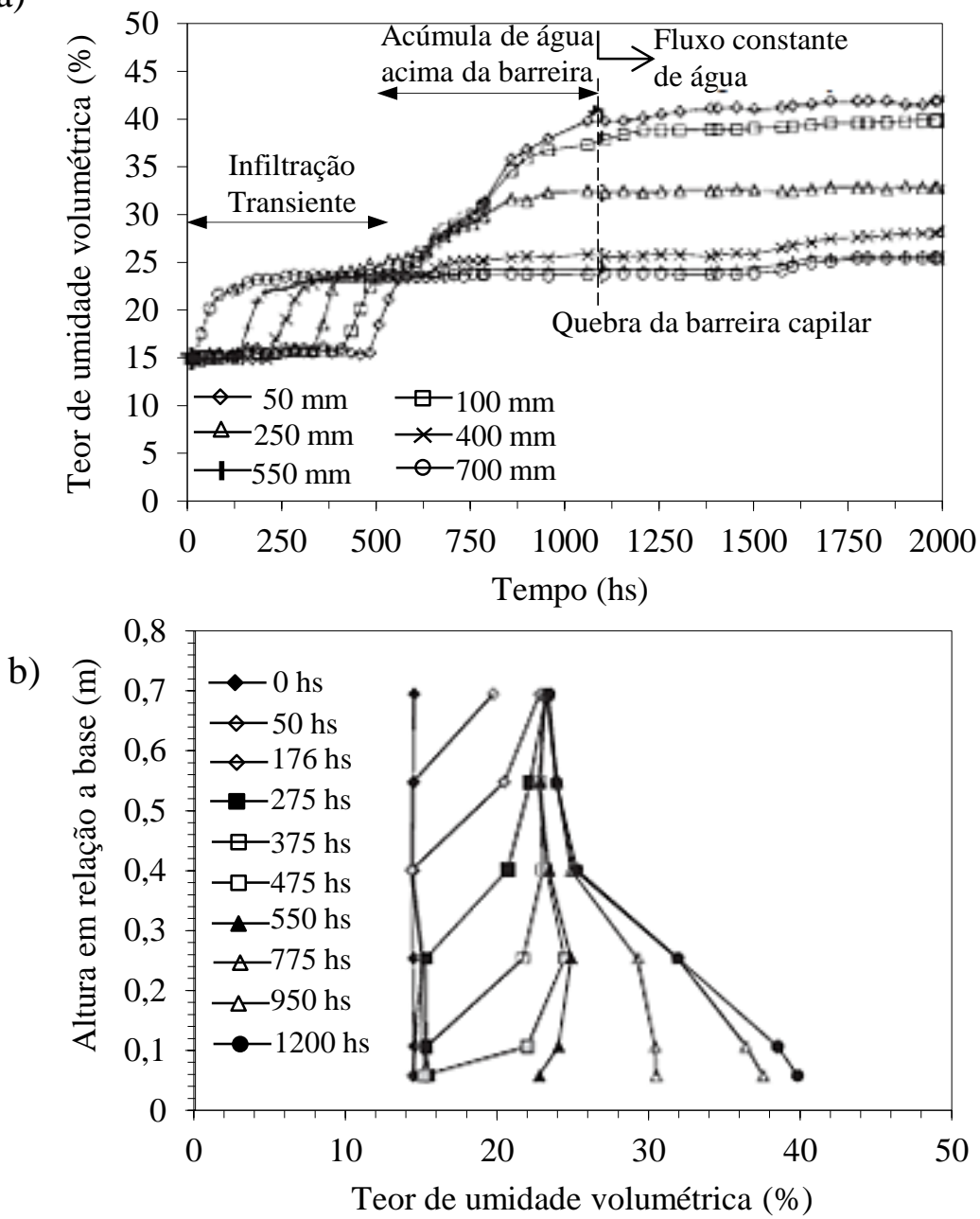

Figura 3.5. Resultados de ensaios de coluna de infiltração: (a) teor de umidade volumétrica TDR versus tempo para diferentes alturas com relação à base da amostra; (b) perfis de infiltração teor de umidade versus profundidade (ZORNBERG; BOUAZZA; MCCARTNEY, 2010).

A armazenagem de água ocorre até uma determinada pressão de água que irá promover a saturação do geotêxtil, e a quebra da barreira capilar é caracterizada. Neste momento, a água passa a infiltrar nos vazios do geotêxtil. Neste caso, o valor de sucção que permite a quebra da barreira capilar é correspondente ao teor de umidade volumétrica de $40 \%$ da curva de retenção de água do solo. Este valor de sucção é consistente com o ponto de cruzamento das curvas de função-k do solo e do geotêxtil. Portanto, pode-se prever a ruptura da barreira capilar determinando-se o valor do ponto de sucção de ruptura da barreira hidráulica, projetando-se este valor na curva de retenção de ambos os materiais, e obtendo o grau de saturação máximo do solo e mínimo do geotêxtil, assim como ilustrado na Figura 3.6. O volume de água armazenado nos vazios do solo irá depender dos níveis de sucção do solo e geotêxtil. 
a)

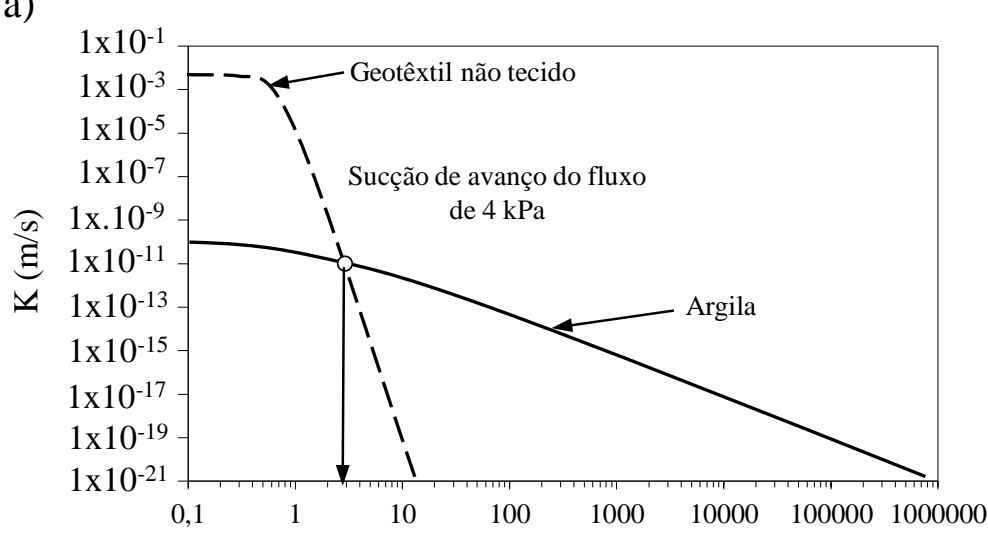

b)

Sucção Matricial (kPa)

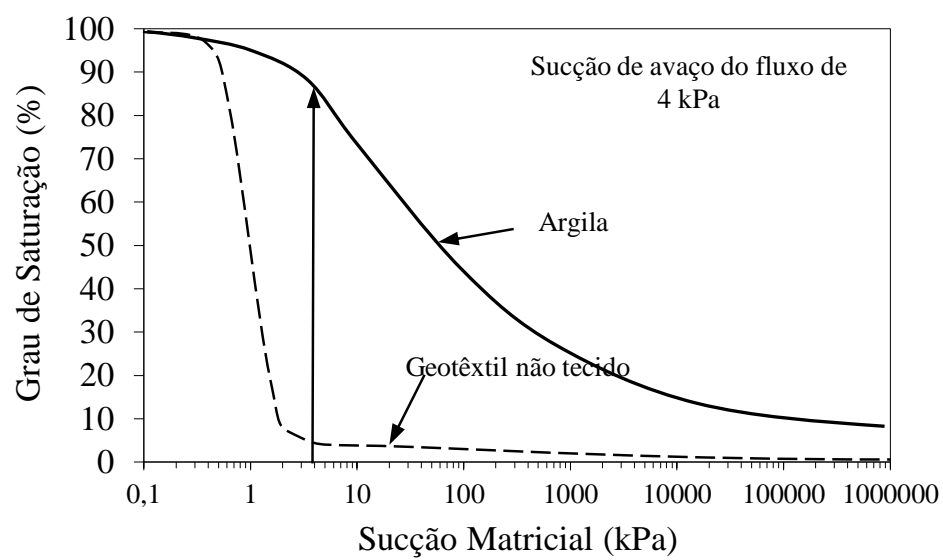

Figura 3.6. Exemplo conceitual do ponto de quebra de barreira capilar por meio de curvas das funções-k e retenção de água do solo e geotêxtil não tecido (ZORNBERG; BOUAZZA; MCCARTNEY, 2010).

O conceito de barreira capilar é baseado na continuidade da sucção ao longo de um suposto perfil de solo, mesmo na interface entre diferentes materiais geotécnicos. As formas das curvas de retenção de água no solo e geotêxteis mostrados na Figura 3.6, indicam que o grau de saturação de dois diferentes materiais pode ser diferente para o mesmo valor de sucção. Por exemplo, quando o sistema apresenta-se na condição inicial de sucção $10 \mathrm{kPa}$, a argila tem grau de saturação de $70 \%$ (relativamente úmido), enquanto o geotêxtil apresenta-se no teor de umidade residual de 3\% (muito seco) (Figura 3.6b). A Figura 3.6a indica que nesta sucção de $10 \mathrm{kPa}$ a argila possui uma condutividade hidráulica de aproximadamente $10^{-9} \mathrm{~m} / \mathrm{s}$, enquanto o geotêxtil não tecido tem uma considerável impedância do fluxo. Consequentemente, a água irá infiltrar no geotêxtil somente após alcançar um nível de sucção em que ambos os materiais apresentem os mesmo valores de k. Este valor é chamado de breakthrough suction (sucção de avanço do fluxo). Neste caso, a sucção de avanço de fluxo é igual a $4 \mathrm{kPa}$, valor significantemente abaixo do valor de capacidade de campo $(33 \mathrm{kPa})$, o que demonstra que o grau de saturação na argila seria muito elevado (95\%) quando a quebra da barreira ocorre.

Em soluções de estruturas de solos finos reforçados com geotêxteis não tecidos, onde estes reforços cumprem simultaneamente a função de drenagem, a barreira capilar pode se tornar um problema. De fato, os reforços não tecidos só irão passar a drenar a água do interior do maciço 
após o solo e o reforço alcançarem o valor de sucção de avanço do fluxo. Muitas vezes esse valor só é alcançado em condições em que o solo apresenta-se perto da saturação.

Iryo e Rowe (2005) utilizaram elementos finitos para simular a resposta hidráulica e mecânica de um aterro reforçado com geossintéticos. Simulações numéricas foram realizadas de modo a examinar o efeito dos arranjos de geotêxteis não tecidos e as condições de infiltração, e ainda, avaliar a efetividade destes reforços na drenagem interna da estrutura. Utilizando pressões da água obtidas nas análises de elementos finitos, as análises no fluxo da água indicaram que geotêxteis não tecidos podem retardar o fluxo em situações em que as pressões da água são negativas, cumprindo a função de drenagem em situação em que as pressões da água passam a alcançar valores positivos. Alguns dos resultados obtidos neste estudo são mostrados na Figura 3.7, indicando que os geotêxteis não tecidos contribuíram mais significativamente como drenos do que como reforço.

O resultados experimentais obtidos por Garcia et al. (2007) corroboram com as constatações numéricas de Iryo e Rowe (2005). Neste estudo, modelos de aterros foram construídos usando duas camadas de geossintéticos permeáveis, cujos comportamentos foram avaliados sob as condições de infiltração e evaporação. Resultados indicaram que os geossintéticos alcançaram a saturação somente quando as pressões da água do solo foram próximas à zero. Uma ruptura local foi observada durante a infiltração, causada pela água acumulada acima do reforço. A ruptura ocorreu devido aos aumentos nas pressões da água no solo, imediatamente acima das camadas de geossintéticos. Ainda, os autores observaram que os geotêxteis localizados em forma de tira minimizaram o efeito da barreira capilar e facilitaram a drenagem da água. Portanto, barreira capilar desenvolvida em interface solo-geotêxtil pode vir a ser desfavorável na estabilidade de estruturas reforçadas. 

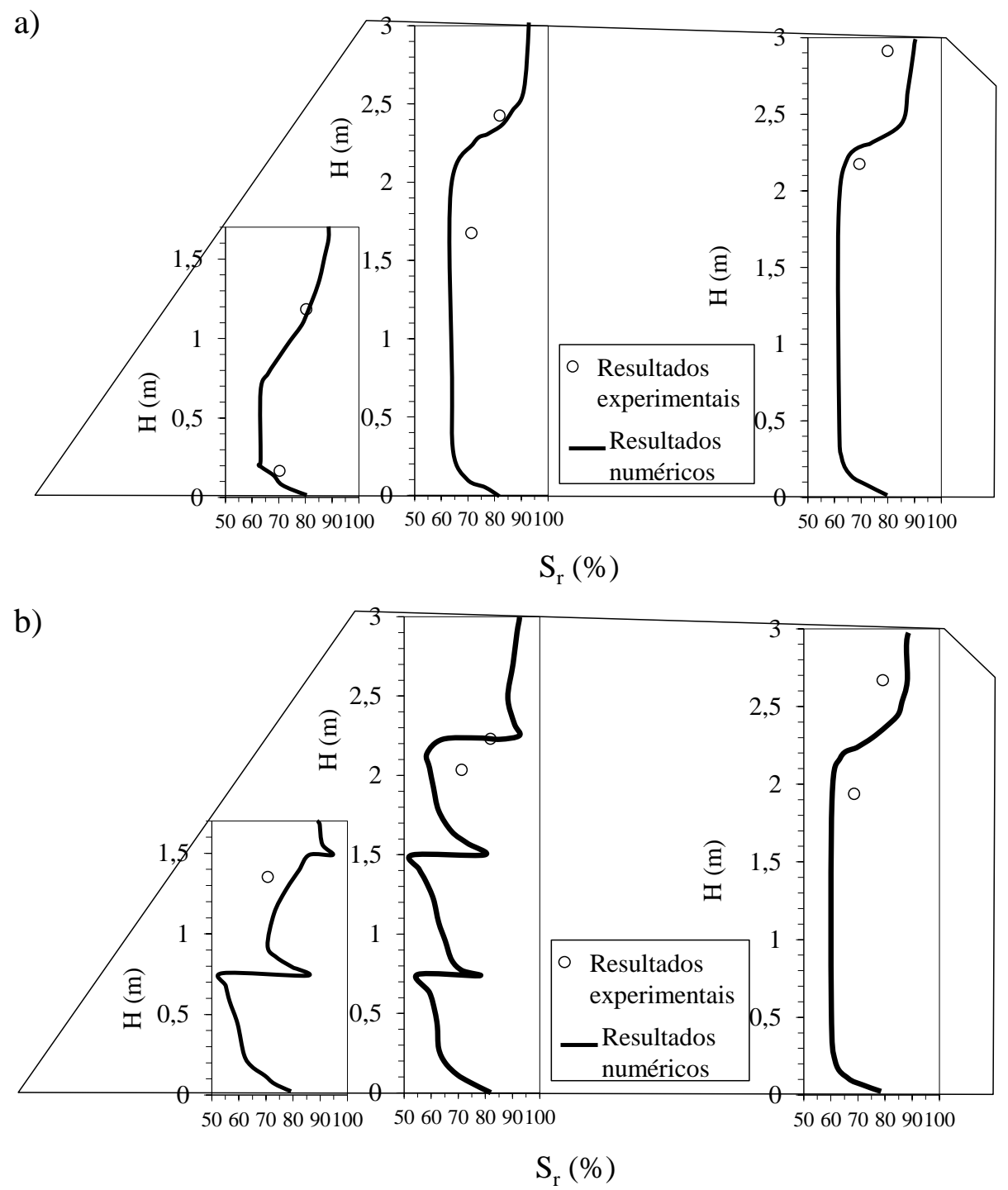

Figura 3.7. Comparação da infiltração de água em aterros reforçados com geotêxteis não tecidos: (a) sem reforços; (b) com reforços (IRYO; ROWE, 2005). 


\section{CAPÍTULO 4}

\section{MATERIAIS E MÉTODOS}

A pesquisa contempla avaliações do comportamento de estruturas de solo reforçado com geotêxteis não tecidos por meio de ensaios em protótipos executados em laboratório. Foram construídos protótipos de laboratório com intuito de avaliar a influência do avanço de umedecimento de água proveniente de precipitações no desempenho de muros reforçados com geotêxteis não tecidos, bem como identificar e avaliar a influência das propriedades hidráulicas dos geotêxteis não tecidos no comportamento deste tipo de estrutura. Neste capítulo, descrevemse os materiais empregados (solos e reforços), métodos construtivos, instrumentação, medidas, ensaios e investigações realizadas nos ensaios de laboratório.

\subsection{Solo}

O solo utilizado na construção dos protótipos consiste num material típico do interior do Estado de São Paulo, coletado no Campus II da Universidade de São Paulo, cidade de São Carlos - SP. Esse é um solo laterítico cuja origem geológica é sedimentar cenozoica, produto do retrabalhamento dos materiais do Grupo Bauru e das Formações Serra Geral e Botucatu, através de transporte em meio aquoso, e depositado em formas de aluviões e coluviões (BJORNBERG, 1965), posteriormente laterizados.

De modo a conhecer o material utilizado na construção dos protótipos, o solo foi caracterizado por ensaios de análise granulométrica conjunta (ABNT NBR 7181, 1984), massa específica dos sólidos (ABNT NBR 6508, 1984), limites de liquidez (ABNT NBR 6459, 1984), limites de plasticidade (ABNT NBR 7180, 1984) e limite de contração (ABNT NBR 7183, 1983). Adicionalmente, ensaios de compactação na energia de Proctor Normal foram realizados de modo a obter os parâmetros para a compactação do material a ser compactado na caixa metálica de ensaios. A Figura 4.1 apresenta a curva granulométrica do solo, enquanto a Figura 4.2 mostra a curva de compactação do mesmo.

Uma vez que o presente trabalho compreende na análise de comportamento de estruturas de solo reforçado sob condições de infiltração de água no sistema, a determinação da condutividade hidráulica saturada passa a ser de grande importância para o entendimento do avanço do umedecimento no interior do maciço. Com isso, ensaios de condutividade hidráulica em permêametro de carga variável de corpos de prova com dimensões de $70 \mathrm{~mm}$ x $100 \mathrm{~mm}$ (diâmetro x altura) foram realizados de acordo com a (ABNT NBR 14545, 2000). Os corpos de prova foram moldados no teor ótimo de umidade e grau de compactação de 98\% (Proctor normal). Na Tabela 4.1 resumem-se os resultados de todas as propriedades de caracterização citadas. 


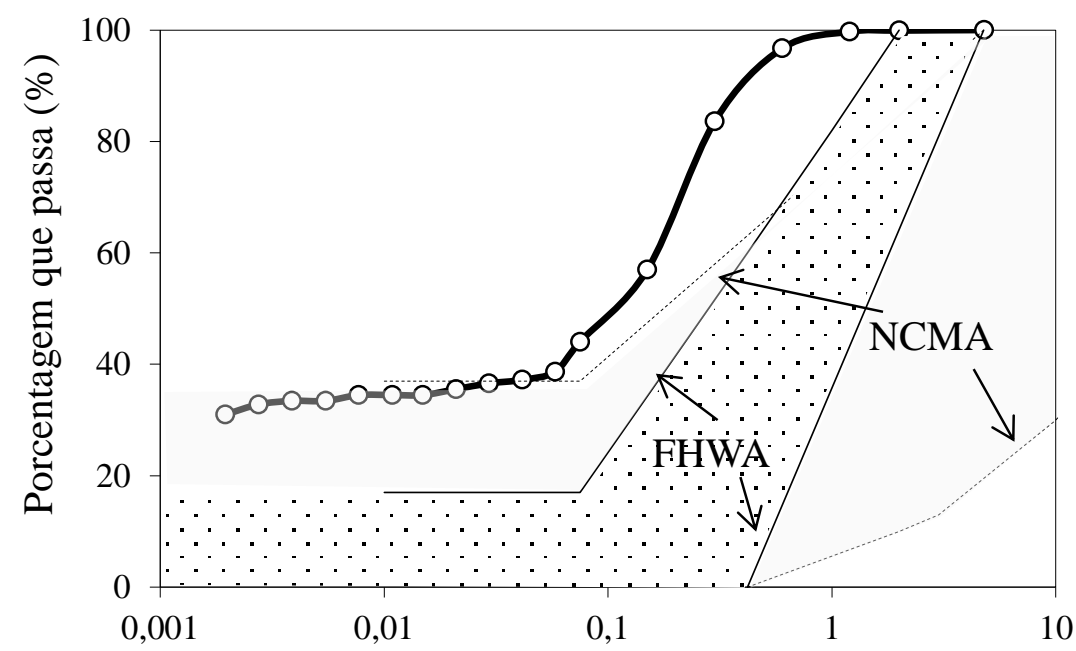

Diâmetro dos grãos (mm)

Figura 4.1. Curva de distribuição granulométrica do solo.

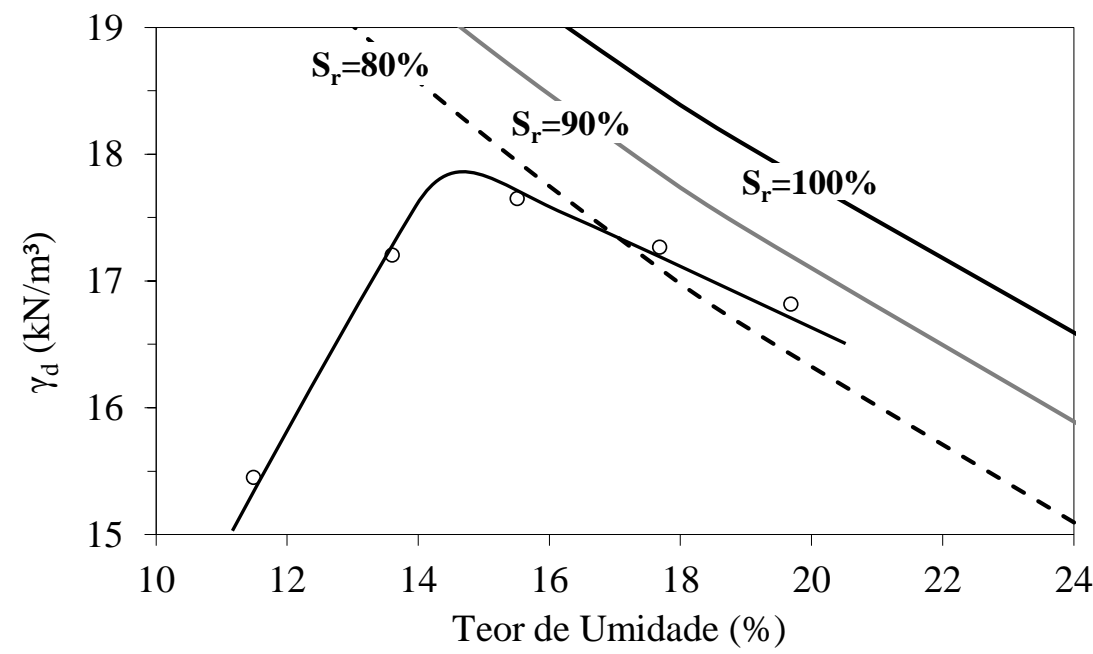

Figura 4.2. Curva de compactação do solo.

Tabela 4.1. Propriedades características do solo.

\begin{tabular}{lc}
\hline Propriedades & Valores \\
\hline Fração areia (\%) & 56 \\
Fração silte (\%) & 12 \\
Fração argila (\%) & 32 \\
Peso específico dos sólidos $\left(\mathrm{kN} / \mathrm{m}^{3}\right)$ & 27,5 \\
Limite de Liquidez $(\%)$ & 40 \\
Limite de Plasticidade $(\%)$ & 20 \\
Índice de Plasticidade (\%) & 20 \\
Limite de Contração (\%) & 19 \\
Peso específico seco máximo $\left(\mathrm{kN} / \mathrm{m}^{3}\right)$ & 17,9 \\
Teor de umidade ótimo $(\%)$ & 14,6 \\
Classificação SUCS & $\mathrm{SC}$ \\
Condutividade hidráulica $(\mathrm{m} / \mathrm{s})$ & $4,9 \times 10^{-7}$ \\
\hline
\end{tabular}




\subsubsection{Resistência ao cisalhamento do solo}

Os parâmetros de resistência do solo foram determinados por meio de ensaios triaxiais em corpos de prova de $50 \mathrm{~mm}$ de diâmetro e $120 \mathrm{~mm}$ de altura, moldados nas condições iniciais de umidade (umidade de compactação), no grau de compactação de $98 \%$. Foram conduzidos ensaios triaxiais consolidados drenados (CD), com velocidade de cisalhamento de $0,045 \mathrm{~mm} / \mathrm{min}$, e ensaios consolidados não drenados (CU), com velocidade de cisalhamento de $0,076 \mathrm{~mm} / \mathrm{min}$. Tais velocidades foram determinadas de acordo com a proposta de Head (1986), considerando a curva de consolidação obtida na fase de adensamento da amostra saturada por contrapressão e ruptura com $10 \%$ de deformação axial. No entanto, os valores de velocidade obtidos de acordo com o método de Head (1986) foram dez vezes maiores do que os valores adotados nesta pesquisa. Optou-se, portanto, por reduzir a velocidade de ensaio de modo a garantir a total dissipação das pressões da água nos ensaios CD e a equalização destas nos ensaios CU. As mesmas velocidades foram utilizadas em ensaios com amostras saturadas e não saturadas (umidade de compactação). Para ensaios saturados, as amostras foram saturadas por contrapressão até alcançarem valores de parâmetros B de Skempton de no mínimo 0,95 e, posteriormente, adensadas e cisalhadas. Já para os ensaios "não saturados", ou melhor, ensaios em amostras no teor de umidade de compactação (sem saturação por contrapressão), as amostras foram diretamente adensadas e posteriormente cisalhadas.

Os resultados dos ensaios triaxiais $\mathrm{CD}$ e $\mathrm{CU}$ em amostras nas condições saturadas e não saturadas são apresentados na Figura 4.3. Os ensaios CD foram conduzidas para os níveis de confinamento de $50 \mathrm{kPa}, 100 \mathrm{kPa}$ e $150 \mathrm{kPa}$, enquanto os ensaios $\mathrm{CU}$ foram realizados sob tensões confinantes de $25 \mathrm{kPa}, 50 \mathrm{kPa}$ e $100 \mathrm{kPa}$. Os resultados dos ensaios triaxiais CD mostraram que as tensões desviatórias na ruptura dos ensaios não saturados apresentaram-se $25 \%$, $10 \%$ e $25 \%$, respectivamente, maiores que àquelas obtidas em ensaios saturados. Em comparação com ensaios do tipo CU, estes aumentos foram muito relativamente menores (Figura 4.3a).

Os resultados dos ensaios triaxiais mostraram que as tensões desviatórias na ruptura de ensaios CU não saturados foram 60, 70 e 100\% maiores em relação aos ensaios saturados (Figura 4.3b). Em amostras saturadas, a pressão da água máxima (positiva) de $50 \mathrm{kPa}$ foi observado na amostra confinada sob tensão de $100 \mathrm{kPa}$ a partir da deformação axial de $1 \%$. Para as amostras confinadas sob as tensões de 25 e $50 \mathrm{kPa}$, desenvolvimento de pressões de água ocorreram entre 0 a $1 \%$ de deformação, com valores na ordem de 20 a $30 \mathrm{kPa}$, que sofreram posterior redução à 0 ou valores negativos, como pode ser observado na amostra com confinamento de $25 \mathrm{kPa}$. (Figura $4.3 b)$. 
a)
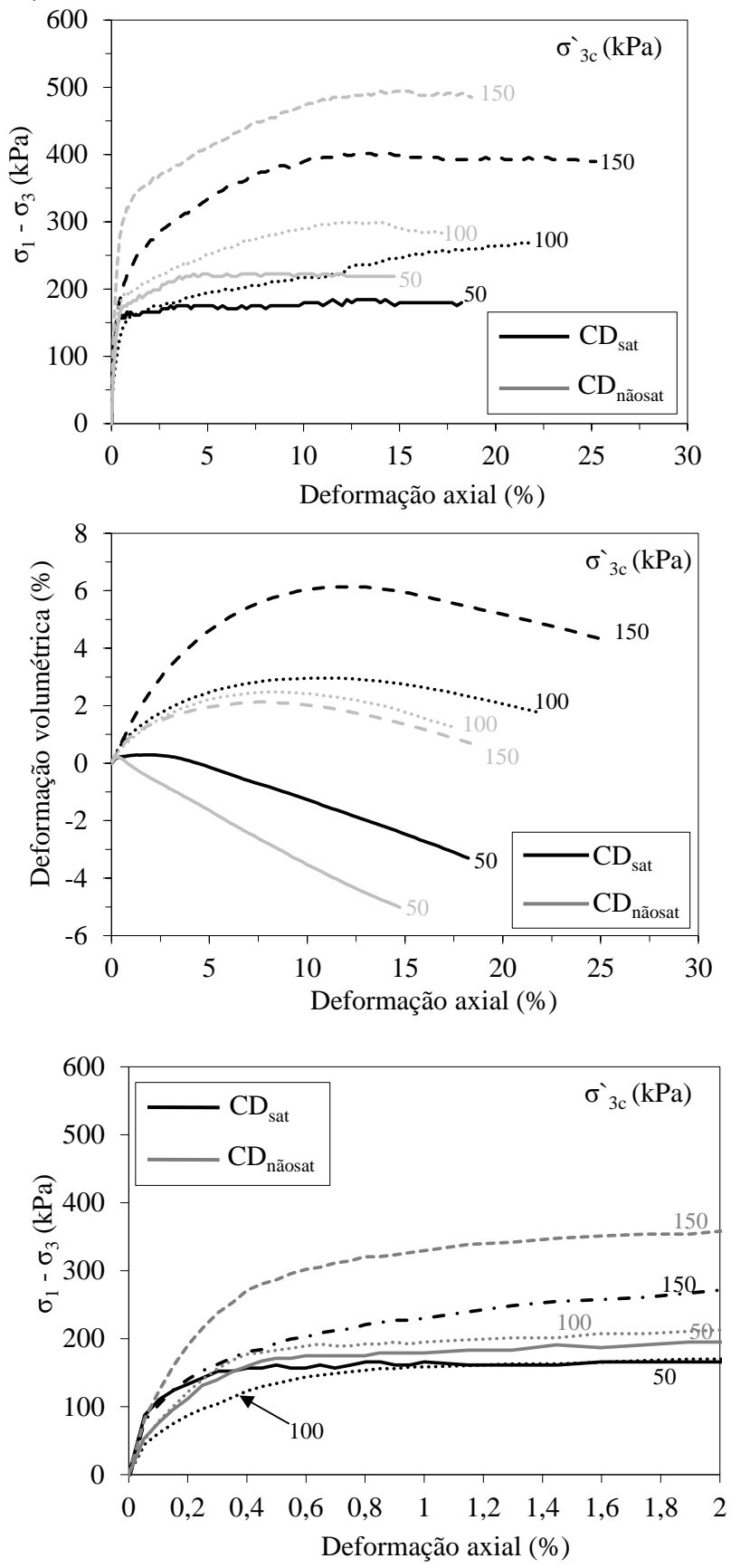

b)
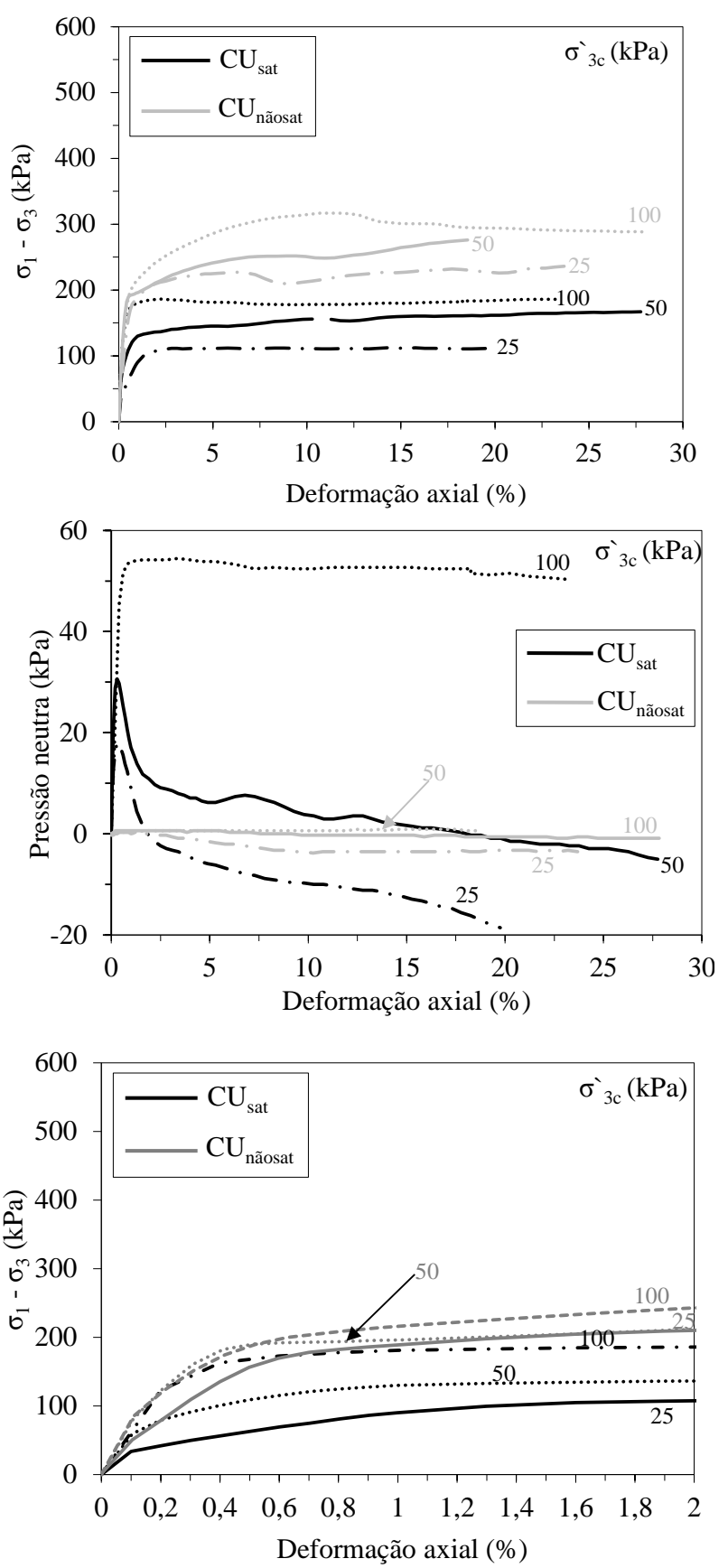

Figura 4.3. Resultados de ensaios triaxiais em amostras saturadas e não saturadas: Ensaios CD; (b) Ensaios CU.

As envoltórias de resistência plotadas na Figura 4.4b mostram que os parâmetros de resistência do solo em termos de tensões totais (ensaios CU) são: coesão de $30 \mathrm{kPa}$ e ângulo de atrito de $25^{\circ} \mathrm{em}$ amostras saturadas; e coesão de $65 \mathrm{kPa}$ e ângulo de atrito de $24,5^{\circ}$, de amostras não saturadas. Cabe mencionar que o comportamento observado entre amostras saturadas e não saturadas estão coerentes com o modelo proposto por Fredlund et al. (1978), em que o ângulo de atrito interno é constante, enquanto a resistência ao cisalhamento cresce com a sucção matricial, atribuindo tal aumento à coesão do solo. As envoltórias efetivas dos ensaios CD e CU foram 
também plotadas na Figura 4.4a. Ambas envoltórias foram semelhantes, resultando em valores de coesão de $15 \mathrm{kPa}$ e $27 \mathrm{kPa}$ para amostras saturadas e não saturadas, respectivamente, e ângulos de atrito de $32^{\circ}$. As mesmas constatações com relação ao modelo de Fredlund et al. (1978) ficou evidente para os ensaios CD.

a)

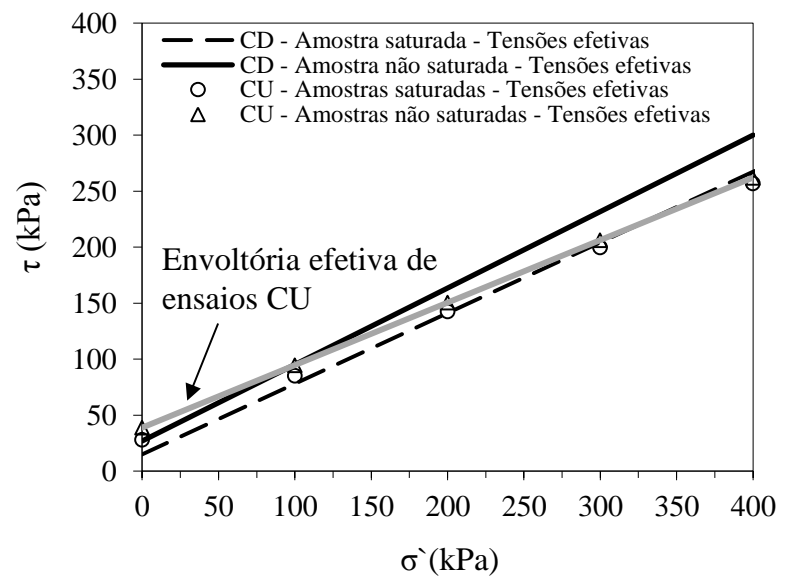

b)

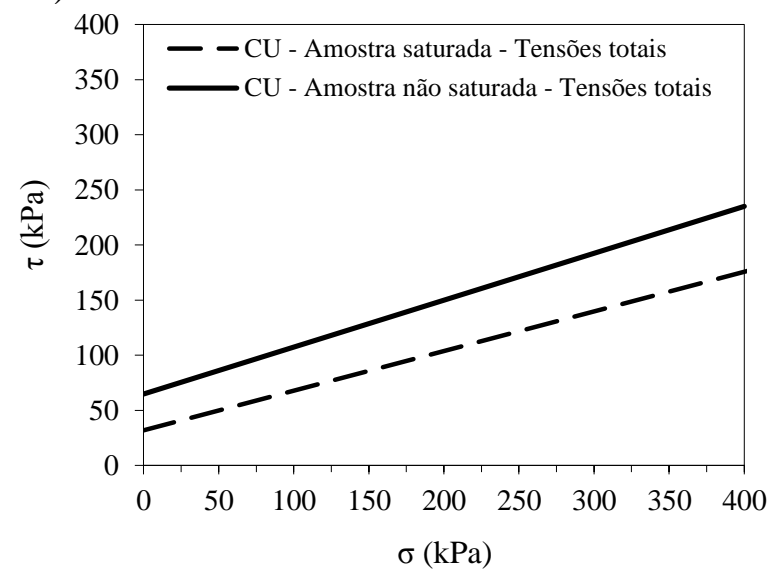

Figura 4.4. Envoltórias de resistência do solo de ensaios triaxiais CU e CD: (a) em termos de tensões efetivas; (b) em termos de tensões totais para amostras saturadas e não saturadas.

Associadamente foram também avaliados os parâmetros de resistência de ensaios de cisalhamento direto. Estes foram conduzidos com taxa de deslocamento de $0,5 \mathrm{~mm} / \mathrm{min}$, em equipamento convencional de pequeno porte em amostras de altura de $2,45 \mathrm{~cm}$ de altura, largura e comprimento de $100 \mathrm{~mm}$, nas condições de umidade de compactação e em amostras inundadas durante 3 horas. Os resultados dos ensaios de cisalhamento direto em amostras na umidade de compactação dos protótipos (umidade ótima) e amostras inundadas são apresentados na Figura 4.5. Observa-se que os aumentos da resistência ao cisalhamento foram na ordem de 45\%, 30\% e $30 \%$, entre amostras saturadas e não saturadas, sob condições de confinamento de $25 \mathrm{kPa}, 50 \mathrm{kPa}$ e $100 \mathrm{kPa}$, respectivamente. As envoltórias de resistência de Mohr-Coulomb dos ensaios de cisalhamento direto para ambas as condições de umidade das amostras são mostradas na Figura 4.6. Os parâmetros de resistência obtidos foram: coesão nas condições saturada e não saturada são $18 \mathrm{kPa}$ e $32 \mathrm{kPa}$, respectivamente; e ângulos de atrito de $29^{\circ}$ e $32^{\circ}$.

Na Tabela 4.2 são resumidos os parâmetros de resistência do solo obtidos por ensaios triaxiais consolidados drenados (CD) e consolidados não drenados (CU) nas condições saturadas e não saturadas das amostras, bem como os resultados dos ensaios de cisalhamento direto nas condições não saturadas e inundadas.

$\mathrm{Na}$ Figura 4.7 foram plotados os valores de módulo secante de rigidez do solo, determinados por meio de ensaios triaxiais, para diferentes valores de deformações dos ensaios triaxiais $\mathrm{CD}$ e $\mathrm{CU}$, e para os valores de grau de saturação correspondentes ao teor de umidade ótima de compactação $\left(S_{\mathrm{r}}=75 \%\right)$ e a saturação do solo $\left(\mathrm{S}_{\mathrm{r}}=100 \%\right)$. Uma vez que o comportamento de estruturas de solo reforçado é dependente da compatibilidade de rigidez do 
solo e reforço, tal parâmetro é de suma importância para o embasamento das discussões futuras. Uma observação importante quanto ao comportamento de rigidez do solo é a diminuição deste parâmetro com o aumento do grau de saturação do solo. Portanto, umedecimento de uma camada de solo em uma estrutura de solo reforçado pode vir a reduzir a rigidez do solo e exigir a mobilização de maiores tensões nos reforços. Cabe observar também, que este fenômeno de redução é maior na condição não drenada do solo em comparação com a condição drenada.
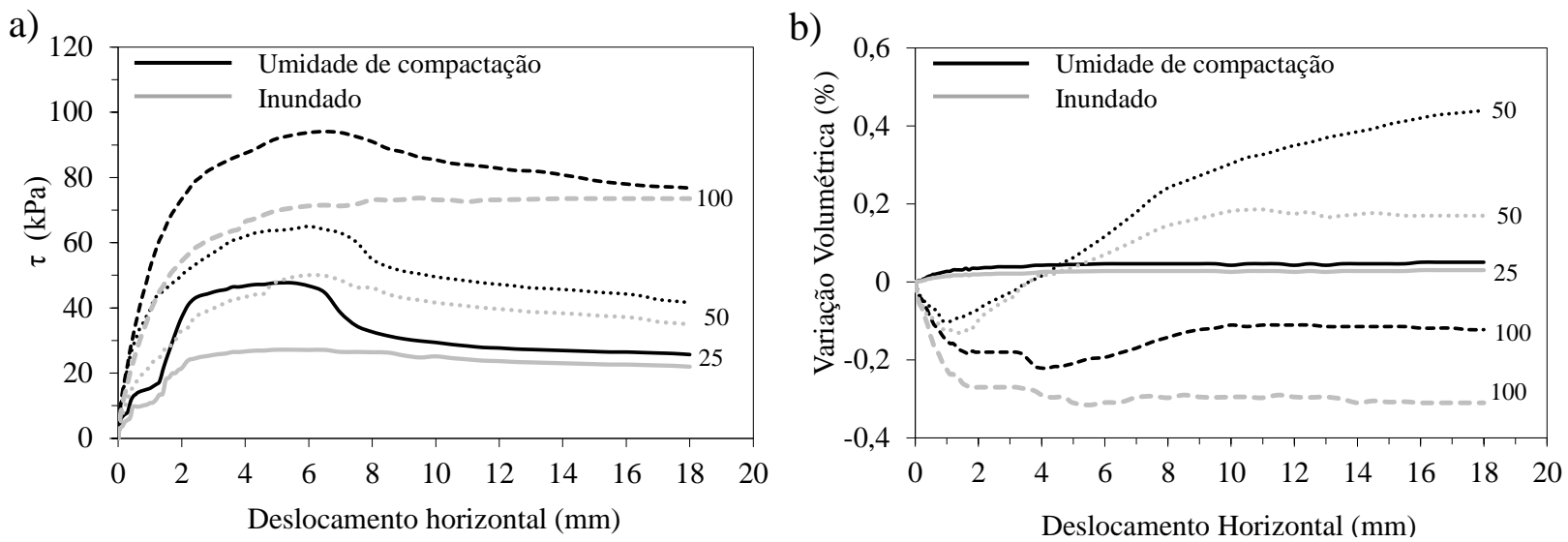

Figura 4.5. Resultados dos ensaios de cisalhamento direto em amostras não saturadas e inundadas.

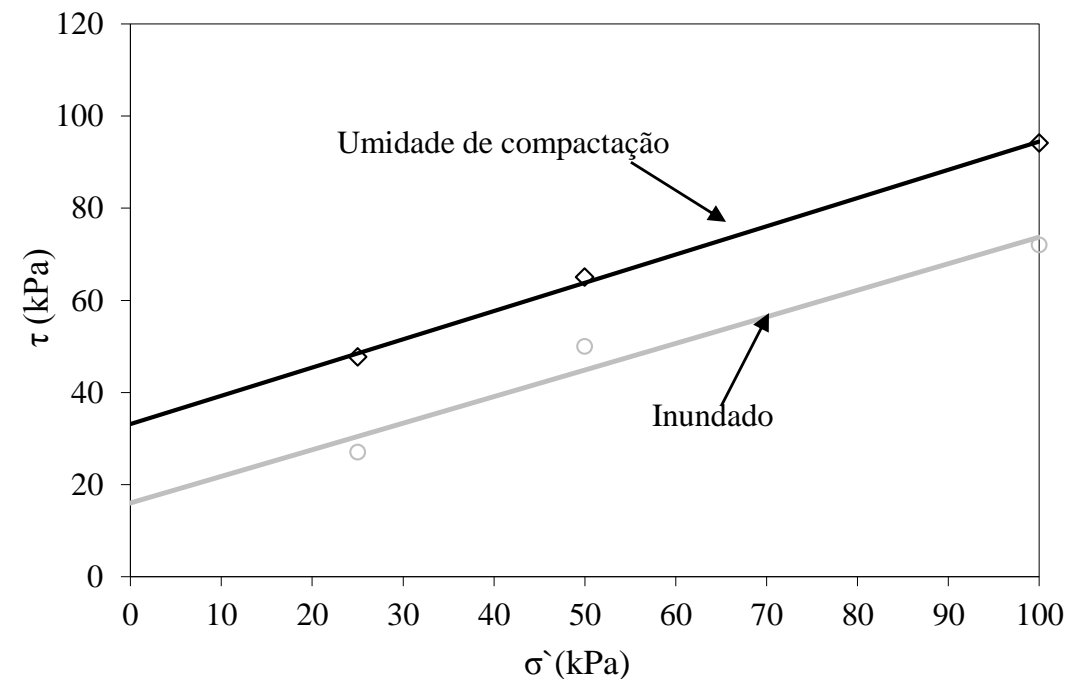

Figura 4.6. Envoltórias de resistência de ensaios de cisalhamento direto em amostras na umidade de compactação e amostras inundadas.

Tabela 4.2. Resumo dos parâmetros de resistência do solo.

\begin{tabular}{lccccccc}
\hline \multirow{2}{*}{ Corpo de prova } & \multicolumn{4}{c}{ Triaxiais } & \multicolumn{2}{c}{ Cisalhamento direto } \\
\cline { 2 - 7 } & \multicolumn{3}{c}{$\mathbf{C D}$} & \multicolumn{2}{c}{$\mathbf{C U}$} & & \\
& $\mathbf{c}^{\prime}(\mathbf{k P a})$ & $\boldsymbol{\phi}{ }^{\prime}\left({ }^{\mathbf{C}} \mathbf{C}\right)$ & $\mathbf{c}(\mathbf{k P a})$ & $\boldsymbol{\phi}\left({ }^{\mathbf{0}} \mathbf{C}\right)$ & $\mathbf{c}^{\mathbf{\prime}}(\mathbf{k P a})$ & $\boldsymbol{\phi}^{\prime}\left({ }^{\mathbf{0}} \mathbf{C}\right)$ \\
\hline Saturado (inundado) & 32 & 15 & 25 & 30 & 29 & 18 \\
Umidade inicial & 32 & 27 & 24,5 & 65 & 32 & 32 \\
\hline
\end{tabular}


a)
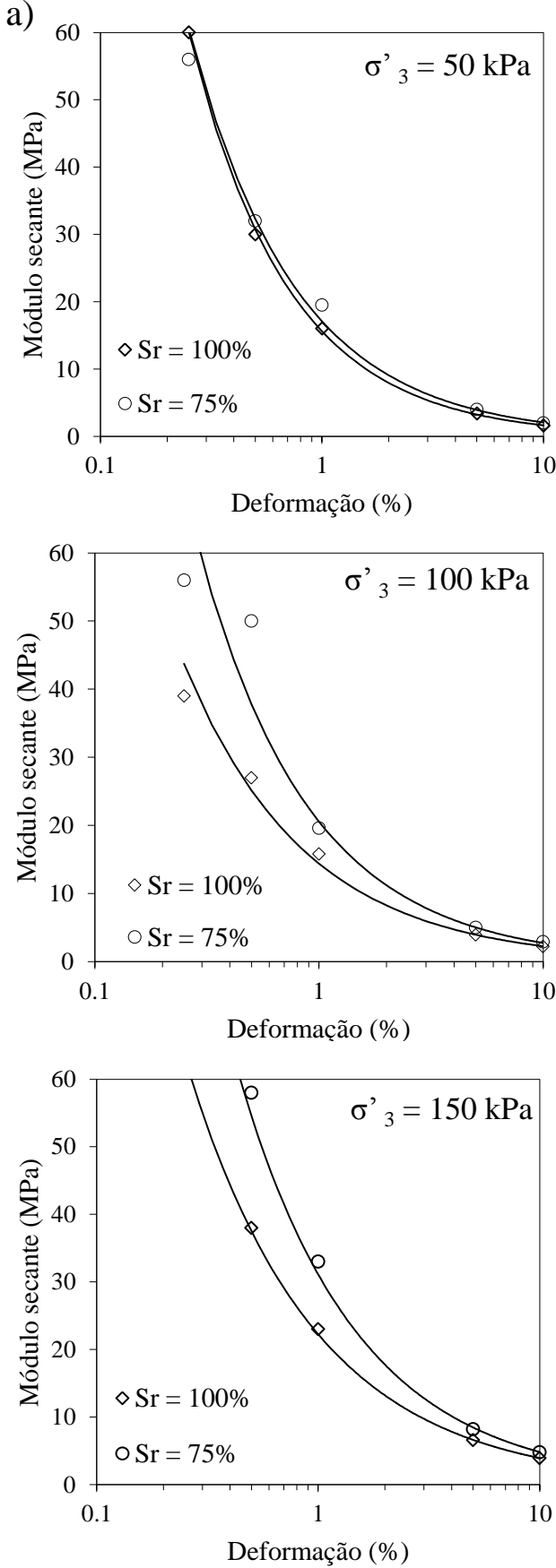

b)
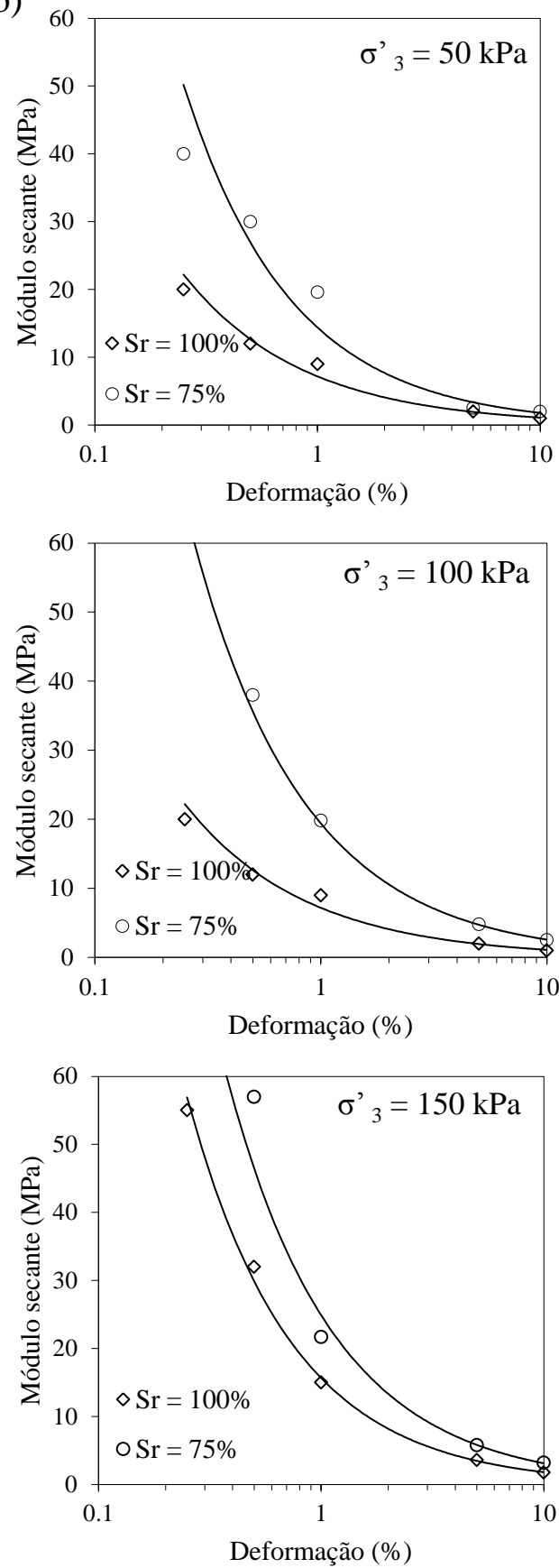

Figura 4.7. Curvas módulo secante do solo x deformação para os valores de grau de saturação de $75 \%$ e 100\%: (a) Ensaios CD; (b) Ensaios CU.

\subsubsection{Curva de Retenção de água do solo}

A curva de retenção de água do solo foi caracterizada por meio de ensaios de funil de placa porosa e papel filtro. Fez-se necessária a utilização de ambas as técnicas de ensaio frente à limitação dos níveis de sucção dos ensaios de papel filtro. Assim, a curvas de retenção sob condições de umedecimento e secagem foram determinadas pela técnica do papel filtro, mas com pontos de menores níveis de sucção (1 a $13 \mathrm{kPa})$ determinados pela técnica do funil de pedra 
porosa. Ajustes do modelo de van Genutchen (1980), utilizando o software SWRC (versão 3.00 beta) desenvolvido por Dourado Neto et al. (2001), foram realizados nos pontos obtidos experimentalmente. A curva de retenção de água do solo com valores experimentais e ajuste teórico é ilustrada na Figura 4.8. Com base no comportamento experimental observado, optou-se por ajustar duas curvas aos pontos experimentais, uma até $200 \mathrm{kPa}$ de sucção e outra para sucções maiores que esse valor. A Tabela 4.3 sintetiza os parâmetros de ajusta da equação de van Genutchen.

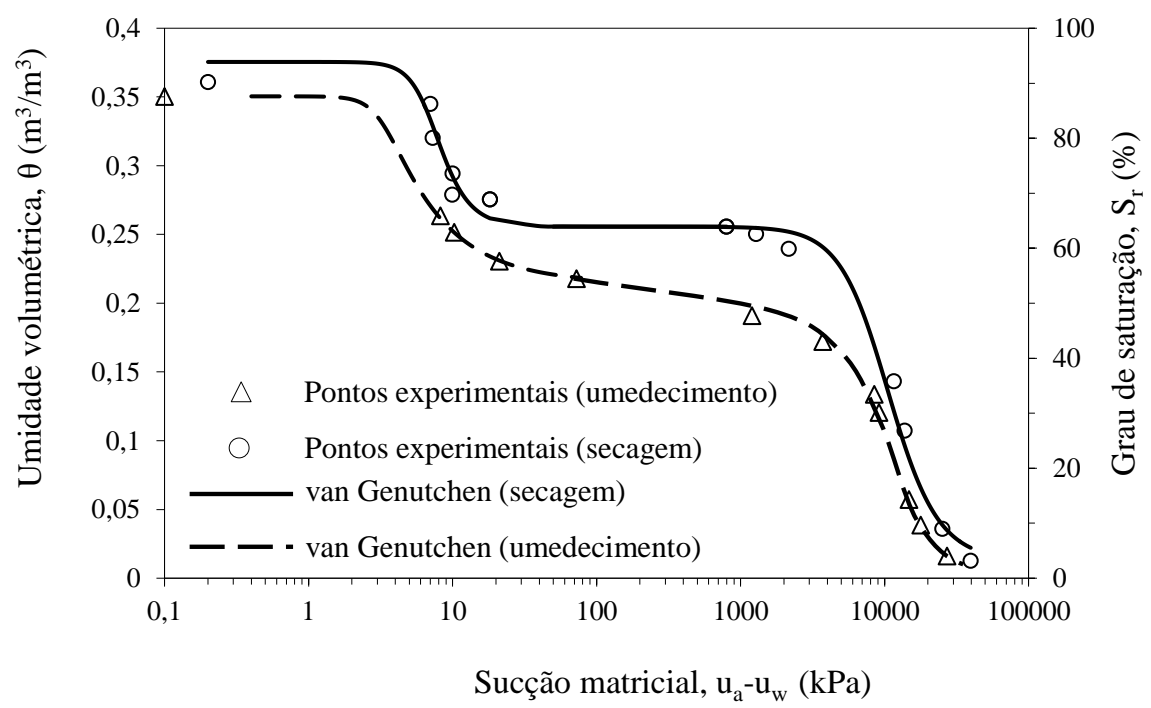

Figura 4.8. Curvas de retenção de água do solo utilizadas nesta pesquisa.

Tabela 4.3. Parâmetros de ajuste de van Genutchen da curva de retenção de água do solo.

\begin{tabular}{lcccccc}
\hline Processo & Trecho & $\boldsymbol{\theta}_{\text {res }}$ & $\boldsymbol{\theta}_{\text {sat }}$ & $\mathbf{m}$ & $\mathbf{n}$ & $\boldsymbol{\alpha}$ \\
\hline Umedecimento & $<200 \mathrm{kPa}$ & 0,256 & 0,375 & 0,673 & 4,74 & 0,14 \\
Umedecimento & $>200 \mathrm{kPa}$ & 0,022 & 0,256 & 0,884 & 2,63 & 0,0001 \\
Secagem & $<200 \mathrm{kPa}$ & 0,215 & 0,35 & 0,211 & 5,3 & 0,313 \\
Secagem & $>200 \mathrm{kPa}$ & 0,0183 & 0,215 & 3,303 & 1,796 & 0,0001 \\
\hline
\end{tabular}

\subsection{Geossintéticos}

Para a execução dos protótipos em laboratório, foram utilizados geotêxteis não tecidos agulhados de filamentos curtos. Três dos protótipos foram executados com geotêxteis não tecidos de poliéster (NT-PET), e um destes com não tecidos de polipropileno (NT-PP) de maior gramatura. Para a caracterização dos materiais foram realizados ensaios de gramatura (NBR 12568, 2003), espessura (NBR 12569, 2003), permissividade (ASTM D4491, 2009) e abertura de filtração (AFNOR G38017, 1986). As propriedades características dos geotêxteis são mostradas na Tabela 4.4. 
Tabela 4.4. Propriedades características dos geotêxteis.

\begin{tabular}{lcccc}
\hline \multirow{2}{*}{ Propriedade } & Unidade & Norma & NT-PET & NT-PP \\
\cline { 4 - 5 } & & & 300 & 600 \\
\hline Gramatura & $\left(\mathrm{g} / \mathrm{m}^{2}\right)$ & ABNT NBR12568 & 2,69 & 4,85 \\
Espessura nominal & $(\mathrm{mm})$ & ABNT NBR12569 & 1,96 & 0,43 \\
Permissividade & $\left(\mathrm{s}^{-1}\right)$ & ASTM D 4491 & 93 & 71 \\
Abertura de filtração & $(\mu \mathrm{m})$ & AFNOR G 38017 & 9300 \\
\hline
\end{tabular}

\subsubsection{Comportamento de tração dos geotêxteis}

O comportamento de tração dos geotêxteis foi determinado por ensaios de tração faixa larga de acordo com a NBR 12824 (1993). Na Figura 4.9 ilustram-se as curvas de tração no sentido longitudinal e transversal de fabricação e as curvas dos módulos secantes para diferentes níveis de deformação no sentido longitudinal. Destaca-se que os geotêxteis foram instalados no sentido longitudinal. O módulo de rigidez prever as cargas de tração nos reforços, desde que as deformações sejam monitoradas. No caso de geotêxteis não tecidos, essas podem não corresponder às cargas reais, uma vez que o confinamento influencia os valores de módulos à tração.
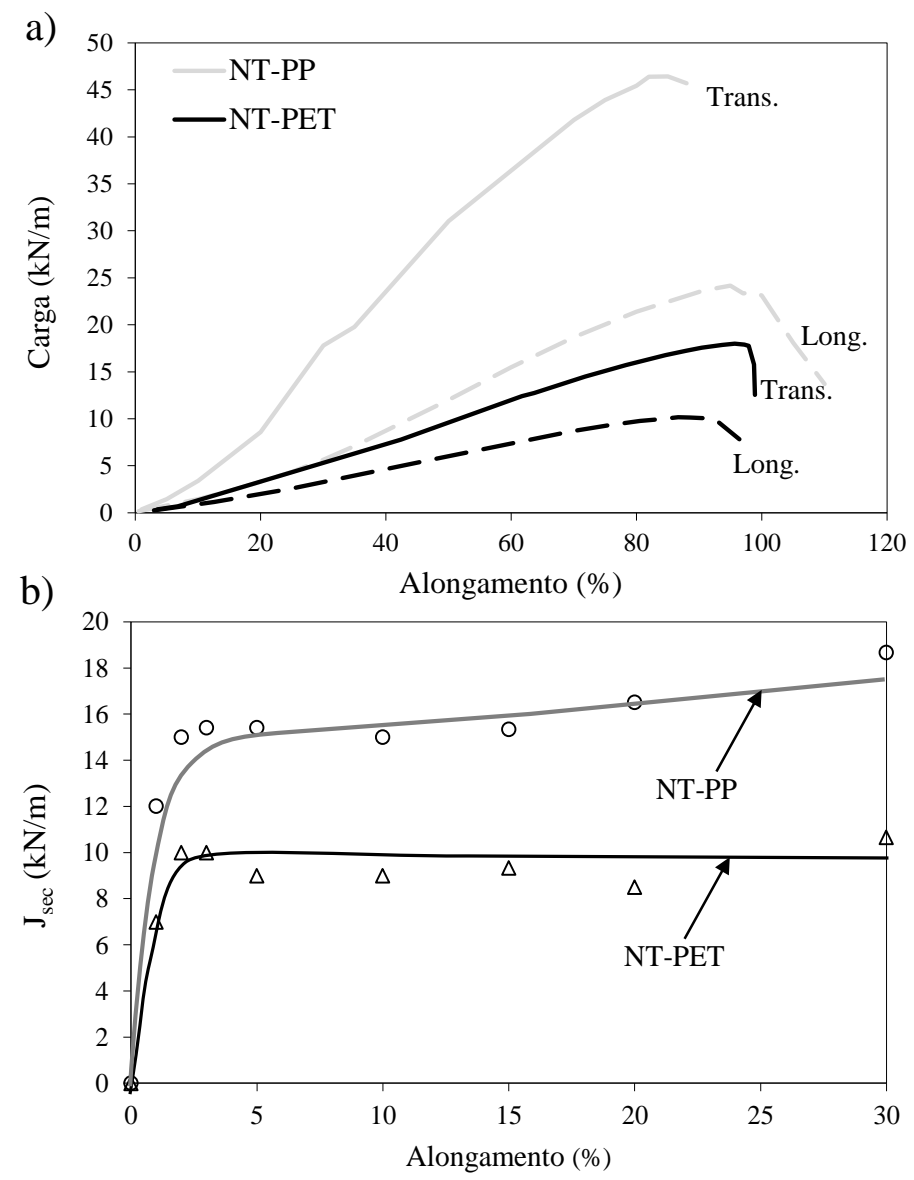

Figura 4.9. Resultados dos ensaios de tração faixa larga dos geotêxteis: (a) curvas carga versus alongamento; (b) curva módulo secante versus alongamento no sentido longitudinal. 


\subsubsection{Fluência dos geotêxteis}

Ensaios de fluência não confinada dos geotêxteis foram realizados no sentido longitudinal das fibras, de acordo com a NBR 15226 (2005). Na condição confinada, ensaios de fluência do material NT-PET com $40 \%$ da carga última de tração e confinamento de $50 \mathrm{kPa}$, foram realizados pelo aluno Francisco Paulo B. Avesani, para compor a dissertação de mestrado sobre o comportamento de fluência confinada acelerada de geossintéticos (em andamento). $\mathrm{O}$ comportamento de fluência dos geotêxteis é apresentado na Figura 4.10. Para verificar a influência da carga aplicada nas deformações ao longo do tempo, procedeu-se um ajuste de uma função logarítmica nos pontos das curvas alongamento versus log (tempo), onde $\varepsilon(\%)=$ $\mathrm{a}+\mathrm{b} \cdot \log (\mathrm{t})$, em que a e b são as constantes de ajuste, $\varepsilon$ o alongamento (ou deformação) e t é o tempo (horas). O coeficiente angular da reta gerada pelo ajuste logarítmico aos dados experimentais pode ser utilizado para quantificar a susceptibilidade à fluência dos geotêxteis. Os valores de b (coeficiente angular) demonstram a dependência com a carga aplicada, denotando a relação crescente entre o nível de carregamento e as deformações ao longo do tempo. Nota-se, portanto, maior suscetibilidade à fluência do geotêxtil NT-PP (maiores gramatura e resistência), do que do geotêxtil NT-PET.
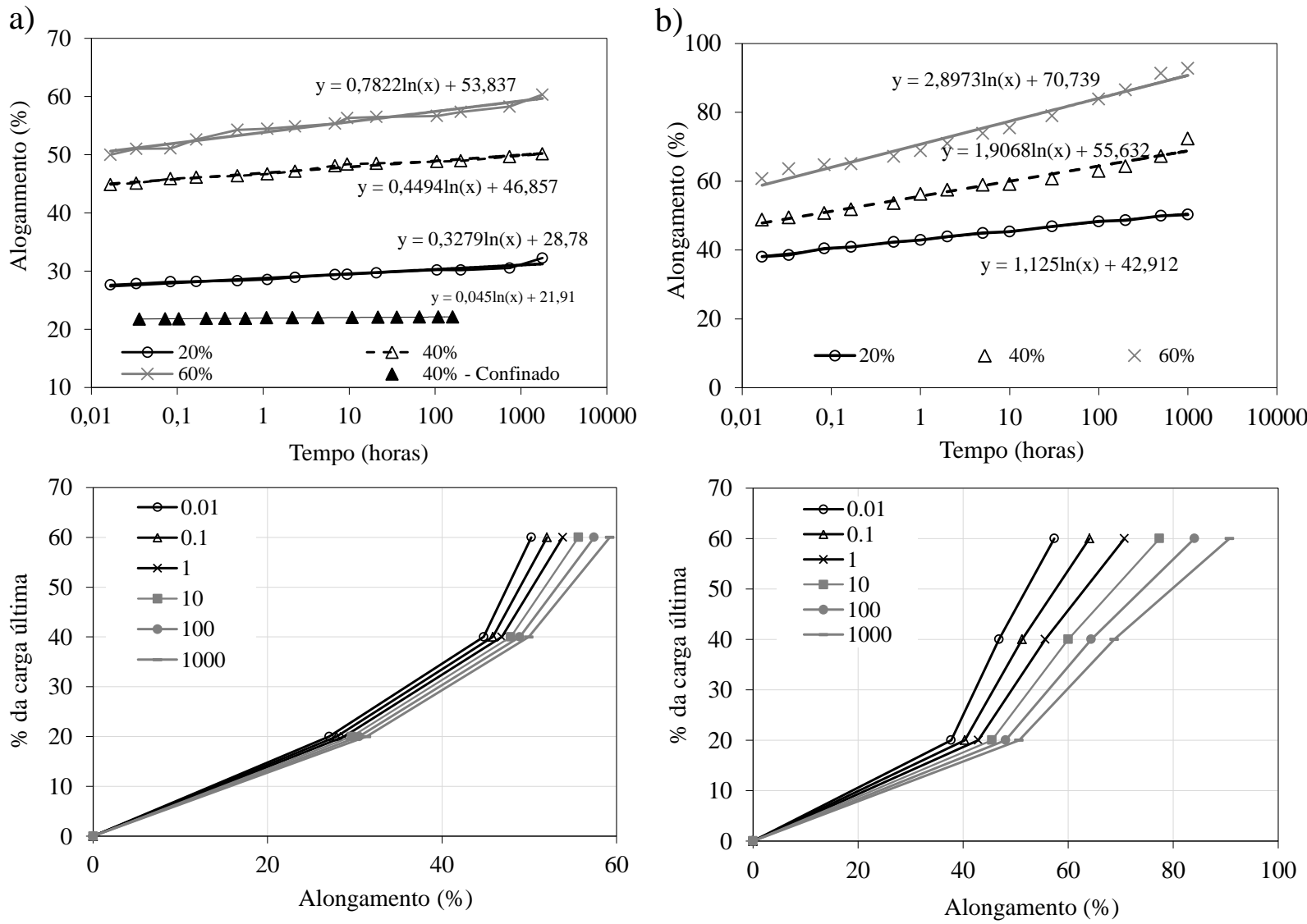

Figura 4.10. Comportamento de fluência dos geotêxteis não tecidos: (a) NT-PET; (b) NT-PP. 
As curvas de módulos secantes versus tempo para os níveis de deformações de $2 \%, 5 \%$ e $10 \%$ dos ensaios de fluência dos geotêxteis são plotadas na Figura 4.11. Nota-se que os valores de módulos não foram alterados para estes níveis de deformação para ambos os geotêxteis. Portanto, para este caso é coerente trabalhar com módulos secantes ao nível de $2 \%$ devido à duas razões: $2 \%$ é bastante usual para muros reforçados e, pelo fato dos valores de módulo não terem sido influenciados pelos níveis de deformações.

Com relação ao comportamento de fluência do geotêxtil na condição confinada, neste caso em areia, nota-se que a redução do comportamento de fluência de $90 \%$ para $40 \%$ da carga última a tração no reforço, com tensão confinante de $50 \mathrm{kPa}$. No trabalho de França (2011) verificou-se que a tensão vertical de $30 \mathrm{kPa}$ causou uma redução de cerca de $80 \%$ no índice de fluência de uma geotêxtil de gramatura $300 \mathrm{~g} / \mathrm{m}^{2}$ (fibra curta), semelhante ao utilizado na pesquisa.

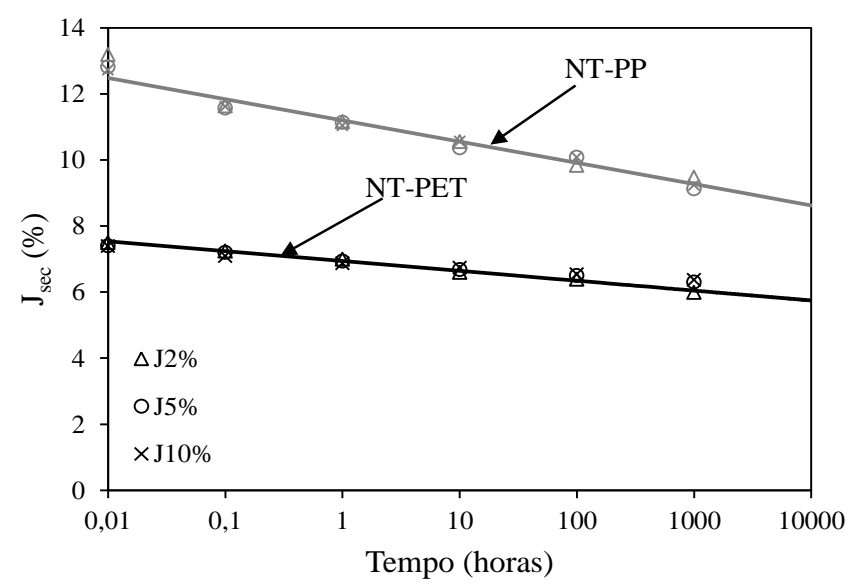

Figura 4.11. Curvas de módulo secante versus tempo para diferentes níveis de deformação do reforço.

\subsubsection{Comportamento hidráulico dos geotêxteis}

A permeabilidade ao longo do plano do geotêxtil foi determinada de acordo com a ASTM D 4716 (2008). Os resultados dos ensaios de permeabilidade sob as diferentes condições de confinamento são ilustrados na Figura 4.12.

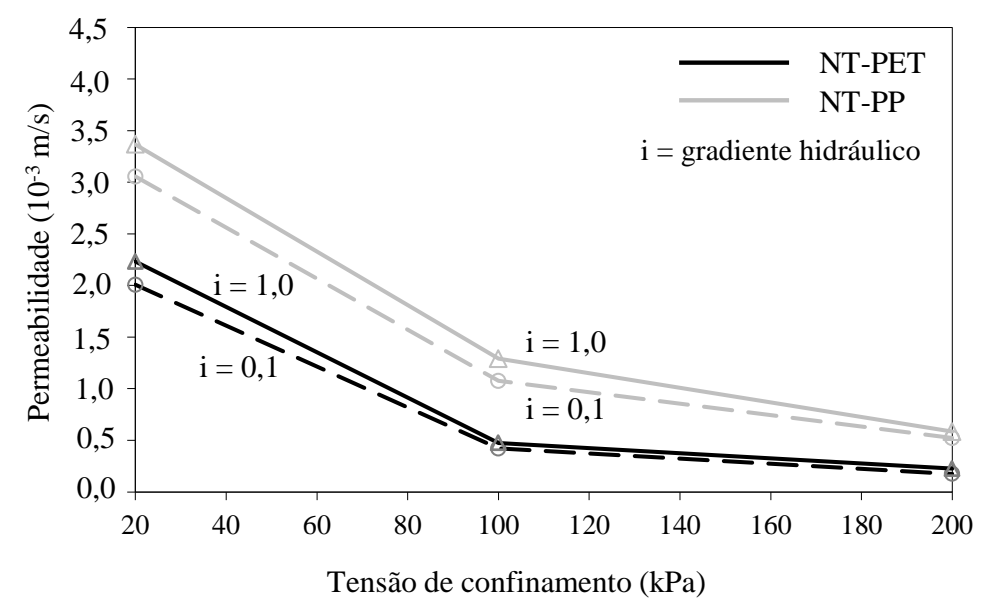

Figura 4.12. Resultados dos ensaios de permeabilidade ao longo do plano de tração dos geotêxteis. 
Observa-se que as tensões de confinamento influenciaram mais significativamente na permeabilidade dos reforços de menores gramaturas. Já o gradiente hidráulico parece não influenciar tão significativamente quanto as tensões confinantes. Propositalmente, os valores de permeabilidade ao plano dos geotêxteis selecionados são muito maiores do que o valor da condutividade hidráulica do solo, com isso tem-se camadas de drenagem interna no interior das estruturas estudadas.

\subsection{Concepção e projeto dos protótipos}

A concepção dos protótipos foi inicialmente baseada nas configurações usuais da atual prática da técnica no campo. No caso de muros reforçados com geotêxteis não tecidos, a experiência construtiva tem limitado o espaçamento vertical máximo entre reforços de $40 \mathrm{~cm}$. Experiências anteriores mostraram que espaçamentos maiores podem vir a prejudicar o desempenho do envelopamento do reforço na face (GOURC; MATICHARD, 1992). Com base nesta limitação, espaçamentos entre reforços de $30 \mathrm{~cm}$ foram definidos como padrão para todas as camadas reforçadas até alcançar altura final de $165 \mathrm{~cm}$, considerando que o protótipo foi construído sob uma camada de base de $15 \mathrm{~cm}$, executada sobre a laje de reação. Dos quatro protótipos avaliados, três foram construídos com reforços não tecidos NT-PET e face envelopada revestida com argamassa de cimento, aqui chamados Muro 1 (M1), Muro 2 (M2), Muro 3 (M3). O outro muro foi construído com a mesma geometria, porém com reforços mais espessos (NT-PP) e condições de face envelopada exposta, designado como Muro 4 (M4). Na Figura 4.13 apresentamse as seções transversais típicas adotadas no programa experimental e na Tabela 4.5 resumem-se as características de cada protótipo avaliado.

a)

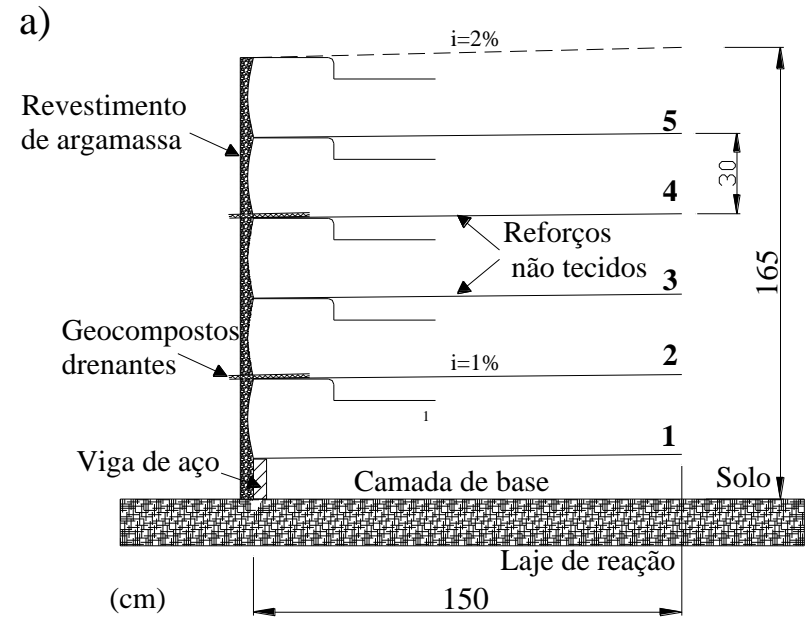

b)

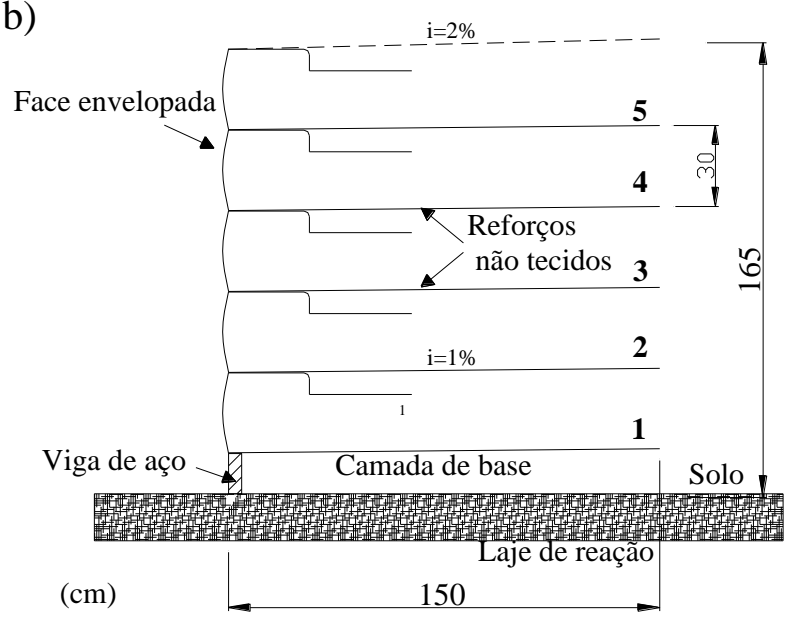

Figura 4.13. Seções típicas dos protótipos: (a) M1, M2, M3; (b) M4.

Os reforços foram instalados com declividade de $1 \%$ em direção ao faceamento no intuito de auxiliar na drenagem da água infiltrada ao longo do comprimento de reforço. Esse 
procedimento foi realizado em todos os protótipos. Na superfície do topo dos protótipos, uma declividade de $2 \%$ em direção à face foi também previsto de modo a proporcionar o escoamento da água da chuva simulada.

Tabela 4.5. Características dos protótipos

\begin{tabular}{ccccccc}
\hline Protótipo & Designação & Solo & Reforço & $\begin{array}{c}\text { Espaçamento } \\
\text { vertical }\end{array}$ & $\begin{array}{c}\text { Comprimento } \\
\text { do reforço } \\
\text { (L) }\end{array}$ & Acabamento da face \\
\hline Muro 1 & M1 & & NT-PET & & & Argamassa \\
Muro 2 & M2 & Areia & NT-PET & $30 \mathrm{~cm}$ & $150 \mathrm{~cm}$ & $\begin{array}{c}\text { Argamassa } \\
\text { Argamassa } \\
\text { Muro 3 }\end{array}$ \\
Muro 4 & M4 & argilosa & $\begin{array}{c}\text { NT-PET } \\
\text { NT-PP }\end{array}$ & & & Geotêxtil exposto \\
\hline
\end{tabular}

Nos protótipos M1, M2 e M3, geocompostos drenantes MacDrain ${ }^{\circledR}$ foram instalados na face entre as camadas reforçadas 1 e 2 , e 3 e 4 , com comprimento de $30 \mathrm{~cm}$, de modo a conduzir o eventual acúmulo de água para fora da zona reforçada, substituindo a função dos tradicionais "barbacãs" convencionalmente utilizados em estruturas de solo reforçado (Figura 4.14a). Como o protótipo M4 foi avaliado na condição de face envelopada exposta, não houve a necessidade destes condutores. Cabe observar que a face envelopada exposta é em uma condição bastante comum durante o período construtivo, que pode influenciar no comportamento hidráulico dos geotêxteis não tecidos sob a condição de precipitação.

\subsection{Execução dos protótipos}

\subsubsection{Caixa de ensaios de grande porte}

Protótipos de estruturas de solo reforçado foram construídos em uma caixa metálica com dimensões internas altura x largura x comprimento de $1,8 \mathrm{~m}$ x 1,55 m x 1,8 m. A caixa de ensaios foi projetada com paredes de aço reforçadas de modo a suportar elevadas tensões laterais de solo com deformações laterais resultantes próximas de zero, garantindo assim o estado plano de deformações das estruturas avaliadas. A fundação da estrutura da caixa de ensaios consiste em uma laje de reação rígida em concreto armado projetada para suportar um esforço de tração de 8200 kN. A Figura 4.14 apresenta as dimensões e os componentes da caixa metálica de ensaios. Nota-se na figura que a caixa é composta por quatro paredes, sendo duas laterais, uma no fundo e outra frontal (Figura 4.14a). Na execução de protótipos de estruturas de solo reforçado, a parede frontal é dispensada (Figura 4.14b).

As paredes de aço são parafusadas em quatro pilares chumbados na laje de reação, que compõe um sistema com elementos estruturais (pilares e paredes) que podem ser considerados engastados entre si. A rigidez total da estrutura passa a ser garantida pela tampa de reação parafusada no topo de cada parede lateral. Essa tampa em aço reforçado completa o sistema de 
transferência de cargas, onde as cargas aplicadas por um bolsão de ar são transmitidas da tampa de reação para a estrutura avaliada, e desta para a laje de reação. O sistema de aplicação de carga será abordado mais detalhadamente adiante. Detalhes com relação a construção da caixa de ensaios podem ser consultados no trabalho de Viana (2003).

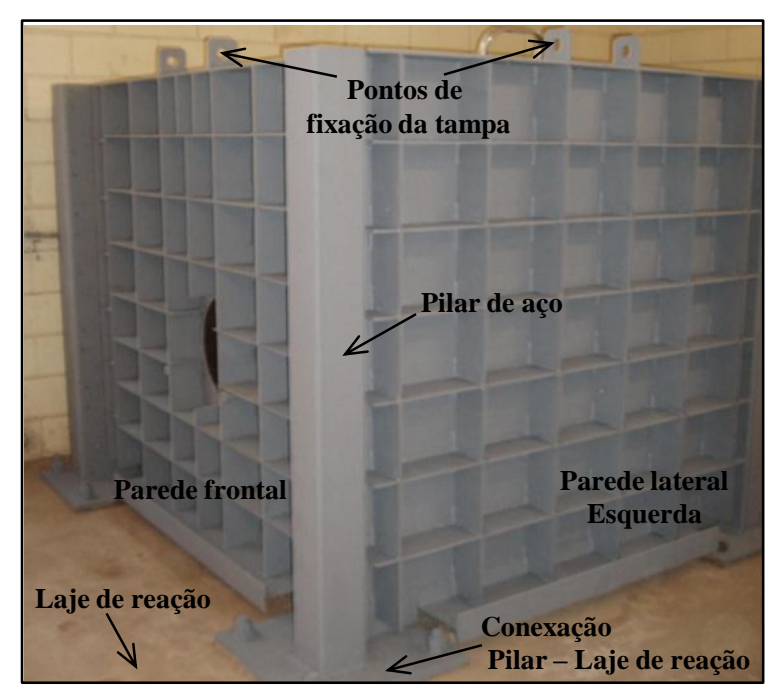

(a)

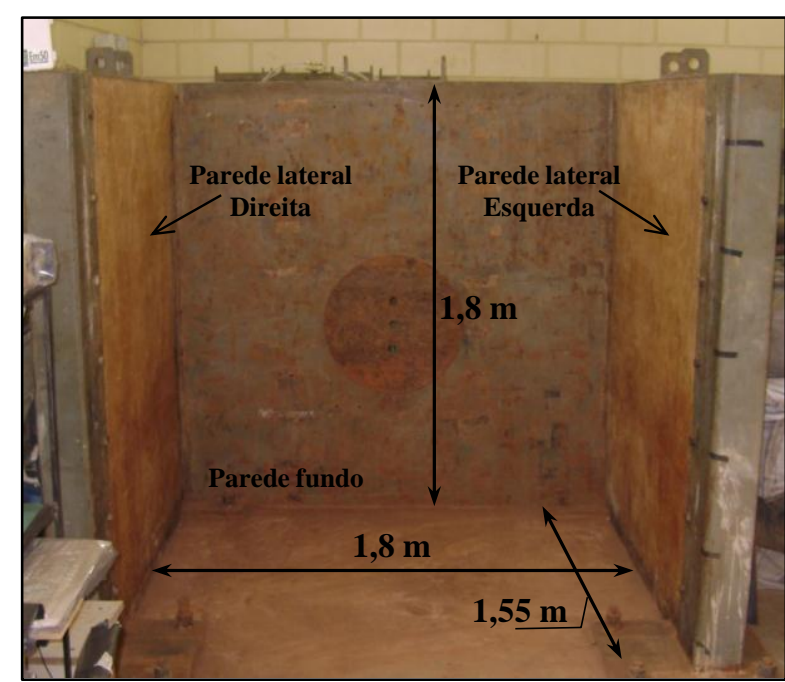

(b)

Figura 4.14. Caixa de ensaios de grande porte: (a) paredes externas e componentes; (b) dimensões internas.

\subsubsection{Preparação preliminar}

Preliminarmente à construção de cada protótipo, uma etapa de preparação da caixa de ensaios foi devidamente realizada. Esta etapa consistiu na limpeza das paredes da caixa de ensaios e no revestimento destas com membranas de PVC, que foram coladas nas paredes laterais. Neste caso, a limpeza é bastante importante para que o efeito adesivo não seja prejudicado. $\mathrm{O}$ intuito do revestimento das paredes laterais com membranas de PVC foi de proporcionar uma superfície mais lisa e não passível de corrosão. A segunda etapa consistiu em lubrificar a geomembrana com lubrificante a base de petróleo (vaselina) e, posteriormente, instalar uma folha Mylar ${ }^{\circledR}$ (folha lisa de celulose) sobre a superfície lubrificada. As etapas de preparação das superfícies internas das paredes são ilustradas na Figura 4.15. 


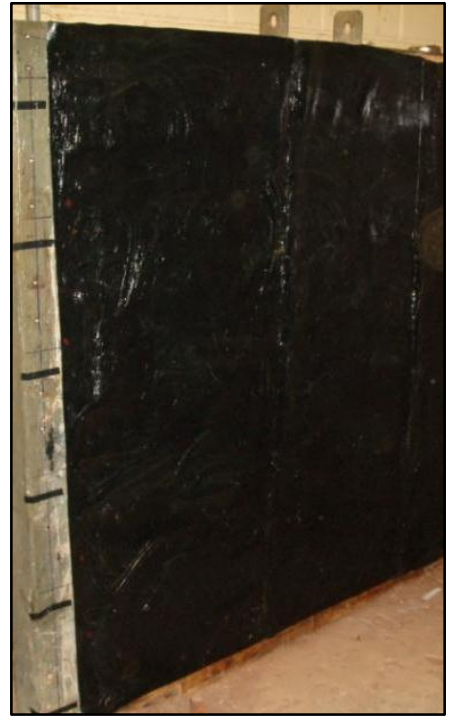

(a)

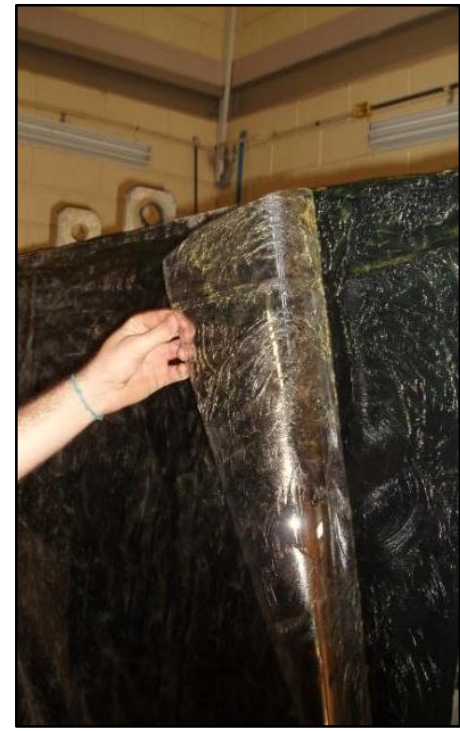

(b)

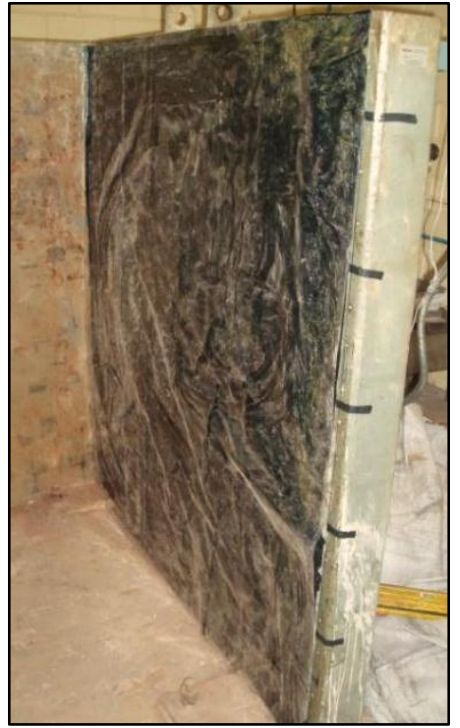

(c)

Figura 4.15. Preparação da superfície interna das paredes laterais da caixa de ensaios: (a) colagem e lubrificação da geomembrana; (b) instalação da folha Mylar ${ }^{\circledR}$; (c) aspecto final.

No trabalho de Arthur e Roscoe (1965), o atrito lateral de $14^{\circ}$ na interface areia seca e vidro foi um fator que não influenciou nas deformações na seção transversal central da estrutura avaliada. Assim, partindo do princípio de que as estruturas avaliadas nesta pesquisa foram devidamente lubrificadas, estas possivelmente apresentaram valores menores do que aos verificados pelos autores. Ainda, atrito de interface entre solo-lona-graxa-lona, em condições próximas às utilizadas neste trabalho, foram medidos por Benjamim (2006), onde se determinou valores de $5,2^{\circ}$ para solo argilo-siltoso e $4,9^{\circ}$ na interface com areia siltosa. Pode-se assumir que o atrito na interface solo-parede (lubrificada) não prejudica o estado de deformações planas.

\subsubsection{Preparação do solo}

O solo foi estocado em compartimentos devidamente protegidos e, posteriormente, seco ao ar, destorroado e passado na peneira de malha $4,2 \mathrm{~mm}$. O material peneirado e seco era estocado em bolsões, em porções separadas de $200 \mathrm{~kg}$. O processo de preparação é ilustrado na Figura 4.16. A utilização dos bolsões foi indispensável para a movimentação do solo da área externa para a área interna do laboratório, além da movimentação interna durante a execução dos protótipos com o auxílio de uma ponte rolante de capacidade de 2 toneladas. Em cada protótipo foi necessário um total de 8 toneladas de solo (40 bolsões). 


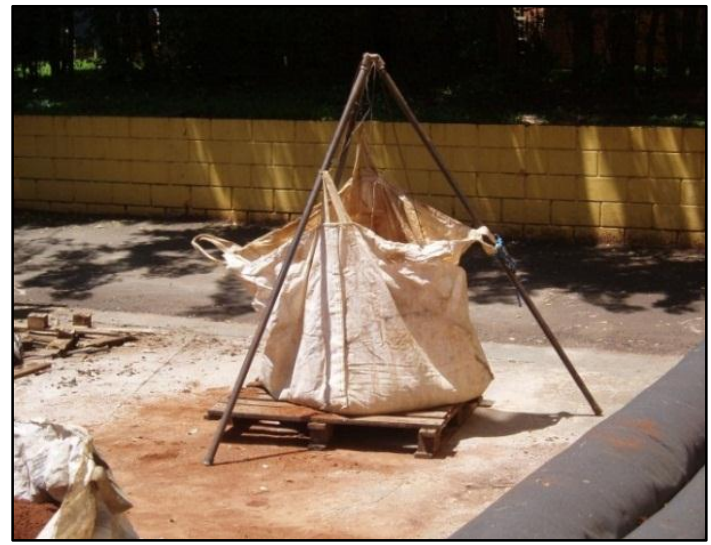

(a)

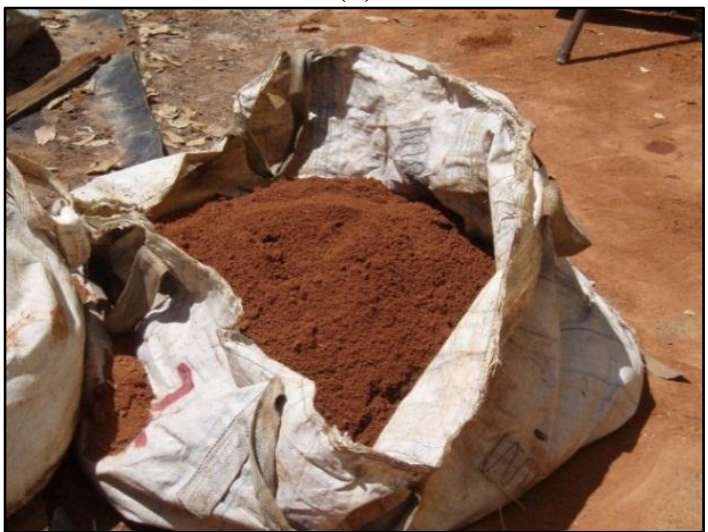

(c)

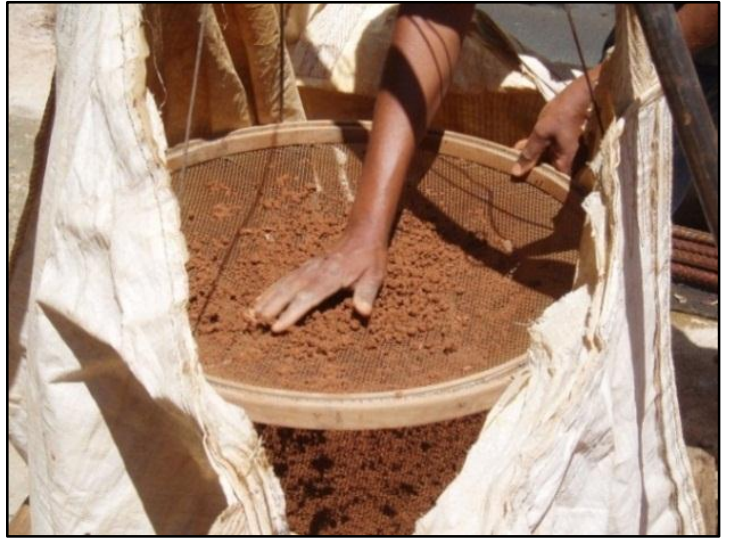

(b)

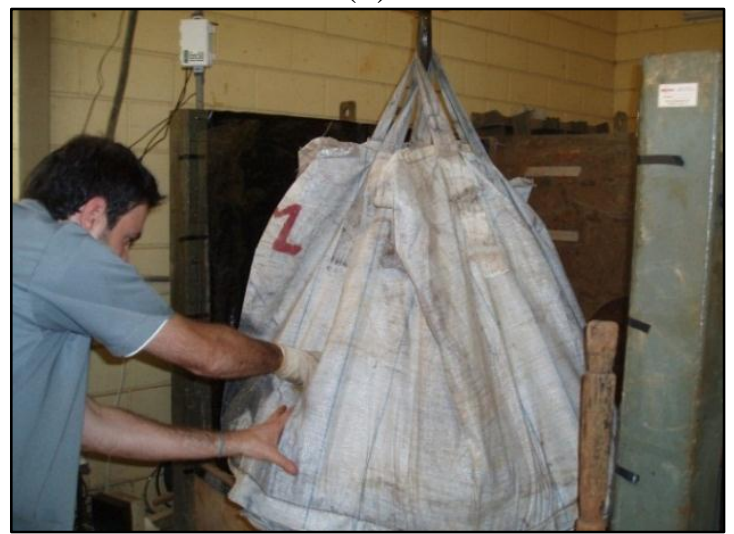

(d)

Figura 4.16. Processo de preparação do solo: (a) preparação do bolsão; (b) peneiramento do solo; (c) bolsão preparado; (d) movimentação do solo para a caixa de ensaios.

Durante o processo de compactação dos protótipos, o teor de umidade foi controlado e determinado por aquecimento em forno microondas. A curva de calibração do microondas para o solo estudado na pesquisa é plotada na Figura 4.17. A determinação da curva de calibração e procedimento de determinação dos teores de umidade seguiram as diretrizes da ASTM-D4643 (2008). O tempo de aquecimento do solo foi determinado através de ciclos de aquecimento de $1 \mathrm{a}$ 5 minutos, com pesagem da amostra de solo entre ciclos. O menor tempo consiste no tempo ideal de secagem do solo. Portanto, o tempo de aquecimento ideal para secagem do solo é de 10 minutos, conforme apresentado na Figura 4.17. No entanto, a determinação do teor de umidade do solo foi executada em ciclos menores (3 minutos) para evitar um sobreaquecimento do solo. 


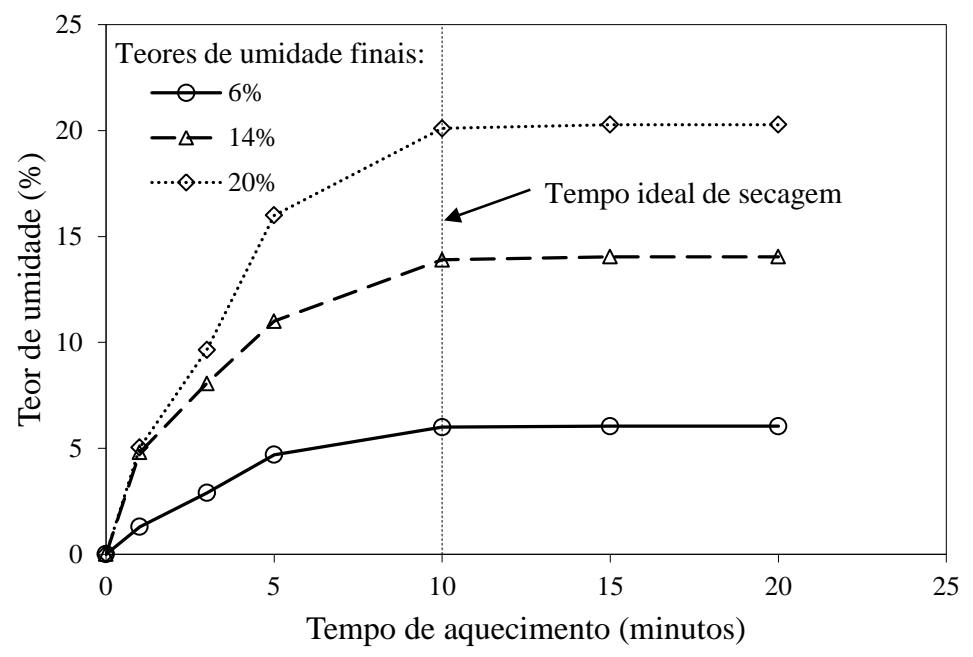

Figura 4.17. Curva de calibração para a determinação do teor de umidade por secagem no microondas.

O processo de correção da umidade para o teor de compactação foi realizado em duas etapas: (1) mistura do solo na umidade inicial na betoneira, com intuito de obter um teor de umidade inicial homogêneo para toda a massa de solo; (2) determinação do teor de umidade e posterior adição de água e homogeneização na betoneira. Após essas duas etapas, o teor de umidade era novamente determinado e, caso alcançasse o valor almejado, solo estava pronto para ser compactado. A ilustração da homogeneização é apresentada na Figura 4.18.

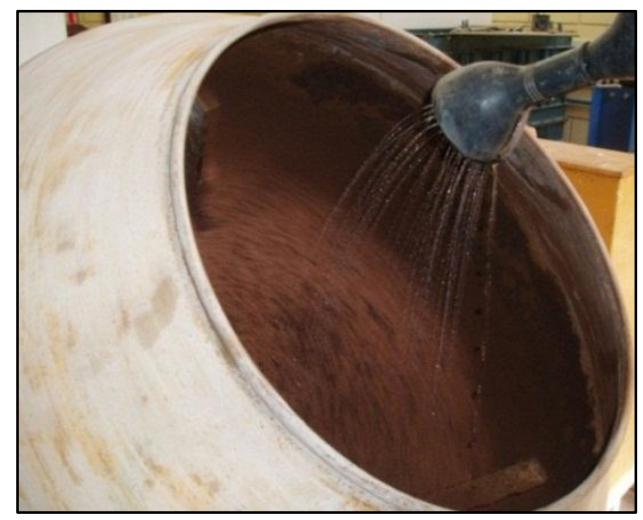

(a)

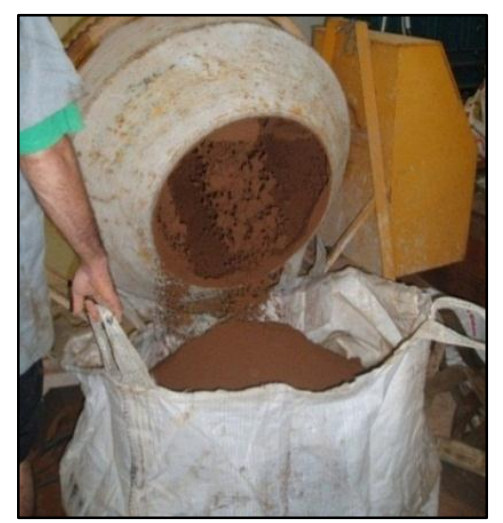

(b)

Figura 4.18. Homogeneização do solo: (a) correção para a umidade de compactação do solo; (b) colocação no bolsão para transporte e compactação no interior da caixa de ensaios.

\subsubsection{Compactação do solo}

Antes de iniciar a compactação definitiva das camadas reforçadas, uma camada experimental foi compactada de modo a definir a altura apropriada das camadas de compactação, o número de passadas do compactador, a massa e a altura de queda do compactador. Tal teste foi conduzido medindo-se o grau de compactação com o uso do cilindro de cravação (ABNT NBR 9813, 1984) após cada passada do compactador. Calculou-se inicialmente a massa de solo 
necessária para compactar uma camada de $5 \mathrm{~cm}$ nas condições de teor ótimo de umidade e peso específico aparente seco máximo da curva de Proctor normal. Com isso, definiu-se que para se obter uma camada compactada final de $5 \mathrm{~cm}$ eram necessárias uma massa de solo de $290 \mathrm{~kg}$ e três passadas do compactador de massa de $15 \mathrm{~kg}$, com golpes do compactador parcialmente sobrepostos. Para obter uma massa compactada suficientemente homogênea, padronizou-se a altura de queda do compactador aproximadamente de $60 \mathrm{~cm}$.

A compactação definitiva compreendeu as seguintes etapas: (1) correção do teor de umidade do solo; (2) correção da massa do bolsão para $290 \mathrm{~kg}$; (3) transporte do bolsão para a caixa de ensaios com o uso da ponte rolante; (4) espalhamento do solo ao longo de toda a área a ser compactada; (5) compactação manual; e (6) controle de compactação pelo método do cilindro de cravação. O processo de compactação é ilustrado na Figura 4.19.

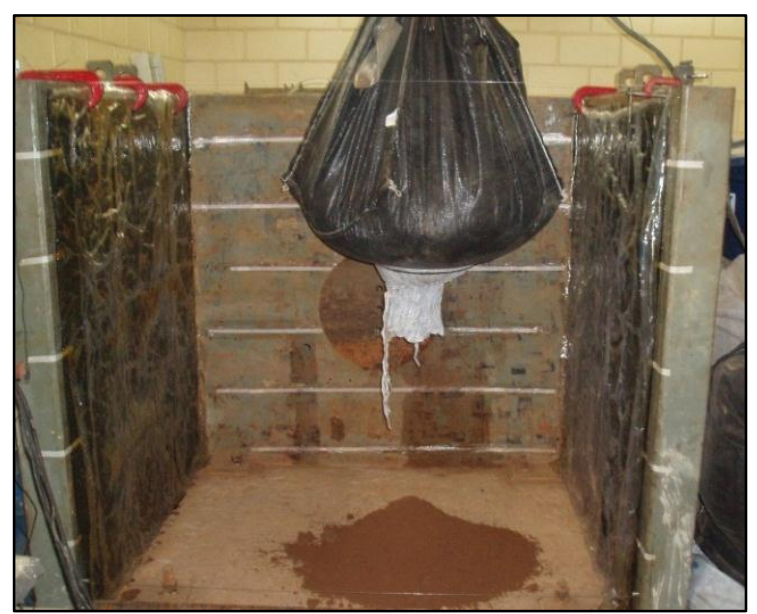

(a)

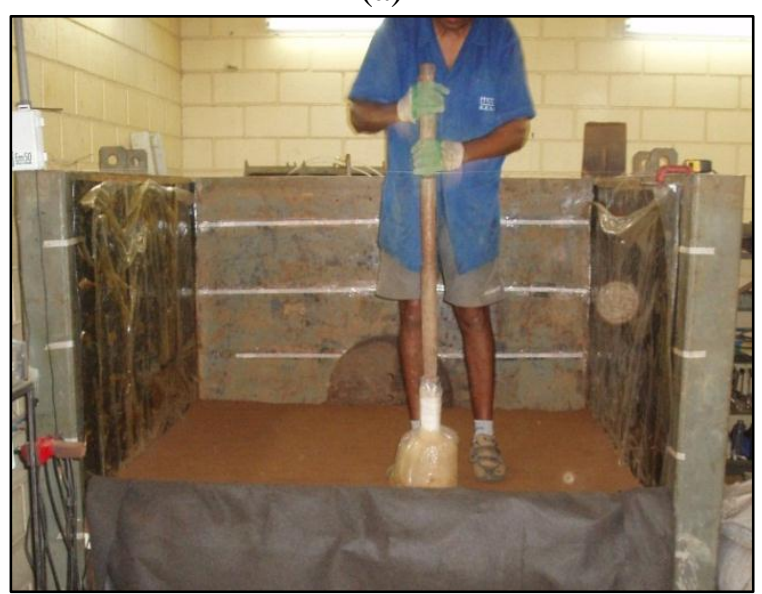

(c)

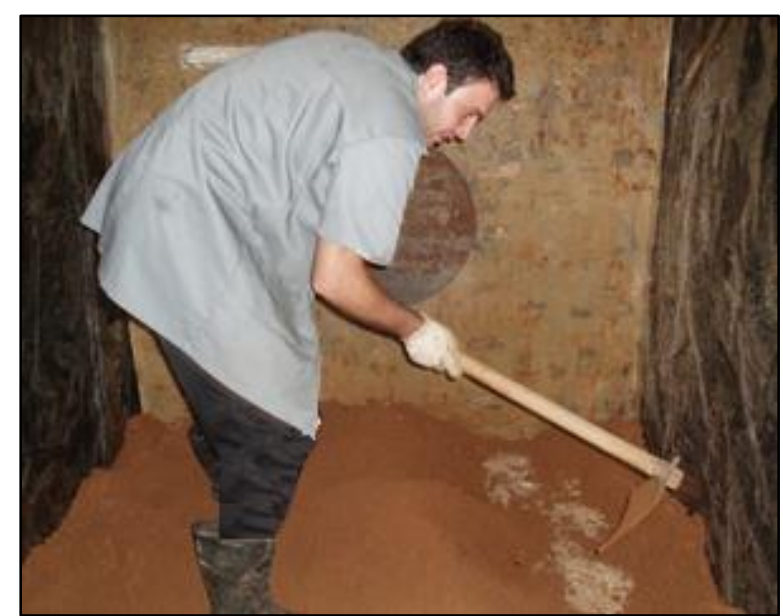

(b)

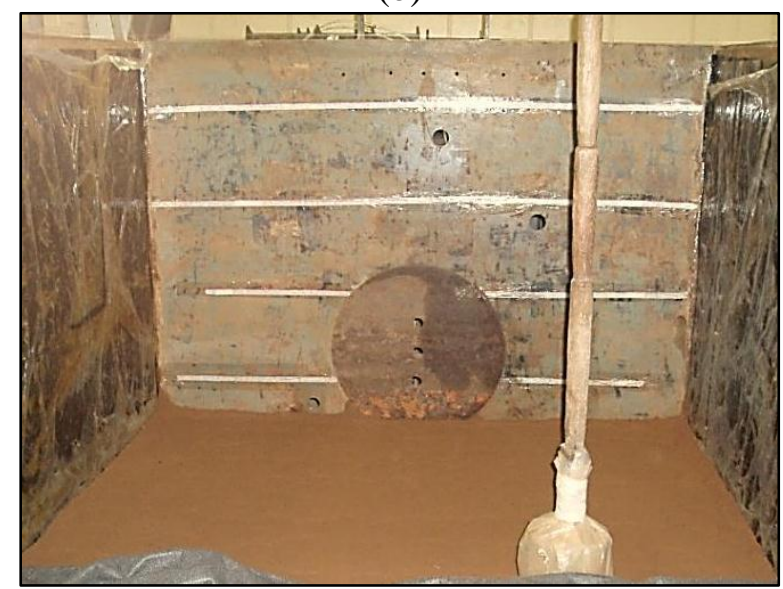

(b)

Figura 4.19. Processo de compactação do solo na caixa de ensaios: (a) transporte do bolsão para a caixa; (b) espalhamento do solo; (c) compactação manual; (d) aspecto final de uma camada compactada.

Como foram definidas as camadas reforçadas com alturas totais de $30 \mathrm{~cm}$, o controle de compactação era realizado no final de cada camada reforçada, ou seja, quando alcançados os 30 $\mathrm{cm}$ desejados. Os cilindros foram cravados em três pontos em cada camada, sendo um próximo da 
face, um no meio e outro próximo ao fundo da caixa de ensaios. Os três pontos foram determinados na seção central, alinhados ortogonalmente à face do muro. Um croqui com a localização dos pontos de cravação e ilustrações do controle de compactação pelo método do cilindro de cravação é apresentado na Figura 4.20.

Os critérios de aceitação dos parâmetros de compactação adotados neste trabalho foram variações nos teores de umidade de $\pm 0,5 \%$ e grau de compactação de $\pm 5 \%$. Em nenhum momento fez-se necessária a retirada do solo compactado, uma vez que o teor de umidade era previamente corrigido e controlado antes da compactação das camadas.

Os resultados dos parâmetros de compactação obtidos no controle de compactação pelo método do cilindro de cravação das camadas reforçadas de cada protótipo estão resumidos na Tabela A.1 do apêndice A. Embora durante todo o processo construtivo utilizou-se o teor de umidade determinado com o uso do forno microondas, no controle de compactação os teores de umidades eram determinados em estufa, uma vez que este método apresenta-se como mais confiável.

Parede do fundo

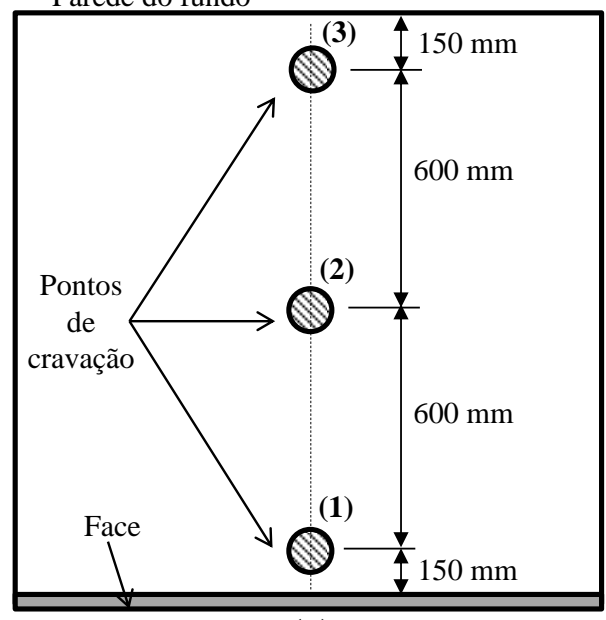

(a)

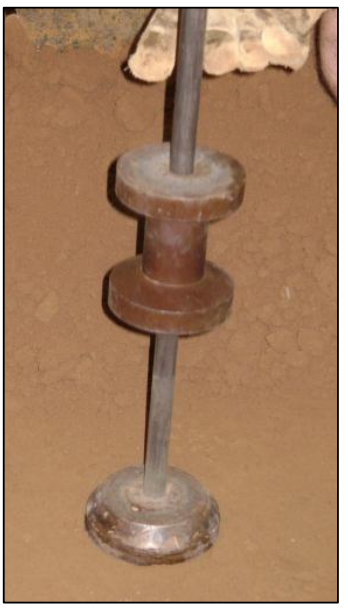

(b)

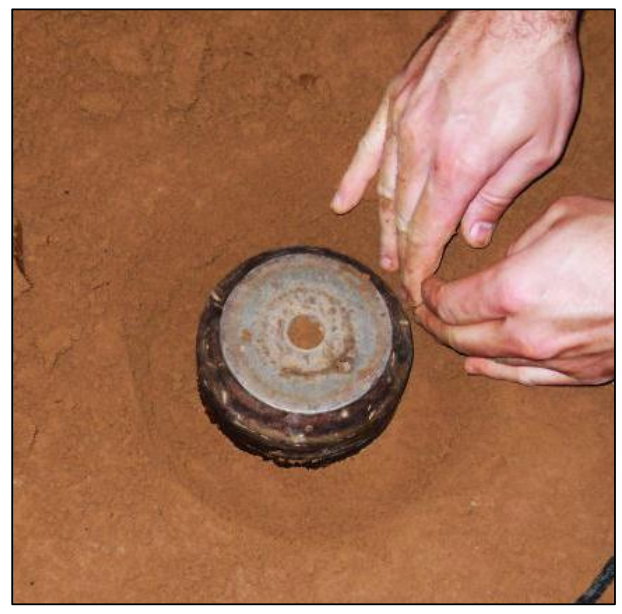

(c)

Figura 4.20. Controle de compactação: (a) localização dos pontos de cravação; (b) cravação do cilindro; (c) retirada do cilindro de cravação.

\subsubsection{Método construtivo}

Para a execução dos protótipos de muros de solo reforçado, utilizou-se a técnica de solo envelopado com o uso de formas móveis para construção das camadas reforçadas, adaptadas para as condições de laboratório. As fôrmas móveis de fixação consistiram em chapas de madeira compensada de $50 \mathrm{~mm}$ de espessura, escoradas externamente por uma viga metálica fixada lateralmente nos pilares frontais da caixa de ensaio. Chapas dobradas de aço em forma de cantoneira foram distribuídas ao longo do comprimento da fôrma de madeira na função de assegurar a verticalidade do faceamento $\left(90^{\circ}\right)$. O sistema de fôrmas e o resultado final das 
camadas são ilustrados na Figura 4.21. O deslocamento da fôrma foi acompanhado durante a compactação do solo, utilizando-se linhas de referência fixadas entre os pilares laterais da caixa de ensaio. Após cada etapa de compactação, a distâncias entre a fôrma e a linha de referência eram determinados em diferentes pontos ao longo do comprimento da fôrma de madeira. Caso fosse observado qualquer deslocamento excessivo da fôrma, escoras transversais eram utilizadas para assegurar a verticalidade da face.

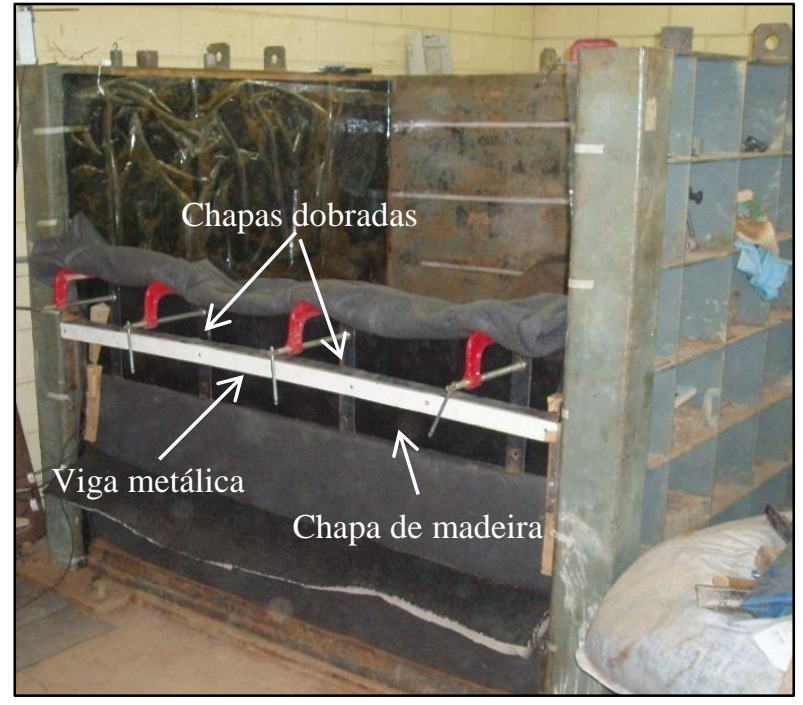

(a)

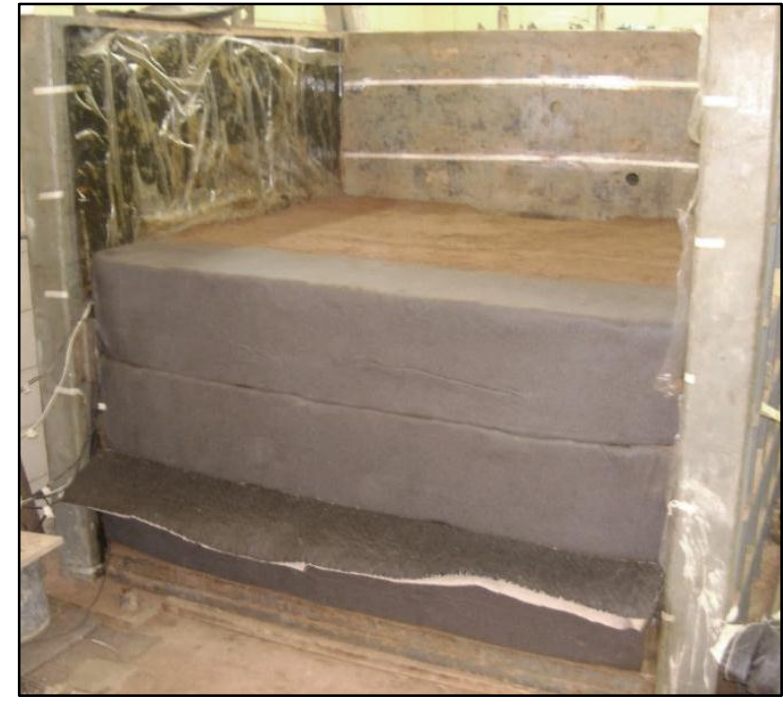

(b)

Figura 4.21. Técnica de envelopamento: (a) sistema de fôrmas, (b) resultado final das camadas.

Após a instalação do sistema de fôrmas, o geotêxtil era devidamente desenrolado e instalado na camada a ser reforçada. Cabe salientar que o comprimento total do reforço utilizado era composto pelo comprimento que compõe a estrutura reforçada, ou seja, $150 \mathrm{~cm}$, somados ao comprimento de envelopamento, que consiste na soma entre o espaçamento entre reforços $(30 \mathrm{~cm})$ e o comprimento responsável pela ancoragem no envelopamento $(70 \mathrm{~cm})$. Portanto, o comprimento total do reforço foi de $250 \mathrm{~cm}$, sendo $150 \mathrm{~cm}$ referente à zona reforçada.

Sobre a manta geotêxtil, o solo era lançado, espalhado e compactado em camadas de $5 \mathrm{~cm}$, como anteriormente relatado. No final dos $30 \mathrm{~cm}$ de solo compactado, a vala de escoramento era escavada a uma distância de $30 \mathrm{~cm}$ da fôrma de madeira com $15 \mathrm{~cm}$ de profundidade e $25 \mathrm{~cm}$ de largura. Posteriormente, o reforço que havia sobrado externamente ao sistema de formas era dobrado em direção à vala de escoramento. A extremidade do reforço dobrado em direção a vala foi devidamente grampeado no solo de modo a esticar e ancorar o comprimento de envelopamento acima da vala de ancoragem. A camada era finalizada com o lançamento e compactação do solo no comprimento de reforço na vala de ancoragem escavada, que gerava um tensionamento do reforço e um bom acabamento da face. Após compactação do solo na vala de ancoragem, a viga de escoramento, as cantoneiras de fixação e a prancha de madeira eram retiradas e preparadas para a execução da camada acima. O procedimento de instalação das fôrmas, instalação dos reforços, 
compactação do solo e ancoragem do sistema era repetido em cada camada reforçada até alcançar a altura final da estrutura. O método construtivo é detalhado ilustrativamente na Figura 4.22.

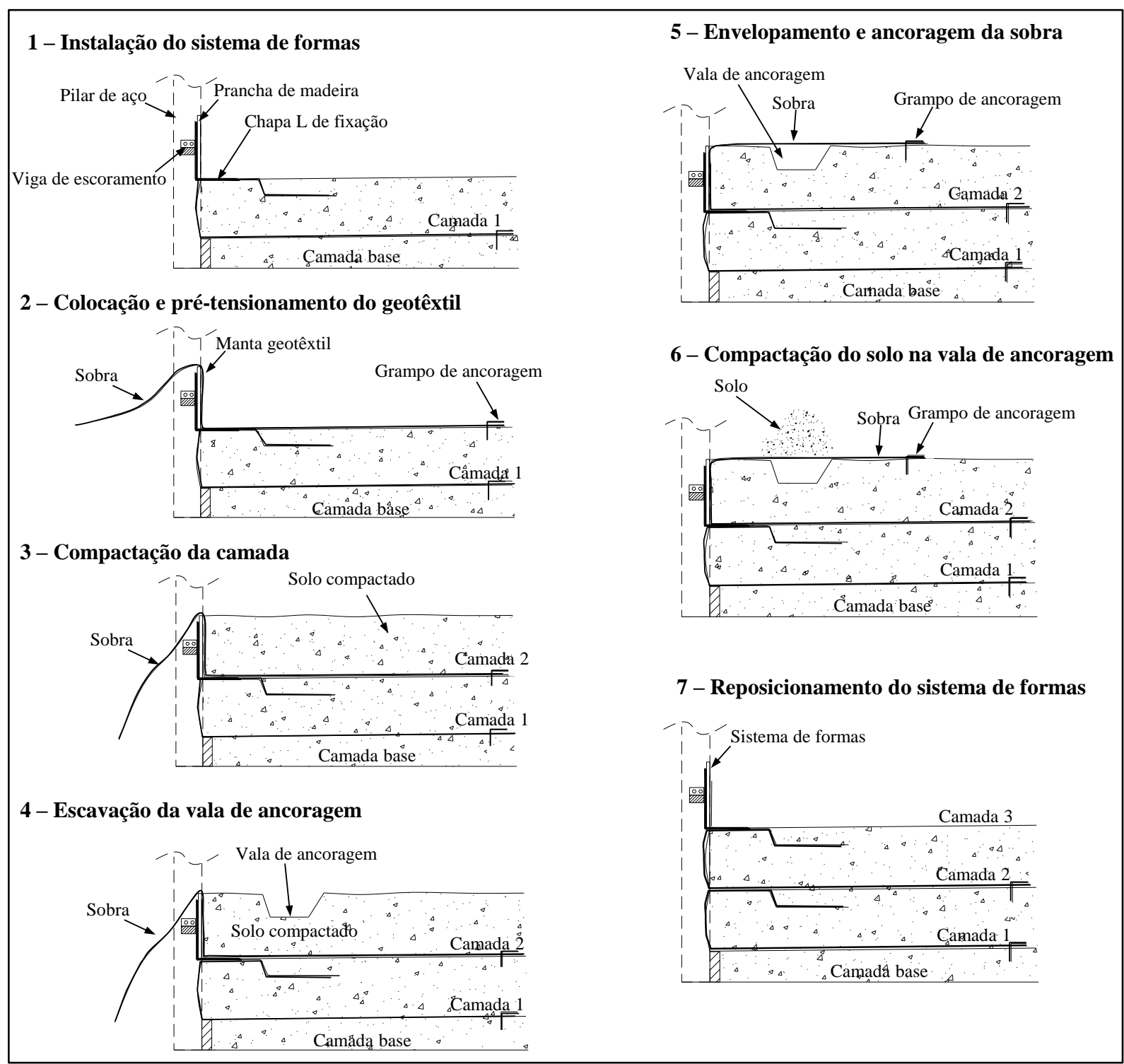

Figura 4.22. Método construtivo adotado na execução dos protótipos.

Para os protótipos M1, M2 e M3 executou-se um revestimento de face com argamassa de cimento no traço 1:3 (cimento: areia) com espessura variando entre 50 e $80 \mathrm{~mm}$. Para uma boa aderência entre a face envelopada e a argamassa de revestimento, utilizou-se a impregnação com uma calda de cimento nos vazios dos geotêxteis expostos e a fixação de uma tela metálica em toda a área de faceamento. O revestimento era lançado manualmente com o auxílio de uma colher de assentamento (colher de pedreiro), diretamente em contato com a tela metálica. A sequência da execução do revestimento de face é mostrada na Figura 4.23. No caso do protótipo M4, o comportamento deste sob as condições de avanço de umidade foi avaliado com o envelopamento da face exposta. Com isso, tem-se uma segunda condição em que a água poderia ser conduzida 
livremente ao longo do comprimento do reforço até a face envelopada, sem a redução da área de descarga imposta pela impermeabilização da face.

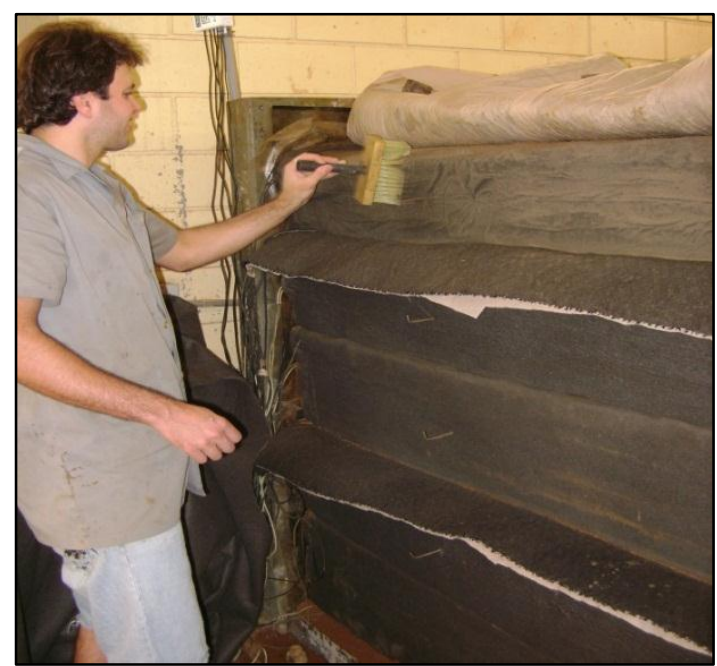

(a)

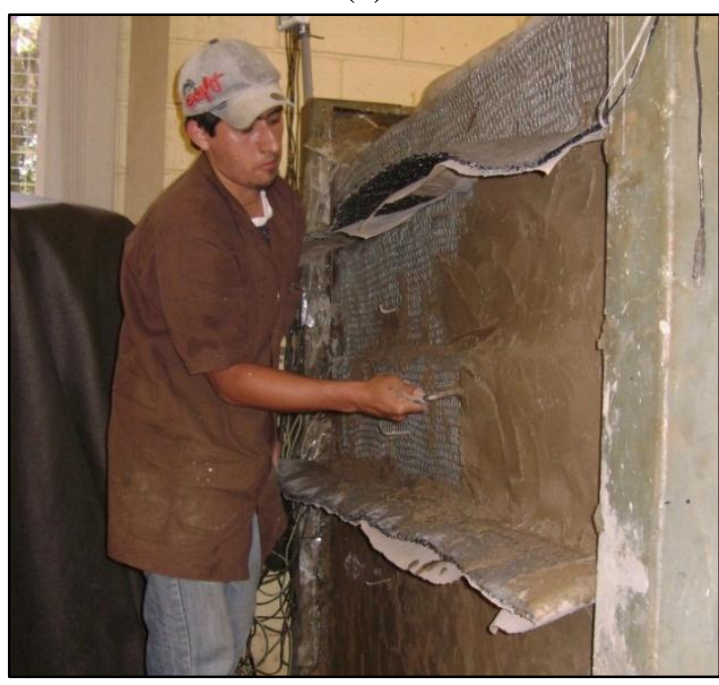

(c)

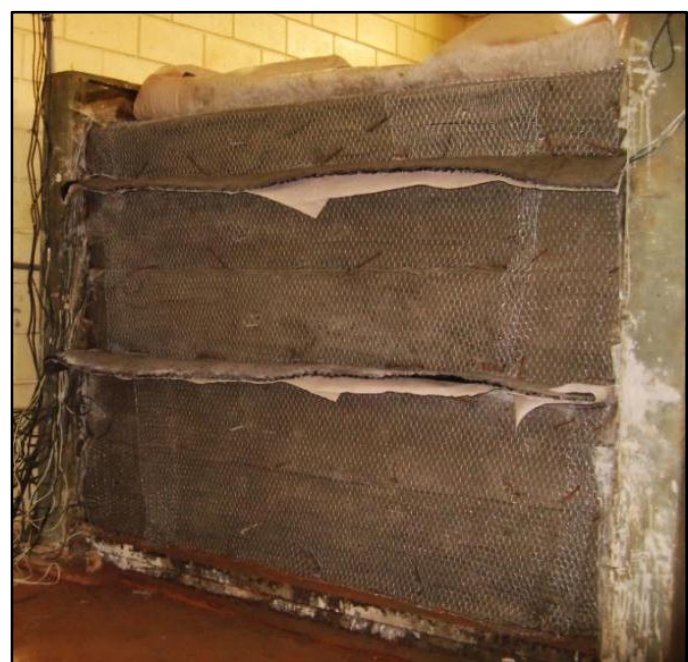

(b)

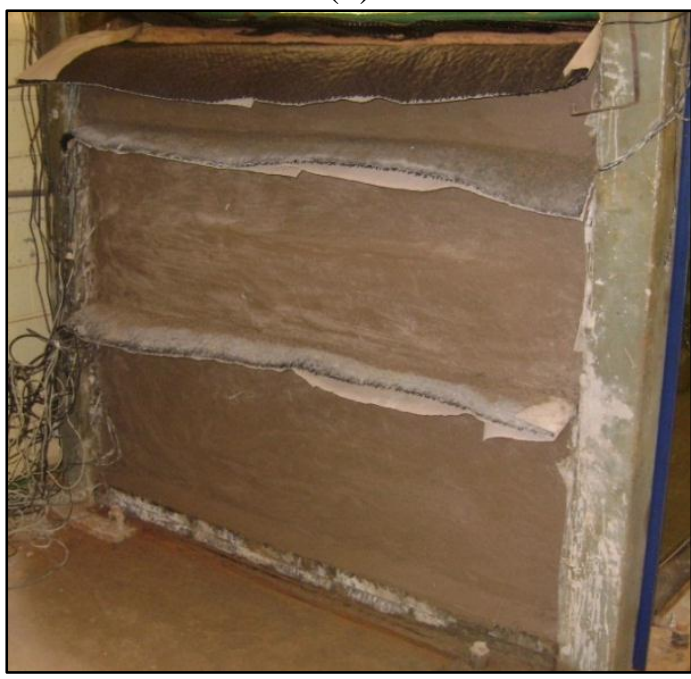

(d)

Figura 4.23. Processo de execução do revestimento da face: (a) impregnação com calda de cimento; (b) instalação da tela metálica de aderência; (c) execução do revestimento; (d) aspecto final com revestimento de argamassa de cimento.

Optou-se por avaliar estruturas com faceamento revestido no intuito de buscar uma aproximação com a real condição da estrutura nas condições de serviço. $O$ fato é que geotêxteis não tecidos podem cumprir tanto com a função reforço como a de drenagem sob a condição de infiltração de água no sistema reforçado, conduzindo as pressões de água para fora do sistema. No caso da utilização de faceamento revestido com argamassa ou concreto projetado, a área de descarga de água passa a ser limitada pelo fato da face ser parcialmente impermeabilizada, assim, drenos de face devem ser previstos. Tal fato foi considerado neste trabalho, em que drenos de face de geocompostos foram devidamente dispostos a cada duas camadas reforçadas, ou seja, espaçados a cada $60 \mathrm{~cm}$. Na Figura 4.24 são apresentadas fotografias dos protótipos de laboratório 
logo após a construção, aqui designados como Muro 1 (M1), Muro 2 (M2), Muro 3 (M3) e Muro 4 (M4).

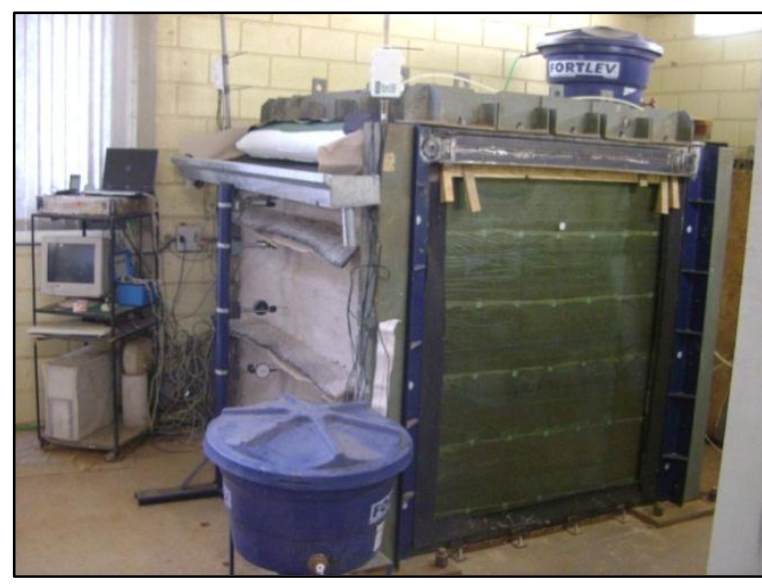

(a)

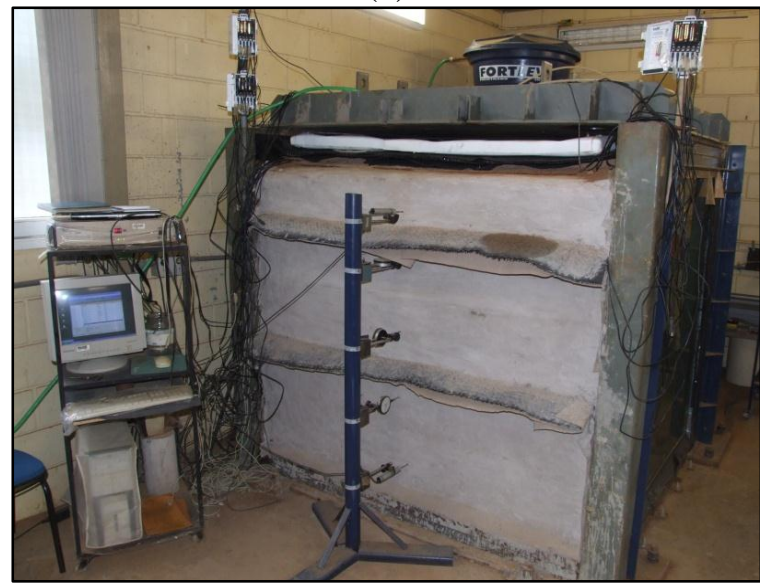

(c)

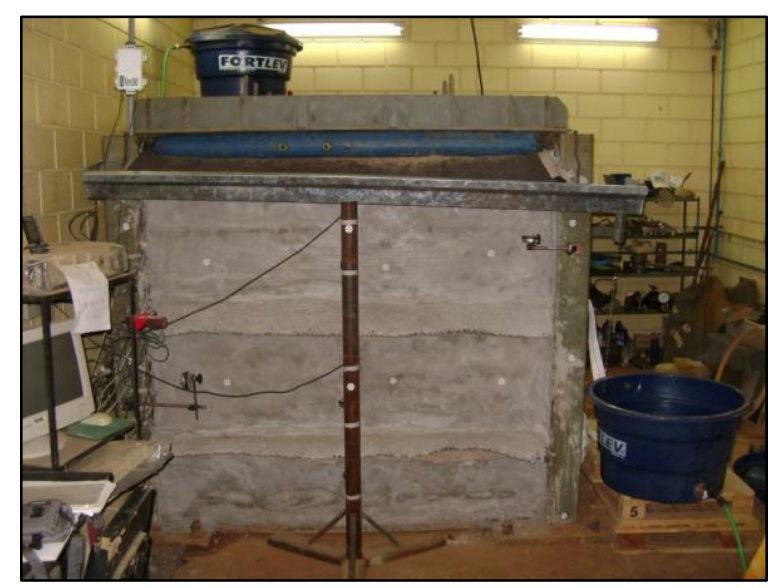

(b)

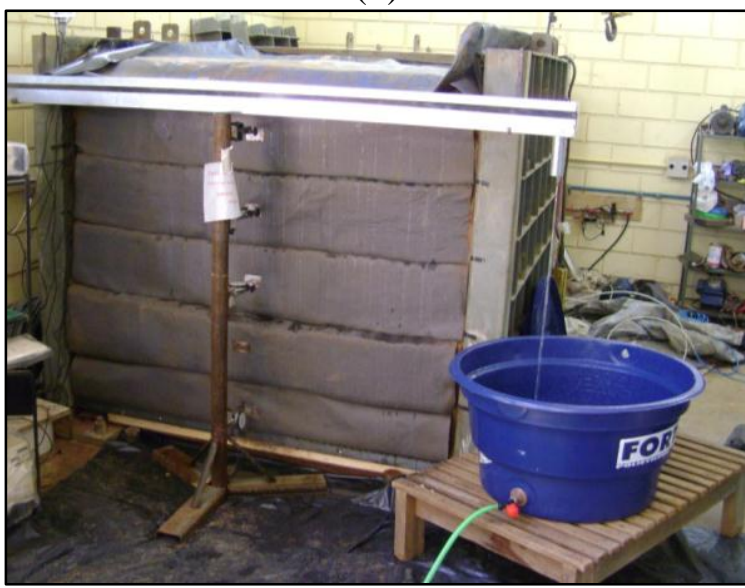

(d)

Figura 4.24. Protótipos de laboratório: (a) M1; (b) M2; (c) M3; (d) M4.

\subsection{Sistema de simulação de lâmina de chuva}

Após a execução dos protótipos, um sistema de simulação do avanço de infiltração de água foi instalado na superfície do topo da estrutura. Para isso, a superfície do topo foi preparada para ter uma declividade de $2 \%$ em direção à face do protótipo com intuito de descarregar parte da água para um coletor, permitindo a determinação da vazão de saída da água. Este coletor tem a função de conduzir a água para um reservatório inferior, instalado no pé da estrutura.

O sistema de alimentação de água consistiu em um reservatório superior instalado a uma altura de $1,0 \mathrm{~m}$ em relação à cota de arrasamento do topo do muro. O nível de água no reservatório era mantido constante por meio de uma torneira boia que cessava a alimentação de água assim que o nível almejado era alcançado. Como as vazões de saída eram geralmente muito pequenas, o nível era mantido constante. Uma vez que a carga hidráulica era mantida constante, a manutenção da intensidade de chuva aplicada era também garantida. 
Do reservatório de alimentação, a água era conduzida para quatro tubos rígidos de distribuição (PEAD), com de diâmetros internos de $5 \mathrm{~mm}$, espalhados em diferentes pontos no topo de uma camada de distribuição de água executada no topo do protótipo. Uma torneira foi instalada na tubulação entre o reservatório de alimentação e os tubos de distribuição de água de modo a controlar a vazão direcionada à camada de distribuição água. A camada de distribuição de água era composta por uma camada de areia bem graduada de $15 \mathrm{~cm}$ de altura, executada sobre um geocomposto MacDrain ${ }^{\circledR}$. O geocomposto MacDrain ${ }^{\circledR}$ consiste em um "sanduíche" de geotêxteis não tecidos e núcleo de geomanta, que era instalado para cobrir toda a área no topo da estrutura cuja função é conduzir a água para o coletor. Na região entre o coletor e a face da estrutura, uma geomembrana foi instalada abaixo do geocomposto para que a água que escoava em direção ao coletor fosse completamente coletada com o mínimo de perda possível. Outro geocomposto drenante do tipo Mirafi ${ }^{\circledR}$ ("sanduíche" de geotêxteis não tecidos e núcleo drenante de pata simples) foi instalado no topo da camada de areia, cuja configuração garantiu a boa distribuição de água na camada de areia. A camada de distribuição de água no topo da estrutura é esquematizada na Figura 4.25.

Portanto, o sistema de simulação da lâmina de chuva compreendeu em três componentes: (1) sistema de alimentação de água (reservatório superior e tubulação de controle da vazão); (2) sistema de distribuição de água (tubos de distribuição e camada de distribuição), e; (3) sistema de coleta de água (coletor e reservatório inferior). O sistema completo de simulação de lâmina de água da chuva é apresentado na Figura 4.26.

O sistema desenvolvido permite que a vazão de entrada na camada de distribuição possa ser medida pela massa de água coletada na saída do controlador de vazão do reservatório superior, num determinado espaço de tempo. Do mesmo modo, a vazão de saída do sistema era medida na boca de saída do coletor de água. Com isso, foi possível obter as vazões aproximadas de entrada e saída do sistema. A diferença entre o volume de entrada e o volume de saída resulta no volume de água infiltrado no interior da estrutura. Cuidados foram tomados para que a água não tomasse caminhos preferências na interface parede-solo, impermeabilizando toda a área de interface com aplicação de parafina.

Cuidados foram tomados também para que não houvesse a perda de água para fora do sistema. Por precaução, vazões relativamente pequenas foram adotadas para que não houvesse o transbordamento excessivo de água para fora do sistema. Inicialmente, observou-se vazamento abaixo do geocomposto drenante $\mathrm{McDrain}^{\circledR}$ por tratar-se de um material permeável. A solução tomada consistiu na utilização de uma membrana impermeável abaixo da interface geocompostoface, conduzindo toda a água para o coletor assim como esquematizado na Figura 4.25. Vazamentos de mangueiras, tubulações e torneiras foram devidamente estancados com a utilização de fitas de vedação. 

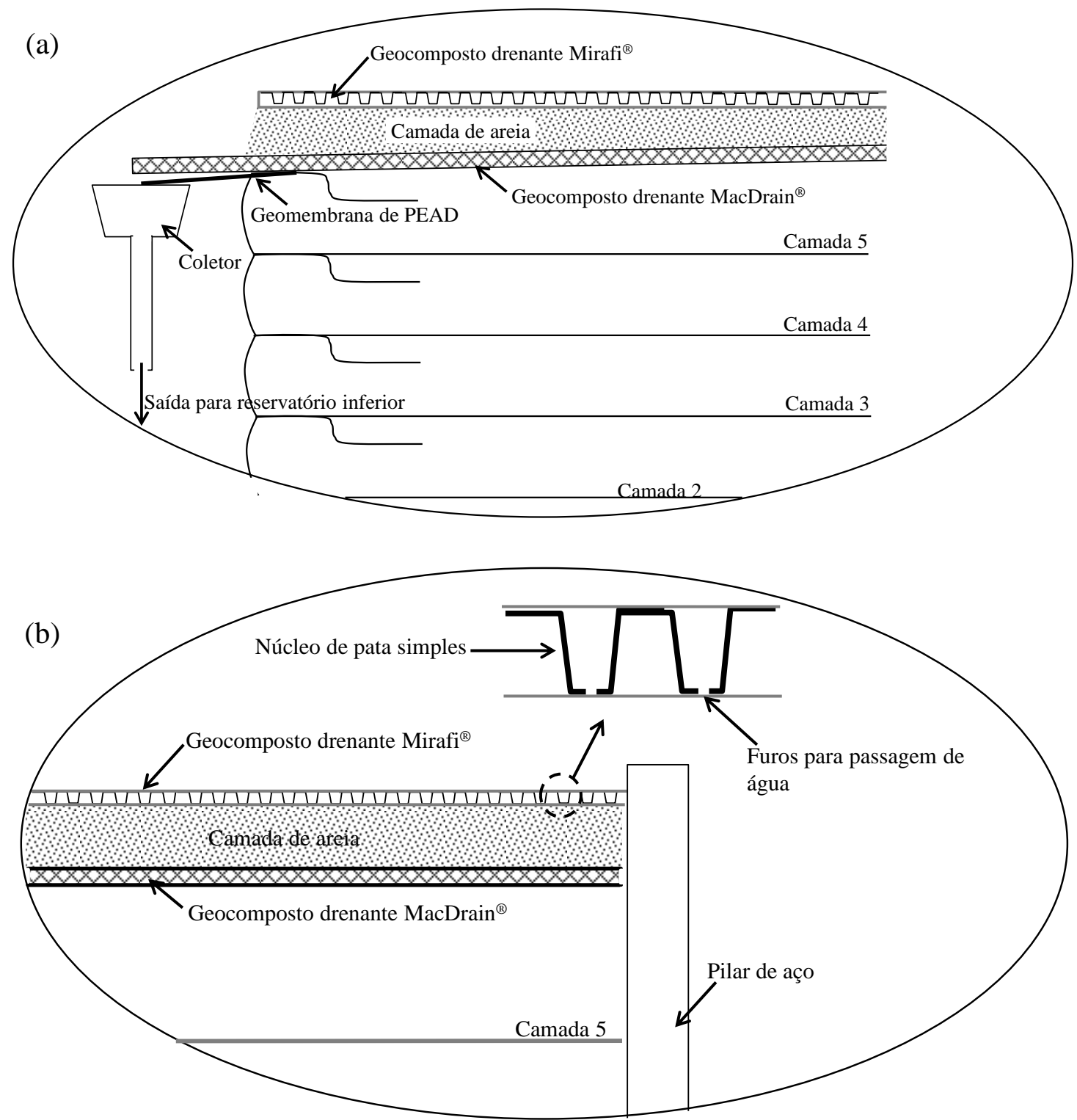

Figura 4.25. Esquema representativo da camada de distribuição de água no topo do protótipo: (a) seção transversal; (b) seção longitudinal. 


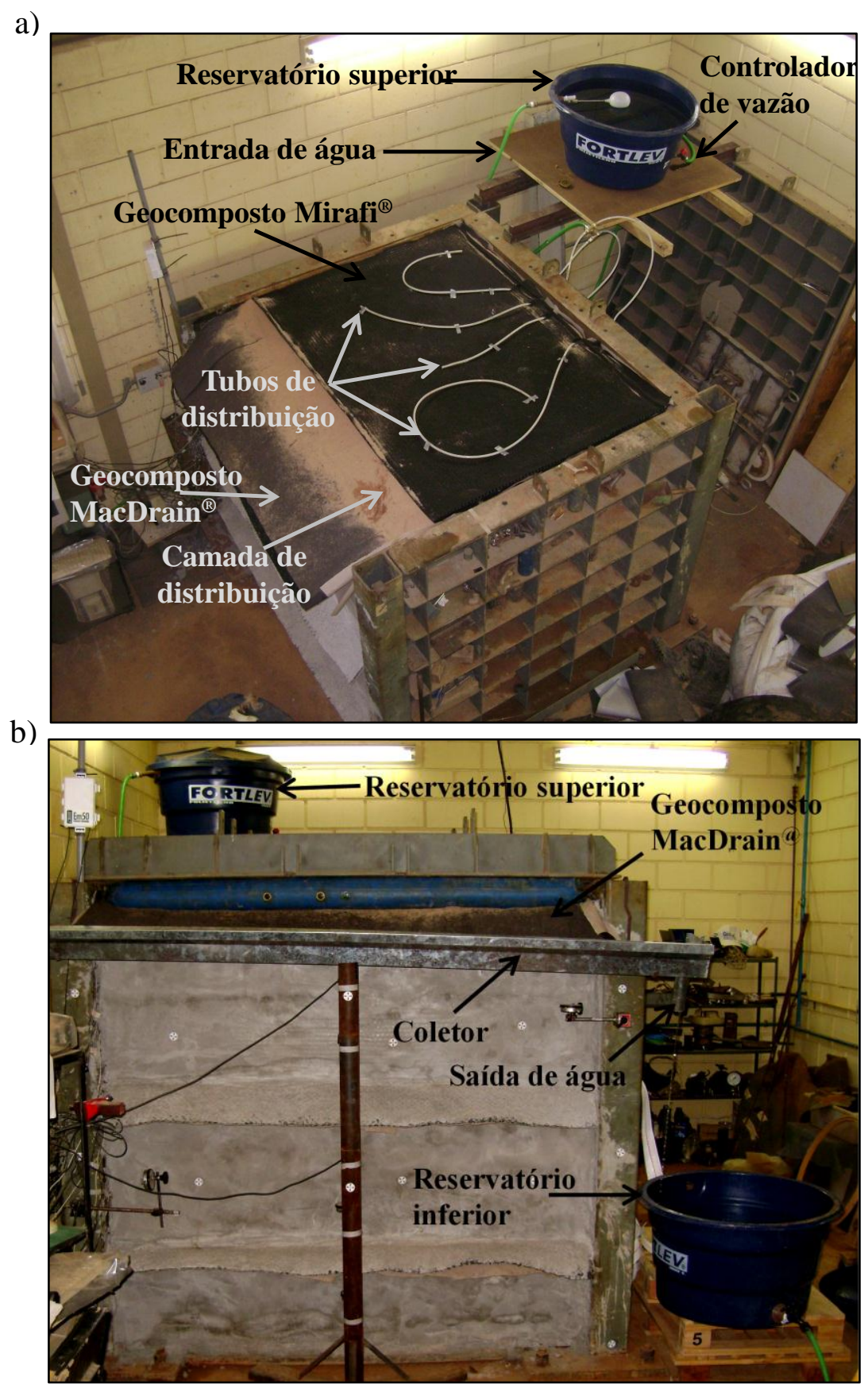

Figura 4.26. Sistema completo de simulação de lâmina de chuva.

\subsection{Sistema de aplicação de tensões verticais}

As tensões verticais atuantes sobre a estrutura reforçada foram reproduzidas por meio da aplicação de ar pressurizado em uma bolsa inflável com dimensões de 160 x 150 x $30 \mathrm{~cm}$, fabricada com geomembrana de policloreto de vinila (PVC), reforçada com malha de polietileno de alta densidade (PEAD), fornecida pela Sansuy Ltda. A bolsa inflável foi posicionada no topo da camada de distribuição de água, entre a tampa de reação e o topo da estrutura. De modo a evitar o contato entre a bolsa de ar e os tubos de distribuição de água, uma manta de geotêxtil não 
tecido foi instalada na interface para promover proteção, tanto da tubulação quanto da própria bolsa de ar.

O sistema de reação da tensão aplicada pela bolsa de ar consistiu em uma tampa de reação fixada nas paredes da caixa de ensaios, que transmite as tensões para os quatro pilares de aço que compõem a caixa de ensaios, que, por sua vez, transmite as tensões para serem absorvidas pela laje de reação. Este sistema é projetado para suportar tensões de até $200 \mathrm{kPa}$.

$\mathrm{O}$ enchimento da bolsa de ar foi efetuado utilizando-se do sistema de rede de ar existente no Laboratório de Geossintéticos da EESC/USP, alimentado por um compressor de ar industrial Schulz Ltda., com capacidade de $2100 \mathrm{kPa}$. A pressão de ar aplicada no interior da bolsa de ar foi controlada por um sistema composto por um manômetro de capacidade de $200 \mathrm{kPa}$ (precisão de $10 \mathrm{kPa}$ ), válvulas de interrupção e válvulas de controle de vazão. O sistema completo de aplicação de tensões verticais nos protótipos é ilustrado na Figura 4.27.
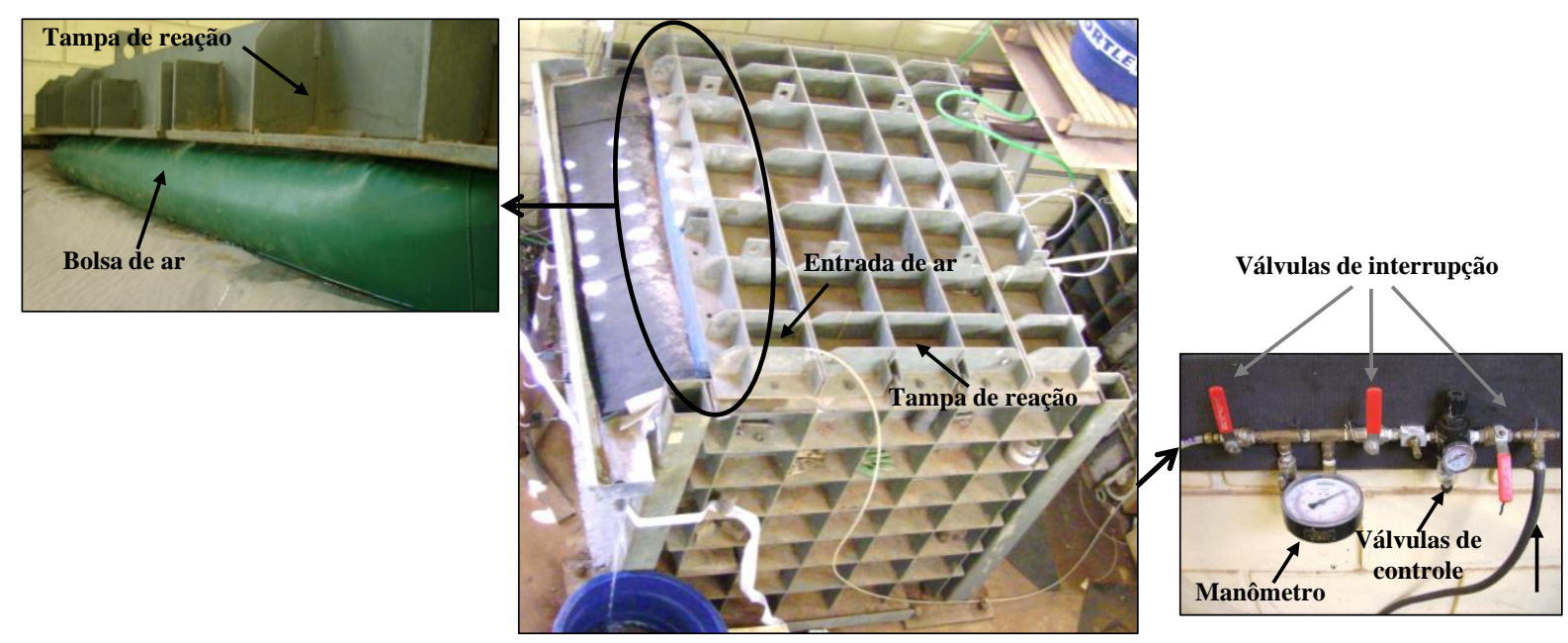

Figura 4.27. Sistema de aplicação de tensões verticais.

\subsection{Instrumentação}

O programa de instrumentação foi idealizado para se obter informações quanto ao comportamento hidráulico e mecânico dos protótipos, de modo que a relação entre ambos pudesse ser avaliada. Assim, o comportamento hidráulico foi monitorado por sensores de umidade e tensiômetros devidamente posicionados no corpo do muro reforçado. Já o comportamento mecânico foi monitorado por medidores de deslocamentos horizontais de face (LVDTs), medidores de deslocamentos horizontais internos (extensômetros mecânicos tell-tales) e células de tensões totais. As seções com o posicionamento da instrumentação nos protótipos M1, M2, M3 e M4 são apresentadas nas Figuras 4.28, 4.29 e 4.30, respectivamente. 


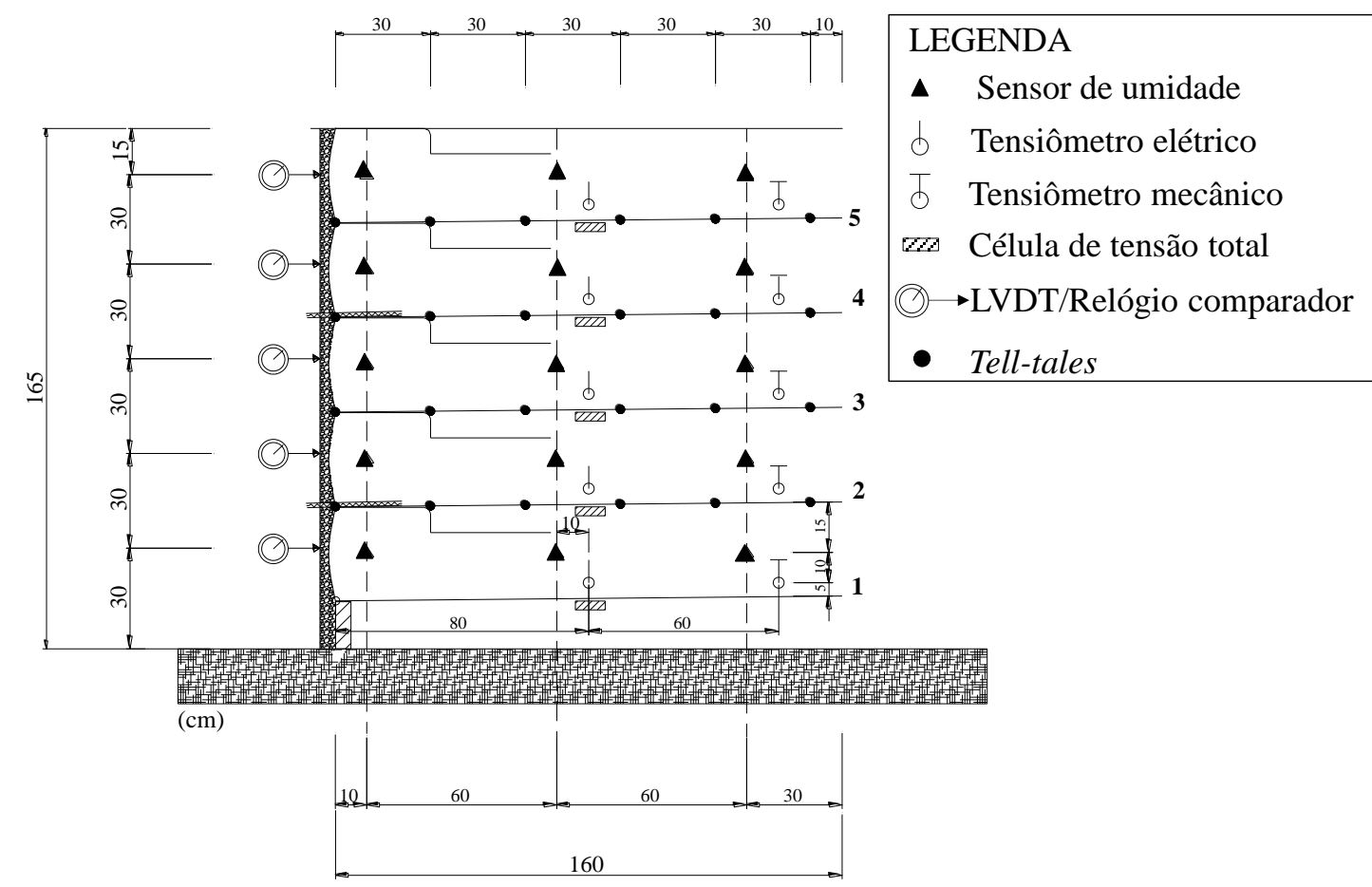

Figura 4.28. Localização da instrumentação nos protótipos M1 e M2.

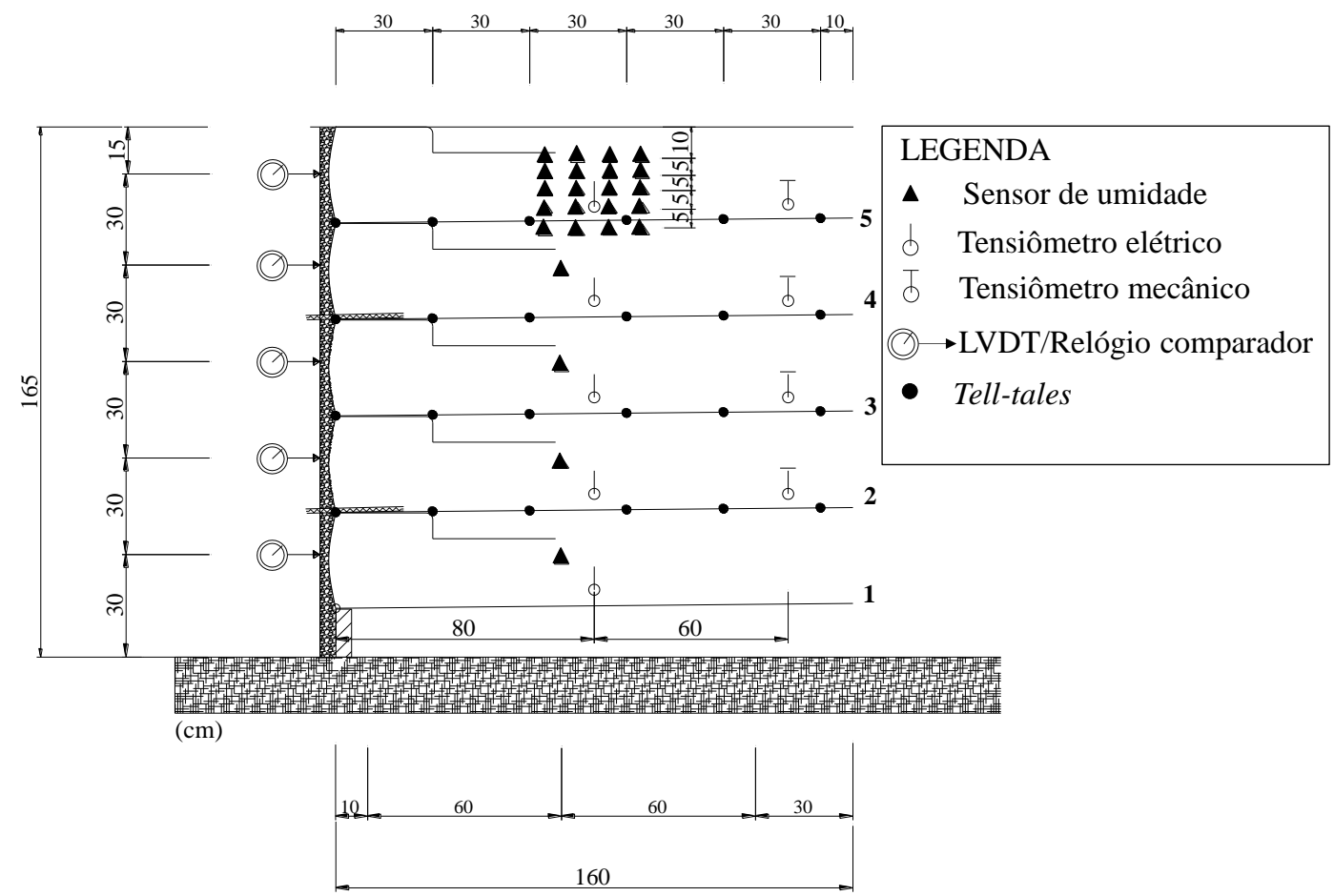

Figura 4.29. Localização da instrumentação no protótipo M3. 


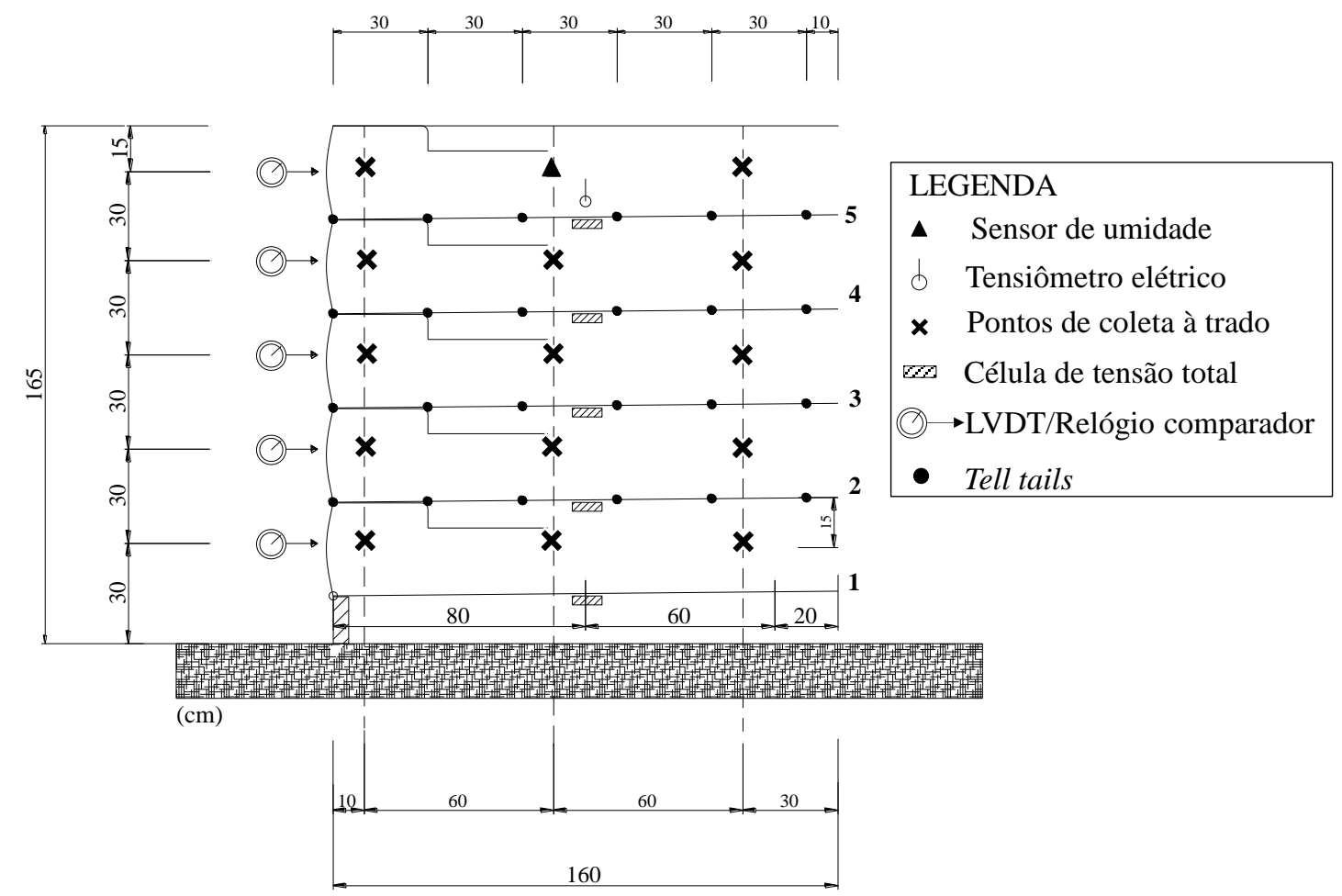

Figura 4.30. Localização da instrumentação no protótipo M4.

As diferentes configurações dos instrumentos no interior dos protótipos foram planejadas de acordo com o objetivo de cada estudo. Os protótipos M1 e M2 foram executados para comparar comportamentos de um protótipo sob a condição de umidade constante de compactação e outro sob a condição de avanço da frente de umedecimento. Por tal motivo, optou-se por utilizar da mesma configuração de instrumentação, nos quais diferentes pontos abrangendo a área da seção transversal do protótipo foram monitorados (Figura 4.28). No protótipo M3, utilizou-se de uma configuração em que colunas de sensores monitorassem as variações de umidade ao longo de toda a altura da camada mais superficial, no intuito de avaliar o comportamento hidráulico na interface solo-geotêxtil (Figura 4.29). Já no protótipo M4, pode-se dizer que a mesma localização dos pontos de medidas dos protótipos M1 e M2 foi adotada, porém, devido à falta de uma quantidade apropriada de instrumentos no período de teste deste protótipo, optou-se por técnicas alternativas de monitoramento dos teores de umidade, neste caso, com o uso de amostras extraídas por trado manual e determinação do teor de umidade em estufa à $105^{\circ} \mathrm{C}$ (Figura 4.30).

\subsubsection{Sensores de umidade}

O monitoramento do teor de umidade volumétrica $(\theta)$ em diferentes pontos no interior do maciço reforçado foi realizado com a utilização de sensores de umidade modelo EC-5 da Decagon Devices, Inc. Este sensor consiste num dispositivo do tipo Frequency Domain Reflectometry (FDR) que relaciona a medida da constante dielétrica com o teor de umidade volumétrica do solo. Uma vez que a constante dielétrica da água é muito maior que a constante dielétrica do ar e das 
partículas sólidas que compõem o solo, a constante dielétrica passa a ser consideravelmente sensitiva à variação do teor de umidade do sistema solo-ar-água.

O sensor EC-5 possibilita medições de teores de umidade volumétrica numa faixa entre 0 e $100 \%$ (sendo que solos saturados apresentam geralmente valores entre 40 e $60 \%$, dependendo do tipo de solo), com resolução de $0,02 \%$ (ou $0,002 \mathrm{~m}^{3} / \mathrm{m}^{3}$ ) e intervalos mínimos de leituras de 10 ms, sendo este programável para períodos maiores.

O sistema de leitura utilizado consiste em um aquisitor específico para sistemas FDR, o Em50, desenvolvido pela própria Decagon Devices Inc., com cinco portas para sensores EC-5 e capacidade de armazenamento de 5000 dados, alimentando os sensores com uma voltagem de $2500 \mathrm{mV}$. As leituras são programadas e armazenadas com o uso do software $\mathrm{ECH}_{2} \mathrm{O}$ Utility. $\mathrm{O}$ sistema de medição dos teores de umidade é mostrado na Figura 4.31.

A instalação dos sensores EC-5 no solo é facilitada pelo formato "garfo" e espessura de 2 mm, que permitiu a cravação destes no aterro compactado. A cravação foi realizada manualmente nos pontos de medidas definidos conforme apresentados no tópico anterior. O processo da instalação dos sensores e o posicionamento dos aquisitores são apresentados na Figura 4.32.

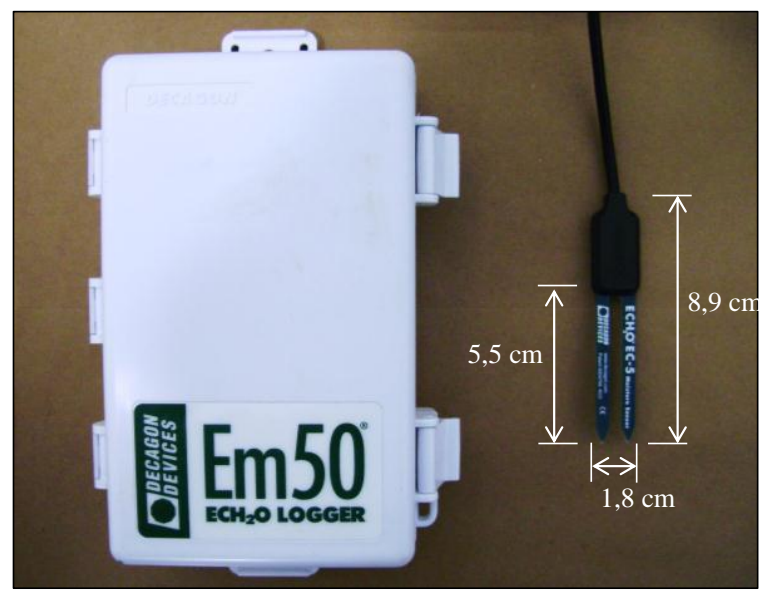

Figura 4.31. Sistema de leitura do teor de umidade volumétrica: aquisitor Em50 e sensor EC-5.

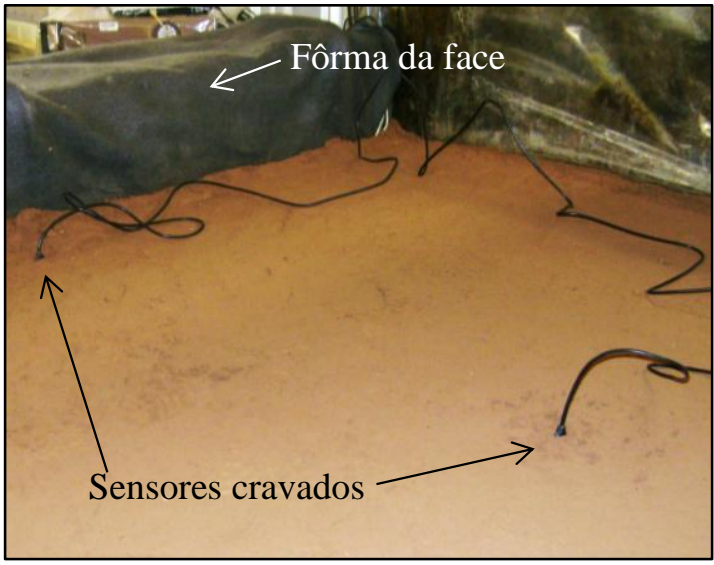

(a)

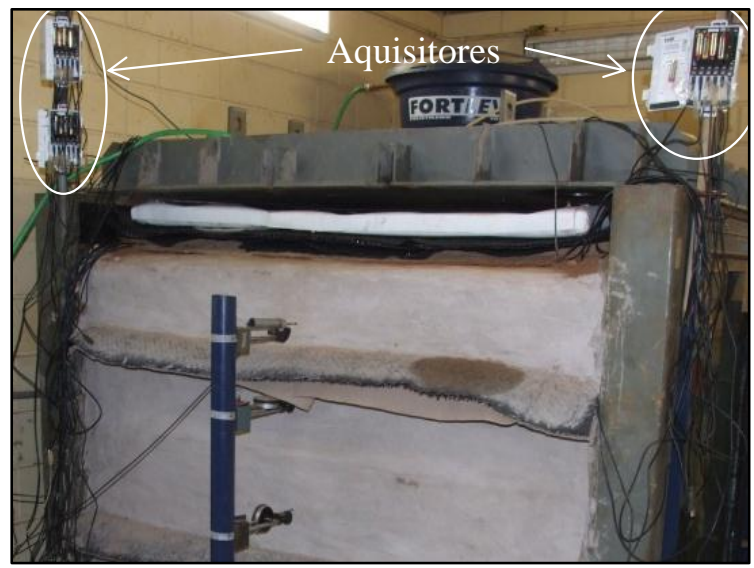

(b)

Figura 4.32. Sensores de umidade: (a) instalação dos sensores; (b) posicionamento dos aquisitores. 
A calibração dos sensores foi realizada para o solo utilizado nesta pesquisa e nas condições de compactação propostas nos ensaios. O procedimento de calibração consistiu na moldagem de corpos de prova em tubos de acrílico com dimensões de $15 \mathrm{~cm}$ x $25 \mathrm{~cm}$ (diâmetro x altura). Foram moldados 8 corpos de prova no grau de compactação de $98 \%$ e sob diferentes condições de umidade gravimétrica entre 10 e $22 \%\left(0,15\right.$ a $\left.0,4 \mathrm{~m}^{3} / \mathrm{m}^{3}\right)$. A ilustração do processo e a curva de calibração são apresentadas na Figura 4.33.

a)

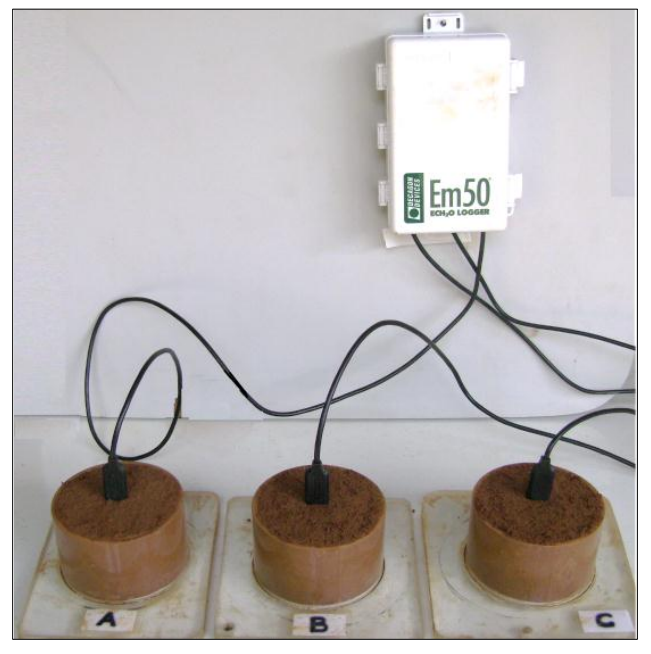

b)

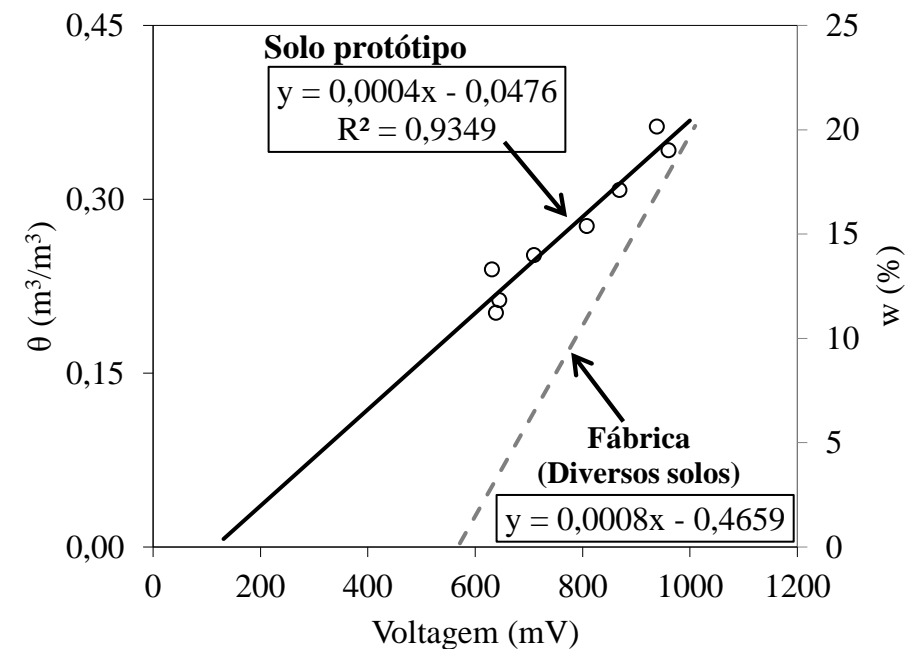

Figura 4.33. Calibração dos sensores de umidade: (a) processo de calibração; (b) curva de calibração.

\subsubsection{Tensiômetros}

Para medidas diretas de sucção matricial do solo durante as condições de serviço dos protótipos, tensiômetros mecânicos e elétricos foram instalados em cada camada reforçada em diferentes pontos ao longo da largura do protótipo.

Os tensiômetros elétricos utilizados são fabricados pela $U M S G m b H$, modelo T4, cuja faixa de medidas está entre $-100 \mathrm{kPa}$ a $100 \mathrm{kPa}$, o que possibilita a utilização deste instrumento na função de um piezômetro, uma vez que tanto sucções positivas quanto negativas podem ser registradas. Os tensiômetros T4 foram alimentados com voltagem de $10 \mathrm{~V}$ e possuem precisão de leitura de $0,2 \mathrm{kPa}$. No presente trabalho foi utilizado um sistema de aquisição SYSTEM 5000, modelo 5100a, fabricado pela Vishay measurements group Inc.

Os tensiômetros mecânicos possuem intervalos de medidas de sucção entre 0 e $200 \mathrm{kPa}$, portanto, pressões da água positivas não foram possíveis de serem medidas por estes instrumentos. Os tensiômetros mecânicos utilizados nesta pesquisa foram fabricados pela Soil moisture equipament corp. Na Figura 4.34 são mostrados os tensiômetros elétricos e mecânicos utilizados na pesquisa. 


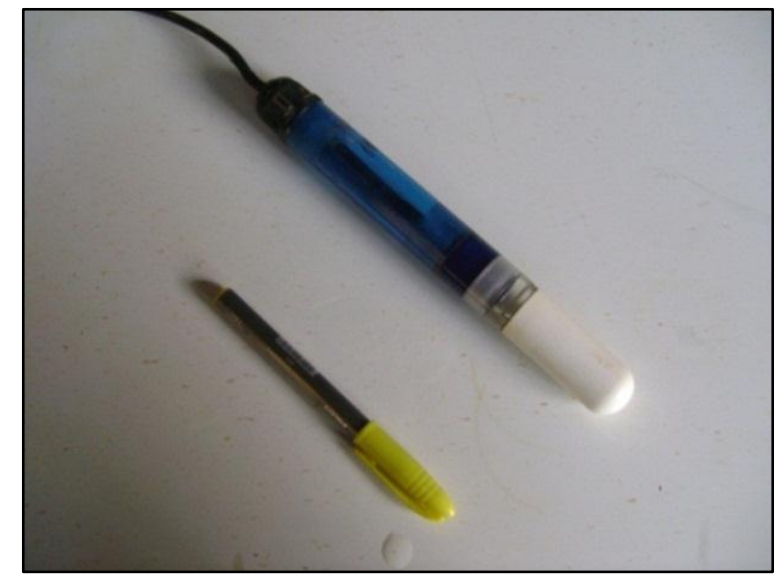

(a)

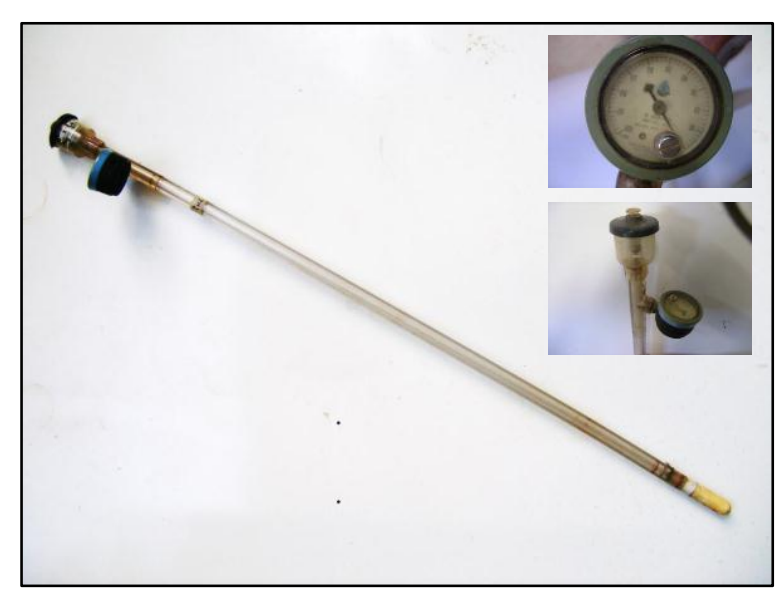

(b)

Figura 4.34. Tensiômetros: (a) elétrico; (b) mecânico.

A calibração dos tensiômetros elétricos foi baseada nos resultados fornecidos pelo fabricante. Embora a calibração própria para o solo da pesquisa não tenha sido realizada, as curvas de retenção do solo medidas pelas técnicas laboratoriais (papel filtro e funil de pedra porosa) foram comparadas com pontos da curva de retenção obtidos pelos tensiômetros. As medidas dos tensiômetros foram realizadas em corpos de provas com dimensões de $30 \mathrm{~cm}$ x 30 cm (diâmetro x altura), compactados no grau de compactação dos protótipos em diferentes teores de umidade. Com isso, puderam-se aferir as medidas determinadas pelos tensiômetros. No caso dos tensiômetros mecânicos, não é necessário à calibração do sistema, mas somente da aferição do manômetro. A comparação entre as curvas de retenção determinadas em laboratório e pelos tensiômetros é apresentada na Figura 4.35.

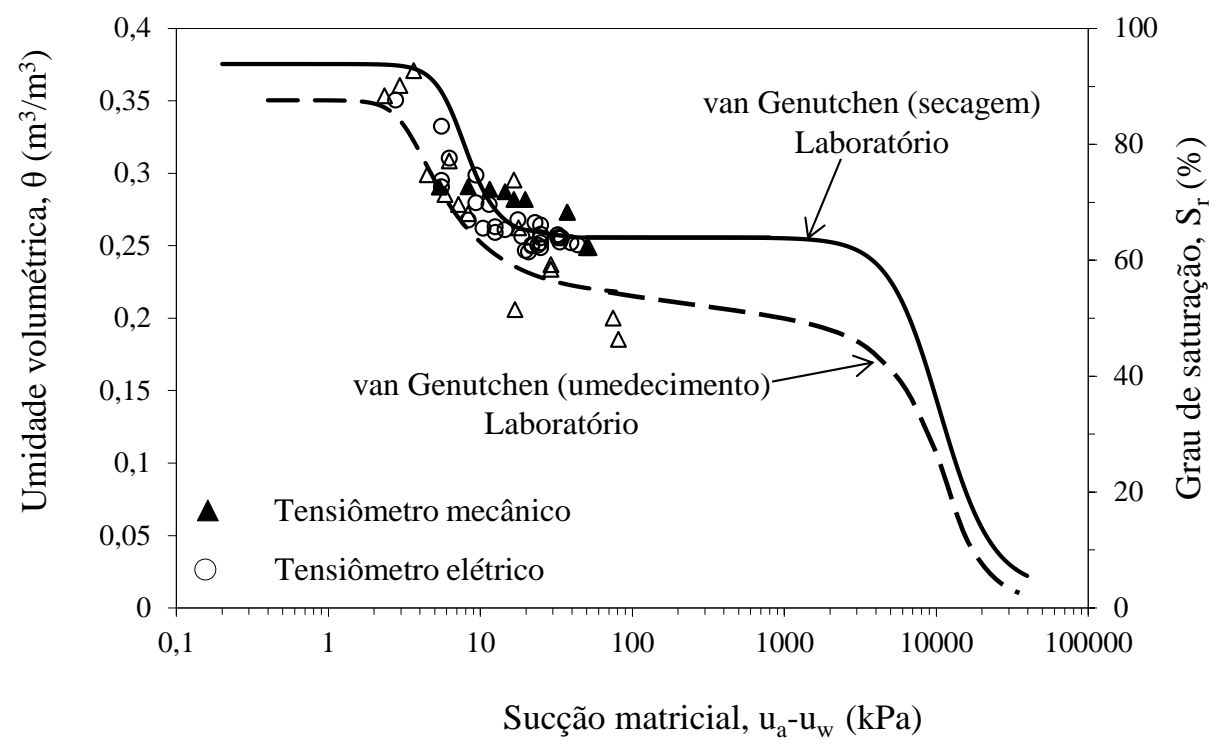

Figura 4.35. Comparações entre curvas de retenção de ensaios de laboratório e medidas dos tensiômetros. 
O processo de instalação dos tensiômetros nos protótipos foi realizado primeiramente com a escavação por trado em um orifício de diâmetro bastante próximo da ponteira porosa dos tensiômetros, porém um pouco menor para que o contato solo-ponteira fosse garantido, e profundidade que garantisse o posicionamento da ponteira porosa a uma distância de $5 \mathrm{~cm}$ do reforço. Posteriormente, uma calda do solo foi colocada no interior do orifício e o tensiômetro era levemente cravado para que não fosse danificado durante a instalação. Os tensiômetros foram instalados com inclinação de $45^{\circ}$ em relação à superfície da camada compactada. Os mesmos procedimentos foram utilizados tanto para os tensiômetros elétricos quanto para os mecânicos. Devido ao grande comprimento dos tensiômetros mecânicos, estes foram instalados em pontos próximos da parede do fundo da caixa. Assim, furos previamente executados na parede do fundo da caixa permitiam que parte do corpo do tensiômetro ficasse fora da caixa de ensaios e as medidas pudessem ser realizadas externamente. A Figura 4.36 ilustra o processo de instalação dos tensiômetros nos protótipos.

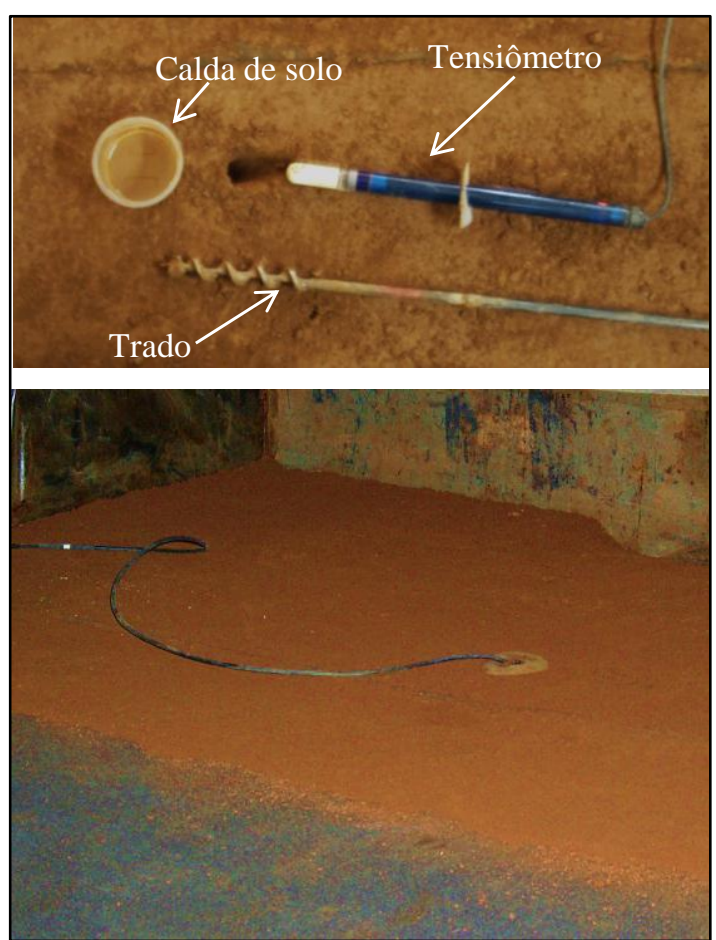

(a)

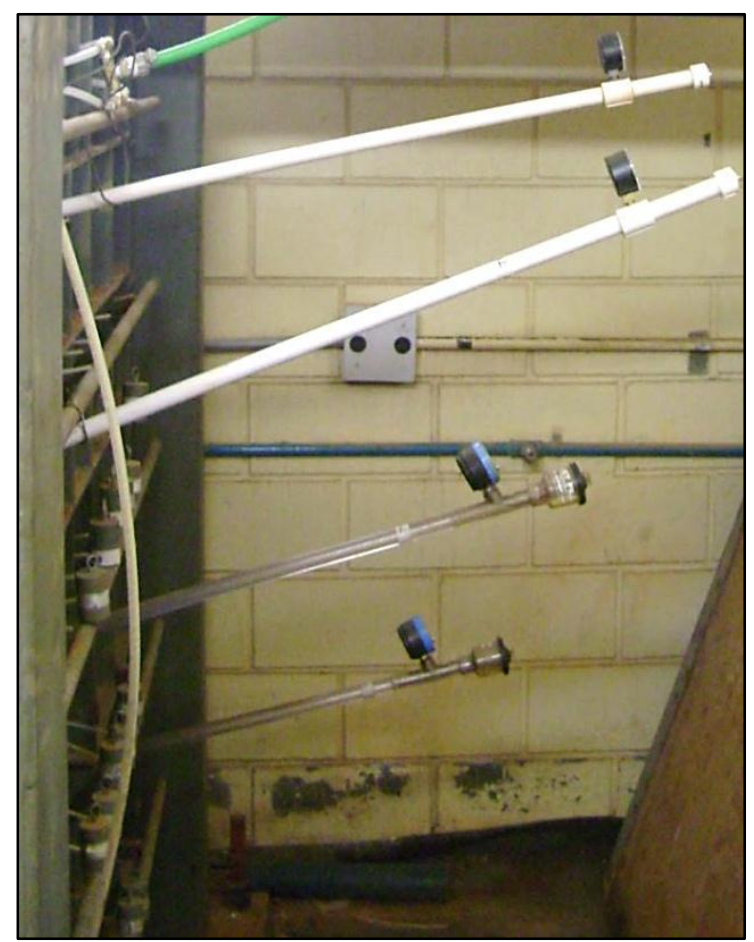

(b)

Figura 4.36. Processo de instalação dos tensiômetros: (a) tensiômetro elétrico; (b) tensiômetro mecânico.

\subsubsection{Células de tensão total}

Células de tensão total foram utilizadas para o monitoramento das tensões verticais em cada camada reforçada dos protótipos. As células utilizadas são fabricadas pela Kyowa Eletronic Instruments Co. Ltd., modelo BEC A-200 kPa, com capacidade máxima de $200 \mathrm{kPa}$, alimentadas com voltagem de $5 \mathrm{~V}$. Este dispositivo consiste num corpo oco de aço inoxidável com straingages do tipo diafragma na base. O corpo é preenchido com mercúrio de modo que as tensões 
aplicadas externamente ao corpo da célula sejam devidamente transferidas para o gage. A célula de tensão total e suas dimensões são apresentadas na Figura 4.37. O sistema de aquisição utilizado nas leituras das células consistiu no mesmo utilizado para a leitura dos tensiômetros elétricos.

Antes do início da construção dos protótipos, as células de tensão foram calibradas com o solo a ser utilizado na pesquisa. As calibrações foram efetuadas em uma caixa retangular de dimensões $15 \mathrm{~cm}$ x $25 \mathrm{~cm}$ x $30 \mathrm{~cm}$ (altura x largura x comprimento), preenchidas com o solo no grau de compactação dos protótipos. As células foram instaladas no meio da camada compactada a uma altura de $7,5 \mathrm{~cm}$, instaladas em uma pequena vala escavada para a colocação da mesma. A vala foi escavada com profundidade de $2 \mathrm{~cm}$ e diâmetro de $15 \mathrm{~cm}$ que era preenchido com areia após a colocação da célula. O sistema de aplicação de carga consistiu em uma bolsa inflável comprimida, cuja pressão era controlada via manômetro de pressão.

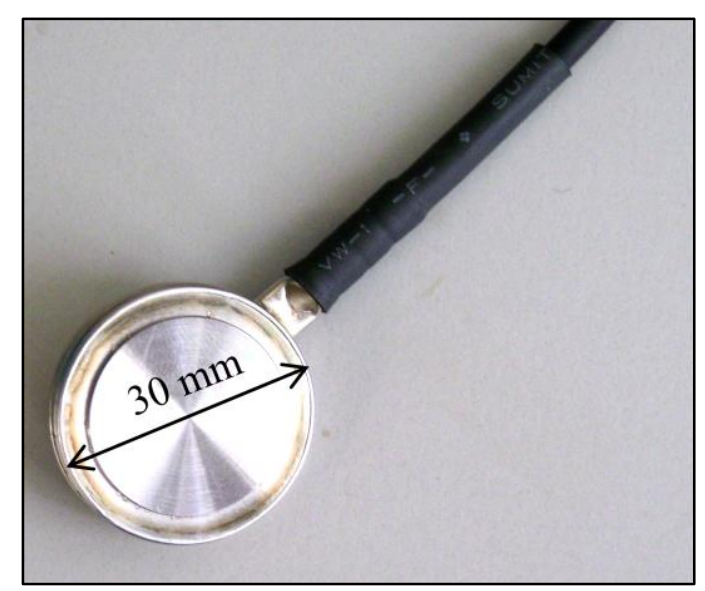

(a)

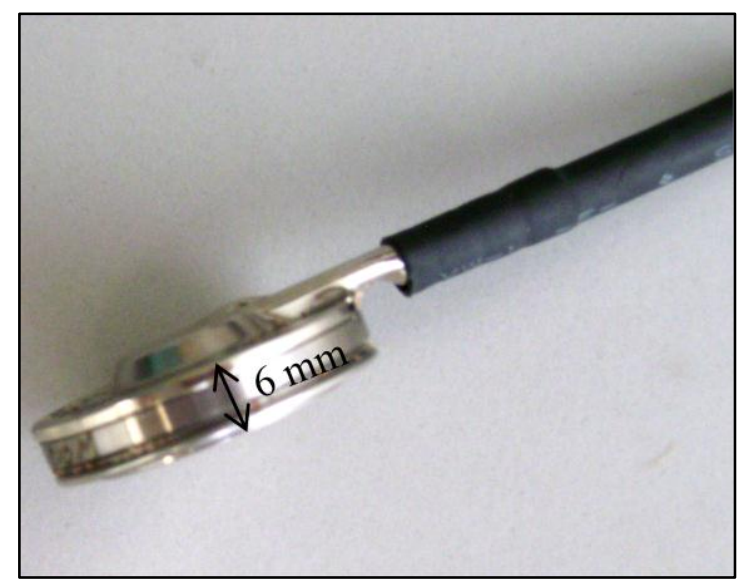

(b)

Figura 4.37. Célula de tensão total: (a) detalhe do diâmetro; (b) detalhe da espessura.

O processo de calibração consistiu no incremento de pressões de $10 \mathrm{kPa}$ após a estabilização de cada leitura efetuada. A cada nível de pressão imposta, a voltagem de saída era registrada. O coeficiente angular das retas ajustadas aos pontos consiste no fator de calibração. A precisão média obtida na calibração das células foi de $0,8 \mathrm{kPa} / \mu \mathrm{V} / \mathrm{V}$. A curva de calibração típica é apresentada na Figura 4.38.

$\mathrm{Na}$ instalação das células nos protótipos, buscou-se executar o mesmo procedimento utilizado na calibração, ou seja, as células foram instaladas em um furo previamente escavado, com profundidade de $2 \mathrm{~cm}$ e diâmetro de $15 \mathrm{~cm}$, que após o posicionamento almejado, era preenchido com areia. Tal procedimento foi adotado por resultar em melhores coeficientes de regressão linear nos pontos de calibração, em comparação àqueles em que as células foram instaladas diretamente à superfície compactada do solo. Ainda, esse procedimento consiste numa melhor proteção das células de tensão total contra esforços de compactação. As células eram ainda plastificadas e devidamente isoladas para evitar qualquer contato com a água do solo. $\mathrm{O}$ procedimento de instalação das células de tensão total é ilustrado na Figura 4.39. 


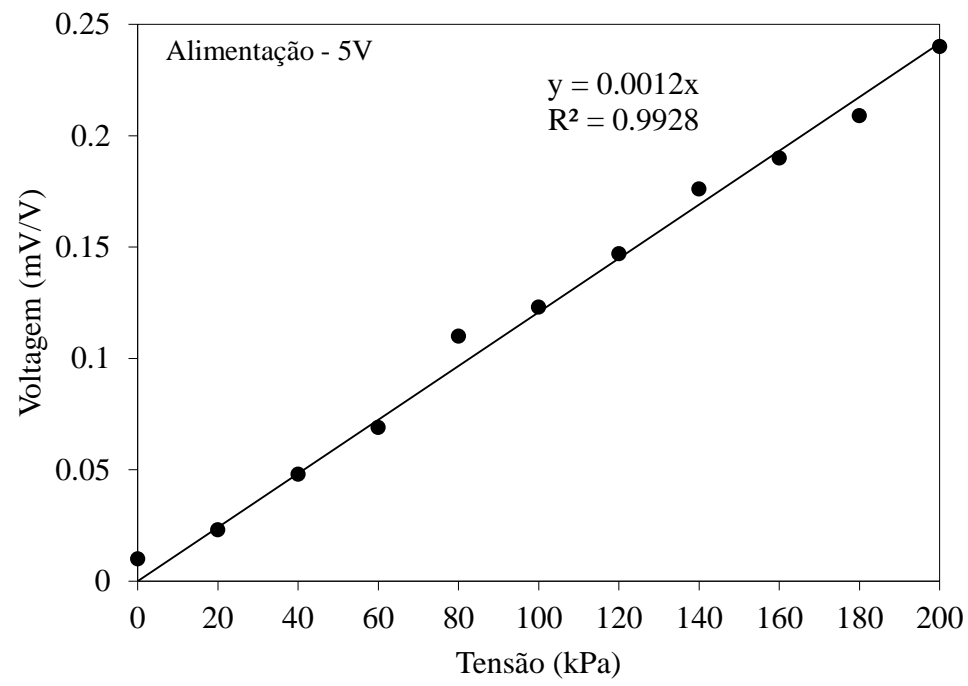

Figura 4.38. Curva de calibração típica das células de tensão total.

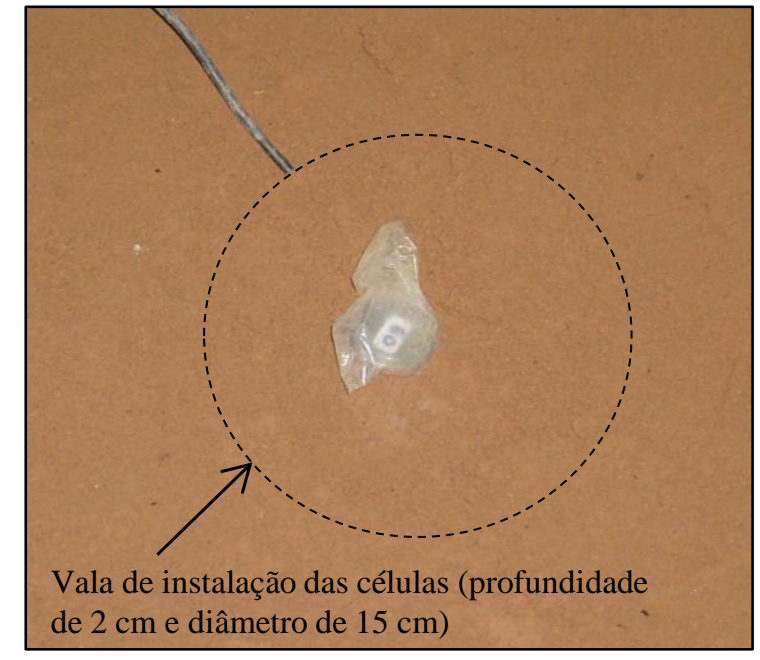

(a)

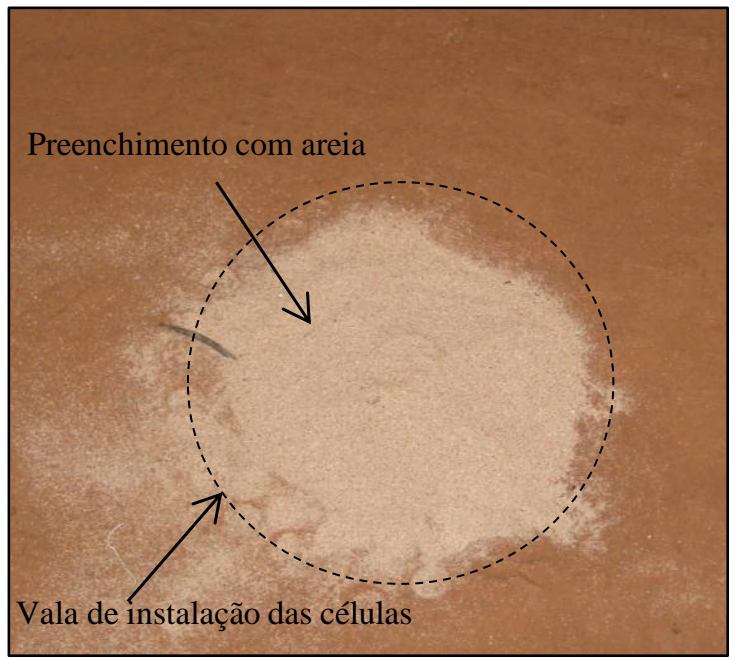

(b)

Figura 4.39. Procedimento de instalação das células de tensão total: (a) vala de instalação; (b) preenchimento com areia.

\subsubsection{Medidas de deslocamentos horizontais internos - Sistema Tell-tales}

Os deslocamentos horizontais internos de diferentes pontos ao longo do reforço foram obtidos por extensômetros mecânicos do tipo tell-tales. Este dispositivo de medição consiste em fios de aço inoxidável com capacidade de tração de 22,24 kN (5 lbf.), encapsulados com mangueiras rígidas de PEAD. Uma das extremidades é fixada em um ponto definido ao longo do reforço geotêxtil (costurado e posteriormente colado com adesivo a base de epóxi), e a outra extremidade conectada a um sistema de pesos (massa de $1,5 \mathrm{~kg}$ ) com marcas de referência. A função do sistema de pesos é manter o fio esticado ao longo de todo o ensaio, bem como referenciar as medidas de deslocamento relativo entre peso e a referência fixa externa.

As extremidades conectadas aos pesos de medidas foram posicionadas na parte externa da parede do fundo da caixa de ensaios. A referência indeslocável adotada para realização dos 
deslocamentos dos pontos internos da estrutura consistiu em uma barra de aço soldada à parede de fundo da caixa de ensaios. As medidas dos deslocamentos entre pesos referenciados e referências fixas foram realizadas por meio de um paquímetro digital com resolução de $0,01 \mathrm{~mm}$. O sistema tell-tales de medidas de deslocamento internos horizontais é detalhado na Figura 4.40.
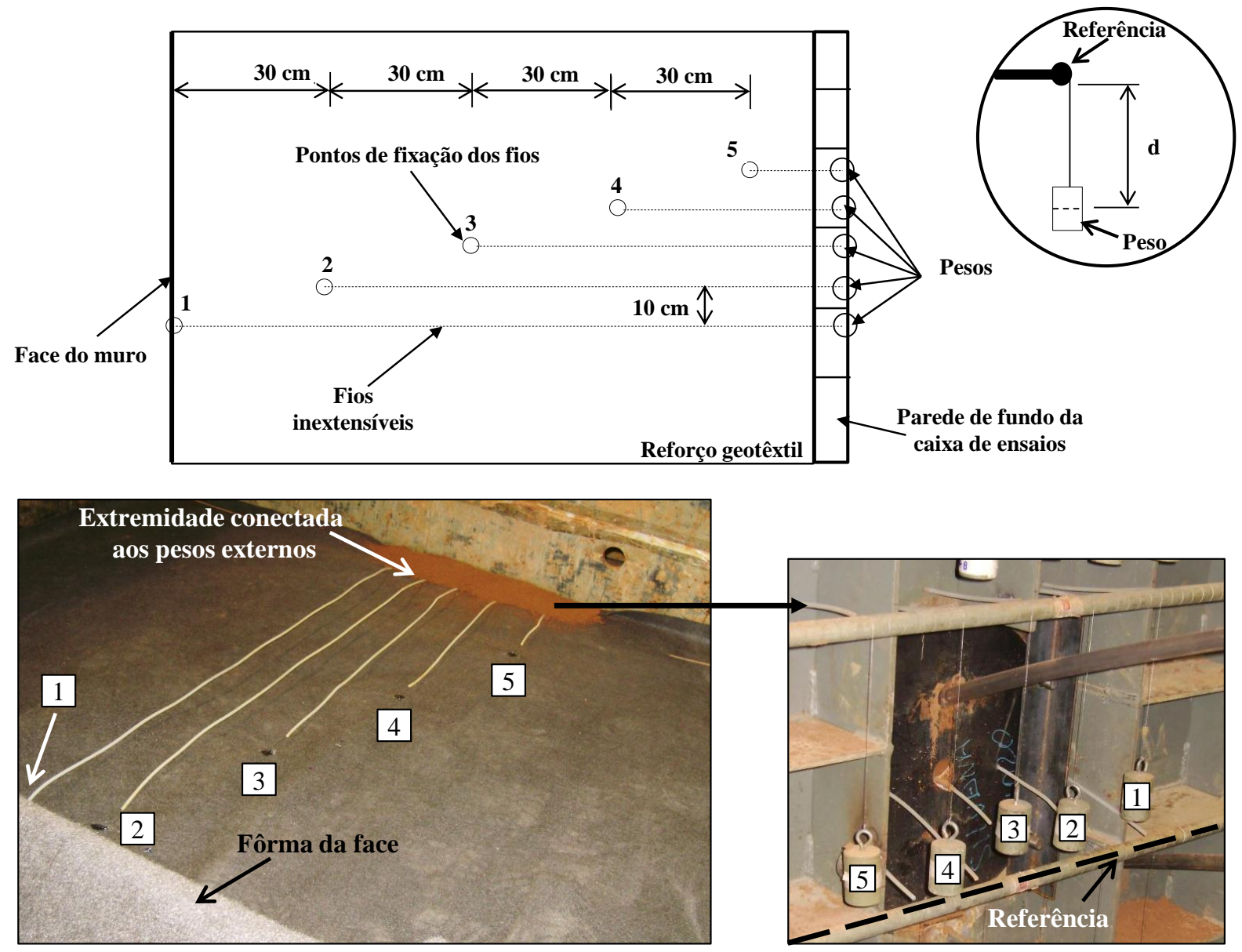

Figura 4.40. Detalhamento do sistema tell-tales de medida de deslocamento horizontal interno.

\subsubsection{Medidas de deslocamentos horizontais de face}

Os deslocamentos horizontais de face dos protótipos foram monitorados por relógios comparadores e LVDTs instalados na altura média de cada camada reforçada da seção central da estrutura. Para isso, foi necessária a utilização de uma estrutura externa fixa que mantivesse cada relógio comparador fixo, e assim, somente o cursor posicionado nos pontos da face se deslocasse livremente. Esta estrutura consistiu em um pilar de ferro que possibilitasse a utilização de conectores magnéticos para a fixação dos relógios comparadores. O sistema de medidas da face é detalhado na Figura 4.41.

Tanto os relógios comparadores quanto os LVDTs foram fabricados pela Vishay measurements group Inc., e apresentam precisão de $0,1 \mathrm{~mm}$. As leituras dos relógios comparadores foram realizadas manualmente e diariamente. Os LVDTs foram alimentados com 
5,0 V, usando no mesmo sistema de aquisição utilizado para a aquisição dos dados das células de tensão total e tensiômetros. Os LVDTs foram devidamente calibrados antes de instalados nos protótipos.

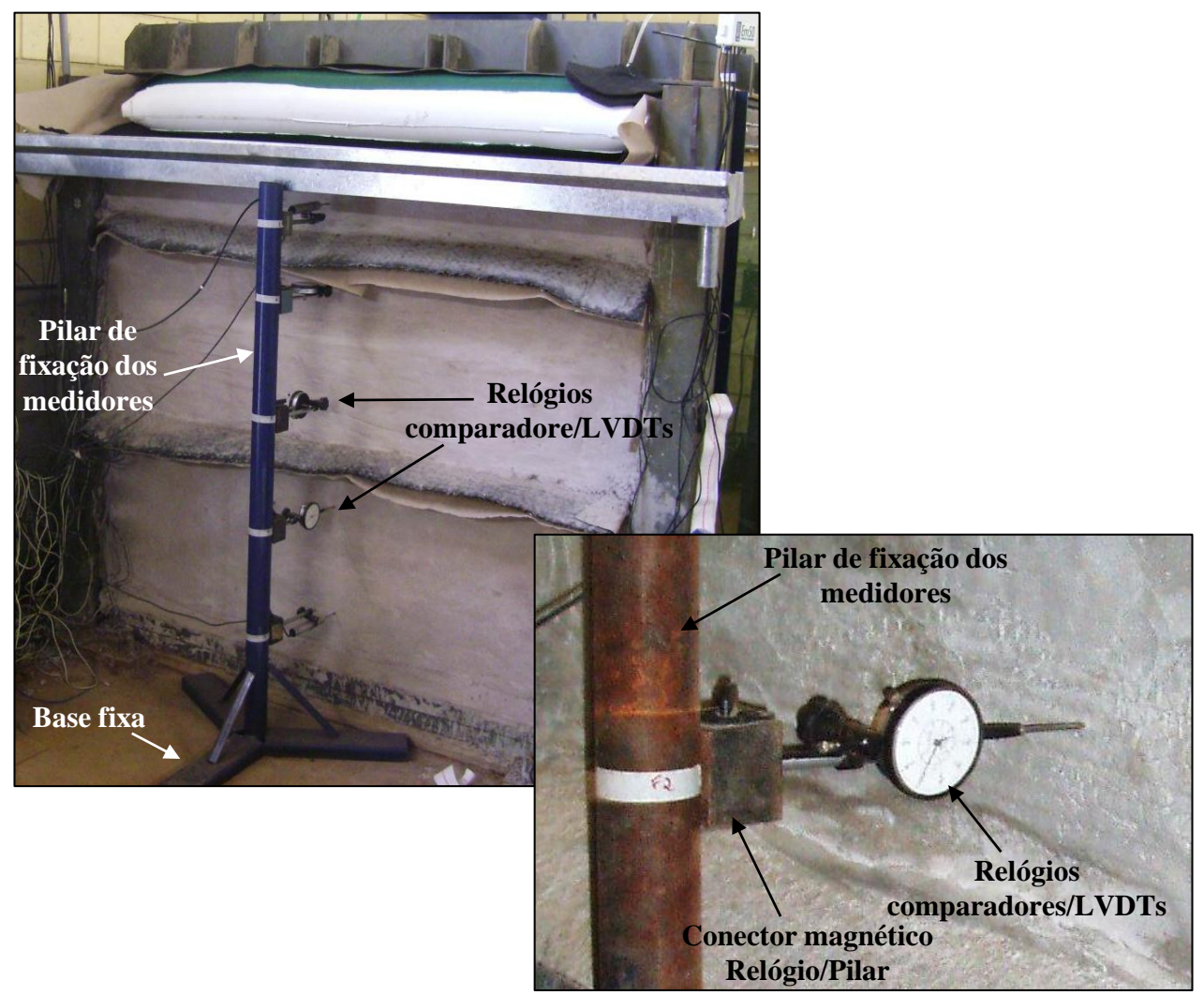

Figura 4.41. Sistema de medidas de deslocamentos horizontais de face.

As leituras dos medidores de deslocamento horizontal de face foram registradas somente nas condições de serviço da estrutura, uma vez que o sistema não permitia ser instalado durante a construção.

\subsubsection{Sistema de aquisição de dados e alimentação}

O sistema de aquisição e alimentação de dados utilizado nesta pesquisa foi o SYSTEM 5000, modelo 5100a, fabricado pela Vishay measurementes group Inc. Este sistema permite acompanhar medidas de diferentes configurações e tipos de strain-gages em 20 canais, simultaneamente, com opções de alimentação de $1 \mathrm{~V}, 2,5 \mathrm{~V}, 5 \mathrm{~V}$ e $10 \mathrm{~V}$. O sistema possibilita leituras numa frequência de até $100 \mathrm{~Hz}$. Dentre os sistemas de medidas passíveis de acompanhamento pelo SYSTEM 5000 estão, strains-gages, LVDTs, termopares, sensores de alto nível, entre outros. A programação das leituras e alimentação foi realizada com o auxílio do software StrainSmart da Vishay measurements group Inc. A Figura 4.42 ilustra o sistema de aquisição. 


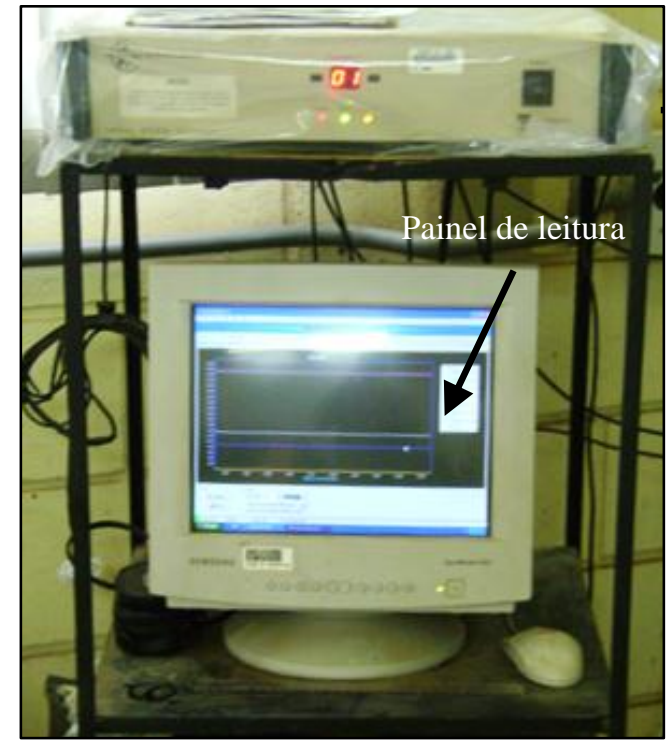

(a)

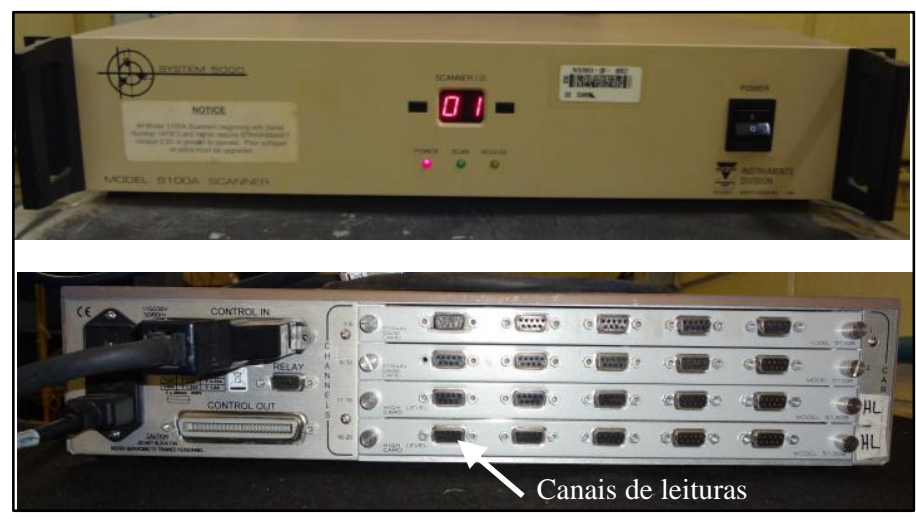

(b)

Figura 4.42. Sistema de aquisição de dados: (a) Em funcionamento; (b) Visão frontal e posterior (canais de leitura).

\subsection{Método de cálculo das deformações nos geotêxteis}

Uma vez que, em uma determinada seção de uma estrutura reforçada, os deslocamentos internos são monitorados em pontos igualmente distanciados ao longo do comprimento do reforço, as deformações nos reforços podem ser calculadas. Com relação aos cálculos, existem dois métodos que são comumente utilizados. O primeiro consiste no cálculo a partir da distância relativa entre dois pontos consecutivos de medidas, encontrando-se um valor médio do segmento destes dois pontos, ou seja, a deformação seria a diferença entre os deslocamentos medidos em dois pontos consecutivos, dividido pela distância inicial entre estes dois pontos. Tal metodologia foi utilizada por Benjamim (2006) na determinação de deformações de muros reforçado com geossintéticos. Porém, esse procedimento apresenta limitações com relação à incerteza quanto à localização exata da superfície de ruptura, em vista de não fornecer com precisão o local exato da deformação dos reforços ao longo do comprimento entre os dois pontos consecutivos Neste caso, assume-se que as deformações ocorrem centralizadas entre estes pontos de medidas. Este procedimento seria bastante preciso se a distância entre os pontos de medidas fosse os menores possíveis.

O outro procedimento de cálculo das deformações, adotado na presente pesquisa, consiste em representar os deslocamentos internos em gráficos deslocamentos relativos versus distância da face, e ajustar curvas sigmoidais nestes pontos. Com isso, a distribuição dos deslocamentos passa a ser representada por uma formulação matemática que possibilita sua manipulação para a obtenção das deformações. Sabe-se que a distribuição das deformações ao longo do comprimento do reforço apresenta, em algum ponto, um valor de pico. Sendo assim, o método assume que a 
derivação da equação gerada pelo ajuste sigmoidal resulta na distribuição das deformações ao longo do comprimento do reforço. Assim, tem-se uma melhor definição da localização da deformação de pico. Resultados de análises de deformações que utilizaram ajustes sigmoidais podem ser consultados nos trabalhos de Zornberg et al. (1995) e Zornberg e Arriaga (2003), Benjamim et al. (2007). Cabe informar que neste método, a face é admitida como referência e, a partir da distância relativa de cada ponto com relação à face da estrutura é realizado o ajuste dos pontos em uma curva sigmóide. A equação sigmoidal de distribuição dos deslocamentos é mostrada na Equação 4.1.

$$
\delta=\frac{1}{\alpha+b e^{-c x}}
$$

em que $\delta$ é o deslocamento de cada ponto relativo à face, $x$ é a distância entre cada ponto e sua respectiva referência, $e$ é a base natural logarítmica e $a, b$ e $c$ são parâmetros de ajuste. Os parâmetros de ajuste são utilizados para determinar analiticamente o valor de pico da deformação e a sua localização em relação à face do talude, para cada camada de reforço. A distribuição das deformações dos reforços ao longo do comprimento é dada pela derivação da função sigmóide como representado pela Equação 4.2:

$$
\varepsilon=\frac{d \delta}{d x}
$$

As expressões que definem o valor máximo de deformação e sua respectiva localização ao longo do comprimento do reforço são representadas pelas Equações 4.3 e 4.4.

$$
\begin{gathered}
\varepsilon_{\text {máx }}=\frac{c}{4 a} \\
x_{\text {máx }}=\frac{1}{c} \ln \left(\frac{b}{a}\right)
\end{gathered}
$$

As características da curva sigmoidal ajustada aos pontos de deslocamentos internos, bem como o resultado típico da derivação da curva sigmoidal são apresentadas na Figura 4.43. 


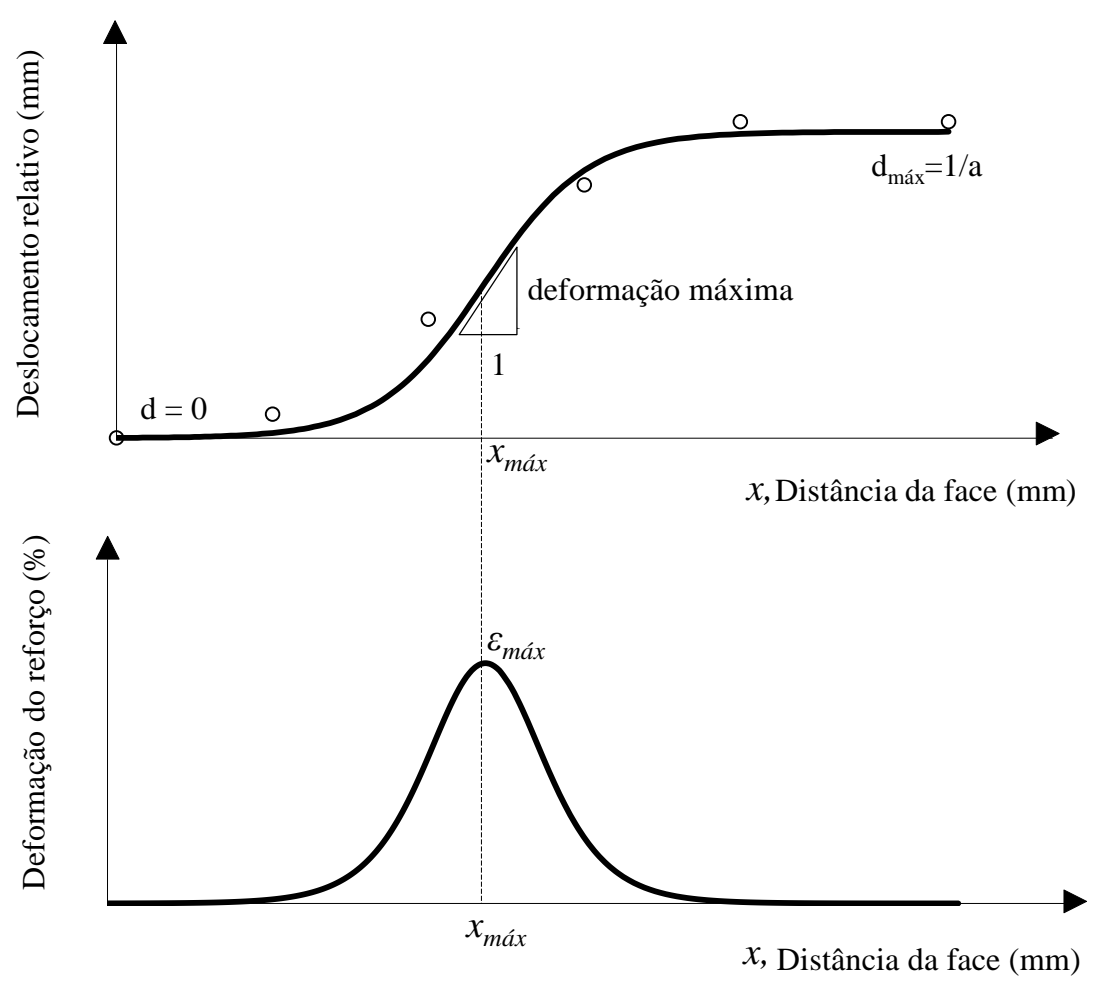

Figura 4.43. Método de determinação da distribuição de deformações: (a) características do ajuste sigmoidal nos pontos de deslocamentos relativos; (b) resultado da derivação da função sigmóide.

\subsection{Programa de ensaios}

O programa de ensaios consistiu em testes em quatro protótipos sob diferentes regimes de chuvas e tensões impostos. Os protótipos M1, M2 e M3 são semelhantes no que se trata de reforços, solo e configurações adotadas. No entanto, alguns aspectos com relação ao regime de chuvas imposto consistem na principal diferença e no principal enfoque desta pesquisa.

O protótipo M1 foi idealizado para avaliar o comportamento do protótipo sob a condição de umidade constante de compactação ao longo do ensaio, ou seja, sem impor precipitações. Além de fornecer informações quanto o comportamento de muros sob a condição não saturado do solo, este protótipo terá extrema importância quando comparados àqueles sob o efeito dos eventos de chuvas simulados. Para isso, as mesmas configurações e geometrias, posicionamento da instrumentação e sobrecargas $(100 \mathrm{kPa})$ foram considerados.

No protótipo M2 foi verificada a influência do avanço da frente de infiltração de água no comportamento mecânico de um muro reforçado com geotêxteis não tecidos, na tentativa de simular condições de precipitação bastante próximas da real ocorrência no campo. Dessa forma, adotou-se neste protótipo um regime de chuvas aleatórias de diferentes intensidades e durações. As intensidades de chuvas simuladas neste ensaio foram maiores que a condutividade hidráulica do solo compactado, o que possibilitou o escoamento de água na superfície do topo do protótipo, a 
coleta da água e o monitoramento da vazão de saída do sistema. Simultaneamente aos regimes de chuvas, uma sobrecarga de $100 \mathrm{kPa}$ foi também imposta.

Com relação ao protótipo M3, a mesma configuração, geometria e sobrecarga (100 kPa) foram também adotadas. No entanto, mudanças no posicionamento da instrumentação foram consideradas, uma vez que o objetivo deste protótipo foi, principalmente, avaliar o comportamento hidráulico na interface solo-reforço, bem como o efeito deste no comportamento mecânico do protótipo. Ainda, o regime de chuva adotado vislumbrou estabelecer uma condição de fluxo constante (estacionário), cuja intensidade do evento fosse menor que a condutividade hidráulica do solo $\left(0,6 \mathrm{~mm} / \mathrm{hr}\right.$ e vazão de $\left.4,5 \times 10^{-7} \mathrm{~m}^{3} / \mathrm{s}\right)$, para que todo o volume de água imposto fosse totalmente infiltrado sem escoamento de água na superfície do topo do protótipo.

Já com protótipo M4, buscou-se verificar o comportamento de um muro reforçado com geotêxteis não somente sob o efeito do avanço do umedecimento, mas também dos incrementos de sobrecarga ao longo do ensaio. Para isso, adotou-se regime de chuvas aleatórias e intensas antes e durante os incrementos de sobrecargas. De modo a aumentar a efetividade da função de drenagem interna dos geotêxteis não tecidos sob as condições de sobrecargas impostas, optou-se por manter a face envelopada exposta e utilizar de geotêxteis não tecidos mais espessos. Acreditase que desta maneira a água seja eficientemente drenada para fora da zona reforçada, sem os obstáculos proporcionados pela impermeabilização da face. As características de ensaio de cada um dos protótipos são resumidas na Tabela 4.6.

Tabela 4.6. Características dos ensaios

\begin{tabular}{cccccccc}
\hline Protótipo & Designação & Solo & Reforço & Chuvas & Carregamento & Face & $\begin{array}{c}\text { Tempo } \\
\text { (dias) }\end{array}$ \\
\hline Muro 1 & M1 & & NT-PET & - & Constante & Argamassa & 30 \\
Muro 2 & M2 & Areia & NT-PET & Aleatórias & Constante & Argamassa & 60 \\
Muro 3 & M3 & argilosa & NT-PET & Constante & Constante & Argamassa & 80 \\
Muro 4 & M4 & & NT-PP & Aleatórias & Variável & Exposta & 90 \\
\hline
\end{tabular}

Na Figura 4.44 são apresentados os regimes de chuvas impostos em um cada um dos protótipos avaliados. Nota-se que no protótipo M3, a vazão de água constante foi considerada nas análises. As condições de carregamento dos protótipos são representadas na Figura 4.45.

Para cada um dos protótipos avaliados as leituras da instrumentação foram efetuadas diariamente durante os períodos de ensaio conforme estabelecido na Tabela 4.6. No caso do protótipo M3, as leituras foram efetuadas diariamente, com exceção das leituras de sensores de umidade, as quais foram programadas para serem registradas a cada minuto. Assim, a formação de barreiras capilares na interface solo-reforço pôde ser identificada e monitorada. 


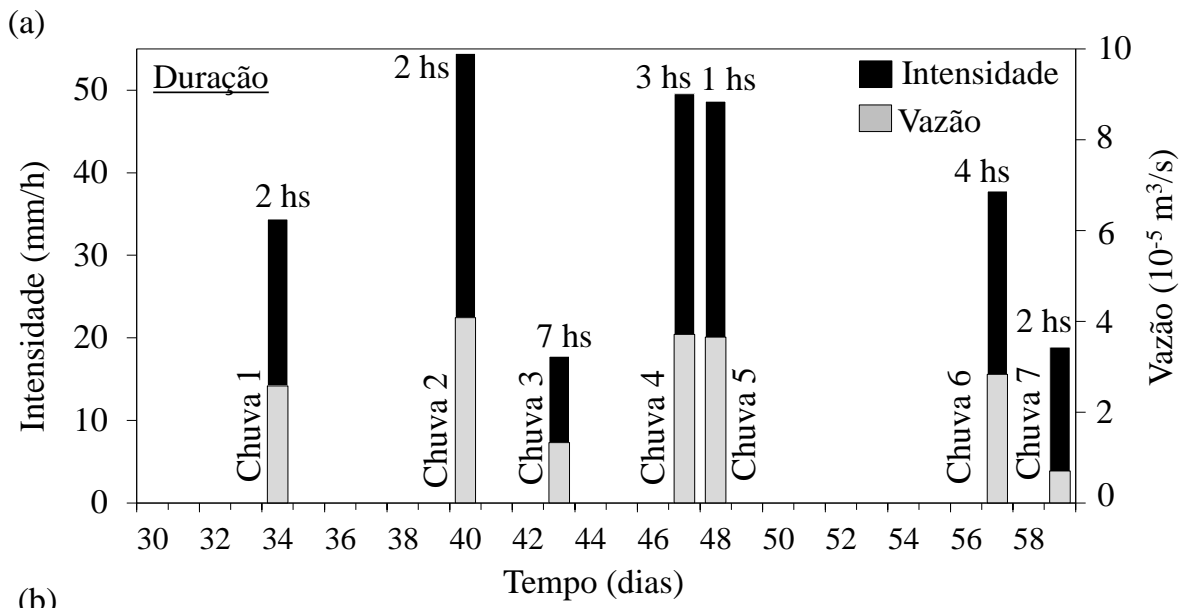

(b)
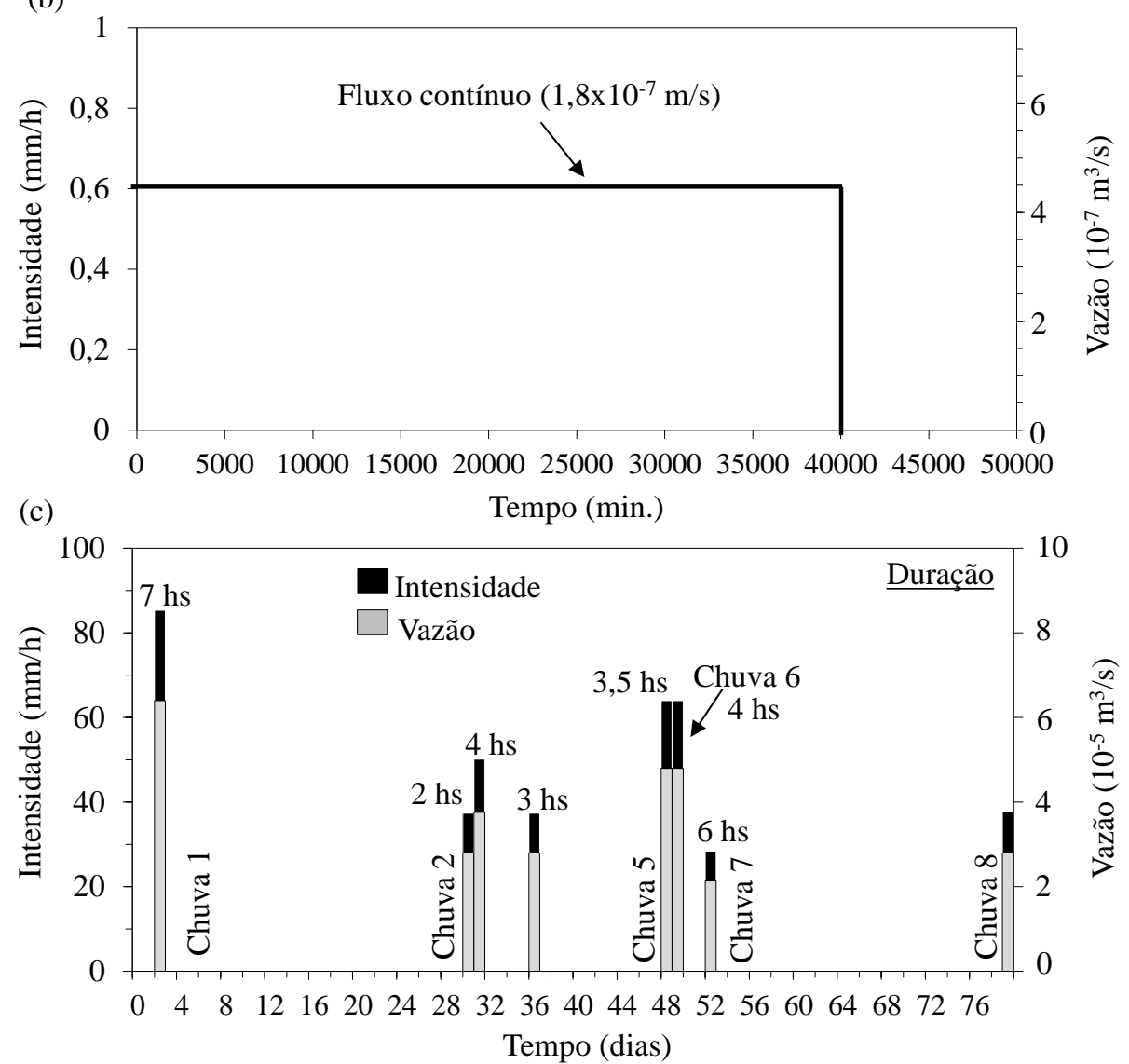

Figura 4.44. Regimes de chuvas adotados nos protótipos (a) M2; (b) M3; (c) M4. 

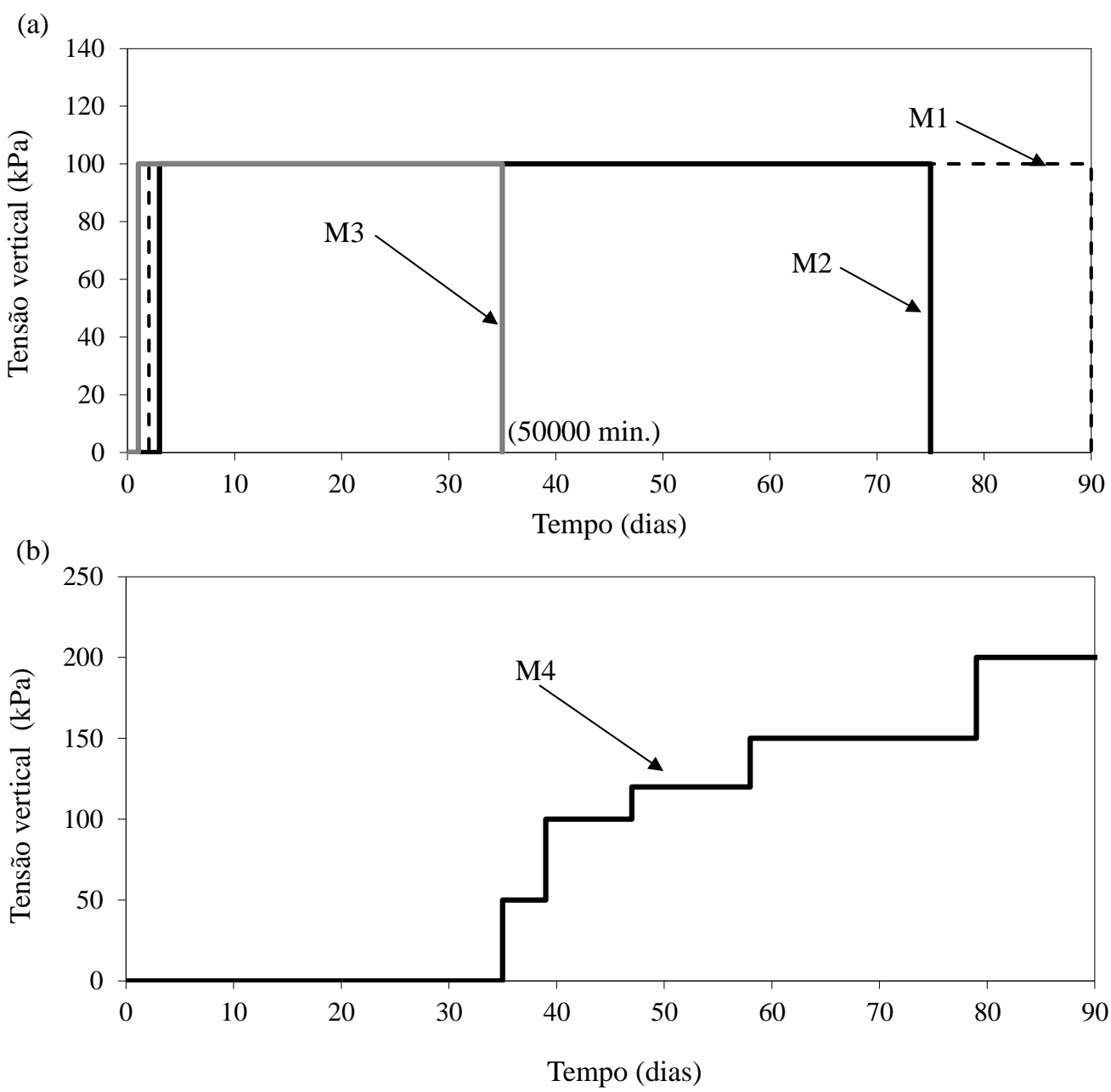

Figura 4.45. Regime de carregamento vertical para os protótipos: (a) M1, M2e M3; (b) M4. 
$-142-$ 


\section{CAPÍTULO 5}

\section{COMPORTAMENTO DE UM PROTÓTIPO REFORÇADO COM GEOTÊXTIL NÃO TECIDO SOB A CONDIÇÃO DE UMIDADE CONSTANTE DE COMPACTAÇÃO}

Este capítulo consiste na avaliação dos resultados do monitoramento do comportamento do protótipo M1, no qual eventos de chuva não foram impostos ao longo do ensaio, mantendo-se constante a umidade de compactação. Existem grandes vantagens em se trabalhar com estruturas de solos não saturados reforçados e muitas delas serão relatadas neste capítulo.

\subsection{Monitoramento da saturação e sucção matricial do solo}

O plano de instrumentação definido para o protótipo M1 permitiu o monitoramento do teor de umidade e sucção matricial do solo em diferentes pontos distribuídos ao longo da seção transversal central da estrutura (próximo da face, no centro e no fundo do protótipo). $\mathrm{O}$ posicionamento da instrumentação na seção transversal do protótipo M1 foi apresentado na Figura 4.28 do Capítulo 4.

Os resultados das leituras dos sensores de umidade e dos tensiômetros, obtidos durante o ensaio, são apresentados na Figura 5.1. De modo geral, os valores de grau de saturação do solo nos pontos localizados a $10 \mathrm{~cm}, 80 \mathrm{~cm}$ e $130 \mathrm{~cm}$ da face mostram-se praticamente constantes ao longo do tempo para todas as camadas reforçadas, não apresentando evidencias da secagem do solo durante o ensaio (90 dias). Por alguma razão, o grau de saturação do solo na região central da camada 5 (80 cm da face) aumentou de $60 \%$ para $75 \%$, cujo motivo não foi associado ao umedecimento do solo, mas supostamente, por razões de acomodação do sensor de medida ou, até mesmo, da heterogeneidade na compactação e no teor de umidade, que podem ter sido alterados durante o ensaio.

Com relação à sucção matricial do solo (Figura 5.1), nota-se o aumento desta com o tempo, na maioria das vezes em pequenas taxas. Este comportamento é coerente com o trecho da curva de retenção de água do solo entre 20 a $1000 \mathrm{kPa}$, em que, para um determinado grau de saturação (70\%) a sucção pode apresentar tal variação. A distribuição dos valores de grau de saturação ao longo da altura do protótipo em pontos a $10 \mathrm{~cm}, 80 \mathrm{~cm}$ e $130 \mathrm{~cm}$ em relação à face é ilustrada na Figura 5.2. Verifica-se nesta figura, que os valores medidos de grau de saturação foram consistentes com o valor inicial de $67 \%$, mantendo-se constante a umidade de compactação durante o ensaio. Pode-se dizer que, de modo geral, os níveis de sucção registrados são relativamente elevados para condições de campo. 
(a)
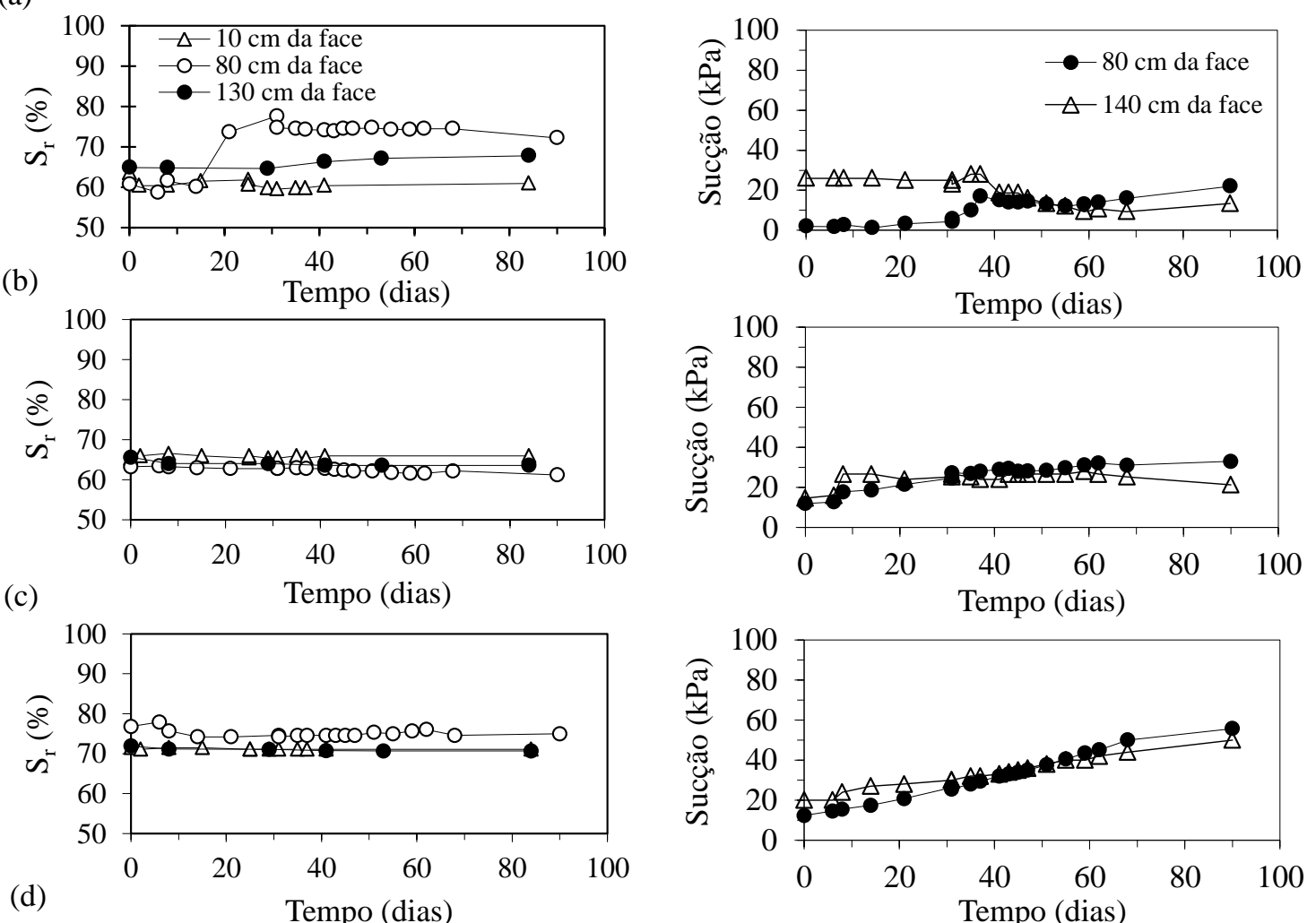

(d)

Tempo (dias)

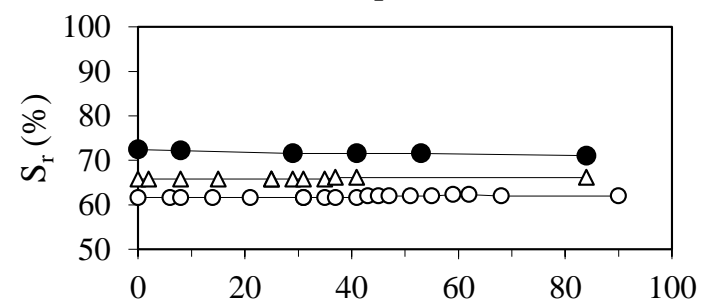

(e)
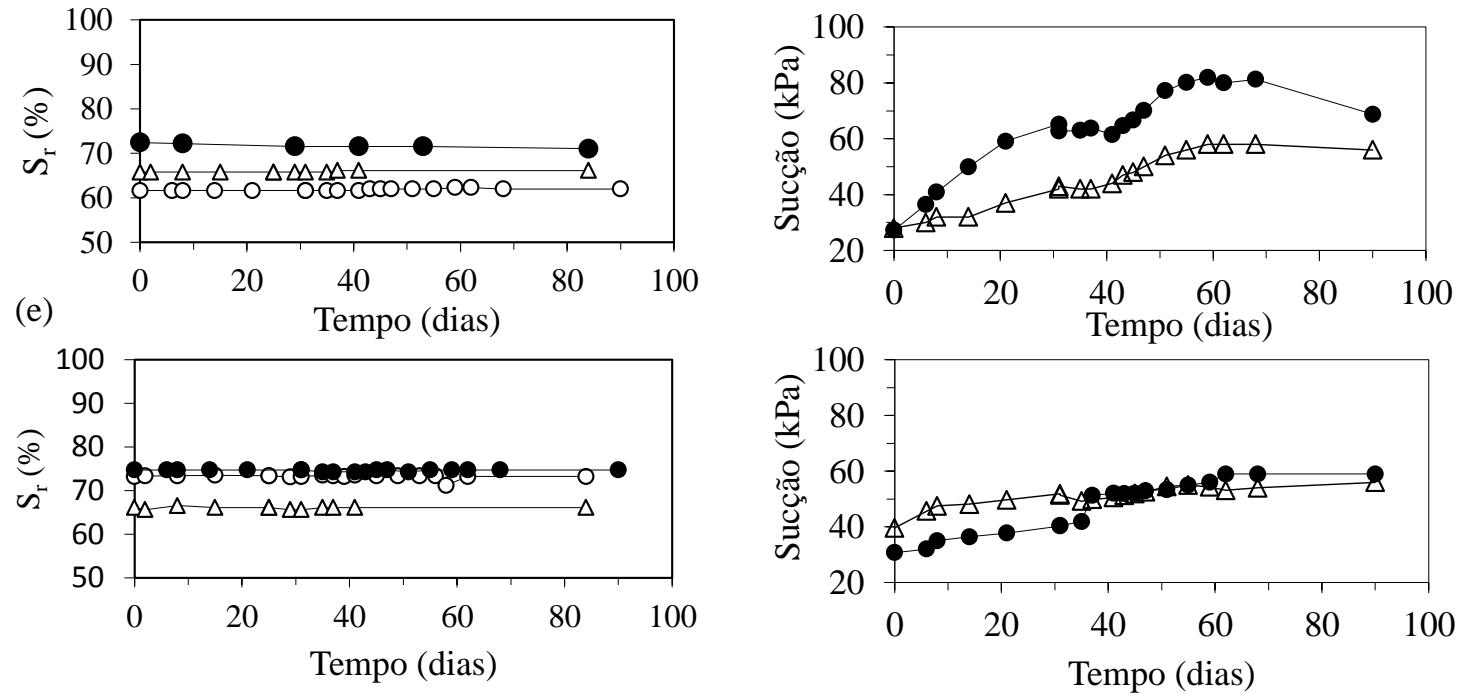

Figura 5.1. Variação do grau de saturação e sucção matricial do solo durante o ensaio: (a) camada 5; (b) camada 4; (c) camada 3; (d) camada 2 e; (e) camada 1. 
a)

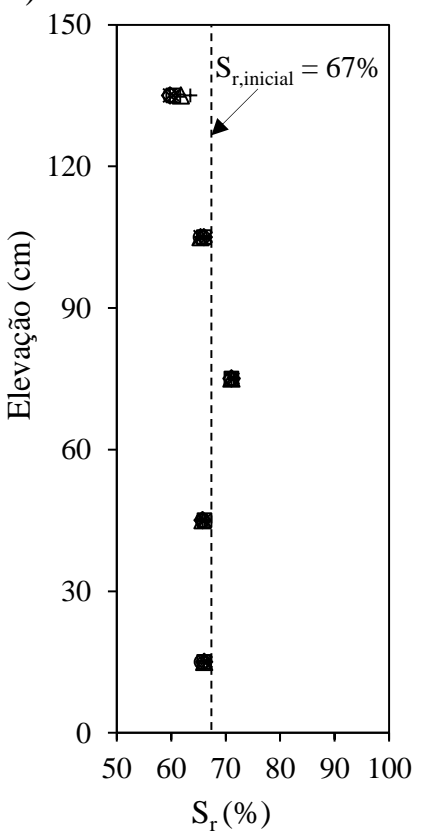

b)

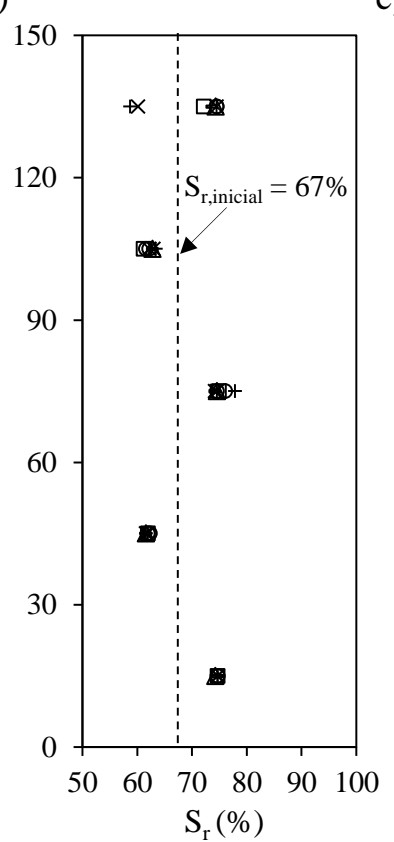

c)

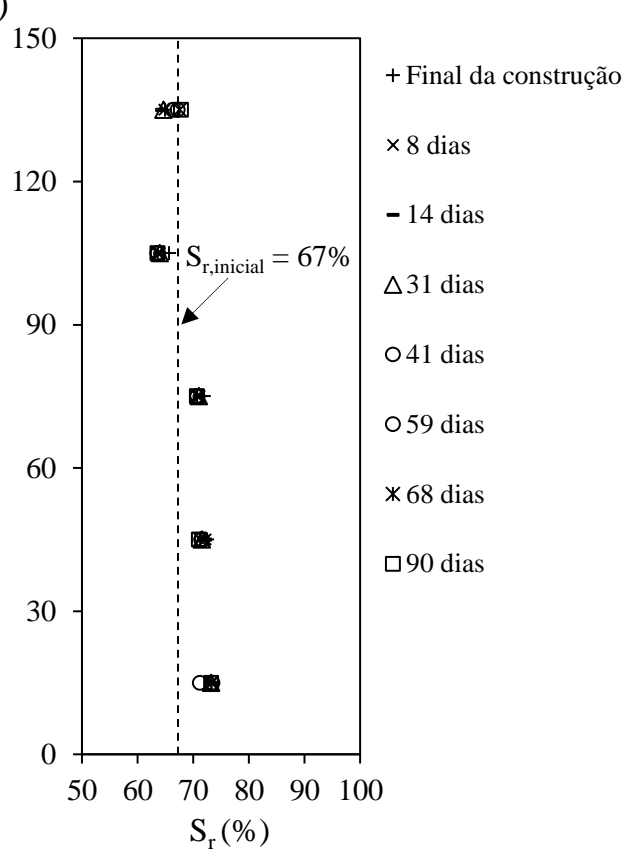

Figura 5.2. Distribuição dos valores de grau de saturação ao longo da altura do protótipo M1: (a) $10 \mathrm{~cm}$ da face; (b) $80 \mathrm{~cm}$ da face; e (c) $130 \mathrm{~cm}$ da face.

\subsection{Comportamento do protótipo}

A instrumentação mostrou que o grau de saturação de compactação do solo foi mantido durante o ensaio. Cabe agora, conhecer o comportamento da estrutura nas condições estabelecidas. Para representar o comportamento do protótipo foram monitoradas as tensões verticais, os deslocamentos horizontais internos e de face, e as deformações nos reforços.

\subsubsection{Tensões verticais}

As tensões atuantes no protótipo M1 são devidas ao peso próprio do solo do aterro, acrescidas de uma tensão devido à uma sobrecarga de $100 \mathrm{kPa}$, mantida durante o ensaio. A Figura 5.3 apresenta as tensões verticais previstas e medidas. Comparando-se as tensões medidas às previstas, verifica-se que, de modo geral, as tensões medidas foram menores, porém consistentes com a teoria. Observa-se que, durante o processo de construção as tensões medidas apresentam-se maiores que as previstas, o que pode ser atribuído ao acúmulo de tensões promovido pelo processo de compactação. Como o comportamento do protótipo durante o processo de construção não está incluído no foco de análises desta pesquisa, a Figura 5.4 apresenta as tensões atuantes na estrutura nas condições de serviço, ou seja, a partir do final da construção. 
a)
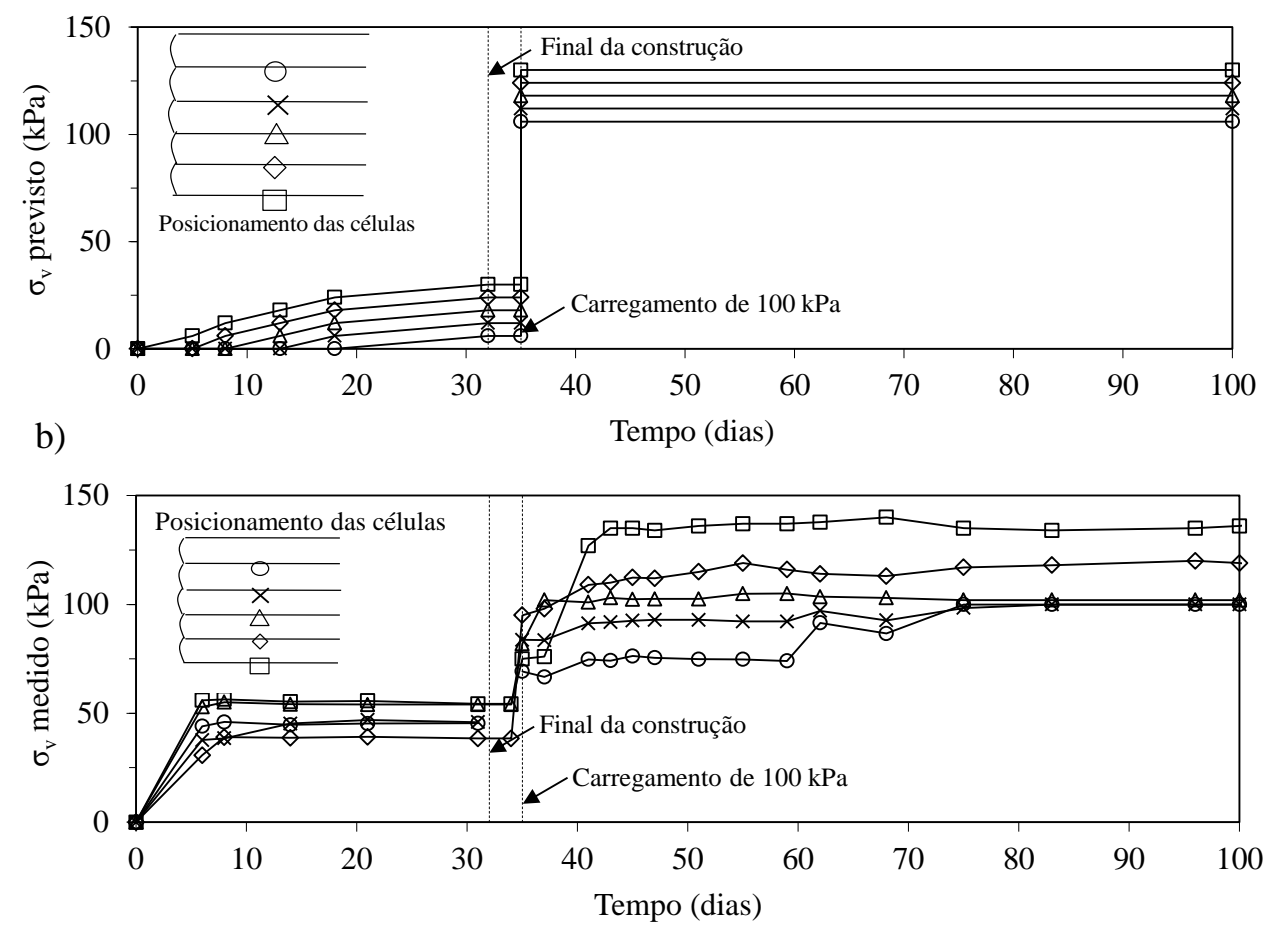

Figura 5.3. Tensões atuantes na estrutura reforçada M1: (a) tensões previstas; (b) tensões medidas.

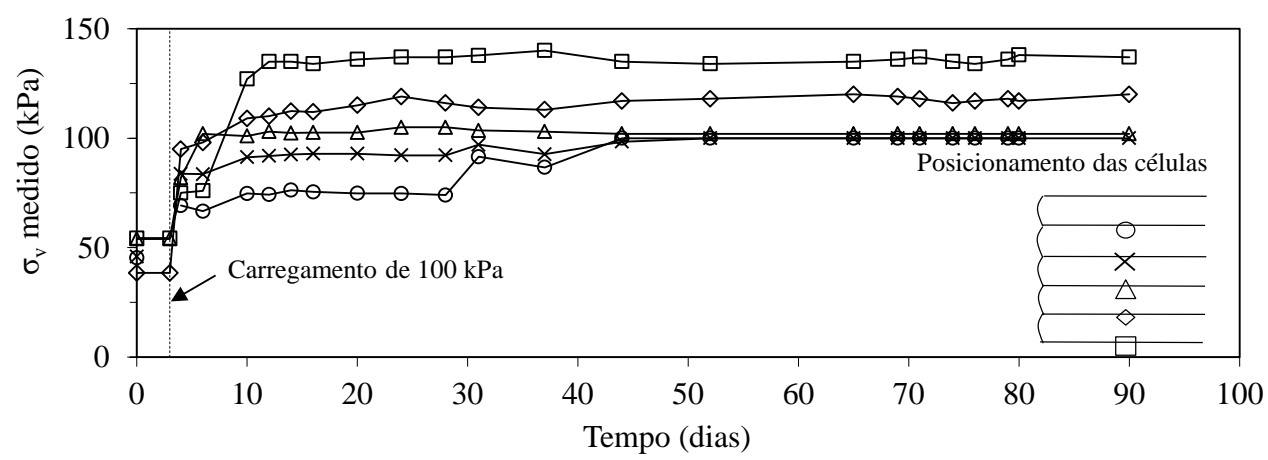

Figura 5.4. Tensões atuantes nas condições de serviço no protótipo M1.

Na Figura 5.5 foram plotadas as tensões verticais medidas ao longo da altura do protótipo, para obter a distribuição destas durante o período de ensaio. Ainda nesta figura, a distribuição das tensões medidas foi comparada à distribuição teórica, mostrando-se aproximadas, principalmente no que se refere à tendência linear de aumento das tensões com a profundidade. É importante observar que as tensões praticamente se mantiveram constantes ao longo do ensaio, após a aplicação da sobrecarga ( $3^{\circ}$ dia). 


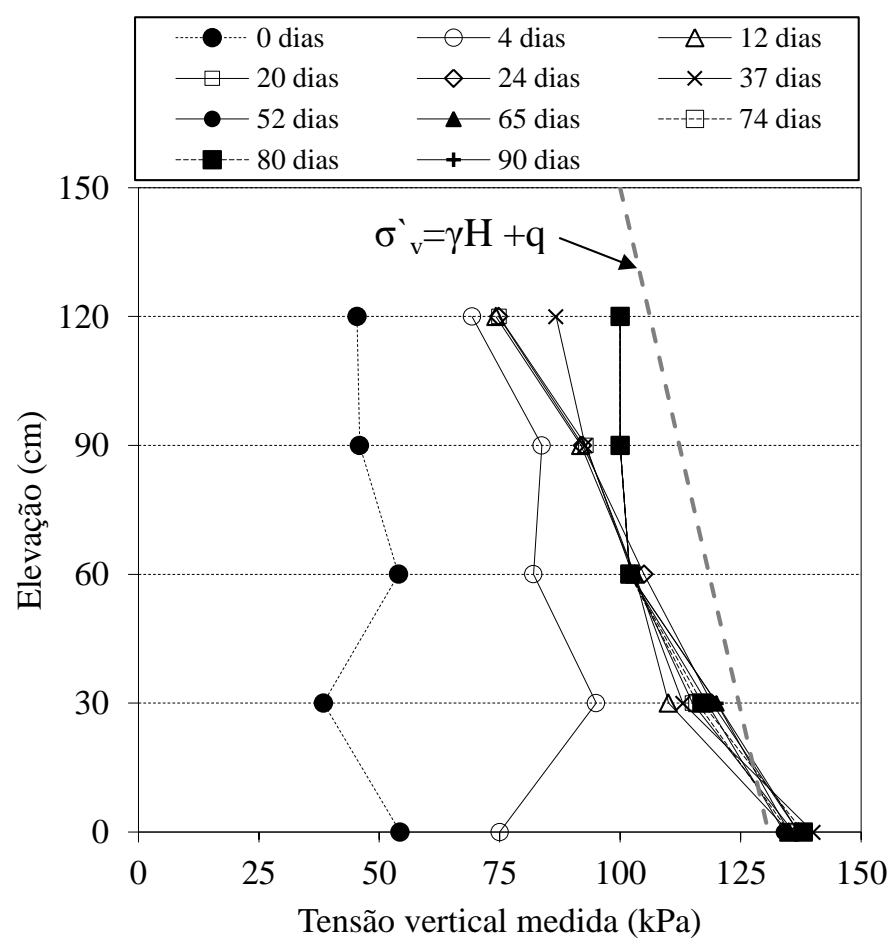

Figura 5.5. Distribuição das tensões totais ao longo da altura do protótipo M1 para diferentes tempos durante o ensaio.

\subsubsection{Deslocamentos horizontais}

Os resultados dos deslocamentos horizontais internos $\left(\delta_{\mathrm{i}}\right)$ determinados por extensômetros do tipo tell-tales, em pontos fixados em diferentes distâncias em relação à face, são apresentados na Figura 5.6. Devido às condições de saturação impostas neste protótipo, os deslocamentos internos foram relativamente pequenos. Aumentos expressivos dos deslocamentos ocorreram apenas logo após a aplicação da tensão vertical de $100 \mathrm{kPa}\left(3^{\circ}\right.$ dia), sendo que após esse período, as leituras dos deslocamentos estabilizaram-se com valores praticamente constantes durante o ensaio. A respeito da distribuição dos deslocamentos ao longo do comprimento do reforço, os maiores valores foram medidos na face, com a diminuição destes à medida que os pontos se afastam da face. Este comportamento é consistente com o verificado por Benjamim et al. (2007) e Zornberg e Arriaga (2003).

Para melhor interpretação do comportamento dos deslocamentos internos e do efeito da das condições de saturação do solo do aterro, na Figura 5.7 são plotados os deslocamentos internos máximos $\left(\delta_{i, \text { máx }}\right)$ de cada camada reforçada durante o ensaio, juntamente aos valores médios de sucção matricial calculados com os valores medidos nas diferentes posições de monitoramento. Destaca-se que os deslocamentos internos permanecem constantes com o tempo devido à influência do parâmetro de sucção do solo. A sucção matricial tem um importante papel no comportamento da estrutura por impor a rigidez ao solo na condição não saturada, fazendo com que este mobilize grande parte das tensões aplicadas. 
a)
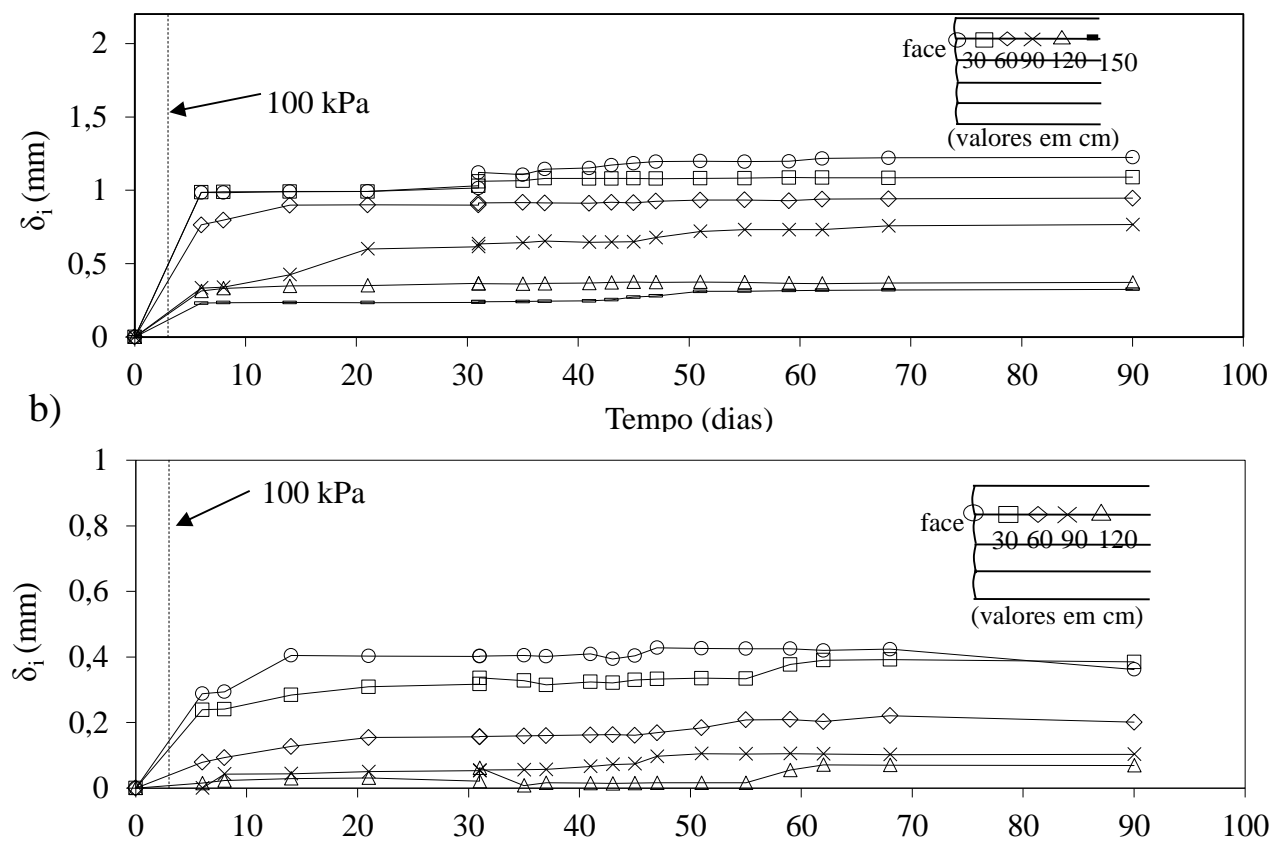

c)

Tempo (dias)
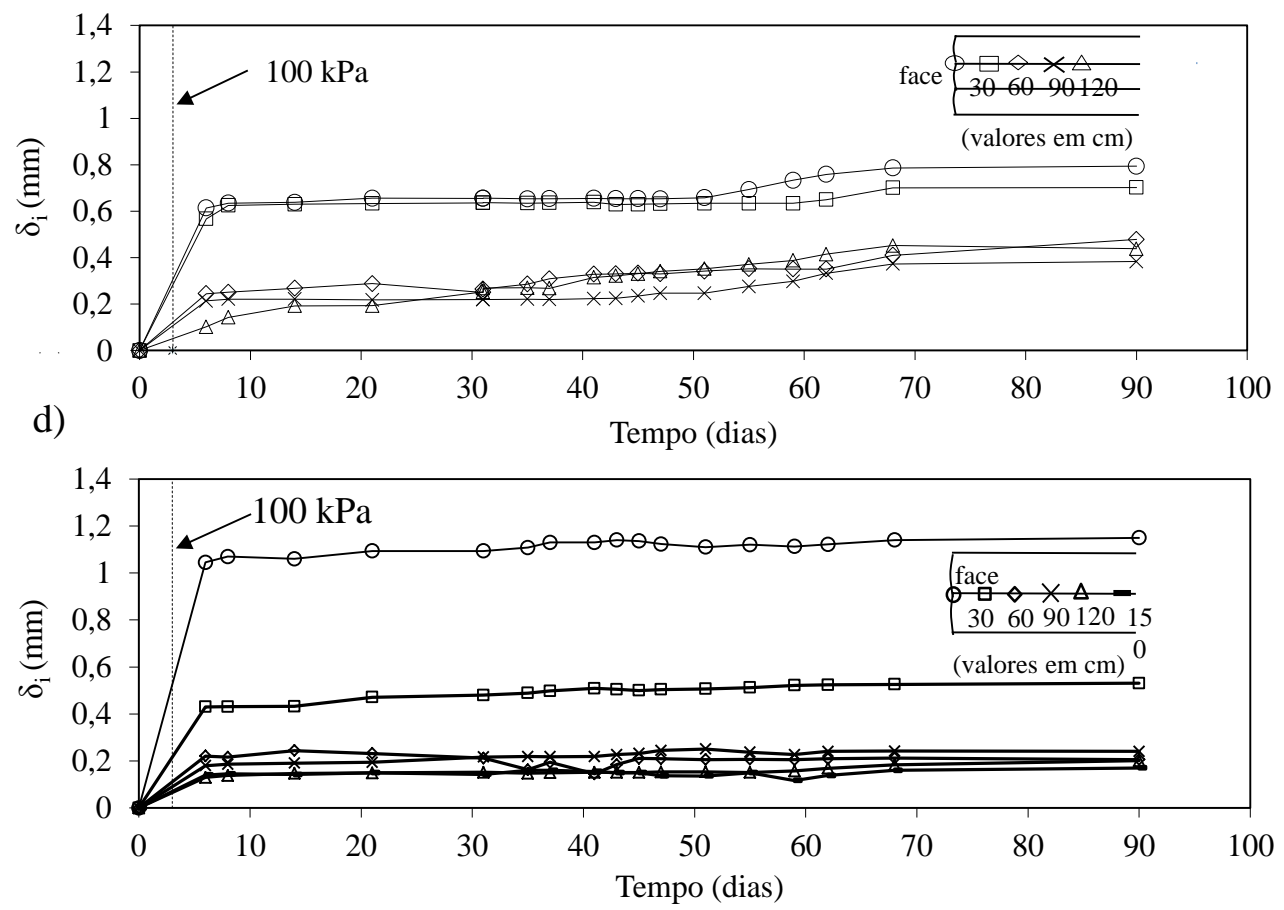

Figura 5.6. Deslocamentos horizontais internos do protótipo M3: (a) camada 5; (b) camada 4; (c) camada 3; (d) camada 2. 
a)

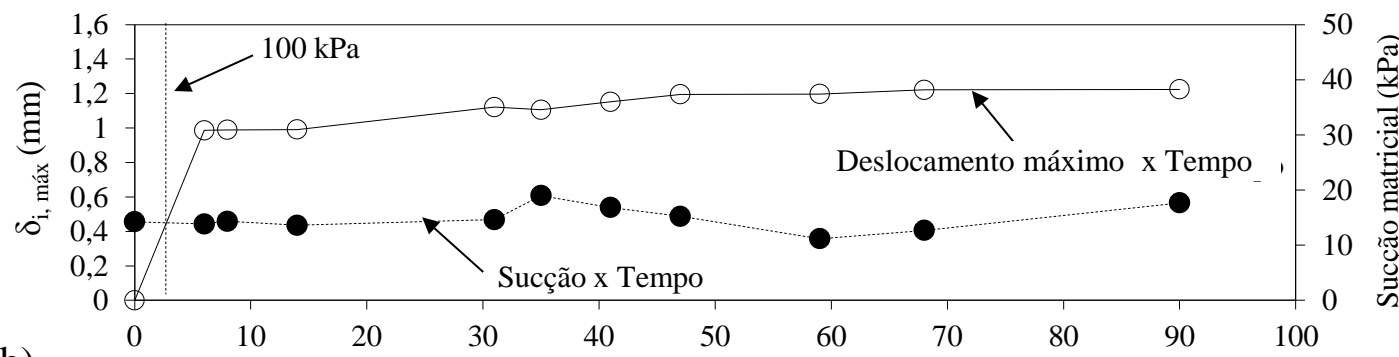

b)
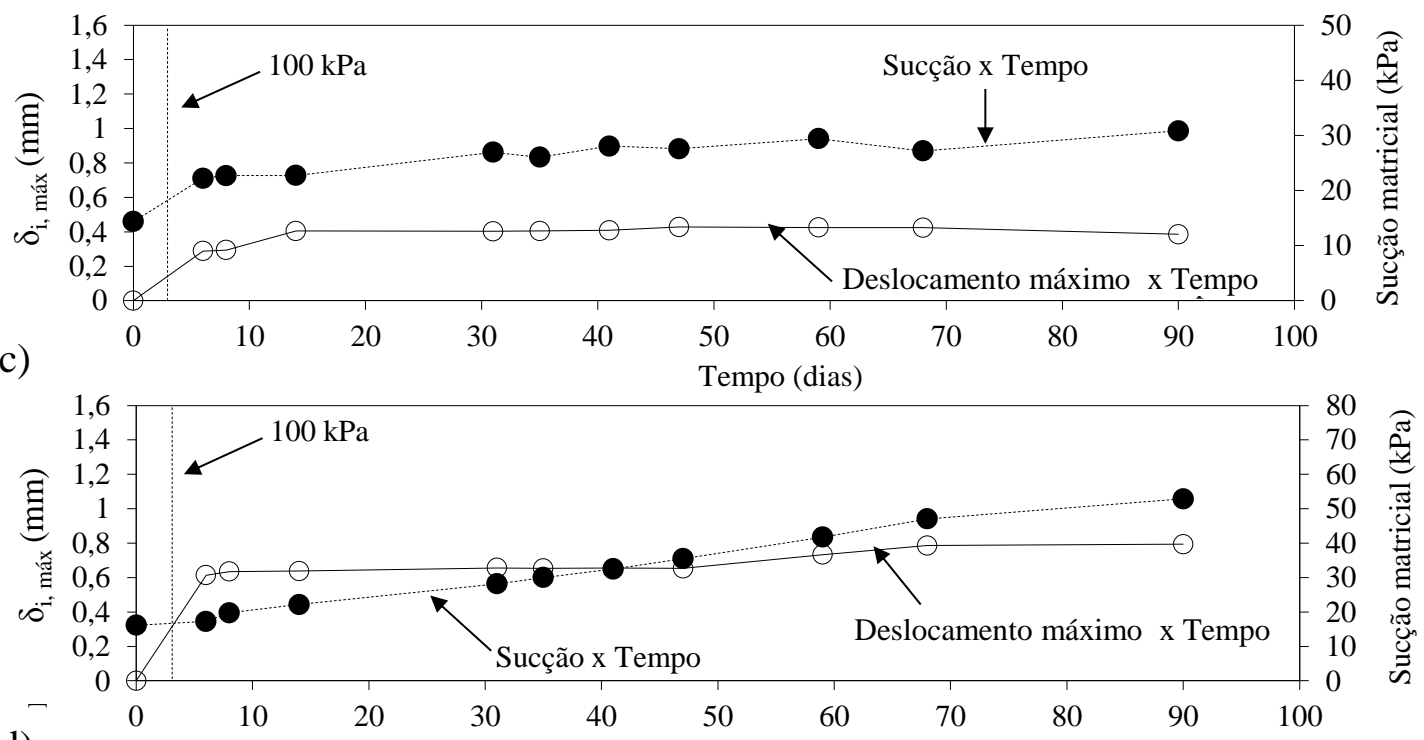

d)

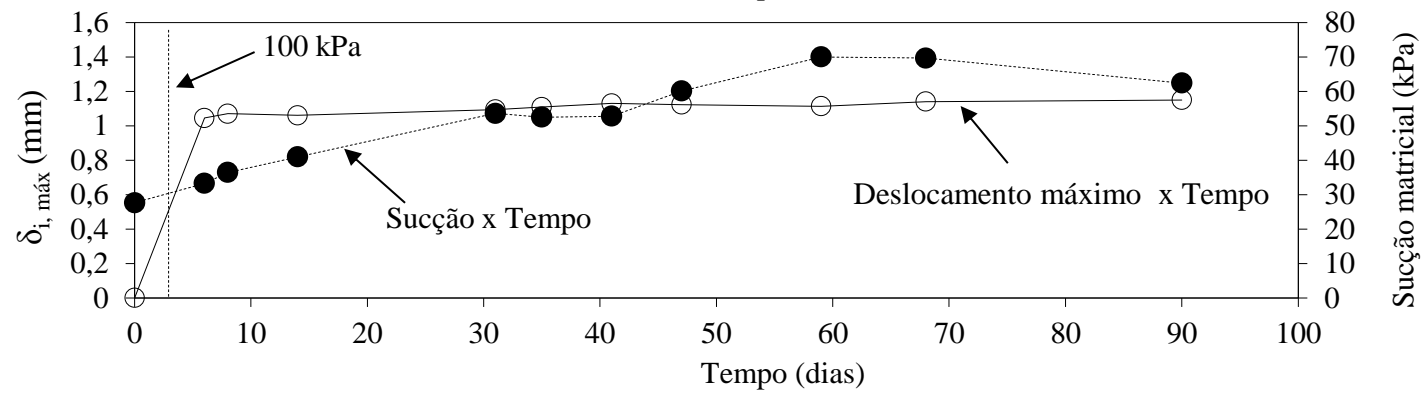

Figura 5.7. Evolução do deslocamento interno máximo e da sucção matricial média no protótipo M1: (a) camada 5, (b) camada 4, (c) camada 3; (d) camada 2.

As medidas externas de deslocamento de face, bem como os valores médios de sucção matricial de cada camada são apresentadas na Figura 5.8. Assim como os deslocamentos internos, os deslocamentos de face foram relativamente pequenos, chegando ao valor máximo de $6 \mathrm{~mm}$ (camada 1). Após certo período de ensaio, os deslocamentos de face se estabilizaram, permanecendo constantes ao longo do tempo. Portanto, as condições impostas neste trabalho resultaram em deslocamentos praticamente imperceptíveis na estrutura. 
a)

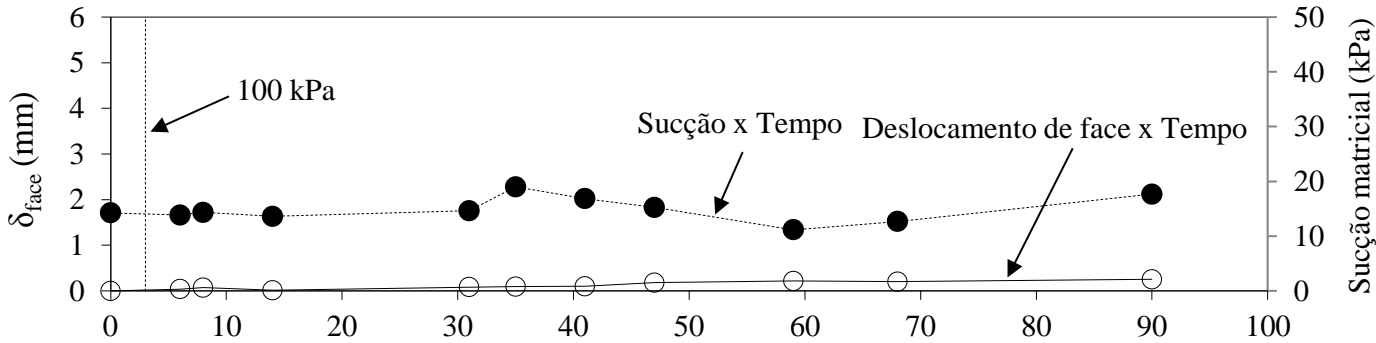

b)

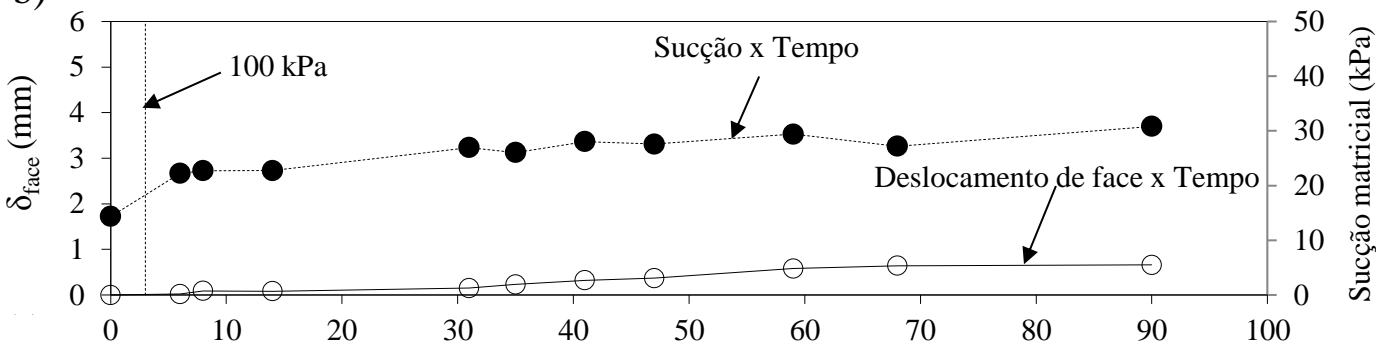

c) Tempo (dias)

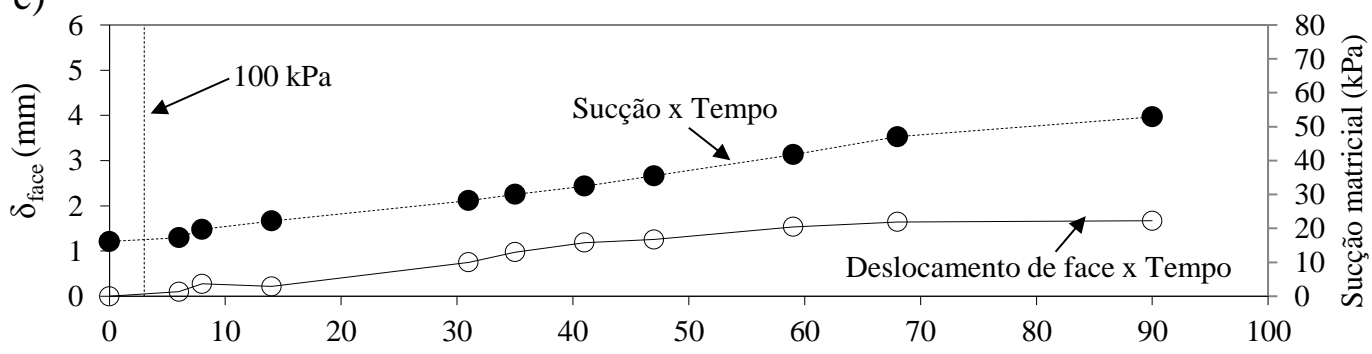

d) Tempo (dias)

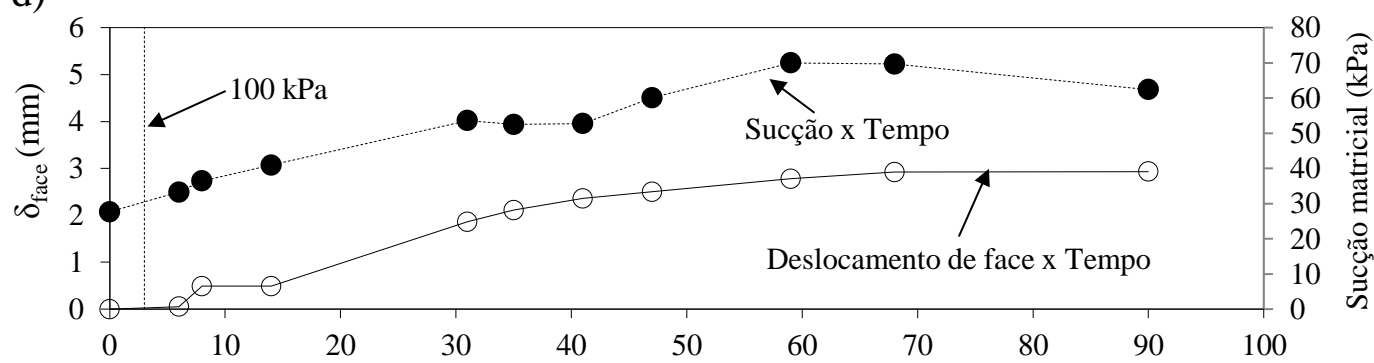

e) Tempo (dias)

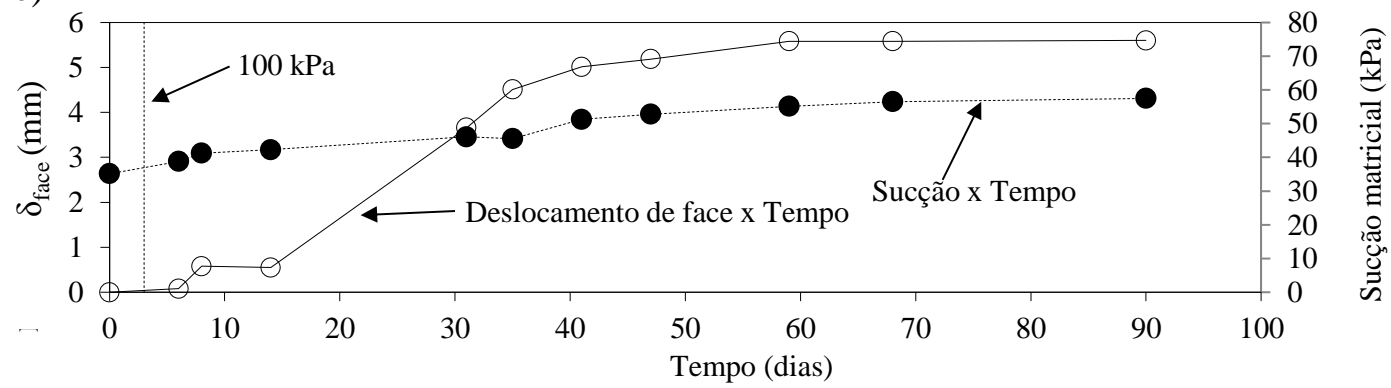

Figura 5.8. Evolução dos deslocamentos de face e da sucção matricial méida no protótipo M1: (a) camada 5; (b) camada 4; (c) camada 3; (d) camada 2; (e) camada 1.

A Figura 5.9 mostra a distribuição dos deslocamentos de face $\left(\delta_{\text {face }}\right)$ ao longo da altura do protótipo M1, na qual se visualiza que estes sofreram insignificantes alterações até $14^{\circ}$ dia de ensaio, com pequenos acréscimos nas camadas reforçadas 2 e 3 , chegando a valores máximos de 
0,6 mm. Após os 14 dias de ensaio, o protótipo apresentou deslocamentos adicionais, principalmente nas camadas inferiores, embora estes muito pequenos. Em adição, a distribuição mostrou que o máximo valor de deslocamento de face ocorreu próximo do primeiro terço da altura do protótipo, em concordância com as estruturas de geotêxtil não tecido relatadas por Zornberg et al. (1995) e Benjamim et al. (2007).

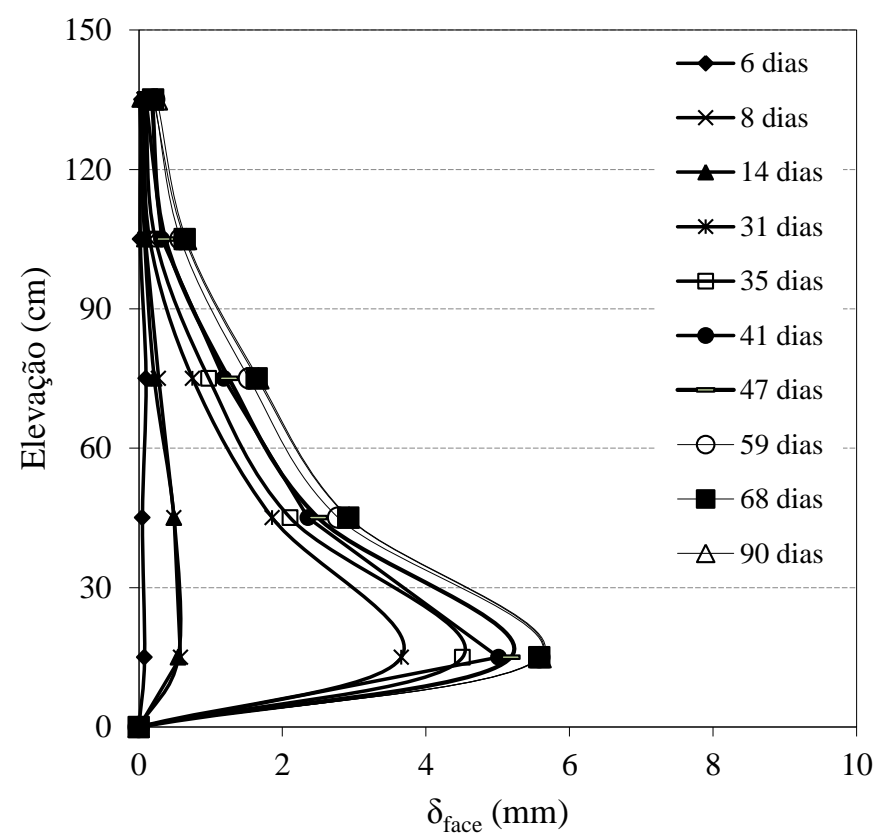

Figura 5.9. Distribuição dos deslocamentos de face ao longo da altura do protótipo M1.

\subsubsection{Deformações nos reforços}

No presente trabalho, determinaram-se os níveis de deformações nos reforços e a distribuição destes ao longo do comprimento. As distribuições das deformações consistiram no resultado da derivação de ajustes sigmoidais nos pontos experimentais de deslocamentos internos plotados ao longo do comprimento do reforço. Esta metodologia de cálculo de deformações foi detalhada no Capítulo 4 deste trabalho.

A distribuição dos deslocamentos internos ao longo do comprimento dos reforços geotêxteis do protótipo M1 é apresentado na Figura 5.10. Como mencionado, tal distribuição é apresentada somente para possibilitar o ajuste sigmoidal nos pontos de deslocamentos. Com base nesta figura, pode-se verificar que o uso da equação de uma sigmóide consiste num procedimento aplicável nas condições impostas nesse trabalho. Cabe observar que nesta metodologia, a face é fixada como referência em relação aos outros pontos de medidas e, por esse motivo, os deslocamentos relativos são nulos na face, sendo que, na verdade, seriam deslocamentos máximos. As distribuições das deformações nos geotêxteis, resultantes da derivação das curvas de distribuição ajustadas aos pontos experimentais de deslocamentos em cada camada reforçada, são mostradas na Figura 5.11. As principais constatações observadas nesta figura são deformações 
relativamente pequenas (máxima de 0,4\%) e distribuições de deformações coerentes em cada nível de reforço, em que os picos definem uma superfície de ruptura.

a)

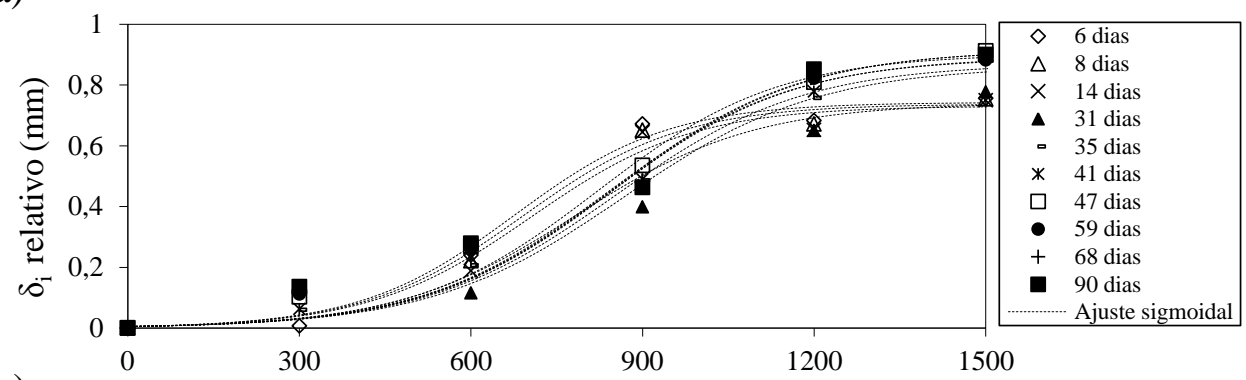

b)

Distância da face $(\mathrm{mm})$

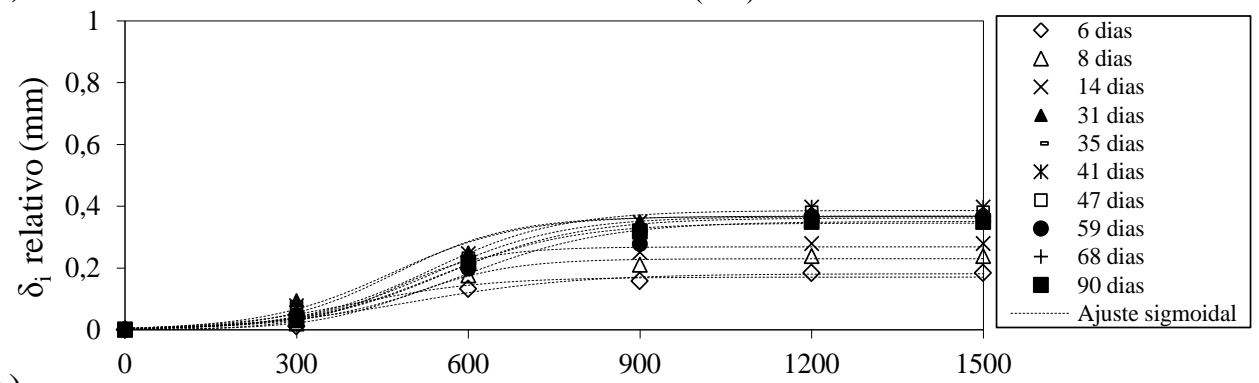

c)

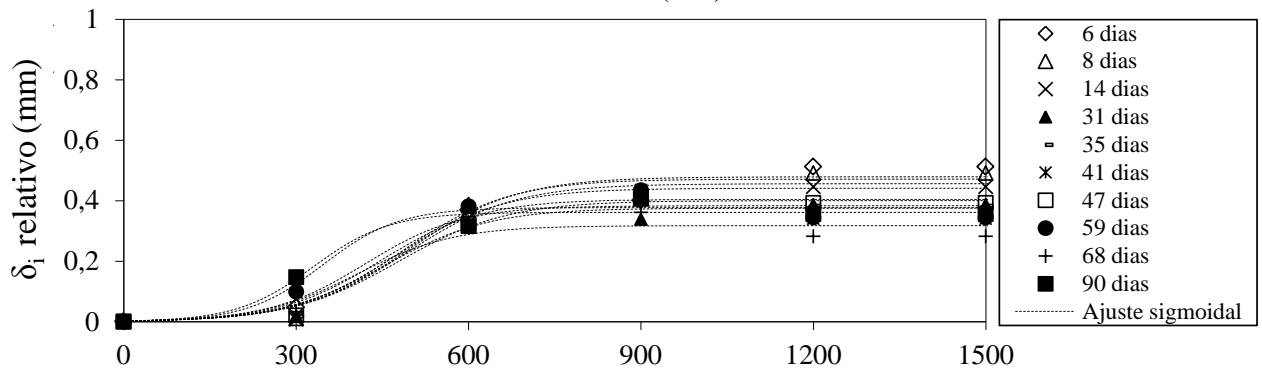

d)

Distância da face $(\mathrm{mm})$

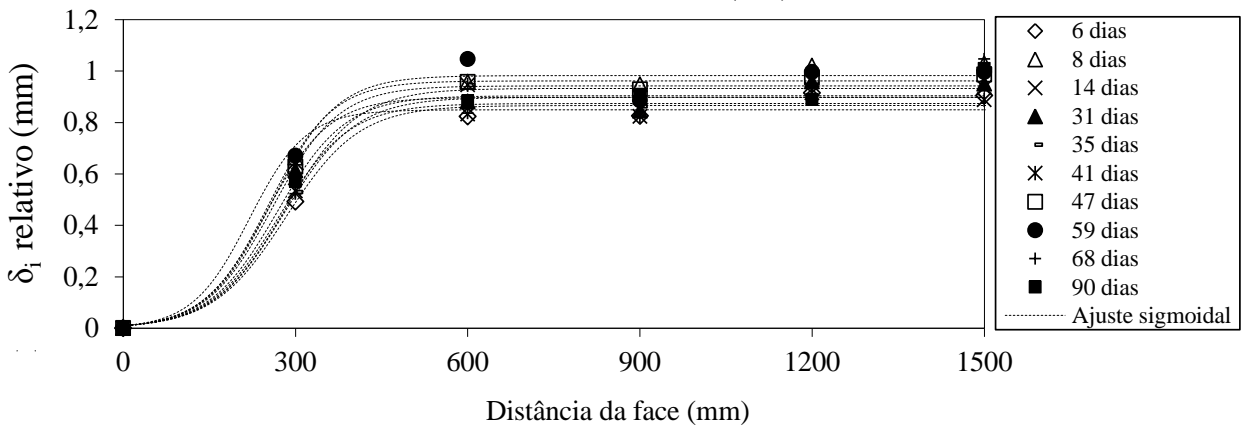

Figura 5.10. Distribuição dos deslocamentos internos ao longo do comprimento dos reforços geotêxteis e ajustes sigmoidais no protótipo M1: (a) camada 5; (b) camada 4; (c) camada 3; (d) camada 2. 
a)
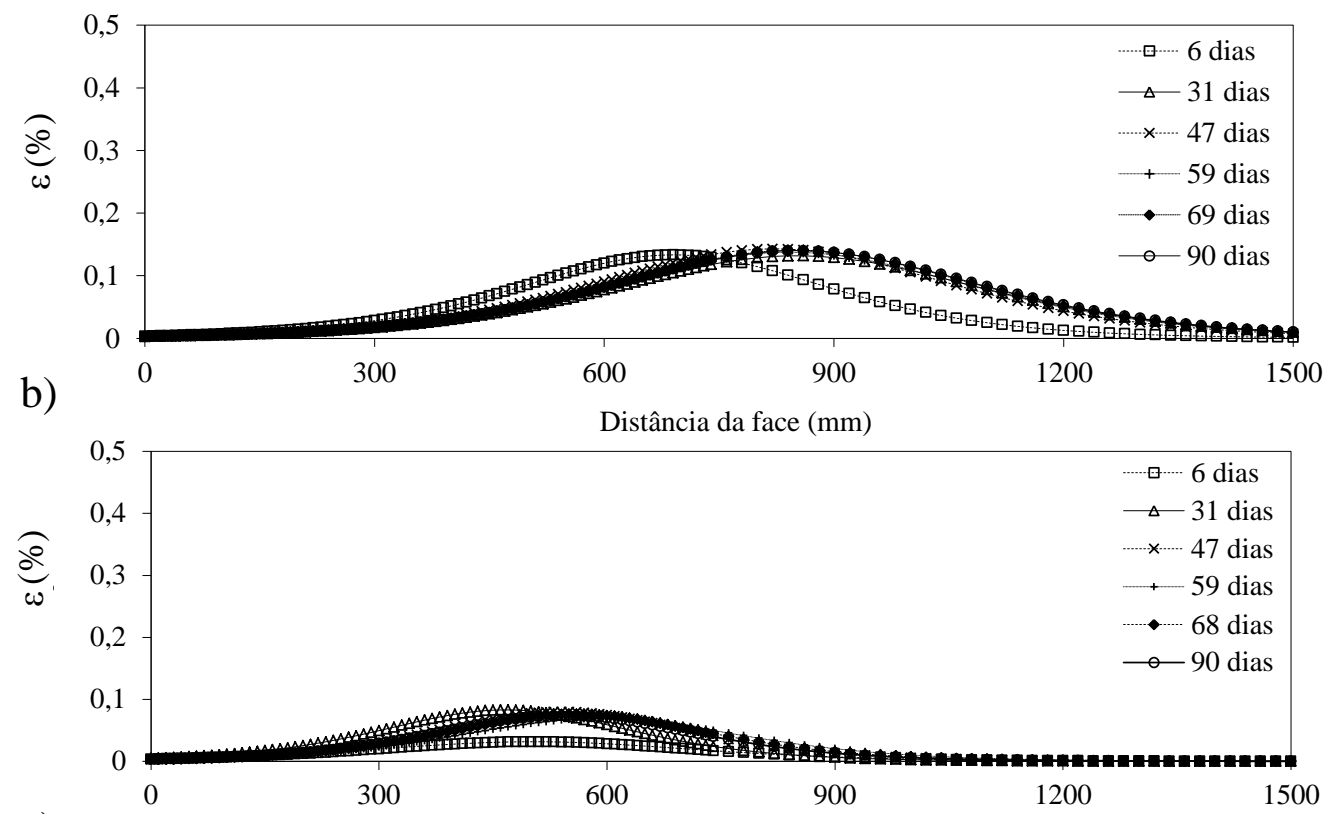

c)

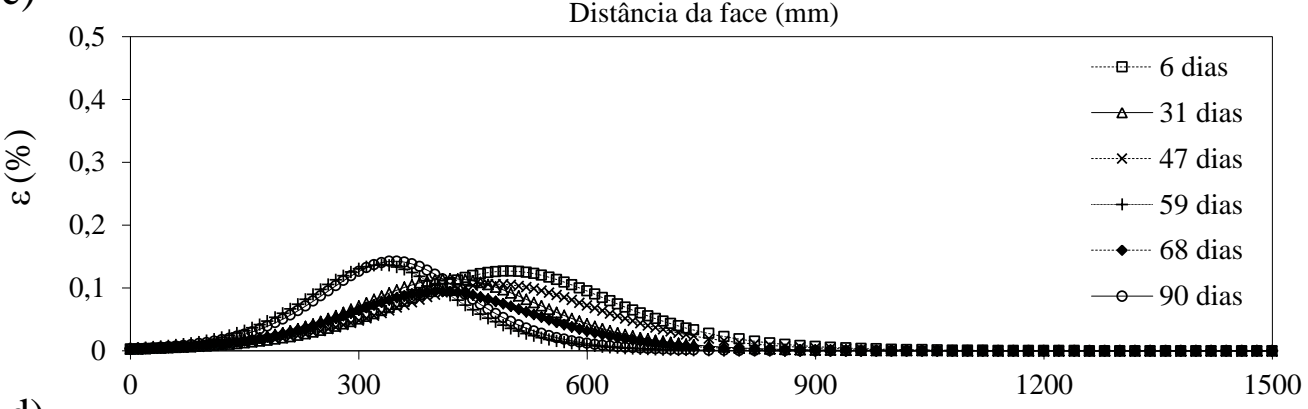

d)

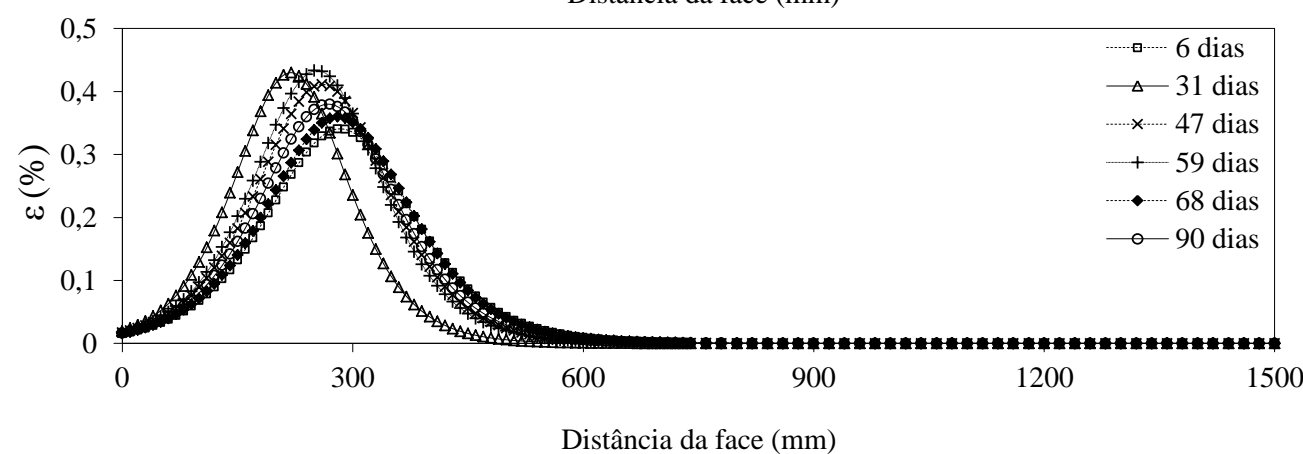

Figura 5.11. Distribuição das deformações ao longo do comprimento dos reforços geotêxteis do protótipo M1: (a) camadas 5; (b) camada 4; (c) camada 3; (d) camada 2.

As deformações de pico $\left(\varepsilon_{\text {máx }}\right)$ medidas ao longo do ensaio são apresentadas na Figura 5.12, associadamente aos valores médios de sucção matricial medidos em cada camada reforçada. Verifica-se que as deformações de pico aumentam somente após a aplicação da sobrecarga para todas as linhas de reforços avaliadas, mantendo-se constantes após este evento. Tratam-se de deformações de pico máximas de $0,4 \%$ na camada 2 e deformações menores que $0,2 \%$ nas outras camadas. Considerando o comportamento de tração não confinada do reforço, tal nível de deformação é correspondente à forças relativamente pequenas transmitidas aos reforços. Nas 
condições reais de trabalho, em que os geotêxteis se apresentam confinados ao solo, esses níveis de forças são maiores, uma vez que a rigidez do reforço é aumentada nessa condição. Mesmo assim, a elevada rigidez do solo na condição não saturada faz com que pequenas forças sejam mobilizadas pelos geotêxteis. Sugere-se, portanto, que o mesmo maciço poderia se manter estável mesmo sem a presença dos reforços. Neste caso, os reforços funcionariam somente para permitir que um muro ou aterro fosse construído com faceamento vertical. Em reais condições de campo, períodos chuvosos poderiam vir a reduzir a sucção matricial do solo e, a partir disso, os reforços atuariam efetivamente.

a)

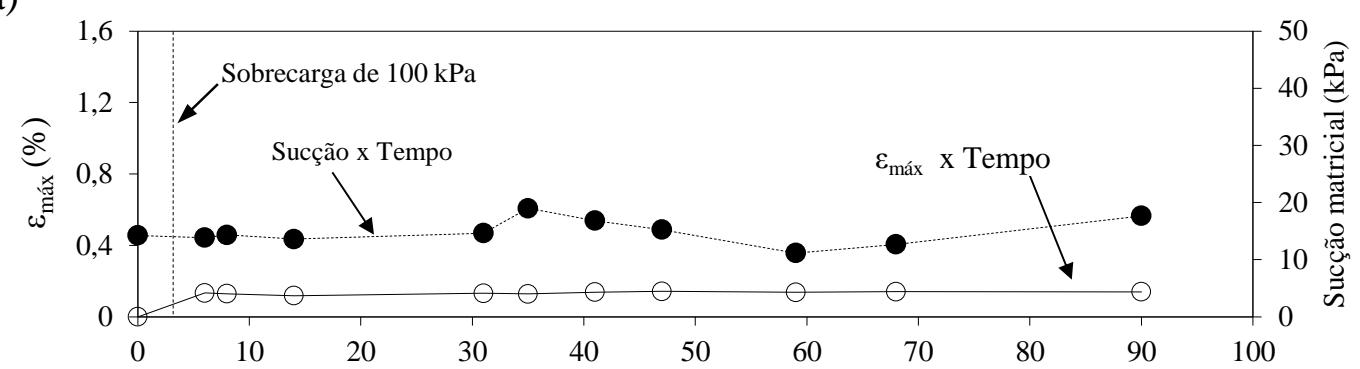

b)

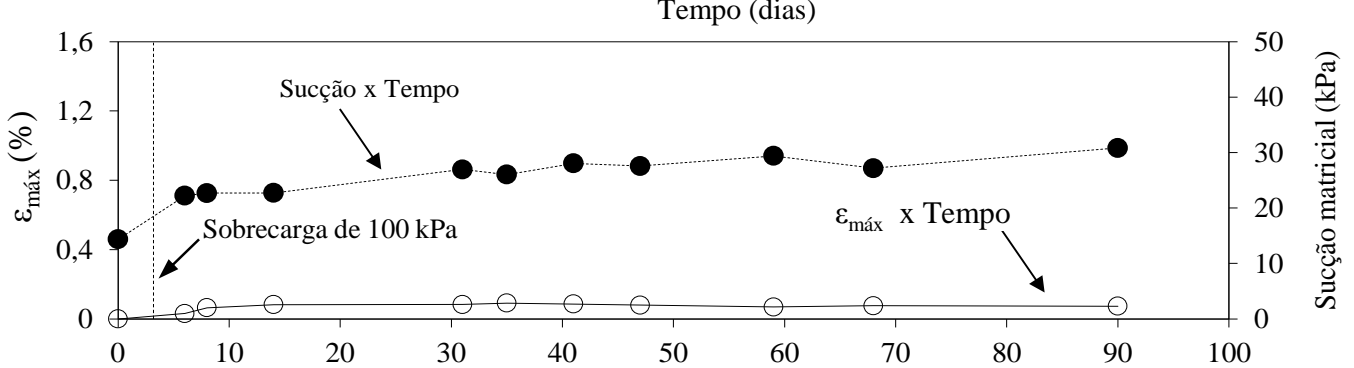

c)

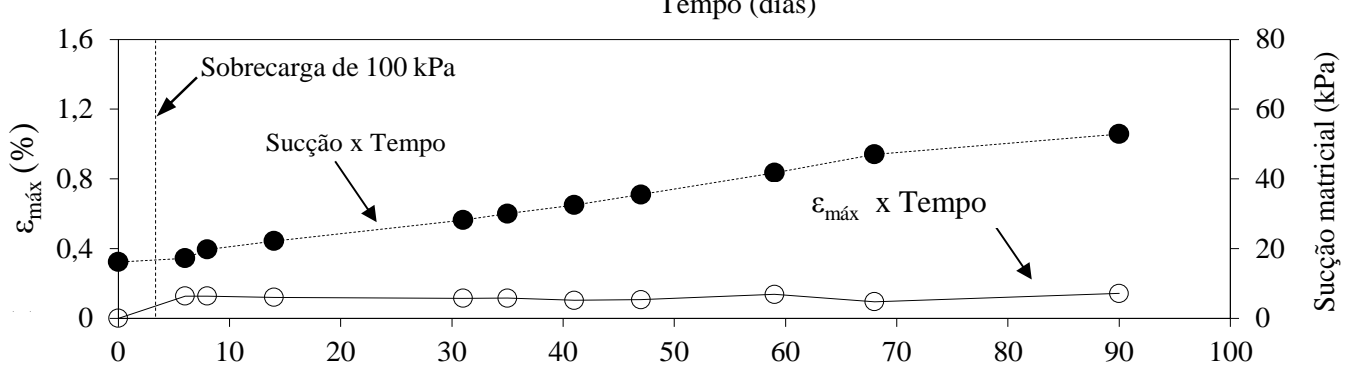

d)

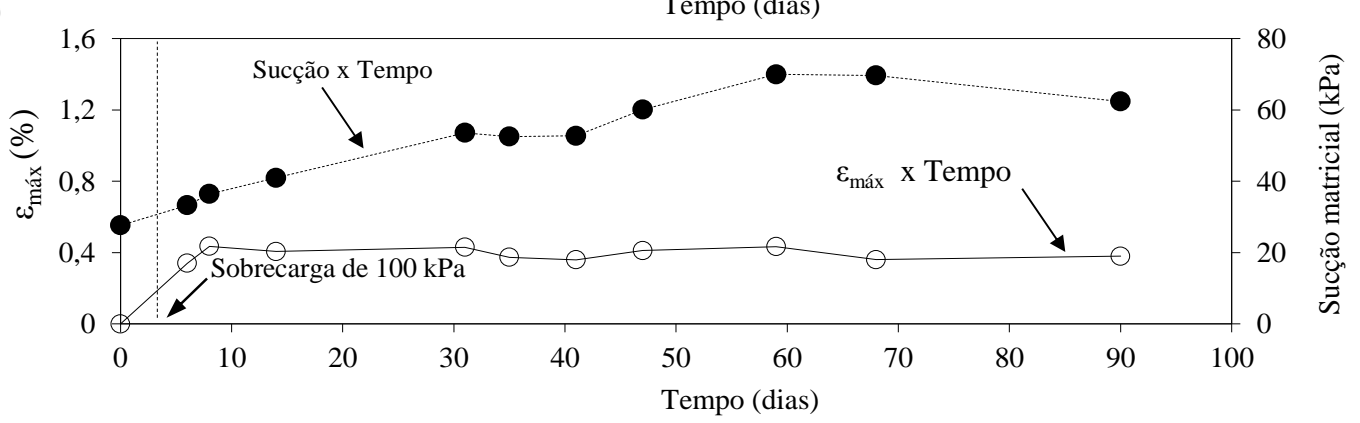

Figura 5.12. Deformações máximas e sucção matricial versus tempo do protótipo M1: (a) camada 5; (b) camada 4; (c) camada 3; (d) camada 2. 
Ainda, como as deformações medidas permaneceram sem aumentos significativos ao longo do tempo, pode-se concluir que o reforço não apresentou comportamento de fluência. Essa é uma grande vantagem de manter a condição não saturada do solo em estruturas de solo reforçado, já que a sucção do solo elimina o comportamento de fluência do geotêxtil. Naturalmente, a manutenção da não saturação do solo nesse tipo de estrutura demanda custos relacionados às barreiras de avanço de água, tais como as geomembranas. Neste caso, cabe avaliar a relação custo-benefício entre soluções de barreiras de avanço e o uso de reforços de maiores resistência e rigidez em projetos que levam em conta a condição crítica de saturação.

A definição das distribuições das deformações ao longo do comprimento dos reforços em cada camada, apresentada na Figura 5.11, permitiu a localização dos picos de deformação em cada camada reforçada. Na Figura 5.13 são apresentadas as localizações dos picos de deformações e as distribuições das deformações de pico ao longo da altura do protótipo, em diferentes tempos durante o ensaio. As superfícies foram definidas por ajustes potenciais (Figura 5.13a), embora ajustes lineares pudessem também ser representativos. Não se pretende com isso estabelecer definições teóricas de superfícies de ruptura, mas somente representar as superfícies reais visualizadas nos protótipos.

a)

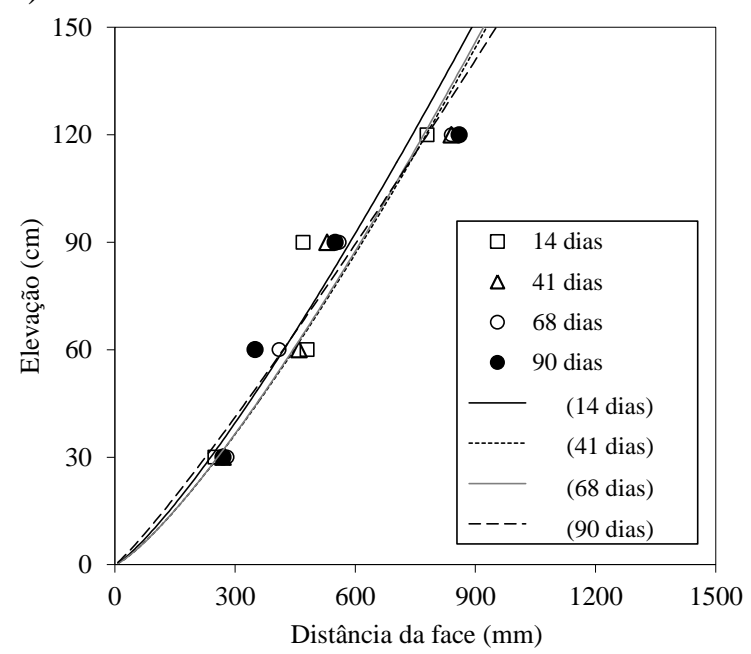

b)

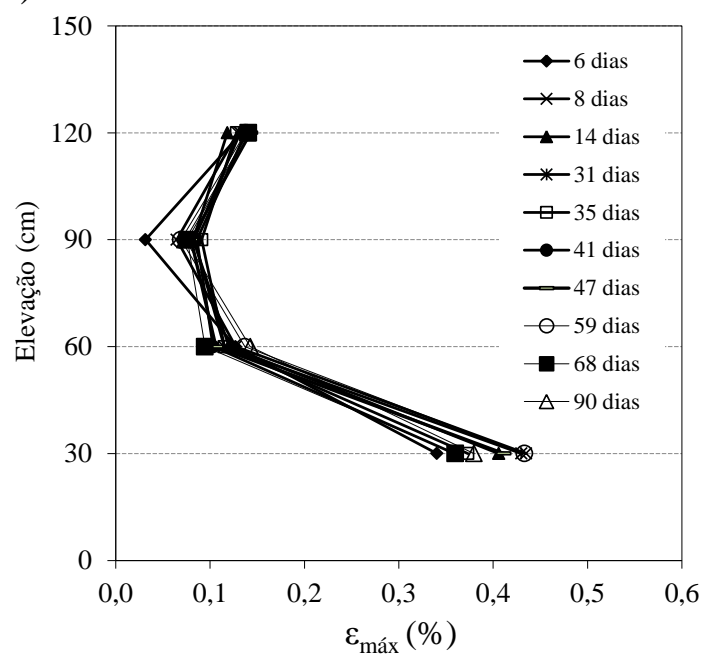

Figura 5.13. Deformações de pico ao longo do comprimento dos geotêxteis do protótipo M1: (a) definição de superfícies reais de rupturas; (b) distribuição das deformações.

Com relação à distribuição das deformações de pico (Figura 5.13b), os níveis nos reforços das camadas 3, 4 e 5 foram menores que os níveis medidos na camada instrumentada inferior (camada 2).

\subsubsection{Relações entre parâmetros do solo não saturado e o comportamento do protótipo}

Neste tópico, busca-se relacionar o comportamento do protótipo com os valores grau de saturação e sucção matricial medidos durante ensaio. Nas Figuras 5.14 e 5.15 são mostradas as 
relações das deformações de pico $\left(\varepsilon_{\text {máx }}\right)$ com o grau de saturação e sucção matricial de cada camada instrumentada. Pode-se identificar na Figura 5.14, a manutenção das deformações uma vez que o grau de saturação manteve-se constante durante o ensaio. Já na Figura 5.15, mostra-se que mesmo com o aumento da sucção matricial, as deformações mantiveram-se constantes, sem nenhum sinal de retração do reforço.

a)

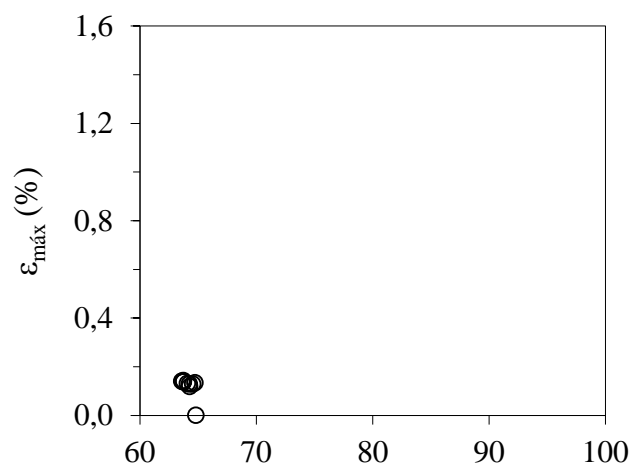

c)

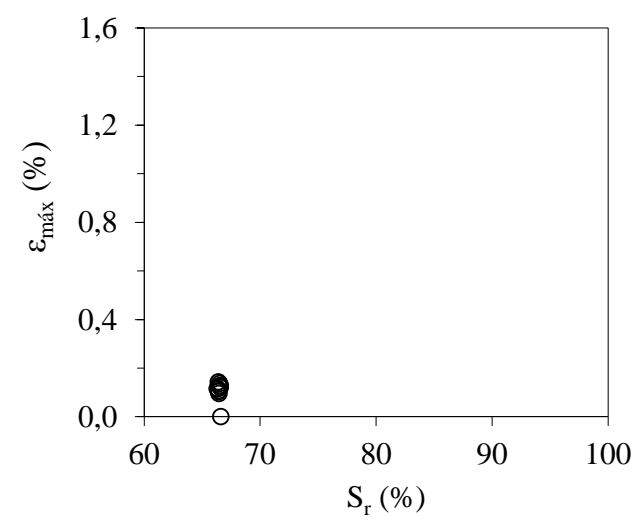

b)

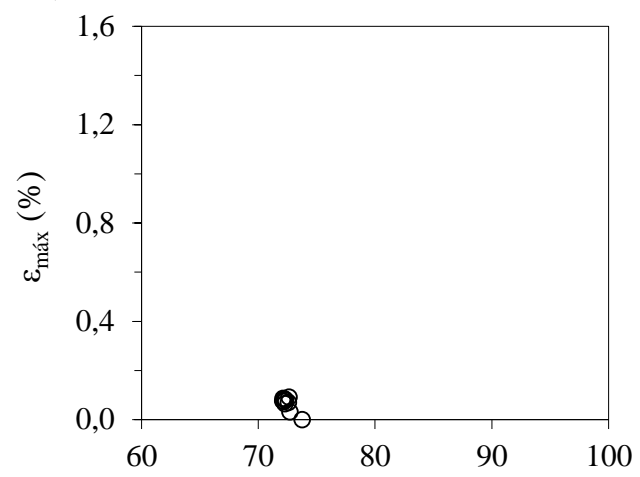

d)

$\mathrm{S}_{\mathrm{r}}(\%)$

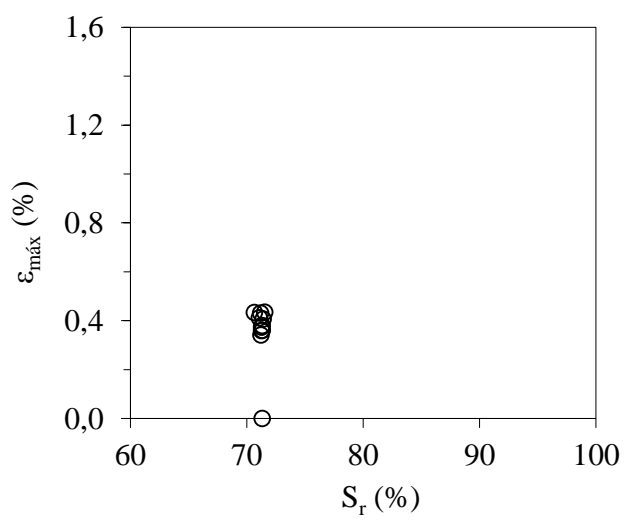

Figura 5.14. Relação deformação de pico versus grau de saturação do protótipo M1: (a) camada 5; (b) camada 4; (c) camada 3; (d) camada 2.

Na Figura 5.16 são apresentadas as relações das deformações de pico máximas $\left(\varepsilon_{\text {máxmáx }}\right)$ com a média dos valores de grau de saturação e sucção matricial medidos em toda a massa de solo. Constata-se nesta figura, que o aumento da sucção matricial não altera as deformações máximas de pico nos reforços, podendo essa relação ser descrita por uma linha horizontal, conforme apresentado na Figura 5.14b. Nota-se que nenhum sinal de retração pôde ser evidenciado. Considerando as condições estabelecidas durante o ensaio, a manutenção das deformações está associada a não alteração da média do grau de saturação do solo ao longo do ensaio (Figura 5.14a). 

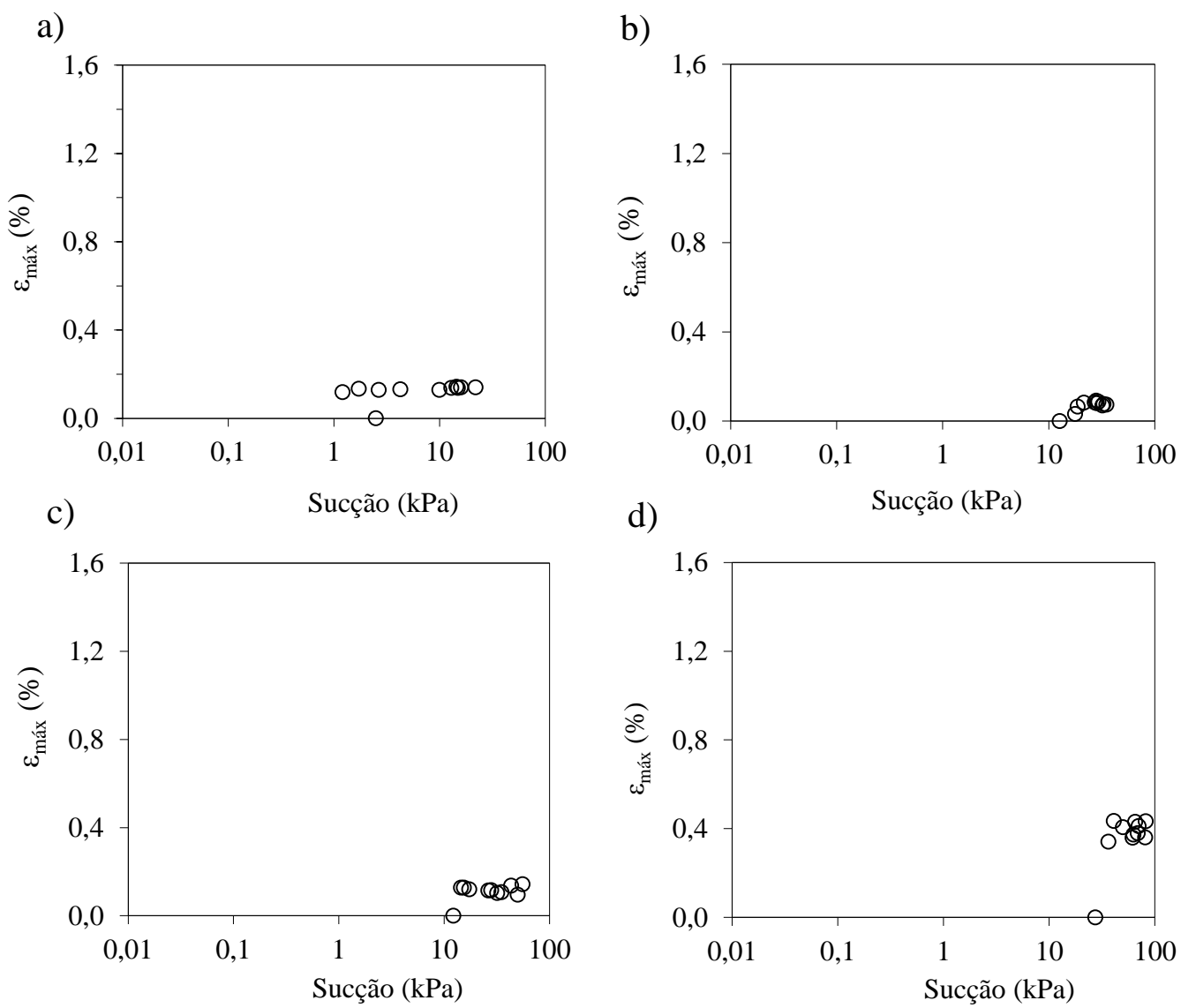

Figura 5.15. Relação deformação de pico versus sucção matricial do protótipo M1: (a) camada 5; (b) camada 4; (c) camada 3; (d) camada 2.

a)

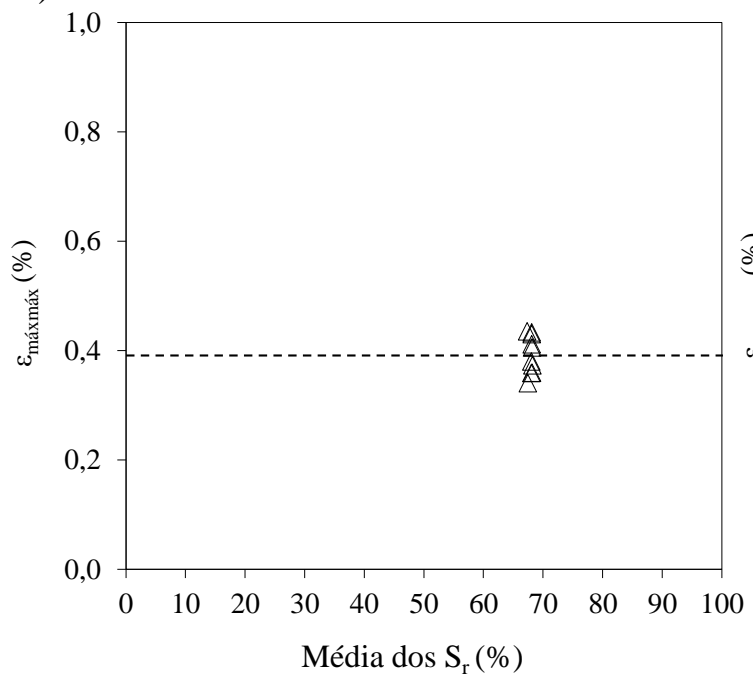

b)

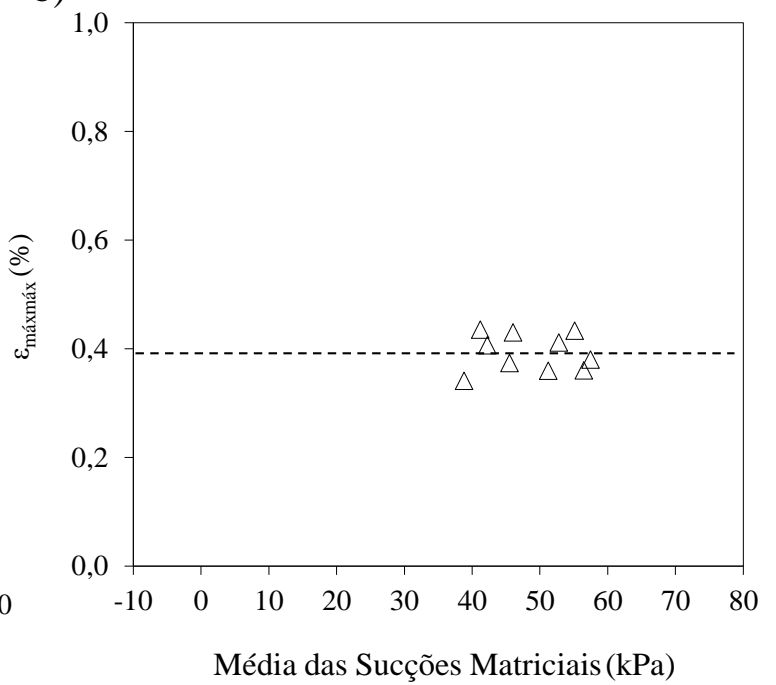

Figura 5.16. Relação deformação de pico máxima versus (a) média geral do grau de saturação e (b) média geral da sucção matricial do protótipo M1. 


\subsubsection{Análises de equilíbrio limite nas condições de umidade constante de compactação}

Análises de equilíbrio limite utilizando o software UTEXAS3 (WRIGHT, 1990), considerando as condições não saturadas do solo, foram realizadas para diferentes períodos ao longo do ensaio. A consideração da condição não saturada do solo foi realizada inserindo os valores de pressões de água negativas registradas durante o ensaio (sucção matricial) nos diferentes pontos de monitoramento. O software possibilita que as pressões de água na superfície de ruptura sejam determinadas pela interpolação dos valores medidos.

Os resultados das análises de equilíbrio limite e a relação entre estes e as deformações máximas de pico $\left(\varepsilon_{\text {máxmáx }}\right)$ são apresentados na Figura 5.17. Observa-se que a condição de não saturação resultou em pequenos aumentos no fator de segurança (FS) com o tempo, devido aos aumentos da sucção matricial, sendo estes aumentos praticamente desprezíveis. Se o fator de segurança for relacionado com as deformações máximas de pico, nota-se que a relação pode também ser representada por uma linha horizontal, uma vez que as deformações permanecem constantes. Portanto, para fatores de segurança maiores que 2,0, as deformações nos reforços permaneceriam constantes independente do aumento da sucção matricial do solo.

a)

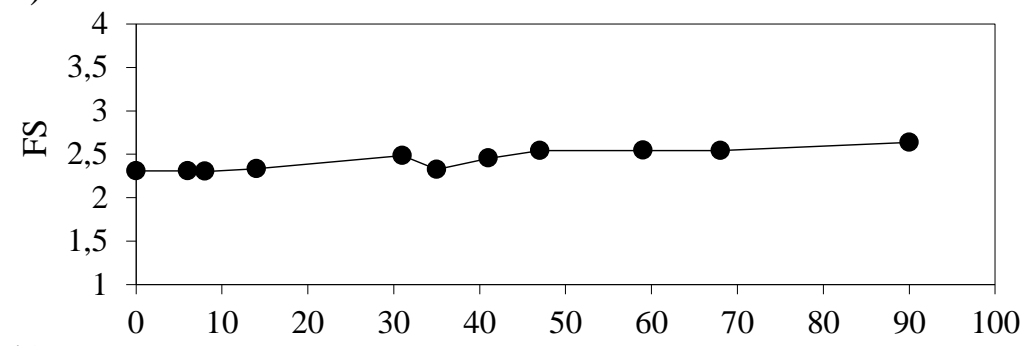

b)

Tempo (dias)

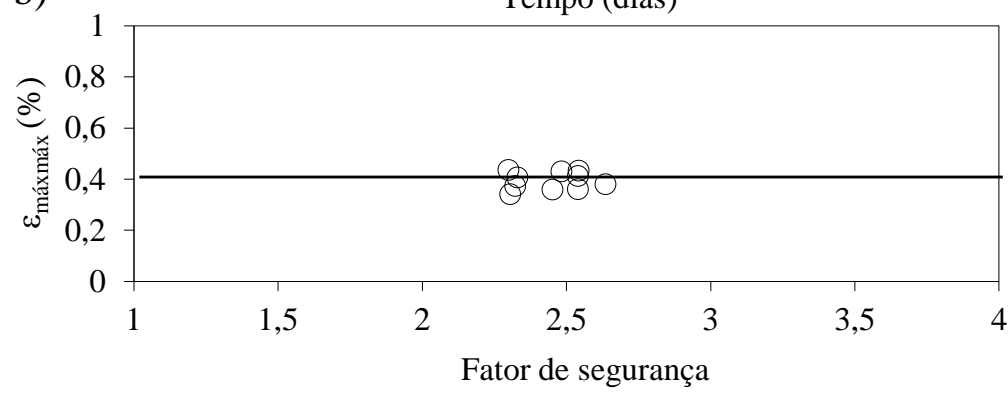

Figura 5.17. Resultados das análises de equilíbrio limite: (a) fator de segurança com o tempo; (b) relação entre fator de segurança de deformação máxima de pico nos reforços.

Na Figura 5.18 é apresentado o efeito da sucção matricial tanto nos fatores de segurança como nas deformações máximas de pico registradas no ensaio. Observa-se que o aumento da sucção matricial promove uma maior estabilidade da estrutura enquanto as deformações permanecem inalteradas. Aparentemente, o aumento da sucção matricial promove maior estabilidade devido ao aumento da rigidez do solo. Como a deformação máxima é significativamente pequena (próxima de zero), a força mobilizada também pode estar próxima de 
zero. Isso é um indicativo de que a estrutura poderia se manter estável mesmo com a ausência dos reforços, devido ao aumento significativo no módulo de rigidez do solo. Uma maneira de avaliar qualitativamente o efeito do grau de saturação na rigidez do solo é utilizar os valores de módulos de rigidez dos ensaios triaxiais das amostras saturadas e não saturadas, descritos no capítulo 4 . A Figura 5.19 apresenta as curvas que representam o efeito do grau de saturação nos valores de módulo de rigidez secante do solo em análise para os diferentes níveis de deformações.

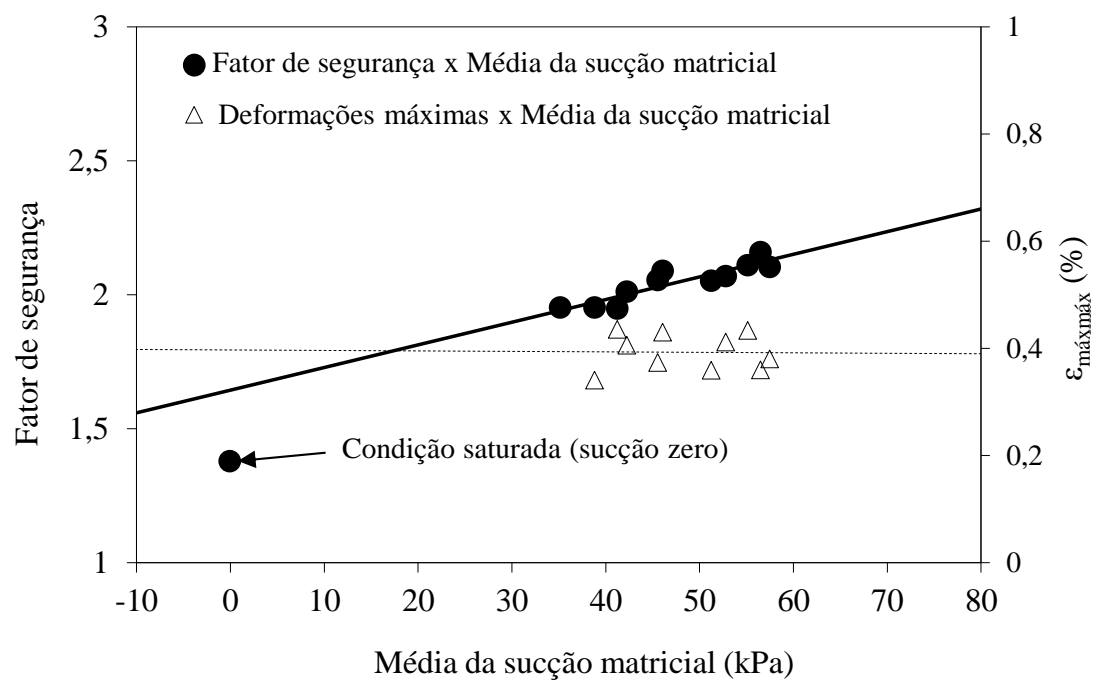

Figura 5.18. Relação entre fator de segurança e deformação máxima com a média da sucção matricial medida.

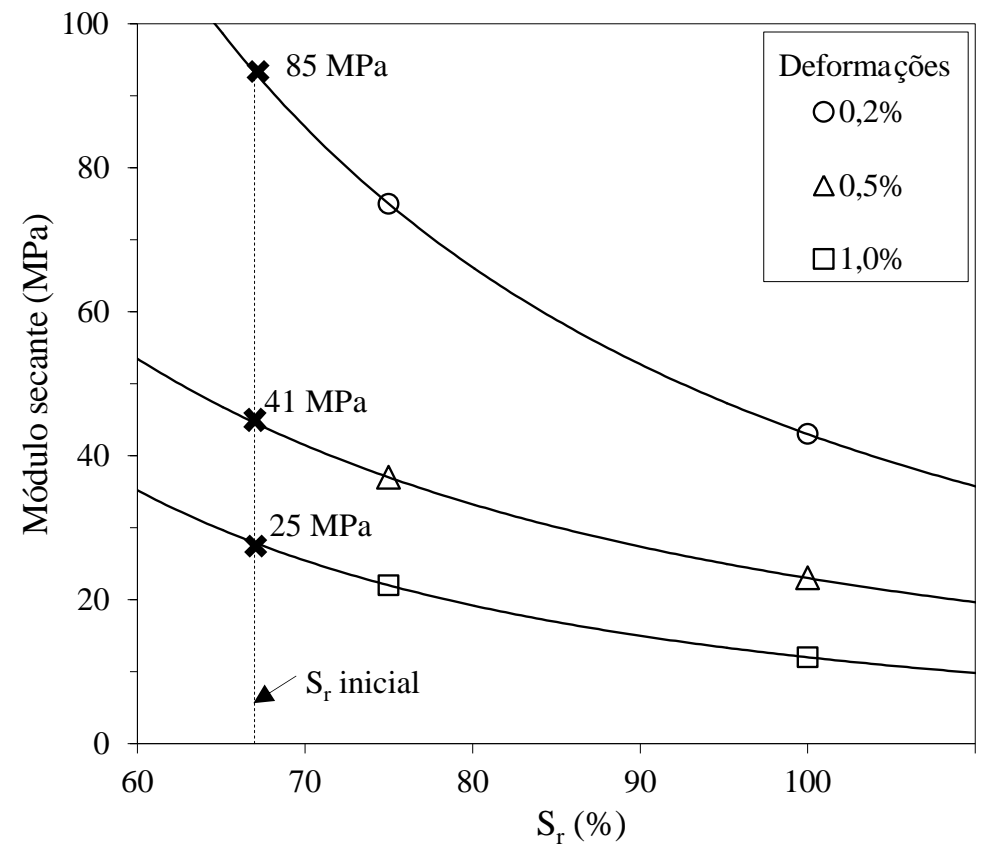

Figura 5.19. Curva do efeito da saturação no módulo de rigidez do solo por ensaios triaxiais.

Nota-se na Figura 5.19 que, considerando o grau de saturação inicial do solo, os valores de módulos são relativamente elevados em comparação com o módulo do solo saturado $\left(S_{\mathrm{r}}=100 \%\right)$. 
Supõe-se, portanto, que os elevados módulos de rigidez do solo na condição não saturada consistem no principal motivo para o bom comportamento do protótipo M1.

$\mathrm{Na}$ Figura 5.20 são comparadas as superfícies de ruptura obtidas pelas análises de equilíbrio limite às localizações dos pontos de deformações de pico que compõem as superfícies reais de ruptura. Neste gráfico são comparados os pontos experimentais às superfícies teóricas circulares, bilineares e a superfície linear de Rankine. Neste caso, a superfície de Rankine representou mais apropriadamente a superfície de ruptura do protótipo M1, muito embora as superfícies circulares e bilineares sejam razoáveis para análises em projetos desse tipo de estrutura.

a)

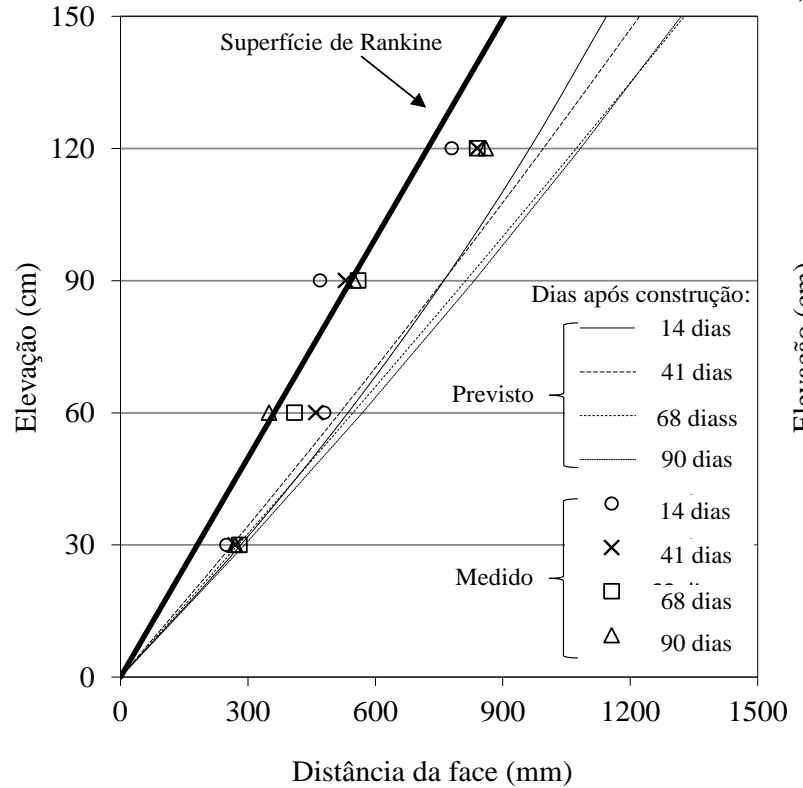

b)

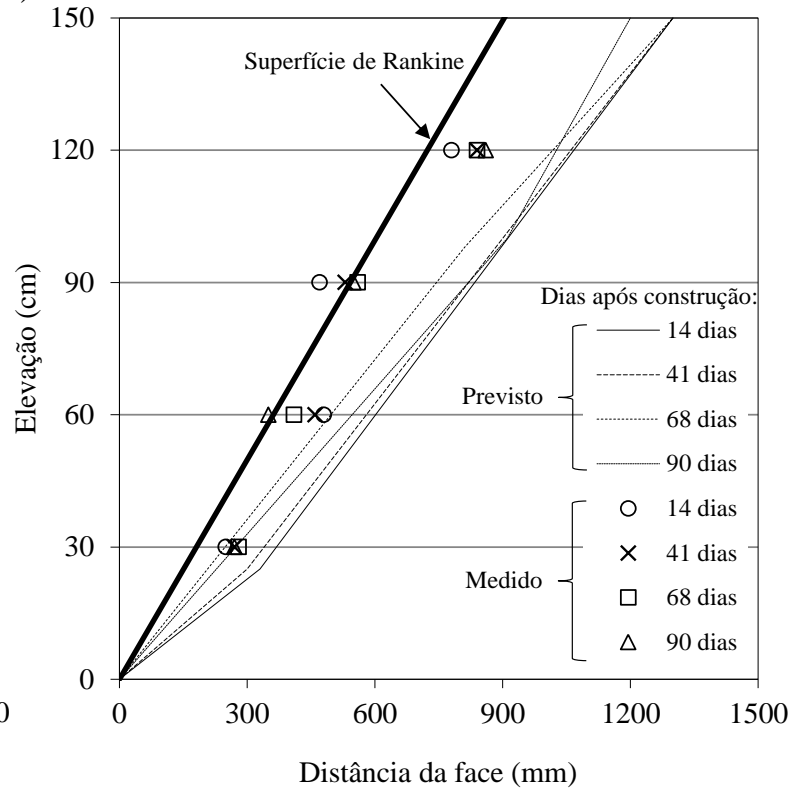

Figura 5.20. Comparações entre superfícies de rupturas reais e superfícies previstas pelo método de equilíbrio limite e superfície de Rankine do protótipo M1: (a) circulares; (b) bilineares.

Portanto, as evidências experimentais associadas às análises de projetos aqui apresentadas mostram que análises de estabilidade considerando a ruptura dos reforços podem ser conduzidas pelo método de equilíbrio limite. Embora a superfície de ruptura teórica desse tipo de análise não seja tão consistente quanto à superfície de ruptura de Rankine, análise de equilíbrio limite costuma ser menos conservadoras em comparação ao método das tensões de serviço utilizando a teoria de empuxo de Rankine. 


\section{CAPÍTULO 6}

\section{INFLUÊNCIA DO AVANÇO DO UMEDECIMENTO NO COMPORTAMENTO DE UM PROTÓTIPO DE MURO REFORÇADO COM GEOTÊXTIL NÃO TECIDO}

O principal objetivo deste capítulo é entender o efeito do processo de umedecimento no comportamento de um muro reforçado com geotêxtil não tecido. Neste, apresentam-se os resultados do monitoramento do comportamento do protótipo M2, no qual eventos de chuvas intermitentes foram impostos aleatoriamente, buscando condições de precipitação próximas da realidade. Foi analisado o efeito do avanço do umedecimento no comportamento do protótipo, buscando estabelecer relações entre as alterações no grau de saturação e no desempenho da estrutura. Os parâmetros representantes do comportamento do solo foram comparados à resultados de análises de equilíbrio limite nas condições de saturação impostas pelos eventos de chuvas.

\subsection{Infiltração de água no protótipo}

Para uma melhor compreensão da infiltração de água no protótipo, buscou-se quantificar não somente a intensidade das chuvas impostas (Figura 4.44a), como também, o volume de água infiltrado no sistema. Na Figura 6.1 é mostrado o volume de água aplicado no topo do protótipo em cada evento isolado de chuva, bem como o volume de água aplicado acumulado. Mostra-se ainda, o volume de água drenado para fora do sistema e captado pelo coletor de água (volume escoado no topo). Portanto, uma estimativa do volume infiltrado pode ser realizada pela diferença entre os volumes aplicados e drenados. Já o volume infiltrado real consiste no determinado com base na profundidade média da frente de infiltração, definida pelas leituras dos teores de umidade volumétrica dos sensores instalados ao longo da altura do protótipo. Desta forma, o volume de água pode ser calculado pela diferença entre os volumes correspondentes aos teores de umidades inicial e final durante o processo infiltração. As definições dos perfis de infiltração serão posteriormente detalhadas neste capítulo.

O volume teórico de água necessário para completar os vazios de toda a massa compactada de solo é de $0,45 \mathrm{~m}^{3}$. Nota-se, com base neste valor, que o volume de água acumulado aplicado foi muito maior que o volume necessário para saturar o solo. Pelo fato da intensidade de precipitação ser maior que a permeabilidade saturada do solo, grande parte desse volume de água escoou na superfície do topo da estrutura. Dessa forma, o volume de água infiltrado, seja estimado ou real, não alcançou o valor necessário para saturar o solo. Ainda, por se tratar de uma infiltração sob o efeito da ação da gravidade, a água infiltrada não preenche totalmente os vazios do solo, o que dificulta a saturação do solo. 


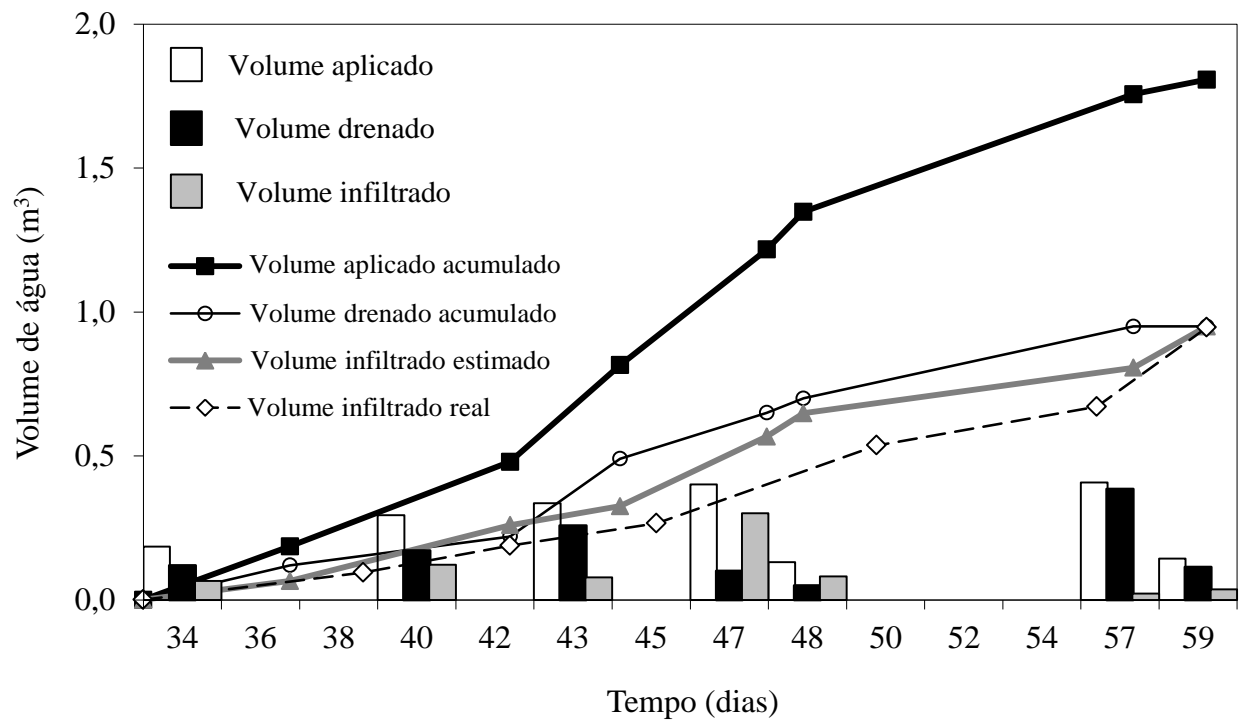

Figura 6.1. Volumes de água no protótipo M2: volume aplicado no topo; volume drenado para fora (escoado); e volume infiltrado no corpo do aterro.

Outro aspecto importante nesta figura é o fato do volume infiltrado real ter sido menor que o volume infiltrado estimado. Supõe-se que essa diferença seja decorrente da drenagem interna da água proporcionada pelos reforços permeáveis. Portanto, parte da água infiltrada foi drenada pelos reforços e conduzida aos drenos de face. Esta verificação consiste em uma das grandes vantagens do uso de reforços permeáveis, conforme relatado no capítulo 2. O efeito hidráulico de interface de reforços permeáveis será exclusivamente discutido no próximo capítulo.

As respostas dos sensores de umidade e tensiômetros instalados no protótipo M2 são apresentadas na Figura 6.2. Os sensores foram posicionados no meio da altura de cada camada reforçada, em pontos próximos da face $(10 \mathrm{~cm})$, a $70 \mathrm{~cm}$ e a $130 \mathrm{~cm}$ da face. Já os tensiômetros foram instalados a $5 \mathrm{~cm}$ acima de cada reforço, no meio e no fundo de cada camada (Figura 4.28). Ainda na Figura 6.2, indica-se o tempo que a frente de infiltração levaria para alcançar o ponto de leitura dos sensores, considerando o coeficiente de permeabilidade do solo saturado (z de infiltração, $\mathrm{k}_{\text {sat. }}$.) Tal valor foi estabelecido como uma referência para comparação em relação ao tempo real de alcance da infiltração em cada sensor. No entanto, como o ensaio de permeabilidade foi realizado em corpos de prova saturados e condições de compactação bem controladas, a diferença de comportamento em comparação com as condições do solo do protótipo é esperada. Mesmo assim, nota-se que os tempos previstos pelo $\mathrm{k}_{\text {sat }}$ e os medidos nos protótipos são bastante aproximados. O procedimento mais correto seria a comparação com a permeabilidade teórica do solo não saturado, definida pela função-k que relaciona o coeficiente de permeabilidade com o comportamento da curva de retenção de água do solo. Porém, essa previsão é relativamente complexa, uma vez que a permeabilidade sofre mudanças durante a infiltração pela variação a sucção matricial do solo. Por não se tratar do foco desse trabalho, as análises considerando a permeabilidade do solo não saturado não foram efetuadas. 
a)
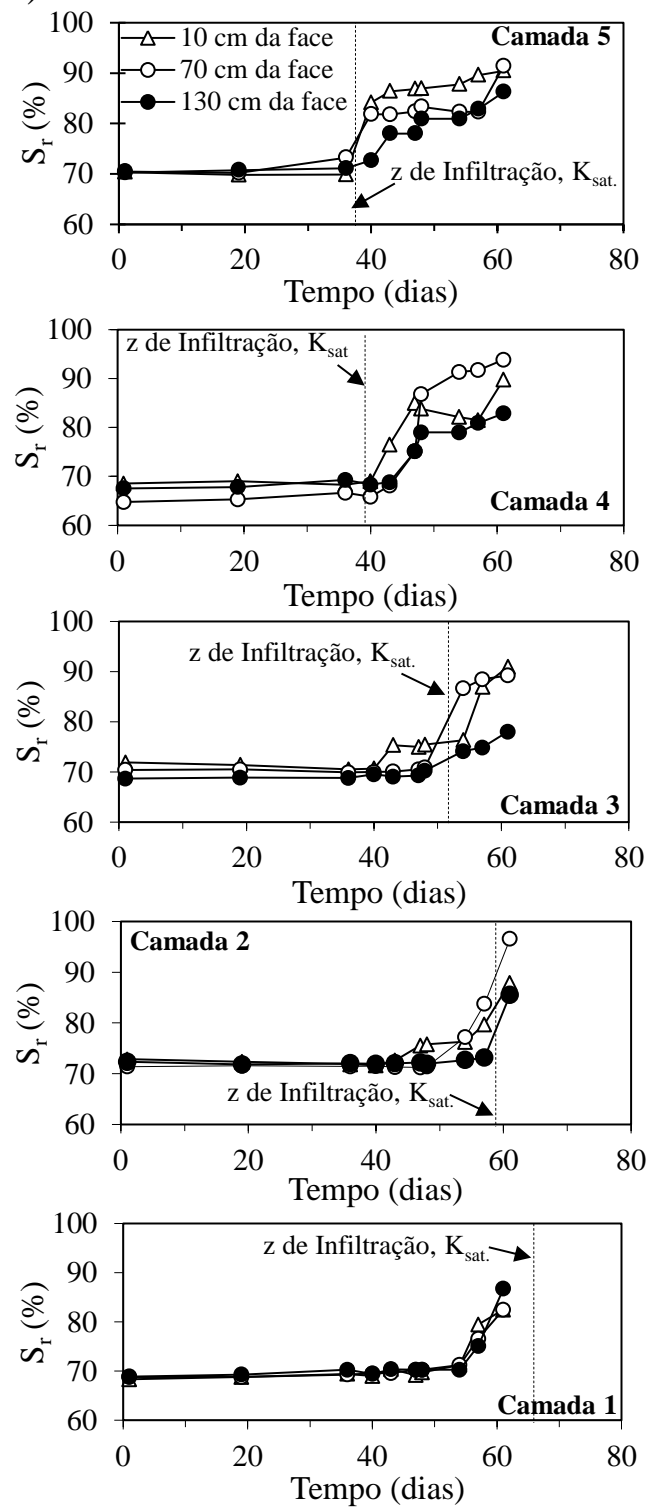

b)
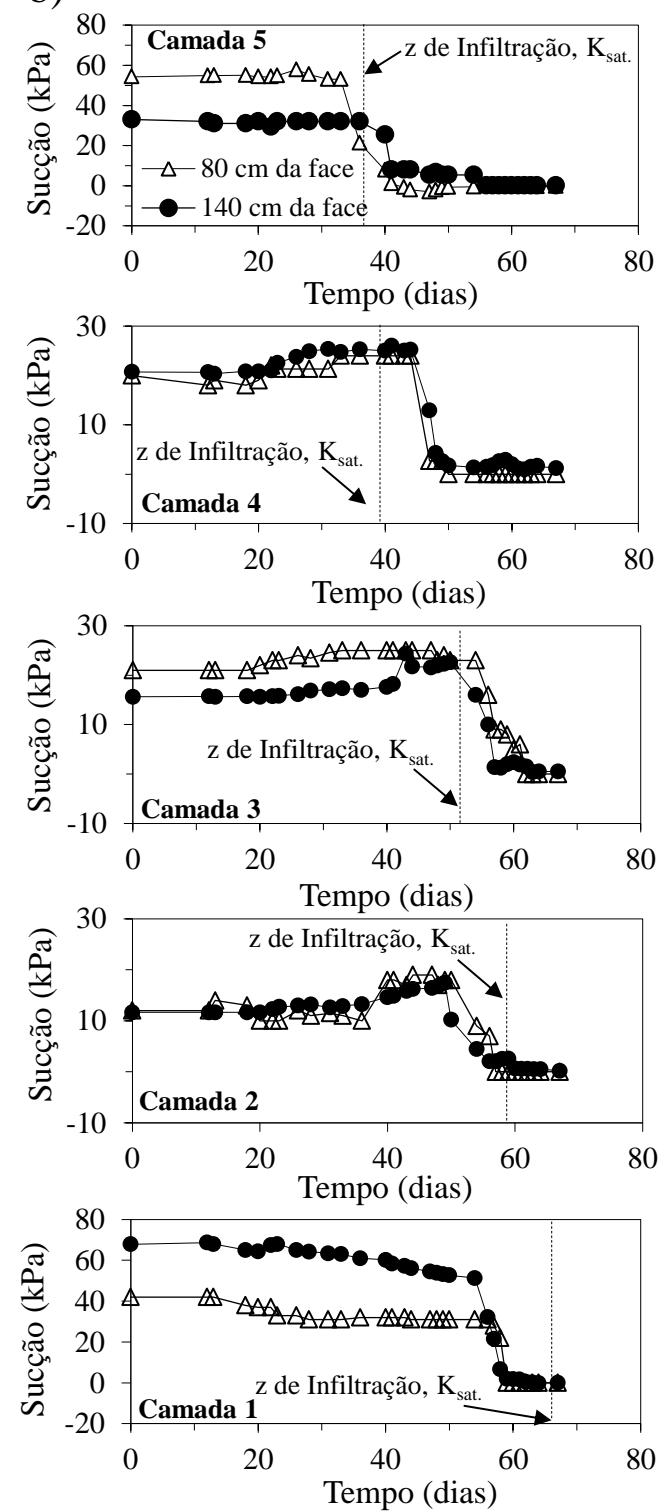

Figura 6.2. Resultados dos sensores de umidade e tensiômetros do protótipo M2: (a) grau de saturação versus tempo; (b) sucção versus tempo.

Verifica-se na Figura 6.2 que o avanço do umedecimento ocorre preferencialmente em regiões próximas da face $(10 \mathrm{~cm})$. Dentre os principais motivos estão: menores valores de grau de compactação nas proximidades da face, devido à dificuldade de compactação em regiões próximas às fôrmas de envelopamento e; declividade da superfície do topo da estrutura em direção à face, projetada para facilitar o escoamento da água superficial para fora da estrutura. Cabe observar que, estas condições são comuns nas reais aplicações da técnica no campo.

De modo geral, os valores de grau de saturação não alcançaram $100 \%$, ou seja, o solo não foi saturado mesmo sob a infiltração de água dos eventos de precipitação impostos. Os valores de sucção foram próximos de zero (entre 0,5 a $2 \mathrm{kPa}$ ), com valores de saturação próximos a 90\%, sendo estes níveis consistentes com o estabelecido pela curva de retenção de água do solo 
(umedecimento). Em adição, não se observou a secagem da água do solo nos períodos entre chuvas, o que pode estar associado ao fato do protótipo estar em ambiente controlado.

A faixa de valores de umidades medidas nos protótipos durante o ensaio corresponderam ao trecho mais inclinado da curva de retenção (valores de sucção entre 3 e $10 \mathrm{kPa}$ ), no qual pequenas alterações na umidade resultam em decréscimos significativos na sucção do solo. Esse fenômeno é importante no comportamento da estrutura, podendo resultar em uma redução significativa na rigidez e na resistência ao cisalhamento do solo, sob a ação do umedecimento.

Para um melhor entendimento do avanço da frente de umedecimento no protótipo M2, o perfil de infiltração é definido plotando-se os valores de grau de saturação em relação à profundidade, para diferentes tempos ao longo do ensaio. Neste caso, um perfil de infiltração típico, baseado no comportamento hidráulico de estruturas reforçadas com geotêxteis não tecidos, tais como os obtidos por Iryo e Rowe (2005), foram definidos com base nos três valores de umidade volumétrica que quantificam o armazenamento de água nos vazios do solo e geotêxteis durante a infiltração sob a ação gravitacional. Os valores de umidade correspondem a: umidade volumétrica inicial $\left(\theta_{\mathrm{i}}\right)$, umidade volumétrica correspondente à capacidade de campo $\left(\theta_{\mathrm{cc}}\right)$, e umidade volumétrica na saturação $\left(\theta_{\text {sat }}\right)$. As definições destes três parâmetros foram apresentadas no capítulo 3 de revisão bibliográfica. No presente trabalho, estes valores foram determinados com base nas constatações experimentais e cálculos teóricos. Por exemplo, sabe-se que o teor de umidade inicial de compactação corresponde ao valor de umidade volumétrica de 0,26 , enquanto na saturação esse valor passa a ser a porosidade, ou seja, 0,34 (34\%). Durante o processo de infiltração, verificou-se que o valor de umidade poderia ser definido como 0,31 , com base na média dos valores medidos pelos sensores, o que definiu o teor de umidade de capacidade de campo.

Os perfis de infiltração foram também definidos em termos de sucção matricial, utilizando os valores de sucção medidos pelos tensiômetros, bem como os valores de sucção obtidos da curva de retenção de água do solo. Dessa forma, os mesmos perfis de infiltração, anteriormente definidos em termos de grau de saturação, puderam ser representados em termos de sucção matricial. Para isso, definiram-se os três valores de sucção matricial típicos durante o processo de infiltração (inicial, na capacidade de campo e na saturação), utilizando dos valores de umidade volumétrica utilizados para definir os perfis de infiltração. Os valores de teor de umidade volumétrica que representam a capacidade de armazenamento de água nos vazios do solo e as correspondentes sucções matriciais da curva de retenção de água do solo são mostrados na Figura 6.3 . 


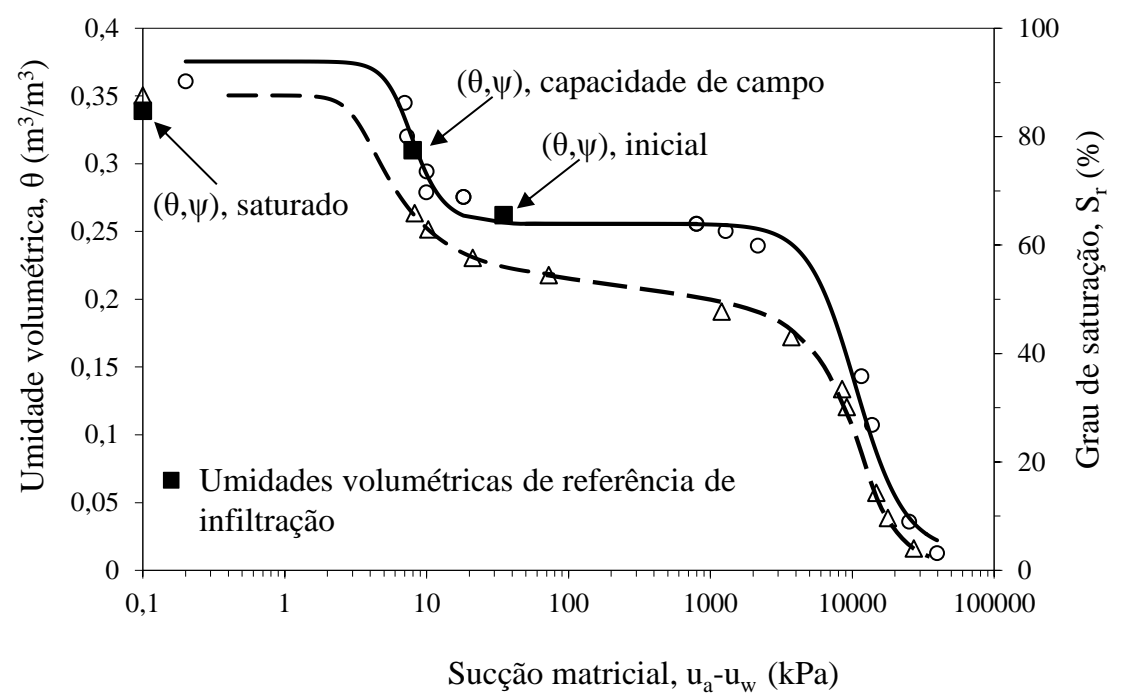

Figura 6.3. Valores de umidade volumétrica representantes da capacidade de armazenamento do solo.

Os perfis de infiltração determinados para os períodos de ensaio de 40, 50 e 60 dias, são resumidos nas Figuras 6.4, 6.5 e 6.6, respectivamente. Foram plotados os pontos experimentais e as linhas teóricas ajustadas que melhor representam a infiltração no protótipo de um muro reforçado com materiais permeáveis. Os perfis de infiltração para tempos intermediários aos apresentados estão ilustrados nas Figuras B1 a B6 do apêndice B. De modo geral observa-se nestes resultados que, antes da frente de infiltração alcançar uma determinada profundidade, o solo permanece no teor de umidade inicial. Quando a frente de umedecimento avança para esta profundidade, o teor de umidade aumenta para o valor de capacidade de campo. O solo apresentase no teor de umidade de saturação somente nas proximidades dos geotêxteis, o que é decorrente de um acúmulo de água acima do geotêxtil devido à formação de uma barreira capilar e posterior drenagem preferencial ao longo do comprimento do geotêxtil. O esclarecimento deste fenômeno será abordado no próximo capítulo.

A constatação de que a infiltração ocorre preferencialmente em regiões próximas da face fica mais evidente visualizando-se estes perfis de infiltração (Figura 6.4, 6.5 e 6.6). Observa-se que após 60 dias de ensaio (Figura 6.6) a linha de infiltração alcançou o pé do protótipo, sem que a saturação do solo tenha ocorrido. Também, nota-se os pontos experimentais se ajustaram com coerência à linha teórica de infiltração. Mesmo considerando que a quantidade de pontos de leituras de umidade é relativamente pequena para definir precisamente um perfil de infiltração, ficam definidos perfis aproximados para auxiliar as futuras análises deste trabalho. Análises serão conduzidas posteriormente para definir o efeito da linha de infiltração nos deslocamentos e deformações da estrutura. A confirmação das características hidráulicas da linha teórica de infiltração na interface solo-geotêxtil não tecidos será realizada no capítulo seguinte. 
a)

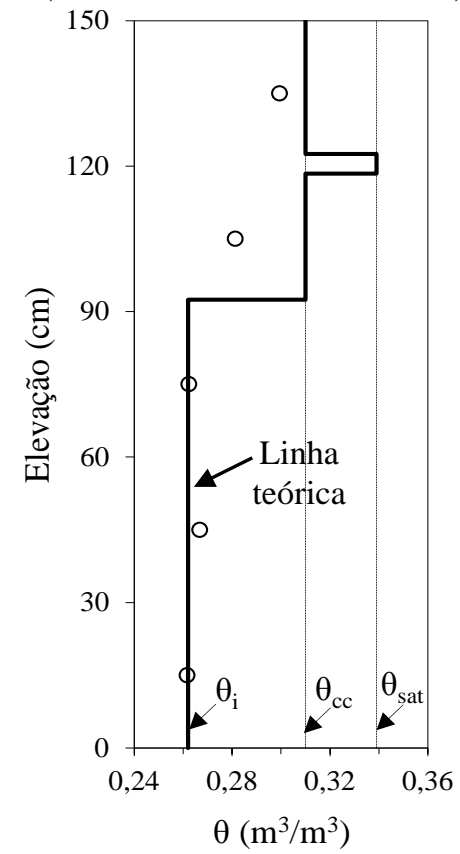

b)

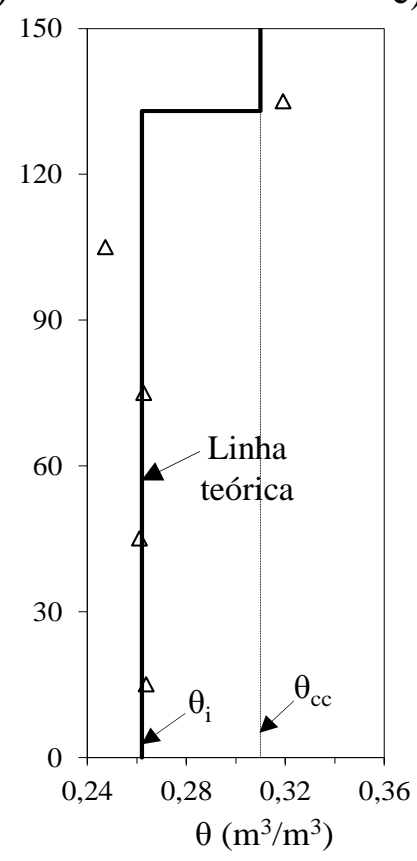

c)

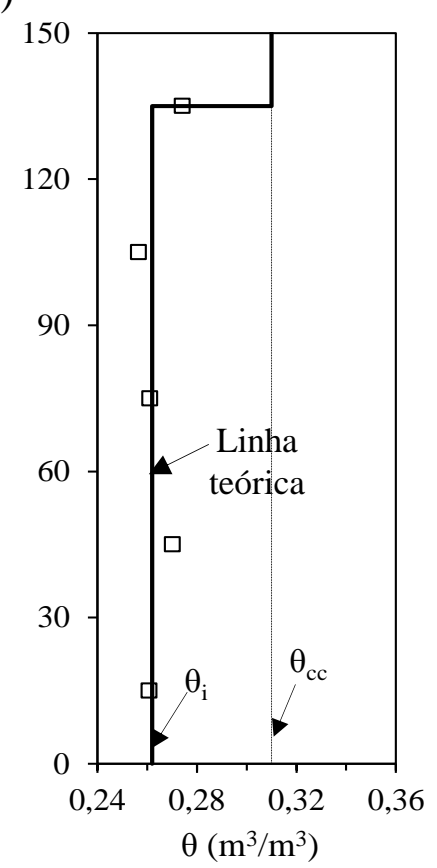

Figura 6.4. Perfis de infiltração após 40 dias de ensaio: (a) $10 \mathrm{~cm}$ da face; (b) $70 \mathrm{~cm}$ da face; (c) $130 \mathrm{~cm} \mathrm{da}$ face.

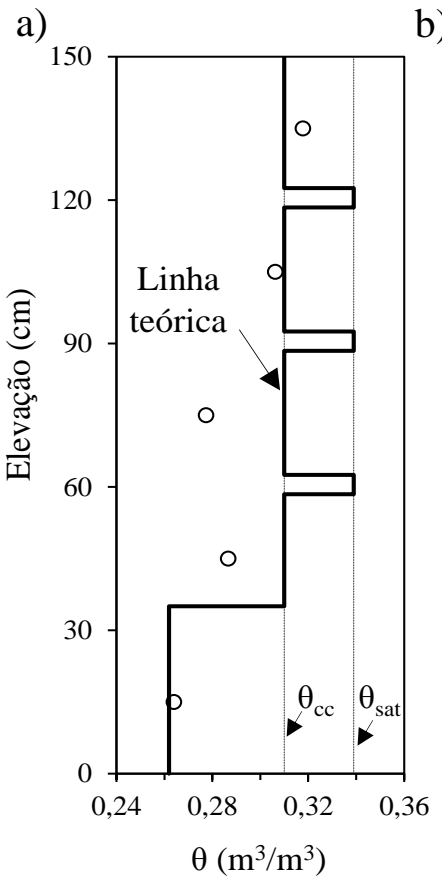

b)

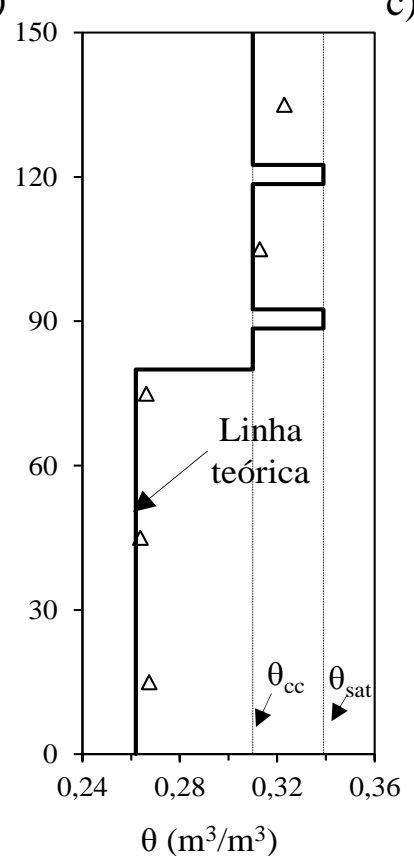

c)

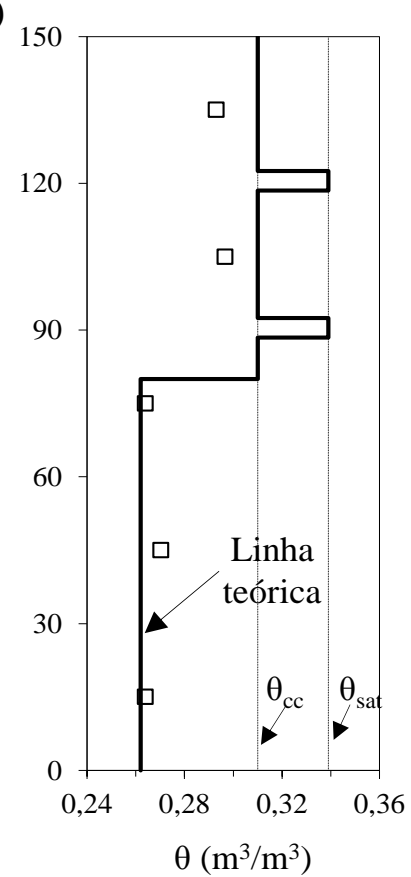

Figura 6.5. Perfis de infiltração após 50 dias de ensaio: (a) $10 \mathrm{~cm}$ da face; (b) $70 \mathrm{~cm}$ da face; (c) $130 \mathrm{~cm}$ da face.

Os perfis de infiltração foram também plotados em termos da sucção matricial e são apresentados nas Figuras 6.7, 6.8 e 6.9. Dessa forma, os perfis, em função da sucção, foram ajustados aos valores experimentais obtidos pelos tensiômetros, bem como aos valores obtidos na curva de retenção de água do solo. A definição dos perfis em termos de sucção terá devida 
importância em tópicos posteriores, nos quais análises de equilíbrio limite serão realizadas considerando o perfil de infiltração em termos de sucção para cada período analisado.

a)

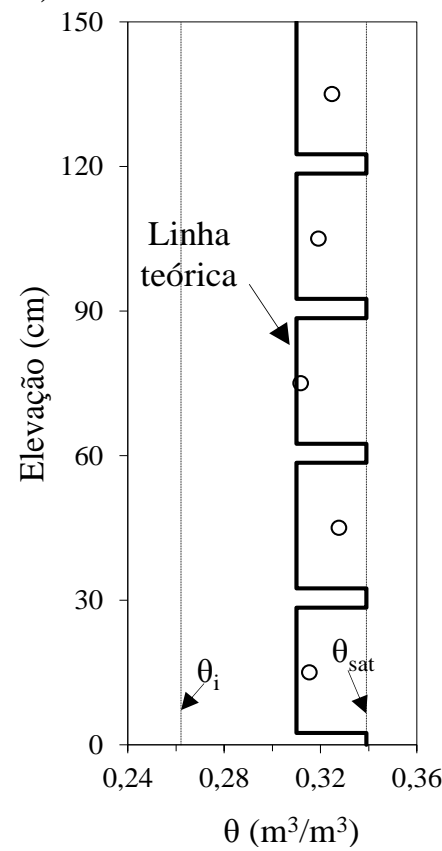

b)

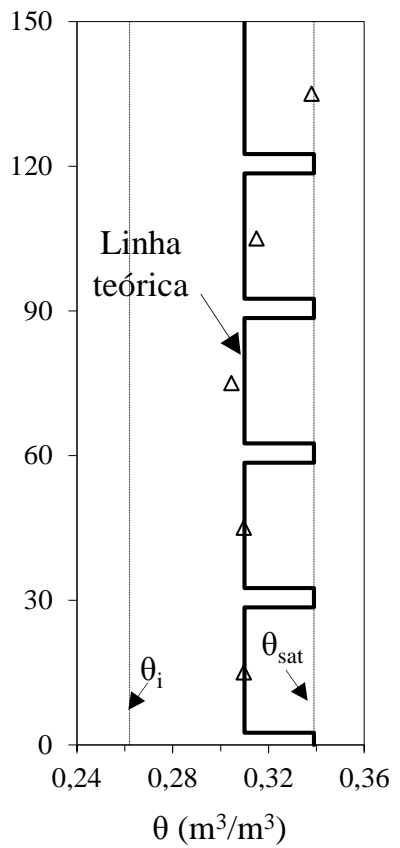

c)

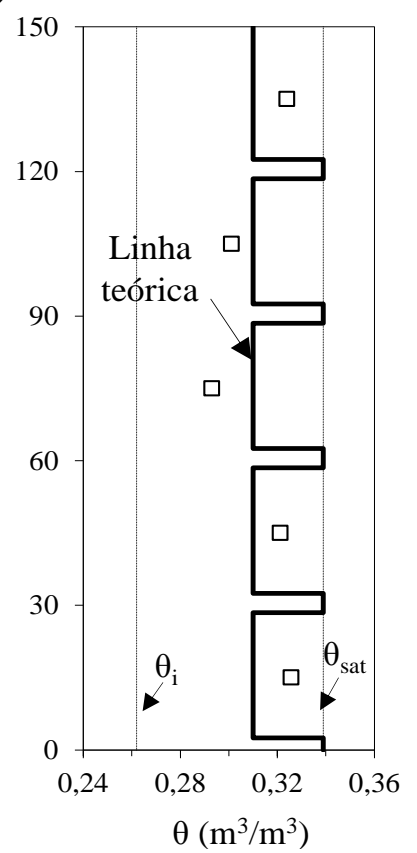

Figura 6.6. Perfis de infiltração após 60 dias de ensaio: (a) $10 \mathrm{~cm}$ da face; (b) $70 \mathrm{~cm}$ da face; (c) $130 \mathrm{~cm}$ da face.

a)

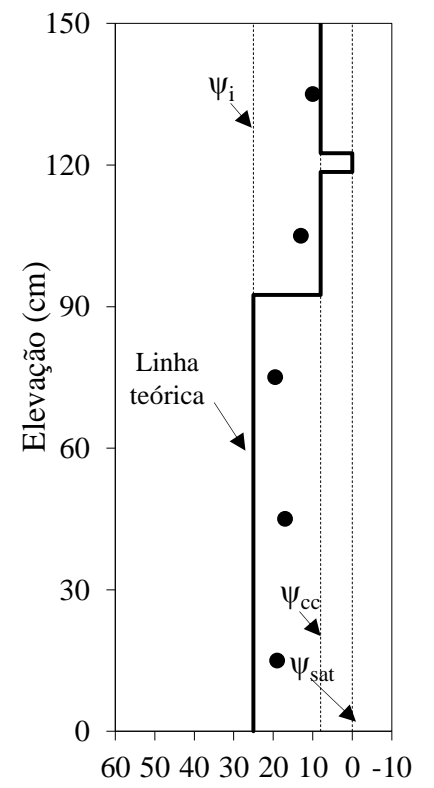

$605040302010 \quad 0 \quad-10$

Sucção $(\mathrm{kPa})$ b)

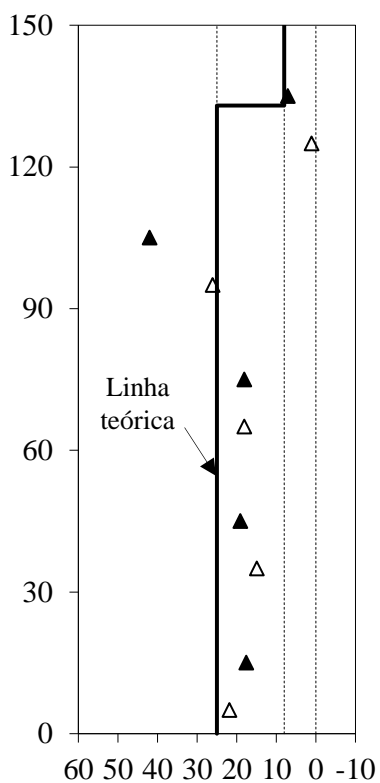

$605040302010 \quad 0 \quad-10$

Suç̧ão $(\mathrm{kPa})$ c)

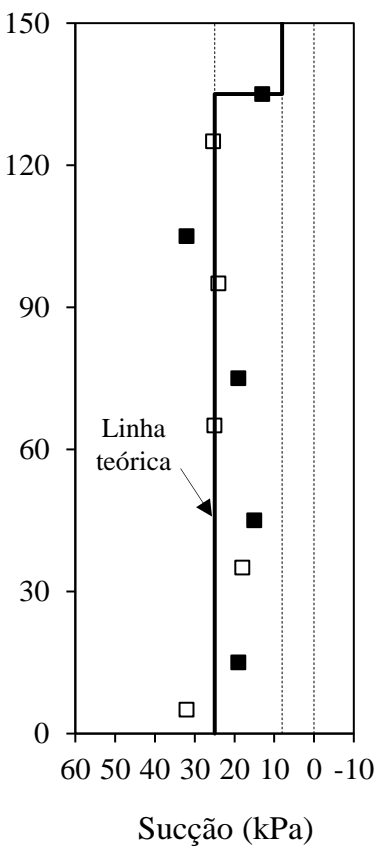

Figura 6.7. Perfis de infiltração em termos de sucção matricial após 40 dias de ensaio: (a) $10 \mathrm{~cm}$ da face, (b) $70 \mathrm{~cm}$ da face e (c) $130 \mathrm{~cm}$ da face. 
a)

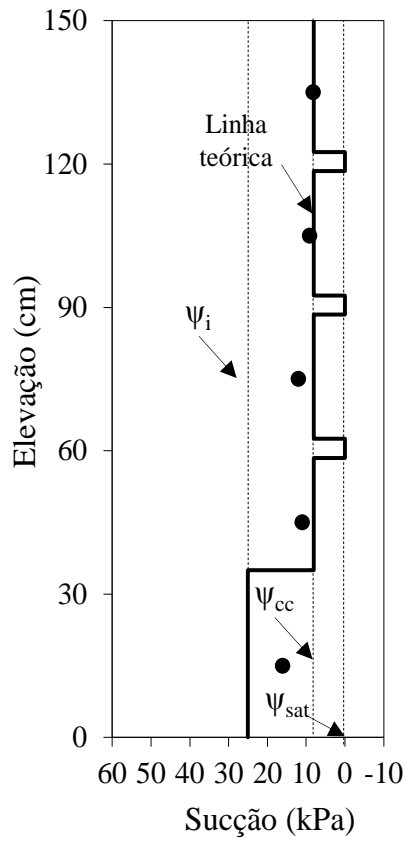

b)

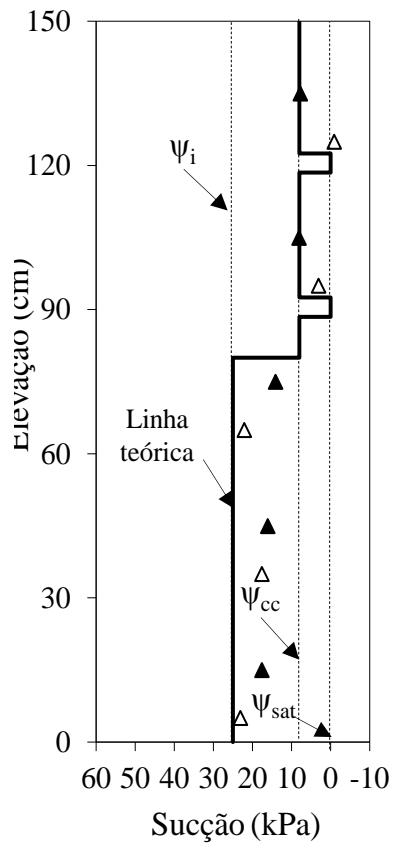

c)

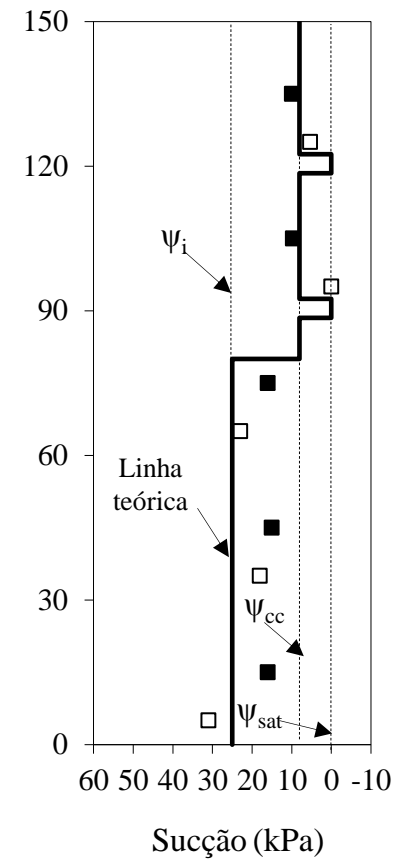

Figura 6.8. Perfis de infiltração em termos de sucção matricial após 50 dias de ensaio: (a) $10 \mathrm{~cm}$ da face, (b) $70 \mathrm{~cm}$ da face e (c) $130 \mathrm{~cm}$ da face.

a)

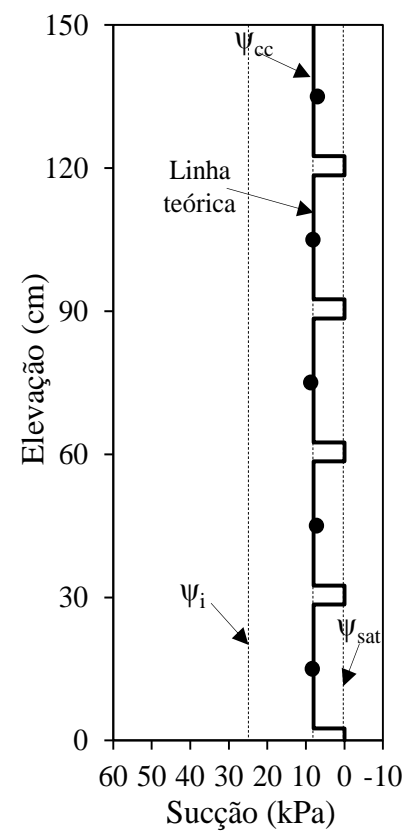

b)

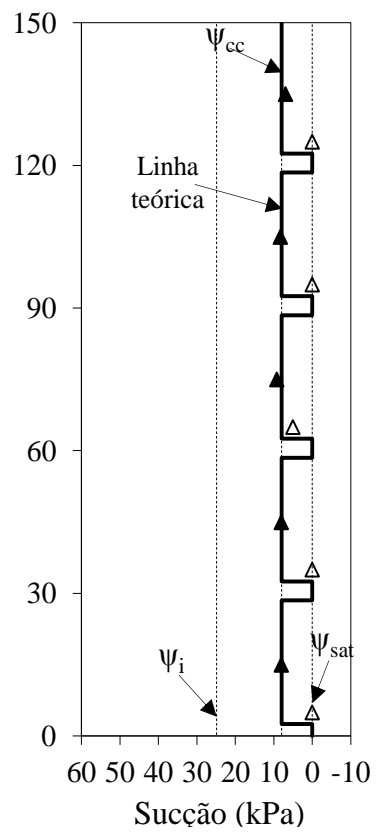

c)

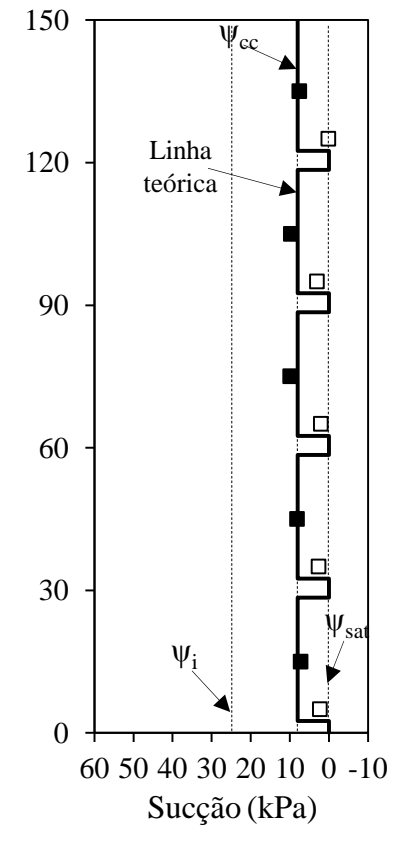

LEGENDA

- \ Pontos da curva de retenção do solo

$\triangle \square$ Tensiômetro

Figura 6.9. Perfil de infiltração em termos de sucção matricial após 60 dias de ensaio: (a) $10 \mathrm{~cm}$ da face, (b) $80 \mathrm{~cm}$ da face e (c) $130 \mathrm{~cm}$ da face. 
Com base nos perfis de infiltração nas três regiões instrumentadas, definiu-se, portanto, o avanço da frente de umedecimento durante o ensaio, conforme ilustrado na Figura 6.10. A velocidade da infiltração experimental é comparada no gráfico à infiltração teórica correspondente ao coeficiente de permeabilidade de solo saturado.

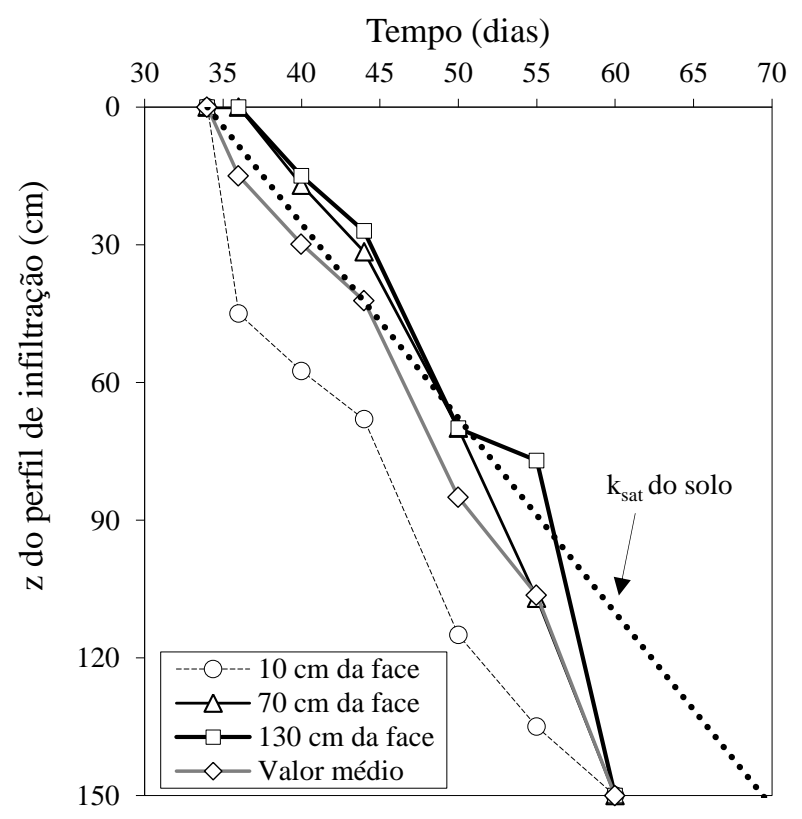

Figura 6.10. Avanço da frente de umedecimento para regiões a $10 \mathrm{~cm}, 70 \mathrm{~cm}$, e $130 \mathrm{~cm}$ da face.

Contata-se que a velocidade de infiltração nas regiões próximas da face foi maior que a velocidade considerando o meio saturado. Já paras as regiões a $70 \mathrm{~cm}$ da face e a $130 \mathrm{~cm}$ da face, as velocidades foram menores em determinadas profundidades. Isso pode ser decorrente da permeabilidade não saturada do solo, geralmente menor que a permeabilidade saturada. Cabe observar que a linha correspondente à média dos três perfis de infiltração definidos (face, meio e fundo) foi relativamente aproximada à linha correspondente à permeabilidade do solo saturado, mostrando coerência no avanço identificado experimentalmente. Em regiões próximas da face, a velocidade de infiltração foi maior devido o fluxo preferencial de água imposto pela inclinação da superfície do topo do protótipo.

\subsection{Comportamento do protótipo}

O protótipo foi instrumentado e o comportamento monitorado ao longo do período de ensaios concomitantemente ao monitoramento da infiltração de água na estrutura. Tal monitoramento contemplou medidas das tensões verticais totais, deslocamentos horizontais internos e de face e deformações nos reforços. 


\subsubsection{Tensões verticais totais}

As tensões impostas no protótipo M2 consistem em tensões devido ao peso próprio do solo compactado e de uma sobrecarga constante de $100 \mathrm{kPa}$. De modo a verificar os reais níveis de tensões atuantes em cada camada reforçada, células medidoras de tensões totais foram instaladas na região central e ao longo da altura do protótipo (Figura 4.28). As previsões teóricas das tensões atuantes durante o ensaio, bem como as tensões medidas pela instrumentação são mostradas na Figura 6.11. Com relação às tensões medidas pelas células de tensões medidas, notase a similaridade de tendência com as tensões previstas, porém com tensões medidas menores que as tensões previstas, fato também observado no protótipo M1. Neste trabalho, não serão discutidas as tensões desenvolvidas durante o processo de compactação, pelo fato do equipamento utilizado na compactação do protótipo não competir com a realidade construtiva no campo. No entanto, qualquer esforço adicional devido ao processo de compactação está embutido nos valores apresentados durante o ensaio.
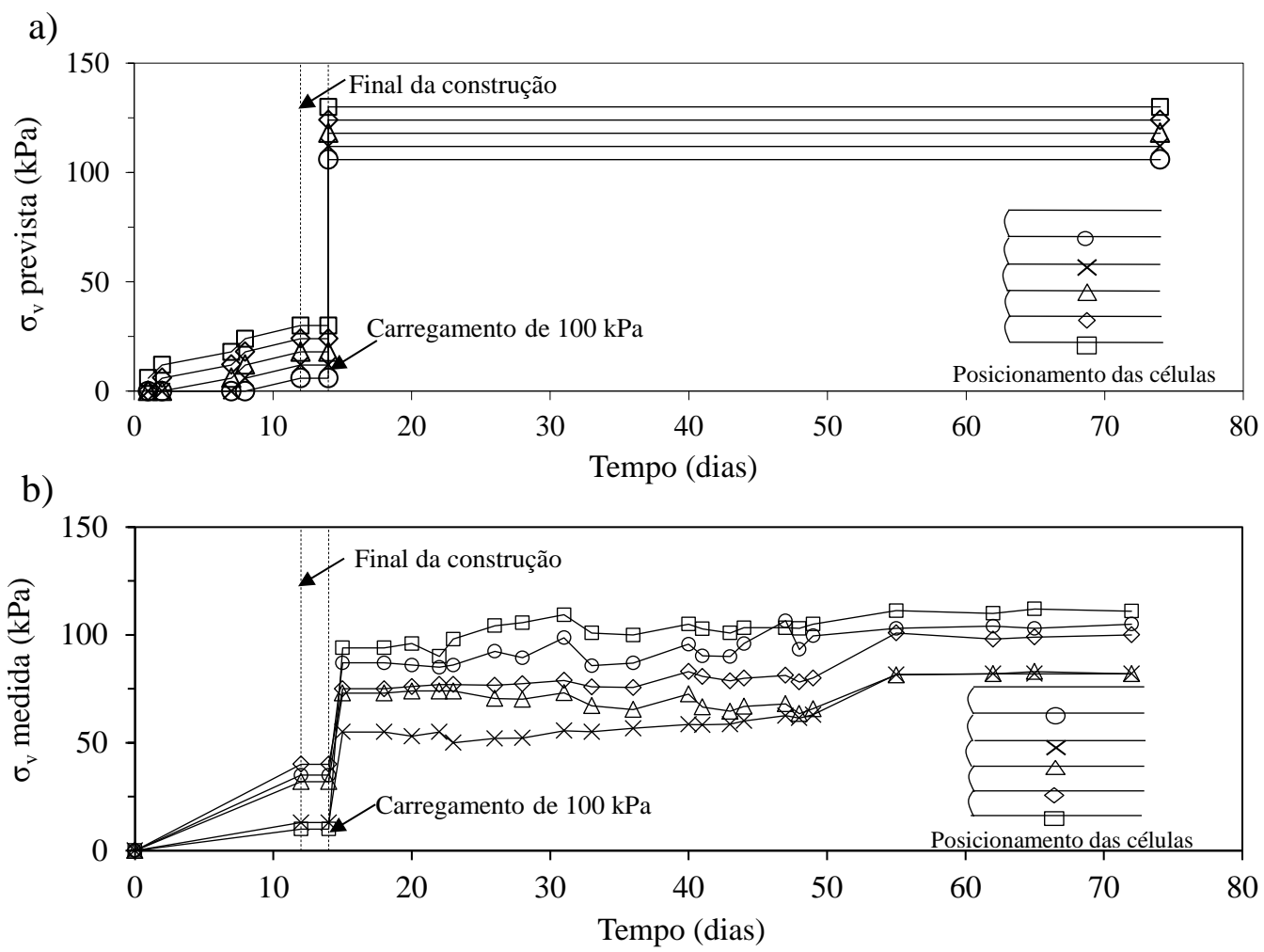

Figura 6.11. Tensões atuantes na estrutura reforçada M2: (a) tensões previstas; (b) tensões medidas.

Optou-se nessa pesquisa, por conduzir as análises do comportamento da estrutura sob as condições de serviço, ou seja, considerando o comportamento de tensões e deformações dos reforços ocorridas somente após a construção. Por esse motivo, as tensões atuantes durante o serviço da estrutura são plotadas na Figura 6.12. 


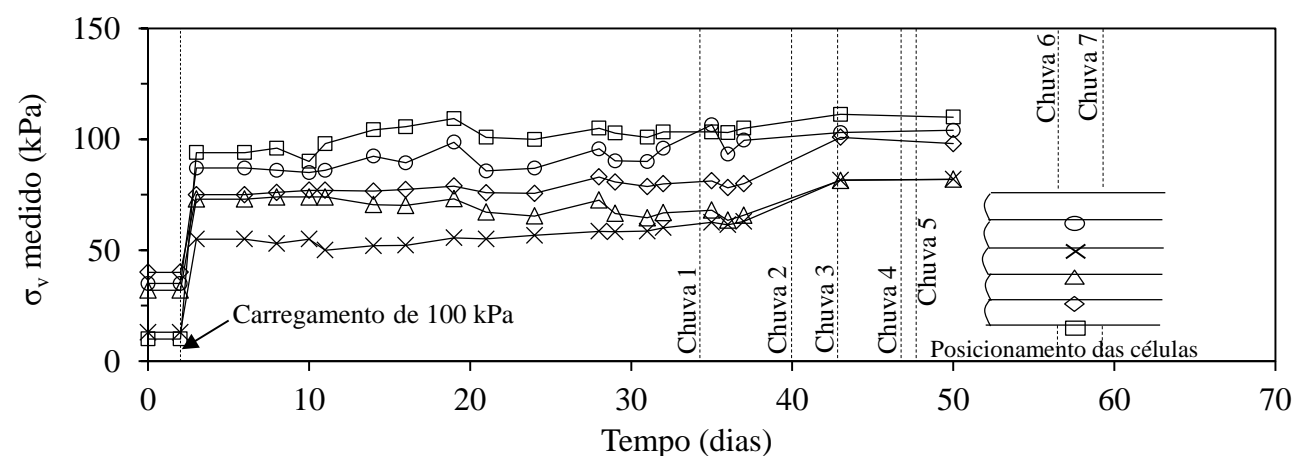

Figura 6.12. Tensões atuantes nas condições de serviço do protótipo M2.

Após a aplicação do carregamento $\left(2^{\circ}\right.$ dia $)$ as tensões se mantiveram praticamente constantes até o $35^{\circ}$ dia. Após este período, as tensões aumentaram de modo geral, porém expressivamente nas camadas 2, 3 e 4. Dentre as possíveis atribuições para tal comportamento está no armazenamento de água nos vazios de solo durante infiltração, promovendo um aumento nas tensões verticais totais (Figura 6.12). Cabe observar que estes aumentos não foram verificados no protótipo M1, no qual a umidade inicial de compactação foi mantida durante o ensaio.

A distribuição das tensões ao longo da altura do protótipo pode ser observada na Figura 6.13. Constata-se que, antes da aplicação do carregamento, a distribuição das tensões é coerente com a distribuição teórica $\left(\sigma_{\mathrm{v}}=\gamma \mathrm{H}\right)$, no qual o aumento das tensões com a profundidade é observado seguindo uma tendência linear de aumento assim como é verificado quando somente tensões geostáticas atuam no sistema. Pode-se dizer, portanto, que as medidas efetuadas apresentam-se coerentes.

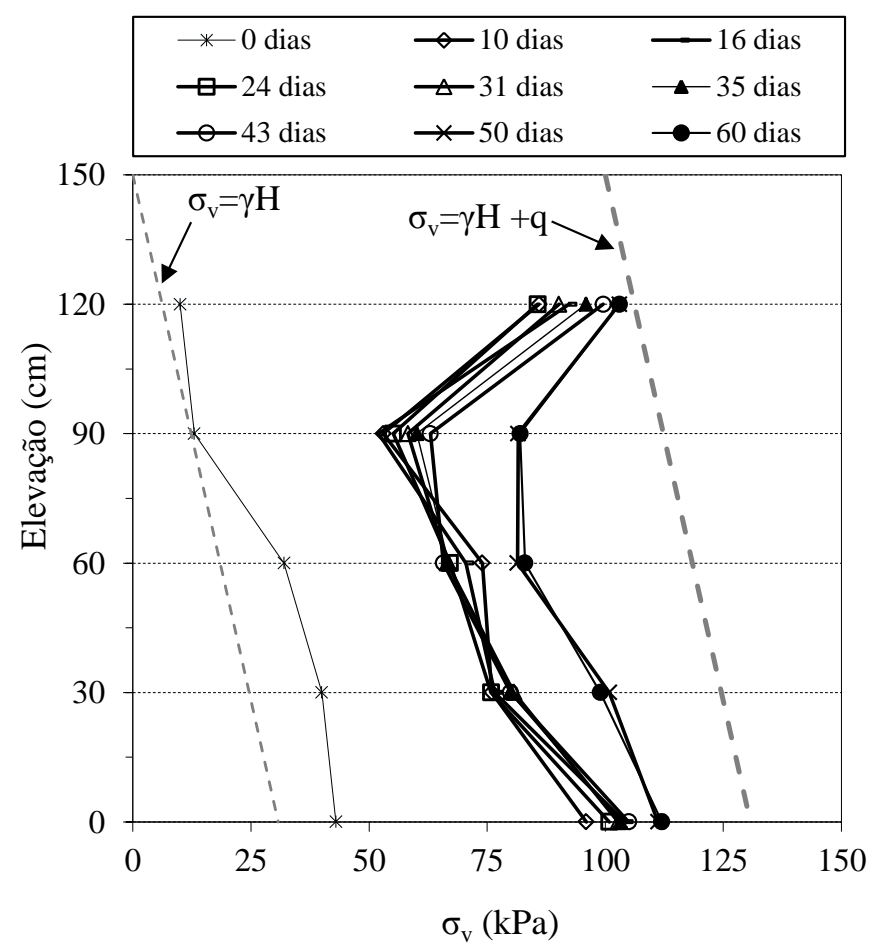

Figura 6.13. Distribuição das tensões totais ao longo da altura do protótipo M2 para diferentes tempos ao longo do ensaio. 


\subsubsection{Deslocamentos horizontais}

Os deslocamentos horizontais internos $\left(\delta_{\mathrm{i}}\right)$ monitorados em pontos de tell-tales fixados na face, a $30 \mathrm{~cm}, 60 \mathrm{~cm}, 90 \mathrm{~cm}$ e a $120 \mathrm{~cm}$ da face, em cada camada reforçada do protótipo M2, são apresentados na Figura 6.14. Como verificado no protótipo M1, em todos os reforços instrumentados, os deslocamentos diminuem na medida em que os pontos se afastam da face. Ainda, os deslocamentos apresentaram aumento com o tempo sob as condições de carregamento constante e precipitações impostas. Tal comportamento seria comumente associado ao comportamento de fluência do reforço; no entanto, o processo de avanço de umedecimento promove alterações na rigidez do solo e, consequentemente, nas tensões transmitidas aos reforços.
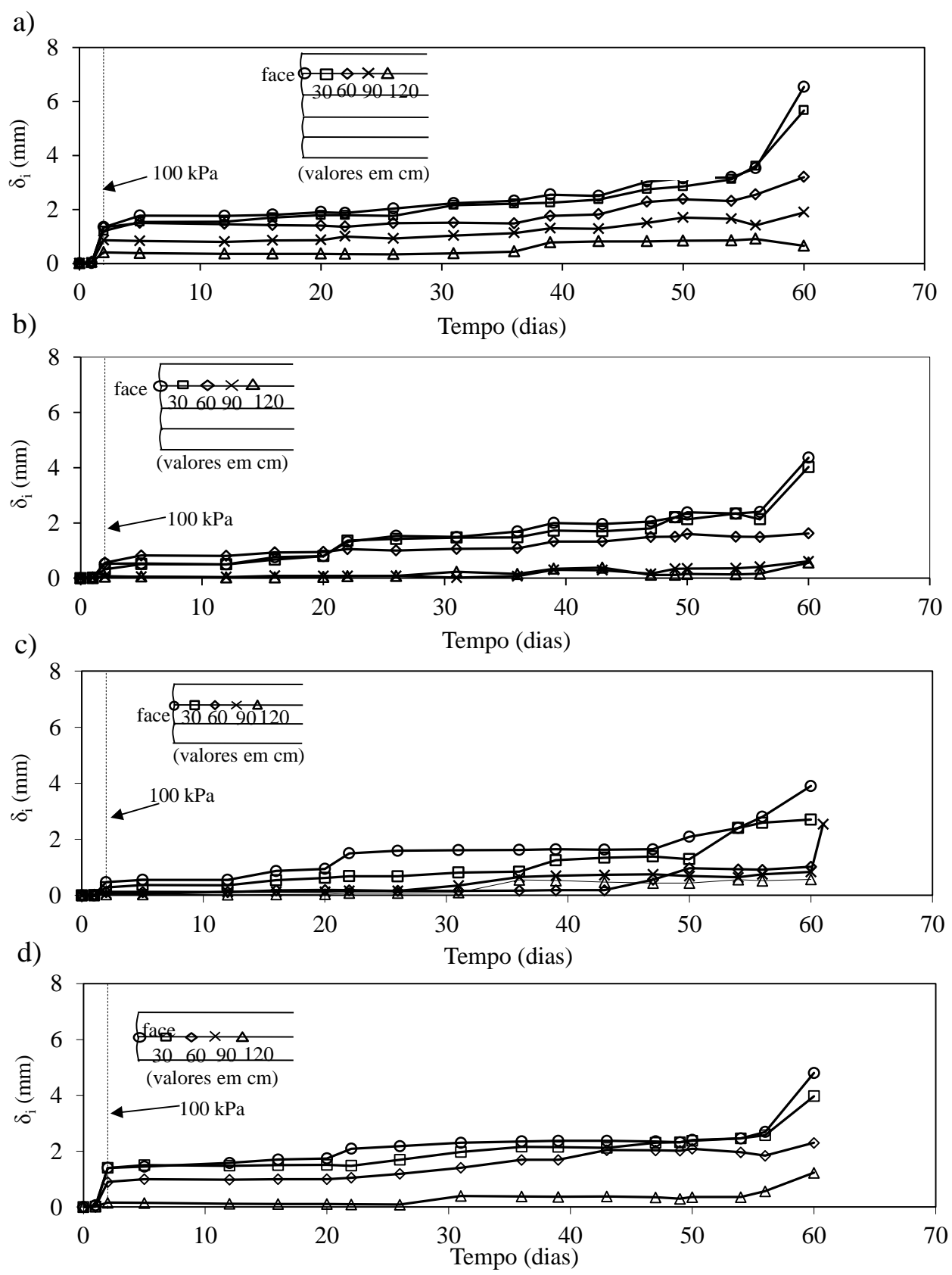

Figura 6.14. Deslocamentos horizontais internos do protótipo M2: (a) camada 5; (b) camada 4; (c) camada $3 ;$ (d) camada 2. 
A Figura 6.15 apresenta a evolução do deslocamento máximo $\left(\delta_{\mathrm{i}, \mathrm{máx}}\right)$ de cada camada reforçada, juntamente plotado com os valores de sucção obtidos durante o ensaio. Com isso, a visualização do efeito do avanço de umedecimento no deslocamento interno máximo pode ser facilitada. Observa-se que existe uma relação entre a redução dos valores de sucção matricial e o aumento dos deslocamentos internos máximos. Verifica-se que o umedecimento das camadas superiores pode vir a ocasionar aumento dos deslocamentos de camadas inferiores, fato este que pode ser atribuído à redução da rigidez do solo de parte da massa ao longo da superfície potencial de ruptura. Embora essas alterações sejam bastante pequenas, são evidências para este comportamento.

De modo geral, os reforços de todas as camadas sofreram aumentos significativos nos deslocamentos após 55 dias de teste. De fato, nesse período, a massa de solo foi completamente umedecida, com valores de sucção próximos de zero e valores máximos de grau de saturação de 90\%. Assim, a rigidez do solo diminuiu como um todo, promovendo tais alterações significativas. Mesmo tratando-se de níveis de deslocamentos relativamente pequenos $(0,5 \mathrm{~mm}$ a $5,5 \mathrm{~mm})$, as alterações proporcionadas pelo avanço do umedecimento são expressivas com relação aos deslocamentos iniciais (sem a presença da água). Em comparação com os deslocamentos internos observados no final do ensaio do protótipo M1, no qual o teor de umidade foi mantido constante, a diferença foi bastante expressiva. 

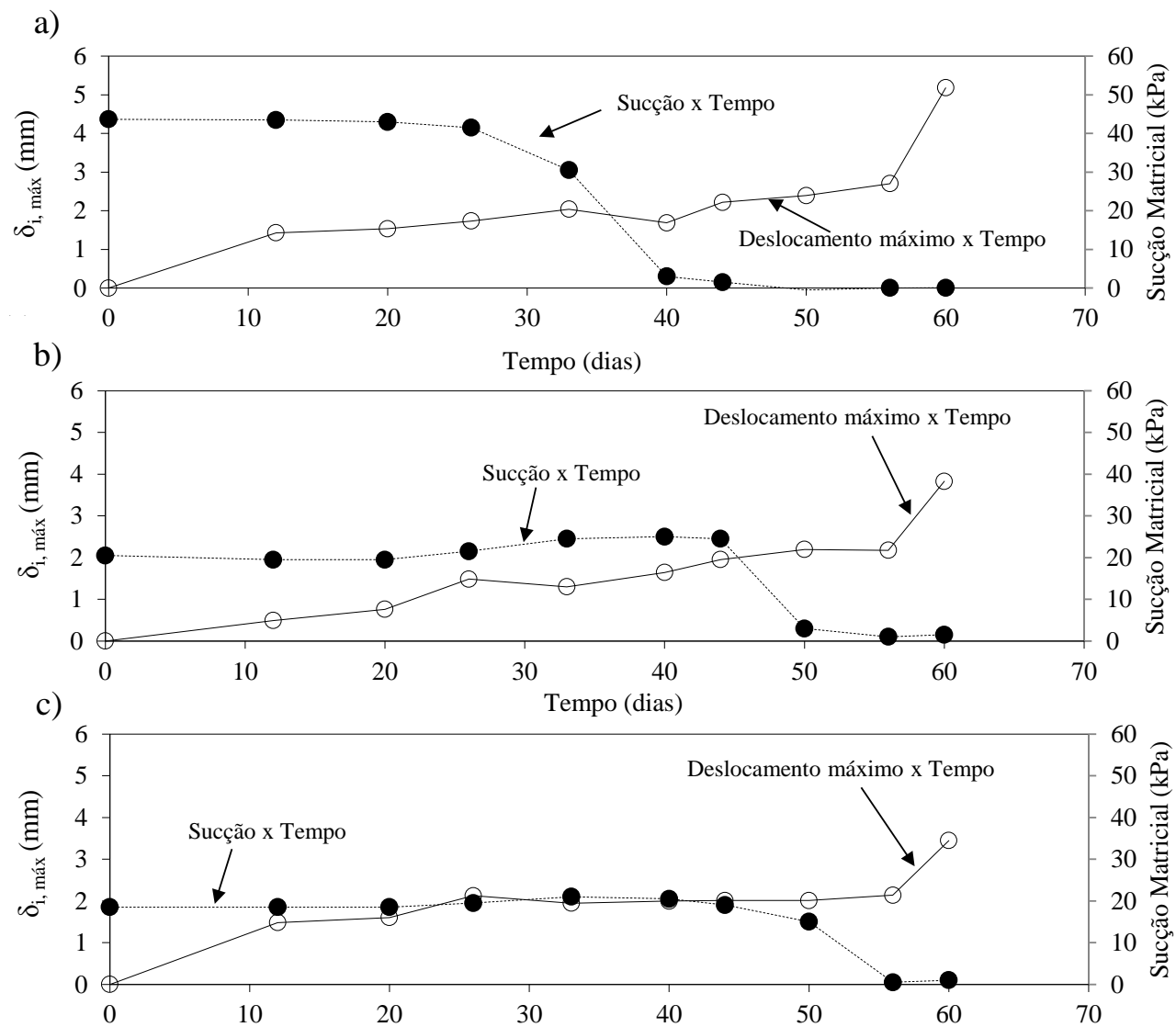

d)

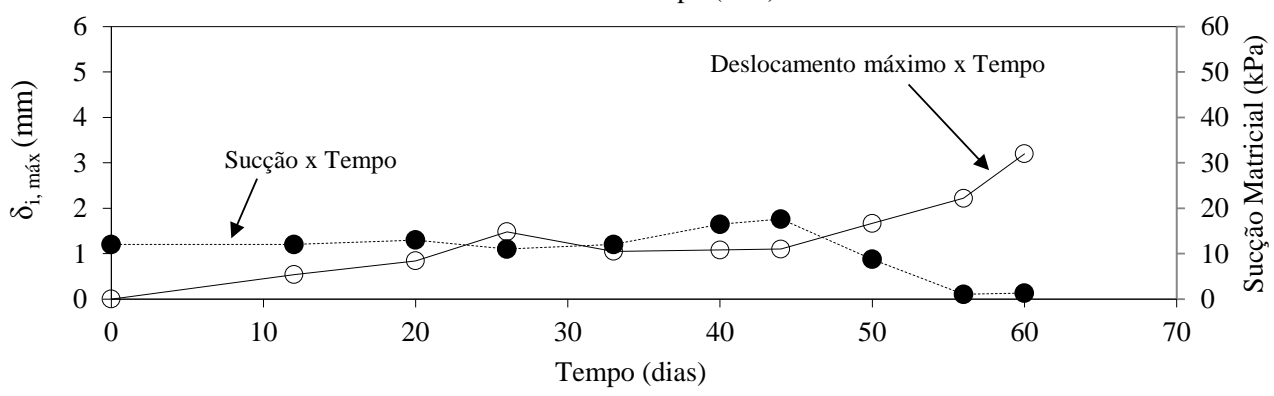

Figura 6.15. Evolução do deslocamento interno máximo e sucção matricial do protótipo M2: (a) camada 5; (b) camada 4; (c) camada 3; (d) camada 2.

Avaliação semelhante à mostrada na Figura 6.15 foi efetuada para os deslocamentos de face obtidos durante o ensaio, conforme apresenta a Figura 6.16. Do mesmo modo, os deslocamentos de face mostraram-se dependentes da sucção matricial do solo. A redução na sucção matricial promoveu aumento nos deslocamentos de face em cada camada, sendo estes já levemente influenciados pelo umedecimento das camadas superficiais. Com o umedecimento completo do solo do protótipo, os aumentos foram mais expressivos, chegando ao valor máximo de $14 \mathrm{~mm}$ (após 60 dias). 

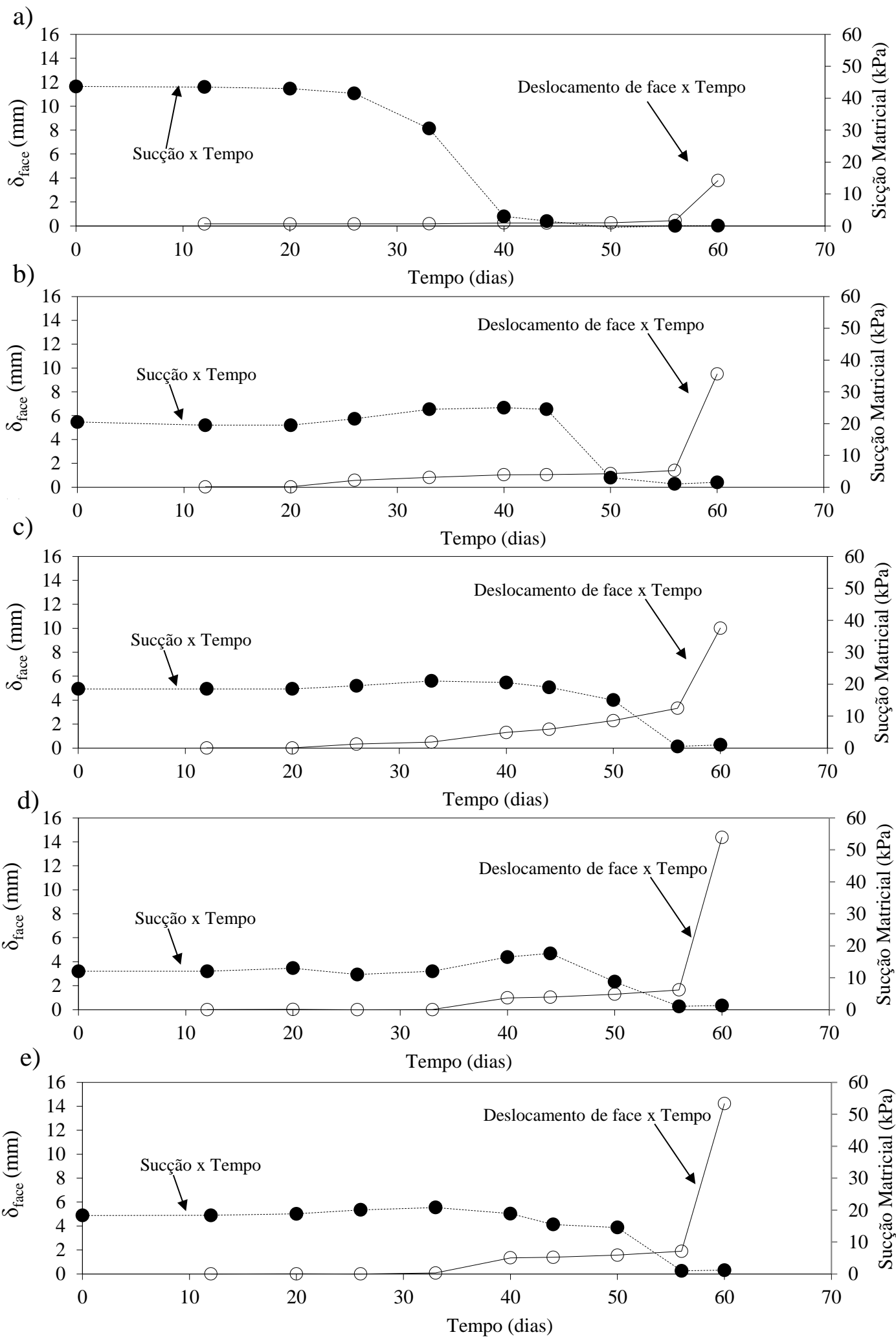

Figura 6.16. Evolução dos deslocamentos de face e sucção matricial do protótipo M2: (a) camada 5; (b) camada 4; (c) camada 3; (d) camada 2; (e) camada 1.

A Figura 6.17 apresenta as distribuições dos deslocamentos de face ao longo da altura do protótipo M2, bem como a influência do avanço do umedecimento nas alterações destas. $\mathrm{Na}$ 
Figura 6.17a, assim como verificado no protótipo $\mathrm{M} 1$, os deslocamentos de face não foram significativos em períodos em que chuvas não foram aplicadas (até 34 dias). No final de ensaio, notam-se os maiores valores de deslocamentos ocorrendo também no primeiro terço da altura da estrutura.

a)

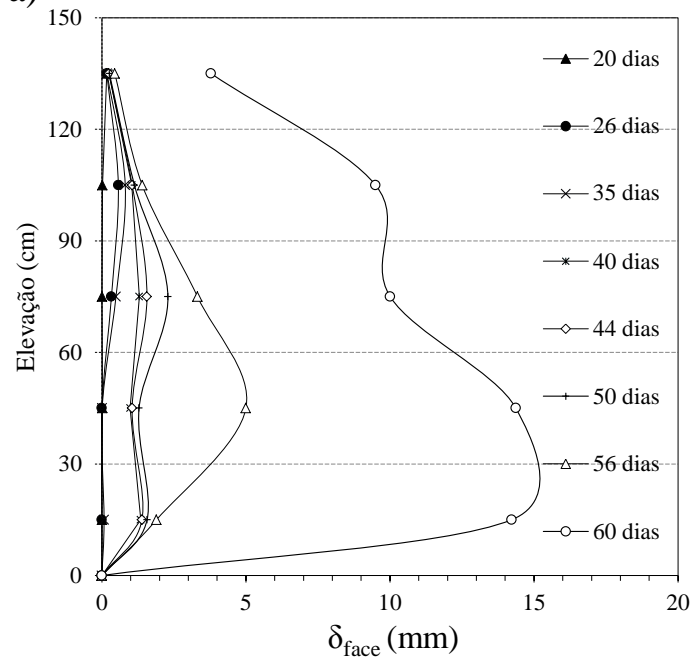

b)

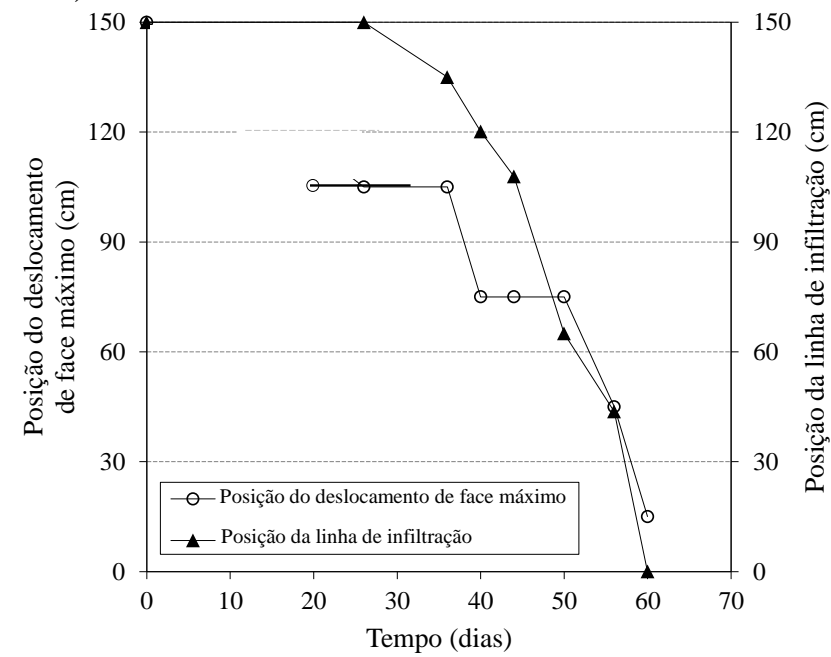

Figura 6.17. Distribuições dos deslocamentos de face: (a) ao longo da altura do protótipo M2; (b) influência do avanço do umedecimento.

Curiosamente, neste protótipo, a localização dos deslocamentos máximos ao longo da altura do protótipo alterou-se no decorrer do ensaio. Tal fenômeno é representado na Figura 6.17b, na qual a posição de ocorrência do deslocamento máximo é plotada nos diferentes dias de leitura. No mesmo gráfico, foi plotado também a posição da frente de infiltração durante o ensaio, de modo a associar o processo de avanço de umedecimento às alterações na localização do deslocamento máximo de face. Com base nestes resultados, observa-se que o deslocamento de face máximo inicial ocorreu na altura de $105 \mathrm{~cm}$, antes da simulação dos eventos de chuva. Após o $34^{\circ}$ dia, período em que se iniciaram os eventos de chuva, a localização do deslocamento de face se mantém constante até que a frente de avanço ultrapassa a posição inicial do deslocamento (até 35 dias). Após este período, a posição dos deslocamentos máximos passa a se alterar com a posição da linha de infiltração. Esta constatação mostra evidências de que a linha de avanço de infiltração pode influenciar diretamente na posição dos deslocamentos de face máximos. Observase que, nos $50^{\circ}$ dia, $56^{\circ}$ dia e $60^{\circ}$ dia, os deslocamentos de face máximos localizam-se na mesma profundidade de alcance da frente de umedecimento. Esse comportamento pôde ser observado pelo fato do deslocamento máximo ter ocorrido inicialmente em camadas superficiais. Ainda, neste caso houve caminho preferencial da água pela face, o que pode ter resultado neste comportamento.

Com relação à magnitude dos deslocamentos de face, o valor máximo de $14 \mathrm{~mm}$ é considerado pequeno para as condições de umedecimento impostas no final do ensaio. Considerando a relação $\delta_{\mathrm{h} \text {, face }} / \mathrm{H}$ (deslocamento horizontal de face máximo normalizado) de 0,009 
observada experimentalmente, uma estrutura de 10 metros teria deslocamento de face de $9 \mathrm{~cm}$. Em comparação ao caso relatado por Burwash e Frost (1991), em que o desempenho de um muro de geogrelha de 9 metros de altura foi prejudicado pelo valor máximo de deslocamento de face de $32 \mathrm{~cm}$, o deslocamento normalizado obtido neste ensaio pode ser considerado pequeno para as condições de umedecimento impostas.

\subsubsection{Deformações nos reforços}

As distribuições dos deslocamentos ao longo do comprimento dos reforços e o ajuste sigmoidal para o cálculo das deformações são apresentados na Figura 6.18. Os resultados das derivações das curvas sigmoidais para a determinação das distribuições das deformações nos reforços são mostrados na Figura 6.19.

As deformações calculadas resultaram em valores mínimos de $0,1 \%$ e máximos de $1,46 \%$, sendo que os maiores níveis de deformações foram observados nas camadas 2 e 5 . Nota-se que as distribuições das deformações ao longo do comprimento dos reforços sofreram alterações durante o ensaio, deslocando os pontos de pico em direção ao faceamento (Figura 6.19). É importante salientar que, este fenômeno não foi constatado no protótipo M1. Dessa forma, supõe-se que tais alterações foram decorrentes do avanço preferencial da frente de umedecimento em regiões próximas da face, reduzindo assim então a sucção do solo nessa região.

Como as intensidades dos eventos de chuvas aplicados foram maiores que a permeabilidade do solo, e uma declividade de $2 \%$ em direção a face foi estabelecida, um grande volume de água escoou no topo e para fora do sistema. Associadamente, o grau de compactação em regiões próximas das fôrmas de envelopamento (face) é menor em relação ao restante do maciço, resultando no avanço preferencial. 

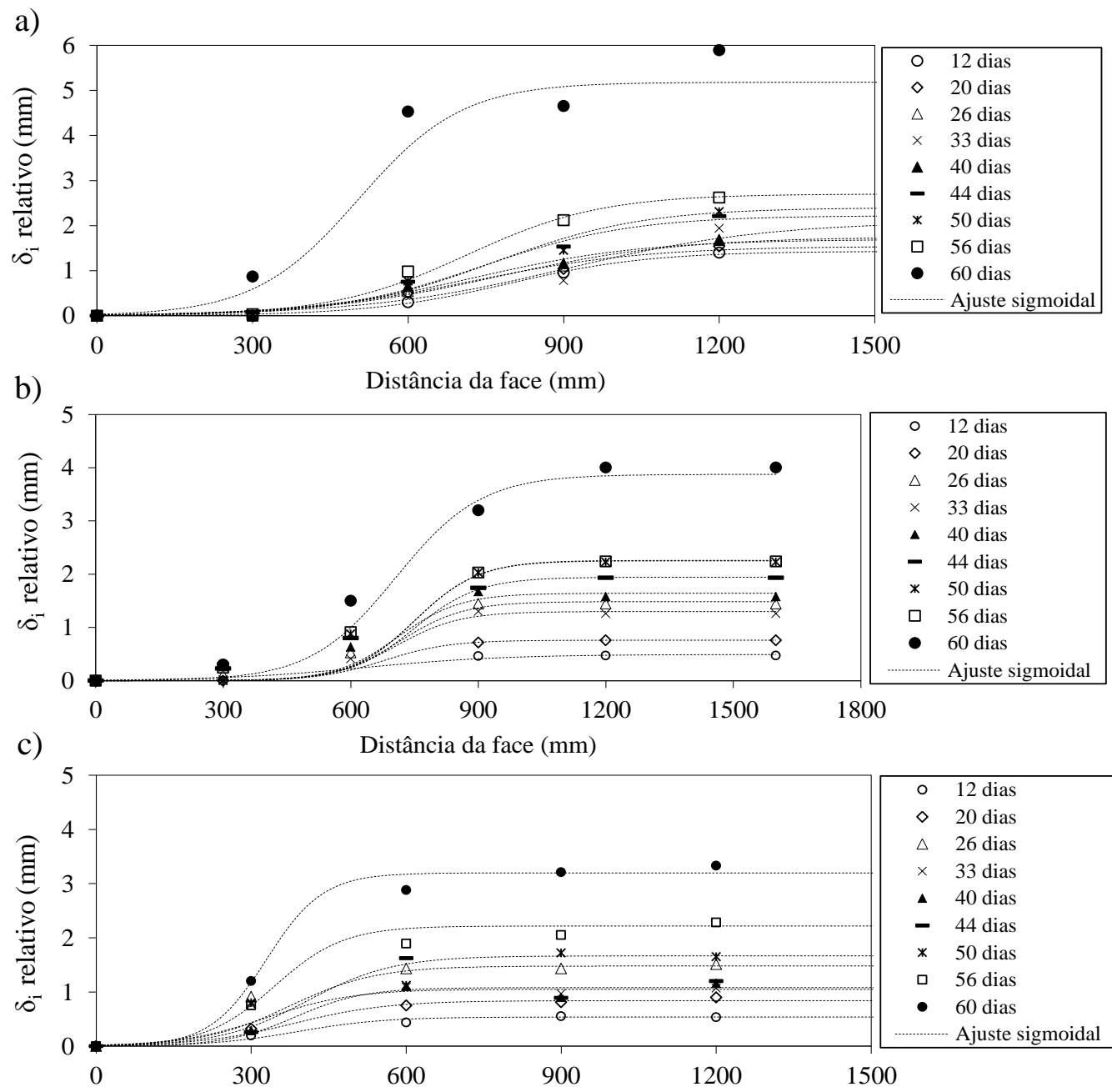

d) Distância da face (mm)

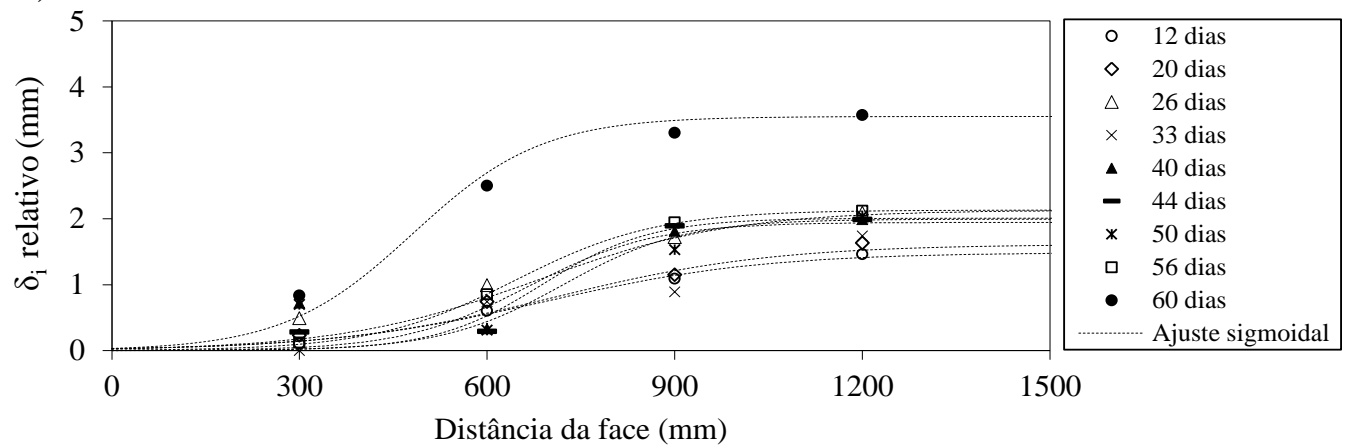

Figura 6.18. .Distribuição dos deslocamentos internos nos reforços geotêxteis do protótipo M2: (a) camada 5; (b) camada 4; (c) camada 3; (d) camada 2. 

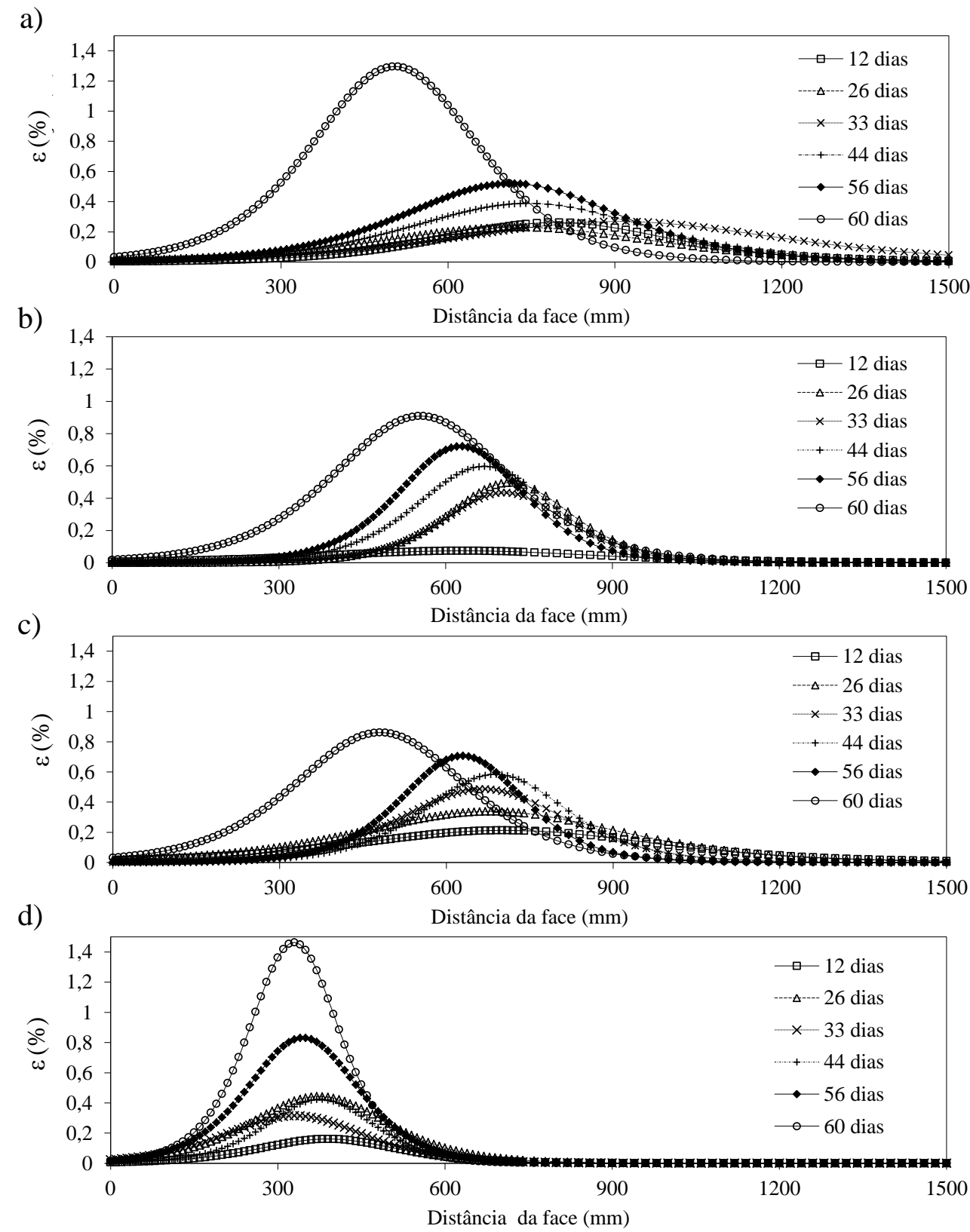

Figura 6.19. Distribuição das deformações nos reforços geotêxteis do protótipo M2: (a) camada 5; (b) camada 4; (c) camada 3; (d) camada 2.

Ainda na Figura 6.19, as deformações nos reforços aumentaram progressivamente durante o ensaio. Naturalmente, o avanço da frente de umedecimento promoveu a diminuição progressiva da sucção do solo, exigindo maior mobilização das tensões dos reforços, o que resultou em aumentos nas deformações. Na Figura 6.20 é plotada a evolução das deformações máximas e dos valores de sucção matricial de cada linha de reforço. Verifica-se nesta figura, que as deformações nos reforços aumentaram durante o ensaio, sendo que as maiores taxas de aumento foram registradas após o umedecimento de cada camada. Quando a frente de umedecimento alcançou a base do protótipo $\left(56^{\circ}\right.$ dia) os aumentos foram mais expressivos, principalmente na camada 2 . Acredita-se que este aumento é decorrente da redução da sucção de todas as camadas que compõe 
o protótipo. Observa-se também que, inicialmente, quando a frente de umedecimento alcançou as camadas superficiais, aumentos nas deformações puderam ser verificados nas camadas subjacentes, embora em taxas relativamente menores. Assim, este comportamento pode ser atribuído à redução da sucção de parte de maciço. Em muros de maior altura, esse fenômeno poderia ser mais expressivo. Esta é uma importante constatação, uma vez que tal fenômeno é levado em consideração em análises de estabilidade utilizando métodos de equilíbrio limite, mas dificilmente considerado em métodos tradicionais de tensões de serviço.
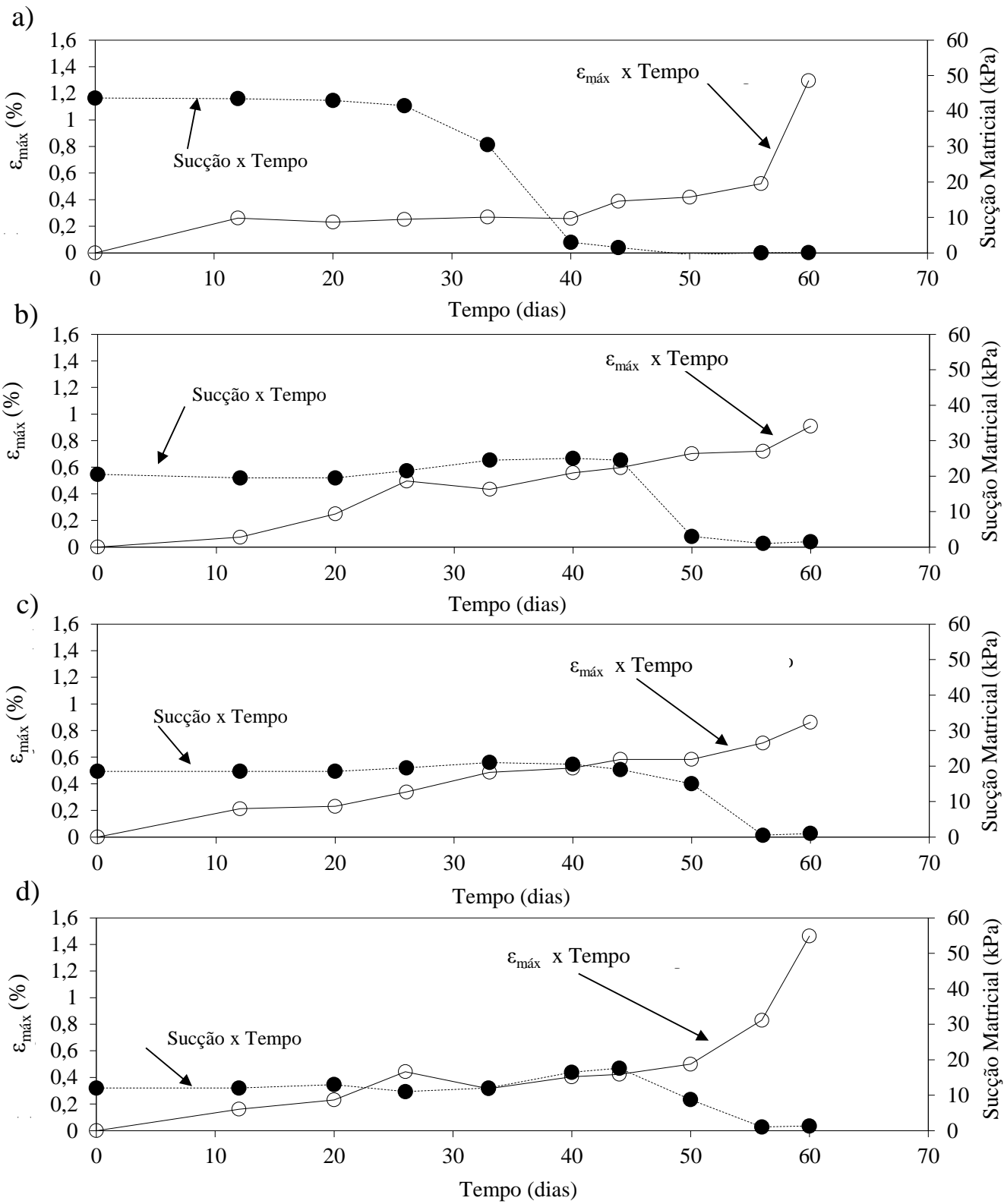

Figura 6.20. Deformações máximas e sucção matricial versus tempo do protótipo M2: (a) camada 5; (b) camada 4; (c) camada 3; (d) camada 2.

Pode-se dizer que, de modo geral, as deformações de pico medidas ao final do ensaio (após 60 dias) foram relativamente pequenas para as condições impostas (máxima de 1,46\%). Muitos trabalhos da literatura mostram que essas condições de saturação resultaram em problemas de 
deformação excessiva (BURWASH; FROST, 1991, KOERNER; SOONG, 2001) e, em alguns casos, a ruptura da estrutura (KOERNER; SOONG, 2001, SCARBOROUGH, 2005, YOO; JUNG, 2006). Curiosamente, estes relatos são de muros reforçados com geossintéticos impermeáveis.

Uma vez identificados os níveis e as posições dos picos de deformações em cada reforço, torna-se possível definir as superfícies reais de ruptura e a distribuição de deformações ao longo da altura do protótipo M2, como indica a Figura 6.21. Na tentativa de definir uma equação para a superfície de ruptura real, ajustes resultaram em equações potenciais (Figura 6.21a). Análises comparativas de superfícies teóricas com superfície reais serão abordadas em tópicos posteriores deste capítulo. Verifica-se que as superfícies de ruptura foram semelhantes no início do ensaio (entre 20 e 40 dias), com leves alterações após 50 dias, e mais expressivas no $60^{\circ}$ dia de ensaio. Este comportamento é resultante das alterações das posições dos picos de deformações durante o ensaio devido ao avanço preferencial da água em regiões próximas da face. Cabe notar que, estas alterações não foram evidenciadas no protótipo M1, corroborando com a constatação do efeito do avanço preferencial na região da face.
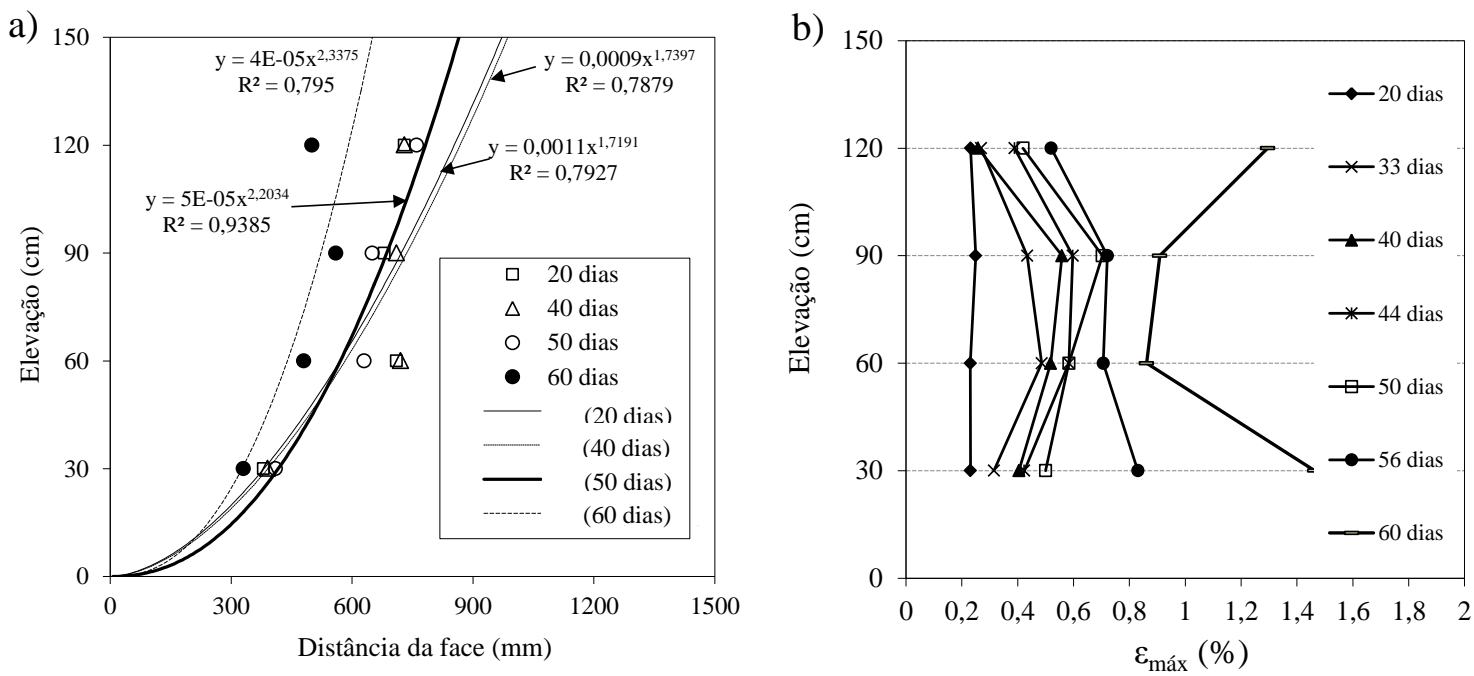

Figura 6.21. Deformações de pico ao longo do comprimento dos geotêxteis do protótipo M2: (a) definição de superfícies reais de rupturas; (b) distribuição das deformações.

Constata-se na Figura 6.21b que, as máximas deformações de pico concentraram-se na porção central da altura do protótipo até o $50^{\circ}$ dia de ensaio. Após este período, as deformações tornaram-se máximas nas camadas reforçadas inferiores. Assim como verificado nas distribuições dos deslocamentos de face (Figura 6.17), o efeito do avanço de umedecimento pode alterar a posição da deformação de pico máxima ao longo da altura do protótipo. 


\subsection{Relações entre os parâmetros de avanço de umedecimento e o comportamento dos protótipos}

Este tópico buscar associar o efeito das alterações do teor de umidade e sucção matricial nas deformações e deslocamentos de uma estrutura reforçada com geotêxtil não tecido. Esta análise será efetuada com base no comportamento dos protótipos M1 e M2. Na Figura 6.22 são plotadas as relações entre as deformações de pico $\left(\varepsilon_{\text {máx }}\right)$ e a média do grau de saturação de cada camada reforçada dos protótipos.

a)

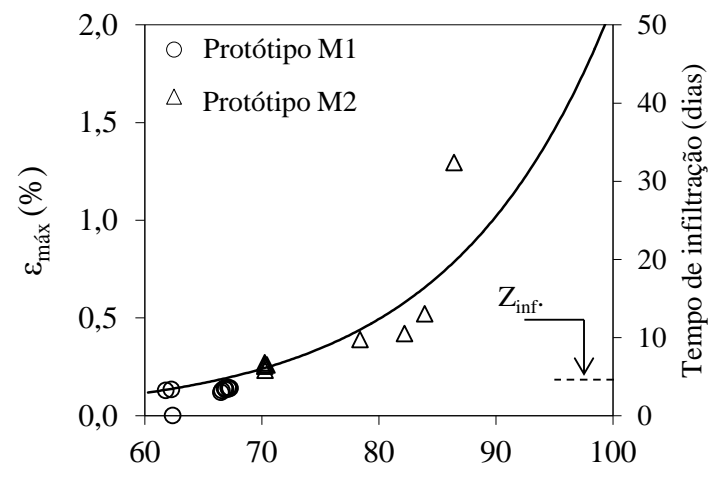

c)

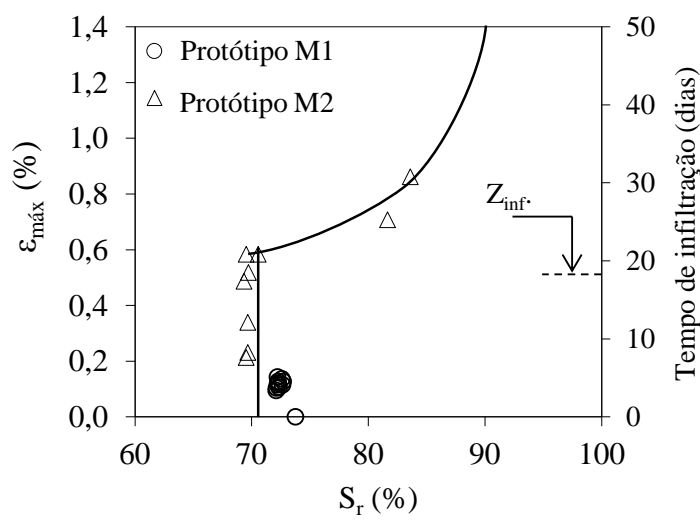

b)

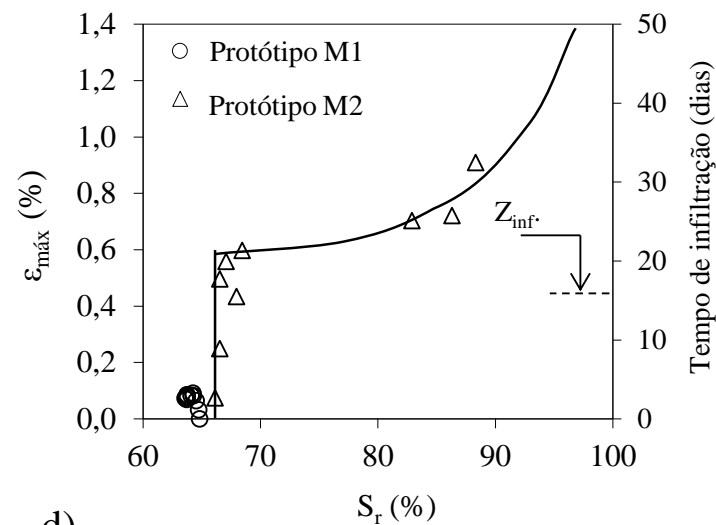

d)

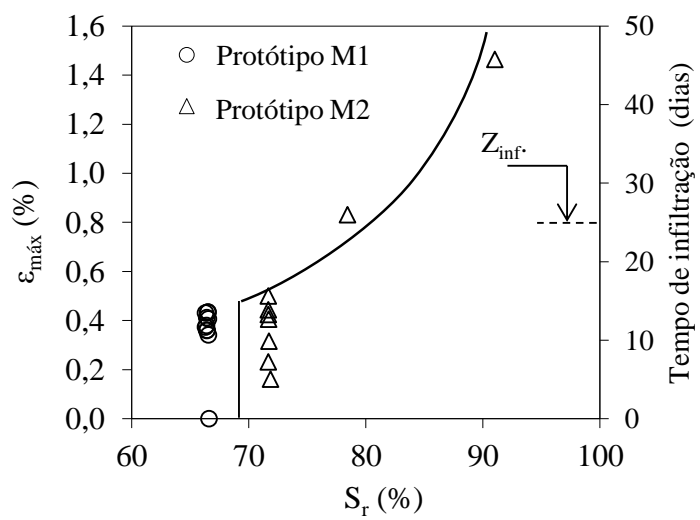

Figura 6.22. Variação da deformação nos reforços com a média do grau de saturação dos protótipos M1 e M2: (a) camada 5; (b) camada 4; (c) camada 3; (d) camada 2.

Os gráficos da Figura 6.22 mostram que as deformações nos reforços aumentam exponencialmente com o grau de saturação em todas as camadas reforçadas. Inicialmente, isso pode ser identificado durante o avanço da infiltração na camada superficial (Figura 6.22a). Ainda, constatou-se que o avanço da frente de umedecimento na camada superficial foi suficiente para promover aumentos nas deformações das camadas subjacentes, mesmo sob a umidade constante de compactação. No instante em que o avanço alcança a camada subjacente, a relação exponencial de aumento da deformação com o grau de saturação torna a ocorrer (Figura 6.22b). Tal comportamento acontece sucessivamente para as outras camadas que compõe a estrutura (Figuras $6.22 \mathrm{c}$ e $6.22 \mathrm{~d}$ ). Conclui-se com isso que, o comportamento global da estrutura é dependente do 
efeito do avanço da frente de umedecimento e, consequentemente das alterações no grau de saturação do solo. Isso pode ser também identificado pelas alterações nas curvas exponenciais, em que a influência do aumento do grau de saturação é mais significativa em direção às camadas inferiores. Esta é uma condição na qual o avanço de umedecimento é proveniente do topo da estrutura. Seria de importante constatação verificar o avanço de umedecimento em diferentes direções, tais como no caso de ascensão do lençol freático ou de fontes de água provenientes do aterro natural não reforçado.

Na Figura 6.23 é ilustrado o efeito da sucção matricial nas deformações de pico de cada camada reforçada. Os dados experimentais mostram indícios de que a relação entre sucção e deformações de pico é semelhante à relação estabelecida na curva de retenção de água do solo, o que é consistente com o esperado já que a sucção tem papel importante na rigidez do solo.

(a)

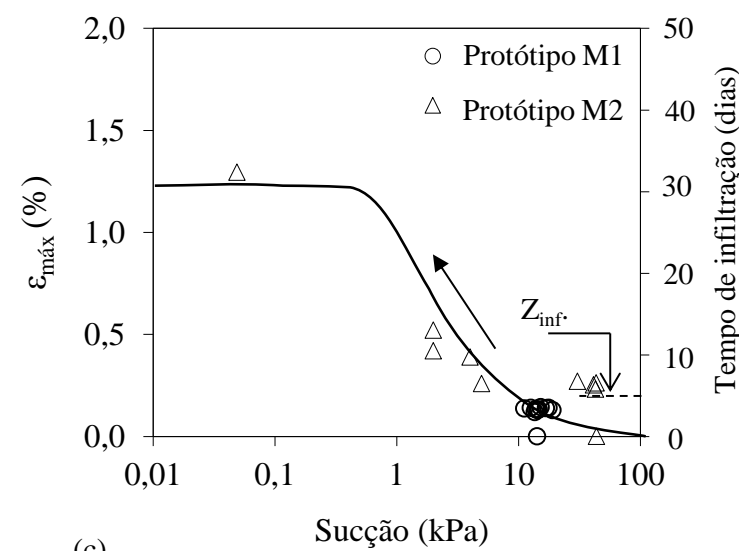

(c)

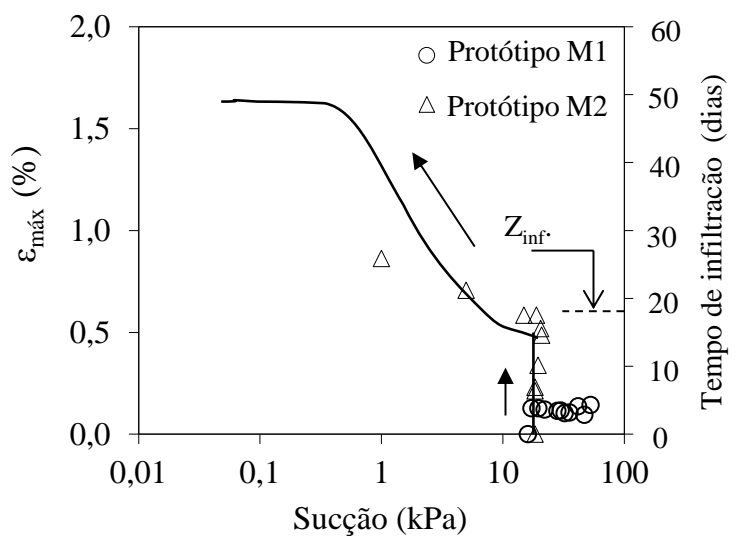

(b)
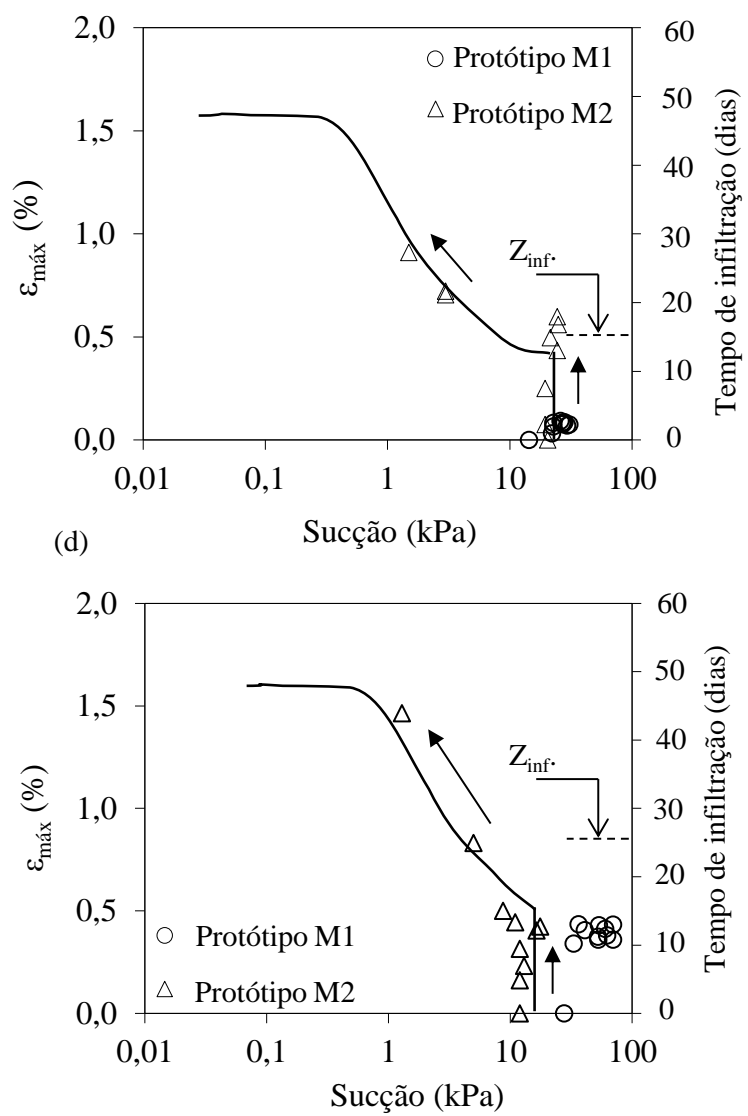

Figura 6.23. Variação da deformação nos reforços com a média da sucção matricial dos protótipos M1 e M2: (a) camada 5; (b) camada 4; (c) camada 3; (d) camada 2.

Comparando as relações estabelecidas no protótipo M2 com as definidas para o protótipo M1, também plotadas nas Figuras 6.22 e 6.23, verifica-se que as deformações iniciais são praticamente as mesmas. Para o protótipo M1, as deformações mantiveram-se constantes com a manutenção do grau de saturação do solo, mostrando que as condições não saturadas restringem o 
comportamento de fluência dos reforços, possivelmente devido à rigidez imposta pela sucção do solo.

Como as relações estabelecidas anteriormente mostraram que o avanço do umedecimento influencia no comportamento global da estrutura desde o início do processo de infiltração, relações podem também ser estabelecidas entre o comportamento do protótipo e os valores médios de sucção matricial e grau de saturação. Com base nesta hipótese, na Figura 6.24 são apresentadas relações entre as deformações de pico máximas ( $\left.\varepsilon_{\text {máxmáx }}\right)$ com a média dos valores de grau de saturação e sucção matricial medidos durante o ensaio.
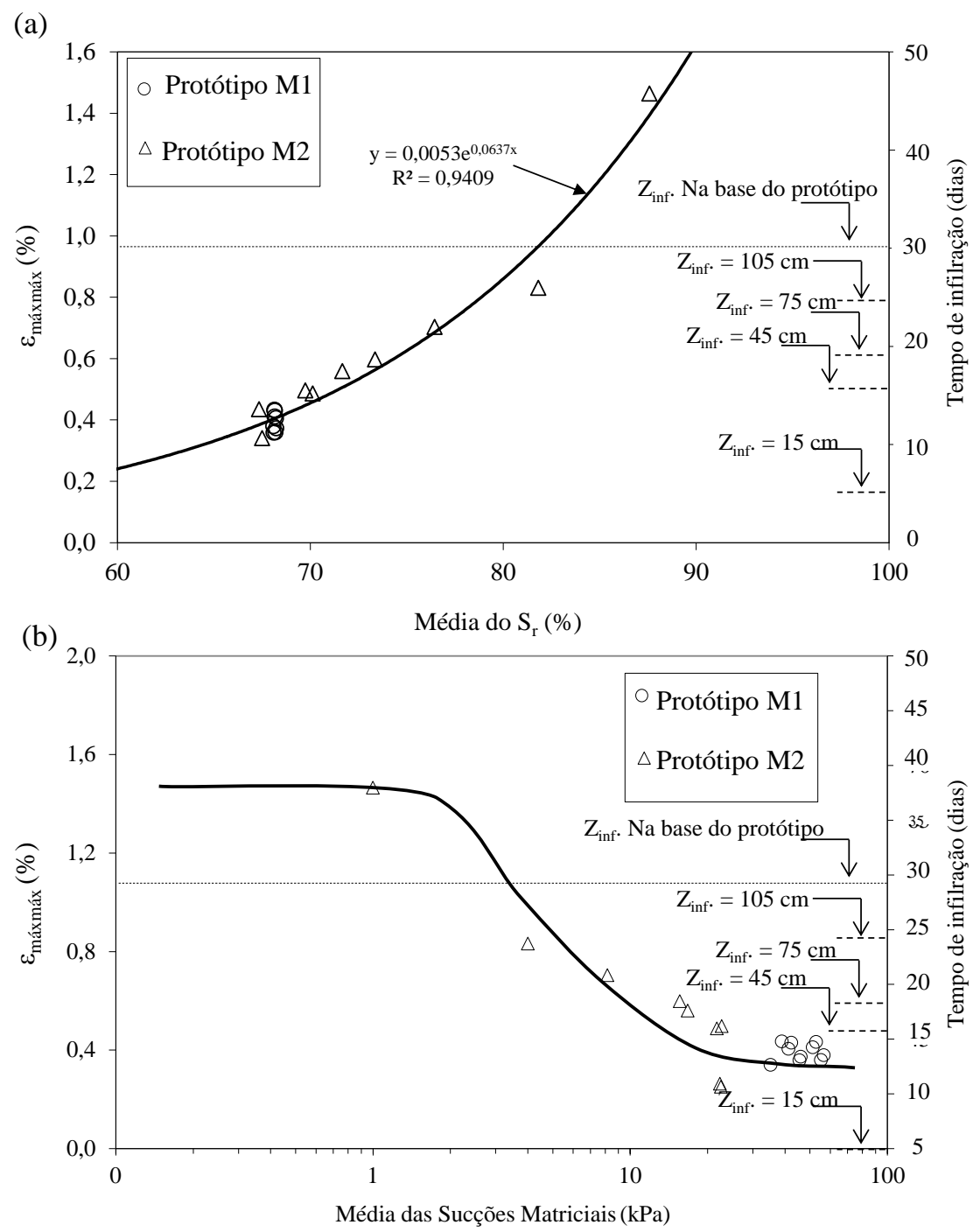

Figura 6.24. Relações entre as deformações de pico máximas dos protótipos M1 e M2 com: (a) o grau de saturação médio; (b) a sucção matricial média.

Pode-se notar que, as deformações de pico máximas apresentaram uma relação exponencial bem definida com o valor médio do grau de saturação do solo durante a infiltração (Figura 6.24a). Este tipo de relação pode representar coerentemente o comportamento real de um muro reforçado, uma vez que aumentos consideráveis no grau de saturação poderiam conduzir à ruptura dos reforços (curva assíntota ao eixo das deformações). Por outro lado, para baixos 
valores de grau de saturação (menores que 60\%), as deformações seriam constantes e mínimas (curva assíntota ao eixo do grau de saturação). Observa-se na Figura 6.24b, que a relação entre deformações e valores médios de sucção matricial foi semelhante ao comportamento da curva de retenção de água do solo (Figura 4.8 - processo de umedecimento), assim como observado na Figura 6.23.

Na Figura 6.25 são plotados os deslocamentos de face e média do grau de saturação de cada camada. Verifica-se nesta figura o mesmo comportamento observado nas relações estabelecidas com as deformações de pico (Figura 6.22). Curiosamente, sistemas de medidas diferentes (deformações internas e deslocamentos de face externos), resultaram nas mesmas relações.

a)

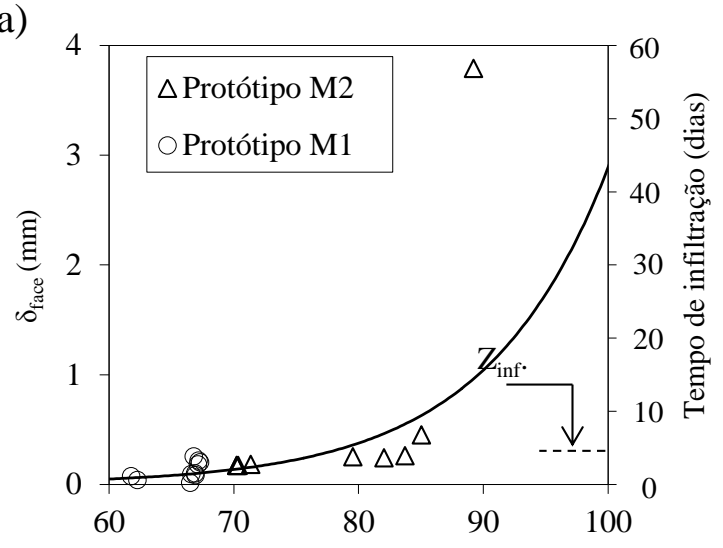

c)

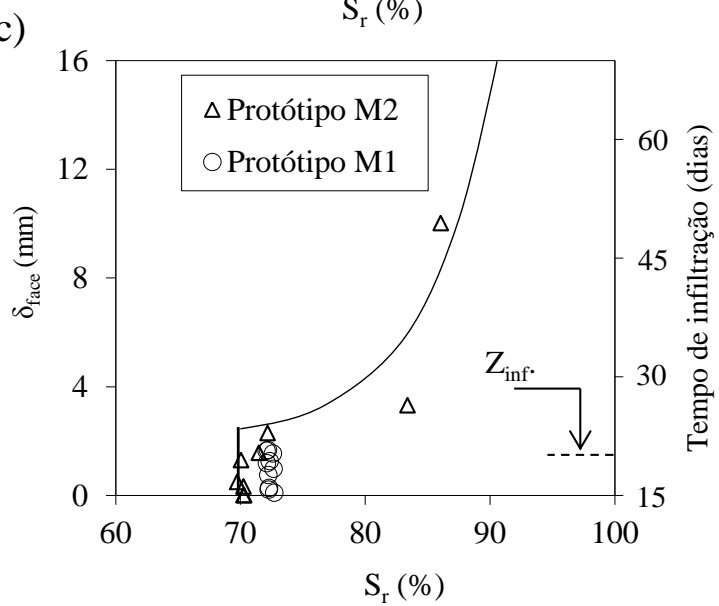

b)

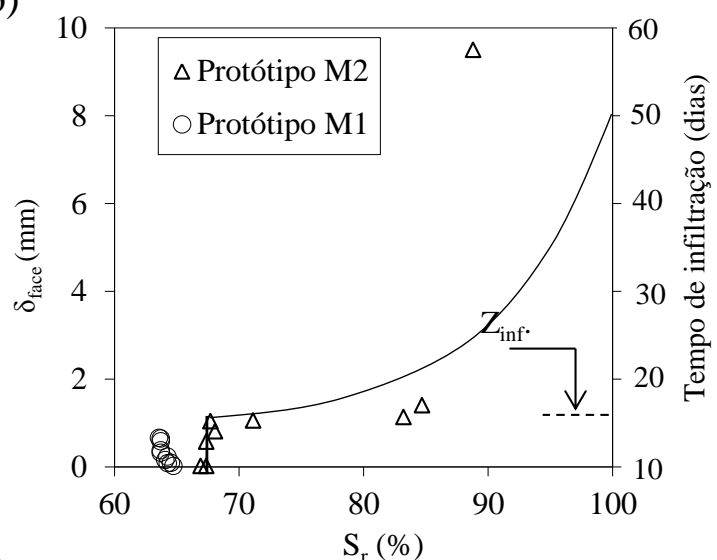

d) ,

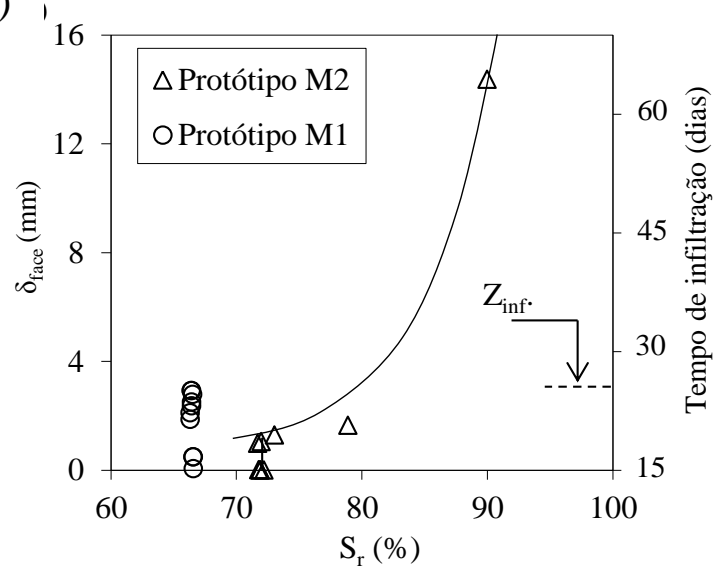

Figura 6.25. Variação do deslocamento de face com a média do grau de saturação dos protótipos M1 e M2: (a) camada 5; (b) camada 4; (c) camada 3; (d) camada 2.

Na Figura 6.26 foram relacionados os deslocamentos de face máximos com as médias do grau de saturação e as médias da sucção matricial do solo do protótipo durante o processo de avanço de umedecimento. Nota-se que estas relações foram semelhantes às observadas nas deformações de pico máximas, no qual os deslocamentos aumentaram exponencialmente com o grau de saturação médio e com a sucção média na mesma tendência da curva de retenção do solo. 

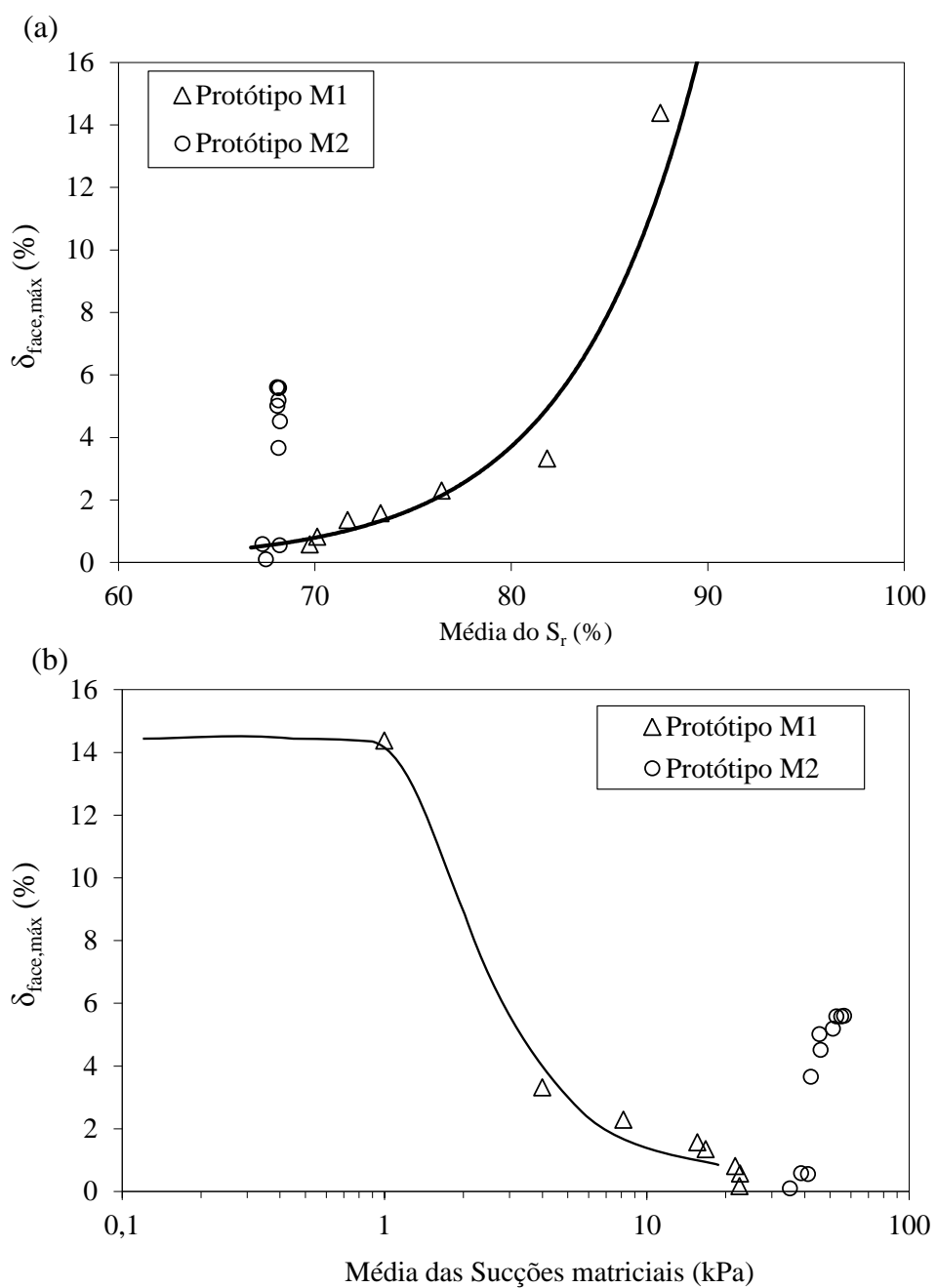

Figura 6.26. Relações entre os deslocamentos de face máximos dos protótipos M1 e M2 com: (a) média geral do grau de saturação e (b) média geral das sucções matriciais.

Um aspecto interessante é que, conhecendo o comportamento da curva de retenção de água do solo, se pode prever o valor mínimo de sucção, o que resultaria em aumentos consideráveis nas deformações de pico máximas e nos deslocamentos de face máximo. Neste caso, o valores médios de sucção matricial menores que $2 \mathrm{kPa}$ apresentam uma relação com parâmetros de comportamento definido pelo trecho mais inclinado da curva, o que resulta em grandes variações das deformações com pequena variação do valor de sucção matricial.

Cabe observar que estas relações, considerando os valores máximos de deformações e valores médios de grau de saturação e sucção, foram constatadas em protótipos de até 1,5 $\mathrm{m}$ de altura. Estudos complementares devem ser realizados em estruturas reais de maior altura, de modo a verificar a validade destas relações, uma vez que instabilidades locais podem ocorrer durante a infiltração.

Outra relação que pode representar o efeito do umedecimento no comportamento do protótipo é o efeito da profundidade da linha de avanço do umedecimento durante o processo de infiltração. Nos gráficos da Figura 6.27 são mostradas as relações entre a profundidade da linha 
média de infiltração e as deformações de pico máximas, e os deslocamentos máximos internos e de face máximos. A linha média de avanço de infiltração representa a média da profundidade da frente de avanço determinada com base nos perfis de infiltração definidos no tópico 6.1. Com isso, nota-se que, tanto para as deformações e os deslocamentos internos quanto para os deslocamentos de face, houve um aumento com o avanço da frente de infiltração. Observou-se que a taxa de aumento torna-se maior quando a profundidade alcança valores maiores que $105 \mathrm{~cm}$. De certa forma, o comportamento constatado nas relações mostradas nas Figuras 6.24 e 6.26 apresentam semelhanças com as relações mostradas na Figura 6.27. Como a média dos parâmetros de umedecimento (sucção e grau de saturação) é calculada com base em todos os valores medidos no corpo do maciço, pode-se dizer que o avanço da infiltração promove um aumento progressivo nesta média, fazendo com que as relações sejam semelhantes.

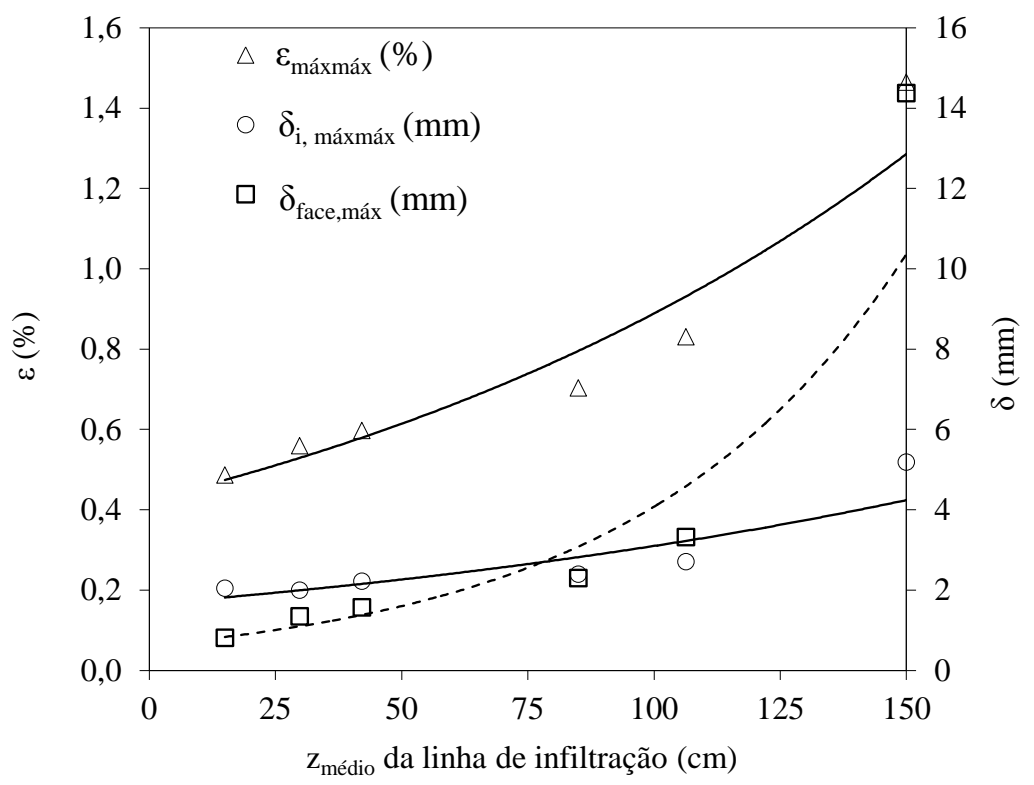

Figura 6.27. Influência da linha média do avanço de infiltração nos valores máximos de deformação de pico, deslocamento interno e deslocamento de face do protótipo M2.

Com o intuito de compreender o efeito da redução da rigidez do solo devido ao umedecimento, definiu-se uma faixa de variação de rigidez durante o processo de avanço com base nos resultados de ensaios triaxiais (Figura 4.7), conforme ilustra a Figura 6.28. De acordo com a relação estabelecida de Figura 6.28, os módulos secantes de rigidez foram obtidos utilizando os valores de saturação monitorados durante o ensaio. Para isso, utilizou-se a curva de módulo secante com o nível de deformação de $1 \%$, por ser o mais representativo dos níveis de deformações registrados nos reforços do protótipo M2. Desta forma, o efeito do módulo de rigidez nas deformações dos reforços é apresentado na Figura 6.29. Observa-se, também, o aumento exponencial das deformações nos reforços com a diminuição do módulo de rigidez (média dos pontos monitorados). 


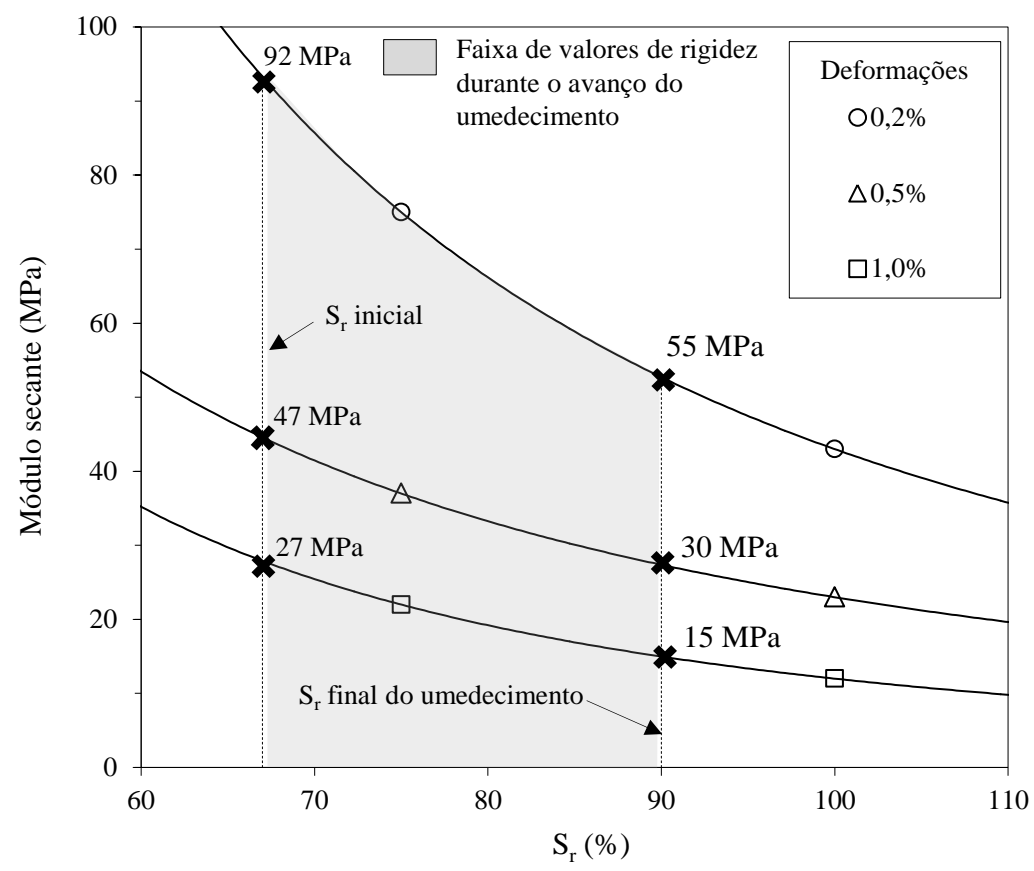

Figura 6.28. Faixa de valores de rigidez durante o processo de umedecimento, obtidos por ensaios triaxiais.

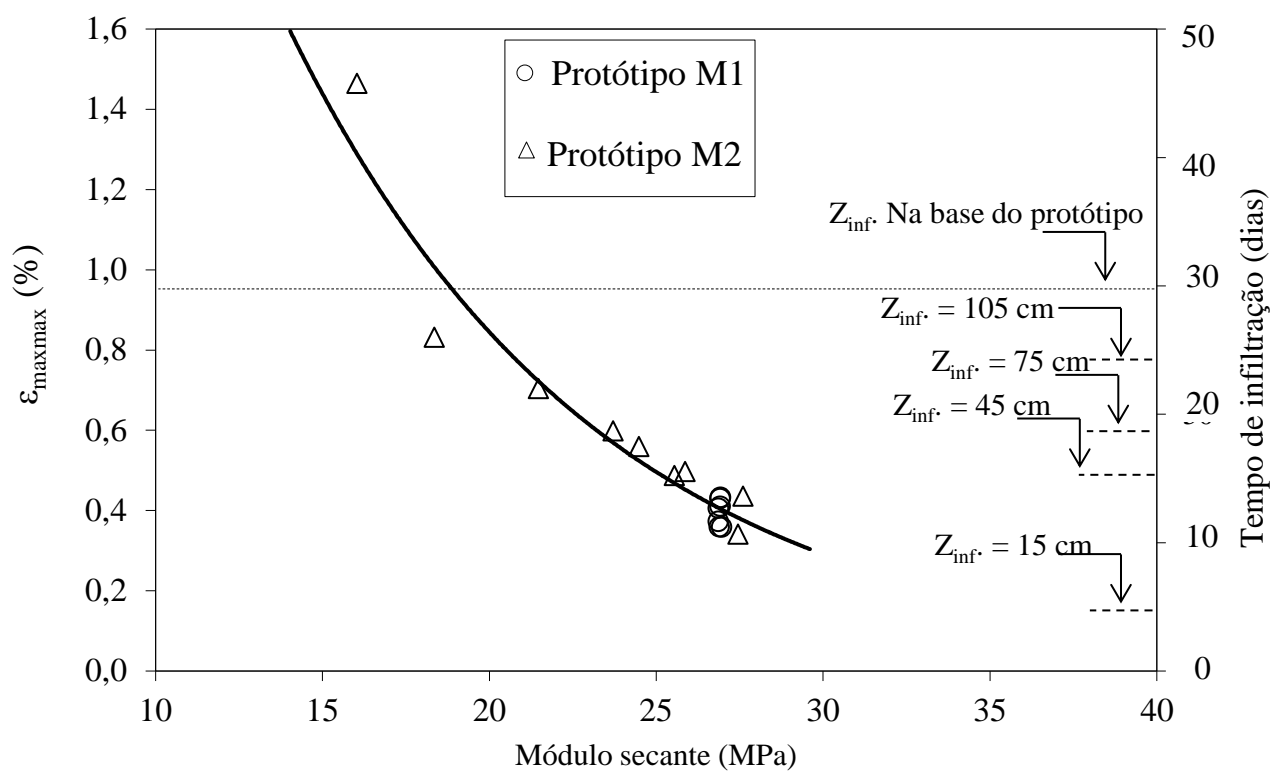

Figura 6.29. Efeito da variação da média do módulo secante devido ao avanço do umedecimento na deformação máxima dos reforços.

\subsection{Efeito do avanço do umedecimento em análises de equilíbrio limite}

Análises de equilíbrio limite foram realizadas considerando o efeito do avanço da frente de umedecimento, cujos resultados de fatores de segurança foram relacionados aos parâmetros de comportamento do protótipo. Assim como no protótipo M1, as análises foram conduzidas utilizando o software UTEXAS3, desenvolvido por Wright (1990). Para isso, os perfis de infiltração, em termos de sucção matricial (Figuras 6.7, 6.8 e 6.9), ou pressões da água negativas, 
foram inseridos nas análises e os fatores de segurança de superfícies de rupturas circulares e bilineares foram calculados. Assim, pôde-se verificar o efeito da variação das pressões da água negativas nas tensões efetivas do solo, e consequentemente, nos fatores de segurança de estabilidade, considerando somente a ruptura do reforço. Nas análises de estabilidade foi utilizado o método das fatias de Spencer (1967), modificado por Wright e Duncan (1991).

Os resultados dos fatores de segurança nas condições de saturação, observadas durante o umedecimento, são mostrados na Figura 6.30. No mesmo gráfico, foi plotada a curva da variação da média do grau de saturação com o tempo. Assim como esperado, o fator de segurança diminui com o aumento do grau de saturação médio durante o processo de infiltração, mostrando que os parâmetros plotados apresentam potencial para serem relacionados entre si. Desse modo, na Figura 6.31 são apresentadas relações entre as médias do grau de saturação e as médias das sucções matriciais com os fatores de segurança obtidos nas análises para os protótipos M1 e M2.

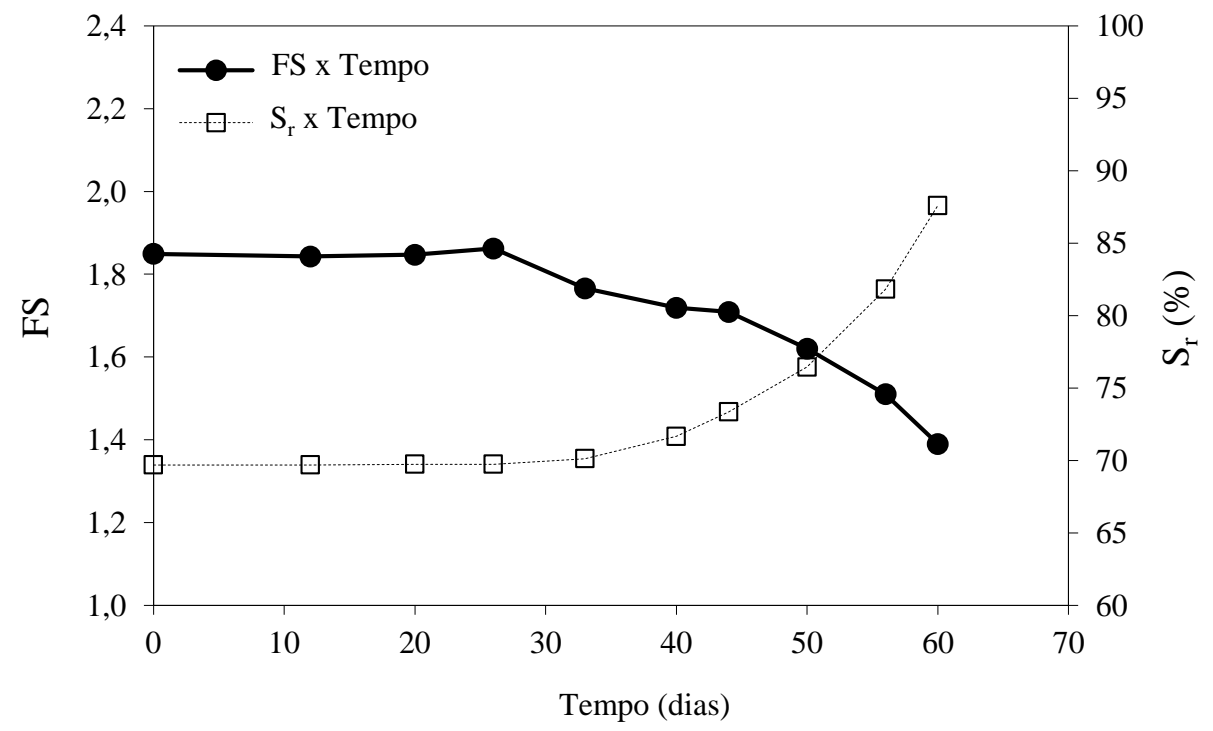

Figura 6.30. Resultados das análises de equilíbrio limite durante o umedecimento do protótipo M2.

Nos gráficos da Figura 6.31, buscam-se evidências quanto às semelhanças entre as relações estabelecidas entre deformações e parâmetros de umedecimento (grau de saturação e sucção matricial), e as relações deste com os fatores de segurança. O que se pode verificar é que a mesma tendência foi também constatada (Figura 6.24). Um aspecto de grande importante é que a relação entre fatores de segurança e sucção matricial sugere uma tendência de comportamento consistente com o da curva de retenção de água do solo. Dessa forma, análises adicionais em projetos de muro reforçados com geotêxteis podem ser realizadas considerando essa relação, desde que a o comportamento de retenção de água do solo seja conhecida. Essa ferramenta permite conhecer a faixa de valores de sucção que podem assegurar a estabilidade da estrutura, caso o avanço de umidade venha a acontecer. 

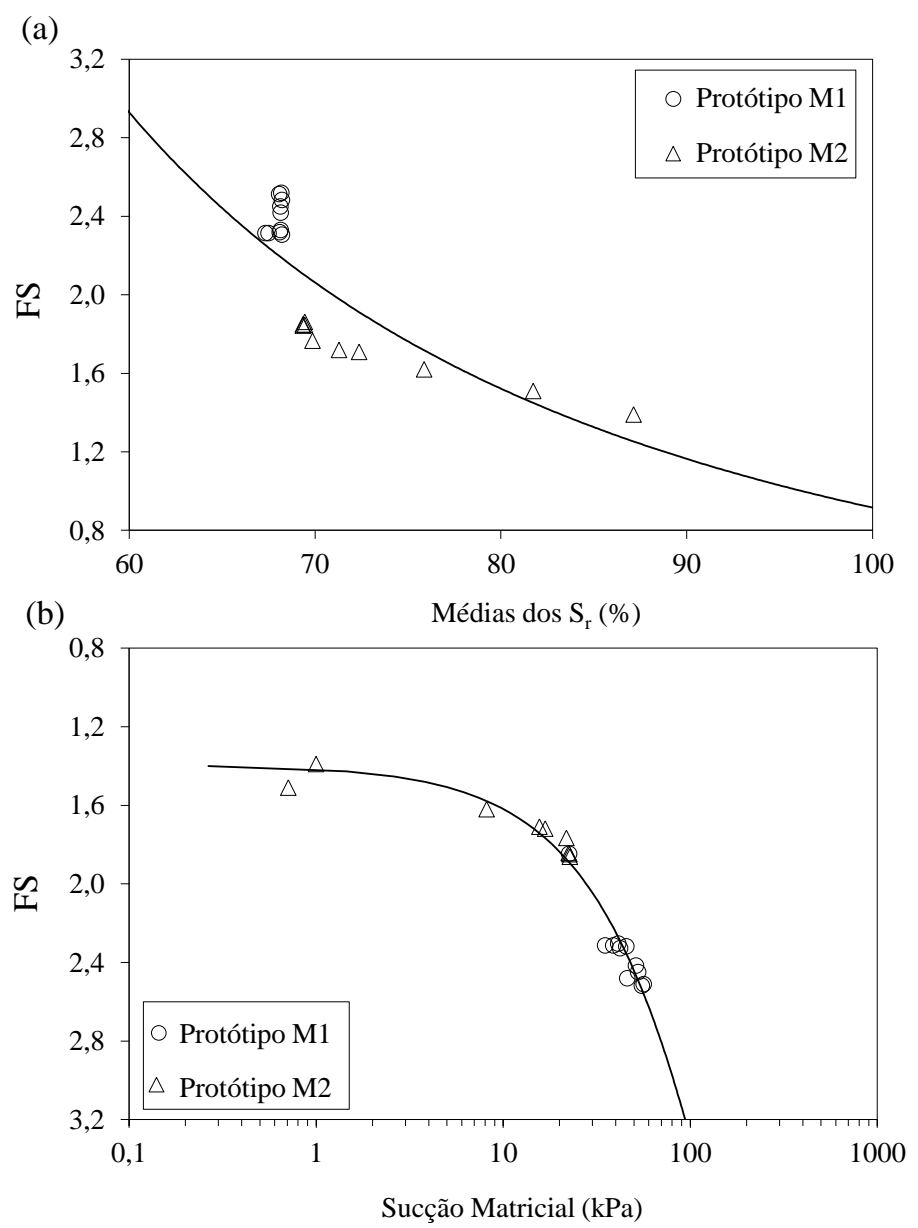

Figura 6.31. Análises de equilíbrio limite para as condições de umedecimento dos protótipos M1 e M2: (a) Fator de segurança versus média do grau de saturação, e (b) Fator de segurança versus média da sucção.

Em análises convencionais de estabilidade interna de estruturas de solo reforçado busca-se sempre o fator de segurança aceitável para garantir a estabilidade, sendo este valor normalmente 1,5. No entanto, esse tipo de análise não permite identificar o nível de deformação ou deslocamento da estrutura nessas condições. Assim, os fatores de segurança foram relacionados às deformações constatadas durante a infiltração, com o intuito de mostrar a existência de uma relação que possa colocar os valores de fator de segurança como indicativo, não somente da estabilidade, mas também da deformação dos reforços dos protótipos estudados. Constatou-se que, a relação entre os dois parâmetros pode ser também representado por uma função exponencial. Esta representação pode ser coerente, considerando que no ponto de ruptura teórica do protótipo (fator de segurança igual a 1), as deformações tenderiam ao infinito, definindo assim a ruptura real. Digno de nota é observar que os valores de fatores de segurança até 1,4 , estão associados a baixos valores de deformação em relação ao valor de deformação na ruptura medida em ensaio do geotêxtil não confinado $(\varepsilon=95 \%)$, o que consiste numa evidência do efeito do confinamento na deformabilidade do geotêxtil. Sob as condições de serviço, constata-se que grandes deformações nos reforços não são necessariamente indicativas da ruptura da estrutura. Normalmente, espera-se que estruturas com reforços flexíveis deformem excessivamente antes da 
ocorrência da ruptura, o que não é evidenciado na Figura 6.32. Com isso, sugere-se que análises de comportamento de resistência à tração de geotêxteis não tecidos na condição confinada ao solo sejam incluídas em rotinas de análises de projetos de muros reforçados com geotêxteis não tecidos.

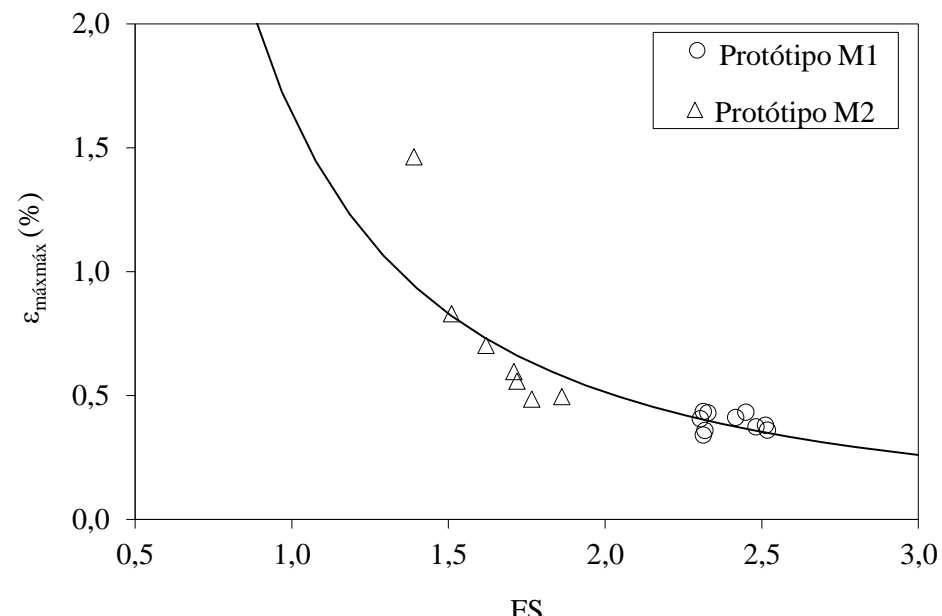

Figura 6.32. Relação entre fator de segurança e deformação de pico máxima das análises dos protótipos M1 e M2.

Superfícies de rupturas circulares e bilineares obtidas por análises de equilíbrio limite foram comparadas aos pontos experimentais obtidos no ensaio do protótipo, com é indicado na Figura 6.33. A superfície de ruptura de Rankine é também comparada nesse gráfico. As superfícies previstas pelo método de equilíbrio limite coincidiram parcialmente com a localização dos pontos de deformações máximas observados experimentalmente. Houve também, uma semelhança ao comportamento experimental, no que se refere à variação das superfícies de ruptura com o tempo. As superfícies circulares e bilineares tenderam a de deslocar em direção a face assim como verificado experimentalmente no protótipo M2.

a)

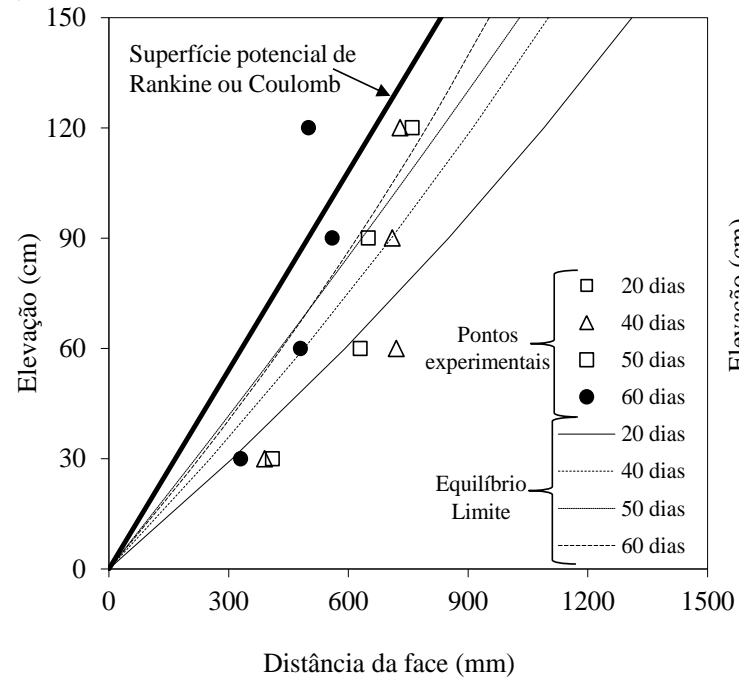

b)

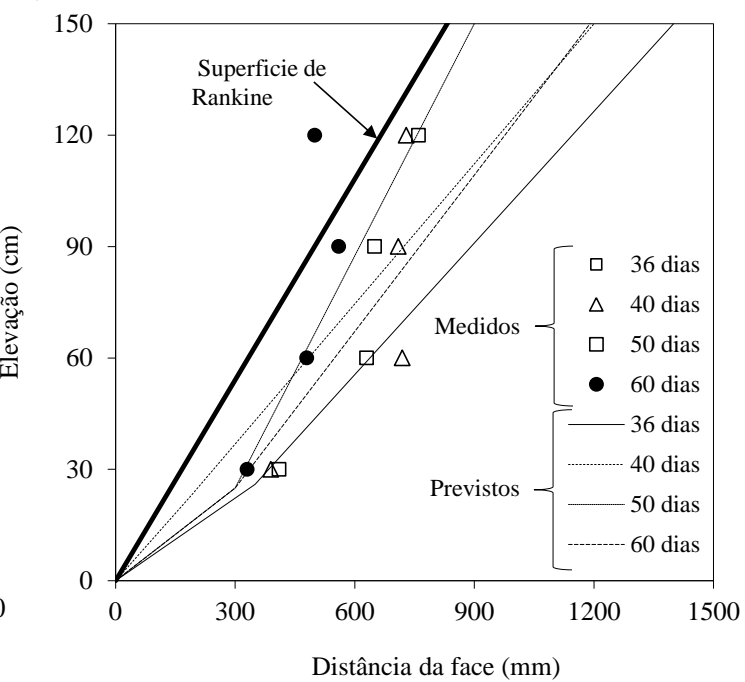

Figura 6.33. Comparação entre superfícies de rupturas reais e previstas pelo método de equilíbrio limite e superfície de Rankine do protótipo M2: (a) circulares; (b) bilineares 
-192- 


\section{CAPÍTULO 7}

\section{AVALIAÇÃO DO COMPORTAMENTO HIDRÁULICO DE INTERFACE SOLO- GEOTÊXTIL NÃO TECIDO EM UM PROTÓTIPO DE MURO REFORÇADO}

Neste capítulo é avaliado o comportamento hidráulico na interface solo-geotêxtil não tecido sob a condição de avanço de umedecimento. Buscou-se constatar a influência da presença de reforços permeáveis na drenagem interna da zona reforçada, assim como a possível formação de barreiras capilares. Neste contexto, sensores de umidade foram concentrados ao longo da altura da camada reforçada superior (protótipo M3), para que o efeito do avanço na interface fosse identificado.

\subsection{Comportamento hidráulico de interface durante o processo de infiltração}

Com relação ao presente tópico, cabe lembrar que no protótipo M3 simulou-se uma condição de chuva constante de intensidade menor que a permeabilidade do solo. Com isso, toda água aplicada infiltrou na estrutura, possibilitando quantificar o volume drenado pelos reforços, além de favorecer a visualização da formação de barreiras capilares nas interfaces.

Na Figura 7.1 é apresentado o volume de água aplicado no topo do protótipo M3 durante o ensaio, bem como o volume infiltrado real, calculado com base na frente de infiltração obtida pelas leituras dos sensores de umidade. Considerando as condições de umedecimento e no caso de um maciço de solo sem a presença de reforços permeáveis, o volume de água infiltrado seria igual ao volume aplicado. No presente protótipo reforçado, o volume de água infiltrado foi menor que o volume de água aplicado durante o ensaio. Dessa forma, a diferença entre o volume aplicado e o volume infiltrado consiste no volume de água drenado pelos reforços. Assim, o volume total drenado pelos reforços foi de aproximadamente $0,20 \mathrm{~m}^{3}$, o que corresponde a $20 \%$ do volume total aplicado. Portanto, a presença dos reforços permeáveis contribuiu na drenagem interna na zona reforçada. Esta constatação foi confirmada pela avaliação visual da face durante a condição de serviço do protótipo. O aspecto da face após 21 dias (30000 minutos) de ensaio, exibida na Figura 7.2, mostra que manchas de umedecimento ocorreram exatamente nas linhas dos reforços não tecidos. Ainda, estas manchas são mais acentuadas nos reforços superficiais, mostrando evidências de que grande parte do volume foi drenada nestas linhas de geotêxteis. 


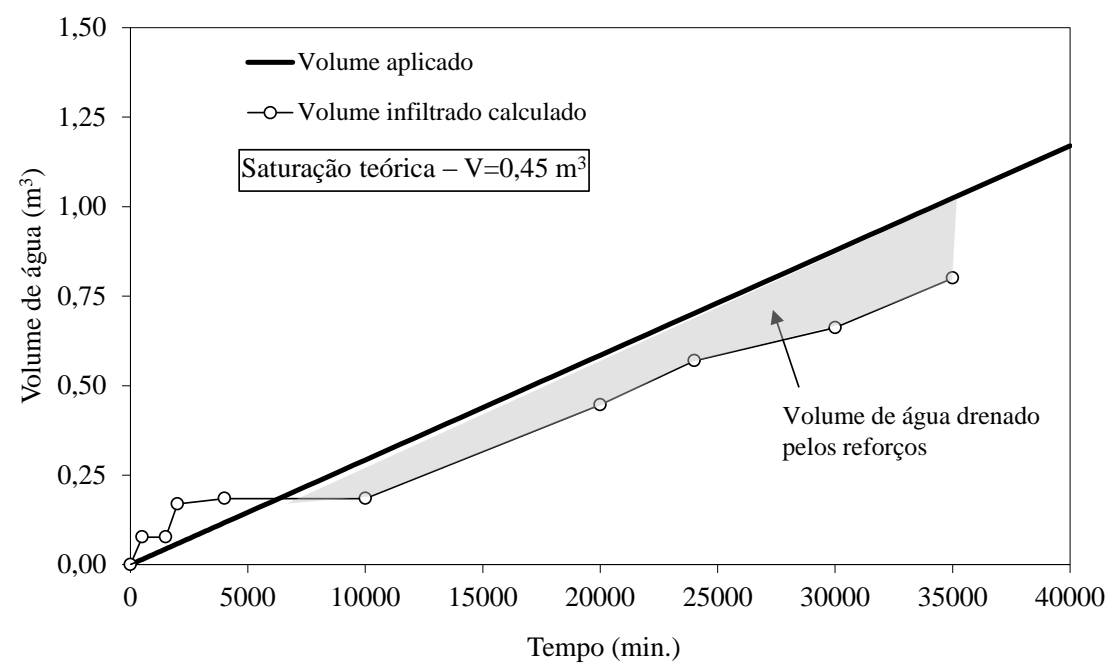

Figura 7.1. Volumes de água aplicado e infiltrado no topo do protótipo M3.

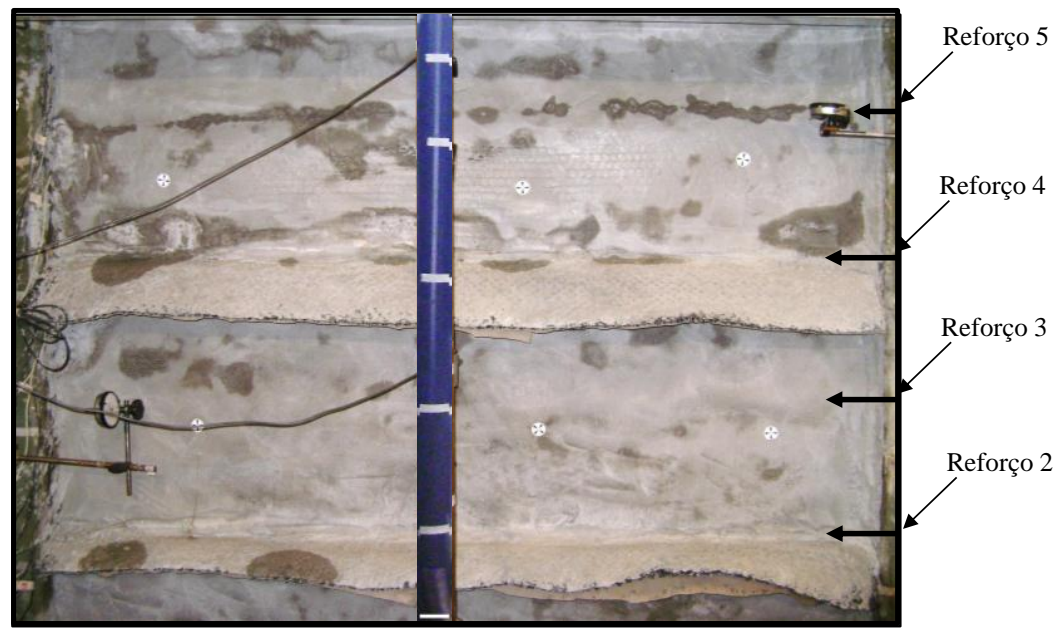

Figura 7.2. Aspecto da face do protótipo M3 após 21 dias (30000 minutos) de ensaio.

Outra hipótese a ser avaliada é a possível formação de barreiras capilares nas interfaces solo - geotêxtil não tecidos. Na tentativa de observar o processo de formação da barreira na camada superficial (camada 5), uma maior quantidade de sensores foi instalada neste local, cuja distribuição é ilustrada na Figura 7.3. Cada uma das colunas de sensores foi nomeada como C1, C2, C3 e C4, enquanto as linhas correspondem à L1, L2, L3, L4 e L5, conforme ilustração. O detalhamento de toda a instrumentação utilizada no protótipo M3 pode ser observado na Figura 4.29 do capítulo 4 .

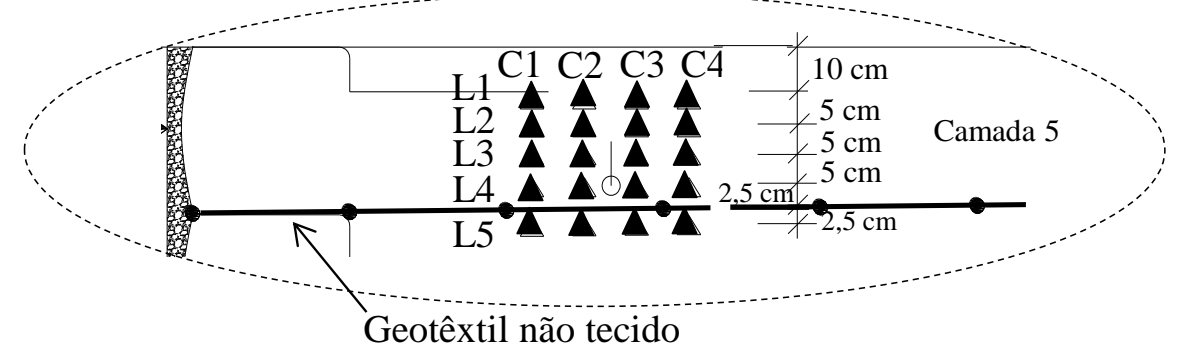

Figura 7.3. Posicionamento dos sensores de umidade na camada reforçada 5. 
As leituras de umidade na coluna $\mathrm{C} 1$ são apresentadas na Figura 7.4, que ilustra os resultados durante o período total do ensaio (Figura 7.4a) e o inicial (Figura 7.4b). O posicionamento dos sensores em colunas foi idealizado com o intuito de identificar a formação de barreiras capilares na interface solo-geotêxtil. Estas são reconhecidas pelo armazenamento de água acima do reforço, sendo que a capacidade é dependente da permeabilidade não saturada do solo e geotêxtil (ZORNBERG; BOUAZZA; McCARTNEY, 2010).
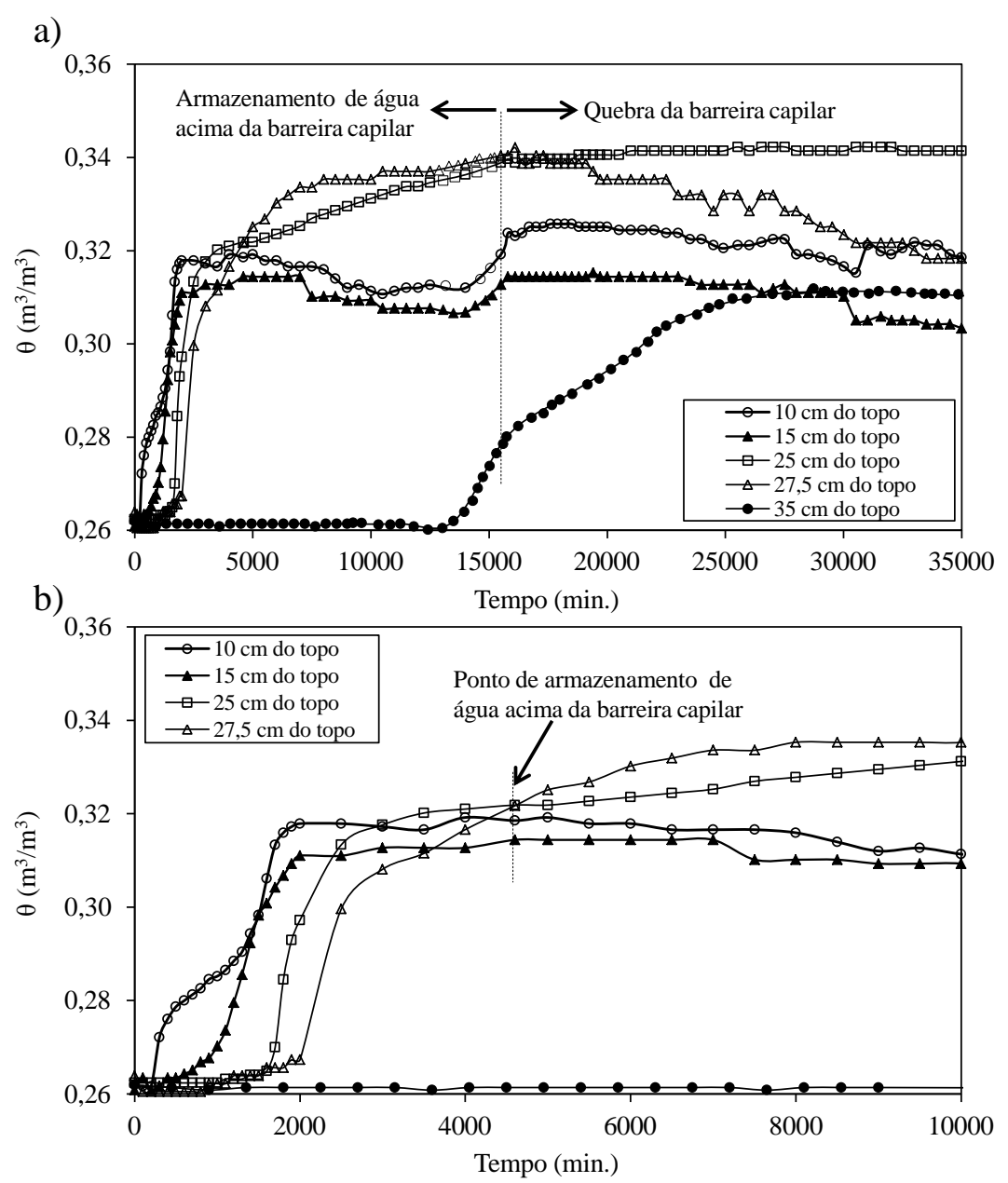

Figura 7.4. Resultados das leituras dos sensores de umidade volumétrica dispostos na coluna C1: (a) período total do ensaio; (b) até $10000 \mathrm{~min}$.

Observa-se na Figura 7.4, que os sensores de umidade posicionados na coluna C1 acusaram aumentos nos teores de umidade volumétrica no sentido normal de infiltração. Inicialmente, os teores de umidade a $10 \mathrm{~cm}$ do topo aumentaram até o valor referente à capacidade de campo $\left(\theta=0,31 \mathrm{~m}^{3} / \mathrm{m}^{3}\right)$. Posteriormente, a frente de umedecimento alcançou a profundidade de $15 \mathrm{~cm}$, promovendo também o aumento até o valor de teor de umidade volumétrica referente à capacidade de campo. Esta tendência de avanço ocorreu para os diferentes níveis de sensores, até alcançar o sensor posicionado a $27,5 \mathrm{~cm}$ do topo (L4), ou seja, a 2,5 cm do reforço não tecido. A formação da barreira capilar pôde ser evidenciada pela continuidade do aumento do teor de umidade volumétrica para o valor referente à saturação $\left(\theta=0,34 \mathrm{~m}^{3} / \mathrm{m}^{3}\right)$, 
inicialmente em regiões próximas ao geotêxtil, indicando a ascensão da água devido à restrição do fluxo e consequente acúmulo de água logo acima do reforço. Nota-se que o armazenamento de água acima da barreira capilar na coluna $\mathrm{C} 1$ ocorreu até o tempo de 15000 minutos (10 dias). Após este período, verifica-se a redução do teor de umidade volumétrica devido à quebra da barreia capilar. Esta rápida redução do teor de umidade é resultante da associação da dissipação parcial da água ao longo do comprimento do geotêxtil com a liberação do fluxo, permitindo que esta retome a infiltração na camada subjacente. O período de armazenamento acima da barreira pode ser definido a partir do tempo em que o teor de umidade volumétrica de capacidade de campo é alcançado em pontos logo acima do geotêxtil não tecido (4600 minutos), até o momento de quebra da barreira capilar (15000 minutos). Portanto, o acúmulo de água ocorreu durante aproximadamente 10400 minutos (7 dias).

O mesmo raciocínio foi utilizado para discutir o avanço de umedecimento nas colunas $\mathrm{C} 2$, C3 e C4. Os resultados das leituras dos sensores de umidade nestas colunas são apresentados nas Figuras 7.5, 7.6 e 7.7. Na Figura 7.5 (coluna C2), o ponto de armazenamento de água iniciou-se no tempo de 6800 minutos e a quebra da barreira ocorreu no tempo de 15200 minutos. Pode-se dizer que o efeito da barreira capilar na coluna $\mathrm{C} 2$ foi bastante semelhante à coluna $\mathrm{C} 1$, porém, com atraso na formação de 2000 minutos (1,4 dias).
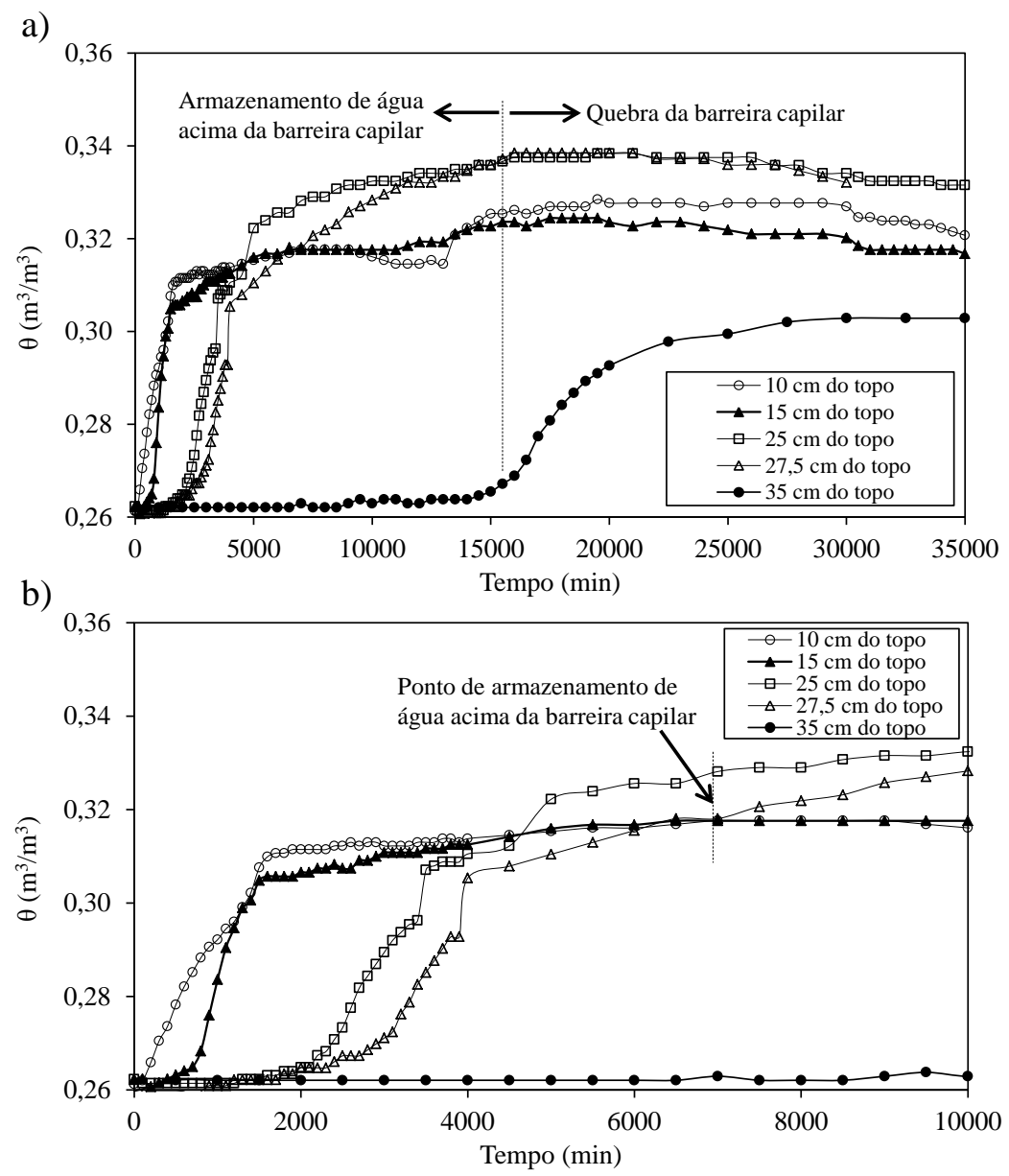

Figura 7.5. Resultados das leituras dos sensores de umidade volumétrica dispostos na coluna C2: (a) período total do ensaio; (b) até $10000 \mathrm{~min}$. 
Na coluna C3 (Figura 7.6), o acúmulo de água acima do reforço (armazenamento) iniciouse no tempo de 7500 minutos, enquanto o ponto de quebra da barreira capilar ocorreu no tempo de 16000 minutos. Nesta coluna, o processo de armazenamento ocorreu depois das colunas C1 e C2 e tempo de quebra semelhante, o que foi também observado na coluna C4 (Figura 7.7). Acreditase que a declividade da superfície do topo do protótipo, bem como a declividade do reforço, motivou um breve escoamento da água em direção à face. Por essa razão, o acúmulo de água ocorreu no sentido de $\mathrm{C} 1$ para $\mathrm{C} 4$ e a quebra aconteceu em períodos aproximadamente iguais, com exceção da coluna $\mathrm{C} 1$.
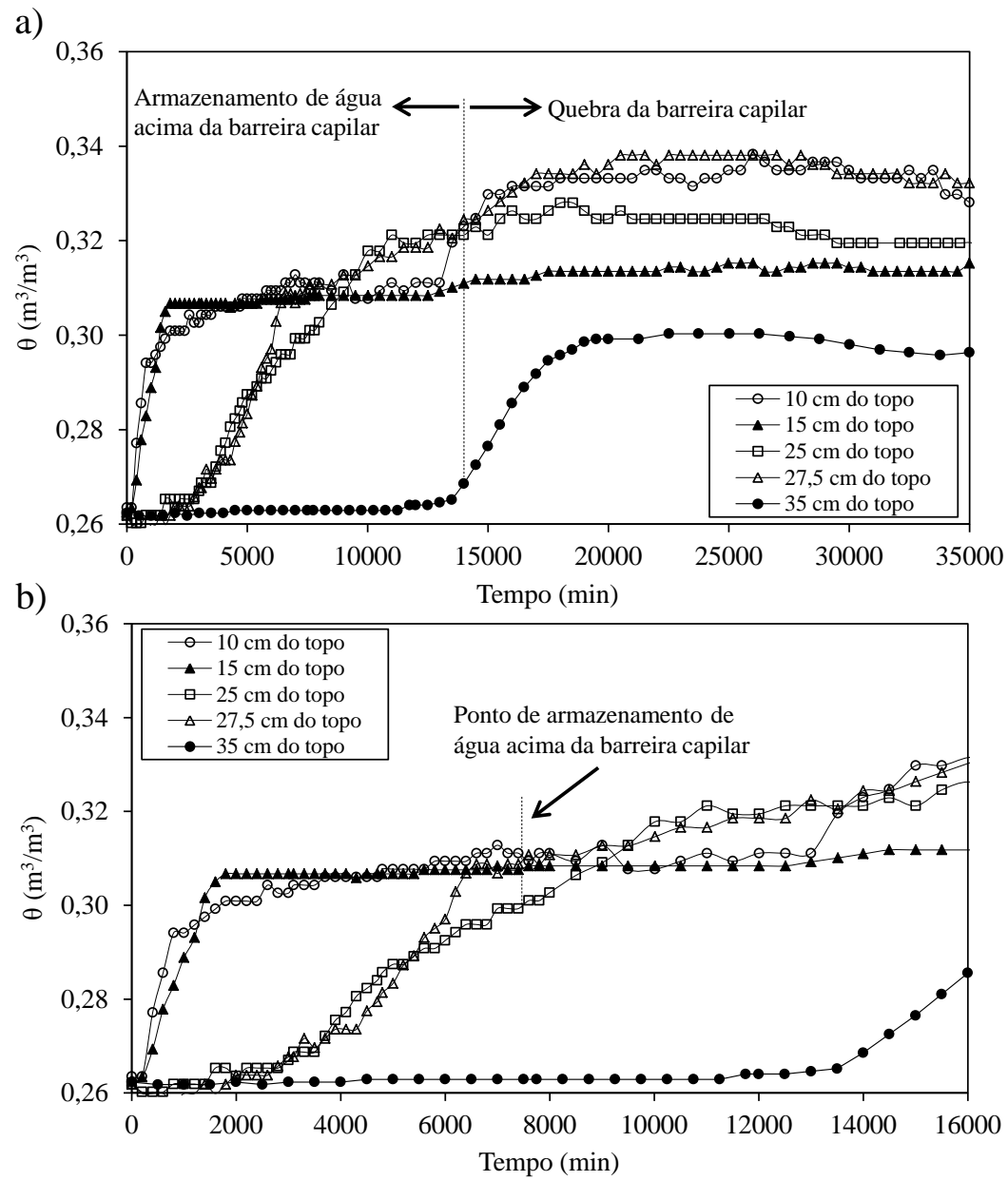

Figura 7.6. Resultados das leituras dos sensores de umidade volumétrica da coluna C3: (a) período total do ensaio; (b) até $16000 \mathrm{~min}$.

Um aspecto importante deste tópico foi verificar que existe a formação de uma barreira capilar entre o contato do solo e geotêxtil, e o tempo de armazenamento pode ser considerado relativamente grande para algumas condições de campo. Nestas condições, o solo está sujeito a ciclos de umedecimento e secagem, fazendo com que a barreira capilar permaneça por períodos mais longos. Por outro lado, sob condições extremas de precipitação, a barreira pode vir a se quebrar rapidamente. Com o conhecimento teórico sobre barreiras capilares em geotêxteis não tecidos, é possível projetar barreiras com base na capacidade de armazenamento necessária. Para 
isso, é importante conhecer as funções de condutividade hidráulica não saturada do solo e do geotêxtil. Esta consiste em uma solução econômica para barreiras de avanço de umidade, porém, suscetíveis às variações internas e externas.

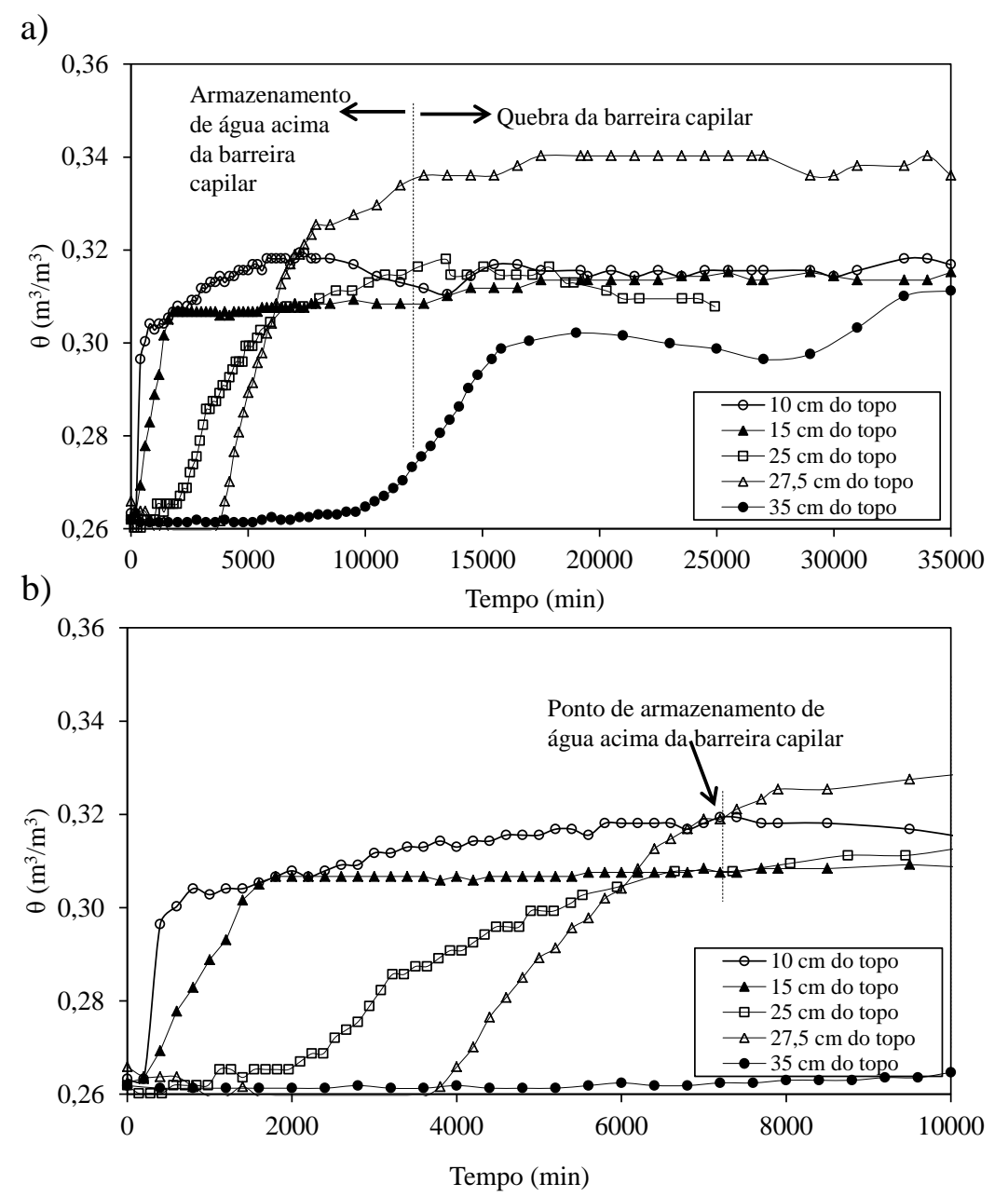

Figura 7.7. Resultados das leituras dos sensores de umidade volumétrica dispostos na coluna C4: (a) período total do ensaio; (b) até $10000 \mathrm{~min}$.

Os resultados das leituras dos sensores de umidade localizados nas linhas L1, L2, L3, L4 e L5 são apresentados nas Figuras 7.8 a 7.12. Foram plotados todos os sensores posicionados na mesma linha, de modo a verificar a diferença entre os níveis de umidade volumétrica em cada coluna. Teoricamente, os sensores localizados nas mesmas linhas devem apresentar valores de teor de umidade volumétrica semelhantes. Ainda, nas condições normais de infiltração, devido à ação gravitacional, as umidades finais devem apresentar valores em torno da capacidade de campo $\left(\theta=0,31 \mathrm{~m}^{3} / \mathrm{m}^{3}\right)$ em pontos em que não há armazenamento de água devido à barreira capilar. Com a restrição do fluxo devido à barreira, os valores devem alcançar àqueles referentes à saturação $\left(\theta=0,34 \mathrm{~m}^{3} / \mathrm{m}^{3}\right)$, dado ao acúmulo de água acima dos geotêxteis.

$\mathrm{Na}$ Figura 7.8, referente à linha de sensores L1, os valores de teor de umidade volumétrica apresentam-se relativamente próximos e em torno do valor de capacidade de campo. Eventuais diferenças nos valores podem ser assumidas pela influência do procedimento de instalação dos 
sensores, ou até mesmo, de uma pequena variação no grau de compactação entre os pontos. De modo geral, pode-se afirmar que os valores são coerentes com o esperado.

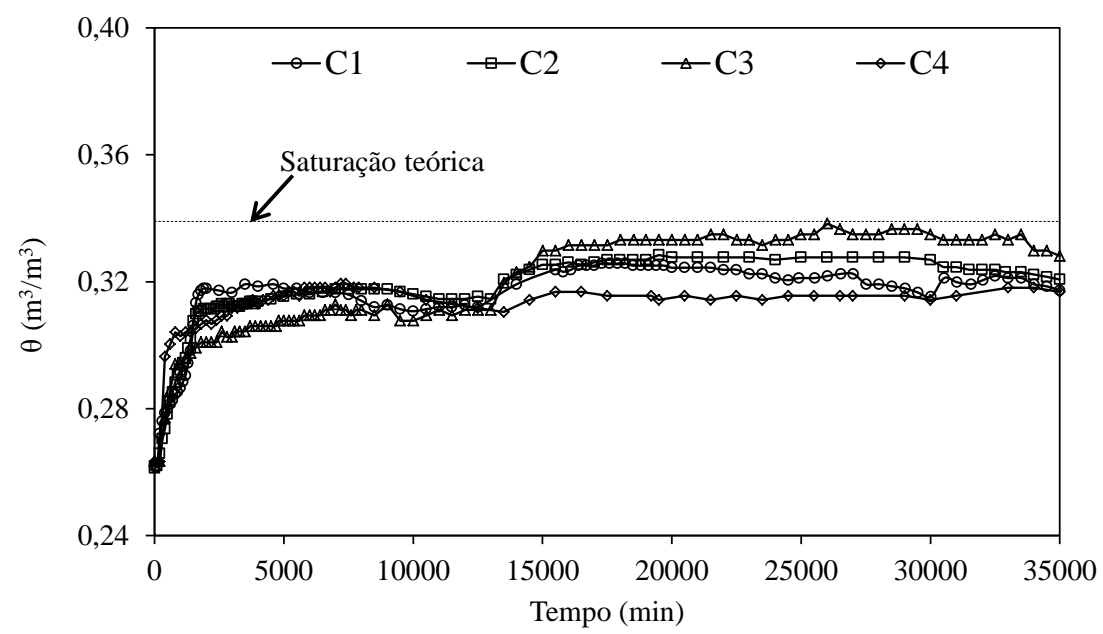

Figura 7.8. Resultados das leituras dos sensores de umidade volumétrica dispostos na linha L1.

Na Figura 7.9, referente à linha de sensores L2, os resultados apresenta-se ainda mais coerentes. De modo geral, os valores de umidade volumétrica foram praticamente os mesmos para todas as colunas instrumentadas, sendo próximos da capacidade de campo. Semelhanças nas tendências de umedecimento podem ser inclusive observadas no trecho da curva até 2000 minutos, entre os valores de umidade inicial e de capacidade de campo.

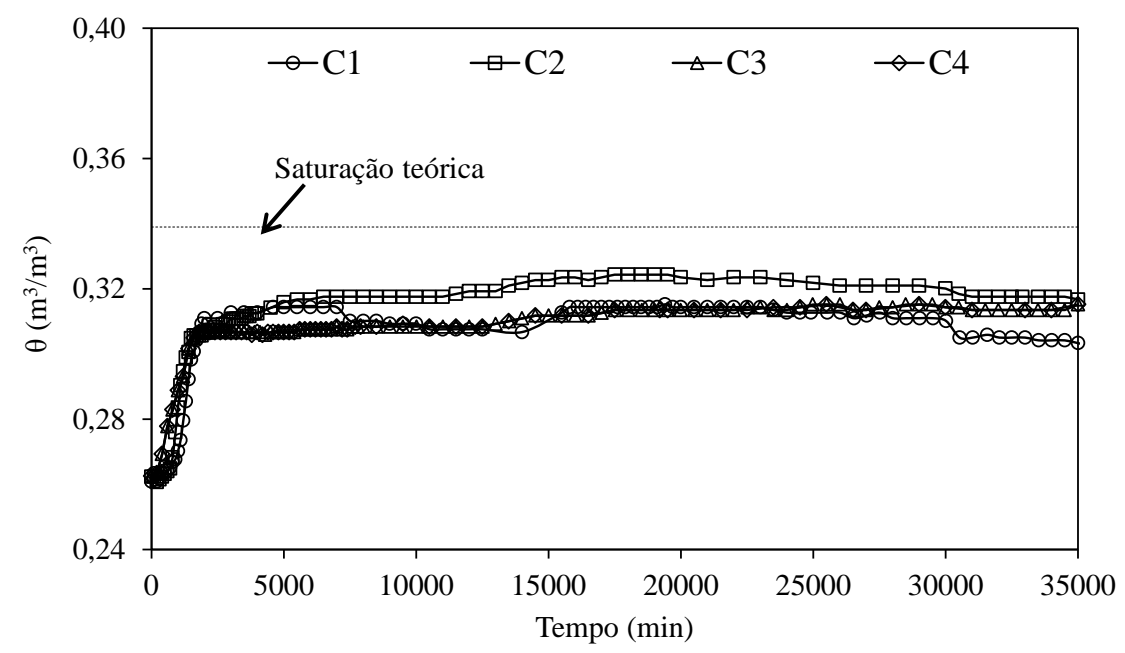

Figura 7.9. Resultados das leituras dos sensores de umidade volumétrica dispostos na linha L2.

Já na linha de sensores L3 (Figura 7.10), posicionados a $20 \mathrm{~cm}$ do topo, observa-se que somente os sensores das colunas C3 e C4 apresentaram valores de teor de umidade de capacidade de campo durante infiltração. Os sensores das colunas C1 e C2 mostram que após a fase de umedecimento, os valores de umidade tenderam à saturação. Este comportamento é decorrente da prévia formação de barreira capilar nas colunas $\mathrm{C} 1$ e $\mathrm{C} 2$, em relação às outras colunas. Constata- 
se com isso que, o acúmulo de água alcançou a altura máxima de 7,5 $\mathrm{cm}$ acima do reforço, o que corresponde a linha L3.

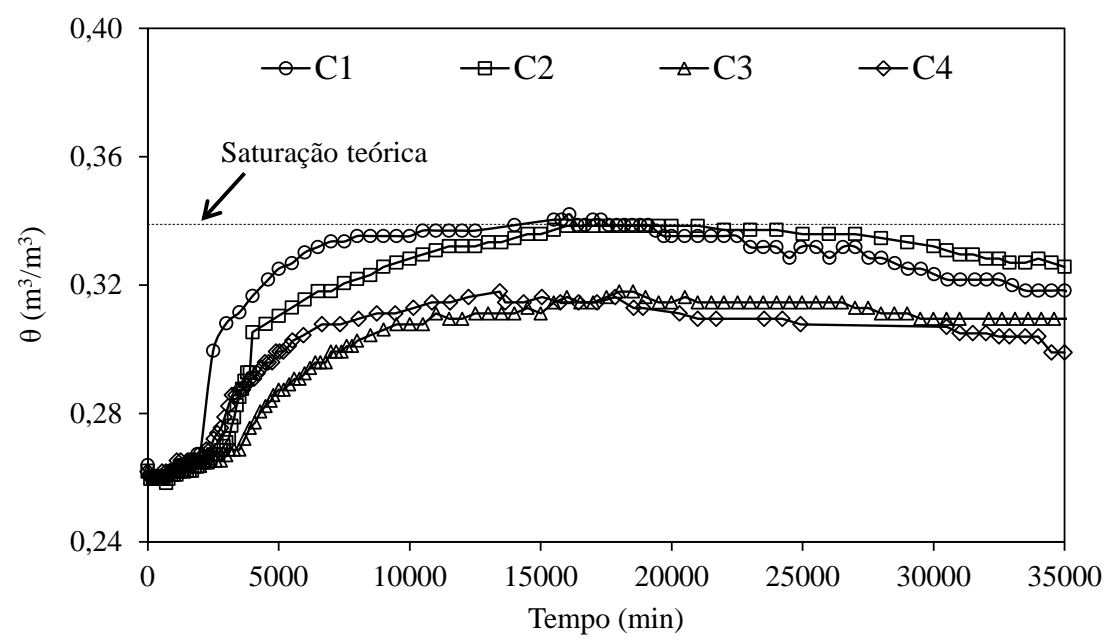

Figura 7.10. Resultados das leituras dos sensores de umidade volumétrica dispostos na linha L3.

Os resultados dos sensores da linha L4 (Figura 7.11), localizada a 2,5 $\mathrm{cm}$ acima do reforço, mostram que todos os sensores alcançaram o teor de umidade referente à saturação do solo após a fase de umedecimento. Portanto, nesta linha de sensores, a barreira capilar promoveu aumentos nos teores de umidade volumétrica devido ao acúmulo de água acima do reforço. $\mathrm{Na}$ fase de umedecimento, em que o teor de umidade volumétrica varia da condição inicial até a capacidade de campo, as trajetórias apresentam-se diferentes entre os sensores das colunas $\mathrm{C} 1 \mathrm{e}$ $\mathrm{C} 2$ e colunas $\mathrm{C} 3$ e C4. Tal comportamento pode ser resultado da trajetória preferencial da água devido ao escoamento superficial.

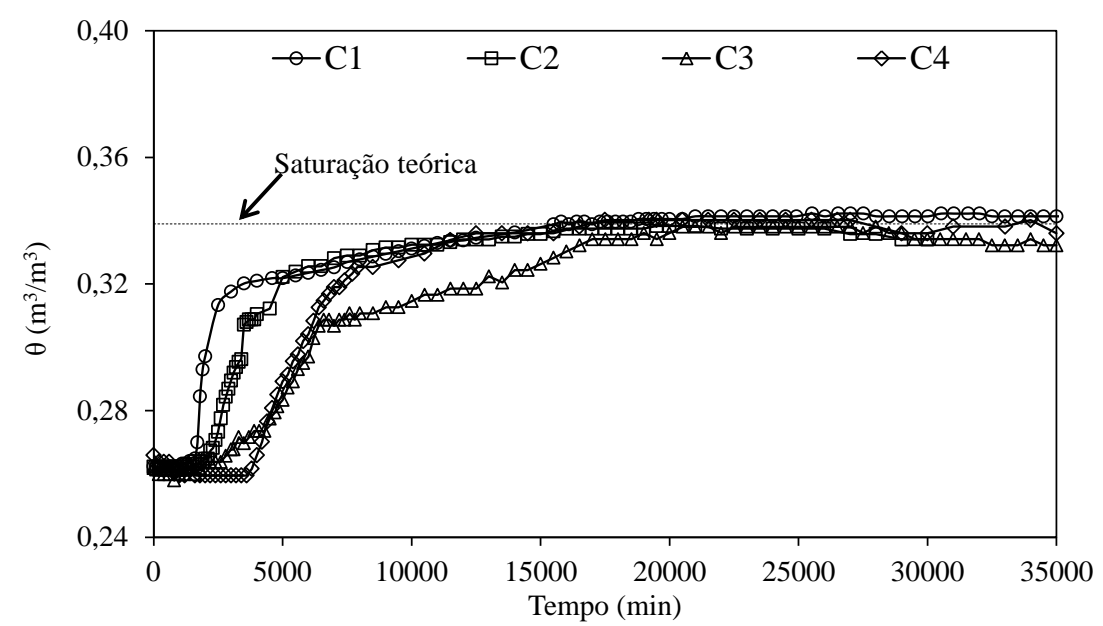

Figura 7.11. Resultados das leituras dos sensores de umidade volumétrica dispostos na linha L4.

Nos sensores da linha abaixo do reforço, ou seja, na linha L5 (Figura 7.12), o avanço do umedecimento sofreu um retardamento em relação à linha L4 devido ao bloqueio do fluxo pela barreira capilar. Isto pode ser verificado com base no umedecimento progressivo entre as linhas 
instrumentadas que não atravessam os reforços, ou seja, entre o topo do protótipo e a linha L4. Naturalmente, sem o geotêxtil não tecido, cada linha de sensores começou a ser umedecida logo após o completo umedecimento da linha anterior. Ao alcançar a linha do reforço, o atraso no umedecimento devido à barreira foi de 2500 minutos, ou seja, aproximadamente dois dias. Após a quebra, a frente de infiltração avançou para a camada reforçada 4, resultando em valores de umidade menores que a capacidade de campo. Isto é um indicativo de que parte da água acumulada pela barreira foi drenada após a quebra.

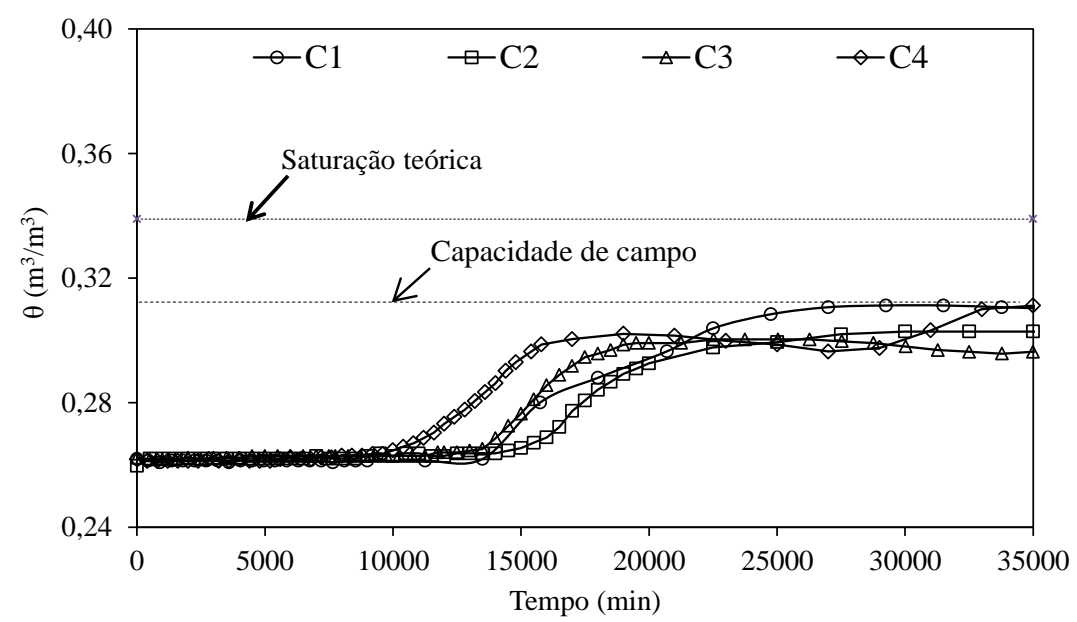

Figura 7.12. Resultados das leituras dos sensores de umidade volumétrica dispostos na linha L5.

Portanto, foi evidenciada a presença de barreiras capilares durante o processo de infiltração, e a posterior drenagem de parte da água acumulada para fora da zona reforçada, conduzida ao longo do comprimento do reforço permeável. Cabe conhecer agora, o processo completo de infiltração para que este seja associado ao comportamento do protótipo. O processo de avanço de umedecimento foi analisado nos mesmos moldes utilizados no Capítulo 6.

Os perfis de infiltração foram definidos com base nas alterações dos valores de teor de umidade ao longo da altura do protótipo durante o processo de avanço de umedecimento. Para o presente protótipo (M3), os perfis foram mais facilmente definidos, em relação aos do protótipo M2, por apresentarem uma maior quantidade de sensores ao longo da mesma seção instrumentada. Ainda, com a concentração dos sensores em torno do reforço geotêxtil, foi possível visualizar como a infiltração ocorreu na interface, podendo-se extrapolar o comportamento hidráulico observado para as outras camadas que compõe o protótipo.

Os perfis de infiltração na seção central do protótipo M3, para os tempos de 0, 1000, 2000, 10000, 24000 e 30000 minutos de ensaio, são apresentados nas Figuras 7.13, 7.14 e 7.15. 

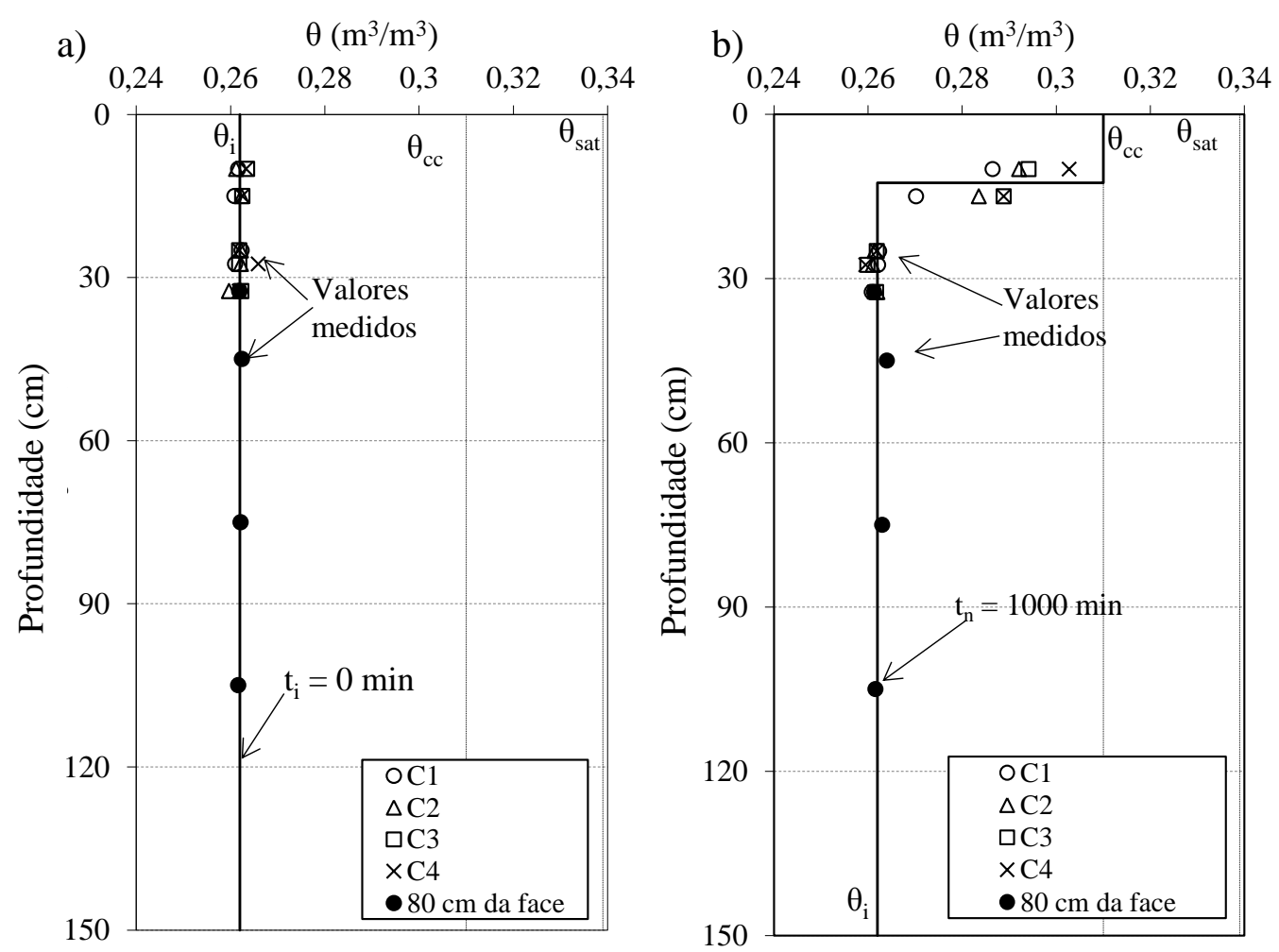

Figura 7.13. Perfil de infiltração na seção central do protótipo: (a) condição inicial de ensaio; (b) após 1000 minutos.
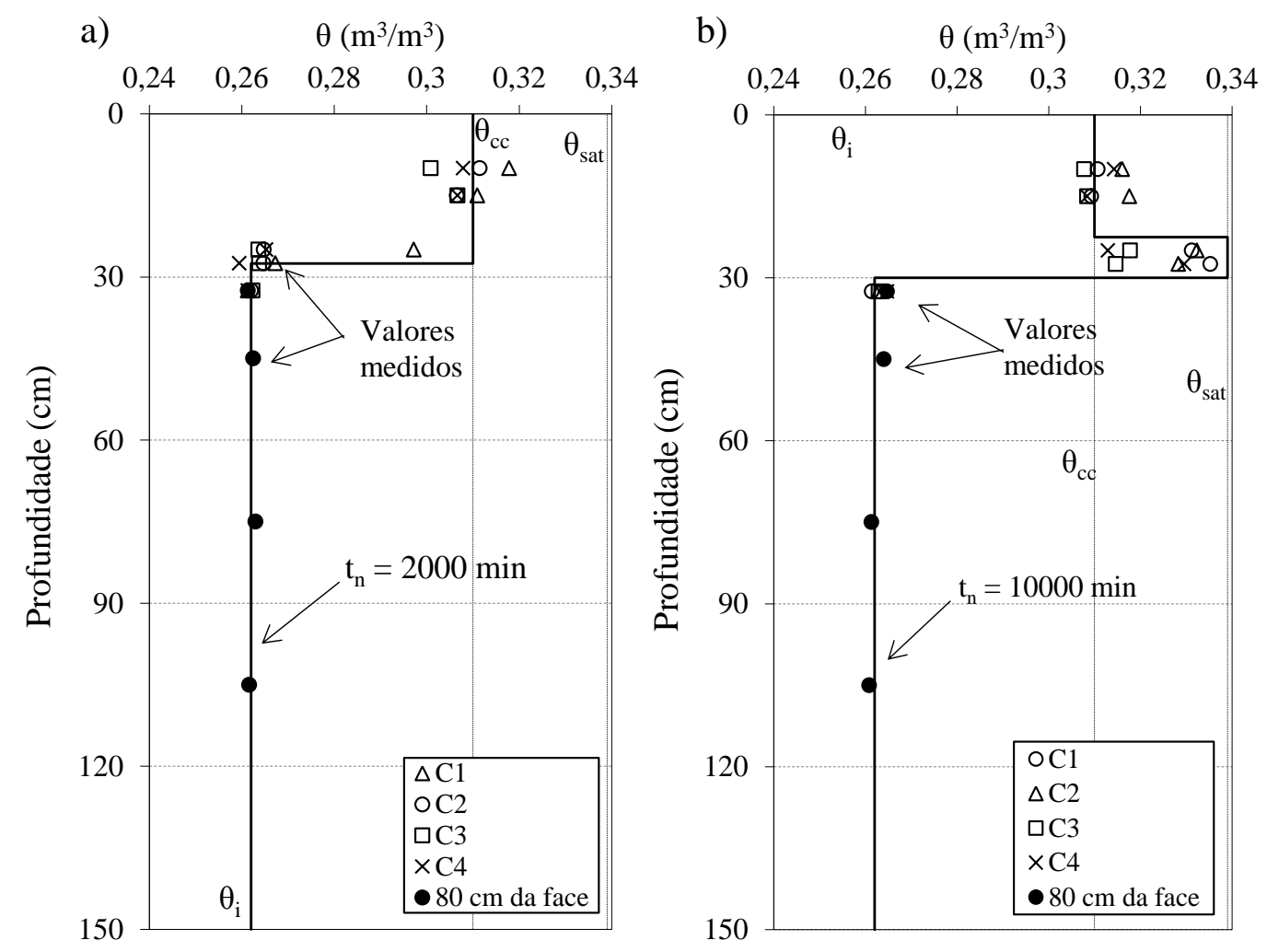

Figura 7.14. Perfil de infiltração na seção central do protótipo: (a) após 2000 minutos; (b) após 10000 minutos de ensaio. 

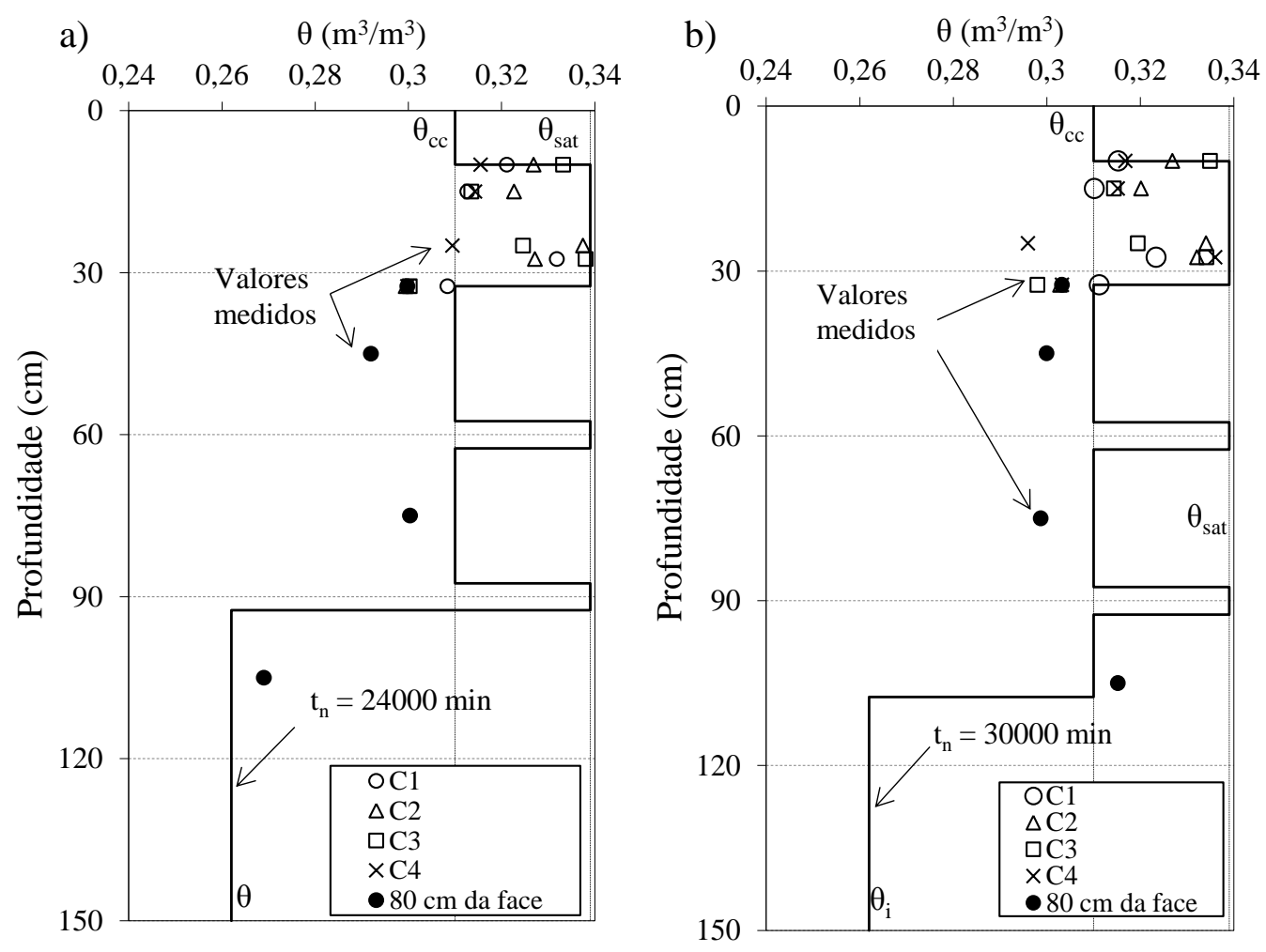

Figura 7.15. Perfil de infiltração na seção central do protótipo: (a) após 24000 minutos; (b) após 30000 minutos de ensaio.

De modo geral, pode-se afirmar que os perfis de infiltração foram bastante consistentes com os valores de teor de umidade volumétrica medidos, inclusive no que se refere ao comportamento em regiões próximas dos geotêxteis não tecidos. A linha de infiltração nas interfaces solo-reforço pode ser representada por maiores valores de umidade volumétrica (umidade na saturação) devido à barreira capilar e a capacidade de drenar água constantemente durante a infiltração. Essa representação é baseada na análise computacional realizada por Iryo e Rowe (2005).

Os perfis de infiltração no início e após 1000 minutos de ensaio são apresentados na Figura 7.13. Durante este período, correspondente a 17 horas de ensaio, o umedecimento avançou $15 \mathrm{~cm}$ em relação ao topo do protótipo. Após 2000 minutos, a frente de umedecimento alcançou a linha de reforço da camada 5, mantendo-se nesta profundidade até o período de 10000 minutos de ensaio, ou seja, durante 7 dias (Figura 7.14). Este retardamento do avanço foi decorrente da restrição do fluxo devido à barreira capilar. Nestes casos, os perfis também descreveram com eficácia o comportamento de infiltração no protótipo. Após estes períodos, a frente de umedecimento foi avançando progressivamente até alcançar a base do protótipo, no tempo de 35000 minutos (24 dias - Figura 7.15). Os perfis de infiltração entre os períodos mostrados neste capítulo são apresentados no Apêndice B.

Foi definido, portanto, o processo de infiltração de água no protótipo M3, bem como o cumprimento da função de drenagem interna dos reforços de geotêxteis não tecidos. De modo a 
verificar a ocorrência do retardamento da infiltração por barreiras capilares nas interfaces das outras linhas de reforços, a profundidade da frente de infiltração (z) foi plotada na Figura 7.16, nos diferentes períodos durante o ensaio. Plotou-se também um linha estimada de infiltração, extrapolando-se o comportamento hidráulico monitorado na camada 5 para as camadas inferiores. Com base nesta extrapolação, verifica-se que barreiras capilares possivelmente se formaram nos reforços das camadas 2, 3 e 4, uma vez que a taxa de infiltração foi bastante aproximada à infiltração estimada. Já na camada 1 , a vida da barreira capilar parece ter sido menor que as outras camadas. Cabe ainda observar que, a taxa de infiltração no solo, considerando a ausência dos reforços, poderia ser representada pela linha tracejada da Figura 7.16, baseada na taxa de infiltração registrada antes da frente de umedecimento alcançar a linha de reforço. Com base nesta taxa, pode-se dizer que o retardamento devido à presença dos reforços foi significativo.

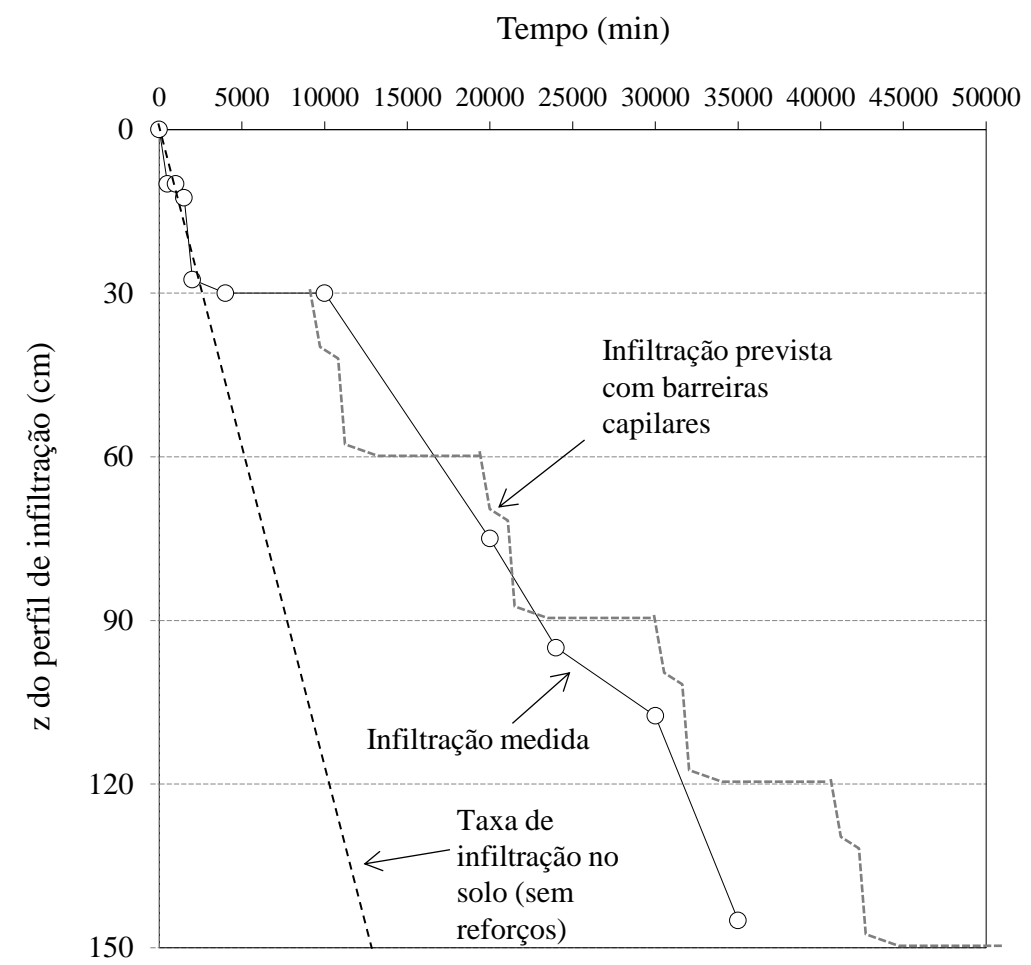

Figura 7.16. Profundidade de infiltração x tempo: infiltração medida e infiltração prevista devido ao efeito da barreira capilar.

Nas Figuras 7.17, 7.18 e 7.19, os perfis de infiltração foram plotados em termos de sucção matricial. Neste caso, foram adotados os valores de sucção correspondentes aos teores de umidade volumétrica inicial, capacidade de campo e na saturação obtidos pela relação estabelecida na curva de retenção de água do solo. Os perfis em função da sucção matricial foram comparados aos valores experimentais obtidos pelos tensiômetros. Com isso, verificou-se que o perfil descreve consistentemente a infiltração no protótipo, mesmo quando representado em termos de sucção matricial. Estes perfis, entre os períodos mostrados nestas figuras, podem ser visualizados no 
Apêndice B. Nas análises de equilíbrio limite, serão utilizados os perfis de infiltração em termos de sucção matricial.

a) Sucção matricial, $\mathrm{u}_{\mathrm{a}}-\mathrm{u}_{\mathrm{w}},(\mathrm{kPa})$

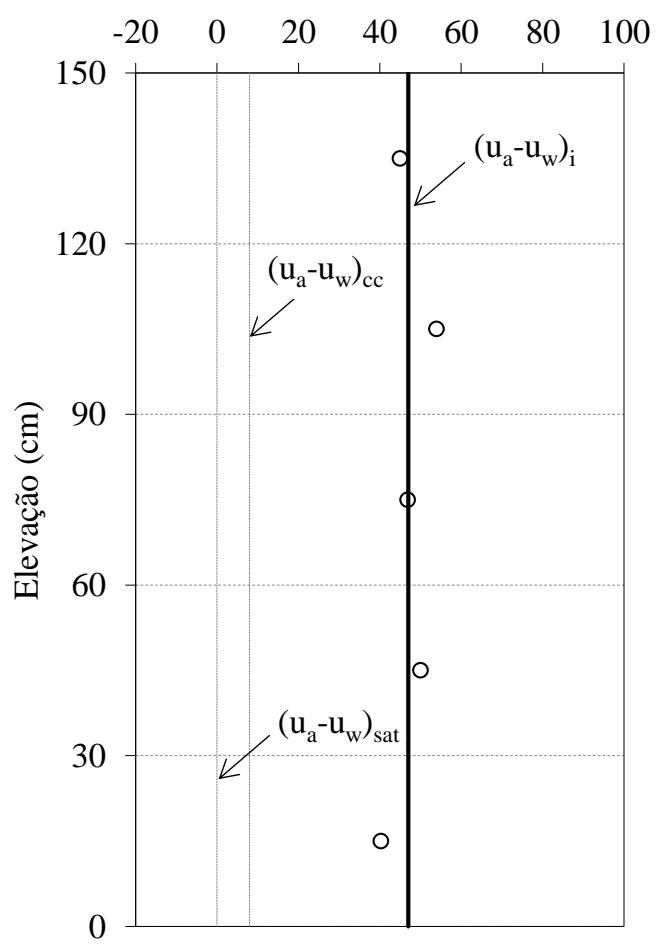

b) Sucção matricial, $\mathrm{u}_{\mathrm{a}}-\mathrm{u}_{\mathrm{w}},(\mathrm{kPa})$

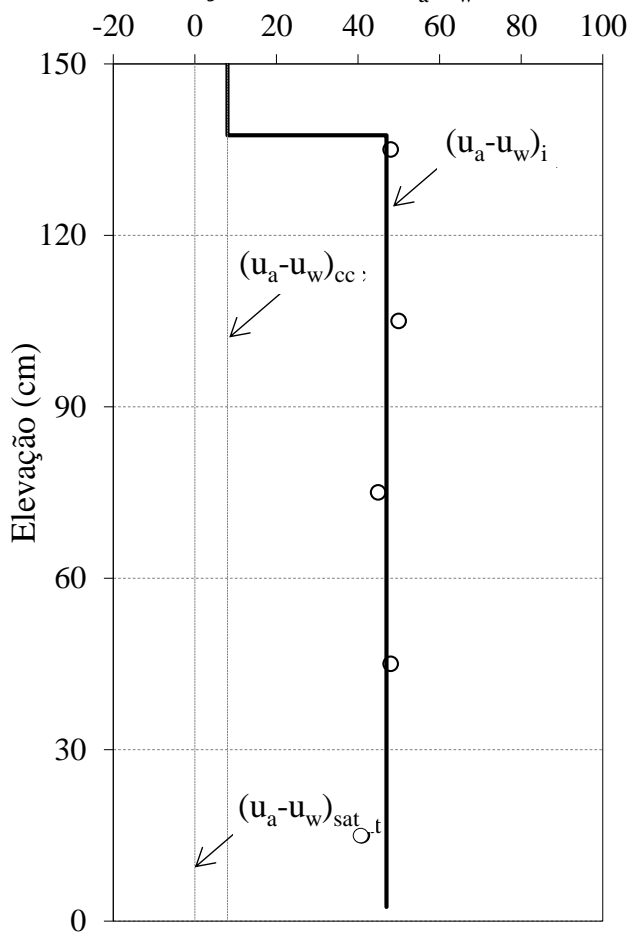

Figura 7.17. Perfil de infiltração em termos de sucção matricial com o tempo: (a) condição inicial de ensaio; (b) 1000 minutos.

a) Sucção matricial, $\mathrm{u}_{\mathrm{a}}-\mathrm{u}_{\mathrm{w}},(\mathrm{kPa})$

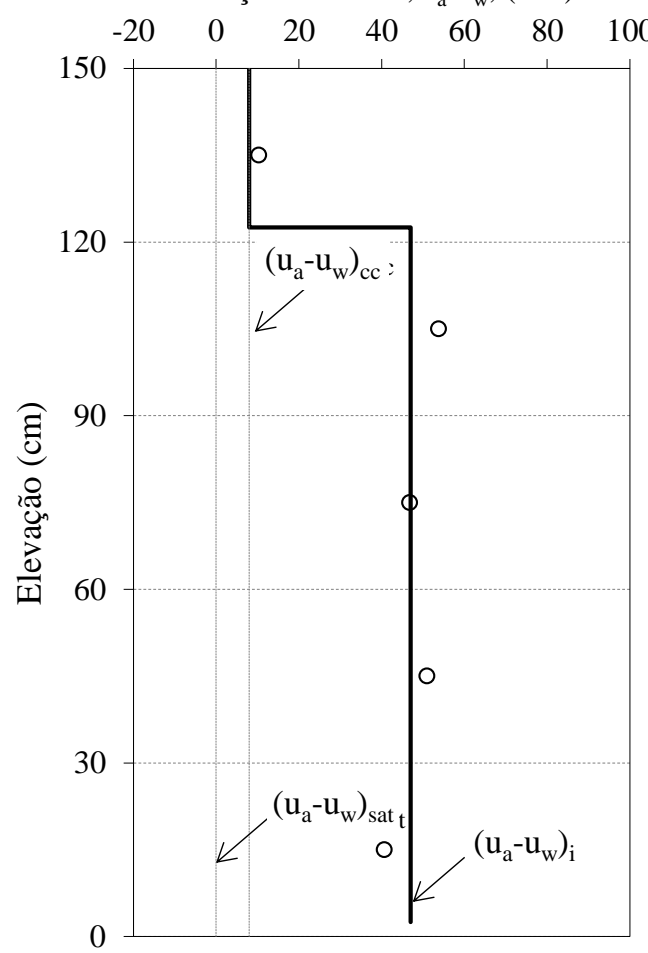

b) Sucção matricial, $\mathrm{u}_{\mathrm{a}}-\mathrm{u}_{\mathrm{w}},(\mathrm{kPa})$

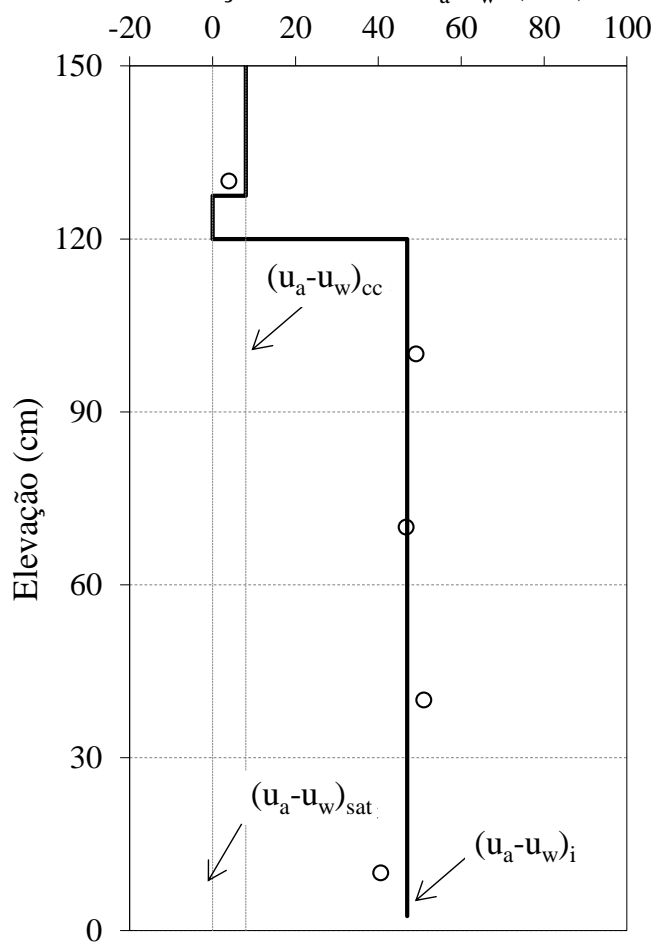

Figura 7.18. Perfil de infiltração em termos de sucção matricial com o tempo: (a) após 2000 minutos; (b) após 10000 minutos. 
a) Sucção matricial, $\mathrm{u}_{\mathrm{a}}-\mathrm{u}_{\mathrm{w}},(\mathrm{kPa})$

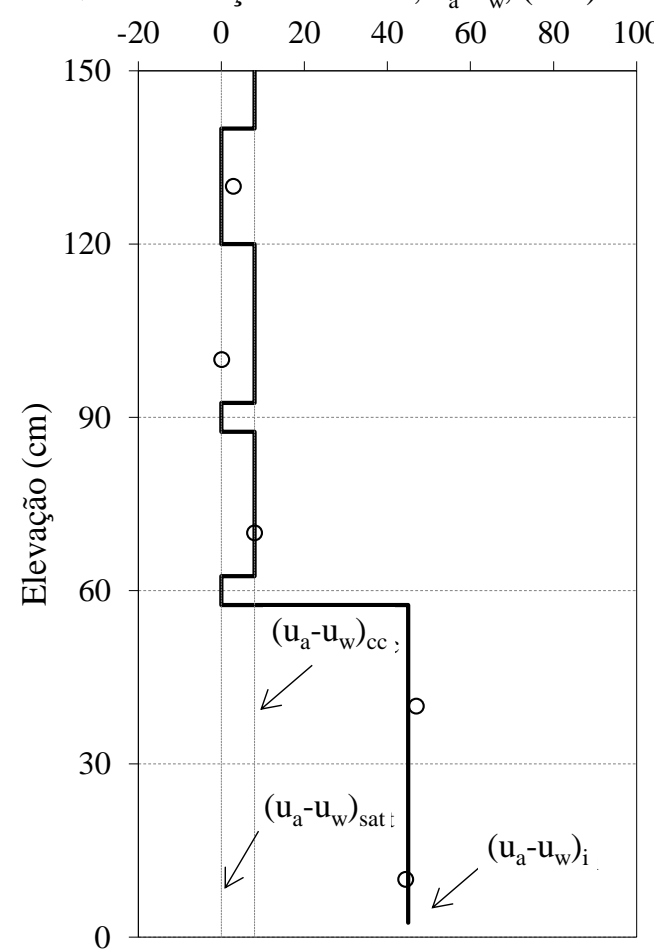

b) Sucção matricial, $\mathrm{u}_{\mathrm{a}}-\mathrm{u}_{\mathrm{w}},(\mathrm{kPa})$

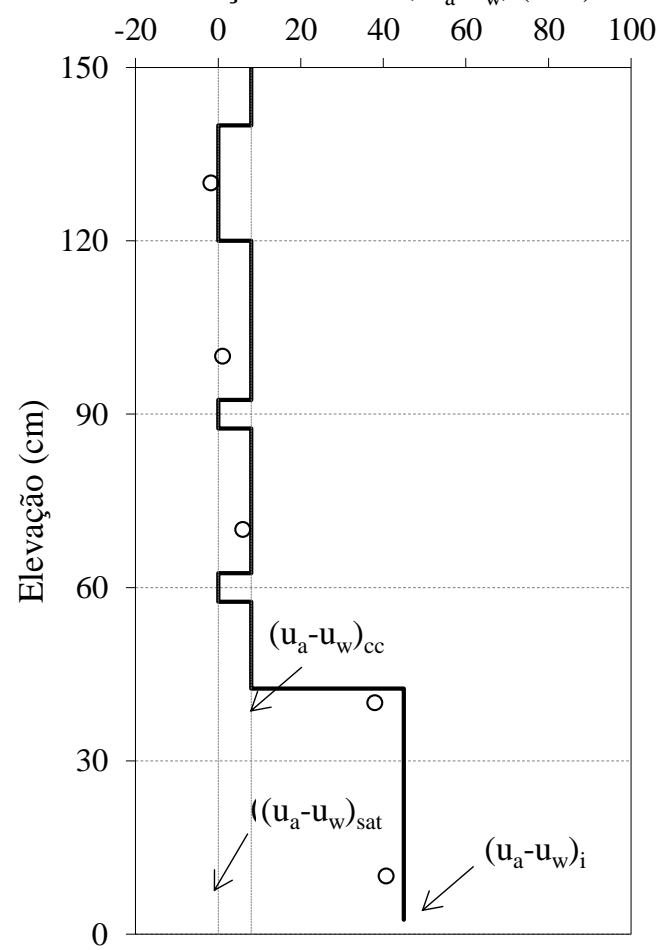

Figura 7.19. Perfil de infiltração em termos de sucção matricial com o tempo: (a) após 24000 minutos; (b) após 30000 minutos.

Assim, duas hipóteses são estabelecidas sobre o efeito da barreira capilar no comportamento de uma estrutura de solo reforçado:

- a restrição do avanço da frente de umedecimento na camada superficial favorece o comportamento da estrutura como um todo, já que a rigidez do solo das camadas abaixo da primeira barreira pode ser mantida durante a vida útil da estrutura. Períodos de secagem podem favorecer o prolongamento da vida da barreira capilar, evitando a quebra. Com isso, somente o solo da camada superficial sofre redução da sucção, e o comportamento global da estrutura é garantido pela manutenção da sucção das outras camadas.

- o armazenamento de água acima da barreira e a possibilidade do desenvolvimento de pressão da água na interface pode prejudicar a estabilidade localmente, ou até mesmo, embarrigar a face da camada atingida pela barreira. Essa é uma situação em regiões com períodos intensos de precipitação que, eventualmente, podem promover a formação e a quebra da barreira nos diferentes níveis de reforços.

Os tópicos posteriores deste capítulo serão dedicados a identificar e confirmar algumas das hipóteses relatadas. 


\subsection{Constatações quanto ao efeito hidráulico da interface no comportamento do protótipo}

\subsubsection{Deslocamentos horizontais}

Os resultados dos deslocamentos horizontais internos $\left(\delta_{\mathrm{i}}\right)$ de cada camada reforçada do protótipo M3 são apresentados na Figura 7.20. De modo geral, os níveis de deslocamentos foram bastante aproximados aos medidos no protótipo M2, com valores máximos de 3,0 $\mathrm{mm}$, sendo estes ocorridos nos pontos fixados na face do protótipo e nas camadas 1 e 5.
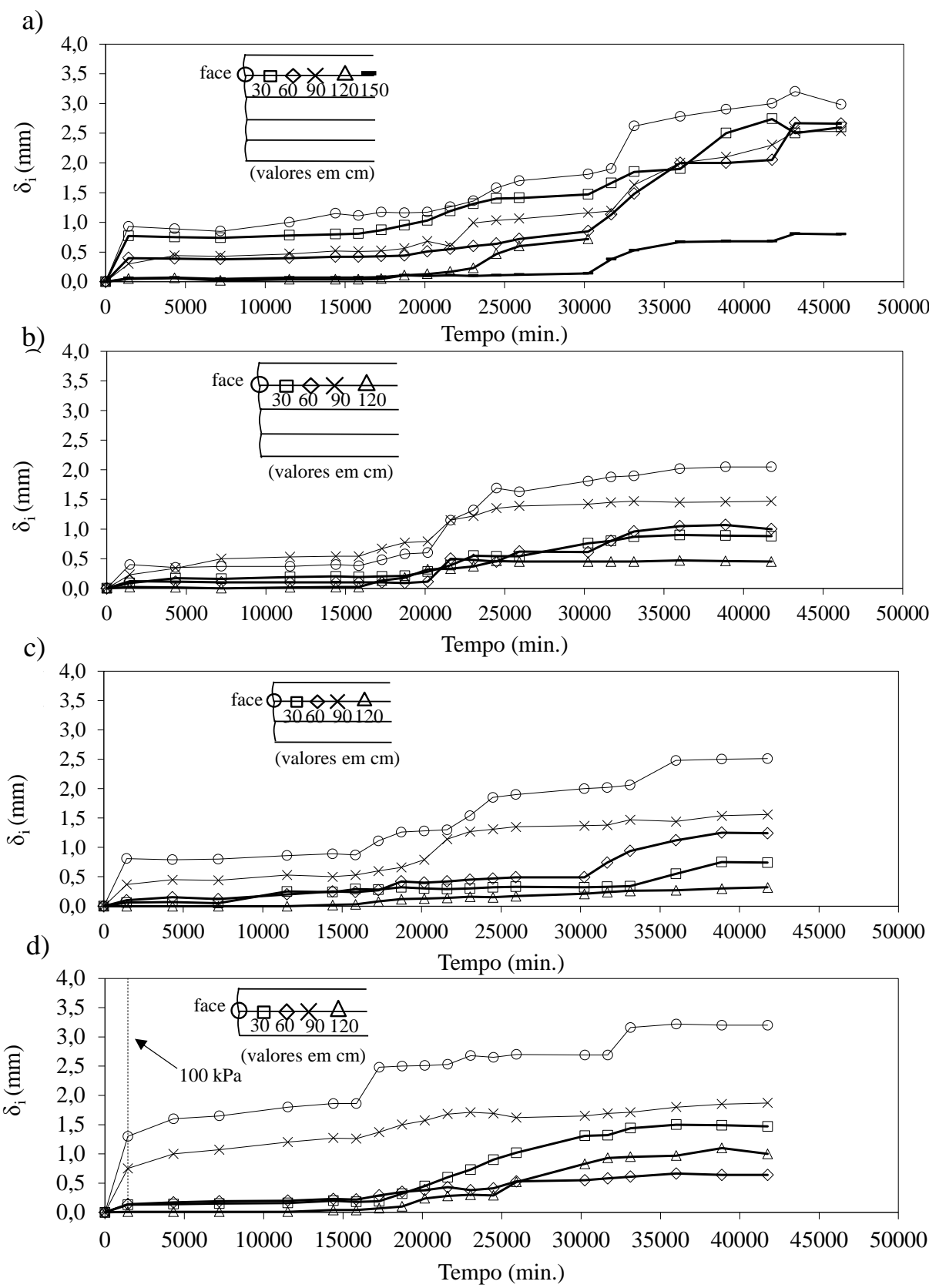

Figura 7.20. Deslocamentos horizontais internos do protótipo M3: (a) camada 5; (b) camada 4; (c) camada 3 ; (d) camada 2. 
Nota-se na Figura 7.20, o aumento dos deslocamentos com o tempo devido ao processo de avanço do umedecimento, sendo estes significativos após 20000 minutos de ensaio. Tais aumentos continuaram até o tempo em torno de 25000 minutos, e posteriormente, voltaram a aumentar em menores taxas.

O efeito do processo de infiltração nos deslocamentos do protótipo pode ser melhor visualizado na Figura 7.21, que mostra a evolução dos deslocamentos internos máximos $\left(\delta_{i, m a ́ x}\right)$ e do teor de umidade volumétrica durante o ensaio. Com isso, consegue-se relacionar as mudanças da umidade com as alterações nos deslocamentos internos máximos de cada camada reforçada. Como no capítulo anterior, os deslocamentos internos máximos aumentaram ao longo do tempo do mesmo modo em que as umidades volumétricas.

a)

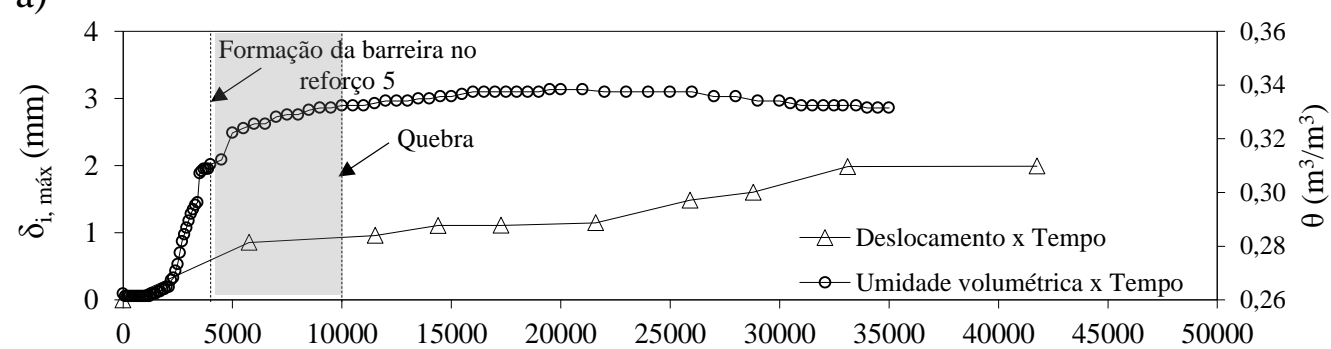

b) Tempo (min.)

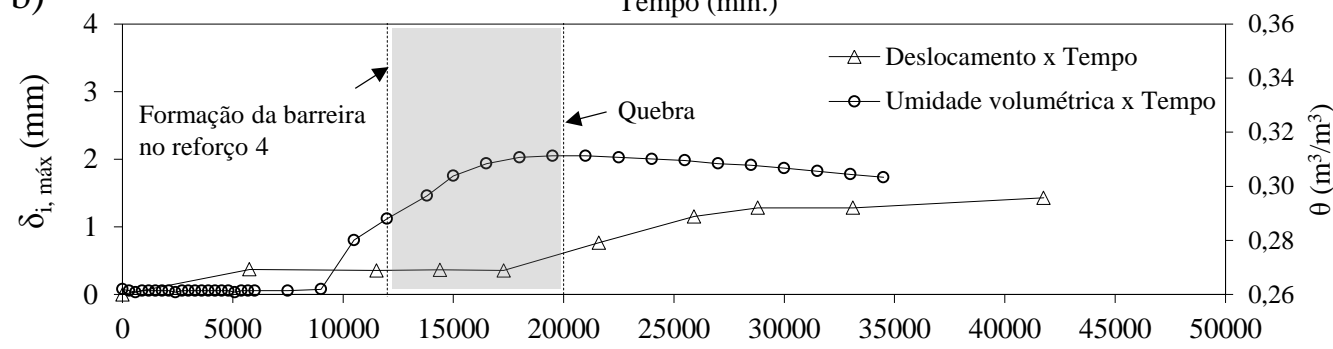

c) Tempo (min.)

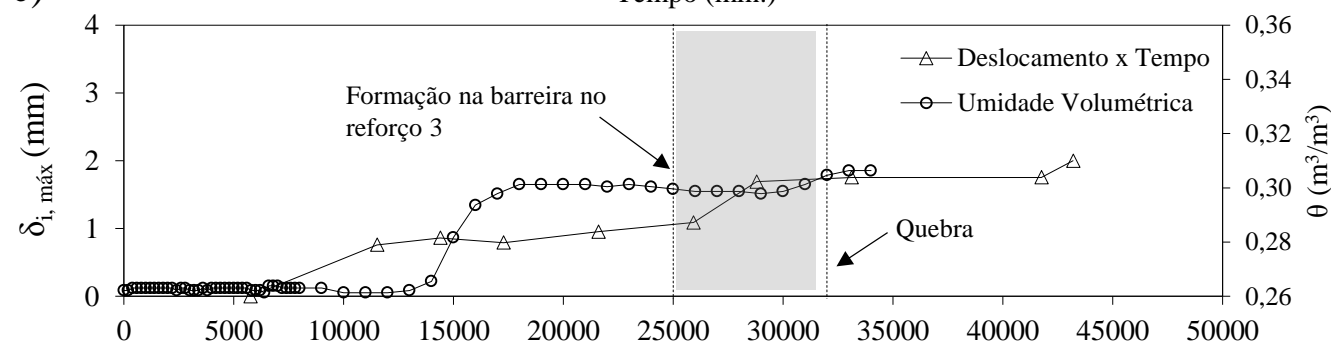

d) Tempo (min.)

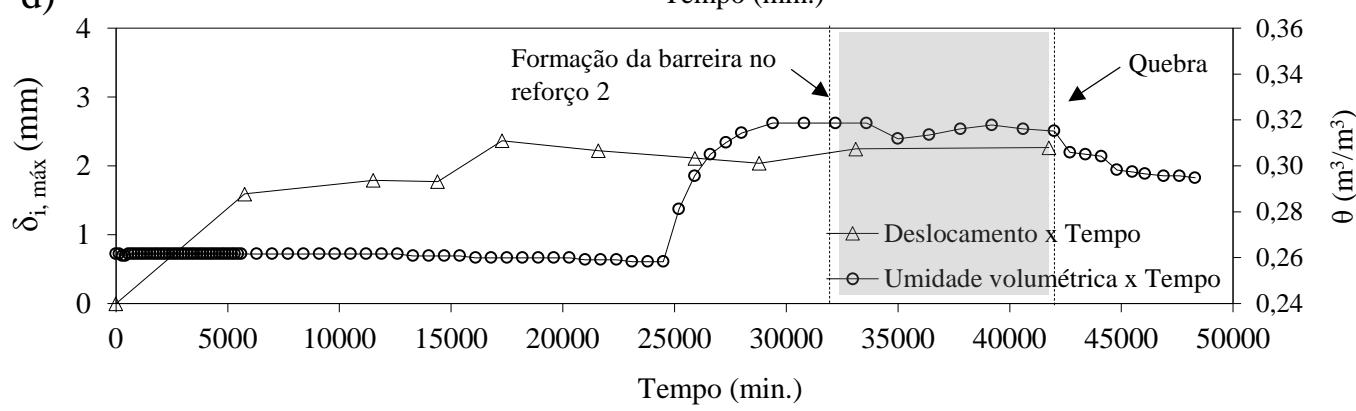

Figura 7.21. Evolução do deslocamento interno máximo e do teor de umidade volumétrica do protótipo M3: (a) camada 5; (b) camada 4; (c) camada 3; (d) camada 2. 
Na Figura 7.22 são apresentadas as medidas dos deslocamentos de face $\left(\delta_{\text {face }}\right)$ durante o ensaio, bem como a evolução dos teores de umidade volumétrica de cada camada reforçada. Os deslocamentos de face medidos externamente apresentam comportamento semelhante aos deslocamentos horizontais internos máximos (Figura 7.21). Assim como verificado no protótipo M2, os deslocamentos de face aumentaram com o tempo devido ao processo de umedecimento do solo. É Importante destacar que os níveis de deslocamentos de face máximos foram significativamente menores que os medidos no protótipo M2. As comparações e discussões entre protótipos serão realizadas no capítulo 10.

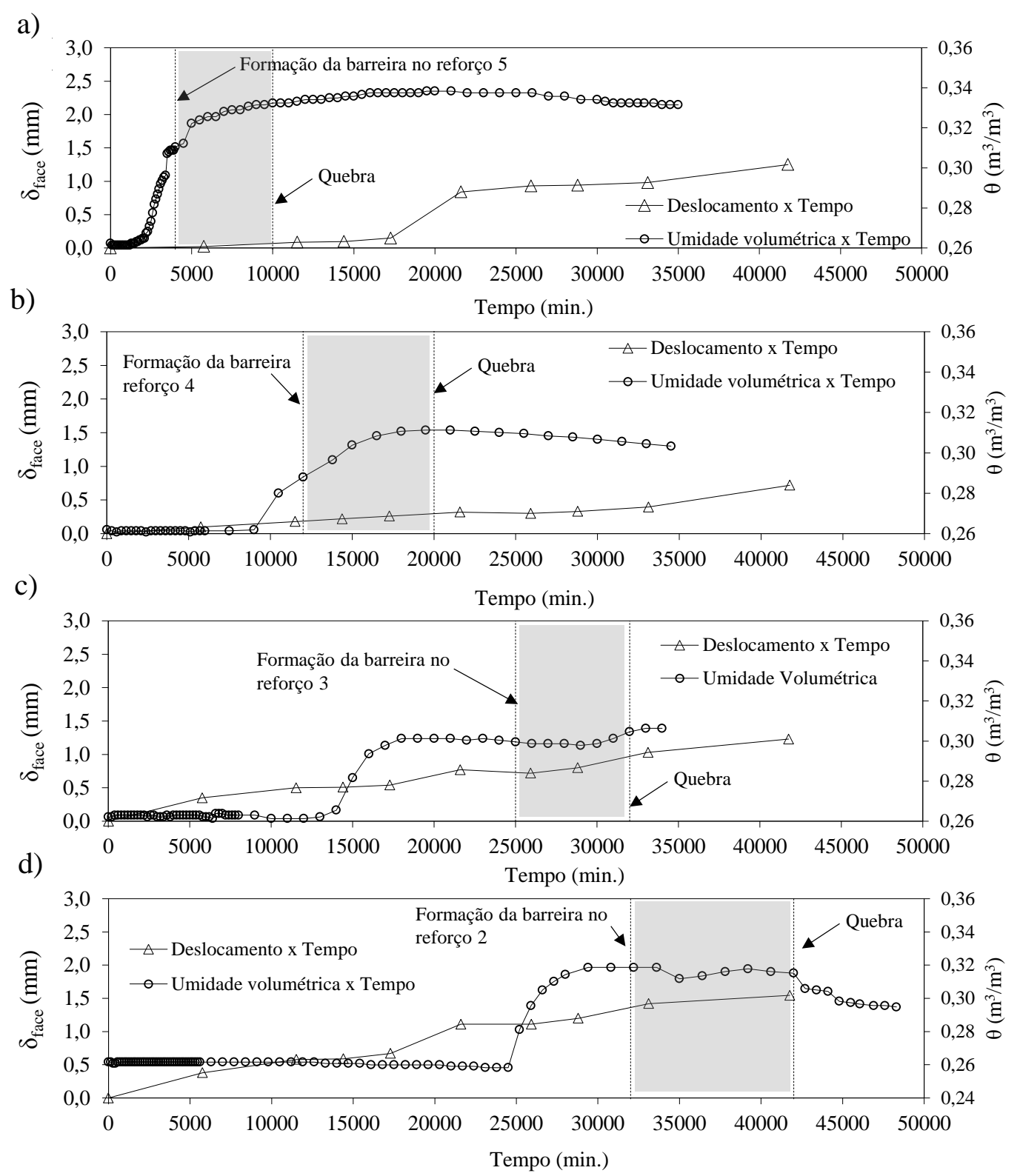

Figura 7.22. Evolução dos deslocamentos de face e teores de umidade volumétrica do solo com o tempo do protótipo M3: (a) camada 5; (b) camada 4; (c) camada 3; (d) camada 2.

De modo a compreender o efeito do comportamento hidráulico de interface nos deslocamentos do protótipo, nas Figuras 7.21 e 7.22 foram identificados os tempos de início de 
formação e quebra das barreiras capilares em cada camada reforçada. Com relação ao efeito da barreira capilar nos deslocamentos da estrutura, dois aspectos gerais são importantes de serem observados: (1) no momento em que a barreira é formada (linha tracejada dos gráficos), os deslocamentos de todas as camadas se estabilizam por um determinado período de tempo, o que é devido à restrição do fluxo nesse período; (2) após esse período de estabilização, os deslocamentos tornam a aumentar, o que pode ser atribuído á liberação do fluxo de água devido à quebra da barreira, promovendo o avanço do umedecimento nas camadas inferiores e reduzindo a sucção do solo das mesmas.

Aparentemente, o processo de armazenamento de água devido à barreira capilar não resultou em efeitos maléficos no comportamento global da estrutura, nem mesmo promoveu instabilidades locais (rupturas localizadas ou deformações excessivas locais). A instabilidade local poderia ser identificada neste trabalho com base nos deslocamentos de face, medidos externamente na região central da face de cada camada reforçada. O "embarrigamento" local das camadas poderia ser um indício do efeito do armazenamento de água nas camadas, o que não foi identificado. Pode-se dizer que o espaçamento entre reforços de $30 \mathrm{~cm}$ não permitiu que tal comportamento acontecesse. Dessa forma, a recomendação de utilizar espaçamentos máximos de $40 \mathrm{~cm}$ para estruturas de não tecidos pode ser eficiente para a eliminação deste fenômeno.

A distribuição dos deslocamentos de face ao longo da altura do protótipo M3 é ilustrada na Figura 7.23, na qual se pode observar que os deslocamentos de face máximos ocorreram no primeiro terço, assim como verificado nos protótipos anteriores. No entanto, durante o processo de infiltração, os deslocamentos de face na camada 5, aumentaram em maiores taxas. Neste caso, pode-se observar o efeito do avanço do umedecimento nas alterações dos deslocamentos de face, assim como verificado no protótipo M2. Embora os deslocamentos de face máximos se mantivessem posicionados no primeiro terço da altura da estrutura, as maiores taxas de incrementos de deslocamentos coincidem com a profundidade da linha de avanço. Em adição, nesta figura fica claramente constatado que barreiras capilares não proporcionaram deslocamentos locais excessivos na face, embora estes tenham aumentado. 


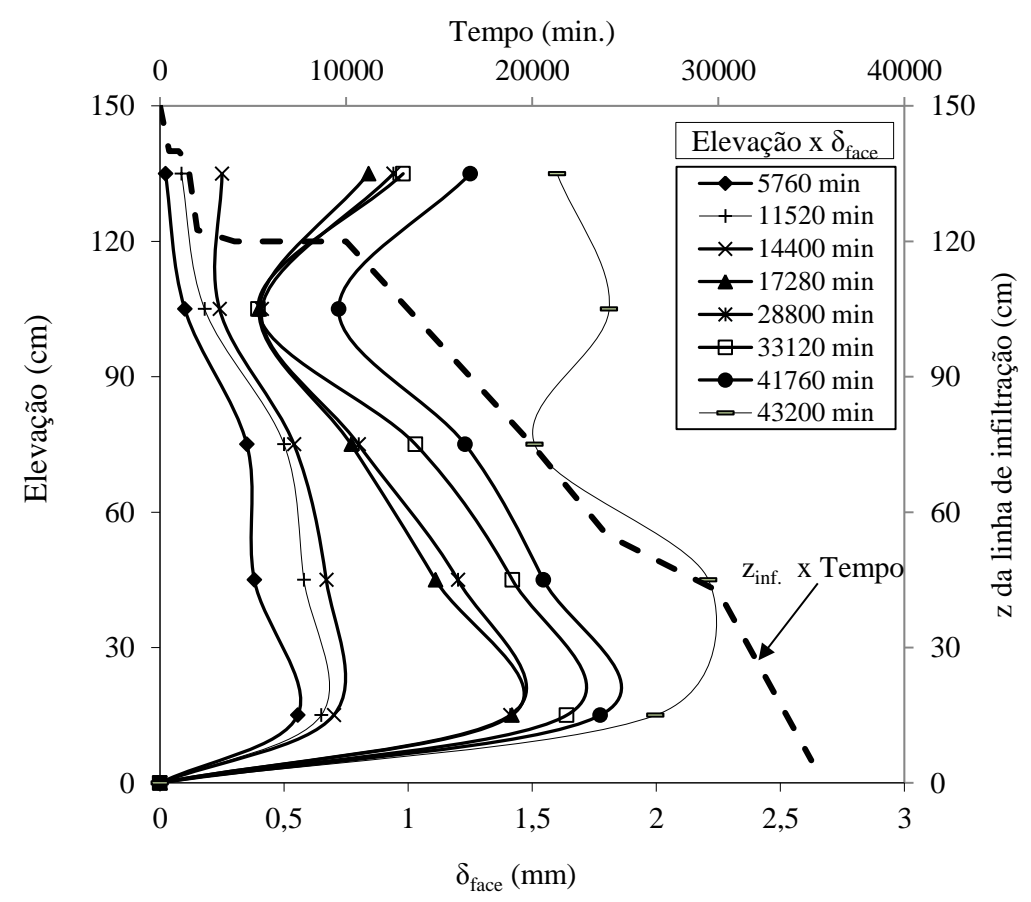

Figura 7.23. Distribuições dos deslocamentos de face do protótipo M3: (a) ao longo da altura do protótipo; (b) influência do avanço do umedecimento.

\subsubsection{Deformação nos reforços}

As deformações nos reforços foram calculadas utilizando da mesma metodologia aplicada aos protótipos M1 e M2. Os ajustes sigmoidais nos pontos experimentais em diferentes tempos durante o ensaio são apresentados na Figura C1, do apêndice C. As distribuições das deformações nos reforços resultantes da derivação das curvas sigmoidais são mostradas na Figura 7.24. Nota-se que, os picos de deformações em cada camada reforçada localizaram-se em diferentes distâncias em relação à face, possibilitando a determinação da superfície de ruptura real. Observou-se, as deformações de pico aumentaram com o tempo devido ao avanço da frente de umedecimento no interior da zona reforçada e consequente diminuição da sucção do solo. Foi observado que as distribuições das deformações em cada camada não se alteraram, ao contrário do observado na Figura 6.19 do Capítulo 6. A diferença entre ambas as estruturas está no regime de chuvas simulado. No capítulo 6, a estrutura foi submetida a chuvas aleatórias de intensidades muito maiores as do protótipo M3. Dessa forma, um grande volume de água escoou no topo do protótipo M2, resultando em avanço preferencial nas regiões próximas da face. Uma vez que esta região passa a ser preferencialmente umedecida, a localização da força máxima no reforço pode ser transferida, já que a sucção do solo foi primeiramente reduzida nesta região (Figura 6.2). 
a)
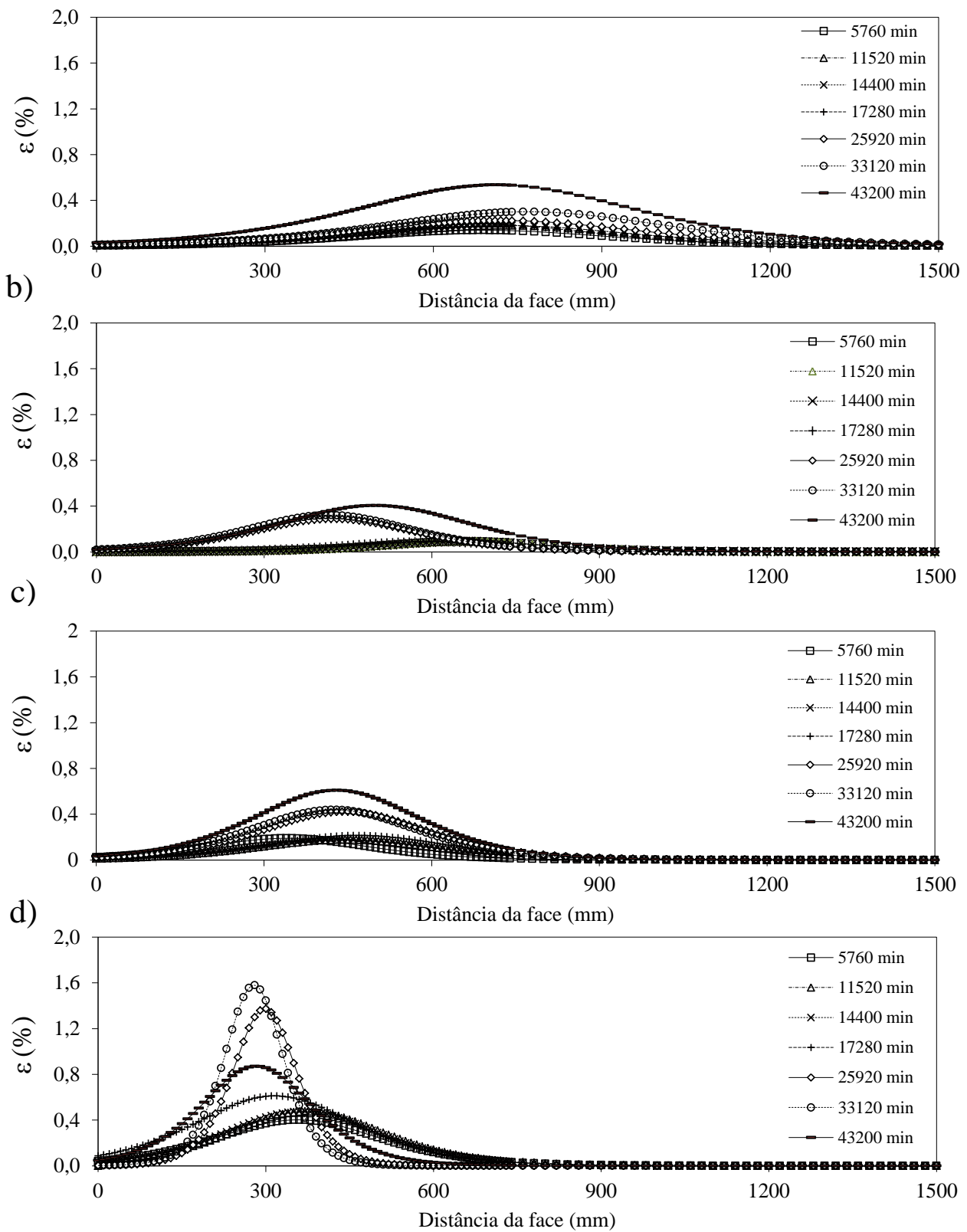

Figura 7.24. Distribuição das deformações ao longo do comprimento dos reforços geotêxteis: (a) camada 5; (b) camada 4; (c) camada 3; (d) camada 2.

As superfícies reais de ruptura e a distribuição das deformações de pico ao longo da altura do protótipo M3 são ilustradas na Figura 7.25. Na tentativa de definir uma equação para a superfície de ruptura real obtida experimentalmente, ajustes resultaram em equações potenciais, do mesmo modo obtidos para o protótipo M2. Fica claro nesta análise que as superfícies de ruptura não sofreram alterações durante o avanço de umedecimento, diferente do ocorrido no protótipo M2 (Figura 7.25a).

$\mathrm{Na}$ Figura 7.25b, pode-se dizer que estas distribuições foram bastante consistentes com as distribuições dos deslocamentos máximos de face, nos quais as deformações aumentam em 
direção à base da estrutura, tendo o valor máximo na camada reforçada inferior. Estas distribuições foram consistentes com às observadas nos protótipo M1 e M2.

a)

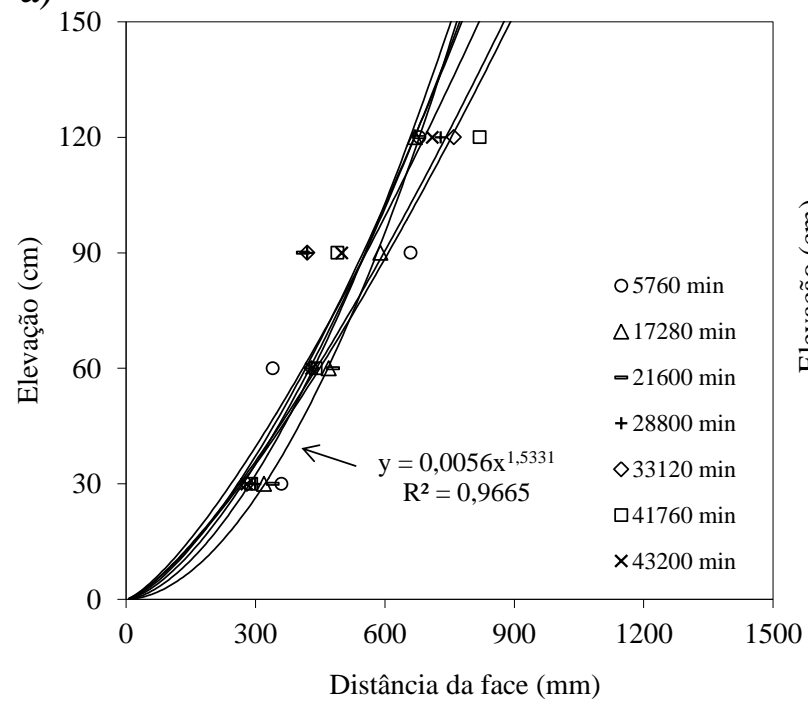

b)

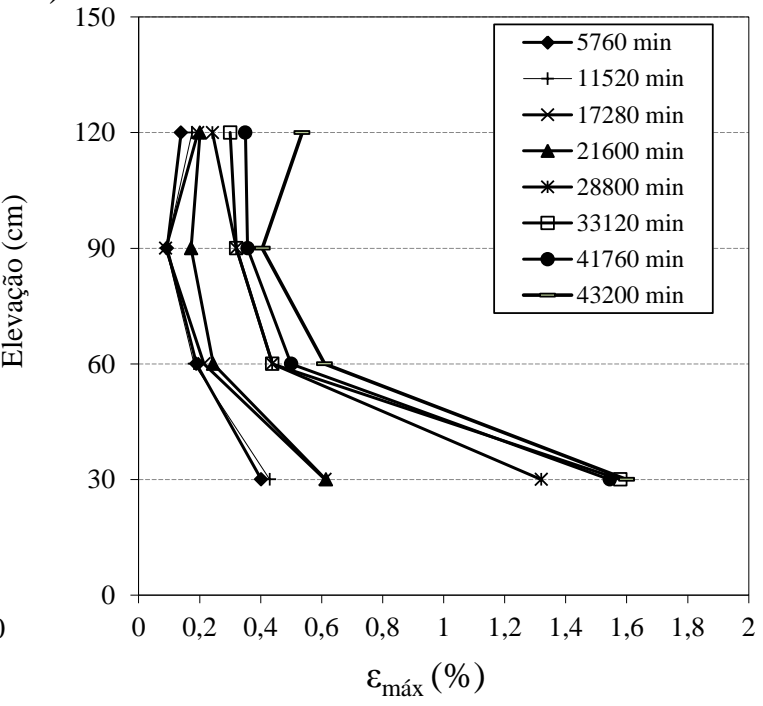

Figura 7.25. Deformações de pico ao longo do comprimento dos geotêxteis do protótipo M3: (a) definição de superfícies reais de rupturas; (b) distribuição das deformações.

Na Figura 7.26 foram plotadas as deformações de pico de cada reforço durante o ensaio, assim como as umidades volumétricas. No mesmo gráfico, os intervalos de tempo da ocorrência de barreiras capilares foram também plotados. O comportamento de deformações nos reforços do presente protótipo foi muito semelhante àquele verificado no protótipo $\mathrm{M} 2$, inclusive com níveis aproximados de deformações (máximos de 1,6\%).

Com relação à influência das barreiras capilares, nota-se que as deformações mantiveramse constantes nas camadas 2, 3 e 4 durante o processo de armazenamento de água, devido à ocorrência da barreira. No entanto, após a quebra, deformações adicionais ocorreram em todas as camadas reforçadas. Estas são, portanto, evidências de que a restrição proporcionada pela barreira pode ter promovido à manutenção das deformações neste período, podendo ser constatações positivas quanto à restrição do fluxo.

Com relação ao efeito da drenagem interna dos reforços não tecidos, supõe-se que esta fez com que pressões da água positivas não se desenvolvessem durante o ensaio. Pode-se dizer que os valores de deformações máximas medidas ao final do ensaio não tenderiam a aumentar com a presença dos reforços, uma vez que o equilíbrio entre a permeabilidade do solo e a transmissividade dos reforços foi alcançado, mantendo o teor de umidade e sucção da capacidade de campo. Destaca-se que o presente ensaio foi conduzido até 40000 minutos. Neste período, a frente de infiltração já havia alcançado a base do protótipo, e mesmo assim, o abastecimento de água foi continuado. Muito embora os sensores de umidade não registrassem leituras após este tempo, pode-se perceber que as leituras de deformações estabilizaram mesmo com o aumento do volume de água aplicado. Esta é uma evidência de que o equilíbrio hidráulico havia se 
estabelecido e as máximas deformações haviam sido alcançadas. Evidências quanto ao efeito da drenagem interna podem ser observadas na Figura 7.26d, nos períodos em que reduções no teor de umidade volumétrica ocorrem mesmo sob o avanço constante de umedecimento no interior do protótipo.

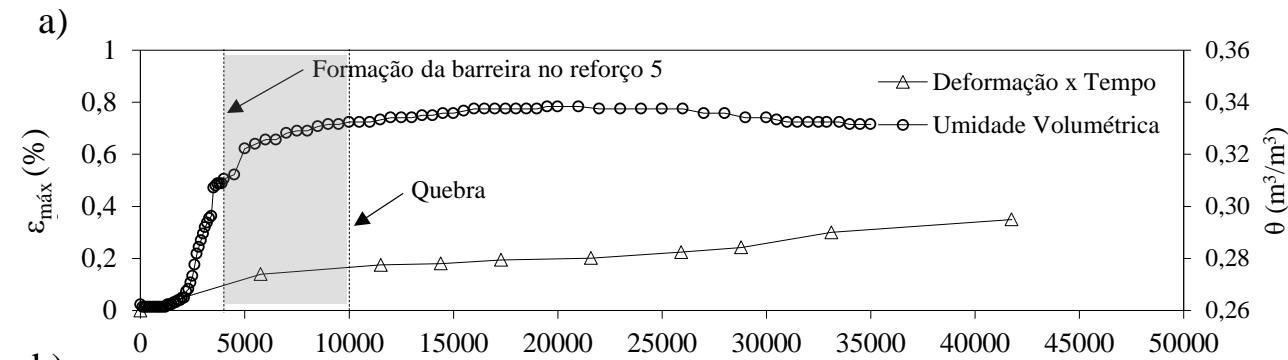

b)

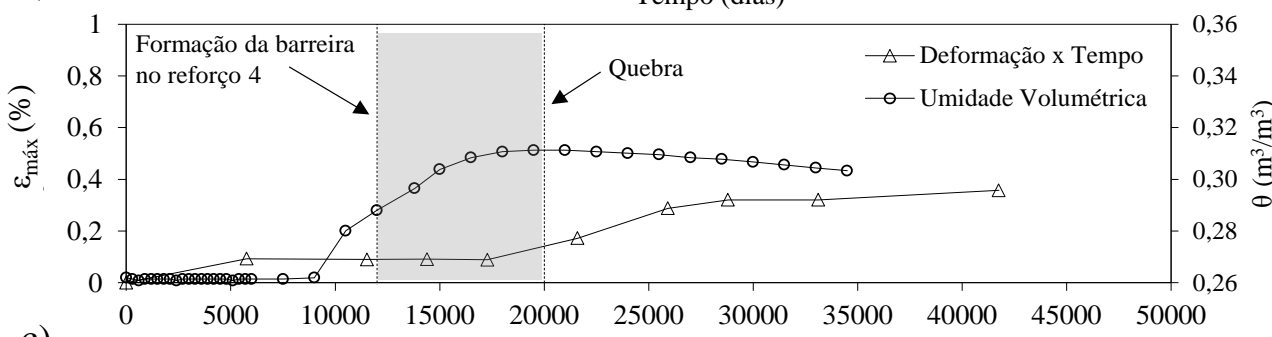

c)
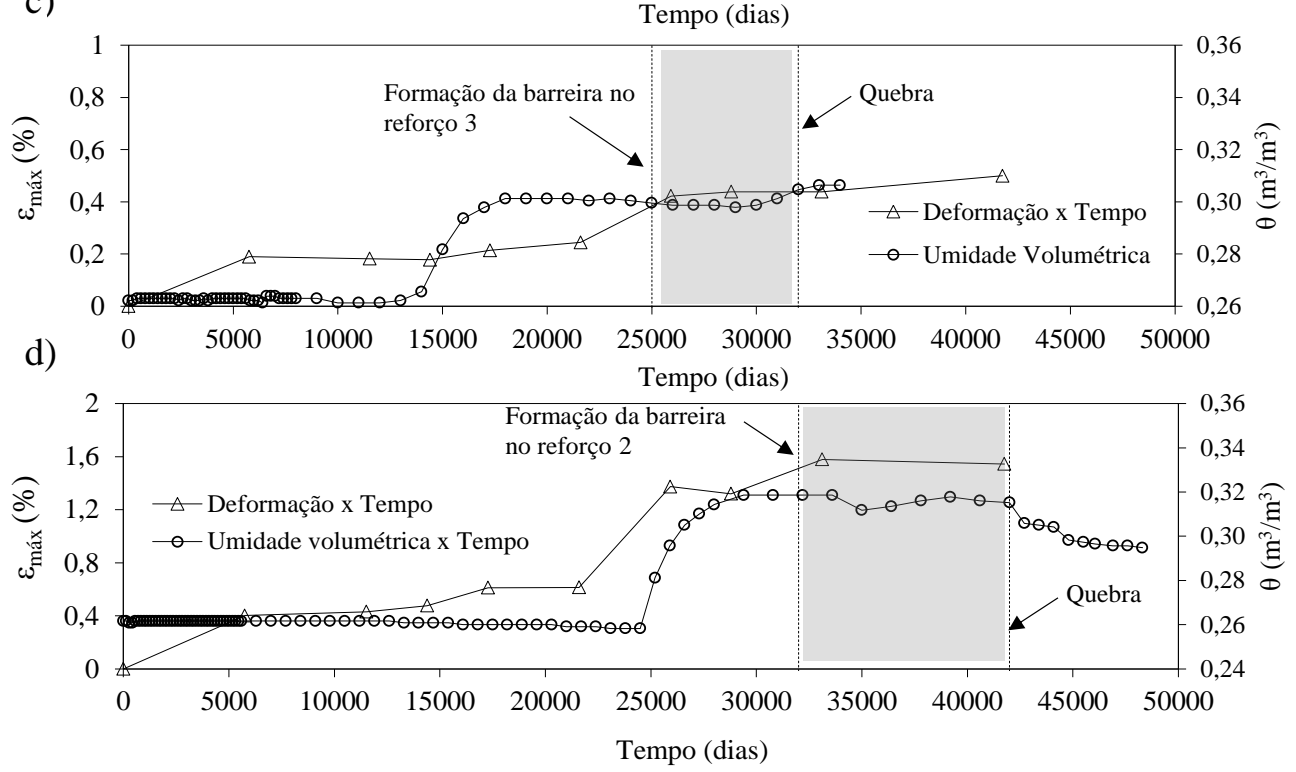

Figura 7.26. Deformações máximas e sucção matricial versus tempo do protótipo M3: (a) camada 5; (b) camada 4; (c) camada 3; (d) camada 2. 


\section{CAPÍTULO 8}

\section{AVALIAÇÃO DO ACRÉSCIMO DE TENSÕES NO COMPORTAMENTO DE UM MURO DE SOLO REFORÇADO COM GEOTEXXTEIS NÃO TECIDOS SOB CONDIÇÕES DE UMEDECIMENTO}

Neste capítulo será relatado o comportamento do protótipo M4, em que condições intensas de precipitação foram impostas antes da aplicação do carregamento, para que o efeito do aumento de tensões fosse avaliado sob as condições úmidas do solo. Neste protótipo, especificamente, foi utilizado um reforço de geotêxtil não tecido de maiores gramatura e transmissividade, de modo a permitir que a água se dissipasse mais facilmente ao longo dos reforços. As condições estabelecidas nesse capítulo consistem naquelas comumente observadas em períodos construtivos.

\subsection{Precipitação e umedecimento do solo}

Os níveis de precipitação impostos no protótipo M4 foram relativamente intensos em comparação aos outros protótipos, e aos níveis medidos em diversas regiões do país. Neste ensaio, o primeiro evento de chuva apresentou uma intensidade de $85 \mathrm{~mm} / \mathrm{hr}$ com duração de 7 horas. A chuva do protótipo M4 resultou no volume de água aplicado de 1,7 $\mathrm{m}^{3}$. Para efeito de comparação, a intensidade de precipitação considerada em projetos de rodovias na região de São Carlos - SP é de aproximadamente $50 \mathrm{~mm} / \mathrm{h}$. Na Figura 8.1 são apresentados os volumes de água aplicados durante o ensaio. Após a aplicação do primeiro evento de chuva, optou-se pela interrupção por um período de 26 dias com o intuito de verificar a efetividade da drenagem interna proporcionada pelos reforços. Após esse período, chuvas de intensidades menores foram impostas aleatoriamente. Na Figura 8.2 é ilustrado o protótipo durante o primeiro evento de chuva simulado.

Cabe lembrar que o primeiro evento de chuva foi aplicado no protótipo antes da aplicação da tensão vertical, com a finalidade de umedecer a estrutura previamente. Esta situação buscou simular uma condição comum durante o processo construtivo, além de favorecer o desenvolvimento de pressões da água positivas. É muito comum em alguns projetos de muros de solo reforçado, a construção de um aterro no topo da estrutura. Além disso, é também comum que períodos de chuva possam ocorrer e umedecer o solo da estrutura durante o processo construtivo. Nesta condição, a construção do aterro sobre a estrutura reforçada pode gerar deformações e deslocamentos excessivos. Diante disso, estas condições foram simuladas no ensaio do protótipo M4. 


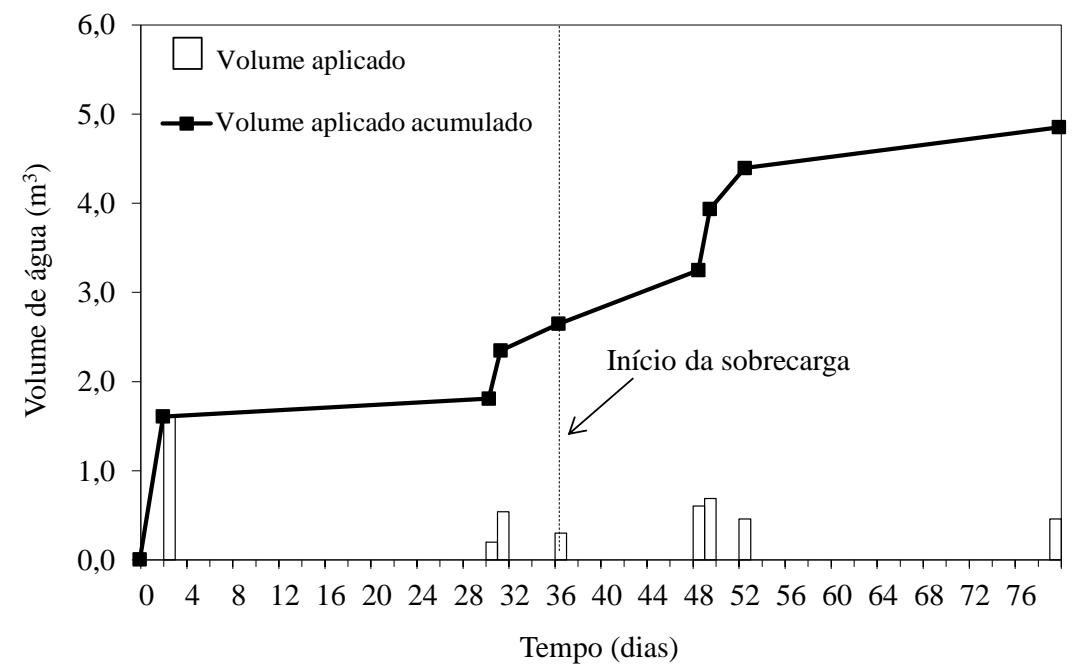

Figura 8.1. Volume de água aplicado no protótipo M4.

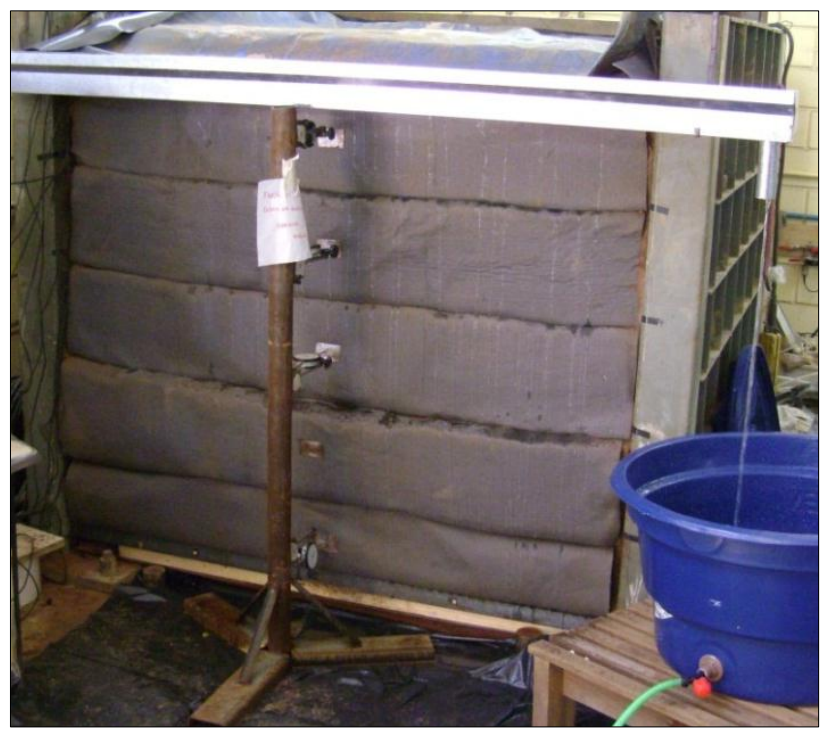

Figura 8.2. Aspecto do protótipo M4 durante o primeiro evento de chuva.

Com relação à Figura 8.1, pode-se verificar que o regime de precipitação estabelecido neste ensaio consistiu em chuvas mais intensas, porém, mais espaçadas, resultando num volume final aplicado de $4,2 \mathrm{~m}^{3}$, praticamente três vezes o volume aplicado no protótipo M2 $\left(1,5 \mathrm{~m}^{3}\right)$. Nota-se que o volume aplicado no primeiro evento de chuva do protótipo M4, antes do início dos incrementos de tensões, correspondeu ao volume final do ensaio do protótipo M2.

Os teores de umidade no protótipo foram monitorados em pontos localizados nas distâncias de $10 \mathrm{~cm}, 80 \mathrm{~cm}$ e $130 \mathrm{~cm}$ em relação à face, na seção central de cada camada reforçada. Adicionalmente, um piezômetro elétrico instalado na camada superficial permitiu observar o comportamento das pressões da água durante o ensaio. Os resultados do monitoramento dos teores de umidade do protótipo são apresentados na Figura 8.3. 
a)
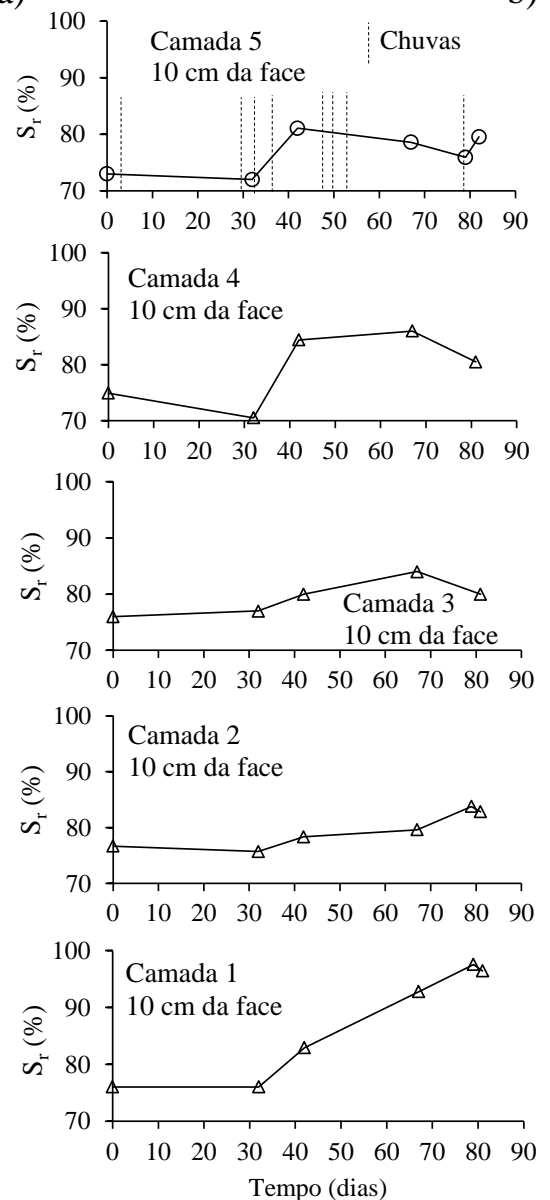

b)
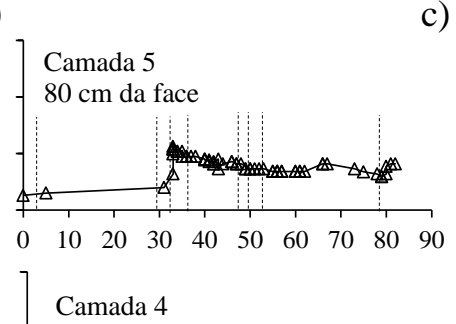

$80 \mathrm{~cm}$ da face
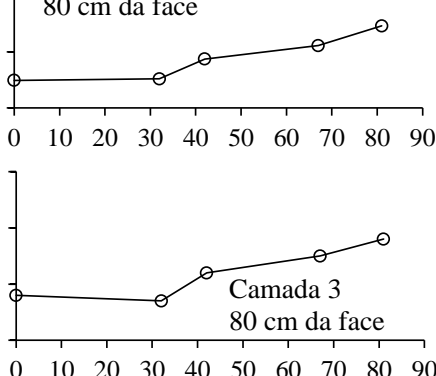

Camada 2

$80 \mathrm{~cm}$ da face
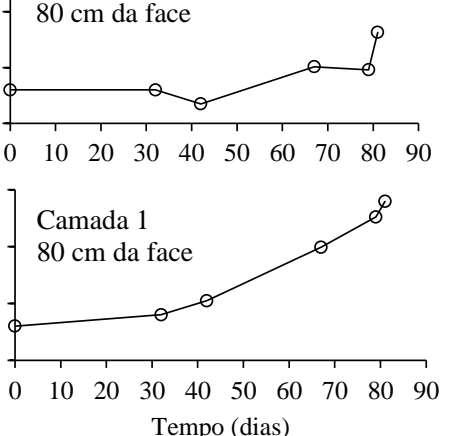

c)
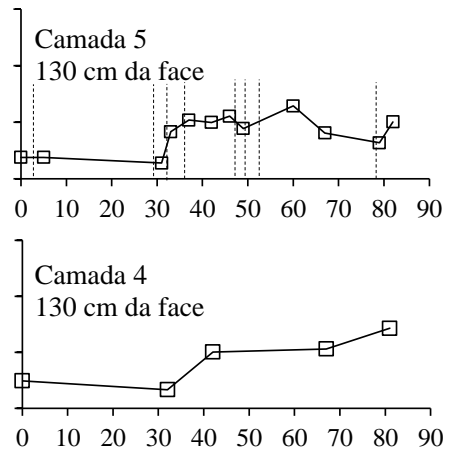

Camada 3

$130 \mathrm{~cm}$ da face

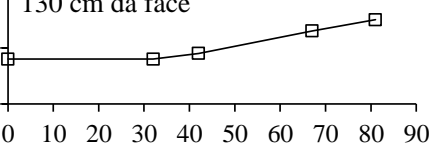

Camada 2

$130 \mathrm{~cm}$ da face
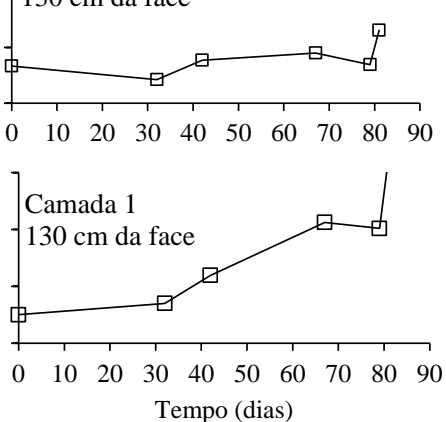

Figura 8.3. Variação do grau de saturação durante o ensaio do protótipo M4: (a) $10 \mathrm{~cm}$ da face; (b) $80 \mathrm{~cm}$ da face; (c) $130 \mathrm{~cm}$ da face.

Com base nos resultados da Figura 8.3, nota-se que o solo umedeceu após os eventos de chuvas, mas nos períodos de interrupção destes eventos, em alguns momentos, houve a redução do grau de saturação solo. Pode-se supor, portanto, que existe uma influência significativa da capacidade drenante dos reforços por manter o grau de saturação do solo em níveis relativamente baixos (máximos em torno de 90\%), considerando as condições de precipitação impostas no ensaio. De modo geral, os maiores valores de grau de saturação foram medidos na camada 1 , próxima da fundação, o que pode ser atribuído ao caminho preferencial da água pela face envelopada, transferindo o umedecimento para o reforço próximo da base do protótipo. Apesar disso, o umedecimento do solo seguiu uma sequencia coerente de infiltração descendente.

Cabe lembrar que os protótipos foram construídos em ambientes controlados, que dificultam a secagem do solo por aumento da temperatura. Mesmo assim, os valores de grau de saturação foram relativamente baixos. Em comparação com os outros protótipos estudados neste trabalho, os níveis de saturação foram menores, o que pode ser atribuído ao uso de reforços de maior permeabilidade, o que proporcionou maior capacidade de drenagem interna. 


\subsection{Comportamento do protótipo}

\subsubsection{Tensões verticais}

Na Figura 8.4 são apresentados os resultados das tensões totais monitoradas e as tensões previstas. De modo geral, as tensões medidas foram consistentes e aproximadas às tensões previstas, apesar das tensões geostáticas e das tensões de compactação durante a construção terem se mostrado menores que o esperado. Na Figura 8.4 são plotadas as tensões nas condições de serviço da estrutura (pós-construção).
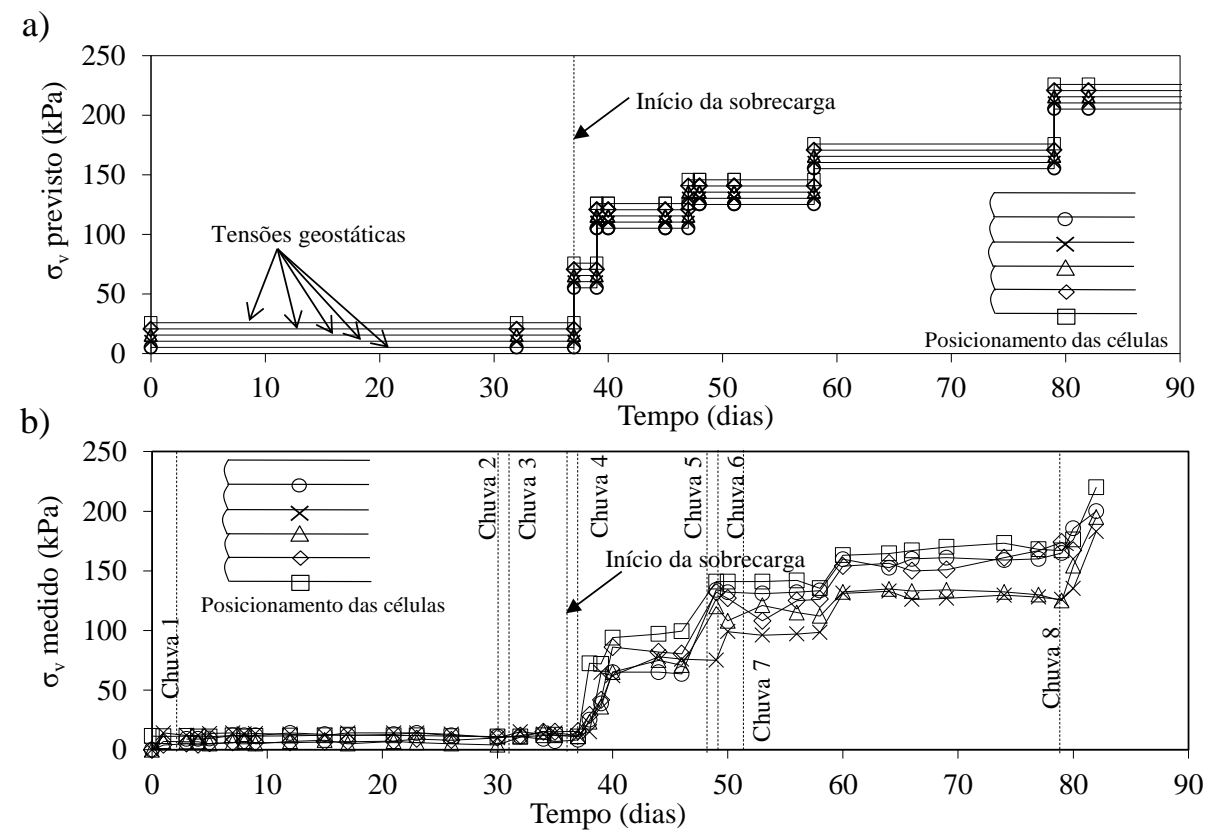

Figura 8.4. Tensões verticais totais nas condições de serviço no protótipo M4.

Na Figura 8.5 são mostradas as distribuições das tensões ao longo da altura durante o ensaio no protótipo M4. Nota-se que as distribuições experimentais foram consistentes com as teóricas (também mostradas na figura) nas quais as tensões aumentam linearmente em direção à base da estrutura. A partir da sobrecarga de $100 \mathrm{kPa}$, nota-se que as tensões na camada superficial aumentam significativamente, mostrando a distribuição semelhante à do protótipo M2, na qual a distribuição de Boussinesq se sobrepõe à distribuição linear. 


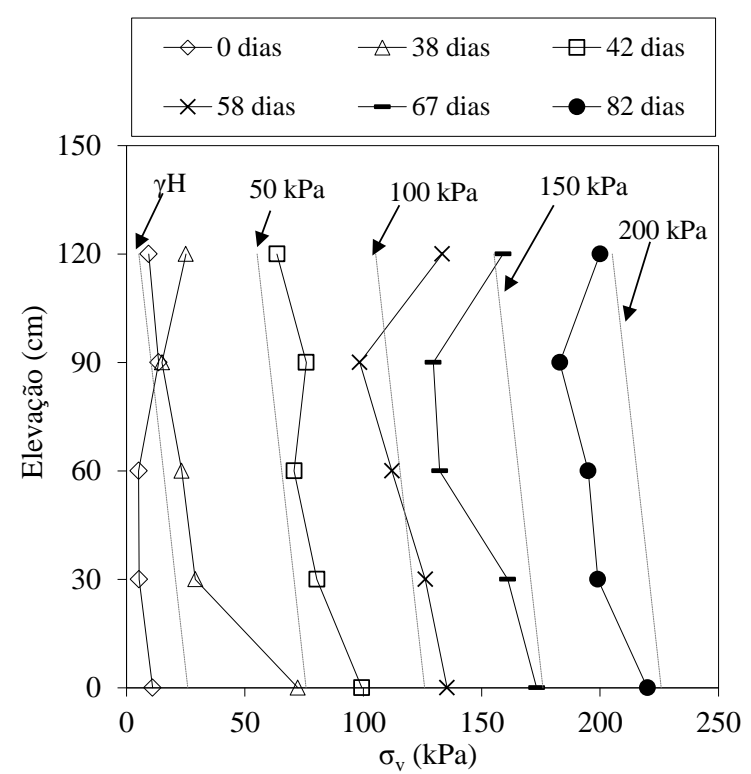

Figura 8.5. Distribuição das tensões totais verticais ao longo da altura do protótipo M4.

\subsubsection{Pressões da água}

O monitoramento das pressões da água foi realizado na camada reforçada superficial (camada 5), com o piezômetro posicionado $5 \mathrm{~cm}$ acima da linha do geotêxtil não tecido. Os resultados das leituras de pressões da água durante as ações das sobrecargas são apresentados na Figura 8.6.

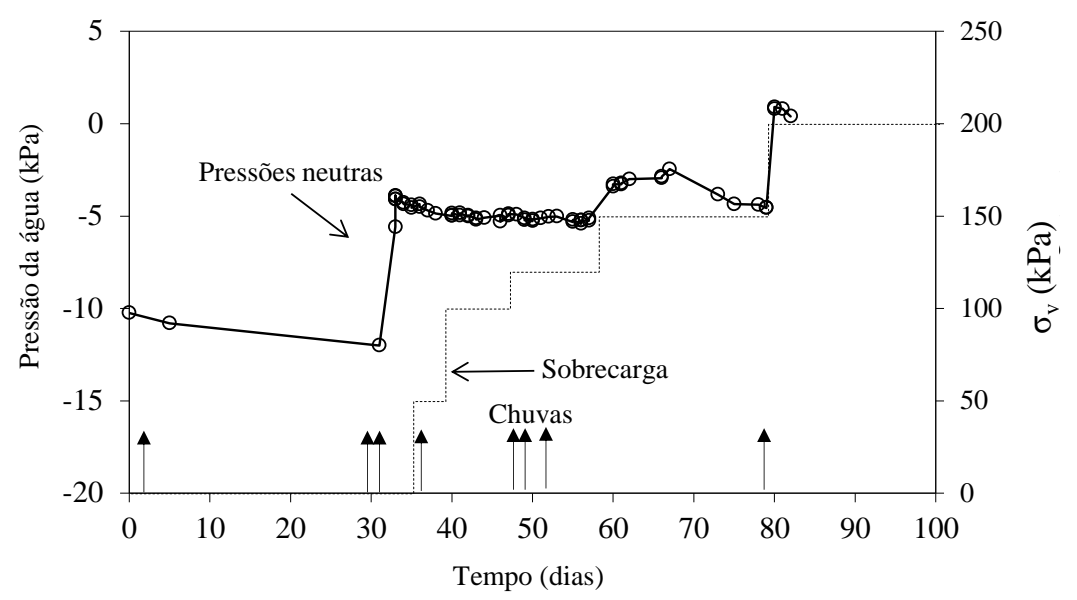

Figura 8.6. Pressões da água medidas na região central da camada reforçada 5.

$\mathrm{O}$ aumento dos valores de pressões da água até o $55^{\circ}$ dia de ensaio foi consequência da infiltração de água na camada, cujas pressões negativas relativamente elevadas tenderam a diminuição até valores em torno de $-5 \mathrm{kPa}$ (valor de capacidade de campo). Durante este período, os acréscimos de carga de $50 \mathrm{kPa}, 100 \mathrm{kPa}$ e $120 \mathrm{kPa}$ não ocasionaram desenvolvimento significativo de pressões da água, mantendo-as estáveis até o $55^{\circ}$ dia de ensaio. Após este período, houve indícios de aumento das pressões da água até valores próximos de zero. Este 
comportamento pode ser atribuído à consolidação do solo pelas ações das tensões até este período, que promoveu a diminuição da permeabilidade, e pelo incremento de tensão até o valor de 150 kPa. Portanto, a dificuldade de dissipação da água, criada pela diminuição da permeabilidade do solo, resultou neste pequeno aumento de pressão da água. Após a aplicação da tensão de $200 \mathrm{kPa}$, o aumento da pressão da água foi mais significativo, alcançando valores positivos (1 kPa). Cabe notar que após a estabilização destas tensões (150 e $200 \mathrm{kPa})$, as pressões da água tenderam a se dissipar em poucos dias. Este comportamento pode ser atribuído à presença do reforço permeável na proximidade do ponto de leitura. Enfatiza-se ainda, que os reforços influenciaram significativamente para que estas pressões da água não se excedessem a ponto de provocar a ruptura do protótipo, já que ensaios triaxiais CU (Figura 4.3) indicaram que pressões da água próximas de $50 \mathrm{kPa}$ são passíveis de ocorrerem sob a tensão confinante de $100 \mathrm{kPa}$ (Figura 4.3b).

\subsubsection{Deslocamentos horizontais}

Os resultados das leituras dos extensômetros tell-tales do protótipo M4 são mostrados na Figura 8.7. Nos gráficos, foi plotado também o regime de tensões estabelecido durante o ensaio. Observa-se que, os aumentos de tensões proporcionaram aumentos nos deslocamentos internos, sendo os valores máximos localizados em pontos mais próximos da face. Até o $47^{\circ}$ dia de ensaio, em que a tensão de $100 \mathrm{kPa}$ foi aplicada, os níveis de deslocamentos internos foram aproximados aos deslocamentos do protótipo M2, o que não dependeu do regime de tensões estabelecido. Dessa forma, a velocidade de carregamento mostrou-se não ter influência no comportamento do protótipo até o nível de tensão de $100 \mathrm{kPa}$, já que pressões da água não foram desenvolvidas nestas condições.

Após este período, os deslocamentos aumentaram em maiores taxas devido às tensões de $150 \mathrm{kPa}$ e $200 \mathrm{kPa}$. Considerando o comportamento das pressões da água, pode-se supor que estes aumentos mais expressivos foram decorrentes dos aumentos nos valores de grau de saturação neste período, assim como pelas pressões da água desenvolvidas durante o ensaio. Tais hipóteses foram levantadas já que os aumentos em maiores taxas ocorreram no mesmo período em que as pressões da água se desenvolveram. Em adição, os níveis de tensões aplicados neste período estavam próximos da tensão de ruptura do solo, o que resultou nos deslocamentos excessivos.

Os níveis de deslocamentos registrados nesta estrutura foram significativos em comparação com os níveis registrados nos outros protótipos, com valores máximos de $32 \mathrm{~mm}$. Considerando a relação $\delta / H$, o valor máximo desta foi de 0,02 , o que resultaria em um deslocamento máximo de $200 \mathrm{~mm}$ para uma estrutura com $10 \mathrm{~m}$ de altura. Embora esta magnitude de deslocamento interno máximo tenha sido muito maior em comparação aos outros protótipos avaliados, se a relação $\delta / H$ for comparada às diversas estruturas monitoradas e relatadas na literatura, o nível registrado seria aproximado aos de estruturas estáveis. Para efeito de comparação, a estrutura de geogrelhas de Burwash e Frost (1991), na qual ações estabilizadoras 
foram providenciadas para evitar a ruptura da estrutura, apresentou $\delta / H$ máximo de 0,037 . Já a estrutura estável de geogrelhas relatada por Sego et. al (1990) apresentou deslocamento normalizado máximo de 0,01 .
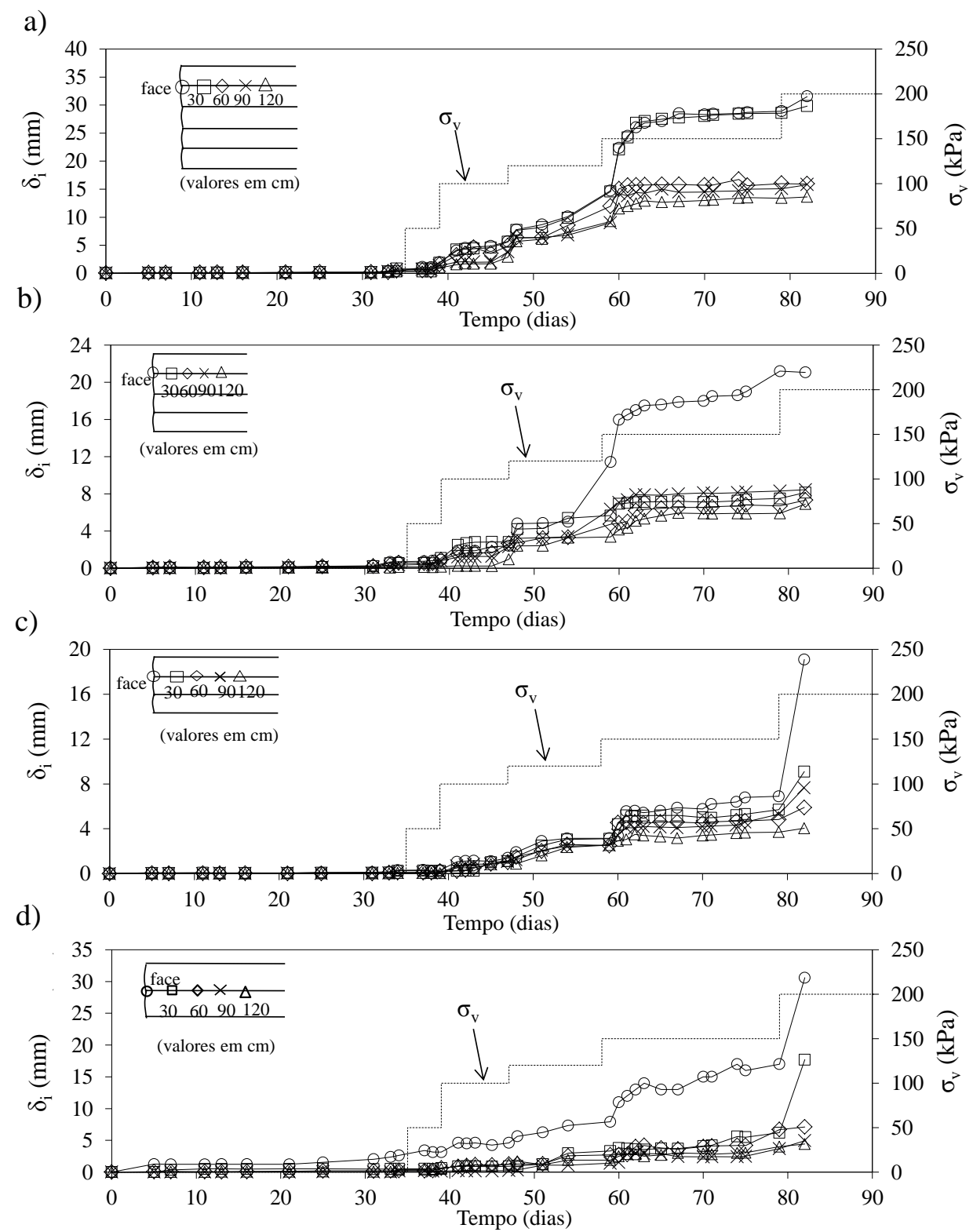

Figura 8.7. Resultados dos deslocamentos internos do protótipo M4: (a) camada 5; (b) camada 4; (c) camada 3 ; (d) camada 2.

Com relação aos deslocamentos de face, os resultados do monitoramento são apresentados na Figura 8.8. Nota-se que o comportamento dos deslocamentos de face foi semelhante aos observados nos deslocamentos internos, tornando as mesmas discussões válidas também para este parâmetro. No entanto, pode-se observar que aumentos mais expressivos nos deslocamentos de face ocorreram na camada inferior. Supõe-se que a água escoada no topo da estrutura foi conduzida pelos geotêxteis do envelopamento da face para as camadas inferiores (Figura 8.2), além do fato das tensões terem sido maiores nestes níveis. 
Como esperado, os níveis de deslocamentos de face medidos neste ensaio foram maiores que os medidos nos outros protótipos. No entanto, pode-se constatar que até o período de 50 dias, os deslocamentos foram muito semelhantes aos níveis medidos até o final dos ensaios dos protótipos M1 e M2, que apresentaram valores em torno de $5 \mathrm{~mm}$. A partir deste período, os deslocamentos aumentaram excessivamente alcançando o valor máximo de $35 \mathrm{~mm}$.

a)

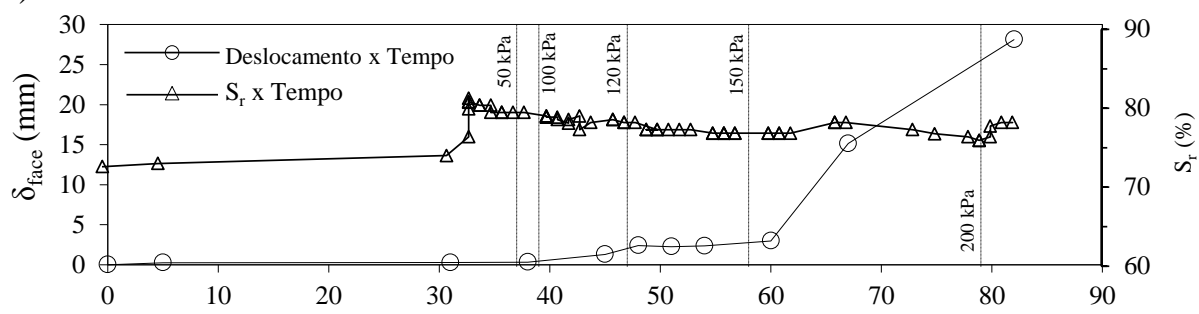

b)

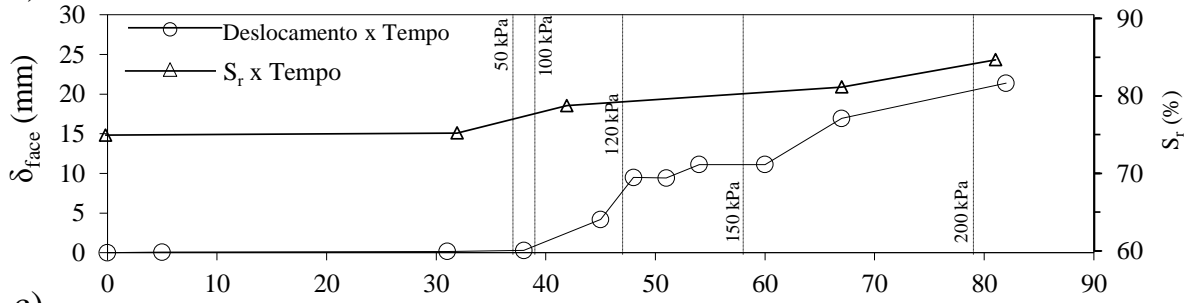

c) Tempo (dias)
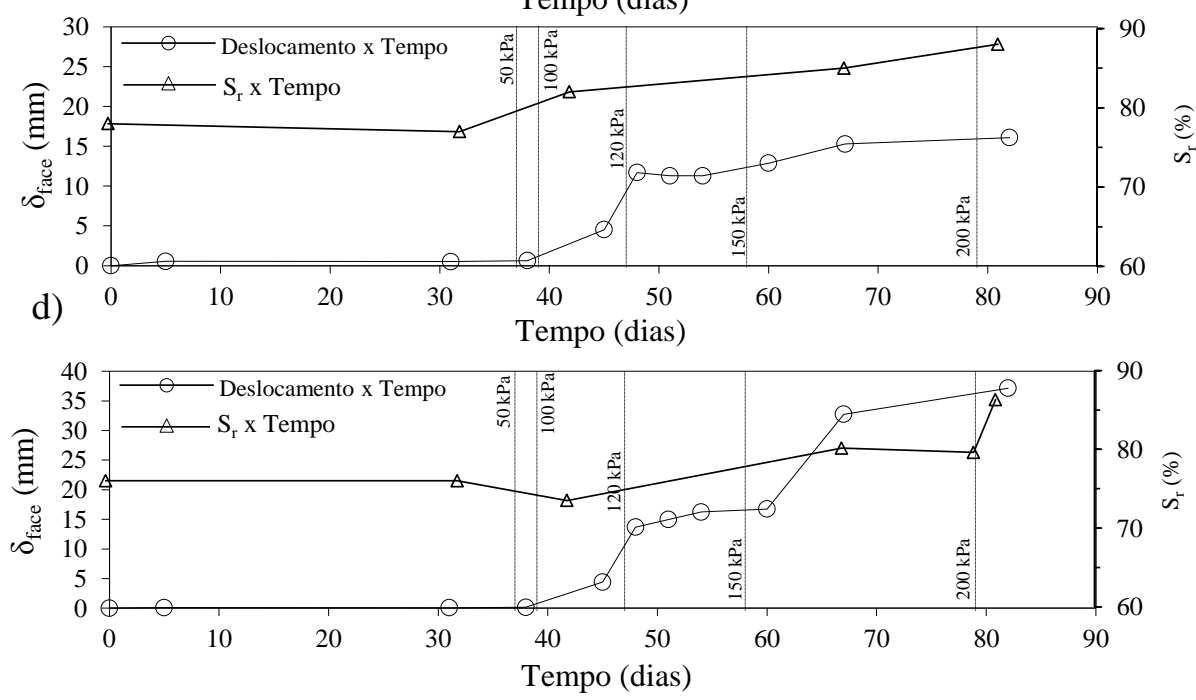

Figura 8.8. Evolução dos deslocamentos de face e grau de saturação do protótipo M4: (a) camada 5; (b) camada 4; (c) camada 3; (d) camada 1.

Na Figura 8.9 são apresentadas as distribuições dos deslocamentos de face da estrutura ao longo da altura do protótipo. De modo geral, os deslocamentos de face aumentaram em direção à base do protótipo. Após 60 dias, os deslocamentos permaneceram máximos na base do protótipo, porém aumentos expressivos foram evidenciados na camada superficial. Este comportamento é coerente com a distribuição das tensões medidas pelas células de tensão total. Ainda, as distribuições aqui observadas são semelhantes às constatadas nos protótipos M1, M2 e M3. 


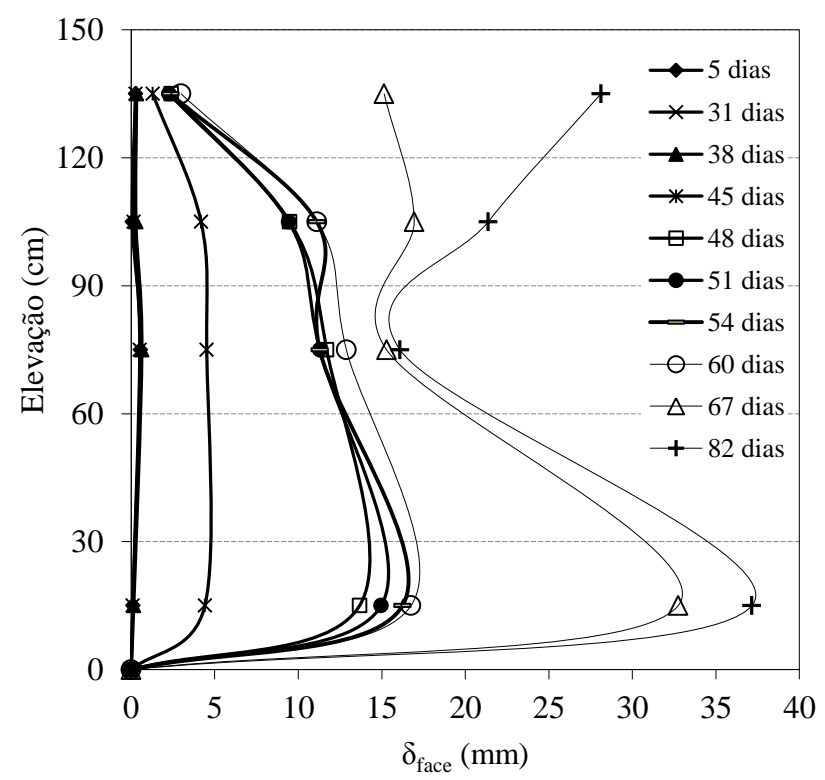

Figura 8.9. Distribuição dos deslocamentos de face ao longo da altura do protótipo M4.

\subsubsection{Deformação nos reforços}

A distribuição dos deslocamentos e os ajustes sigmoidais ao longo dos reforços do protótipo M4 são apresentados na Figura C2 do apêndice C, enquanto as distribuições das deformações nos geotêxteis são exibidas na Figura 8.10. Uma vez determinadas as distribuições para diferentes tempos de ensaio, determinam-se também deformações de pico, plotadas na Figura 8.11 .

Pode-se observar pequenas deformações nos reforços até o período de 55 dias, mesmo após intensas períodos de chuvas e aplicação de sobrecargas de até $120 \mathrm{kPa}$. Ainda neste período, as deformações apresentaram o valor máximo de 4\%, sendo muito próximas aos valores máximos obtidos nos protótipo M2 e M3. Após o incremento até a tensão de $150 \mathrm{kPa}$, as deformações passaram a aumentar significativamente. Aparentemente, as maiores deformações aconteceram nos maiores níveis de saturação registrados sob as maiores tensões aplicadas.

Existe, portanto, a influência de duas variáveis (tensão e saturação), cujo efeito pode ser resumido à redução da rigidez do solo devido ao umedecimento e aos aumentos nas tensões devido às sobrecargas. No presente protótipo, foi alcançada uma condição de níveis de tensão e saturação próximas das condições de plastificação do solo (Figura 4.3). Considerando o aumento exponencial das deformações com o avanço do umedecimento, o comportamento tensão deformação do solo (Figura 4.3), e a aplicação de carregamento em velocidades relativamente grandes, estas condições podem vir a compor uma condição crítica. Conclui-se que a utilização de reforços de elevada permeabilidade foram cruciais para que as deformações não aumentassem prejudicialmente, possibilitando que as pressões da água não se acumulassem pelo acréscimo de carga. Acredita-se que com o uso de um reforço "impermeável" as deformações e deslocamentos seriam maiores. 

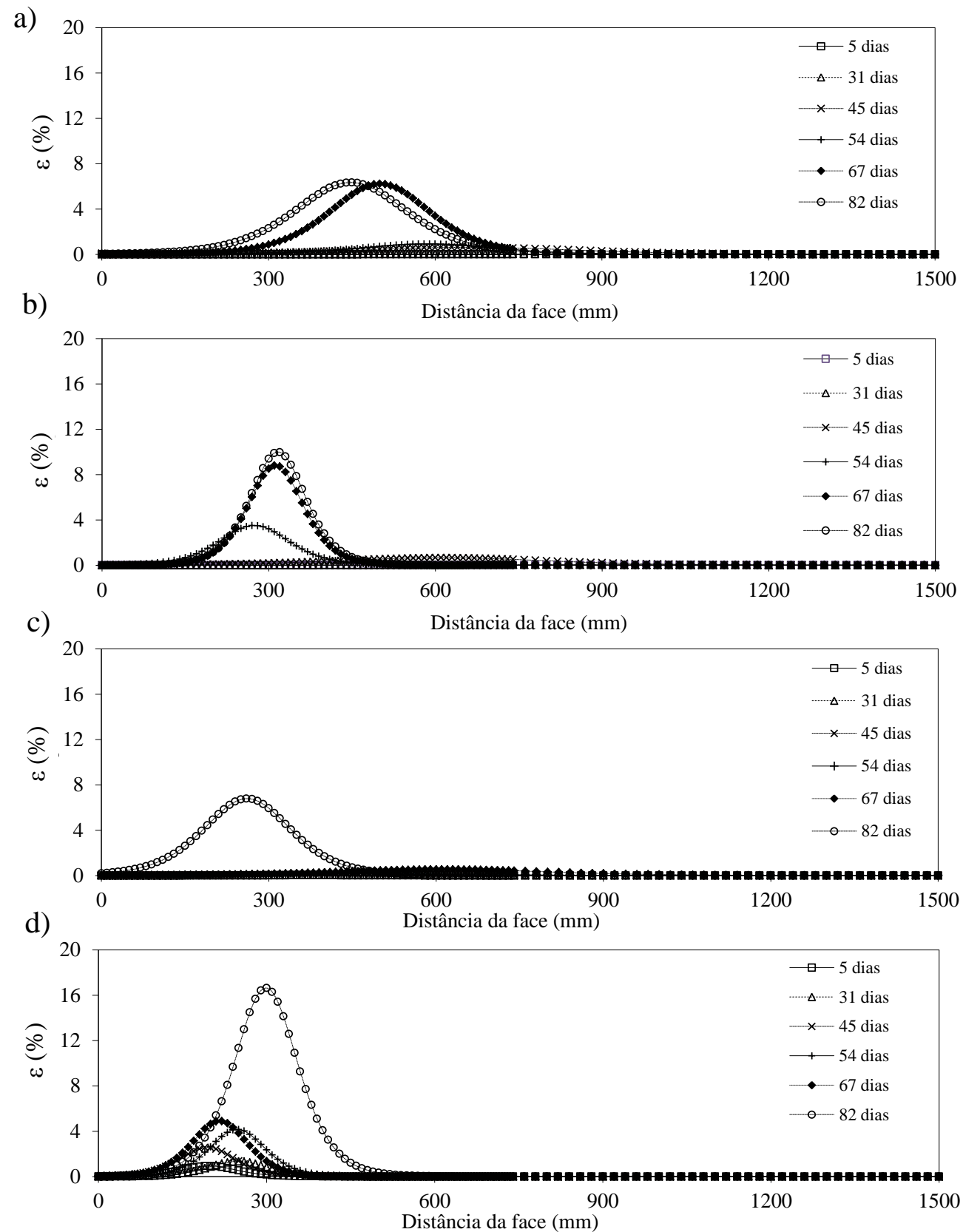

Figura 8.10. Distribuição das deformações ao longo do comprimento dos geotêxteis do protótipo M4: (a) camada 5; (b) camada 4; (c) camada 3; (d) camada 2.

Na Figura 8.12 são mostradas as superfícies reais de ruptura e as distribuições das deformações de pico ao longo da altura do protótipo. Observa-se que, as superfícies reais apresentadas foram se movimentando no sentido da face, assim como verificado no protótipo M2. Sabendo que duas variáveis atuaram na estrutura, as alterações nas superfícies de ruptura do protótipo M4 foram maiores que as verificadas no protótipo M2 (Figura 8.12a). Na Figura 8.12b, constata-se maiores deformações de pico ocorrendo na camada 2. Após a aplicação dos eventos de chuvas associados aos incrementos de tensões aumentos significativos foram registrados na altura da camada 4. Embora as distribuições tenham sido diferentes em relação aos protótipos 
anteriormente estudados, a ocorrência da máxima deformação de pico no primeiro terço da altura da estrutura foi coincidente.
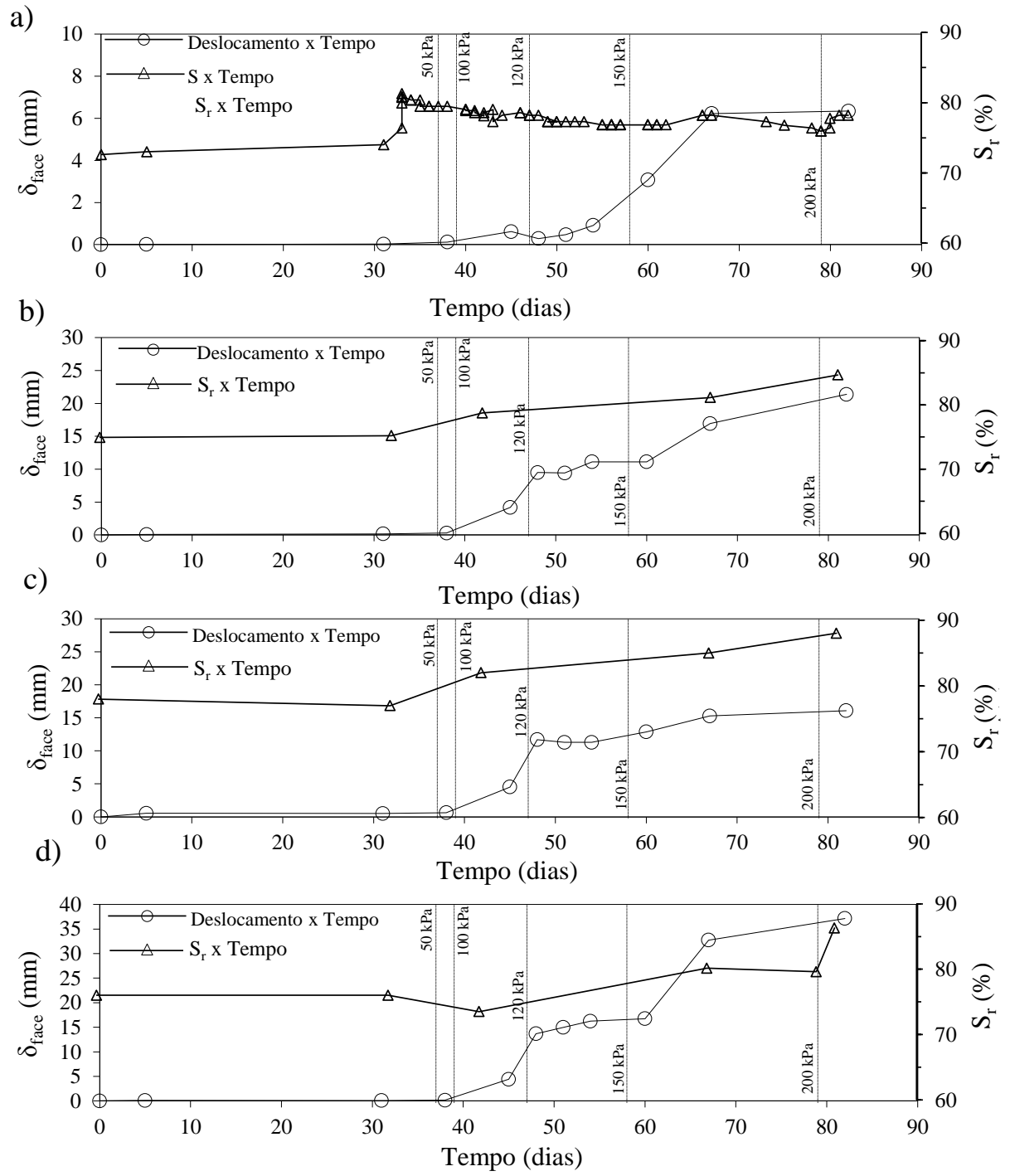

Figura 8.11. Deformações máximas e grau de saturação versus tempo do protótipo M4: (a) camada 5; (b) camada 4 ; (c) camada 3; (d) camada 2.

Uma verificação quanto ao efeito das condições impostas neste ensaio foi realizada utilizando análises de equilíbrio limite, nas quais os efeitos do acréscimo de tensão e umedecimento foram avaliados isoladamente. Os resultados são mostrados na Figura 8.13. As pressões de água inseridas nas análises foram obtidas da curva de retenção de água do solo, com base nos teores de umidade medidos durante o avanço. Foi identificado o efeito significativo do umedecimento na estabilidade do protótipo, chegando a uma redução de $70 \%$ no fator de segurança da condição inicial de compactação para a condição de $90 \%$ de grau de saturação. $\mathrm{O}$ efeito de carga isoladamente, na condição inicial de compactação, reduziu o fator de segurança em $50 \%$. Esta análise mostra o efeito significativo da associação das variáveis umedecimento e acréscimo de tensões. Verifica-se ainda que o carregamento de $200 \mathrm{kPa}$ na estrutura umedecida 
resultou no fator de segurança próximo de 1,0, o que indica a proximidade da ruptura da estrutura. Cabe observar que, pelo fato das pressões da água positivas registradas serem desprezíveis, estas não foram consideradas nas análises. Mas se uma condição hipotética de pressão da água de 10 $\mathrm{kPa}$ fosse considerada, a estrutura resultaria num fator de segurança menor que 1,0.

a)

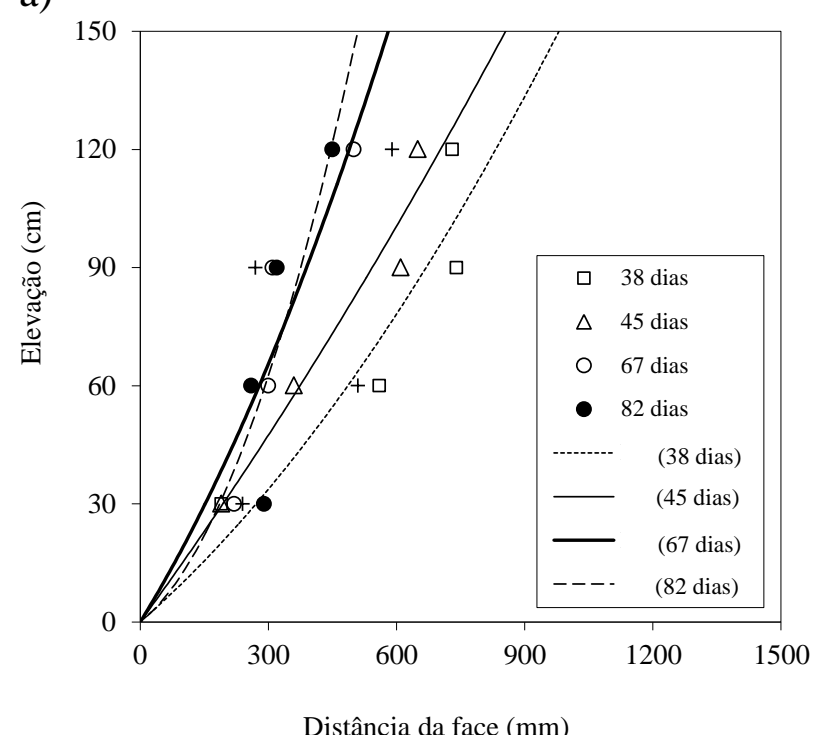

b)

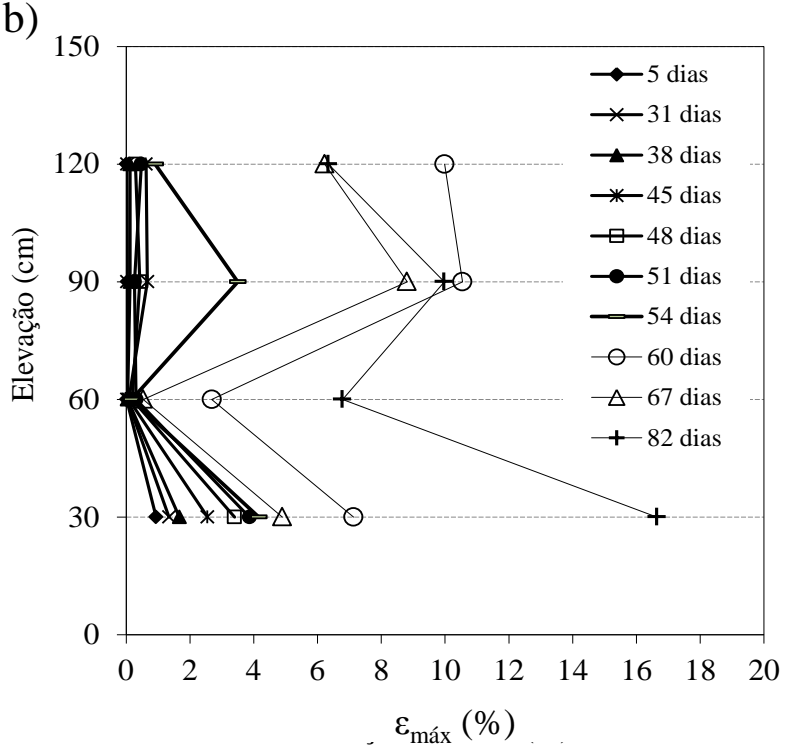

Figura 8.12. Deformações de pico ao longo do comprimento dos geotêxteis do protótipo M3: (a) definição de superfícies reais de rupturas; (b) distribuição das deformações.

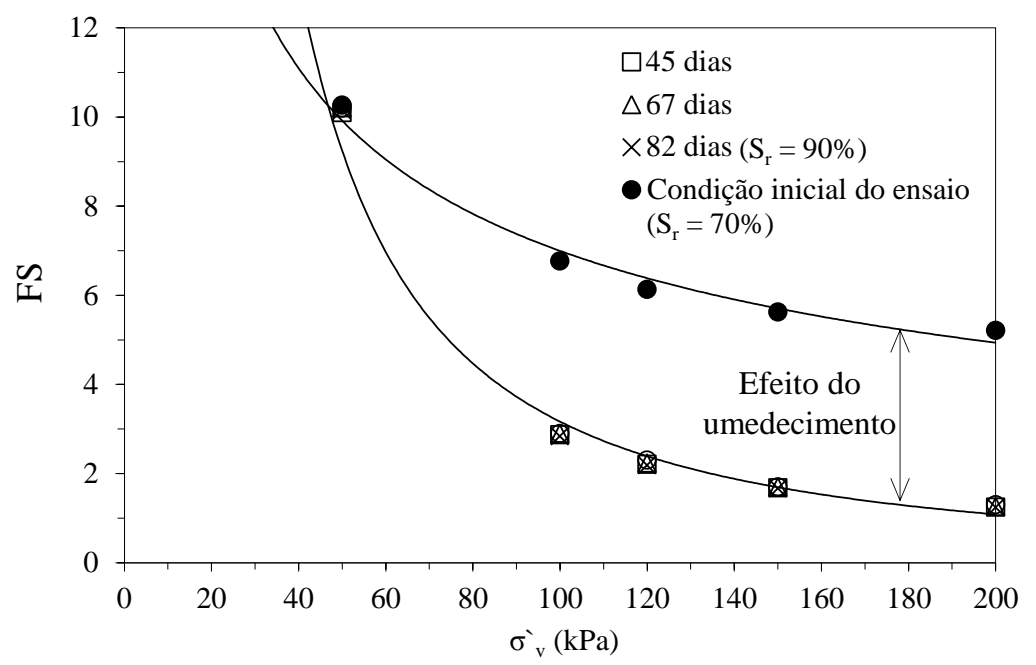

Figura 8.13. Avaliação dos efeitos de umedecimento e sobrecarga por análises de equilíbrio limite.

De modo a verificar a efetividade da função de reforço dos geotêxteis, a comparação entre os módulos do solo e geotêxtil para os valores de grau saturação de $75 \%$ e $100 \%$ é mostrada na Figura 8.14. Os resultados do solo foram obtidos de ensaios triaxiais CD, sob o confinamento de $150 \mathrm{kPa}$, enquanto os resultados de tração confinada do geotêxtil foram estimados com base nos resultados de ensaios de fluência confinada, que indicaram redução de $80 \%$ das deformações por fluência. Considerou-se, também, a redução da espessura do geotêxtil sob condição de confinamento ( $2 \mathrm{~mm}$ para $200 \mathrm{kPa}$ de confinamento), para cálculo do módulo de rigidez em MPa. 
O primeiro aspecto a se observar é que os reforços foram mobilizados na deformação de $2 \%$, no caso do solo na condição inicial do ensaio, e $1,7 \%$ para o solo saturado. No final do ensaio, ou seja, nas deformações de $10 \%$ do solo e reforço, a rigidez do solo é mínima, fazendo com que grande parte das tensões seja mobilizada pelos reforços, resultando nos níveis de deformações verificados. Existe, portanto, uma relação coerente entre as análises de equilíbrio limite e a condição do protótipo no final do ensaio, em que ambas as análises mostraram-se próximas da ruptura. Cabe informar que a análise de compatibilidade de deformações apresentadas na Figura 8.14 possui caráter qualitativo, uma vez que algumas considerações foram realizadas para a obtenção das curvas de módulo de rigidez para ambos os materiais.

Na Figura 8.15 é mostrado o protótipo ao final do ensaio, ilustrando a condição final da estrutura. Foi observado que o protótipo apresentava-se distorcido e o solo com consistência plástica, o que foi preponderante para os aumentos significativos nas deformações nos reforços. Acredita-se que pressões da água positivas comprometedoras não se desenvolveram durante o ensaio, devido à drenagem interna promovida pela elevada permeabilidade dos reforços.

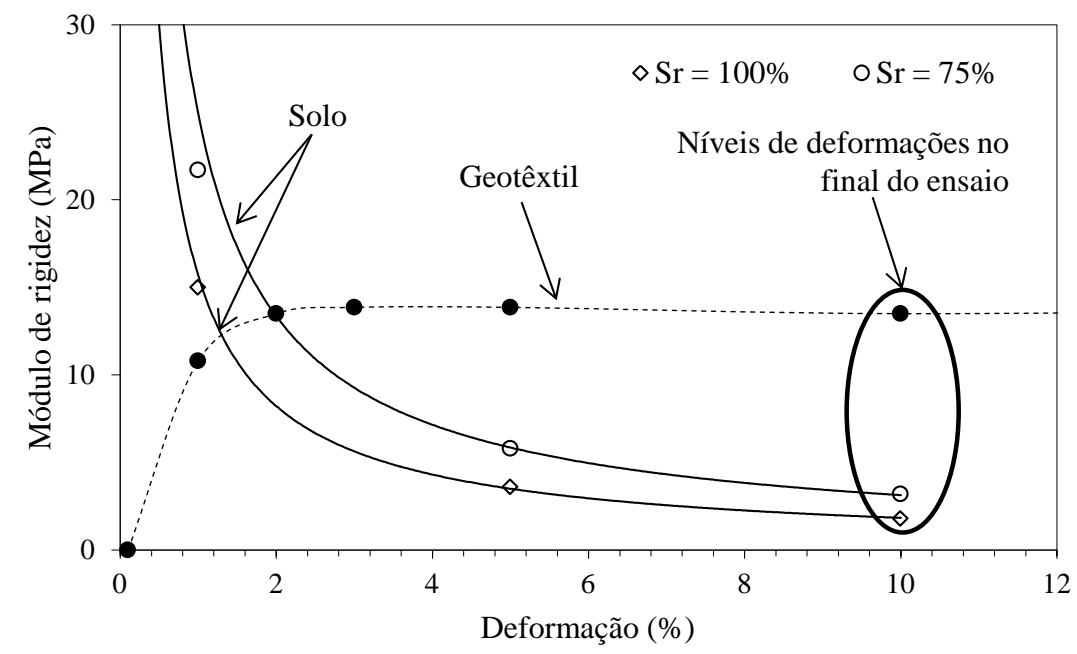

Figura 8.14. Compatibilidade de deformações do solo e reforços.

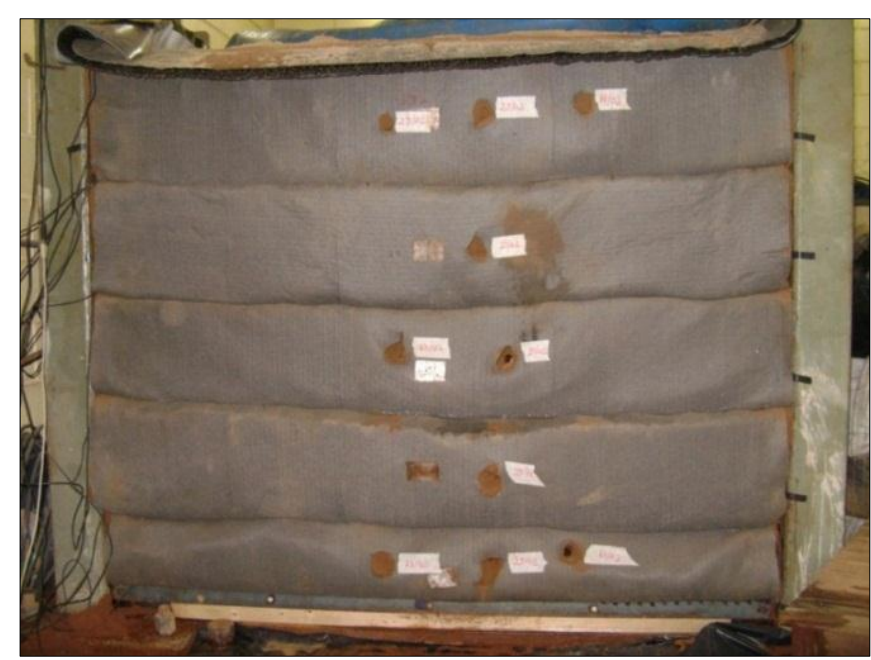

Figura 8.15. Protótipo M4 no final do ensaio. 
$-228-$ 


\section{CAPÍtULO 9}

\section{ANÁLISES DE FORÇAS MOBILIZADAS NOS REFORÇOS DOS PROTÓTIPOS}

Neste capítulo são apresentadas análises de forças mobilizadas nos reforços dos protótipos M1, M2 e M3, comparados a dois métodos de previsão: $k$-stiffness method (ALLEN et al., 2003), posteriormente modificado por (MIYATA; BATHURST, 2008), e AASHTO Simplified Method (AASHTO, 2002).

\subsection{Estimativa do parâmetro de coesão do solo}

Os valores de coesão do solo foram determinados utilizando os conceitos de Fredlund et al. (1978), estabelecidos na Equação 2.2. Estes foram calculados com base nas leituras de sucção medidas durante os ensaios dos protótipos M1, M2 e M3 e com os parâmetros de resistência das envoltórias dos ensaios triaxiais CD (Figura 4.4a), nas condições saturadas e não saturadas do solo. A determinação do parâmetro $\phi_{b}$ foi realizada por Georgetti (2010), por ensaios de resistência não saturada de teor de umidade constante $(\mathrm{CW})$, cujo valor obtido foi de $28,5^{\circ}$.

Nas Figuras 9.1, 9.2 e 9.3 são apresentados os valores de coesão durante os ensaios dos protótipos M1, M2 e M3. Os valores de coesão plotados nas figuras referem-se à média da coesão do solo de todos os pontos em que a sucção matricial foi monitorada. De modo a verificar o efeito da variação no grau de saturação no parâmetro de coesão do solo, plotou-se na mesma figura as curvas de grau de saturação versus tempo. Pode-se observar nas Figuras 9.2 e 9.3 que os valores de coesão do solo diminuíram com o tempo diante do avanço de umedecimento (redução da sucção). Já para o protótipo M1, em que a umidade inicial de compactação foi mantida durante o ensaio, os valores de coesão aumentaram durante o ensaio pelos aumentos da sucção matricial (Figura 9.1).

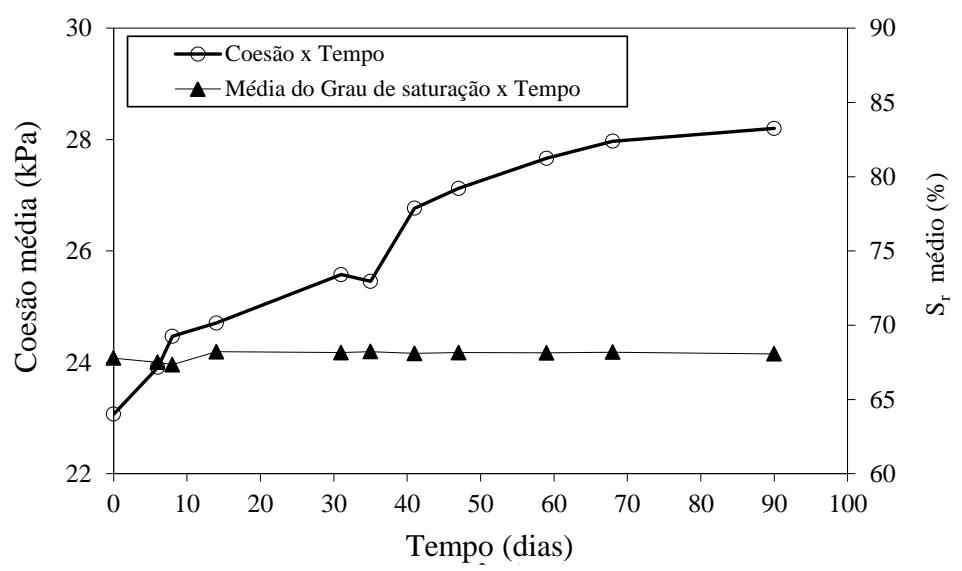

Figura 9.1. Variação da coesão e grau de saturação durante o ensaio do protótipo M1. 


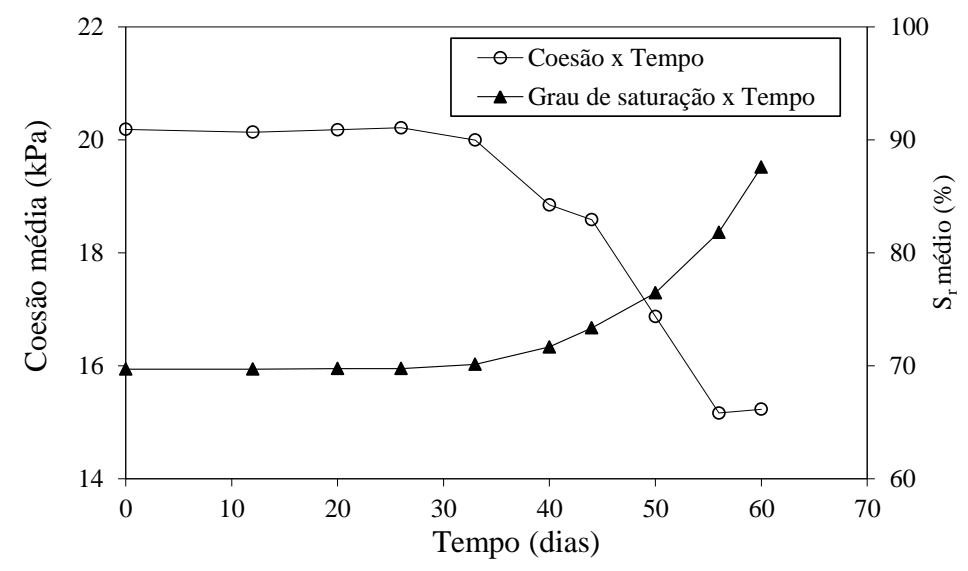

Figura 9.2. Variação da coesão e grau de saturação durante o ensaio do protótipo M2.

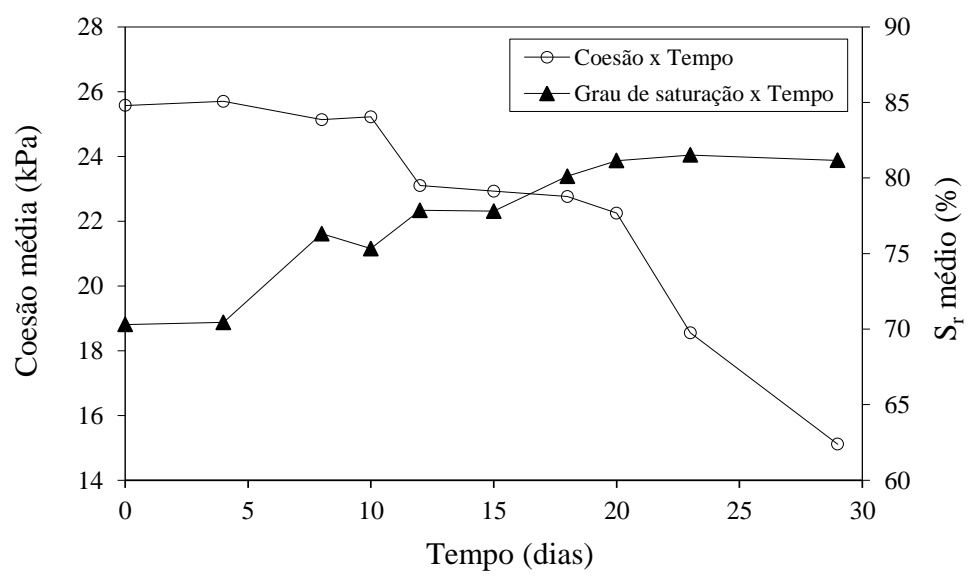

Figura 9.3. Variação da coesão e grau de saturação durante o ensaio do protótipo M3.

\subsection{Comparação entre forças reais calculadas e forças estimadas}

Dois métodos distintos de previsão de forças máximas $\left(\mathrm{T}_{\text {máx }}\right)$ foram utilizados nas análises: a metodologia desenvolvida por Allen et al. (2003), denominada $k$-stiffness method, modificado para solos atritivos e coesivos (MIYATA; BATHURST, 2008); a metodologia AASHTO Simplified Method (AASHTO, 2002), em que as tensões de serviço são calculadas com base na superfície de ruptura de Rankine ou Coulomb.

No capítulo 2, ambas as metodologias são resumidamente apresentadas. Na Equação 2.5, é mostrada a formulação geral do método $k$-stiffness modificado, enquanto a Equação 9.1 apresenta a formulação do método das tensões de serviço da AASHTO Simplified Method:

$$
T_{\text {máx }}=\left[(\gamma H+q) \times k_{a}-2 c \sqrt{k_{a}}\right] \times S_{v}
$$

Os valores de força de tração máxima ( $\mathrm{T}_{\text {máx }}$ ) estimados por ambos os métodos foram comparados aos valores máximos de força de tração calculados com base nas deformações medidas durante os ensaios. Os valores de deformação máxima foram convertidos para valores de 
forças reais utilizando-se o módulo de tração do reforço à $2 \%$ de deformação $\left(\mathrm{J}_{2 \%}\right)$ após 1000 horas de ensaio de fluência, conforme a Equação 9.2:

$$
T_{\text {máx }}=J_{2 \%} \times \varepsilon_{\text {máx }}
$$

Esse método de cálculo da força máxima nos reforços foi o mesmo utilizado nas comparações que levaram ao desenvolvimento do método proposto por Miyata e Bathurst (2008). O grande problema é a consideração do módulo de tração do reforço por meio de ensaios de fluência não confinados. Sabe-se que o efeito do confinamento do solo na resistência à tração de geotêxteis não tecidos é bastante significativo, chegando a valores de módulos cinco vezes maiores comparadas à condição não confinada de ensaio (80\% do valor não confinado) (KAMIJI, 2006; GOMES, 2002, FRANÇA, 2012). Dessa forma, os valores de $\mathbf{J}_{2 \%}$ consistiram em $80 \%$ dos valores de módulo secante $(\mathrm{J})$ não confinado apresentados na Figura 4.11.

\subsubsection{Protótipo M1}

As comparações entre forças nos reforços medidas e teóricas são apresentadas na Figura 9.4. Na Figura 9.4a, são mostradas as distribuições das forças máximas ao longo da altura do protótipo M1, comparada à distribuição teórica das forças estimadas pelo método $k$-stiffness modificado, considerando diferentes valores de coesão durante o ensaio. Com base nesta figura, pode-se verificar que os níveis de forças máximas medidos foram muito próximos aos valores previstos pelo método $k$-stiffness modificado, considerando a coesão inicial do ensaio (aproximadamente $20 \mathrm{kPa}$ ), com exceção dos pontos referentes à camada 2. Embora os níveis medidos tenham sido aproximados ao estimado, a distribuição destes ao longo da altura não coincidiu com a teoria. Em adição, pelo método, uma coesão maior que $20 \mathrm{kPa}$ resultaria em valores negativos de forças de tração, o que indicaria que estas não seriam transmitidas aos reforços.

As distribuições das forças estimadas pelo do método de previsão das tensões de serviço (AASHTO, 2002) comparadas às medidas são apresentadas na Figura 9.4b. Nesse gráfico, é claro o conservadorismo do método, sendo este caráter conservador a principal razão da aceitação no meio técnico, juntamente com a facilidade das formulações e cálculos.

Com base nas Figuras 9.4a e 9.4b, conclui-se que o método $k$-stiffness modificado apresenta-se como o método mais apropriado para previsão de forças nos reforços. Por não apresentar nenhum aspecto conservador, recomenda-se a utilização de fatores de redução da resistência à tração do geotêxtil, para que uma margem de segurança seja estabelecida. Um aspecto interessante nestas análises, é que as forças mobilizadas pelos reforços são próximas de zero. Portanto, pode-se dizer que quase todas as tensões atuantes são mobilizadas pelo elevado módulo de rigidez do solo não saturado. Assim, supõe-se que a estrutura poderia se manter estável 
mesmo com a ausência dos reforços geotêxteis, que neste caso, funcionaram como elementos construtivos que permitiram a execução de uma estrutura íngreme.
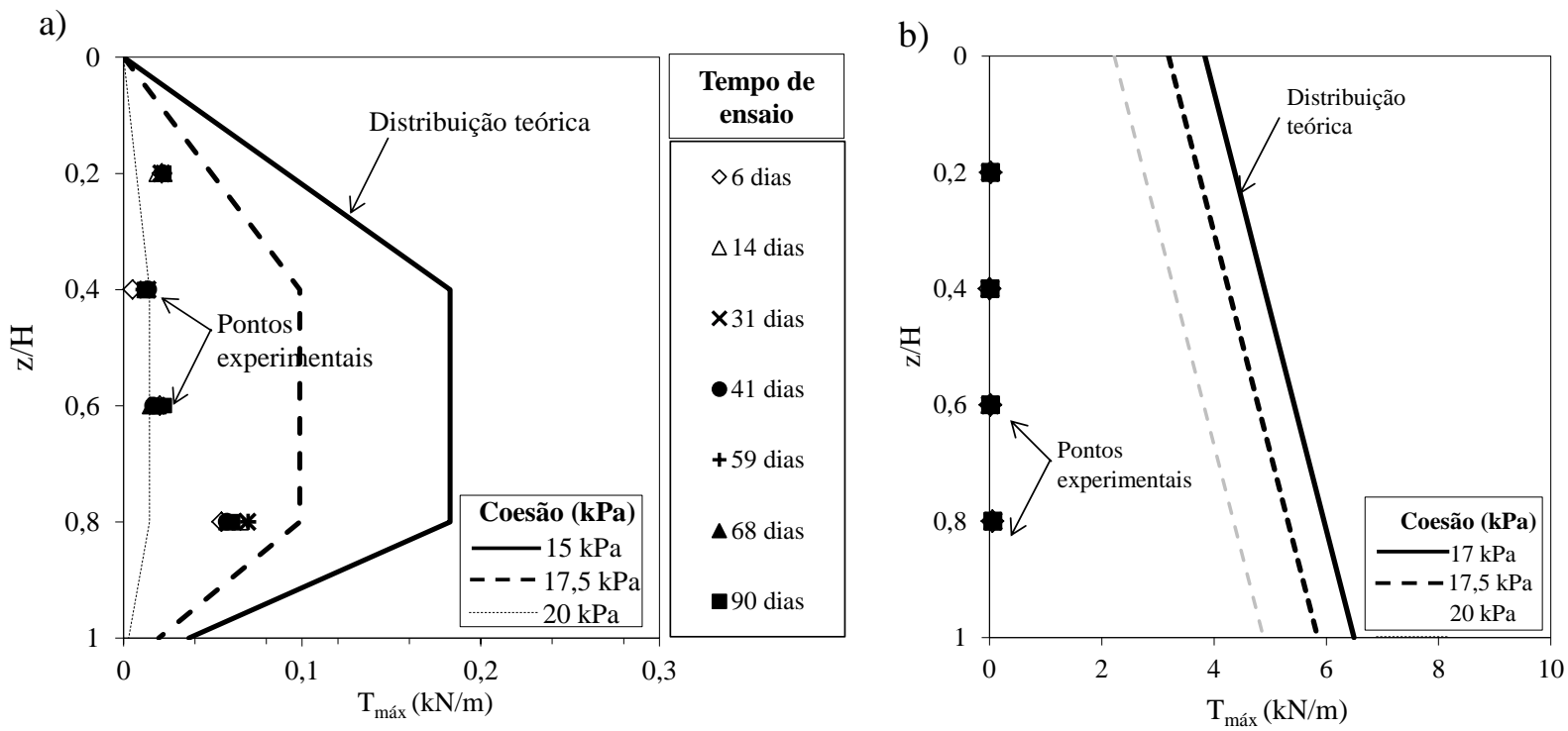

Figura 9.4. Distribuição das forças medidas e teóricas nos reforços do protótipo M1: (a) k-stiffness modificado; (b) AASHTO Simplified Method.

\subsubsection{Protótipo M2}

As comparações entre as forças previstas e as forças medidas durante o ensaio no protótipo M2 são mostradas na Figura 9.5. Como o protótipo M2 foi submetido ao avanço da frente de umedecimento, os valores de sucção matricial e, consequentemente, da coesão do solo, sofreram reduções durante o ensaio. Dessa forma, para a previsão do método $k$-stiffness modificado, utilizaram-se valores de coesão obtidos em diferentes períodos de ensaio. Com base nesta Figura 9.5a, verifica-se que o método $k$-stiffness modificado estimou com boa precisão as forças máximas atuantes nos reforços, com exceção do período correspondente a 67 dias de ensaio, em que as maiores forças foram registradas nas camadas 5 e 2. Foi observado, também, que o método é bastante consistente com a realidade do protótipo, tanto para os níveis de forças registrados, como para a distribuição ao longo da altura. Adicionalmente, as forças medidas nos reforços aumentaram com o tempo devido ao umedecimento, e a distribuição do método acompanhou coerentemente estas alterações. Portanto, o método k-stiffness modificado apresentou-se como uma ferramenta bastante apropriada para análises desse tipo de estrutura, inclusive quando o avanço do umedecimento for considerado em termos da coesão média do solo.

$\mathrm{Na}$ Figura 9.5b foram comparadas as forças medidas nos reforços às forças previstas pelo método das tensões de serviço da AASHTO. Novamente, foi observado o caráter conservador deste método, em que os níveis de forças estimados foram muito maiores que os medidos. Ainda, a distribuição linear deste método foi inconsistente com a distribuição real do protótipo M2, que se aproximou da distribuição do método $k$-stiffness modificado. 

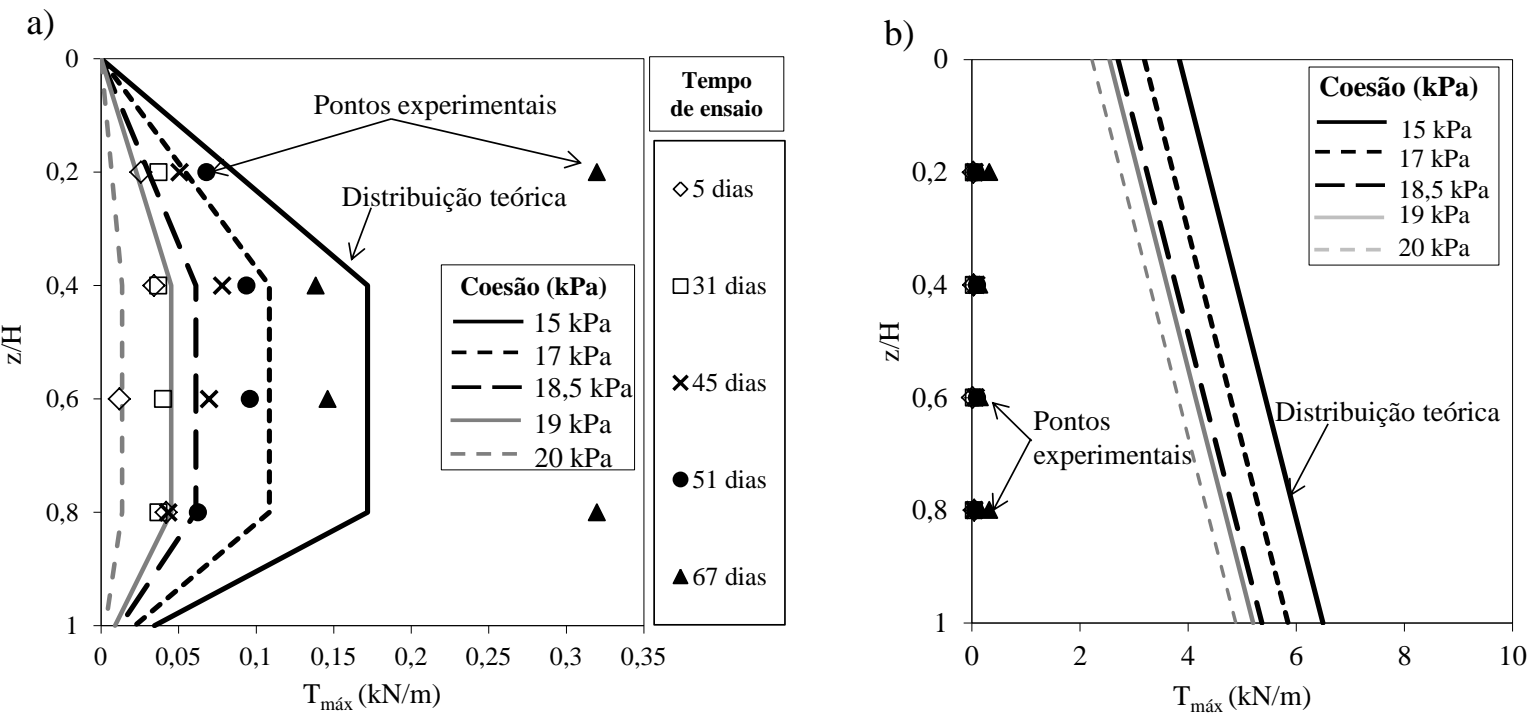

Figura 9.5. Distribuição das forças medidas e teóricas nos reforços do protótipo M2: (a) k-stiffness modificado; (b) AASHTO Simplified Method.

Com a finalidade de verificar a aproximação dos métodos avaliados aos valores medidos, utilizaram-se os gráficos de comparação apresentados nas Figuras 9.6. Verifica-se, portanto, a boa aproximação do método $k$-stiffness com os valores de força medidos no protótipo M2, o que caracteriza o método como não conservador. Em contrapartida, as forças medidas são, muitas vezes, maiores que as forças estimadas, mostrando que o método pode resultar em estruturas subdimensionadas. Já o método que utiliza as tensões de serviço de Rankine (Figura 9.6b) mostrase bastante conservador, assim como discutido anteriormente.
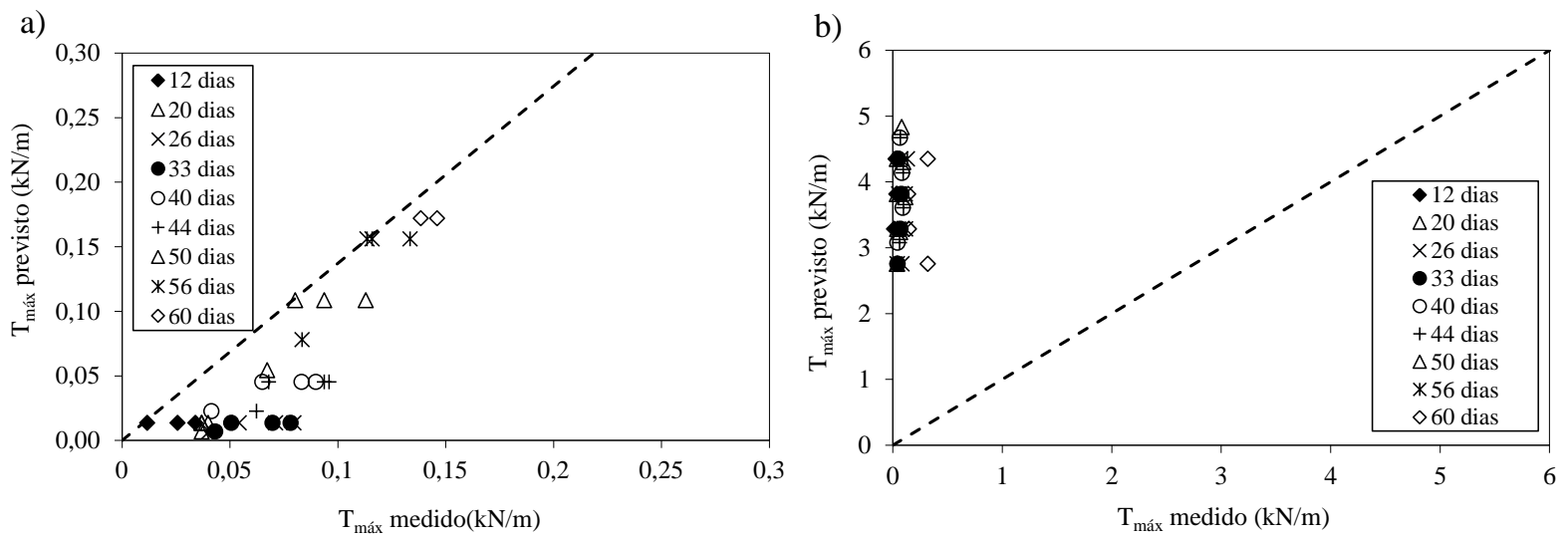

Figura 9.6. Comparação entre força medidas e previstas no protótipo M2: (a) método k-stiffness modificado; (b) AASHTO Simplified Method.

No caso da utilização de parâmetros não confinados, o método da AASHTO geraria resultados ainda mais conservadores, e o método $k$-stiffness apresentaria um aspecto conservador apropriado para a segurança da estrutura, sem considerar que existem fatores de redução que poderia deixar este método ainda mais conservador. Portanto, o método $k$-stiffness consiste em uma boa ferramenta de análise de tração máxima nos reforços desde que algum caráter conservador relatado anteriormente seja considerado. 


\subsubsection{Protótipo M3}

Na Figura 9.7 são apresentadas as distribuições das forças máximas medidas e previstas nos reforços do protótipo M3. Observa-se na Figura 9.7a, que as forças mobilizadas pelos reforços são próximas das forças previstas, embora estas não tenham se apresentado tão consistentes quanto ao verificado no protótipo M2. Ainda, a distribuição não correspondeu à prevista pelo método k-stiffness modificado, já que as maiores forças foram transmitidas nos reforços das camadas inferiores. Este comportamento é consistente com o verificado no protótipo M1.

a)

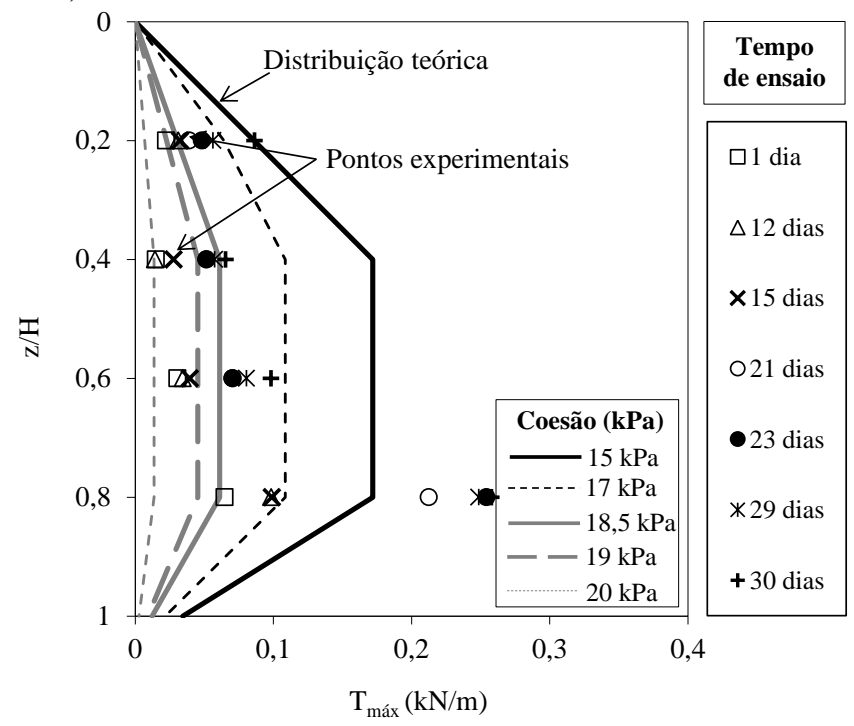

b)

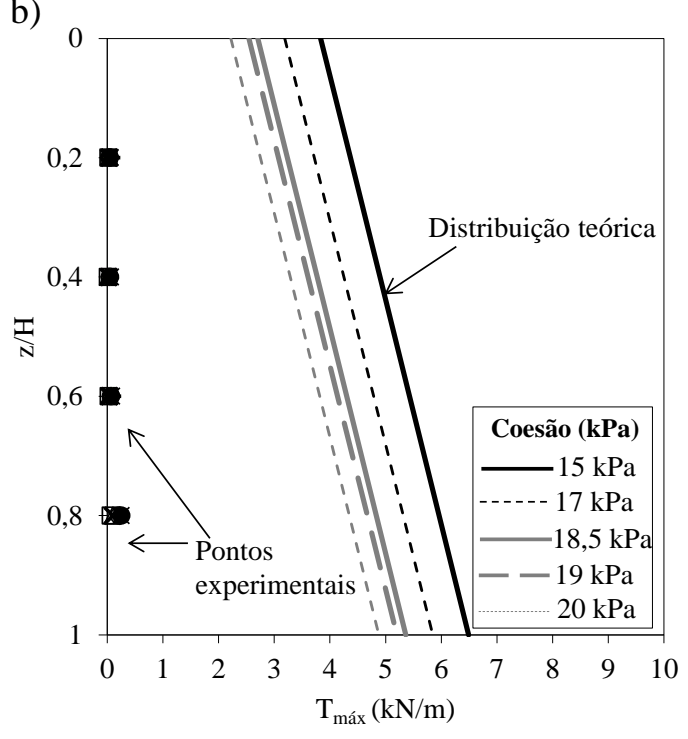

Figura 9.7. Distribuição das forças medidas e teóricas nos reforços do protótipo M3: (a) k-stiffness modificado; (b) AASHTO Simplified Method.

$\mathrm{Na}$ Figura 9.7b são apresentadas as comparações das forças medidas com as forças previstas pelo método da AASHTO (2002), onde se certifica, novamente, o conservadorismo do método mesmo para os elevados níveis de coesão registrados. Neste caso, assim como verificado no protótipo M1, a distribuição das forças é linear e crescente em direção à base do protótipo. Os gráficos de comparação dos métodos $k$-stiffness modificado e AASHTO Simplified method aos valores reais de forças máximas nos reforços são apresentados na Figura 9.8.

Com base nos resultados mostrados neste capitulo, constatou-se que as forças reais mobilizadas pelos reforços foram bastante consistentes com os valores previstos pelo método $k$ stiffness modificado. O método apresentou-se bastante coerente com o comportamento real dos protótipos, inclusive mostrando alterações dos níveis de forças devido ao processo de umedecimento, que ocasionou a perda da parcela de coesão do solo. De fato, o método das tensões de serviço é um método muito conservador. O principal motivo para este conservadorismo está no fato de que este não considera a parcela de tensão mobilizada pelo solo. Pode-se verificar neste trabalho que, a rigidez do solo teve uma influência significativa no comportamento dos protótipos, sendo que em um deles (protótipo M1) toda a tensão atuante foi mobilizada pela elevada rigidez do solo não saturado. 
a)

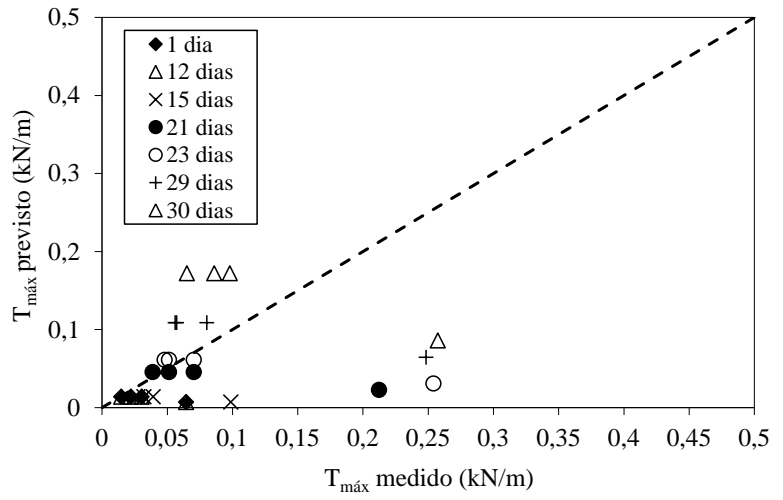

b)

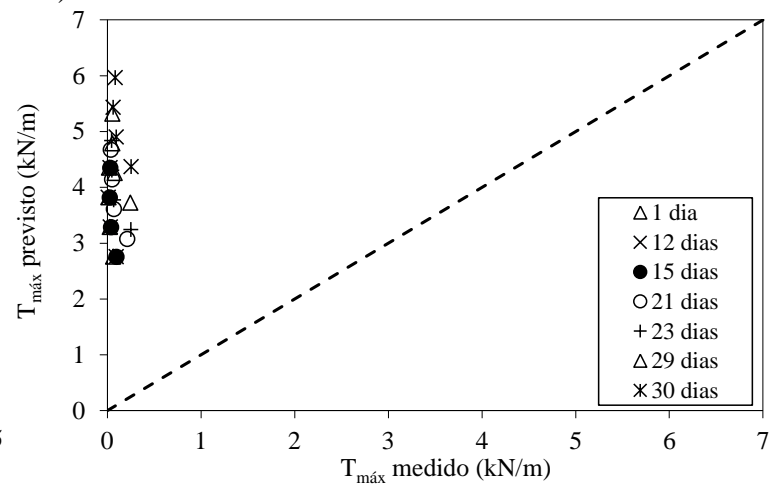

Figura 9.8. Comparação entre força medidas e previstas no protótipo M3: (a) método k-stiffness; (b) AASHTO Simplified Method.

A influência das rigidezes do solo e reforços na mobilização das forças está totalmente associada à compatibilidade de deformações do sistema solo-reforço, conforme ilustra a Figura 9.9. Os parâmetros de rigidez de solo foram obtidos de ensaios triaxiais $\mathrm{CD}$, com tensão confinante de $100 \mathrm{kPa}$, enquanto os parâmetros dos reforços foram obtidos dos ensaios de tração não confinada, porém corrigidos considerando-se o aumento de $80 \%$ na rigidez do reforço, devido ao confinamento do solo. Pode-se notar que, para os níveis de deformações máximas do protótipo M1, o módulo de rigidez do solo foi maior que a rigidez do reforço. Dessa forma, a mobilização do reforço não ocorreu, o que resultou em valores de forças transmitidas aos reforços próximos de zero (Figura 9.4). Já para os protótipos M2 e M3, as deformações máximas ao final dos ensaios estavam próximas do ponto de mobilização do reforço, o que resultou em maiores níveis de deformações registrados. No caso da redução da rigidez devido ao umedecimento, a mobilização dos reforços ocorre para menores deformações, o que deve ser considerado nas deformações máximas dos protótipos M2 e M3. Tal avaliação mostrada na Figura 9.8, consiste numa análise de caráter qualitativo.

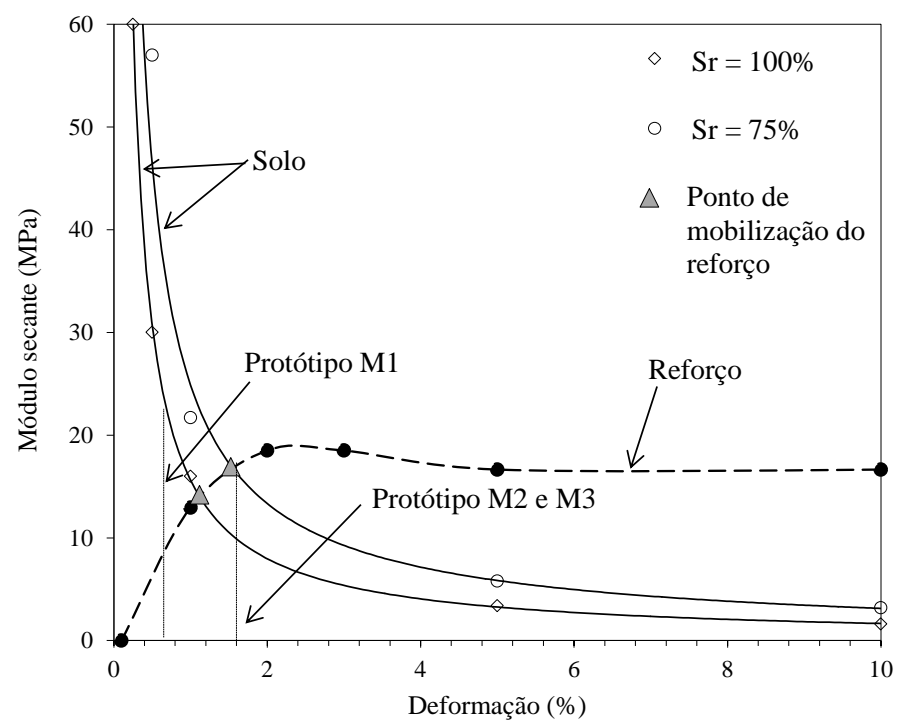

Figura 9.9. Compatibilidade de deformações do solo e reforços dos protótipos. 


\section{COMPARAÇÕES ENTRE OS COMPORTAMENTOS DOS PROTÓTIPOS}

Alguns aspectos do avanço do umedecimento e do efeito no comportamento dos protótipos estudados nesta pesquisa serão comparados, já que diferentes condições de umedecimento e sobrecargas foram avaliadas. Serão comparados os efeitos das condições de chuvas intensas e intermitentes (Protótipos M2 e M4) e de chuvas constantes e baixa intensidade (Protótipo M3), bem como a ação de sobrecargas constante (Protótipos M1, M2 e M3) e crescente (Protótipo M4) durante os ensaios. O efeito de cada condicionante citado será comparado ao protótipo M1, em que a condição de umidade de compactação foi mantida constante durante o ensaio.

\subsection{Comparações dos avanços do umedecimento e dos efeitos no comportamento dos protótipos}

A comparação do avanço da frente de umedecimento entre os protótipos M2, M3 e M4 é apresentada na Figura 10.1. Observa-se que o avanço de umedecimento durante o ensaio foi semelhante para os protótipos M2 e M3, nos quais distintas condições de precipitação foram simuladas. Com base nesta constatação, afirma-se que a chuvas intermitentes de maiores intensidades (Protótipo M2) resultaram em velocidades de infiltração de água muito semelhantes às das condições de intensidade baixa (menor que a permeabilidade do solo) e constante durante todo o ensaio (Protótipo M3). Com isso, pode-se supor que a intensidade passaria a ter maior influência, se a duração da precipitação fosse semelhante à imposta no protótipo M3. Cabe notar, no trecho inicial da Figura 10.1, antes do avanço alcançar a linha de reforço 5, que a velocidade de infiltração do protótipo M2 foi inicialmente maior que para o protótipo M3, mostrando indícios de que esta poderia ser maior, caso não existissem os reforços. De fato, as barreiras capilares nas interfaces solo-geotêxtil podem restringir o fluxo temporariamente, retardando o processo de infiltração e igualando a velocidade de avanço para ambos os casos. No caso do protótipo M4, a velocidade de infiltração foi maior devido aos longos períodos entre os eventos de chuvas ocorridos no $10^{\circ}$ e $30^{\circ}$ dia de avanço (Figura 10.1). Caso este período de intermitência fosse desconsiderando, a velocidade de avanço seria semelhante à dos protótipos M2 e M3.

Na Figura 10.2, são comparados os efeitos do avanço do umedecimento nas deformações máximas de pico e nos deslocamentos de face máximo das estruturas. Uma vez que o avanço do umedecimento nos protótipos M2 e M3 foi semelhante, as deformações máximas de pico foram também aproximadas. Cabe notar, inclusive, que o comportamento de deformação do protótipo M4 foi também análogo aos protótipos M2 e M3 no período correspondente ao intervalo de tempo 
em que o avanço foi semelhante, correspondente ao trecho entre 0 a 10 dias (Figura 10.1). Neste período, as tensões aplicadas em cada protótipo foram semelhantes, muito embora no protótipo M4 tenha ocorrido o incremento de tensões de $50 \mathrm{kPa}$ para $100 \mathrm{kPa}$, o que não resultou em deformações adicionais. Após este período, as deformações medidas no protótipo M4 aumentaram significativamente devido a ação de incrementos de tensões. Em termos de deslocamentos de face (Figura 10.2b), nota-se o mesmo comportamento das deformações, porém, os deslocamentos de face do protótipo M2 aumentaram significativamente em relação ao protótipo M3, a partir de certa profundidade de avanço. Tal comportamento pode ser atribuído ao fluxo preferencial de água em regiões próximas da face, o que não ocorreu no protótipo M3. Com relação ao protótipo M4, o mesmo comportamento da Figura 10.2a foi evidenciado. Destaca-se que a utilização de revestimento de face com argamassa promoveu uma maior rigidez do faceamento reduzindo os deslocamentos.

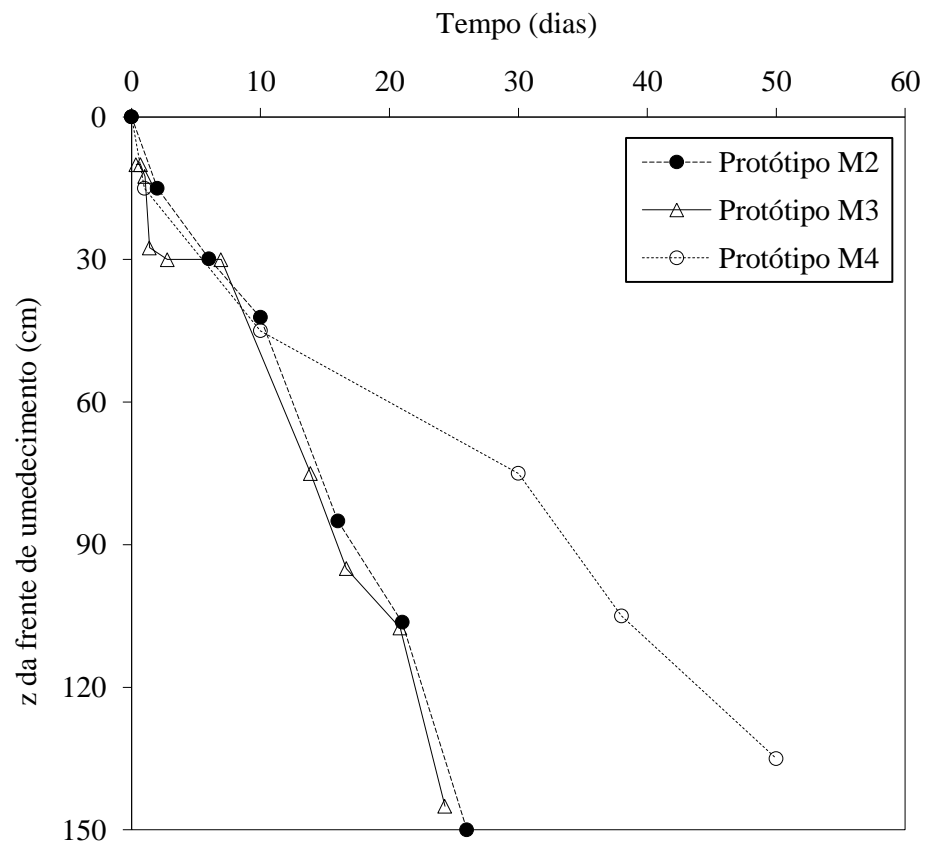

Figura 10.1. Comparação do avanço da frente de umedecimento com o tempo para os protótipos M2, M3 e M4. 

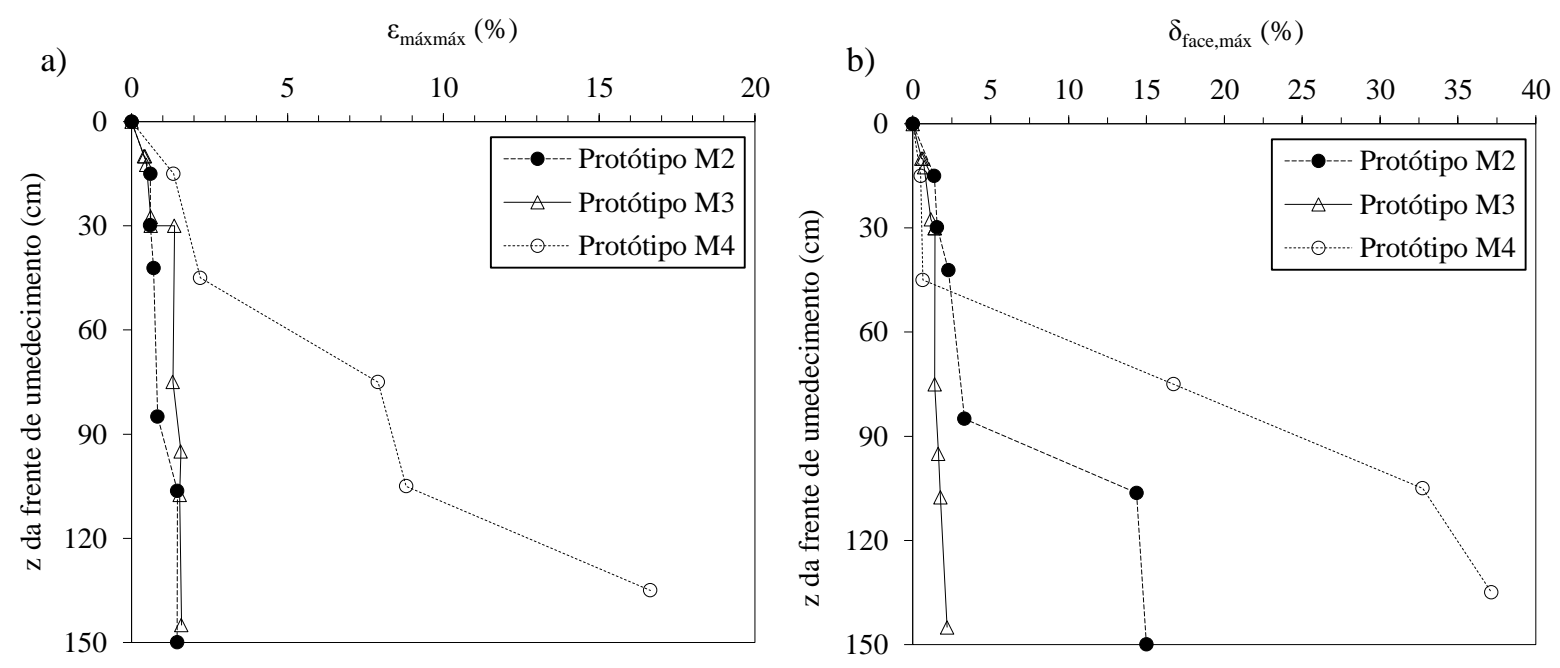

Figura 10.2. Comparação do efeito do avanço do umedecimento no comportamento dos protótipos M2, M3 e M4: (a) deformações máximas de pico; (b) deslocamentos máximos de face.

10.2. Comparações entre os efeitos das alterações do grau de saturação do solo devido às condições de umedecimento

As comparações dos valores de grau de saturação medidas durante os ensaios nos protótipos M2, M3 e M4 são apresentados na Figura 10.3. Os períodos desta análise apresentam-se entre o início dos eventos de precipitação e o final dos ensaios.

Comparando-se os protótipos M2 e M3, pode-se considerar que os valores finais de grau de saturação do protótipo M2 foram maiores que os observados no protótipo M3. O que pode ser associado aos eventos de chuvas mais intensos. Curiosamente, mesmo que as velocidades de infiltração tenham sido semelhantes (Figura 10.1), os valores finais de grau de saturação foram diferentes, sendo estes maiores para o protótipo M2, cujas chuvas foram mais intensas. Os resultados do protótipo M3 mostram que existe uma estabilização do valor final de saturação, indicando que este consiste no valor máximo para as condições hidráulicas estabelecidas no interior do maciço. No caso do protótipo M4, este valor final estabilizado é menor que os valores do protótipo M3, o que pode ser atribuído ao uso de reforços mais permeáveis. Praticamente durante todo o ensaio do protótipo M4, os valores de grau de saturação foram menores que os registrados nos protótipos M2 e M3. 
a)

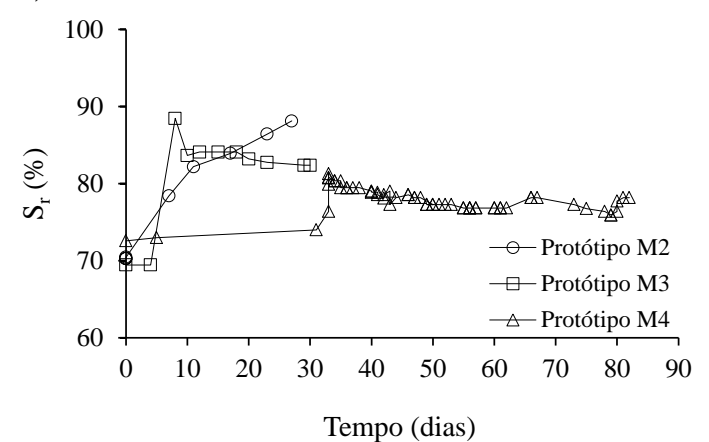

c)

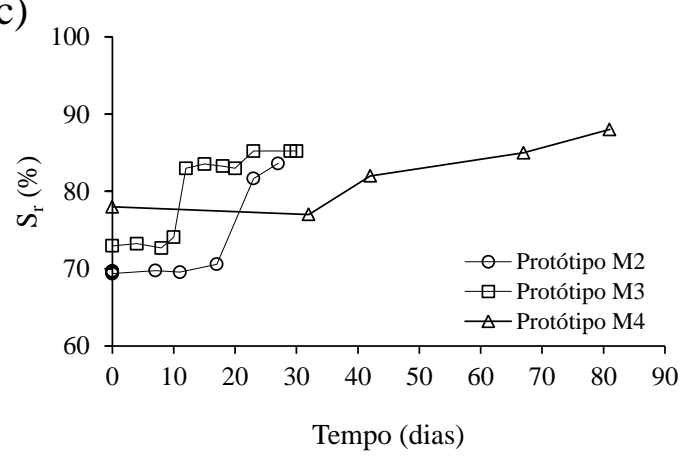

b)

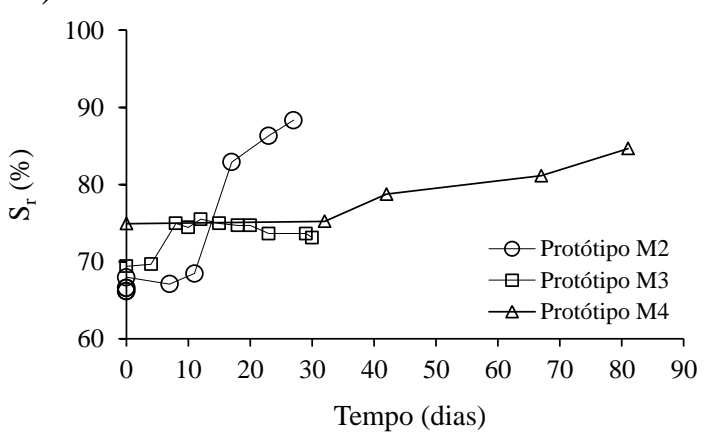

d)

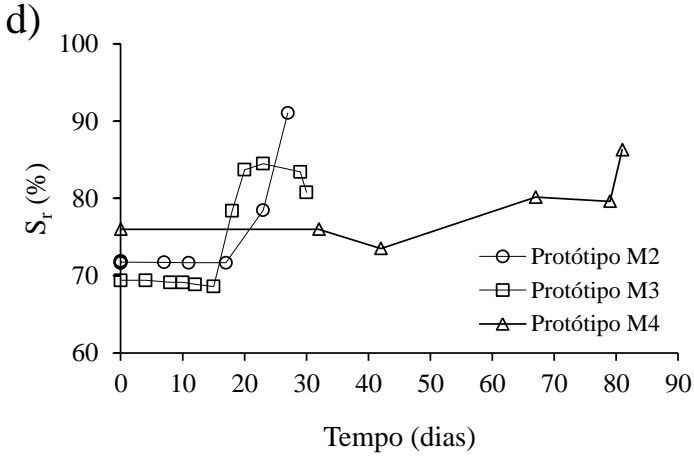

Figura 10.3. Comparação dos valores de grau de saturação dos protótipos M2, M3 e M4: (a) camada 5; (b) camada 4; (c) camada 3; (d) camada 2.

Na Figura 10.4 são comparados os valores de sucção registrados durante os ensaios. Com base nestes resultados, constata-se que, o comportamento de sucção matricial dos protótipos M2 e M3 são bastante semelhantes, embora os valores iniciais de sucção tenham sido diferentes. Esperava-se que durante a infiltração, a aplicação de uma precipitação com intensidade menor que a permeabilidade do solo resultasse em valores de sucção maiores, comparados à situação em que chuvas mais intensas fossem aplicadas. No entanto, o fato da precipitação do protótipo M3 ser relativamente próxima do valor de condutividade hidráulica do solo, as duas situações resultaram em valores de sucção aproximados. No caso do protótipo M4, os valores de sucção durante a infiltração foram maiores, o que pode ser decorrente de uma maior capacidade de drenagem interna. 
a)
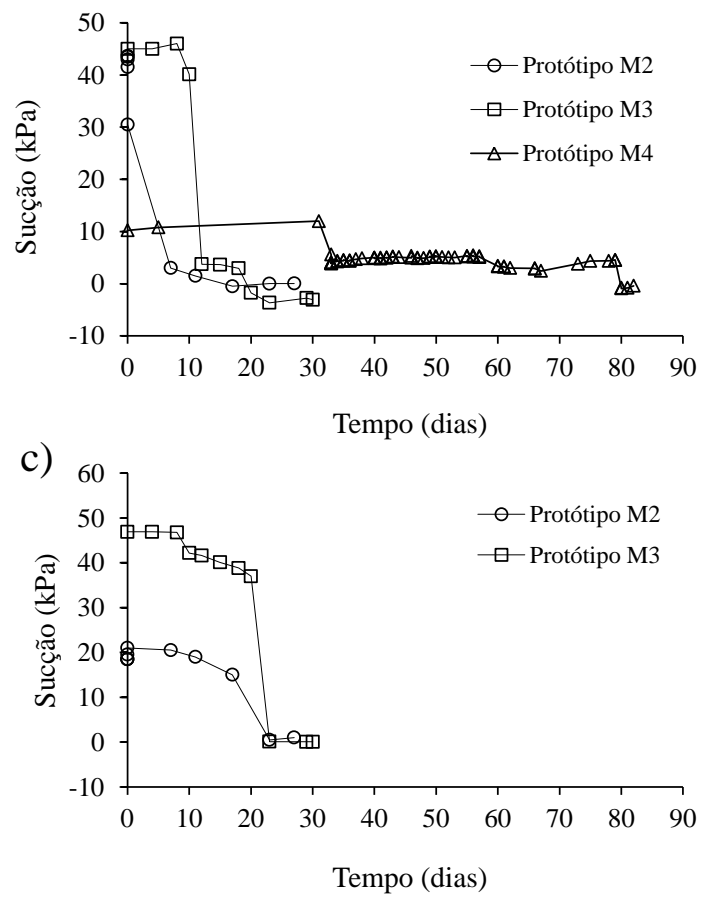

b)

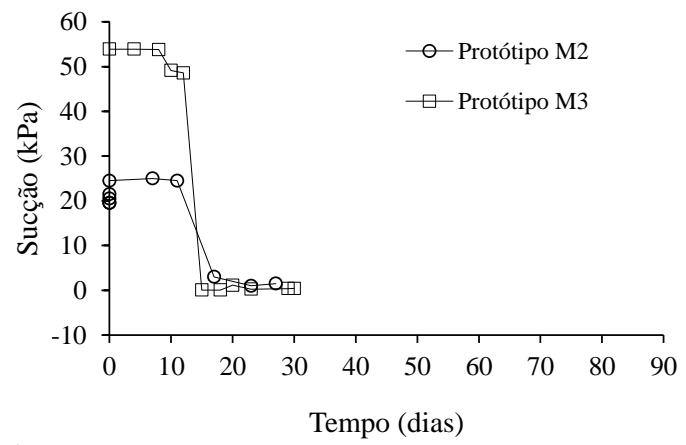

d)

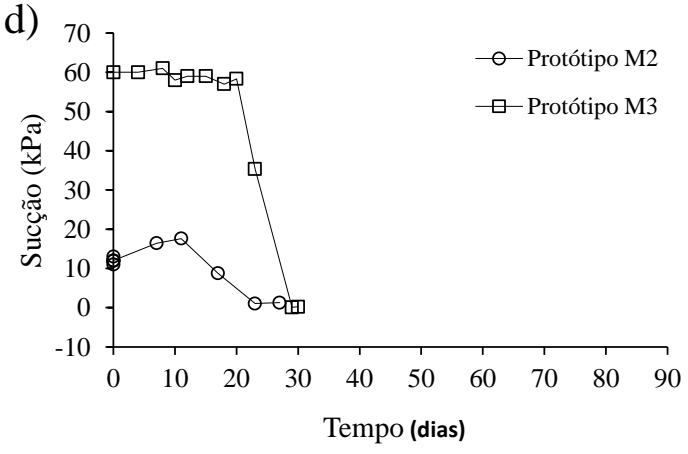

Figura 10.4. Comparação dos valores de sucção matricial dos protótipos M2, M3 e M4: (a) camada 5; (b) camada 4 ; (c) camada 3 ; (d) camada 2.

Na Figura 10.5 são exibidos os efeitos das alterações dos valores médios de grau de saturação do solo medidos durante o ensaio, nas deformações de pico máximas e nos deslocamentos de face máximos. Cabe notar que, os níveis iniciais de deformações e deslocamentos de todos os protótipos, anteriormente ao avanço da frente de infiltração, corresponderam às deformações medidas no protótipo M1. Naturalmente, após o início do avanço, as deformações passam a aumentar exponencialmente com o aumento do grau de saturação médio do solo. Quando incrementos de sobrecargas são aplicados, esta taxa de aumento passa a ser mais significativa, como pode ser verificado na curva do protótipo M4. Comparado o efeito das condições de chuvas simuladas nos protótipos M2 e M3, foi constatado que as implicações no comportamento de deformação no reforço devido às alterações na média do grau de saturação do solo, foram semelhantes tanto quando chuvas mais intensas e intermitentes foram simuladas, quanto em condições de chuvas permanentes e de baixas intensidades. Este comportamento foi consistente com o esperado, uma vez que a velocidade de avanço de umedecimento foi a mesma (Figura 10.1). Em termos de deslocamento de face, pode-se dizer que a diferença entre os comportamentos dos protótipos M2 e M3 é decorrente do umedecimento preferencial da face, que pode ter implicado em deslocamentos localizados. 

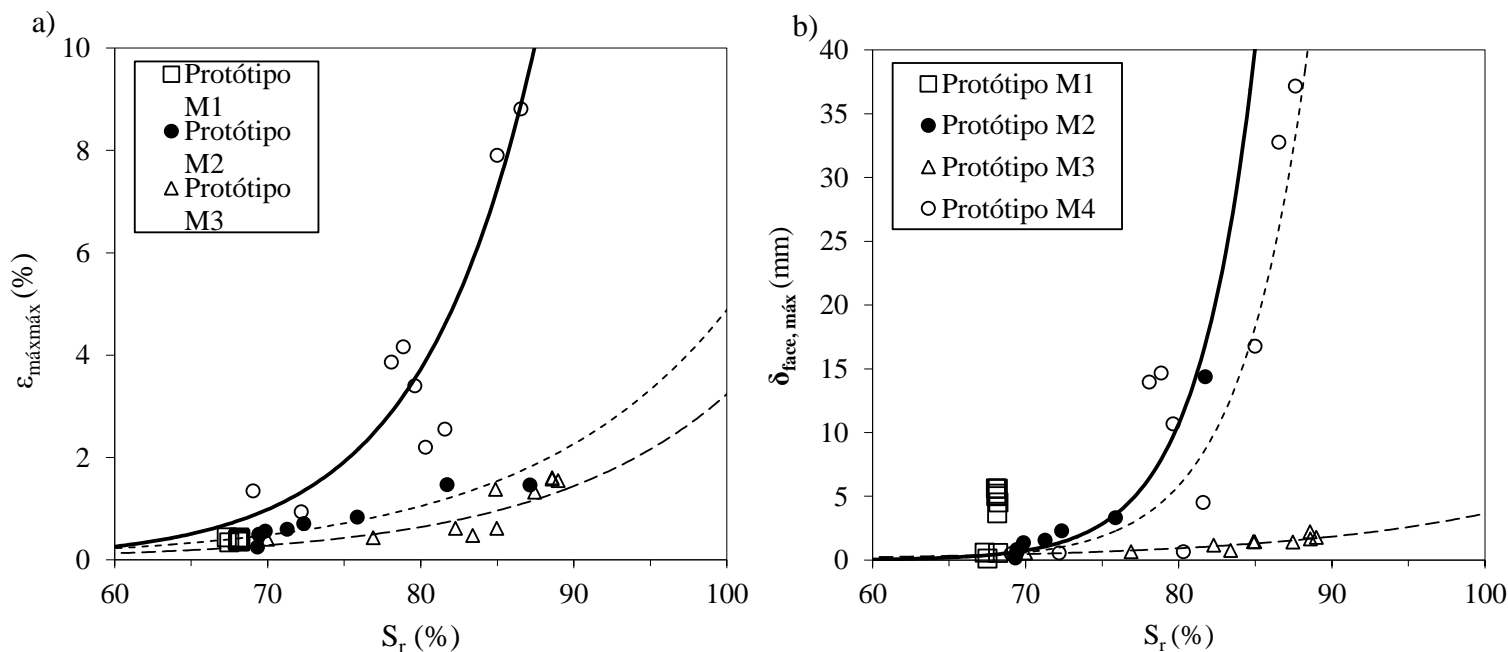

Figura 10.5. Comparação das alterações no grau de saturação médio do solo no comportamento dos protótipos M1, M2, M3 e M4: (a) deformações máximas de pico; (b) deslocamentos máximos de face.

Os efeitos do umedecimento nas alterações dos valores de sucção média do solo nas deformações de pico máximas e nos deslocamentos máximos de face são mostrados na Figura 10.6. Estes dados mostram que, tanto no protótipo M2 quanto no protótipo M3, existe uma tendência similar ao da curva de retenção de água do solo entre os parâmetros avaliados. No entanto, os formatos foram diferentes, sendo a do protótipo M2 com menor inclinação no trecho de transição (entre 5 e $100 \mathrm{kPa}$ ) da curva de retenção em comparação com o protótipo M3. Este comportamento pode estar associado à intermitência das chuvas aplicadas no protótipo M2.

a)

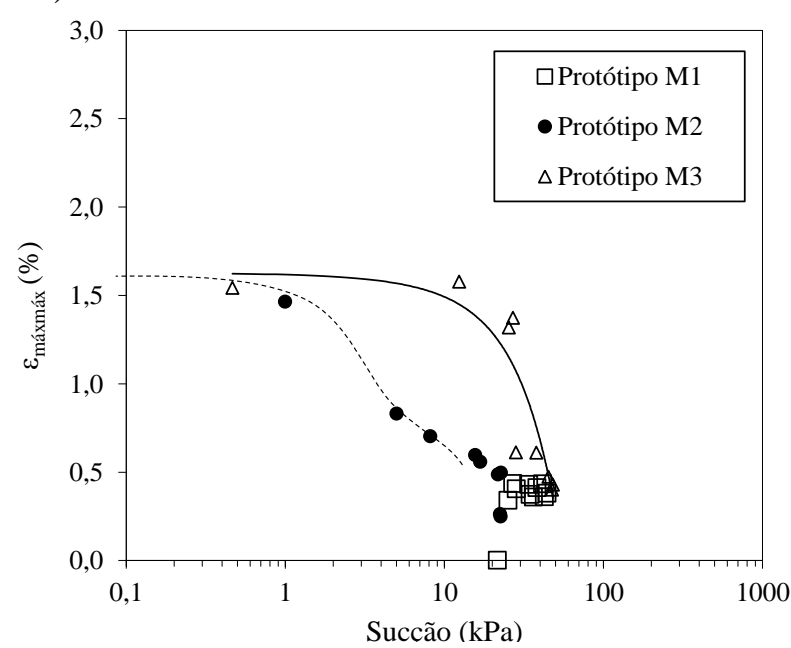

b)

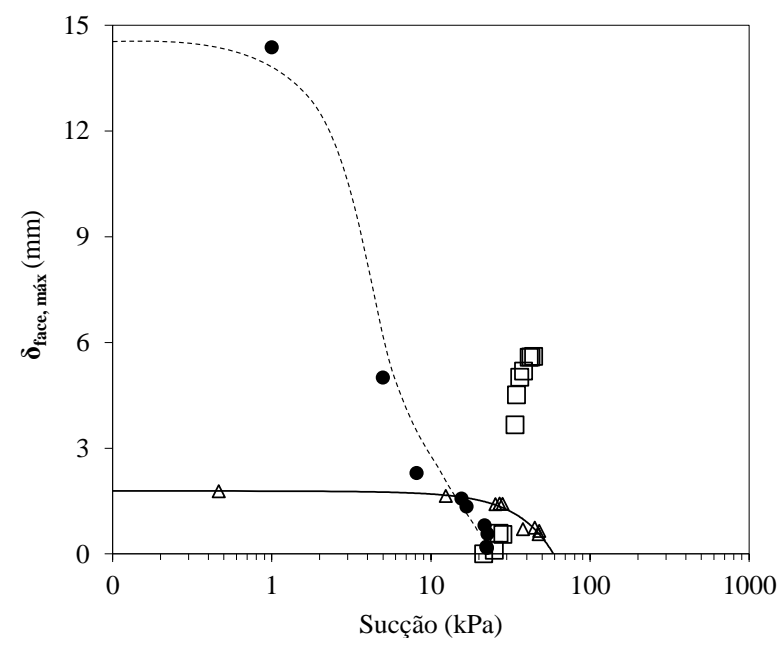

Figura 10.6. Comparação das alterações sucção média do solo no comportamento dos protótipos M1, M2, M3 e M4: (a) deformações máximas de pico; (b) deslocamentos máximos de face.

Nas Figuras 10.7 e 10.8 são mostradas as distribuições das deformações de pico dos reforços e dos deslocamentos de face máximos, respectivamente, ao longo da altura do protótipo. Pode-se verificar nesta figura que tanto os regimes de chuvas adotados no protótipo M2 quanto no 
protótipo M3, resultaram em distribuições e níveis de deformações semelhantes. Ainda, as distribuições iniciais foram também semelhantes à distribuição do protótipo M1 (umidade constante). Com o avanço da frente de umedecimento e alterações no grau de saturação, as deformações aumentaram e algumas alterações nas distribuições foram evidenciadas, principalmente no protótipo M2. Alterações significativas nas deformações foram observadas quando tensões atuaram na estrutura umedecida (protótipo M4).

a)

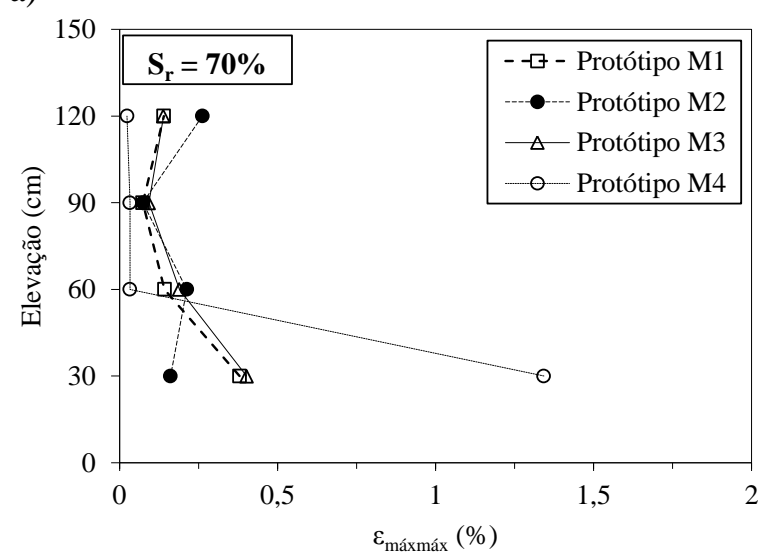

b)

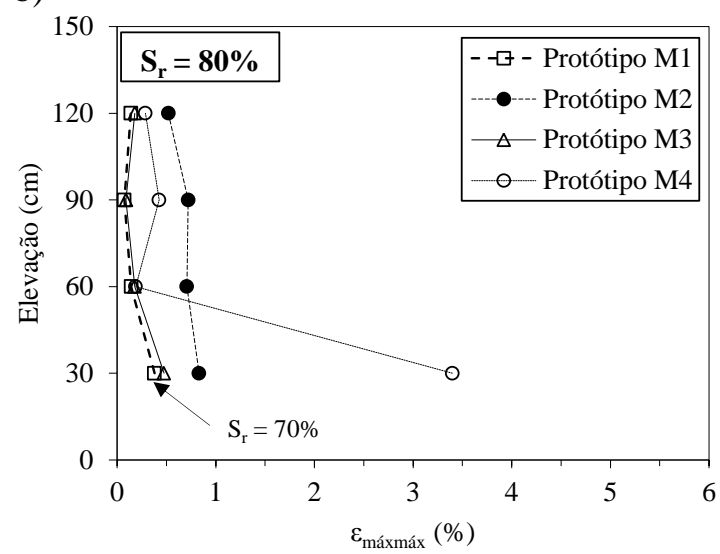

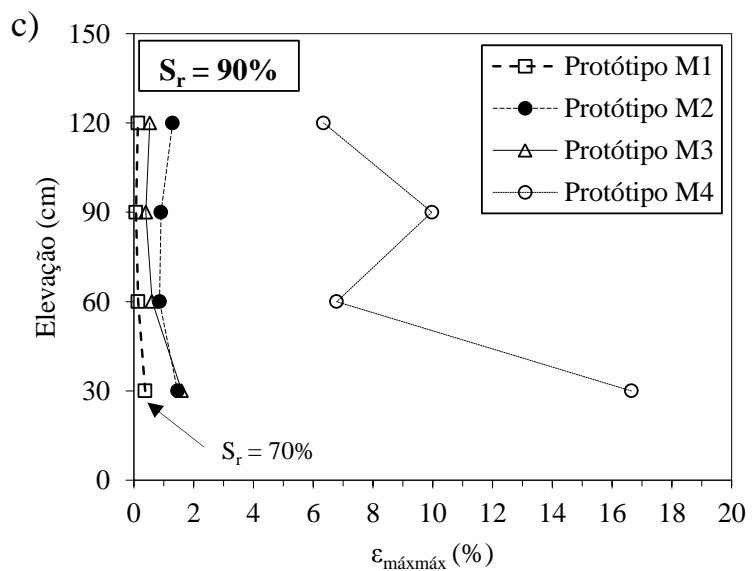

Figura 10.7. Comparação das distribuições das deformações máximas ao longo da altura dos protótipos M1, M2, M3 e M4 (a) $\mathrm{S}_{\mathrm{r}}=70 \%$; (b) $\mathrm{S}_{\mathrm{r}}=80 \%$; (c) $\mathrm{S}_{\mathrm{r}}=90 \%$.

Com relação aos deslocamentos de face máximos (Figura 10.8), foi observado que o comportamento pode ser influenciado pela presença de água em regiões próximas da face, ou seja, em condições em que o escoamento de água ocorre no topo da estrutura. Este foi o caso verificado nos protótipos M2 e M4, em que as intensidades dos eventos de chuvas proporcionaram o escoamento de água no topo, conduzindo a água para as regiões próximas da face. De modo geral, os deslocamentos máximos ocorreram no primeiro terço da altura do protótipo, assim como descrito na literatura. 
a)

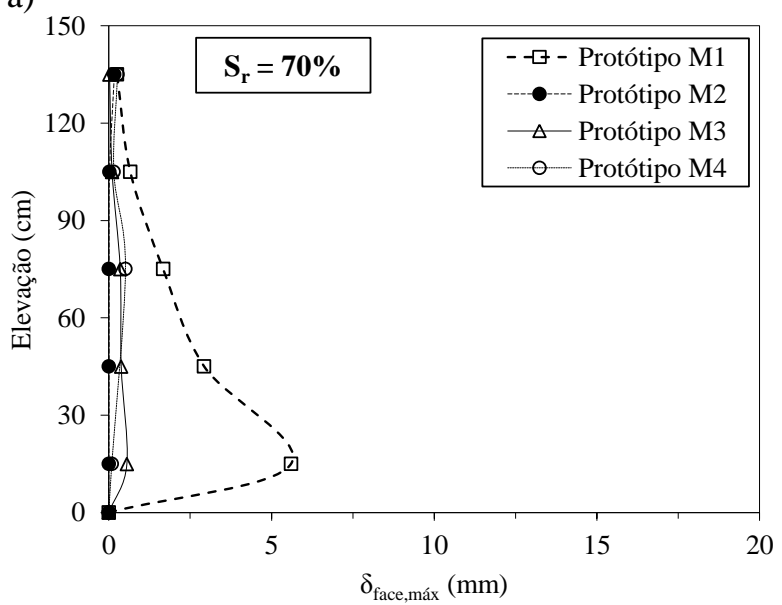

b)

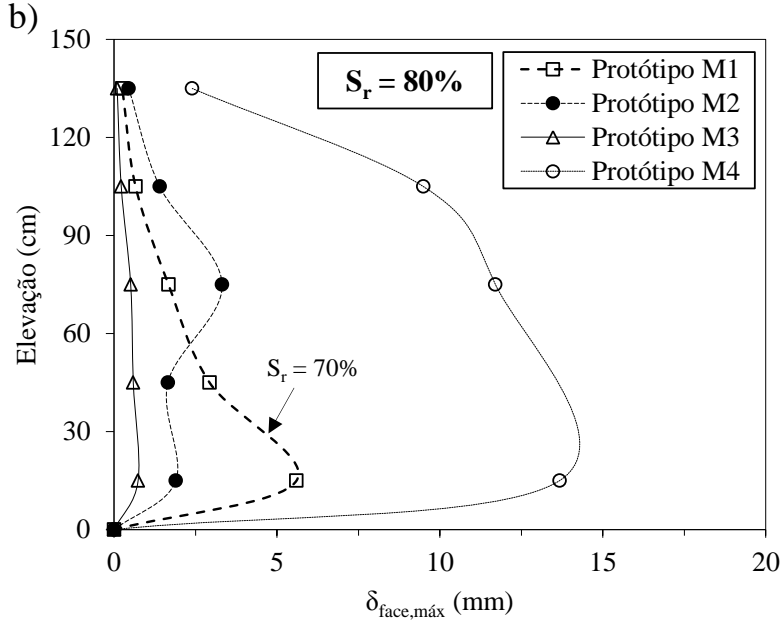

c)

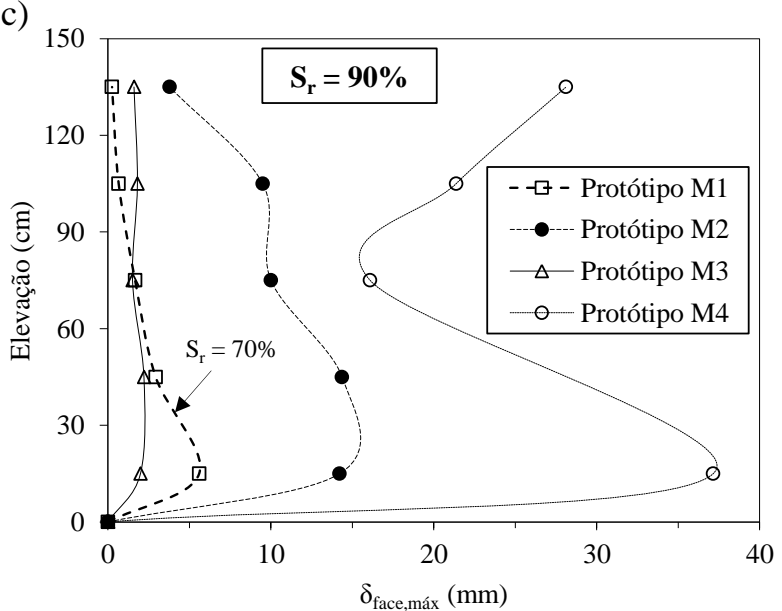

Figura 10.8. Comparação das distribuições dos deslocamentos máximos de face ao longo da altura dos protótipos M1, M2, M3 e M4: (a) $\mathrm{S}_{\mathrm{r}}=70 \%$; (b) $\mathrm{S}_{\mathrm{r}}=80 \%$; (c) $\mathrm{S}_{\mathrm{r}}=90 \%$.

\subsection{Comparações das alterações nas superfícies de rupturas reais durante o avanço do umedecimento}

Na Figura 10.9 são apresentadas as superfícies reais de ruptura obtidas com base na posição dos picos de deformações nas diferentes camadas instrumentadas, para os valores médios do grau de saturação de $70 \%, 80 \%$ e $90 \%$, respectivamente. Nota-se que inicialmente, quando o grau de saturação era de $70 \%$ (Figura 10.9a), as superfícies de ruptura apresentaram-se semelhantes para todos os ensaios. O fato de a infiltração avançar no interior do maciço, e aumentar o grau de saturação do solo (80 e 90\%), não afetou o formato da superfície de ruptura. Isso pode ser evidenciado nas superfícies dos protótipos M1 e M3. No entanto, quando as condições de chuva propiciaram o escoamento de água em direção à face, as superfícies de ruptura passaram a sofrer alterações, se movimentando em direção a face. Tal fenômeno, associado à aplicação de incrementos de tensões, movimentaram ainda mais a superfície de ruptura, como pode ser verificado na superfície do protótipo M3 da Figura 10.9b. Cabe relatar que 
as alterações no protótipo M2 (carga constante) praticamente cessaram a partir do grau de saturação de $80 \%$ (Figura 10.9c).

a)

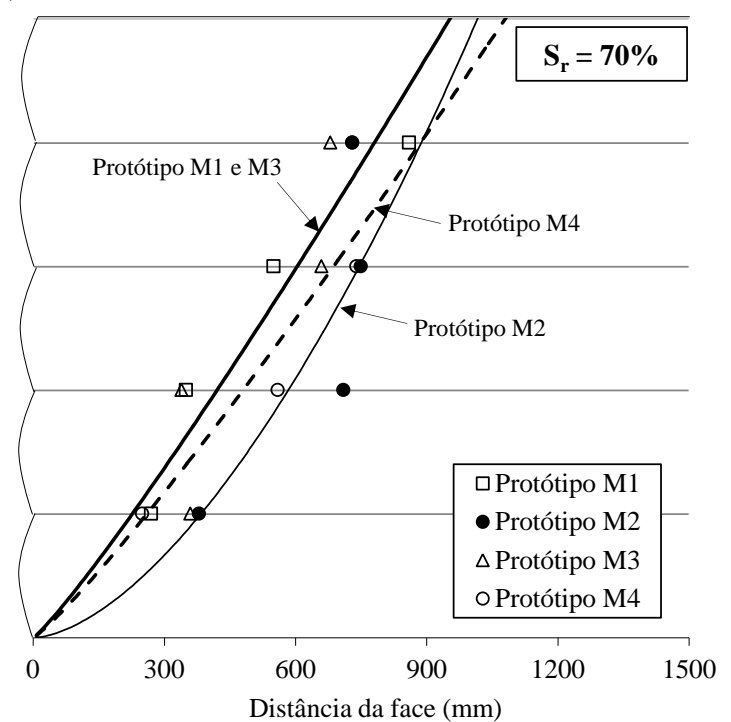

b)

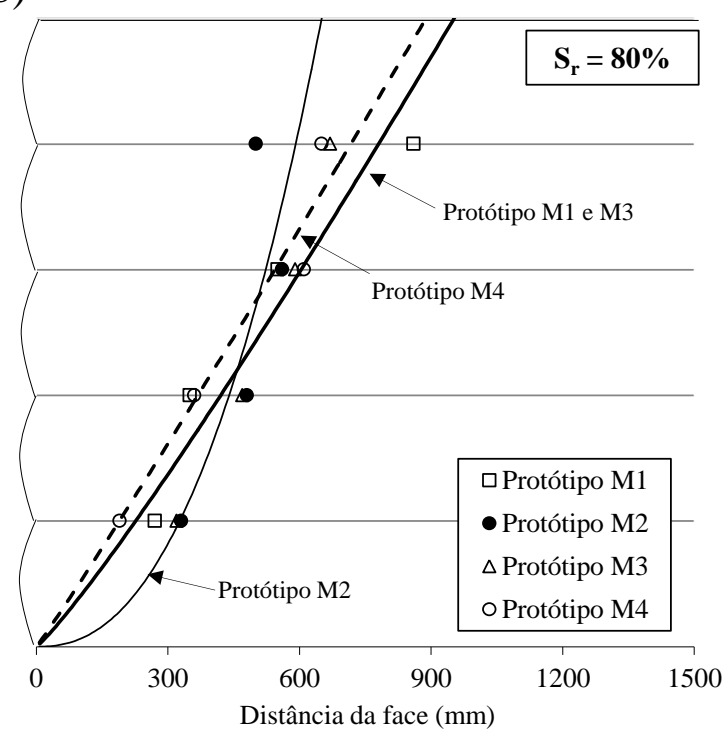

c)

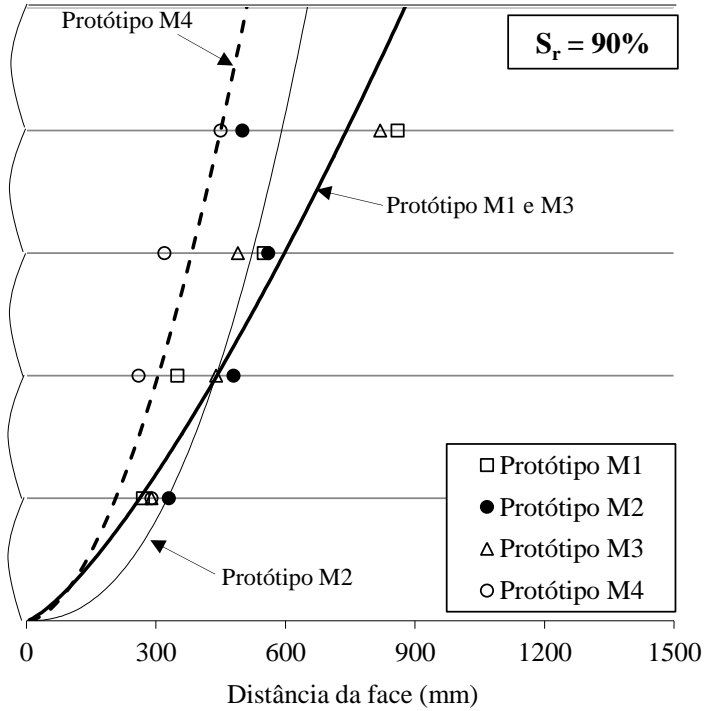

Figura 10.9. Comparação das superfícies reais de ruptura dos protótipos M1, M2, M3 e M4: (a) $\mathrm{S}_{\mathrm{r}}=70 \%$; (b) $\mathrm{S}_{\mathrm{r}}=80 \%$; (c) $\mathrm{S}_{\mathrm{r}}=90 \%$. 


\section{AVALIAÇÃO DO COMPORTAMENTO DE MUROS DE SOLOS FINOS REFORÇADOS COM GEOTÊXTEIS: INVESTIGAÇÃO DE CAMPO}

Este capítulo relata a construção e o monitoramento da instrumentação um muro real de solo reforçado com geotêxteis. Foi avaliada uma seção reforçada com geotêxteis não tecidos, especialmente construída para fins comparativos, e o restante de geotêxteis tecidos, projetada para cumprir a verdadeira função da obra.

\subsection{Informações quanto ao muro instrumentado em campo}

A presente estrutura consiste em um muro de solo reforçado com geotêxteis com a função de contenção de um aterro construído para nivelar a área de implantação do conjunto habitacional Bairro Novo, na cidade de Campinas - SP. O sistema de contenção é composto por muros íngremes de solo reforçado (1H: 10V) com altura de até 9 metros, construído com solo local fino. A estrutura compõe o contorno do aterro do conjunto residencial, totalizando 300 metros de comprimento. Um aterro compactado não reforçado de 4,5 metros de altura foi construído no topo desta estrutura. O muro de solo reforçado foi projetado com reforços de geotêxteis tecidos, incluindo uma seção experimental construída com geotêxteis não tecidos. As seções foram construídas com altura de 5,4 metros, e instrumentadas para comparações dos deslocamentos internos e deformações nos reforços. O geotêxtil não tecido utilizado apresenta $40 \%$ da resistência à tração do geotêxtil tecido. Na Figura 11.1 é apresentada a estrutura após a construção do muro reforçado e durante a construção do aterro não reforçado.

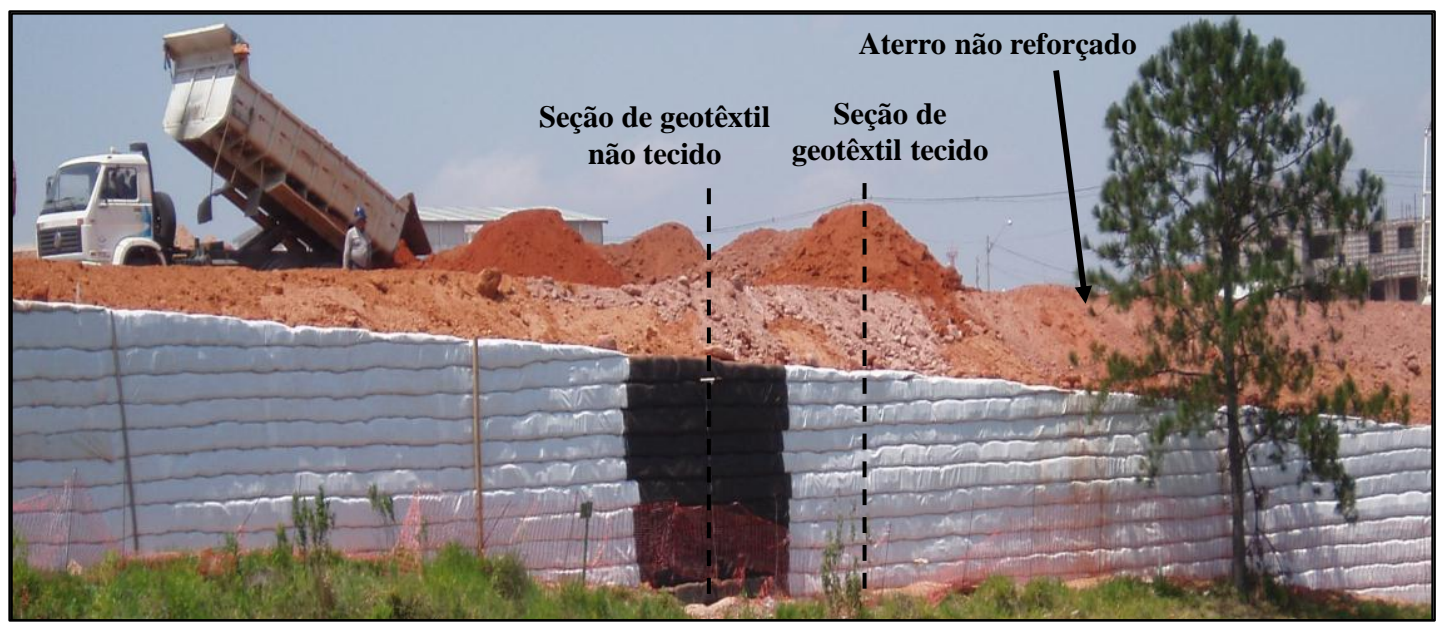

Figura 11.1. Estrutura instrumentada em Campinas - SP. 


\subsection{Concepção de projeto}

A decisão da utilização de solos finos locais foi o aspecto primordial para tornar a solução economicamente competitiva em relação à outras soluções. $\mathrm{O}$ solo consiste em uma areia argilosa não plástica com $23 \%$ passante na peneira \#200, peso específico aparente seco máximo de 19,2 $\mathrm{kN} / \mathrm{m}^{3}$ e teor ótimo de umidade de $11 \%$ (Proctor modificado). Ensaios de limites de consistência do solo resultaram em um material não plástico (NP) com limite de liquidez de 17\%. De acordo com as recomendações da AASHTO (2002), muros de solo reforçados com mais de $15 \%$ de material passante na peneira \#200 não são recomendados para esse tipo de solução; caso contrário, um apropriado sistema de drenagem é requerido. Os resultados dos ensaios triaxiais consolidados drenados (CD) em corpos de prova saturados resultaram em coesão de $19 \mathrm{kPa}$ e ângulo de atrito de $27^{\circ}$.

O reforço selecionado pelo projetista foi um geotêxtil tecido de polipropileno com resistência à tração de $50 \mathrm{kN} / \mathrm{m}$. Já a seção experimental foi reforçada com geotêxteis não tecidos de poliéster com resistência à tração de $20 \mathrm{kN} / \mathrm{m}$ (gramatura de $400 \mathrm{~g} / \mathrm{m}^{2}$ ). A motivação da seleção de um geotêxtil não tecido relativamente mais flexível é o fato deste apresentar melhorias no comportamento mecânico devido ao efeito do confinamento do solo e da impregnação das partículas finas na estrutura do material (McGOWN et al. 1982; LING et al. 1992; MENDES; PALMEIRA 2006).

A geometria de projeto consistiu em linhas de reforços espaçadas verticalmente a cada 40 cm, com comprimentos de 7 metros. A seção de projeto típica é mostrada na Figura 11.2, que ilustra o posicionamento da instrumentação do muro.

O muro foi construído pela técnica de solo envelopado sem o uso de formas móveis, que foram substituídas por sacarias preenchidas com solo local e compactadas manualmente. O revestimento vegetal foi utilizado no faceamento por proporcionar um aspecto natural, além da proteção contra agentes externos. Uma linha de trincheira drenante foi construída na base da estrutura e na interface com o aterro natural a ser estabilizado. Nenhum elemento de drenagem foi construído no topo da estrutura, na face ou na área de contato com o aterro natural estabilizado.

O projeto da estrutura de solo reforçado com geotêxtil tecido foi baseado nas especificações da FHWA (1998), excluindo as recomendações a respeito das limitações do solo de aterro. O método de projeto de tensões de serviço de Rankine, descrito por Mitchell e Villet (1987), foi utilizado no projeto, considerando o coeficiente de empuxo ativo para análises das estabilidades externa e interna. A verificação da estabilidade interna consistiu nas avaliações de ruptura e arrancamento do reforço dos geotêxteis. Os fatores de redução, considerando os danos de instalação, fluência e degradação do reforço, foram considerados para a obtenção da resistência à tração admissível do geotêxtil tecido. Com relação à seção de reforço não tecido, as análises de estabilidade interna pelo método das tensões de serviço de Rankine mostraram que a utilização de reforços não tecidos com $40 \%$ da resistência à tração do geotêxtil tecido resultaria na ruptura dos 
reforços das camadas inferiores da estrutura. Neste caso, os fatores de redução não foram adotados.

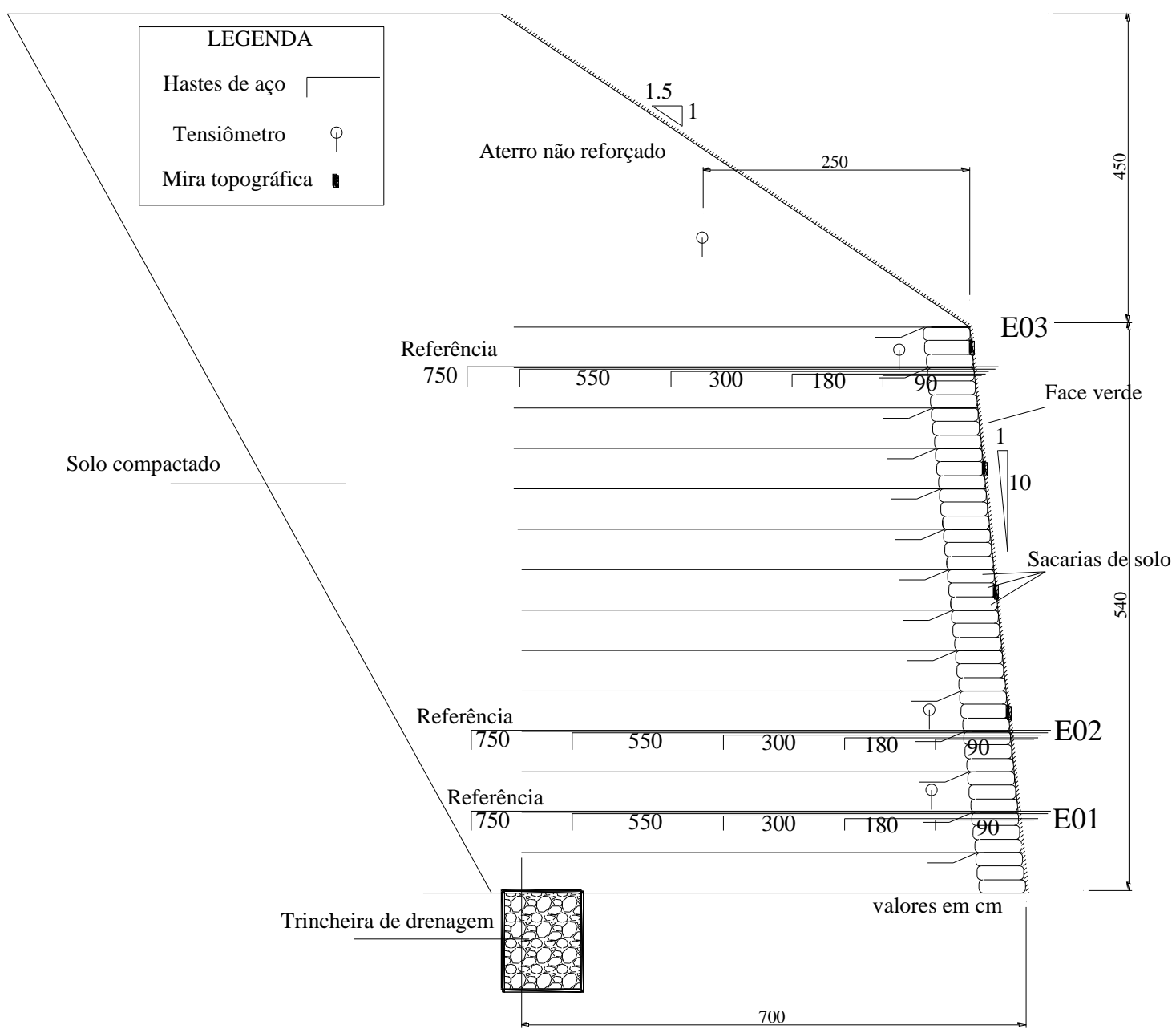

Figura 11.2. Seção de projeto e instrumentação do muro de Campinas - SP.

\subsection{Construção da estrutura}

A estrutura de contenção em solo reforçado foi construída durante 86 dias, desde a preparação da fundação até a construção do aterro compactado não reforçado no topo do muro reforçado. A preparação da fundação e execução da trincheira drenante iniciaram-se em Agosto de 2010. Inicialmente, escavou-se o solo local que compunha o talude natural existente. Durante o processo de escavação, constatou-se que águas da chuva escoavam em direção à base da estrutura promovendo um acúmulo de água na fundação. Esta foi à motivação para a execução da trincheira drenante. Uma vez executada a trincheira, a base foi compactada e nivelada para o início da execução do muro. Os detalhes da preparação da fundação são apresentados na Figura 11.3.

A construção do muro reforçado (após o preparo da fundação) teve início em Setembro de 2010 e foi finalizado em Outubro de 2010. A estrutura completa com o aterro não reforçado 
executado acima da estrutura foi finalizada em Janeiro de 2011. Na Figura 11.4 são mostradas algumas etapas da construção do muro reforçado, principalmente o processo de compactação adotado.

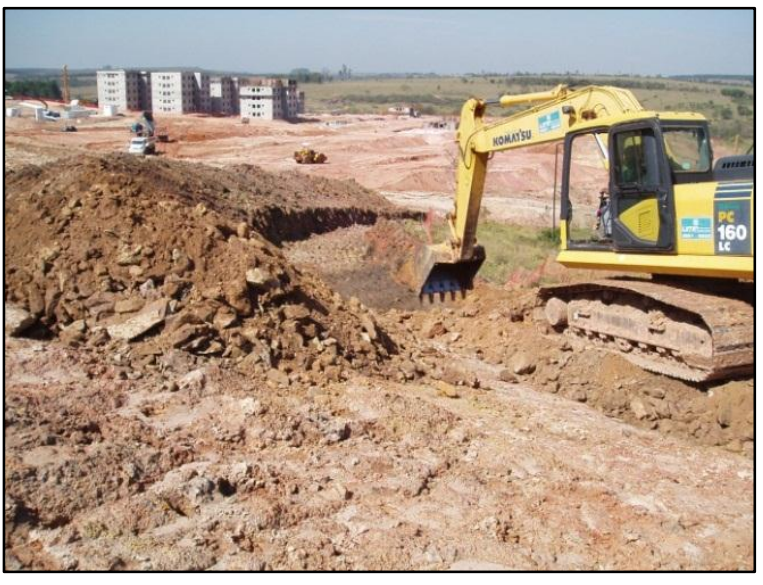

(a)

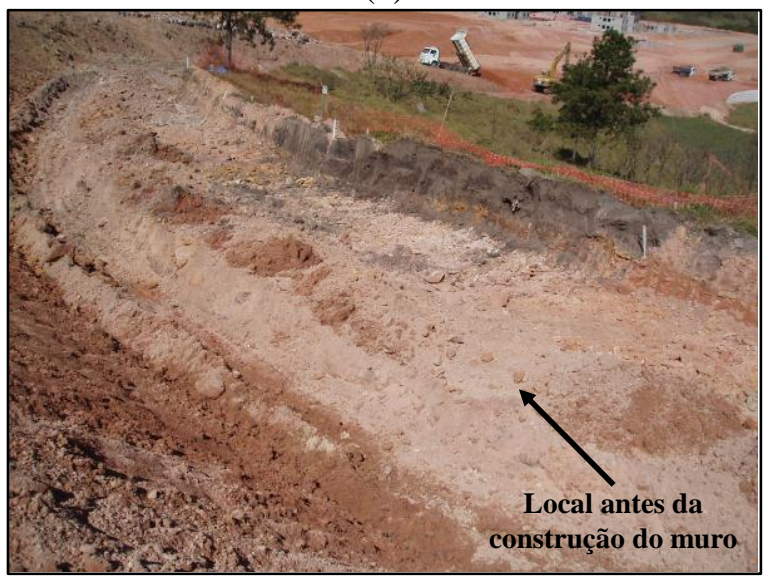

(c)

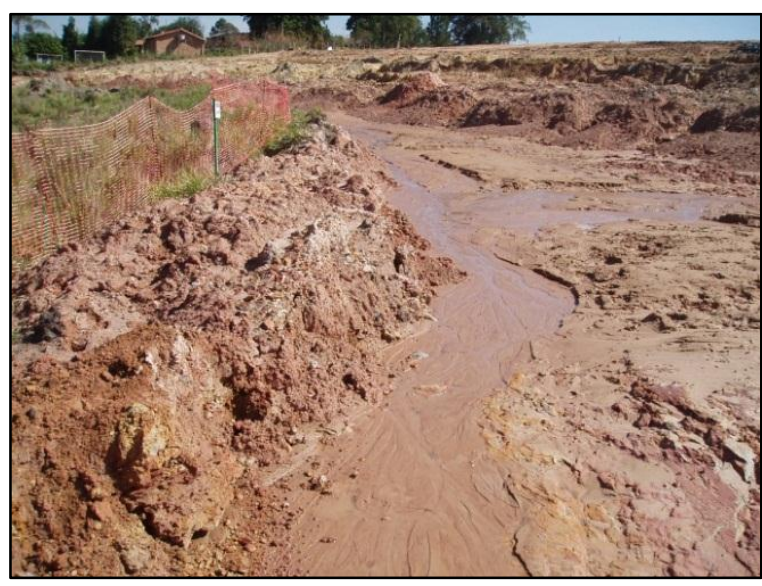

(b)

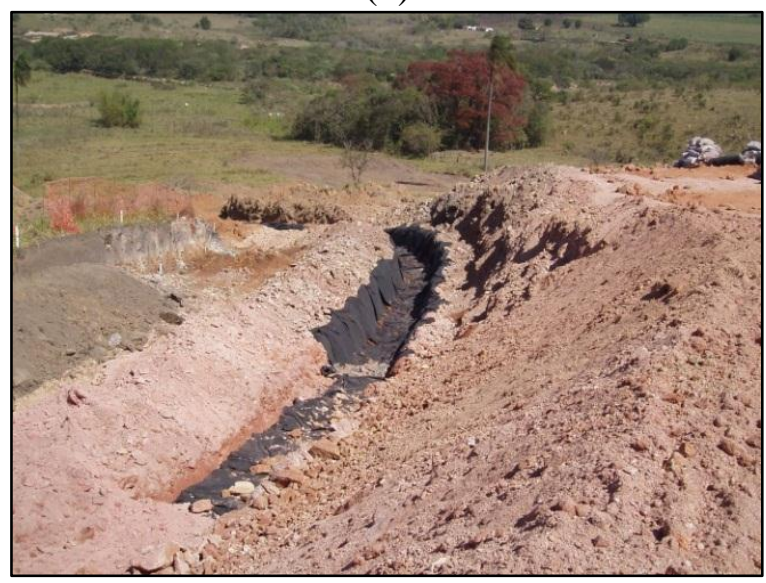

(d)

Figura 11.3. Local da construção do muro: (a) preparação da fundação; (b) acúmulo de água na fundação; (c) base preparada; (d) trincheira drenante no pé do muro.

O solo foi compactado no teor de umidade ótimo de compactação (Proctor modificado), com faixa de aceitação de $\pm 5 \%$, com rolo dentado vibratório DYNAPAC ${ }^{@}$. Na faixa entre a face e $100 \mathrm{~cm}$ desta, utilizou-se uma compactação relativamente leve com o uso de martelo vibratório de modo a evitar excessivos deslocamentos da face durante o processo construtivo. Já na execução das sacarias da face, essas foram preenchidas com solo local e compactadas manualmente com soquete. Depois de concluída a estrutura reforçada, iniciou-se a construção do aterro compactado não reforçado, concluído em Janeiro de 2011. A Figura 11.5 ilustra a evolução da construção da estrutura, bem como o tempo total de monitoramento. 


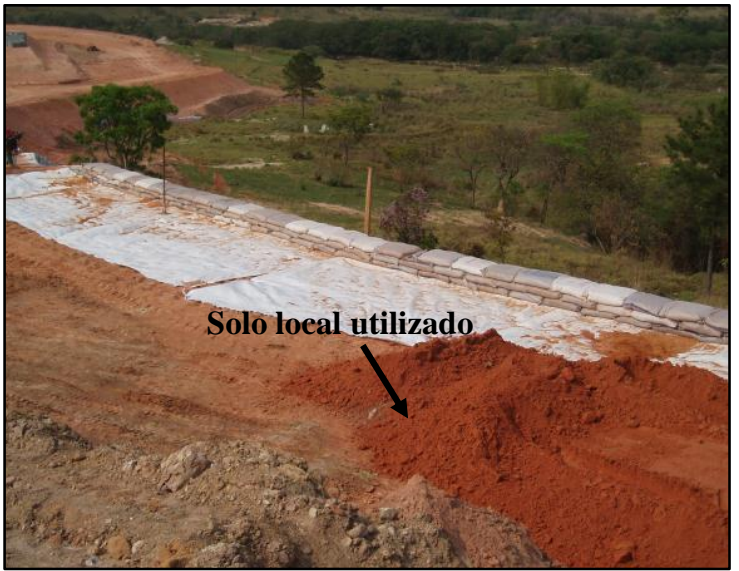

(a)

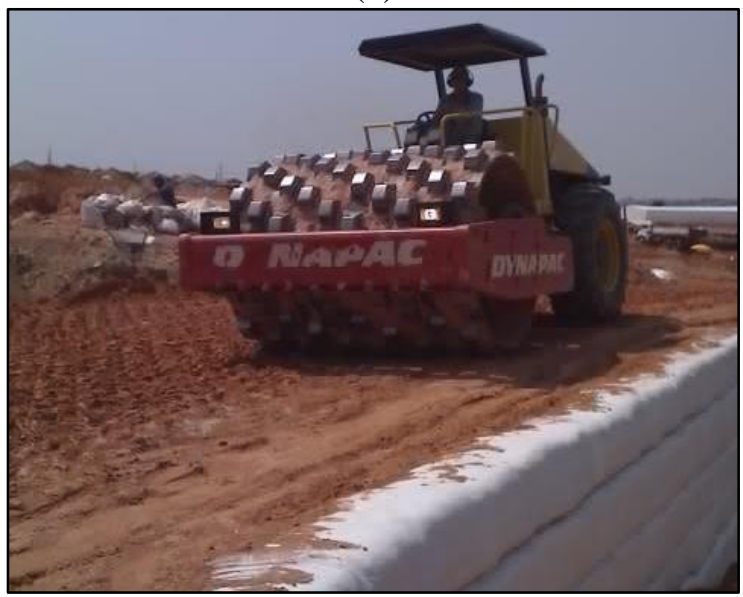

(c)

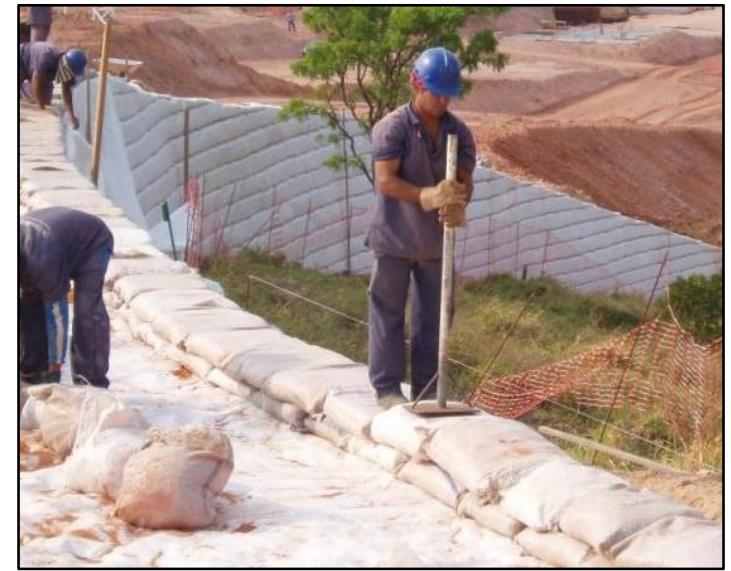

(b)

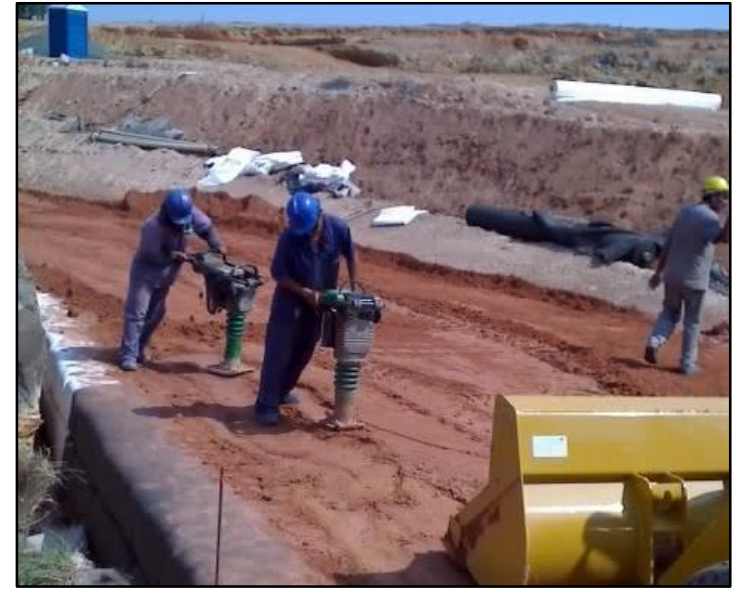

(d)

Figura 11.4. Processo de compactação: (a) espalhamento do solo local utilizado; (b) compactação das sacarias de solo utilizadas como elementos de face; (c) rolo compactador; (d) compactação da face com soquetes mecânicos.

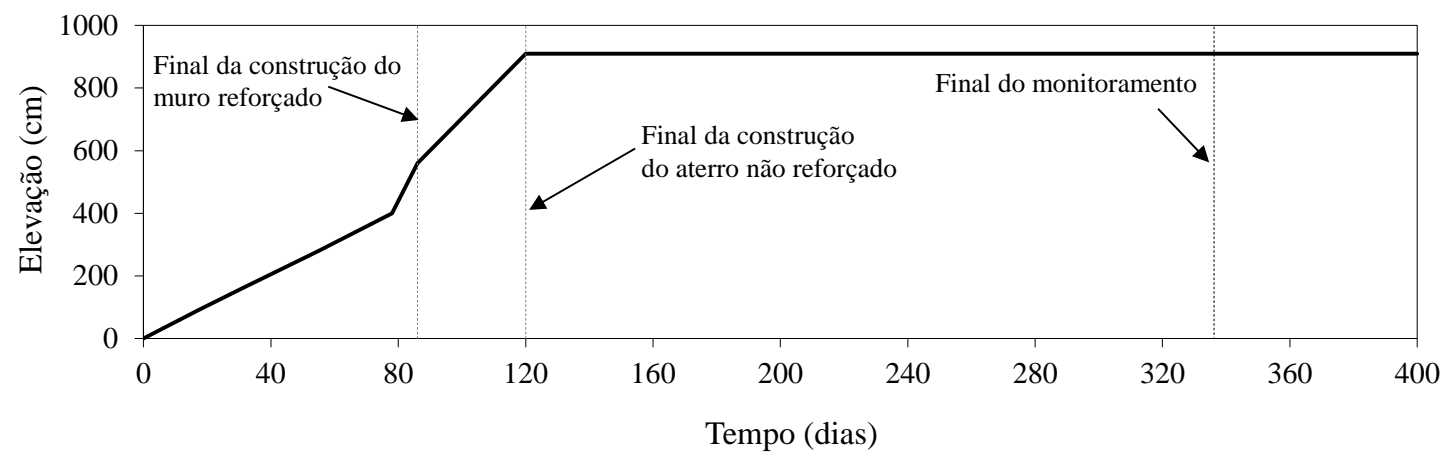

Figura 11.5. Evolução da construção do muro reforçado com geotêxteis.

\subsection{Instrumentação}

O programa de instrumentação foi projetado para monitorar o comportamento do muro durante e após a construção. A técnica de instrumentação envolveu medidas de deslocamentos internos, utilizando extensômetros de hastes metálicas, e monitoramento da sucção do solo com o uso de tensiômetros. Na Figura 11.2 foi detalhado o posicionamento da instrumentação. 
As hastes metálicas lisas foram cravadas no solo abaixo e ao longo do comprimento do reforço em diferentes distâncias em relação à face da estrutura. Uma haste de referência foi fixada fora da zona reforçada de modo a se obter deslocamentos relativos em relação à referência. As hastes metálicas foram fixadas em pontos distanciados a $90 \mathrm{~cm}, 180 \mathrm{~cm}, 300 \mathrm{~cm}$ e $550 \mathrm{~cm}$ da face. Os tensiômetros foram instalados em quatro pontos ao longo da altura do muro, distanciados a $150 \mathrm{~cm}$ da face. Todos os instrumentos foram instalados em três linhas de monitoramento e três diferentes alturas, aqui designadas como E01 (80 cm da base), E02 (160 cm da base) e E03 (500 $\mathrm{cm}$ da base), conforme ilustrado na Figura 11.2. Na Figura 11.6a são mostrados os extensômetros e um tensiômetro instalados em uma das linhas de instrumentação, enquanto na Figura 11.6b é apresentada a vista frontal de ambas as seções instrumentadas.

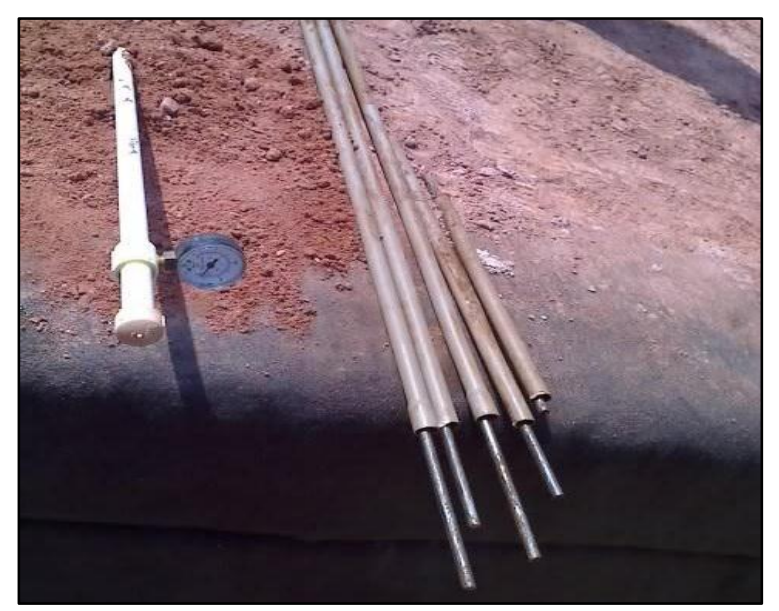

(a)

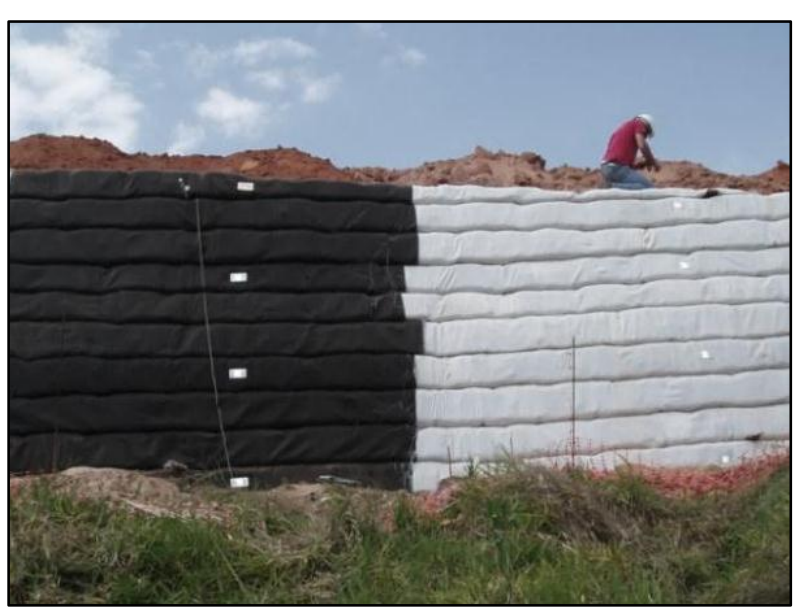

(b)

Figura 11.6. Instrumentação: (a) hastes mecânicas e tensiômetro; (b) seções instrumentadas.

\subsection{Precipitação}

Os dados de precipitações mensais durante o período em que a estrutura foi construída e monitorada (2010 e 2011) foram levantados e estão apresentados na Figura 11.7. A estrutura foi construída durante um período relativamente chuvoso, porém, de precipitação leve. Durante o primeiro mês de construção (Setembro de 2010), foram registrados 11 dias de chuva, alcançando $110 \mathrm{~mm}$ de precipitação. No segundo e no último mês de construção da estrutura reforçada, 13 dias de chuva ocorreram com acúmulo de água de $95 \mathrm{~mm}$.

O período mais chuvoso foi o período da construção do aterro não reforçado em que chuvas ocorreram durante 18 dias alcançando o nível de precipitação de $330 \mathrm{~mm}$. Após o fim da completa construção da estrutura, registrou-se o período de precipitação mais intensa do ano com 18 dias chuvosos e $490 \mathrm{~mm}$ de altura precipitada. Portanto, a presença de água durante e após a construção da estrutura foi bastante evidente. Na Figura 11.8 é mostrado o muro após um intenso período de chuva (150 dias), e o acúmulo de água no pé da estrutura durante a fase de instalação de parte da instrumentação. 


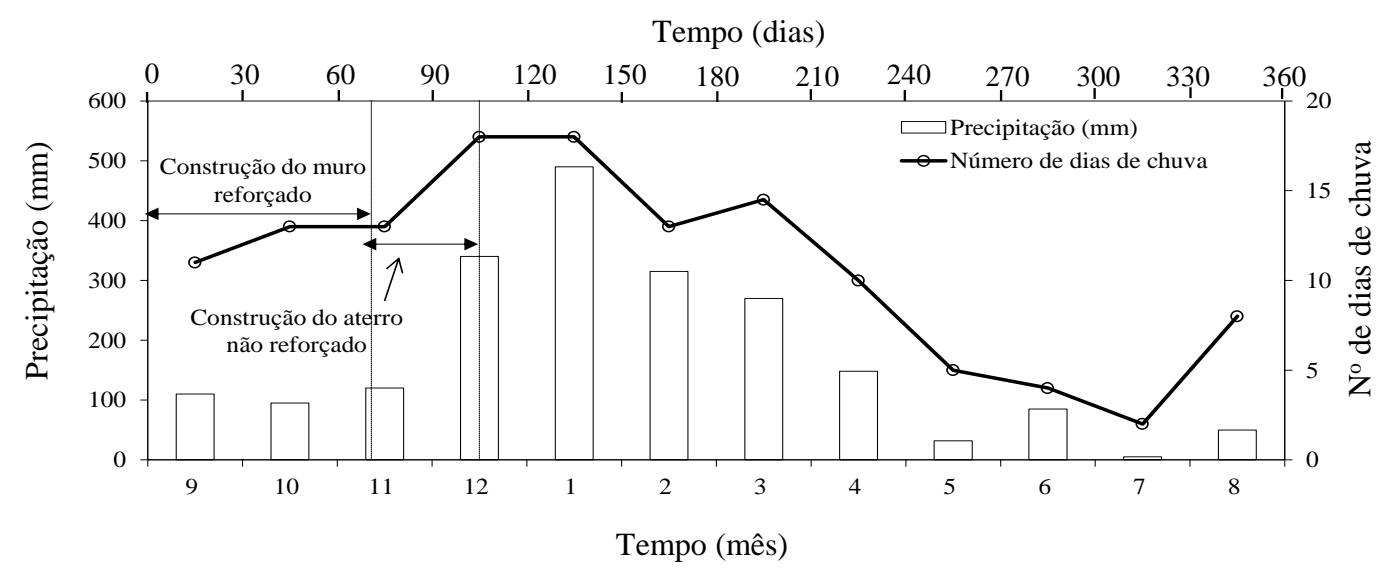

Figura 11.7. Precipitação local em períodos durante e após a construção.

a)

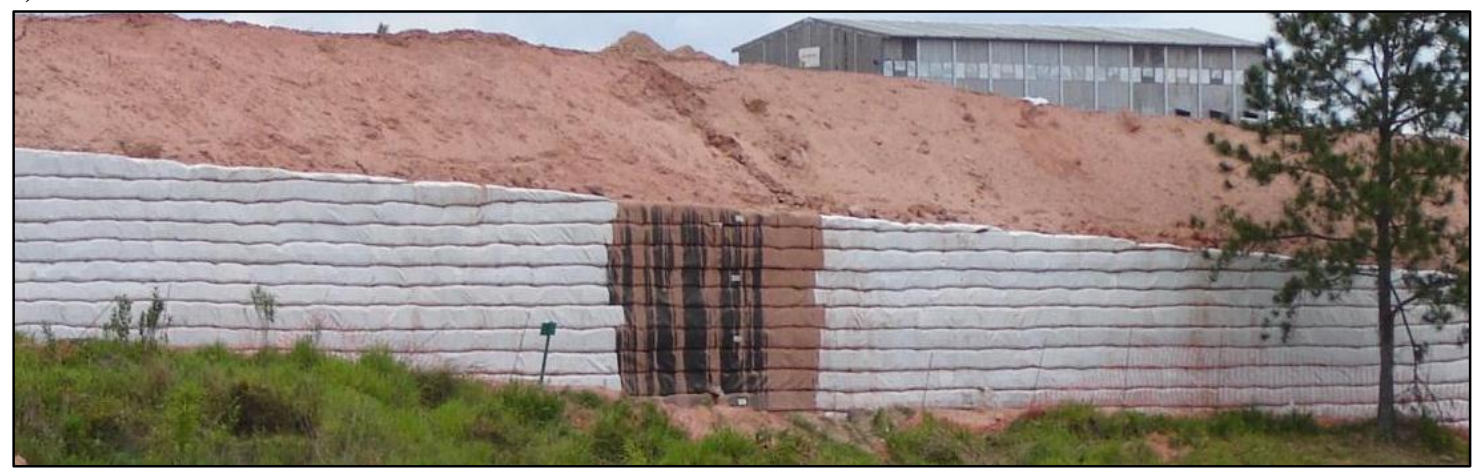

b)

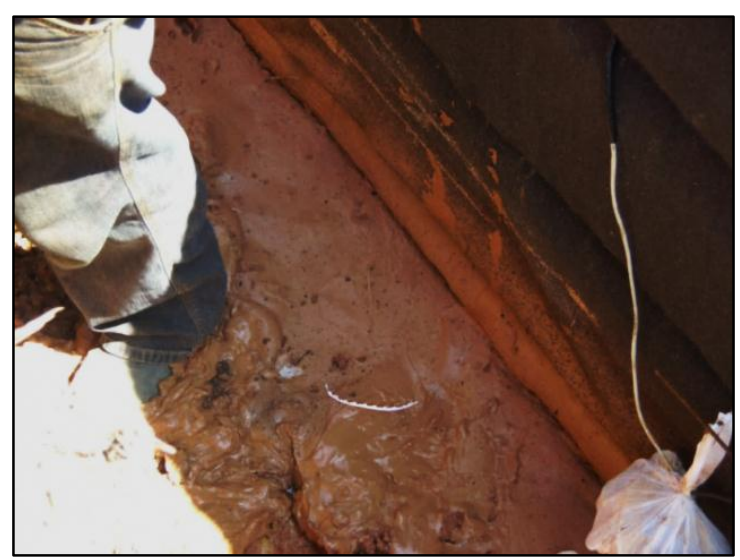

Figura 11.8. Vista das seções avaliadas durante a construção do aterro não reforçado, após eventos de chuva: (a) aspecto da face; (b) acúmulo de água no pé da estrutura. 


\subsection{Resultados da instrumentação}

Neste tópico serão relatados os resultados do monitoramento da instrumentação de ambas as seções de análise.

\subsubsection{Medidas de sucção matricial}

Na Figura 11.9 são plotadas as leituras dos tensiômetros instalados na seção reforçada com geotêxtil não tecido. Nota-se que a sucção matricial da camada instrumentada E01 diminuiu após 40 dias, mostrando que o umedecimento nesta camada ocorreu simultaneamente ao da camada superior. Acredita-se que águas provenientes da chuva escoaram em direção à face da estrutura devido à baixa permeabilidade do solo, assim como verificado nos protótipos de laboratório, proporcionando um acúmulo de água na base da estrutura. Existe ainda, a possibilidade do umedecimento da camada ter ocorrido durante a construção da mesma. De modo geral, as reduções dos valores de sucção matricial nas outras camadas mostram o efeito da infiltração descendente da água. Um comportamento muito semelhante foi evidenciado no protótipo M4.

a)

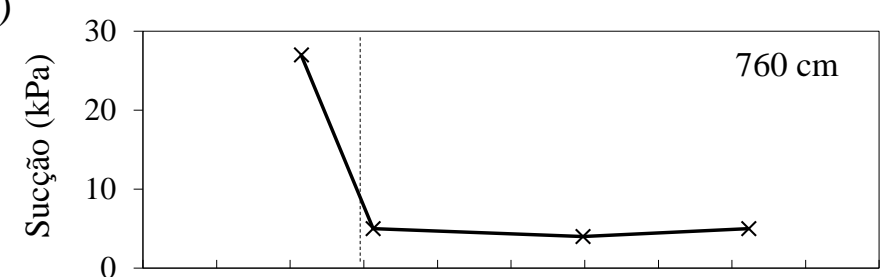

b)

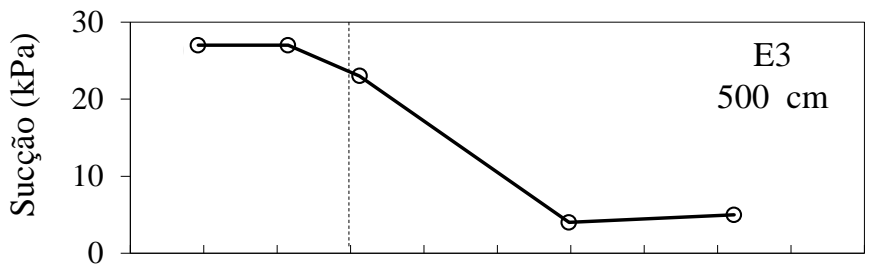

c)

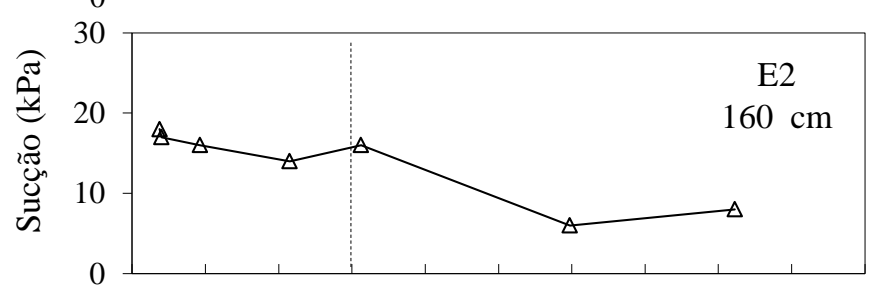

d)

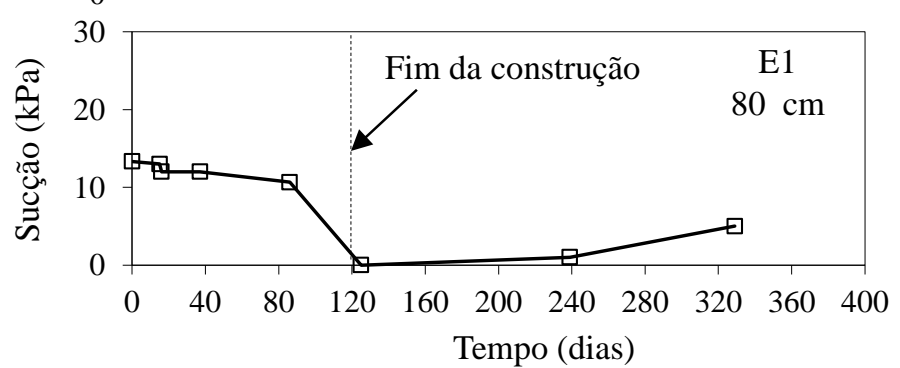

Figura 11.9. Leituras dos tensiômetros no muro reforçado: (a) $760 \mathrm{~cm}$ da base; (b) $500 \mathrm{~cm}$ da base (E03); (c) $160 \mathrm{~cm}$ da base (E02); (d) $80 \mathrm{~cm}$ da base (E01). 
Pode-se observar que as perdas da sucção matricial ocorreram logo após o período construtivo, quando os maiores níveis de precipitação do ano foram registrados. Após esse período, os valores de sucção matricial chegaram a valores zero ou próximos de zero. Após 240 dias do início da construção, a sucção matricial voltou a aumentar, provavelmente devido ao período de menor precipitação do ano, entre Maio e Agosto de 2011. Pode-se supor, portanto, a secagem do solo do aterro durante a vida da estrutura.

\subsubsection{Monitoramento dos deslocamentos}

Os resultados dos deslocamentos internos nas seções reforçadas com geotêxteis não tecidos e tecidos, obtidos por extensômetros de hastes metálicas fixadas em diferentes pontos ao longo do comprimento do reforço, são apresentados nas Figuras 11.10 e 11.11, respectivamente.

(a)

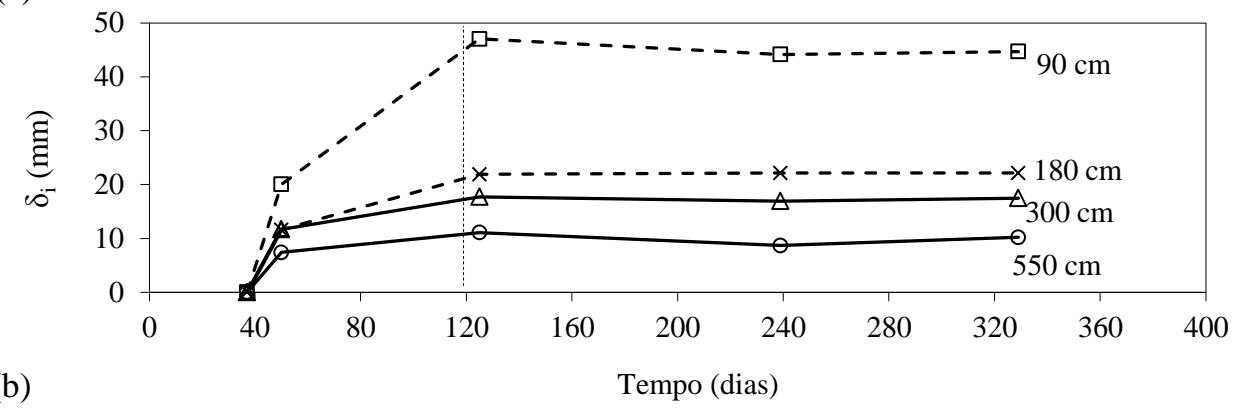

(b)

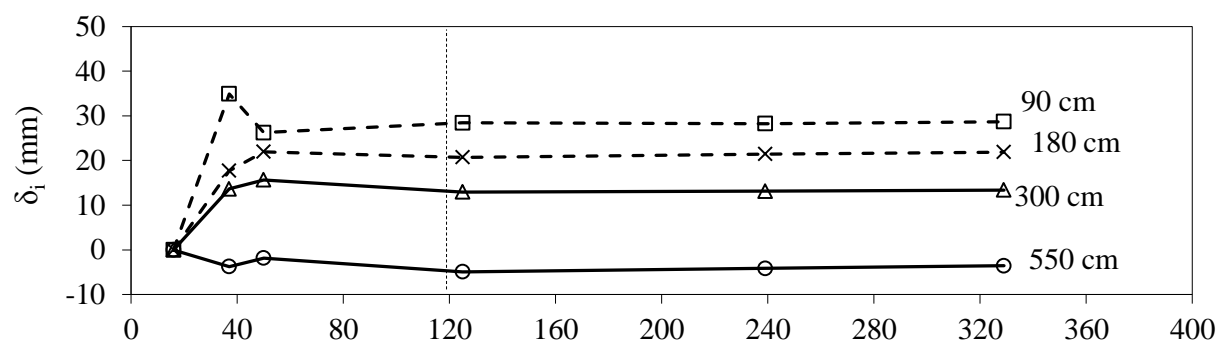

(c)

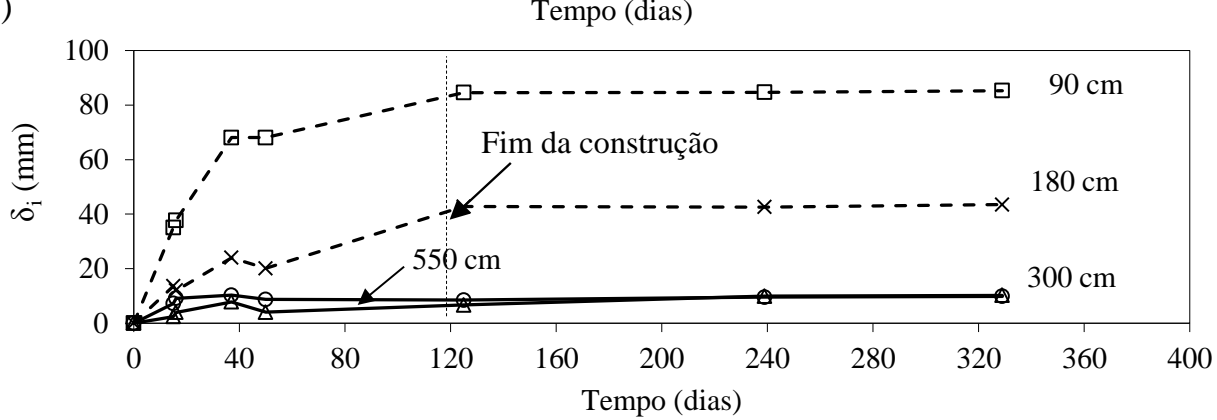

Figura 11.10. Medidas dos deslocamentos internos da seção reforçada com geotêxteis não tecidos: (a) 500 $\mathrm{cm}$ da base (E01); (b) $160 \mathrm{~cm}$ da base (E02); (c) $80 \mathrm{~cm}$ da base (E01).

Na Figura 11.10 verifica-se que, existe uma tendência de aumento dos deslocamentos em direção à face da estrutura para todas as camadas instrumentadas, o que também foi observado nos protótipos de laboratório. Ainda, as maiores taxas de aumento dos deslocamentos ocorreram 
durante o período construtivo devido ao processo de compactação, sendo estas mais significativas em regiões mais próximas da face. Após 86 dias, período correspondente ao final da construção do muro reforçado, os deslocamentos estabilizaram-se para ambas as seções instrumentadas.

É importante destacar que os maiores deslocamentos durante a construção foram constatados na seção de reforço não tecido, muito embora essa diferença seja pouco significativa. Com relação aos deslocamentos pós-construtivos, os valores máximos observados na estrutura de geotêxtil não tecido foram de $80 \mathrm{~mm}$ na camada instrumentada E01 (Figura 11.10c), enquanto para o geotêxtil tecido, o valor máximo foi de $40 \mathrm{~mm}$ na camada instrumentada E03 (Figura 11.10a). Observa-se, portanto, que ambos os deslocamentos máximos ocorreram nos pontos mais próximos da face. Ainda, tratando-se de uma estrutura subdimensionada - segundo a FHWA (1998) - pode-se dizer que as diferenças em relação à estrutura de reforços tecidos foram muito pequenas.

(a)

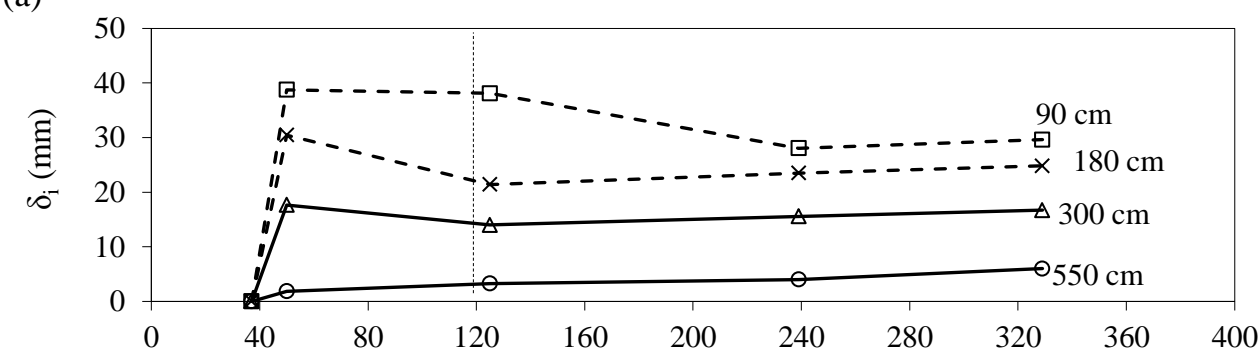

(b)

Tempo (dias)

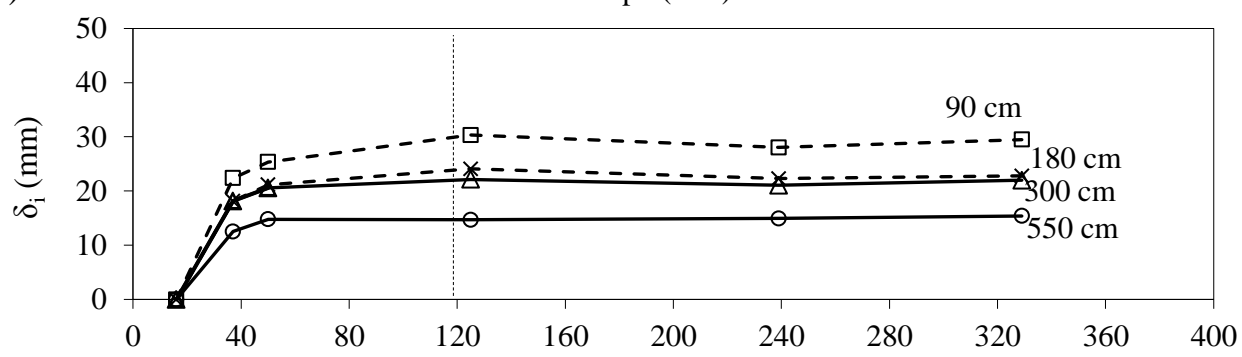

(c)

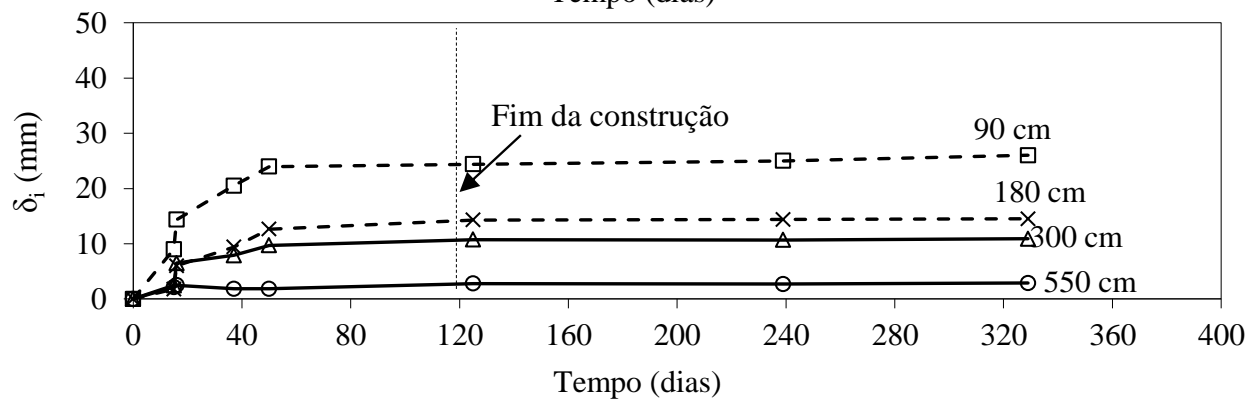

Figura 11.11. Medidas dos deslocamentos internos da seção reforçada com geotêxteis tecidos: (a) $500 \mathrm{~cm}$ da base (E03); (b) $160 \mathrm{~cm}$ da base (E02); (c) $80 \mathrm{~cm}$ da base (E01).

Na Figura 11.12 são comparados os deslocamentos internos máximos $\left(\delta_{\mathrm{i}}\right.$,máx $)$ de ambas as seções instrumentadas. De modo geral, os deslocamentos máximos foram maiores na seção de geotêxtil não tecido, muito embora estes tenham se mostrados muito próximos. Ainda, estes 
deslocamentos são, em grande parte, decorrentes do processo de construção. Nas condições de serviço (pós-construção), estes podem ser considerados de mesmo comportamento.

a)

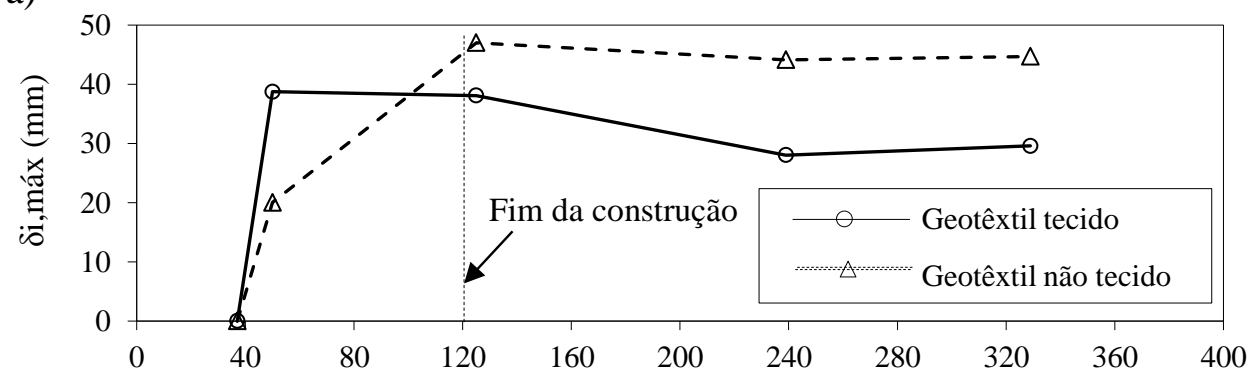

b) Tempo (dias)

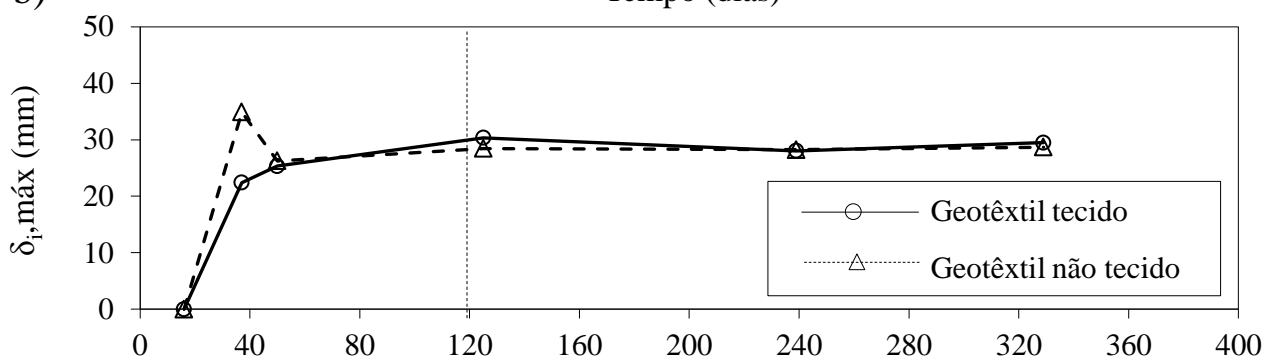

c) Tempo (dias)

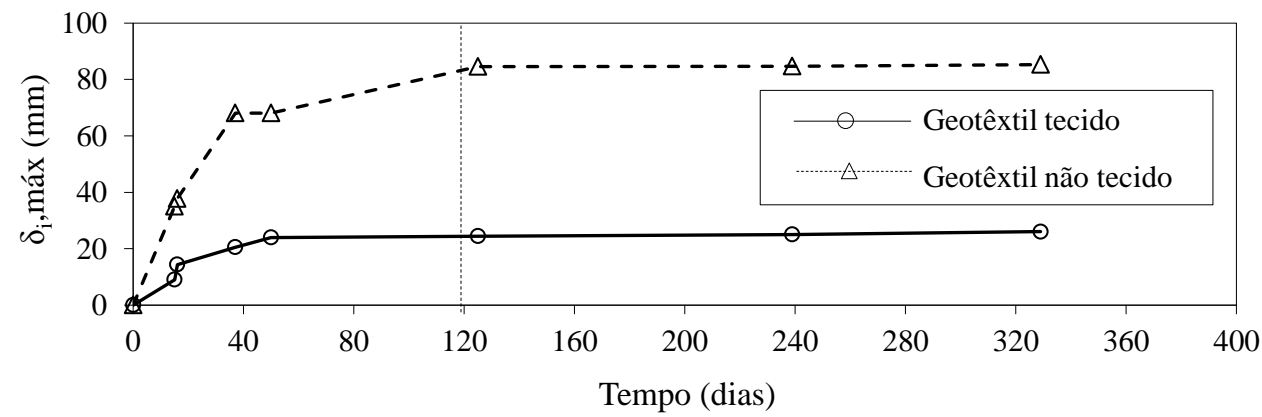

Figura 11.12. Deslocamento máximo interno das seções instrumentadas: (a) $500 \mathrm{~cm}$ da base (E03); $160 \mathrm{~cm}$ da base (E02); (c) $80 \mathrm{~cm}$ da base (E01).

\subsubsection{Análise das deformações nos reforços}

As distribuições das deformações ao longo do comprimento dos reforços foram calculadas utilizando-se o mesmo procedimento nos protótipos avaliados nos capítulos anteriores. A distribuição dos deslocamentos ao longo do comprimento do reforço foi suavizada por um ajuste sigmoidal que equaciona essa distribuição. A derivada dessa curva sigmoidal resulta nas distribuições das deformações ao longo dos comprimentos de reforços. Os detalhes sobre essa metodologia podem ser consultados no capítulo 4. A distribuição dos deslocamentos ao longo do comprimento dos reforços tecidos e não tecidos nas linhas de instrumentação E01, E02 e E03 é exemplificada na Figura 11.13. A distribuição completa pode ser visualizada nas Figuras B5 e B6 do apêndice $B$. 


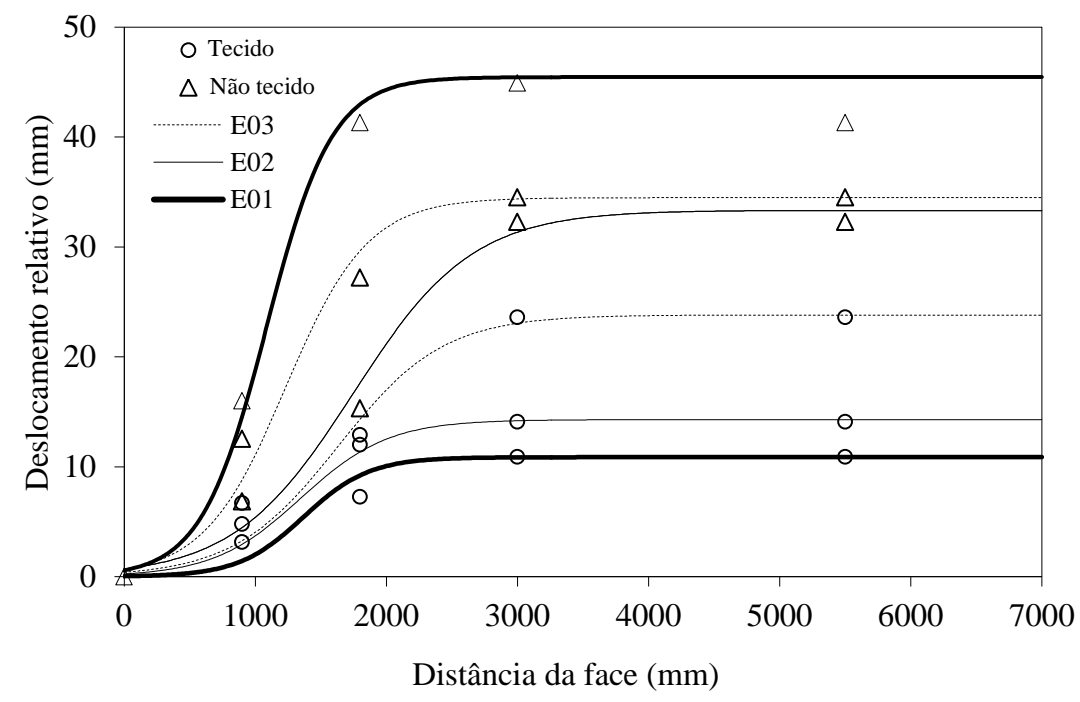

Figura 11.13. Distribuição dos deslocamentos relativos ao longo do comprimento dos reforços das seções de geotêxtil tecido e não tecido.

Nas Figuras 11.14 e 11.15 são mostradas as distribuições das deformações nos reforços das seções de geotêxtil tecido e não tecido, respectivamente, nas três linhas instrumentadas E01, E02 e E03. Ambas as estruturas apresentaram o mesmo nível de deformações nas camadas instrumentadas E02 e E03, muito embora a rigidez à tração do geotêxtil não tecido seja significativamente menor. No entanto, as deformações na base da estrutura foram menores para o reforço mais rígido (tecido). Nota-se que as localizações dos picos de deformações nas camadas instrumentadas geraram superfícies reais de ruptura semelhantes para ambas as seções. Destaca-se a localização do pico de deformação da camada mais superficial ocorrendo em regiões próximas da face, possivelmente devido à elevada inclinação da face, o que pode gerar momentos adicionais durante a compactação nesta região. Ainda, existe a presença da água nesta região que foi constatada pelas leituras nos tensiômetros. 


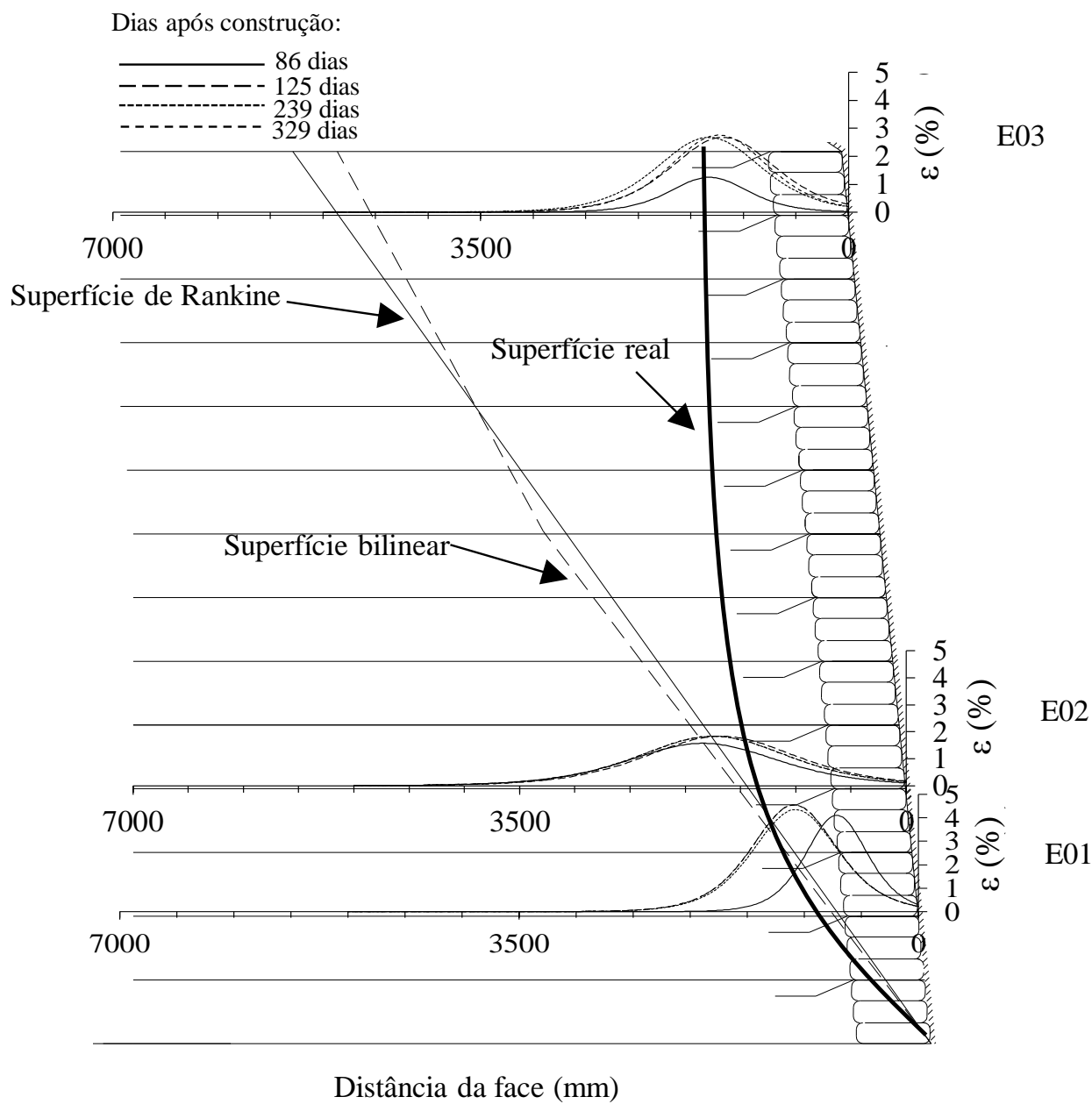

Figura 11.14. Distribuição das deformações ao longo do comprimento dos reforços da seção de geotêxtil não tecido nas linhas instrumentadas E01, E02 e E03.

A evolução das deformações de pico foram plotadas na Figura 11.16. Para efeito comparativo, são plotadas juntamente as deformações máximas de ambas as seções avaliadas. Foi verificado que houve a evolução das deformações dos geotêxteis tecidos, o que não ocorre para os geotêxteis não tecidos. Aparentemente, toda a deformação ocorrida nos reforços de geotêxteis não tecidos é decorrente do processo de construção. Já para a estrutura de geotêxteis tecidos, os aumentos das deformações ocorrem em boa parte durante a construção, mas também sofrem incrementos pós-construtivos. Observa-se que, a maior taxa de aumento ocorreu durante o período de precipitação mais intensa do ano (Novembro a Abril). Digno de nota é o fato de esses incrementos serem maiores na camada mais próxima da superfície. Essas são fortes evidências de que a resistência de interface de reforços impermeáveis pode ser prejudicada Na Figura 11.17, as deformações são plotadas ao longo da altura da estrutura, na qual pode ser verificado que as deformações de pico máximas ocorreram nos reforços instrumentados inferiores, assim como verificados nos protótipos de laboratório. 


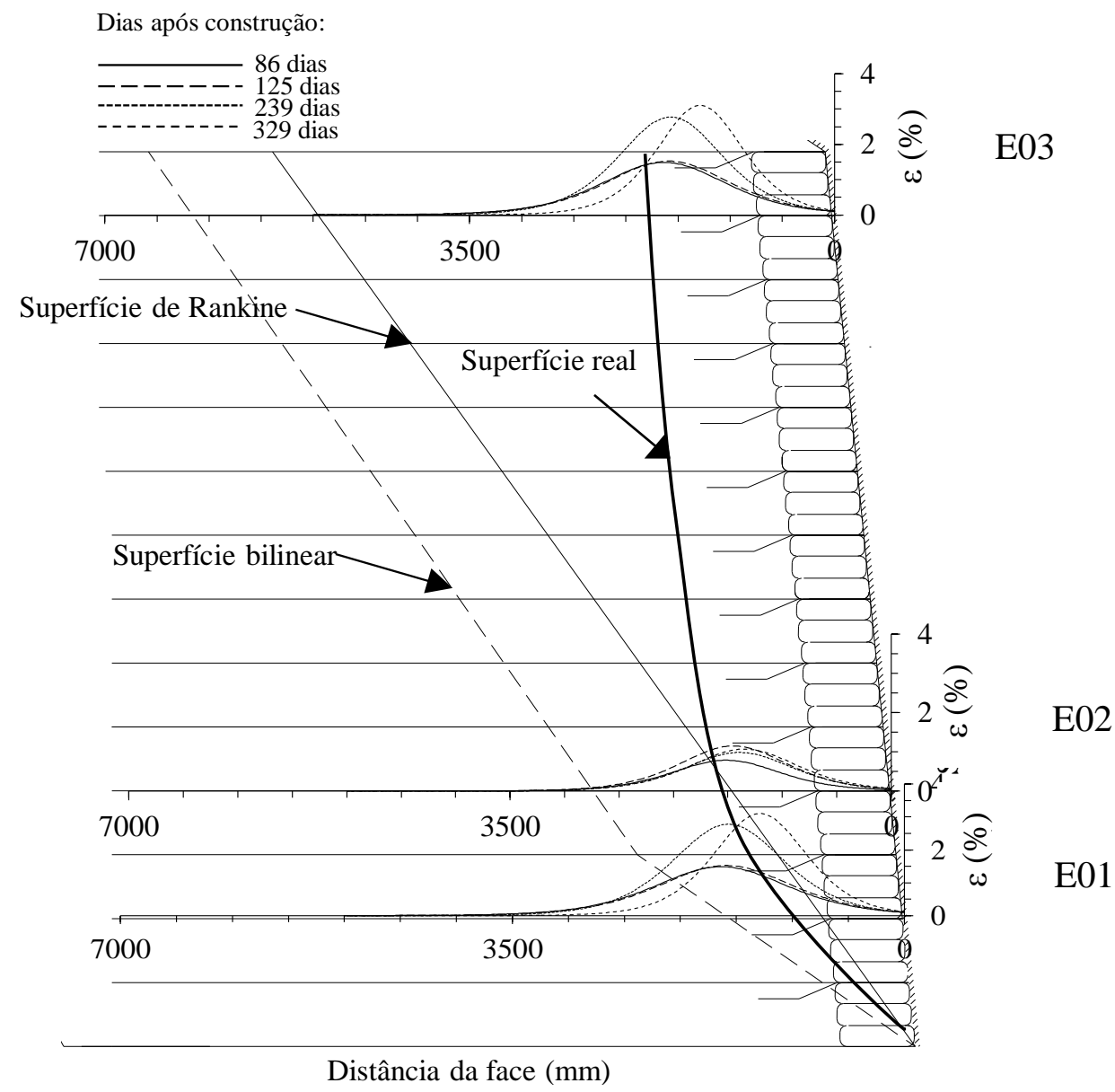

Figura 11.15. Distribuição das deformações ao longo do comprimento dos reforços da seção de geotêxteis tecidos nas linhas instrumentadas E01, E02 e E03.

Com base nos resultados da instrumentação, pôde-se verificar neste caso de obra que grande parte das deformações ocorreu durante o processo construtivo, e praticamente nenhum aumento nas deformações devido ao processo de umedecimento foi verificado. Acredita-se que um pequeno volume de água infiltrou nesta estrutura, porém muito pouco para promover uma alteração significativa no grau de saturação do solo, ou na rigidez média. Portanto, as alterações na sucção do solo evidenciadas pelas leituras dos tensiômetros ocorreram, possivelmente, somente nas regiões próximas da face, em que o grau de compactação do solo foi menor. Pode-se dizer que em estruturas reais, principalmente as de maiores alturas, o efeito do avanço de umedecimento pode ser menos significativo, já que o avanço deverá alcançar profundidades relativamente grandes para implicar em alterações na rigidez média do solo. No entanto, algumas evidências são conclusivas com relação ao uso de geotêxteis não tecidos em muros reforçados. Os geotêxteis não tecidos reforçaram os solos finos, resultando em incrementos de deformações semelhantes às registradas na seção de geotêxtil tecido, sugerindo que nas condições de serviço (pós-construção), os parâmetros de resistência e rigidez a tração dos reforços não tecidos são melhorados. 

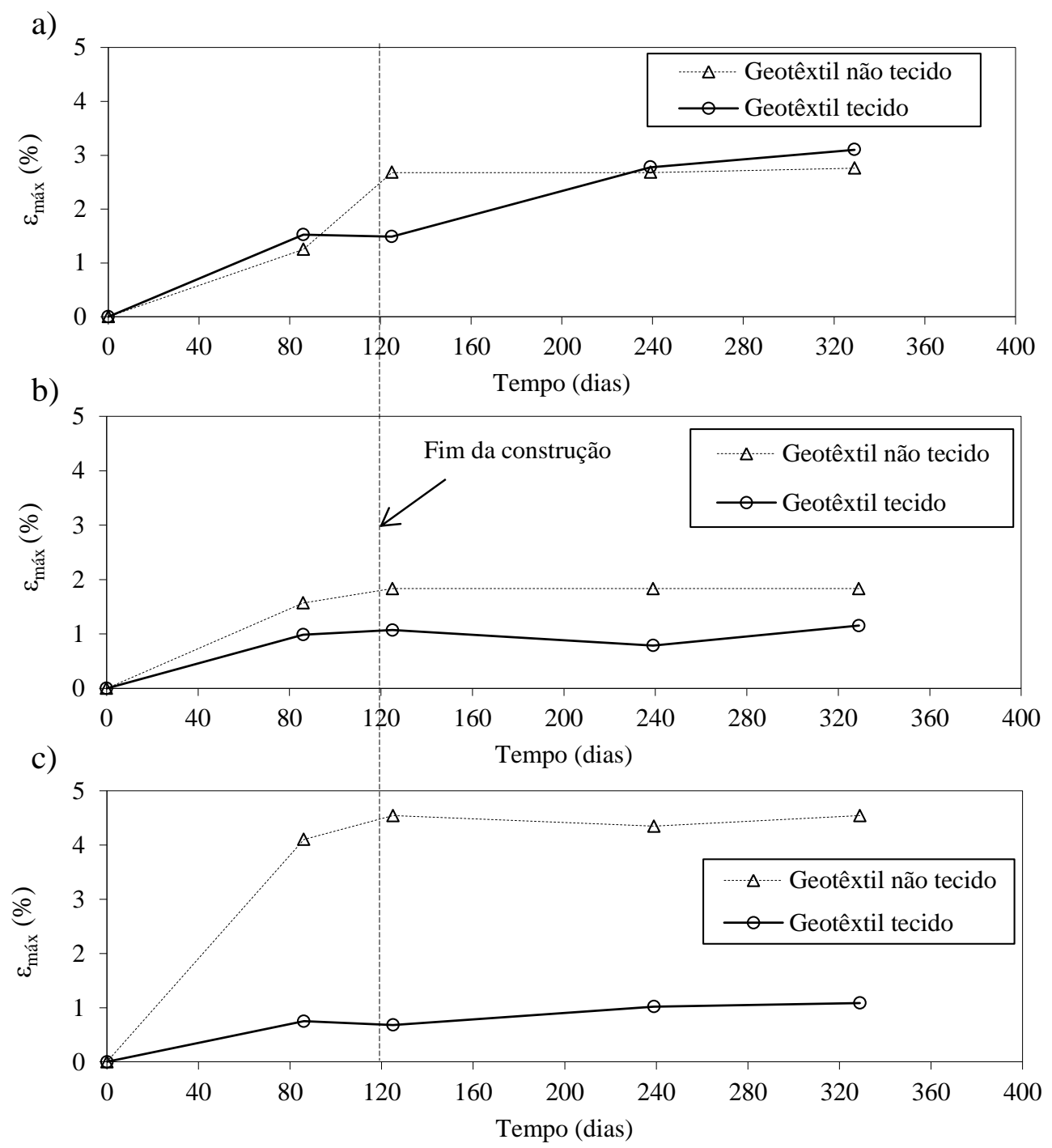

Figura 11.16. Evolução das deformações máximas dos reforços para as seções de geotêxtil tecido e não tecido: (a) $500 \mathrm{~cm}$ da base (E03); $160 \mathrm{~cm}$ da base (E02); $80 \mathrm{~cm}$ da base (E01).

a)

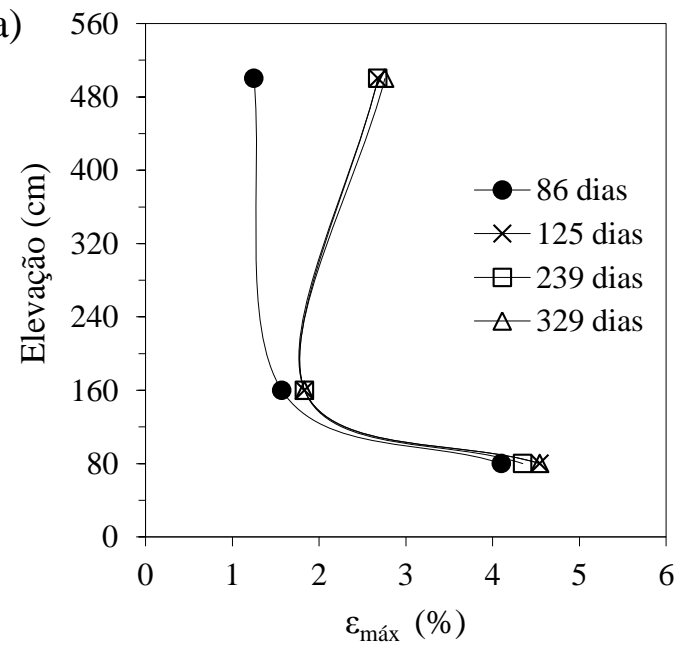

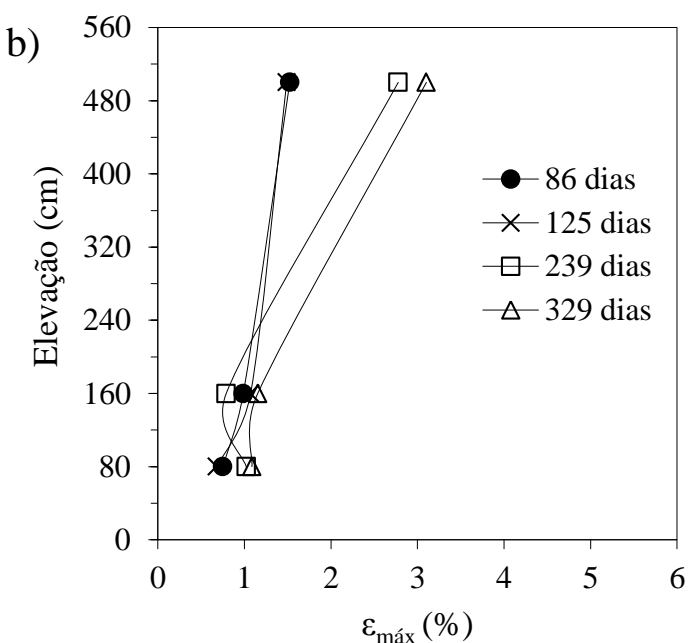

Figura 11.17. Distribuição das deformações máximas ao longo da altura do muro: (a) seção de geotêxtil não tecido; (b) geotêxtil tecido. 


\subsubsection{Aspectos gerais e comparações com laboratório}

Nos projetos convencionais de muros de solo reforçado que utilizam os métodos de tensões de serviço de Rankine ou Coulomb, as forças em cada reforço são calculadas e assim define-se um espaçamento entre os reforços. No caso de taludes reforçados, análises de equilíbrio limite convencionais são utilizadas levando-se em consideração as forças ou os momentos estabilizantes proporcionados pelos reforços. Nas Figuras 11.14 e 11.15 foram mostradas as localizações dos picos de deformações em cada tempo avaliado para ambas as seções reforçadas, o que possibilitou a definição das superfícies de ruptura reais. Nos mesmos gráficos, foram plotados as superfícies potenciais de ruptura de Rankine e as superfícies bilineares obtidas de análises de equilíbrio limite. A superfície de Rankine apresentou certa concordância com a superfície real somente nas camadas instrumentadas inferiores. Não existe um entendimento claro para isto, mas acredita-se que este comportamento pode ter sido ocasionado por tensões devido ao processo de compactação, que promoveram um momento adicional da face íngreme, e/ou avanço do umedecimento nas camadas superiores e em regiões próximas da face. Cabe destacar que a superfície de ruptura obtida nas condições de campo foram bastante semelhantes àquelas obtidas em laboratório no ensaio do protótipo M4. Para a seção de geotêxtil não tecido, a superfície bilinear aproximou-se da superfície de Rankine. Por outro lado, para a seção de geotêxtil tecido, a superfície bilinear de deslizamento não coincide com a superfície de Rankine, assim como não coincide aos pontos de deformação de picos medidos.

Nessa análise, os fatores de segurança da estabilidade interna das estruturas de geotêxteis não tecidos e tecidos foram de 1,64 e 3,02, respectivamente. Portanto, nenhuma ruptura da estrutura devido à ruptura do reforço foi prevista por esse método. No entanto, nas análises de estabilidade interna utilizando o método de tensões de serviço de Rankine, a ruptura do reforço foi prevista nas camadas inferiores com fator de segurança mínimo de 0,88 para a seção de geotêxteis não tecidos, enquanto para a seção de geotêxtil tecido o fator de segurança mínimo foi de 2,19. Assim, pela comparação dos fatores de segurança, o uso de teorias de empuxo de terra para a previsão de cargas nos reforços mostra-se bastante conservador. Neste caso, as análises de equilíbrio limite mostraram-se mais realistas.

De modo a comparar os níveis de deformações e deslocamentos obtidos no monitoramento da estrutura de Campinas e dos protótipos de laboratório, aos níveis apresentados na literatura técnica, os gráficos da Figura 11.18 apresentam as deformações máximas normalizadas (Figura 11.18a) e deslocamentos máximos normalizados (Figura 11.18b). Pode-se dizer, que as estruturas de não tecidos na condição de carregamento constante durante as condições de serviço apresentaram níveis semelhantes de deformações normalizadas. Na maioria das estruturas comparadas, as deformações máximas ocorreram em profundidades em torno de 1/5 da altura da estrutura até o valor de $2 \%$, com exceção do protótipo M4, cujos incrementos de tensões foram aplicados. Em algumas estruturas, as deformações máximas ocorreram na camada 
superficial. Com relação aos deslocamentos máximos normalizados, a grande maioria ocorreu a $1 / 3$ da altura do protótipo, com valores de deslocamentos normalizados entre 0,001 e 0,015.

Portanto, pode-se concluir que tanto os níveis de deslocamentos e deformações obtidos nos protótipo, quanto os níveis registrados na estrutura instrumentada de Campinas, apresentamse bem coerentes com o que se tem relatado na literatura. Isto, de certo modo, vem a validar o comportamento observado em ambas as análises.
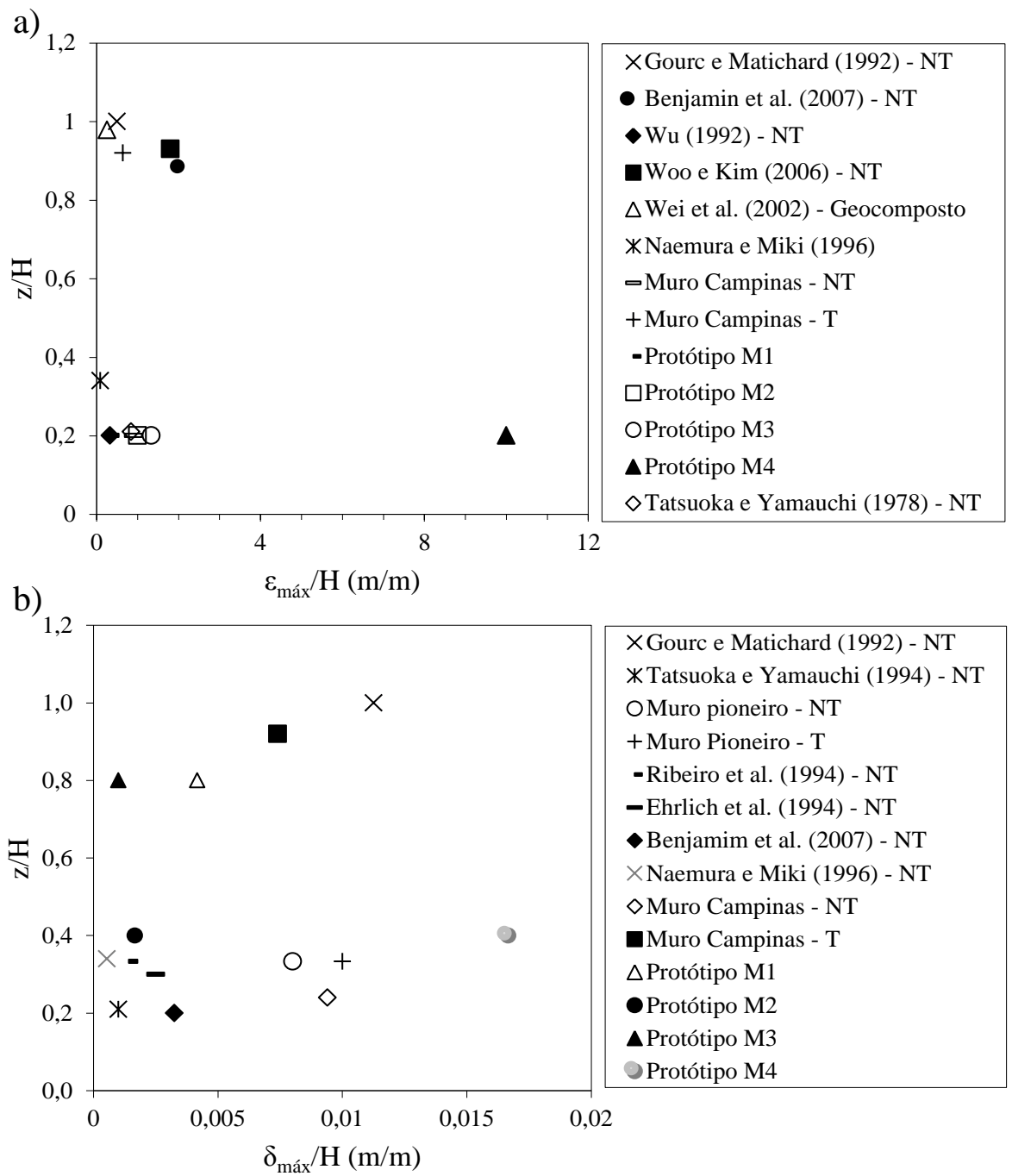

$\times$ Gourc e Matichard (1992) - NT

* Tatsuoka e Yamauchi (1994) - NT

OMuro pioneiro - NT

+ Muro Pioneiro - T

- Ribeiro et al. (1994) - NT

- Ehrlich et al. (1994) - NT

- Benjamim et al. (2007) - NT

$\times$ Naemura e Miki (1996) - NT

$\diamond$ Muro Campinas - NT

Muro Campinas - T

$\triangle$ Protótipo M1

- Protótipo M2

$\Delta$ Protótipo M3

Protótipo M4

Figura 11.18. Comparação entre as estruturas avaliadas na pesquisa e outras relatadas na literatura: (a) deformações máximas normalizadas; (b) dos deslocamentos máximos normalizados. 
$-264-$ 
CAPÍTULO 12

\section{CONCLUSÕES}

O presente trabalho buscou uma avaliação experimental do efeito do avanço do umedecimento no comportamento de muros de solo finos reforçados com geotêxteis não tecidos. Para tanto, foram executados quatro protótipos de laboratório, com diferentes condições simuladas de precipitação e sobrecargas. Adicionalmente, os resultados do monitoramento de uma estrutura real foram avaliados e associados ao comportamento verificado em laboratório. Com o conjunto destas informações, as seguintes conclusões foram obtidas:

a) a manutenção do teor de umidade de compactação favoreceu o bom desempenho do protótipo, resultando em deformações e forças nos reforços praticamente nulas. As análises de compatibilidade de deformações do solo e reforços mostraram que a rigidez do solo, proporcionada em parte pela sucção, foi suficientemente elevada a ponto de mobilizar praticamente todas as tensões aplicadas na estrutura.

b) nas condições impostas de precipitação, foi verificado que a frente de infiltração alcançou a base do muro após 25 dias, tanto para a condição de chuvas intensas e espaçadas como para a precipitação constante de intensidade próxima (inferior) a condutividade hidráulica do solo. $\mathrm{O}$ avanço da frente de umedecimento fez com que o grau de saturação do solo aumentasse para o valor máximo de $90 \%$ e a sucção diminuísse para o valor de capacidade de campo de $8 \mathrm{kPa}$. O fato de aplicar chuvas espaçadas e intensas ou precipitação intermitente de intensidade próxima da condutividade hidráulica do solo não alterou esses valores durante a infiltração;

c) foi constatada a contribuição dos reforços na drenagem interna da zona reforçada, que dissiparam $20 \%$ do volume de água infiltrado. Assim, a presença dos reforços proporcionou a manutenção de níveis satisfatórios de grau de saturação do solo, não favorecendo o desenvolvimento de pressões da água positivas, mesmo sob uma condição de carregamento rápido;

d) durante o avanço do umedecimento, foi verificada a formação de uma barreira capilar na interface solo-geotêxtil não tecido, gerando um armazenamento de água de aproximadamente $10 \mathrm{~cm}$. Após este período, houve a quebra da barreira liberando o fluxo, sendo parte do volume armazenado conduzido para fora do sistema, ao longo da linha de reforço. Embora houvesse um acúmulo de água na camada reforçada devido ao bloqueio do fluxo pela barreira, tal fenômeno não mostrou prejudicar o desempenho da estrutura, nem mesmo gerou indícios de instabilidades locais nas camadas reforçadas;

e) diante do avanço do umedecimento e da sobrecarga constante, as deformações máximas do reforço e os deslocamentos máximos da estrutura aumentaram exponencialmente com 
o grau de saturação do solo. Ainda, estes parâmetros relacionam-se com a sucção matricial de forma semelhante à relação da curva de retenção de água do solo. Tal comportamento está associado às alterações na rigidez do solo devido à perda da sucção pelo umedecimento. Embora estas tendências tenham sido evidenciadas, os níveis finais de deformações e deslocamentos não são considerados excessivos para as condições impostas.

f) constatou-se que os níveis de deformações e deslocamentos de um muro reforçado são influenciados pela rigidez global do solo, ou seja, mesmo que o avanço alcance uma determinada profundidade, e reduza a rigidez até o nível de avanço, a manutenção da rigidez inicial abaixo deste nível minimiza as deformações nos reforços e os deslocamentos. Portanto, os valores máximos são gerados no final do umedecimento do solo do aterro;

g) foi verificado o fluxo preferencial de água em regiões próximas da face sob condições de precipitação intensa, gerando maiores deslocamentos de face em comparação às condições de precipitação menos intensa. Verificou-se que o avanço de umedecimento gera deslocamentos de face adicionais nas profundidades de alcance da frente de infiltração.

h) embora o solo areno argiloso usado na construção dos protótipos não se enquadre na faixa de aceitação recomendada pelas normas internacionais, a rigidez deste, nas condições estabelecidas pelo uso de reforços não tecidos, foi suficiente para que níveis de deformações e deslocamentos satisfatórios fossem registrados, mesmo sob o efeito do umedecimento verificado com a presença dos reforços não tecidos;

i) a aplicação de incrementos de sobrecarga com velocidade de aplicação relativamente elevada não resultou no desenvolvimento expressivo de pressões na água positivas devido à presença de reforços permeáveis. Desse modo, os incrementos de tensões promoveram maiores deslocamentos em comparação aos protótipos de sobrecargas constantes, somente a partir de um nível de tensão próximo da plastificação do solo, que foi alcançado pelo aumento do grau de saturação e tensão associadamente;

j) as forças previstas pelo método $k$-stiffness modificado para solos atritivos e coesivos, resultaram em valores próximos das forças reais considerando a rigidez confinada do reforço, muito embora a distribuição sugerida pelo método não seja consistente com a observada. Já o método das tensões de serviço, utilizando as tensões de Rankine, mostrouse extremamente conservador, inclusive com a consideração da coesão aparente do solo nas análises;

k) as análises de equilíbrio limite em muros reforçados com geotêxteis não tecidos mostraram ser uma ferramenta apropriada para as verificação da estabilidade interna da ruptura do reforço, por consistir em um método menos conservador em comparação ao método de tensões de serviço de Rankine. Os valores de fator de segurança mostraram ser indicativos da deformabilidade de estruturas de solos finos reforçados com geotêxteis não 
tecidos, já que este parâmetro apresenta uma relação exponencial bem definida com as deformações e deslocamentos da estrutura. Tanto as superfícies de ruptura observadas como as previstas sofreram alterações durante o umedecimento preferencial na face, movimentando-as em direção desta;

1) deformabilidades relativamente baixas, em que fatores de segurança de 1,2 corresponderam à deformações de $3 \%$ foram observadas neste trabalho. Portanto, as estruturas de solos finos reforçados com geotêxteis não tecidos não necessariamente se deformam excessivamente antes da ruptura;

m) os níveis de deformações e deslocamentos das estruturas de reforços não tecidos de laboratório e campo foram semelhantes, bem como em comparação aos valores encontrados na literatura, validando as constatações verificadas nesta pesquisa.

Com base nos resultados obtidos nesta pesquisa, pode-se concluir que muros de solos finos reforçados com geotêxteis não tecidos podem ser utilizados como estruturas permanentes mesmo sob a condição de umedecimento. A presença de reforços permeáveis garante uma manutenção de níveis não prejudiciais de saturação, além de evitar o desenvolvimento de pressões da água positivas. Análises de dissipações de pressões neutras e estabilidade na condição úmida de rigidez do solo são recomendadas em projetos.

\subsection{Implicações em projetos de muros reforçados com geotêxteis não tecidos}

Do conjunto de informações e das conclusões obtidas nesta pesquisa, algumas recomendações e sugestões para projetos de muros reforçados com geotêxteis não tecidos, que venham a considerar o avanço da frente de umedecimento, são apresentadas:

a) no caso da existência de um solo local muito fino e plástico, em que geogrelhas altamente rígidas são requisitadas, ou o transporte de material granular de longa distância tenha que ser realizado, recomenda-se um estudo de viabilidade econômica da solução de se utilizar reforços não tecidos e sistemas de barreiras de avanço de umedecimento por precipitação com o uso de geomembranas, geocompostos ou GCLs, além dos sistemas convencionais de drenagem na base e no contato do muro reforçado com o maciço natural;

b) os critérios de escolha do material de aterro para estruturas reforçadas com não tecidos não devem ser baseados apenas em sua composição granulométrica, mas sim nos parâmetros de plasticidade, uma vez que o uso de materiais com argilas menos ativas pode gerar reduções menos expressivas na rigidez do solo com o avanço do umedecimento. No caso do uso de solos mais finos e plásticos, deve-se prever a rigidez do reforço e uma capacidade de drenagem apropriada para esta condição;

c) adicionalmente a análise de estabilidade interna, recomenda-se análises da drenagem interna almejada na zona reforçada da estrutura. Para isso, o parâmetro de transmissividade do reforço deve ser acrescentado em projeto e verificações quanto à 
vazão requerida no reforço deve ser analisadas. Cabe observar que a transmissividade do reforço é reduzida quando confinada ao solo. Tal aspecto deve ser também considerado nas análises, seja ou por meio de fatores de redução ou pela determinação direta destes parâmetros por ensaios especiais;

d) recomenda-se que a prática de limitar o espaçamento máximo de $40 \mathrm{~cm}$ entre reforços seja mantida, uma vez que esta elimina o possível efeito do armazenamento de água pela barreira capilar na ruptura ou em problemas locais da estrutura. Em casos específicos, as barreiras capilares podem ser projetadas desde que se conheça a curva de retenção de água do solo e do geotêxtil não tecido. Dependendo do ponto de quebra da barreira almejado, o solo da camada superficial da estrutura pode ser substituído por um material que aumente a vida útil da barreira. É importante ainda que se conheçam as condições de precipitação e infiltração local;

e) análises de estabilidade podem ser avaliadas conjuntamente e comparativamente por meio de três métodos: equilíbrio limite; tensões de serviço de Rankine; método k-stiffness. Sabendo do caráter de conservadorismo de cada método avaliado neste trabalho, pode-se resultar em especificações de projeto não tão conservadoras.

f) recomenda-se a utilização do método de equilíbrio limite para avaliação de estabilidade interna à ruptura do reforço, em que as alterações nas pressões da água do solo (inclusive negativas) podem ser incluídas e avaliadas. O fator de segurança é um indicativo da deformabilidade, já que se sabe que a relação deste é exponencial com as deformações máximas nos reforços. Indica-se, assim, a análise de compatibilidade de deformações em termos de módulo de rigidez dos materiais para que possa ser observado o ponto de mobilização do reforço;

g) em estruturas elevadas de solos finos, cuidados devem ser tomados para que deformações excessivas locais ou rupturas locais não aconteçam durante o avanço do umedecimento. Tal aspecto pode ser avaliado por análises de equilíbrio limite;

h) a determinação de parâmetros confinados de resistência e rigidez à tração de geotêxteis não tecidos é fundamental para que alguns aspectos conservadores sejam eliminados das análises, resultando em estruturas mais econômicas. Ainda, estes parâmetros devem ser determinados com o solo a ser utilizado na estrutura, uma vez que a granulometria deste solo influencia significativamente no comportamento mecânico dos geotêxteis não tecidos. 


\subsection{Sugestões para trabalhos futuros}

Com base nas constatações verificadas neste trabalho, futuras pesquisas podem ser conduzidas para dar continuidade a este trabalho e sanar algumas dúvidas. Seguem as seguintes sugestões:

a) avaliar o comportamento de protótipos reforçados com geogrelhas e geotêxteis tecidos sob o avanço do umedecimento;

b) avaliar o comportamento de muros de solos finos reforçados com geotêxteis não tecidos na situação de alagamento, e avanços provenientes de diferentes direções;

c) monitorar o comportamento hidráulico de interface de modo a verificar a eficiência da drenagem de diferentes geotêxteis não tecidos combinados a diferentes tipos de solos;

d) comparar os resultados experimentais de infiltração em solos reforçados com simulações numéricas considerando a permeabilidade não saturada do solo;

e) realizar simulações numéricas com MEF para adequar os materiais envolvidos e as condições de contorno de umedecimento desta pesquisa e realizar análises paramétricas e simulações;

f) avaliar o comportamento de deformações nos reforços em diferentes tipos de solos finos, geotêxteis não tecidos, e teores de umidade (ou sucção matricial), de modo a melhor definir as relações apresentadas neste trabalho. 


\section{REFERÊNCIAS ${ }^{1}$}

ABU-FARSAKH, M. Y.; ALMOHD, I.; FARRAG, K. Comparison of field and laboratory pullout test on geosynthetics in marginal soils. Journal of Transportation Research Board, n. 1975, p. 124136, 2006.

ABU-FARSAKH, M.; CORONEL, J.; TAO, M. Effect of soil moisture content and dry density on cohesive soil-geosynthetic interactions using large direct shear tests. Journal of Materials in Civil Engineering, v. 19, n.7, p. 540-549, 2007.

AFNOR G38017-FOS from Hydrodynamics Sieving. French Committee on Geotextiles, France, 1986.

ALLEN, T. M.; BATHURST, R. J.; HOLTZ, R. D.; WALTERS, D. L.; LEE, W. F. A new working stress method for prediction of reinforcement loads in geosynthetic walls. Canadian Geotechnical Journal, v. 40, p. 976-994, 2003.

AMERICAN ASSOCIATION OF STATE HIGHWAY AND TRANSPORTATION OFFICIALS. Standard specifications for highway bridges, AASHTO, $17^{\text {th }}$ Ed., Washington, D.C, EUA, 2002, 829 p.

AMERICAN SOCIETY OF TESTING MATERIALS. ASTM D 4491. Standard test methods for water permeability of geotextiles by permittivity, ASTM, PA, USA, 2009, 6p.

AMERICAN SOCIETY OF TESTING MATERIALS. ASTM D 4643. Standard test method for determination of water (moisture) content of soil by microwave oven heating, ASTM, PA, USA, 2008.

AMERICAN SOCIETY OF TESTING MATERIALS. ASTM D 4716. Standard test method for determining the (in-plane) flow rate per unit width and hydraulic transmissivity of a geosynthetic using a constant head, ASTM, PA, USA, 2008.

AMERICAN SOCIETY OF TESTING MATERIALS. ASTM D 6836-02. Test Methods for Determination of the Soil-Water Characteristic Curve for Desorption Using a Hanging Column, Pressure Extractor, Chilled Mirror Hygrometer, and/or Centrifuge, ASTM,PA, USA, 2003.

AMORIM JR., W.C. Mecanismos de Interação solo-geogrelha. In: Geossintéticos 1992, Brasília, Proceedings..., Volume 2, p. $121-139$.

ANDRAWES, K. Z.; MCGOWN, A.; KABIR, M. H. Uniaxial strength testing of woven and nonwoven geotextiles. Geotextiles and Geomembranes, v. 1, n. 1, p. 41-56, 1984.

ARTHUR, J. R. F.; ROSCOE, K. H. An examination of the edge effects in plane-strain model earth pressure tests. In: VI INTERNATIONAL CONFERENCE ON SOIL MECHANICS AND FOUNATION ENGINEERING, 1965. Proceedings... Montreal, Canada, 1965, v. 2, div. 3-6, p. 363-367.

ASSOCIAÇÃO BRASILEIRA DE NORMAS TÉCNICAS. NBR 15225. Geossintéticos: Determinação da capacidade de fluxo no plano, ABNT, Rio de Janeiro, 2005, 9p.

ASSOCIAÇÃO BRASILEIRA DE NORMAS TÉCNICAS. NBR 6508. Solo: massa específica real dos grãos, ABNT, Rio de Janeiro, 1984.

ASSOCIAÇÃO BRASILEIRA DE NORMAS TÉCNICAS. NBR 7183. Determinação do limite e relação de contração dos solos, ABNT, Rio de Janeiro, 1983.

ASSOCIAÇÃO BRASILEIRA DE NORMAS TÉCNICAS. NBR 9813. Determinação da massa específica aparente in situ com o emprego do cilindro de cravação, ABNT, Rio de Janeiro, 1984.

ASSOCIAÇÃO BRASILEIRA DE NORMAS TÉCNICAS. NBR 12568. Geossintéticos: Determinação da massa por unidade de área, ABNT, Rio de Janeiro, 2003, 3p.

\footnotetext{
${ }^{1}$ De acordo com a Associação Brasileira de Normas Técnicas. NBR6023.
} 
ASSOCIAÇÃO BRASILEIRA DE NORMAS TÉCNICAS. NBR 12569. Geotêxteis: Determinação da espessura, ABNT, Rio de Janeiro, 2003.

ASSOCIAÇÃO BRASILEIRA DE NORMAS TÉCNICAS. NBR 12824. Geotêxteis: Determinação da tração não-confinada - Ensaio de tração de faixa larga, ASTM, Rio de Janeiro, 1993.

ASSOCIAÇÃO BRASILEIRA DE NORMAS TÉCNICAS. NBR 14545. Determinação do coeficiente de permeabilidade de solos argilosos a carga variável, ABNT, Rio de Janeiro, 2000.

ASSOCIAÇÃO BRASILEIRA DE NORMAS TÉCNICAS. NBR 15226. Geossintéticos: Determinação do comportamento em deformação e na ruptura, por fluência sob tração não confinada, ABNT, Rio de Janeiro, 2005.

ASSOCIAÇÃO BRASILEIRA DE NORMAS TÉCNICAS. NBR 6459. Solo: determinação do limite de liquidez, ABNT, Rio de Janeiro, 1984.

ASSOCIAÇÃO BRASILEIRA DE NORMAS TÉCNICAS. NBR 7180. Solo: determinação do limite de plasticidade, ABNT, Rio de Janeiro, 1984.

ASSOCIAÇÃO BRASILEIRA DE NORMAS TÉCNICAS. NBR 7181. Solo: Análise Granulométrica, ABNT, Rio de Janeiro, 1984.

ATHANASOPOULOS, G.A. Results of direct shear tests on geotextile reinforced cohesive soil. Geotextiles and Geomembranes, v. 14, p. 619-644, 1996.

AURIAUlT, J.L.; CORDARY, D.; GIROUD, J. P.; GOURC, J. P. Estudo teórico do papel de drenos têxteis na consolidação de terraplenagem. In: INTERNATIONAL CONFERENCE ON THE USE OF FABRICS IN GEOTECHNICS, 1977. Proceedings... Paris, 1977, v. 2, p. 273-278 (em francês).

BARBOUR, S. L. Reduction of acid generation in mine tailings through the use of moisture-retaining cover layers as oxygen barriers: Discussion. Canadian Geotechnical Journal, v. 27, n. 3, p. 398-401, 1990.

BENJAMIM C. V .S. Avaliação experimental de estruturas de contenção em solo reforçado com geotêxtil. 2006. Tese (Doutorado), Escola de Engenharia de São Carlos, Universidade de São Paulo, São Carlos, 2006.

BENJAMIM, C. V .S.; BUENO, B. S.; ZORNBERG, J. G. Field monitoring evaluation of geotextilereinforced soil-retaining walls. Geosynthetics International, v. 14, n. 2, p. 100-119, 2007.

BERGADO, D. T.; BUKKANASUTA, A.; BALASUBRAMANIAM, A. S. Laboratory pull-out tests using bamboo and polymer - Geogrids including a case study. Geotextiles and Geomembranes, v. 5, p. 153-189, 1987.

BERGADO, D. T.; CHAI, J. C.; ABIERA, H. O.; ALFARO, M. C.; BALASUBRAMANIAM, A. S. Interaction between cohesive-frictional soil and various grid reinforcements. Geotextiles and Geomembranes, v. 12, p. 327-349, 1993.

BERGADO, D. T.; SHIVASHANKAR, R.; SAMPACO, C. L.; ALFARO, M. C. ANDERSON, L.R. Behavior of a welded wire wall with poor quality, cohesive-friction backfills on soft Bangkok clay: a case study. Canadian Geotechnical Journal, v. 28, n. 6, p. 860-880, 1991.

BJORNBERG, A. J. S. Sedimentos pós-crestácios do leste do Estado de São Paulo. 1965. Tese (Livre Docência), Escola de Engenharia de São Carlos, Universidade de São Paulo, São Carlos, 1965.

BLIVET, J. C.; JOUVE, P.; MAILLOT, R. Modelagem numérica de reforço de solo com geotêxteis: função hidráulica. In: III INTERNATIONA CONFERENCE ON GEOTEXTILES, 1986. Proceedings... Vienna, Austria, 1986, v. 1, p. 249-253 (em francês).

BODEN, J. B.; IRWIN, M. J.; POCOCK, R.G. Construction of experimental reinforced earth walls at the TRRL. Ground Engineering, v. 11, n. 7, 1978, p. 28-37.

BONAPARTE, R.; HOLTZ, R. D.; GIROUD J. P. Soil reinforcement design using geotextiles and geogrids. Geotextile Testing and the Design Engineer, ASTM STP 952, p. 69-116, 1987. 
BOUAZZA, A.; ZORNBERG, J. G.; MCCARTNEY, J. S.; NAHLAWI, H. Significance of unsaturated behavior of geotextiles in earthen structures. Australian Geomechanics, v. 41, n. 3, p. 133-142, 2006.

BRAND, S. R.; DUFFY, D. M. Strength and pullout testing of geogrids. In: GEOSYNTHETICS CONFERENCE, 1987. Proceedings... New Orleans, EUA, 1987, v. 1, p. 226-236.

BRITISH STANDARDS INSTITURION. BS 8006. Code of practice for strengthened/Reinforced soils and other fill. British Standard Institution, 1995.

BROMS, B. B. Design of fabric retaining structures. In: SYMPOSIUM ON EARTH REINFORCEMENT, 1978. Proceedings... ASCE, Pittsburg, EUA, 1978.

BROOKS, R. J.; COREY, A. T. Hydraulic properties of porous media. Journal of Hydrology, Colorado State University, Fort Collins, n. 3, 1964.

BUENO, B.S. Long-term performance of geosynthetics. In: International Conference on Geosynthetics, Guarujá, Brazil, Proceedings..., vol. 1, p.439-453, 2010.

BURDINE, N. T. Relative permeability calculations from pore size distribution data. Journal of Petroleum Technology, n. 5, p. 71-78, 1953.

BURWASH, W. J.; FROST, J. D. Case history of a $9 \mathrm{~m}$ high geogrid reinforced retaining backfills. In: GEOSYNTHETICS 91, Atlanta, EUA. Proceedings... v. 2, 1991, p. 485-493.

CARVAlHO, P. A. S.; PEDROSA, J. A. B. A.; WOLLE, C. M. Aterro reforçado com geotêxtil - uma opção alternativa para a engenharia geotécnica. In: CONGRESSO BRASILEIRO DE MECÂNICA DOS SOLOS E ENGENHARIA DE FUNDAÇÕES, 8, 1986, Porto Alegre. Anais... São Paulo: ABMS, 1986, p. 169-178.

CHALATURNYK, R.; CHAN, D. K. H.; SCOTT, J. D. Finite element analysis of reinforced soil. Application of polymeric reinforcement in soil retaining structures, Jarret, P. M. and McGown, A., (Eds), Kluwer Academic Publishers, London, 1988, 557p.

CHANG, D. T.; SUN, T. S.; HUNG, F. Pullout mechanism of geogrids under confinement by sand and clayey soils. Transportation Research Record, n. 1474, p. 64-72, 1995.

CHEN, C.; WU, J. Y. Effects of wetting on the soil-geogrid interaction. In: IX INTERNATIONAL CONFERENCE ON GEOSYNTHETICS, 2010, Proceedings... Guarujá, São Paulo, Brasil, 2010, p. 669-673.

CHEW, S. H.; SCHMERTMANN, G. R.; MITCHELL, J. K. Reinforced soil wall deformations by finite element method. In: INTERNATIONAL REINFORCED SOIL CONFERENCE, 1990. Proceedings... Performance of Reinforced Soil Structures., K. Z. Andrawes and A. McGown, eds., Thomas Telford, Glasgow, Scotland, 1990, p. 34-40.

CHILDS, E.; COLLIS-GEORGE. N. The permeability of porous materials. In: THE ROYAL SOCIETY LONDON A, 1950. Proceedings... London. Reino Unido, v. 201, p. 392-405, 1950.

CHRISTOPHER B. R.; BERG, R. R. Pullout evaluation of geosynthetics in cohesive soils. IV INTERNATIONAL CONFERENCE ON GEOTEXTILES, GEOMEMBRANES AND RELATED PRODUCTS, 1990. Proceedings... Balkema, The Hague, Netherlands, v. 1, 1990, p. 731-736.

CHRISTOPHER, B. R.; FISCHER, G. R. Geotextile filtration principles, practices and problems. Geotextiles and Geomembranes, v. 11, n. 4-6, p. 337-353, 1992.

CHRISTOPHER, B. R.; ZORNBERG, J. G.; MITCHELL, J. K. Design guidance for reinforced soil structures with marginal soil backfills. In: INTERNATIONAL CONFERENCE ON GEOSYNTHETICS, 6, 1998, Atlanta, Estados Unidos. Proceedings... [S. I.s.n.], 1998, p. 797804.

CLANCY, J.; NAUGHTON, P. J. Pullout resistance of a novel multifunctional geosynthetic in fine grained marginal fills. In: IX INTERNATIONAL CONFERENCE ON GEOSYNTHETICS, 2010, Proceedings... Guarujá, São Paulo, Brasil, 2010, p. 679-682.

ClAYBOURN, A. F.; WU, J. T. H. Geosynthetic-Reinforced Soil Wall Design. Geotextiles and Geomembranes, v. 12, p. 707-724, 1993. 
COLLIN, J. G. Earth wall design. Ph. D. Thesis (Physics) - University of California, Berkeley, Berkeley, California, EUA, 1986.

COLLIOS, A.; DELMAS, P.; GOURC, J. P.; GIROUD, J. P. Experiments on soil reinforcement with geotextiles. The use of geotextiles for soil improvement. In: ASCE NATIONAL CONVENTION, 1980. Proceedings... Portland, Oregon, EUA, 1980, p. 53-73.

CONCA, J.; WRIGHT, J. Diffusion and flow in gravel, soil, and whole rock. Applied Hydrogeology, v. 1, p. 5-24, 1992.

CARVALHO, P. A.; WOLLE, C.M. Aterro Reforçado com geotêxteis: Uma opção construtiva que se consagra. Revista Construção, Encarte técnico IPT/PINI, n. 2256, p. 21- 24, 1985.

DELMAS, P.H.; GOURC, J. P.; BLIVET, J. C.; MATICHARD, Y. Geotextile reinforced retaining structures: a few instrumented examples. In: INTERNATIONAL GEOTECHNICAL SYMPOSIUM ON THEORY AND PRACTICE OF EARTH REINFORCEMENT, 1988. Proceedings...Fukuoka, Japan, 1988.

DOURADO-NETO, D.; NIELSEN, D. R.; HOPMANS, J. W. Software to model soil water retention curves. Scientia Agricola, Vol. 57, n. 1, pp. 191-192, 2001.

EHRLICH, M.; MITCHELL, J. K. Working stress design method for reinforced soil walls. Journal of Geotechnical Engineering, v. 120, n. 4, p. 625-645, 1994.

EINGENBROD, K. D.; LOCKER, J. G. Determination of frictional values for the design of sides slopes lined or protected with geosynthetics. Canadian Geotechnical Journal, v. 24, n. 4, p. 509-519, 1987.

ERHLICH, M.; VIDAL, D.; CARVALHO, P. A. Performance of two geotextile reinforced soil slopes. In: INTERNATIONAL SYMPOSIUM ON RECENT DEVELOPMENTS IN SOIL AND PAVEMENT MECHANIS, 1997, Rio de Janeiro. Proceedings...Rotterdam: Balkema, 1997, p. 415-420.

ERHLICH, M.;VIANNA, A. J. D.; FUSARO, F. Comportamento de um muro de solo reforçado. In: CONGRESSO BRASILEIRO DE MECÂNICA DOS SOLOS E ENGENHARIA DE FUNDAÇÕES, 10, 1994, Foz do Iguaçu. Anais... São Paulo, ABMS, 1994, p. 819-824.

ESCARIO, V.; JUCA, J. Strength and deformation of partly saturated soils. In: XII International Conference on Soil Mechanics and Foundation Engineering, 1989. Proceedings... Rio de Janeiro, RJ, 1989, v. 2, p. 43-46.

FABIAN, K. J.; FOURIE, A. B. Performance of geotextile- reinforced clay samples in undrained triaxial tests. Geotextile and Geomembranes, v. 4, n. 1, p. 53- 63, 1986.

FABIAN, K. Time dependent behavior of geotextile reinforced clay walls. In: IV INTERNATIONAL CONFERENE ON GEOTEXTILES, GEOMEMBRANES AND RELATES PRODUCTS. Proceedings... Balkema, Rotterdam, ISBN 906191 1192, 1990, p. 33-38.

FARRAG, K.; MORVANT, M. Evaluation of interaction properties of geosynthetics in cohesive soils, Lab and field pullout tests. Technical Summary Report n. 380, LTRC, Baton Rouge, La, 2004.

FEDERAL HIGHWAY ADMINISTRATION. FHWA 1998. Mechanically stabilized earth walls and reinforced soil slopes design and construction guidelines. FHWA-SA-96-071, Elias, V.; Christopher, B.R., 1998, Washington, DC, September, 371p.

FOURIE, A. B.; FABIAN, K. J. Laboratory determination of clay geotextile interaction. Geotextiles and Geomembranes, v. 6, n. 4, p. 275-294, 1987.

FRANÇA, F. A. N.; AVESANI, F.; BUENO, B. S., ZORNBERG, J. G. Confined creep of geosynthetics. Proceedings of Geosynthetics 2013, Long Beach, California, EUA, 2013.

FRANÇA, F. A. N; BUENO, B. S. Creep behavior of geosynthetics using confined accelerated Tests. Geosynthetics International, v. 18, n. 5, p. 242-254, 2011.

FREDLUND, D. G.; MORGENTERN, N. R.; WIDGER, R. A. The shear strength of unsaturated soils. Canadian Geotechnical Journal, v. 15, n. 3, p. 313-321, 1978. 
FREDLUND, D. G.; XING, A. Equations for the soil-water characteristic curve. Canadian Geotechnical Journal, v. 31, n. 4, p. 521-532, 1994.

GARCIA, E. F.; GALLAGE C. P. K.; UCHIMURA, T. Function of permeable geosynthetics in unsaturated embankments subjected to rainfall infiltration. Geosynthetics International, v. 14, n. 2, p. 89-99, 2007.

GARDNER, W. R. Some steady state solutions of the unsaturated moisture flow equation with application to evaporation from a water table. Soil Science, v. 85, p. 228-232, 1958.

GASSNER, F.W., JAMES, G.M. Failure of two fabric reinforced segmental block walls in South Africa. In: VI INTERNATIONAL CONFERENCE ON GEOSYNTHETICS, 1998. Proceedings... IFAI, Roseville, MN, p. 559-564, 1998.

GEORGETTI, G. B. Resistência de um solo não saturado a partir de ensaios com teor de umidade constante (CW). Dissertação (Mestrado), Escola de Engenharia de São Carlos, Universidade de São Paulo, São Carlos, 2010.

GHIONNA, V. N.; PARLA, P.; SCOTTO, M.; VEGGI, S. Pull-out behavior of a draining geogrids embedded in waste cohesive materials. In: IX INTERNATIONAL CONFERENCE ON GEOSYNTHETICS, 2010, Proceedings...Guarujá, São Paulo, Brasil, 2010, p. 1319-1322.

GILBERT, P. A.; OLDHAM, J. C.; COFFING, L. R. Laboratory measurement of pullout resistance of geotextiles against cohesive soils. Technical Report GL-92-6, Waterways Experiment Station, Corps of Engineers, New Orleans, 1992, 67 p.

GIROUD, J. P. Geotextiles drainage layers for soil consolidation. Civil Enginerring for Practicing and Design Engineers, v. 2, p. 275-295, 1983.

GOURC, J. P.; MATICHARD, Y. Development of geotextile reinforcement techniques in France Application to retaining structures. In: INTERNATIONAL SYMPOSIUM ON GEOSYNTHETICREINFORCED SOIL RETAINING WALLS, 1992. Proceedings... A. A. Balkema Publishers, The Netherlands, 1992, p. 131-152.

GOURC, J. P.; RATEL, A.; DELMAS, P. Design of fabric retaining walls: The displacement method. In: III INTERNATIONAL CONFERENCE ON GEOTEXTILES, 1986. Proceedings... Vienna, Austria, v. 2, p. 289-294.

GRAY, D. H.; OHASHI, H. Mechanics of fiber reinforcement in sand. Journal of Geotechnical and Geoenvironmental Engineering, ASCE, v. 109, n. 3, p. 335-353, 1983.

GRAY, D. H.; REFEAI, T. Behavior of fabric versus fiber reinforced sand. Journal of the Geotechnical Engineering Division, ASCE, v. 112, n. 8, p. 804-820, 1986.

HATAMI K.; BATHURST R. J. Numerical model for reinforced soil segmental walls under surcharge loading. Journal of Geotechnical and Geoenvironmental Engineering, ASCE, v. 132, n. 6, p. 673-684, 2006.

HATAMI, K.; BATHURST, R. J. Parametric analysis of reinforced soil walls with different backfill material properties. In: NAGS'2006 CONFERENCE, 2006. Proceedings... Las Vegas, Nevada, USA, 2005, p. 1-15.

HEAD, K.H., 1986. . Manual of Soil Laboratory Testing, Vol. 3. Pentech Press, London, UK.

HELWANY ET, S. M. B.; REARDON, G.; WU, J. T. H. Effects of backfill on the performance of GRS retaining walls. Geotextiles and Geomembranes, v. 17, p. 1-16, 1999.

HELWANY, M. B. Finite element analysis of geotextile reinforced retaining walls considering creep. Geosynthetic Reinforced Soil Retaining Wall, p. 179-192, 1992.

HENRY, K. S.; PATTON, S. Measurements of the contact angle of water on geotextile fibers. Geotechnical Testing Journal, v. 21, n. 1, p. 11-17, 1998.

HILLEL, D. Applications to soil physics. Academic Press, New York, 1980.

HIRD, C. C. Stability charts for reinforced embankments on soft ground. Geotextiles and Geomembranes, v. 4, p. 107-127, 1986. 
HO, S.K.; ROWE, R. K. Effect of wall geometry on the behavior of reinforced soil walls. Geotextiles and Geomembranes, v. 14, p. 521-541, 1996.

HOLTZ, R. D.; CHRISTOPHER, B. R.; BERG, R. Geosynthetic Engineering. Bitech Publishers. Vancouver, 1997, $452 \mathrm{p}$.

HOLTZ, R. D.; TOBIN, W. R.; BURKE, W. W. Characteristics and stress-strain behavior of a geotextilereinforced sand. In: II INTERNATIONAL CONFERENCE ON GEOTEXTILES, 1982. Proceedings... Las Vegas, Estados Unidos, 1982, p. 805-810.

INGOLD, T. S. A laboratory investigation of soil-geotextile friction. Ground Engineering, p. 21-28, 1984.

INGOLD, T. S. A laboratory simulation of reinforced clay walls. Geotechnique, v. 31, n. 3, p. 399-412, 1981.

INGOLD, T. S.; MILLER, K. S. The behavior of geotextile reinforced clay subjected to undrained loading. In: II INTERNATIONAL CONFERENCE ON GEOTEXTILES, 1982, Las Vegas. Proceedings... Las Vegas, 1982, p. 593-597.

IRYO, T.; ROWE, R. K. Infiltration into an embankment reinforced by nonwoven geotextiles. Canadian Geotechnical Journal, v. 42, p. 1145-1159, 2005.

IRYO, T.; ROWE, R. K. Numerical study of infiltration into a soil-geotextile column. Geosynthetics International, v. 11, n. 5, p. 377-389, 2004.

JEWELL, R. A. Some effects of reinforcement on the mechanical behavior of soils. $\mathrm{Ph}$. $\mathrm{D}$. Thesis (Physics) - University of Cambridge, Cambridge, England, 1980.

JEWELL, R. A., PAINE, N., and WOODS, R. I. Design methods for steep reinforced embankments. Proc, Symp. on Polymer Grid Reinforcement in Civ. Engrg., London, U.K., p. 70-81. 1984.

JEWELL, R.A.; MILLIGAN, G. W. E. Deformation calclations for reinforced soil walls. Proceedings of $12^{\text {th }}$ International Conference on Soil Mechanics and Foundation Engineering, Rio de Janeiro, Vol. 2, p. 1257-1263, 1989.

JONES, C. J. F. P. Geosynthetic in reinforced structures. In: II EUROPEAN GEOSYNTHETICS CONFERENCE, Eurogeo, 2000. Proceedings... Bologna, Italia, 2000.

JURAN, H.; HALIS, M.; FARRAG, K. Strain compatibility analysis for geosynthetics reinforced soil walls. Journal of Geotechnical Engineering, v. 116, n. 2, p. 312- 319, 1990.

KAMIJI, T. S. M. M. Fluência de geotêxteis não tecidos através de ensaios confinados. 2006. Dissertação (Mestrado em Geotecnia) - Departamento de Geotecnia, Escola de Engenharia de São Carlos, Universidade de São Paulo, São Carlos, 2006.

KARPURAPU, R.; BATHURST, R. J. Numerical investigation of controlled yielding of soil-Retaining wall structures. Geotextiles and Geomembranes, v. 11, p. 115-131, 1992.

KEMPTON, G. T.; JONES, C. J. F. P.; JEWELL, R. A.; NAUGHTON, P. J. Construction of slopes using cohesive fills and a new innovative geosynthetic material. In: II EUROPEAN GEOSYNTHETICS CONFERENCE, Eurogeo, 2000. Proceedings... Bologna, Italia, 2000, p. 1-6.

KHIRE, M.; BENSON, C.; BOSSCHER, P. Capillary barriers in semiarid and arid climates: design variables and the water balance. Journal of Geotechnical and Geoenvironmental Engineering, ASCE, v. 126, n. 8, p. 695-708, 2000.

KISCH, M. The theory of seepage from clay-blanketed reservoirs. Geotechnique, v. 9, n. 1, p. 9-21, 1959.

KLUTE, A. Water retention: laboratory methods. Methods of Soil Analysis, Part 1: Physical and Mineralogical Methods, SSSA, Madison, WI, p. 635-662, 1986.

KNIGHT, M. A.; KOTHA, S. M. Measurement of geotextile-water characteristic curves using a controlled outflow capillary pressure cell. Geosynthetics International, v. 8, n. 3, p. 271- 282, 2001.

KOERNER, R. M. Designing with geosynthetics, 3. e. Prentice Hall Publication Co., Englewood Cliffs, U.S.A., 1994, 761 p. 
KOERNER, R. M. Designing with Geosynthetics. 4. e. Prentice Hall Publication Co., Englewood Cliffs, NJ, 1998, $761 \mathrm{p}$.

KOERNER, R. M.; SOONG, T. Geosynthetic reinforced segmental retaining walls. Geotextiles and Geomembranes, v. 19, p. 359-386, 2001.

KRAHN, J.; FREDLUND D. G.; KLASSEN, M. J., Effect of soil suction on slope stability at Notch Hill. Canadian Geotechnical Journal, v. 26, n. 2, p. 269-278, 1989.

LAFLEUR, J.; SALL, M.; DUCHAME, A. Frictional characteristics of geotextiles with compacted lateritic gravels and clays. In: GEOSYNTHETICS 87, New Orleans. Proceedings... New Orleans, Estados Unidos, 1987, v. 1, p. 205- 215.

LEONARDS, C. A.; FROST, J. D.; BRAY, J. D. Collapse of geogrid-reinforced retaining structure. Journal of Performance of Construction Facilities, ASCE, v. 8, n. 4, p. 274- 292, 1994.

LESHCHINSKY, D.; BOEDEKER, R. H. Geosynthetic reinforced soil structures. Journal of Geotechnical Engineering, v. 115, n. 10, 1989.

LESHCHINSKY, D.; PERRY, E. B. A design procedure for geotextile reinforced walls. Geotechnical Fabrics Report, v. 5, n. 4, p. 21-27, 1987.

LESHCHINSKY, D.; VOLK, J. C. Stability charts for geotextile-reinforced walls. Transportation Research Record, v. 1031, p. 5-16, 1985.

LESHCHINSKY, D.; VULOVA, C. Effects of geosynthetic reinforcement spacing on the performance of mechanically stabilized earth walls. Transportation Research Board, Report n. 139, 267 p., 2002.

LI, G. X.; JIE, Y. X.; CHEW, S. H. Excess hydrostatic pressure in reinforced retaining wall with cohesive backfill. In: VII INTERNATIONAL CONFERENCE ON GEOSYNTHETICS, 2002. Proceedings... Delmas, Gourc \& Girard (eds), 2002, p. 295-298.

LING, H. I.; CARDANY, C. P.; SUN, L. X.; HASHIMOTO, H. Finite element study of a geosyntheticreinforced soil retaining wall with concrete-block facing. Geosynthetics International, v. 7, n. 3, p. 163-188, 2000.

LING, H. I.; TATSUOKA, Effect of particle size on the mechanical behavior of sand-geotextile composites. Journal of Geotechnical Engineering, v. 120, n. 7, p. 1166-1184, 1994.

LING, H. I.; TATSUOKA, F.; WU, J. T. H; NISHIMURA, J. Hydraulic conductivity of geotextiles under typical operational conditions. Geotextiles and Geomembranes, v. 12, n. 6, p. 509-542, 1993.

LING, H. I.; WU, J. T. H.; TATSUOKA, F. Short-term strength deformation characteristics of geotextiles under typical operational conditions. Geotextiles and Geomembranes, v. 11, n. 2, p. 185-219. 1992.

LIU, Y.; SCOTT, D. J.; SEGO, D. C. Geogrid reinforced clay slopes in a test embankment. Geosynthetics International, v. 1, n. 1, p. 67-91, 1994.

LONG, N. T.; GUEGAN, Y.; LEGEAY, G. Estudo de terra armada com aparelho triaxial. Laboratório Central de pontes e estradas, Relatório de Pesquisa n, 17, Paris, França, 1972, (em francês).

MCCARTNEY, J. S. Determination of the hydraulic characteristics of unsaturated soils using a centrifuge permeameter. Dissertation (pHD), University of Texas at Austin, Austin, Texas, 2007.

MCCARTNEY, J. S.; KUHN, J. A.; ZORNBERG J. G. Geosynthetic drainage layers in contact with unsaturated soils. In: XVI ISSMGE CONFERENCE: GEOTECHNICAL ENGINEERING IN HARMONY WITH THE GLOBAL ENVIRONMENT, 2005. Proceedings... Osaka, Japan, 2005, p. $12-16$

MCCARTNEY, J. S.; ZORNBERG, J. G. Effects of infiltration and evaporation on geosynthetic capillary barrier performance. Canadian Geotechnical Journal, v. 47, p. 1201-1213, 2010.

MCGOWN, A.; ANDRAWES, K. Z. An approach to laboratory testing of geotextiles. Quarterly Journal of Engineering Geology and Hydrogeology, v. 15, p. 177-185, 1982. 
MCGOWN, A.; ANDRAWES, K. Z.; KABIR, M. H. Load-extension testing of geotextiles confined insoil. In: II INTERNATIONAL CONFERENCE ON GEOTEXTILES, 1982. Proceedings... Las Vegas, Estados Unidos, p. 793-798, 1982.

MCGOWN, A.; ANDRAWES, K. Z.; WILSON-FAHMY, R. F; BRADY, K. C. A new method of determining the load-extension properties of geotechnical fabrics. Transport and Road Research Laboratory Supplementary, Report 704, Berkshire, Reino Unido, 13p., 1981.

MELINDA, F.; RAHARDJO H; K. K., HAN; LEONG, E. C. Shear strength of compacted soil under infiltration. Journal of Geotechnical And Geoenvironmental Engineering, v. 130, n. 8, p. 807$817,2004$.

MENDES, M. J. A.; PALMEIRA, E. M. Effects of confinement and impregnation on nonwoven geotextiles mechanical behavior. In: I PAN AMERICAN GEOSYNTHETICS CONFERENCE \& EXHIBITION, 2008, Cancun, Proceedings... Cancun, México, 2008, p. 540-545.

MILLER, D. YESILLER, N.; YALDO, K.; MERAYYAN, S. Impact of soil type and compaction conditions of soil water characteristic. Journal of Geotechnical And Geoenvironmental Engineering, v. 128, n. 9, p. 733-742, 2002.

MILLIGAN, V.; LA ROCHELLE, P. Design methods for embankments over weak soils. Polymer Grid Reinforcement, Thomas Telford, London p. 95-102, 1984.

MILLINGTON, R. J.; J. M. QUIRK. Permeability of porous solids. Transactions of the Faraday Society, v. 57 , p. $1200-1207,1961$.

MITCHELL, J. K.; HOOPER, D.; CAMPANELLA, R. Permeability of Compacted Clay. Journal of Soil Mechanics and Foundation Division, ASCE, v. 91, n. 4, p. 41-65, 1965.

MITCHELL, J. K.; VILLET, W. C. B. Reinforcement of earth slopes and embankments. National Cooperative Highway Research Program, n. 290, 1987.

MITCHELL, J. K; ZORNBERG, J. G. Reinforced structures with poorly draining backfills. Part II: Case histories and applications. Geosynthetics International, v. 2, n. 1, p. 265-307, 1995.

MIYATA, Y.; BATHURST, R. J. Prediction model of reinforcement load for geogrid soil walls with facing batter. Geosynthetics Engineering Journal, Japan, Chapter of IGS, v. 23, p. 195-200, 2008.

MUALEM, Y.A new model predicting the hydraulic conductivity of unsaturated porous media. Water Resources Research, v. 12, p. 513-522, 1976.

MURRAY, R. T. An analytical study of geotextile reinforced embankments and cuttings. In: II INTERNATIONAL CONFERENCE ON GEOTEXTILES, 1982. Proceedings... Industrial Fabrics Associated Int., Las Vegas, Nevada, EUA, 1982, v. 3, p. 707-713.

MURRAY, R. T.; BODEN, J. B. Reinforced earth wall constructed with cohesive fill. Colloque International sur le Renforcement des Sols, v. 2, Paris, França, p. 569-577, 1979.

NACHABE, M. H. Refining the definition of field capacity in the literature. Journal of Irrigation and Drainage Engineering, v. 124, n. 4, p. 230-232, 1998.

NAEMURA, S.; MIKI, H. Design and construction of geotextile reinforced soil structures for road earthworks in Japan. Geosynthetics International, v. 3, n. 1, p. 49-62, 1996.

NAKAMURA, K.; TAMURA, Y.; TATSUOKA, F.; IWASAKI, K.; YAMAUCHI, H. Roles of facings in reinforcing steep clay slopes with a non-woven geotextile. Theory and Practice of Earth Reinforcement, Yamanouchi, T., Miura, N. and Ochiai, H., In: INTERNATIONAL GEOTECHNICAL SYMPOSIUM ON THEORY AND PRACTICE OF EARTH REINFORCEMENT, Fukuoka Kyushu, Japan, Outubro, 1988. Proceedings... Eds., Balkema, 1988, p. 553-558.

NATIONAL CONCRETE MEASONRY ASSOCIATION. NCMA 1998. Segmental retaining wallsseismic design manual, 1. e., Bathurst (Editor), Herndon, Virginia, EUA.

NICHOLSON, R. V.; GILLHAM, R. W.; CHERRY, J. A.; REARDON, E. J. Reduction of acid generation in mine tailings through the use of moisture-retaining cover layers as oxygen barriers. Canadian Geotechnical Journal, v. 26, p. 1-8, 1989. 
NISHIGATA, T.; YAMAOKA, I. Tensile tests of nonwovens under confined stress. In: ANNUAL CONVENTION OF JAPANESE SOCIETY OF SOIL MECHANICS AND FOUNDATION ENGINEERING, 1989. Proceedings... Tokyo, Japan, p. 1871-1872, 1989.

NOORZAD, R.; MIRMORADI, S. H. Laboratory evaluation of the behavior of a geotextile reinforced clay. Geotextiles and Geomembranes, v. 28, n. 4, p. 386-392, 2010.

O'KELLY, B. C.; NAUGHTON, P. J. On the interface shear resistance of a novel geogrid with in-plane drainage capability. Geotextiles and Geomembranes, v. 26, p. 357-362, 2008.

OLSON, R. E.; LANGFELDER, L. J. Pore water pressures in unsaturated soils. Journal of the Soil Mechanics and Foundations Division, ASCE, v. 91, SM4, p. 127-151, 1965.

OLSON, R.; DANIEL, D. E. Measurement of the hydraulic conductivity of fine-grained soils. Permeability and Groundwater Contaminant Transport, ASTM, Philadelphia, EUA, 1981.

PALMEIRA, E. M.; LIMA, JR., N. R., MELLO, L. G. R., Interaction between soils and geosynthetic layers in large-scale ramp tests. Geosynthetics International, v. 9, n. 2, p. 149-187, 2002.

PATIAS, J. Avaliação de solos não convencionais em estruturas de solo reforçado. 2005. Dissertação (mestrado) - Escola de Engenharia de São Carlos, Universidade de São Paulo, São Carlos, 2005.

PERRIER, H.; BLIVET, J.C.; KHAY, M. Stabilization de Talus par Reinforcement tout Textile: Ouvranges Experimental et Reel, Proceedings of Third International Conference on Geotextiles, Vol. 2, Vienna, pp. 313-318, 1986.

POULOVASSILIS, A. Hysteresis of pore water, an application of the concept of independent domains. Soil Science, v. 93, p. 405-412, 1962.

RAISINGHANI, D. V.; VISWANADHAM, B. V. S. Evaluation of permeability characteristics of a geosynthetic-reinforced soil through laboratory tests. Geotextiles and Geomembranes, v. 28, n. 6, p. 579-588, 2010.

RASMUSSON, A.; ERIKSSON, J. C. Capillary barriers in covers for mine tailing dumps, National Swedish Environmental Protection Board, Report 3307, Royal Institute of Technology, Stockholm, Sweden, 1987.

RIBEIRO, T. S. M. T.; JUNIOR, M. C. V.; PIRES, J. V. Comportamento do aterro de solo reforcado da encosta do Belverede. In: IX CONGRESSO BRASILEIRO DE GEOLOGIA DE ENGENHARIA, 1999. Proceedings... São Pedro, SP, 1999, 16p.

RICHARDSON; G. N.; BEHR, L. H. Geotextile reinforced wall failure and remedy. Geotechnical Fabrics Report, v. 6, n. 4, p. 14-18, 1998.

ROJAGOPAL, K.; BATHURST, R. L. Parametric finite element investigation of reinforced soil retaining walls. In: V INTERNATIONAL CONFERENCE ON GEOTEXTILES, GEOMEMBRANES AND RELATED PRODUCTS, 1994. Proceedings... Singapore, 1994, Edited by G.P. Karunaratne, S.H. Chew, K.S. Wong, and S.A. Tan.

SAWICKI, A.; SWIDZINSKI, W. Unconfined versus confined testing of geosynthetics. Geosynthetics International, v. 6, n. 3, p. 157-169, 1999.

SCARBOROUGH, J. A. A Tale of two walls: Case histories of failed MSE Walls. In: GEO-FRONTIERS, 2005. Proceedings... GSP 140 Slopes and Retaining Structures under Seismic and Static Conditions, Austin, Texas, Estados Unidos, 2005, p. 1-12.

SCHMERTMANN G. R.; CHOUREY-CURTIES V. E.; JOHNSON R. D.; BONAPART R. Design charts for geogrid-reinforced soil slopes. In: GEOSYNTHETICS 87. Proceedings... New Orleans, La., 1987, Industrial Fabrics Association Int., v. 1, p. 108-120.

SCHNEIDER, H. R.; HOLTZ, R. D. Design of slopes reinforced with geotextiles and geogrids. Geotextiles and Geomembranes, v. 3, p. 29-51, 1986

SCOTT, J. D.; SEGO, D. C.; HOFMANN, B. A.; RICHARDS, E. A; BURCH, E. R. Design of the Devon geogrid test fill. In: GEOSYNTHETICS 87, IFAI, 1987. Proceedings... v. 1, New Orleans, LA, USA, 1987, p. 157-168. 
SEGO, D. C.; SCOTT, E. A.; RICHARDS, E. A.; LIU, Y. Performance of a geogrid in a cohesive soil test embankment. In: IV INTERNATIONAL CONFERENCE ON GEOTEXTILES, GEOMEMBRANES AND RELATED PRODUCTS, Balkema, 1990. Proceedings... The Hague, Netherlands, v. 1, 1990, p. 67-72.

SHACKELFORD, C. D.; CHANG, C. K.; CHIU, T. F. The capillary barrier effect in unsaturated flow through soil barriers. In: I ICEG CONFERENCE, 1994. Proceedings... Edmonton, California, EUA, 1994, p. 789-793.

STEWARD, J. E.; WILLIAMSON, R.; MOHNEY, J. Earth reinforcement. Chapter 5. Guidelines for use of fabrics in construction and maintenance of low-volume roads, USDA, Forest Service, Portland, Oregon, 1977.

STORMONT, J. C.; HENRY, K. S.; EVANS, T. M. Water retention functions of four nonwoven polypropylene geotextiles. Geosynthetics international, v. 4, n. 6, p. 661-672, 1997.

STORMONT, J. C.; MORRIS, C. E. Method to estimate water storage capacity of capillary barriers. Journal of Geotechnical and Geoenvironmental Engineering, v. 124, n. 4, p. 297-302, 1998.

STORMONT, J. The effect of constant anisotropy on capillary barrier performance. Water Resources Research, v. 32, n. 3, p. 783-785, 1995.

TAN, S. A.; CHEW, S. H.; NG, C. C.; LOH, S. L.; KARUNARATNE, G. P.; DELMAS, PH.; LOKE, K. $\mathrm{H}$. Large-scale drainage behaviour of composite geotextile and geogrid in residual soil. Geotextiles and Geomembranes, v. 19, p. 163-176, 2001.

TATSUOKA, F.; YAMAUCHI, H. A reinforcing method for steep clay slopes using a nonwoven geotextile. Geotextile and Geomembranes, Barking Essex, v. 4, n. 3-4, p. 241-268, 1986.

TEIXEIRA, S. H. C.; BUENO, B. S.; ZORNBERG, J. G. Pullout resistance of individual longitudinal and transverse geogrid ribs. Journal of Geotechnical and Geoenvironmental Engineering, v. 133, n. 1, p. 37-50, 2007.

TINJUM, J.; BENSON, C.; BLOTZ, L. Soil-water characteristic curves for compacted clays. Journal of Geotechnical and Geoenvironmental Engineering, v. 123, n. 11, p. 1060-1069, 1997.

TOPP, G. C.; MILLER, E. E. Hysteretic water characteristics and hydraulic conductivities for glass-bead media. Soil science society of America, v. 30, p. 156-162, 1966.

VAN GENUCHTEN. A closed-form equation for predicting the hydraulic conductivity. Soil Science of America Journal, v. 44, n. 5, p. 892-898, 1980.

VANAPALLI, S.K.; FREDLUND, D.G.; PUFAHL, D.E.; CLIFTON, A.W. Model for prediction of shear strength with respect of soil suction. Canadian Geotechnical Journal, v.33, p. 379-392, 1996.

VIANA, P. M. F. Geovala - Um novo processo construtivo para dutos enterrados. 2003. Tese (Doutorado), Escola de Engenharia de São Carlos, Universidade de São Paulo, São Carlos, 2003.

VILAR, O. M.; BUENO, B. S. Some Topics Regarding the Influence of Non-saturation on the Behavior of Reinforced Soil Structures Built with Tropical Soils. In: First Pan American Geosynthetics Conference \& Exhibition, 2008, Proceedings..., Cancun, 2008, v. 1. p. 272-280.

WAN, X.; BENSON, C. H. Leak-free pressure plate extractor for the soil water characteristic curve. Geotechnical Testing Journal, v. 27, n. 2, p. 1-10, 2004.

WAYNE, M. H.; PETRASIC, K. W.; WILCOSKY, E.; RAFTER, T. J. An innovative use of a nonwoven geotextile in the restoration of Pennsylvania SR54. In: GEOFILTERS '96. Proceedings... Montreal, Canada, 1996, p. 513-521.

WON, G. W.; HAUSSMANN, M. R.; JANKULOVSKI, E. Performance of websol soil wall bridge abutment in Sydney, Australia. V INTERNATIONAL CONFERENCE ON GEOTEXTILES, GEOMEMBRANES AND RELATED PRODUCTS, 1994. Proceedings... Singapore, 1994, Edited by G.P. Karunaratne, S.H. Chew, K.S. Wong, and S.A. Tan., p 433- 436.

WOYSHNER, M. R.; YANFUL, E. K. Modeling and field measurements of water percolation through an experimental soil cover on mine tailings. Canadian Geotechnical Journal, v. 32, p. 601-609, 1995. 
WRIGHT, S. G. A computer program for slope stability calculations. Shinoak Software, Austin Texas, 1991.

WRIGHT, S. G.; DUNCAN, J. M. Limit equilibrium stability analyses for reinforced slopes.' Transportation Research Record 1330, Transportation Research Board, Washington D.C., USA, p. 40-46, 1991.

YAMANOUCHI, T.; MIURA, N.; MATSUBAYASHI, N.; FUKUDA, N. Soil Improvement with Quicklime and Filter Fabric. Journal of the Geotechnical Engineering Division, ASCE, v. 108, n. GT7, p. 953-965, 1982.

YANFUL, E. K. Oxygen diffusion through soil covers on sulphidic mine tailings. Journal of Geotechnical Engineering, v. 119, n. 8, p. 1207-1228, 1993.

YOGARAJAH, I.; ANDRAWES, K. Z. Modeling construction effects in polymeric grid reinforced soil walls. In V INTERNATIONAL CONFERENCE ON GEOTEXTILES, GEOMEMBRANES AND RELATED PRODUCTS, 1994. Proceedings... Singapore, 1994. Edited by G.P. Karunaratne, S.H. Chew, K.S. Wong, and S.A. Tan., v. 1, p. 177-182.

YOO, C.; JUNG, H. Y. Case history of geosynthetic reinforced segmental retaining wall failure. Journal of Geotechnical and Geoenvironmental Engineering, ASCE, v. 132, n. 12, p. 1538-1548, 2006.

YUNOKI, Y.; NAGAO, A. An Application of non-woven fabrics to embankment of cohesive soil. In: INTERNATIONAL GEOTECHNICAL SYMPOSIUM ON THEORY AND PRACTICE OF EARTH REINFORCEMENT, 1988. Proceedings... Theory and Practice of Earth Reinforcement, Yamanouchi, T., Miura, N. and Ochiai, H., Eds., Balkema, Kyushu, Japan, October 1988, p. 491496.

ZORNBERG, J. G.; KANG, Y. Pullout of geosynthetic reinforcement with in-plane drainage capability. Geosynthetic Research and Development in Progress, GRI-18, 2005.

ZORNBERG, J. G.; ARRIAGA, F. Strain distribution within geosynthetic-reinforced slopes. Journal of Geotechnical Engineering, v. 129, n.1, p. 32-45, 2003.

ZORNBERG, J.G.; BARROWS, R. J.; CHRISTOPHER, B. R.; WAYNE, M. H. Construction and Instrumentation of a Highway Slope Reinforced with High-Strength geotextiles. Proceedings of the conference Geosynthetics 95, Nashville, Tennesse, 1995, p. 13-27.

ZORNBERG, J. G.; BOUAZZA, A., MCCARTNEY, J. S. Geosynthetic capillary barriers: current state of knowledge. Geosynthetics International, v. 17, n. 5, p. 273-300, 2010.

ZORNBERG, J. G.; CHRISTOPHER, B. R.; MITCHELL, J. K. Performance of a geotextile-reinforced slope using decomposed granite as backfill material. In: II SIMPOSIO BRASILEIRO SOBRE APLICACOES DE GEOSSINTETICOS,1995. Proceedings... Geossintéticos - 95, São Paulo, p. 19-29, 1995.

ZORNBERG, J. G.; MCCARTNEY, J. S. Analysis of monitoring data from the evapotranspirative test covers at the rocky mountain arsenal. Geotechnical Research Report, US Environmental Protection Agency, Region 8, December, 227 p. , 2003.

ZORNBERG, J. G.; MCCARTNEY, J. S. Chapter 34: Evapotranspirative cover systems for waste containment. The Handbook of Groundwater Engineering, 2. e, Jacques W. Delleur, Editor, CRC Press, Taylor \& Francis Group, Boca Raton, Florida, EUA, 2007.

ZORNBERG, J. G.; MITCHELL, J. K. Reinforced soil structures with poorly draining backfills. Part I: Reinforcement interaction and functions. Geosynthetics International, v. 1, n. 2, p. 103-147, 1994.

ZORNBERG, J.G.; LESHCHINSKY, D. Comparison of international design criteria for geosyntheticreinforced soil structures. Landmarks in Earth Reinforcement, Ochiai, H., Otani, J., Yasufuku, N., and Omine, K. (Editors), Fukuoka, Japan, November, 2003, v. 2, p. 1095-1106. 


\section{LISTA DE ABREVIATURAS}

\begin{tabular}{|c|c|}
\hline AASHTO & American Association of State Highway and Transportation Officials \\
\hline ABNT & Associação Brasileira de Normas Técnicas \\
\hline ASTM & American Society for Testing and Materials \\
\hline BPM & Blocos pré-moldados \\
\hline BS & British Standards; Blocos segmentados \\
\hline $\mathrm{CD}$ & Consolidado drenado \\
\hline CER & Rouen Roadworks Research Center \\
\hline $\mathrm{CH}$ & Argilas inorgânicas de alta plasticidade \\
\hline CL & Argila pouco plastica com areia \\
\hline $\mathrm{CU}$ & Consolidado e não drenado \\
\hline $\mathrm{CW}$ & Teor de umidade constante \\
\hline DGGT & Deutsche Gesellschaft für Geotechnik \\
\hline EBGEO & Empfehlungen Fur Bewehrungen Aus Geokunststoffen \\
\hline EESC & Escola de Engenharia de São Carlos \\
\hline FHWA & Federal Highway Administration \\
\hline FS & Fator de Segurança \\
\hline GC & Grau de compactação; Geocomposto \\
\hline GG & Geogrelha \\
\hline GCL & Geosynthetic Clay Liner \\
\hline GP & Pedregulho mal graduado \\
\hline GW & Pedregulho bem graduado \\
\hline GT & Geotêxtil \\
\hline LTRC & Louisiana Transportation Research Center \\
\hline LVDT & Linear Vertical Displacement Transducer \\
\hline MH & Silt of high plasticity \\
\hline ML & Silt \\
\hline N/A & Não aplicável ao problema \\
\hline NBR & Norma Brasileira Registrada \\
\hline NCMA & National Concrete Masonry Association \\
\hline NT & Geotêxtil não tecido \\
\hline PEAD & Polietileno de alta densidade \\
\hline PET & Poliéster \\
\hline PP & Polipropileno \\
\hline PSC & Precast Segmental Construction \\
\hline RTA & Rods and Traffic Authority \\
\hline $\mathrm{SC}$ & Areia argilosa \\
\hline SM & Silte arenoso \\
\hline SP & Areia mal graduada \\
\hline SUCS & Sistema de Classificação Unificada dos solos \\
\hline SW & Areias bem graduadas \\
\hline $\mathrm{T}$ & Geotêxtil tecido \\
\hline TDR & Time-domain Reflectometer \\
\hline TRRL & Transport and Road Research Laboratory \\
\hline USP & Universidade de São Paulo \\
\hline UU & Unconsolidated Undrained \\
\hline UV & Ultravioleta \\
\hline
\end{tabular}




\section{LISTA DE SÍMBOLOS}

Abertura da malha da peneira

Fator de adesão

Ângulo em relação à superfície de ruptura; Parâmetro de ajuste d as funções-k

Coesão

Coesão efetiva

Peso específico do solo; Ângulo de contato de umedecimento

Peso espefícico aparente seco máximo

Ângulo de atrito de interface solo reforço

Deformação

Deformação máxima

Valor máximo de deformação máxima

Teor de umidade volumétrico

Umidade volumétrica de capacidade de campo

Umidade volumétrica na saturação

Teor de umidade residual

Teor de umidade na saturação

Coeficiente de coesão

Relação: Diâmetro/Espaçamento

Velocidade de descarga positiva

Densidade da água

Tensão normal ao plano de ruptura

Tensão efetiva

Tensão normal

Tensão normal efetiva

Tensão vertical

Tensão vertical máxima

Tensão principal maior

Tensão principal menor

Tensão principal menor confinante efetiva

Tensão superficial entre a água e o ar

Resistência ao cisalhamento

Resistência ao cisalhamento do solo

Resistência ao cisalhamento no reforço

Resistência ao cisalhamento na interface solo-reforço

Resistência ao cisalhamento de interface

Ângulo de atrito do solo

Ângulo de atrito interno efetivo

Ângulo que indica a taxa de aumento da resistência ao cisalhamento com a sucção

Sucção matricial

Sucção na capacidade de campo

Rigidez global dos reforços

Fator de rigidez da face

Fator de inclinação de face

Fator coesão

Área

Deslocamento 


\begin{tabular}{|c|c|}
\hline $\mathrm{D}_{\text {máx }}$ & Deslocamento máximo \\
\hline $\mathrm{D}_{\text {máxmáx }}$ & Deslocamento máximo máximo \\
\hline $\mathrm{D}_{\operatorname{tmax}}$ & Ditribuição das forças máximas \\
\hline $\mathrm{F}_{\text {arranc }}$ & Força de arrancamento \\
\hline g & Aceleração da gravidade \\
\hline $\mathrm{h}$ & Carga hidráulica total \\
\hline$h_{e}$ & Carga de elevação \\
\hline$h_{c}$ & Altura de ascenção capilar \\
\hline$h_{p}$ & Carga de sucção \\
\hline hs & Horas \\
\hline $\mathrm{H}$ & Altura \\
\hline $\mathrm{H}_{\mathrm{T}}$ & Altura total \\
\hline $\mathrm{i}$ & Gradiente hidráulico; inclinação \\
\hline $\mathrm{J}$ & Rigidez \\
\hline $\mathrm{J}_{\mathrm{sec}}$ & Rigidez secante \\
\hline $\mathrm{k}$ & Permeabilidade \\
\hline $\mathrm{K}_{\mathrm{a}}$ & Coeficiente de empuxo ativo do solo \\
\hline $\mathrm{K}_{\mathrm{o}}$ & Coeficiente de empuxo do solo em repouso \\
\hline $\mathrm{k}_{\mathrm{s}}$ & condutividade hidráulica saturada \\
\hline $\mathrm{k}(\theta)$ & Funcão de condutividade hidráulica dos solos \\
\hline $\mathrm{L}$ & Largura \\
\hline Le & Comprimento do reforço na zona passiva \\
\hline $\mathrm{L}_{\mathrm{r}}$ & Largura do reforço \\
\hline $\mathrm{M}_{\mathrm{w}}$ & Massa de água \\
\hline $\mathrm{M}_{\mathrm{s}}$ & Massa de sólidos \\
\hline $\mathrm{n}$ & Porosidade \\
\hline $\mathrm{P}_{\mathrm{a}}$ & Pressão de ar nos poros \\
\hline$P_{\mathrm{o}}$ & Pressão na água devido o gradiente osmótico \\
\hline $\mathrm{P}_{\mathrm{w}}$ & Pressão de água nos poros \\
\hline q & Carregamento \\
\hline $\mathbf{S}_{\mathbf{h}}$ & Espaçamento horizontal entre as camadas de reforço \\
\hline $\mathrm{Sr}$ & Grau de saturação \\
\hline $\mathbf{S}_{\mathbf{v}}$ & Espaçamento vertical entre as camadas de reforço \\
\hline $\mathrm{t}$ & Tempo \\
\hline $\mathrm{T}_{\mathrm{adm}}$ & Tensão admissível \\
\hline $\mathrm{T}_{\max }$ & Tensão máxima \\
\hline $\mathrm{T}_{\operatorname{maxmax}}$ & Valor máximo de $\mathrm{T}_{\max }$ \\
\hline $\mathrm{u}_{\mathrm{a}}$ & Pressão de ar nos vazios do solo \\
\hline $\mathrm{u}_{\mathrm{f}}$ & Pressão da água no reforço \\
\hline $\mathrm{u}_{\mathrm{w}}$ & Pressão de água nos vazios do solo \\
\hline $\mathrm{u}_{\mathrm{s}}$ & Pressão da água no solo \\
\hline $\mathrm{V}_{\mathrm{T}}$ & Volume total \\
\hline $\mathrm{V}_{\mathrm{w}}$ & Volume de água \\
\hline W & Teor de umidade \\
\hline $\mathrm{w}_{\mathrm{ot}}$ & Teor de umidade ótima \\
\hline $\mathrm{w}_{\mathrm{L}}$ & Limite de liquidez \\
\hline $\mathrm{W}_{\mathrm{P}}$ & Limite de plasticidade \\
\hline
\end{tabular}

Z Altura do solo acima do nível do reforço, profundidade em relação ao topo 
APÊNDICE A: Tabela dos resultados do controle de compactação dos protótipos

Tabela A.1. Resultados do controle de compactação de cada camada reforçada para os protótipos M1, M2, M3 e M4

\begin{tabular}{|c|c|c|c|c|c|c|c|c|c|c|}
\hline \multirow[b]{2}{*}{ Protótipo } & \multirow[b]{2}{*}{ Camada } & \multicolumn{3}{|c|}{ Ponto 1} & \multicolumn{3}{|c|}{ Ponto 2} & \multicolumn{3}{|c|}{ Ponto 3} \\
\hline & & $\begin{array}{c}W \\
(\%)\end{array}$ & $\begin{array}{c}\gamma_{d} \\
\left(k N / m^{3}\right)\end{array}$ & $\begin{array}{l}\text { GC } \\
(\%)\end{array}$ & $\begin{array}{c}w \\
(\%)\end{array}$ & $\begin{array}{c}\gamma_{d} \\
\left(k N / m^{3}\right)\end{array}$ & $\begin{array}{l}\text { GC } \\
(\%)\end{array}$ & $\begin{array}{c}w \\
(\%)\end{array}$ & $\begin{array}{c}\gamma_{d} \\
\left(k N / m^{3}\right)\end{array}$ & $\begin{array}{l}\text { GC } \\
(\%)\end{array}$ \\
\hline \multirow{6}{*}{ M1 } & Base & 14,2 & 17,9 & 100 & 13,8 & 17,7 & 99 & 14,1 & 17,8 & 99 \\
\hline & 1 & 14,1 & 17,5 & 98 & 14 & 18,6 & 104 & 14,2 & 17,8 & 99 \\
\hline & 2 & 14,8 & 18,4 & 103 & 14,5 & 18,3 & 102 & 14,8 & 18,3 & 103 \\
\hline & 3 & 14,6 & 17,8 & 99 & 14,3 & 17,8 & 100 & 14,1 & 17,9 & 100 \\
\hline & 4 & 14,6 & 16,8 & 94 & 13,8 & 17,1 & 96 & 14,5 & 17,3 & 97 \\
\hline & 5 & 13,8 & 16,2 & 90 & 13,1 & 17,0 & 95 & 13,5 & 17,1 & 96 \\
\hline \multirow{6}{*}{ M2 } & Base & 14,2 & 17,8 & 100 & 14,5 & 18,0 & 101 & 14,3 & 18,2 & 102 \\
\hline & 1 & 14,4 & 17,9 & 100 & 14,8 & 18,0 & 101 & 14,7 & 18,1 & 101 \\
\hline & 2 & 14,4 & 17,9 & 100 & 14,1 & 18,0 & 101 & 13,8 & 18,2 & 102 \\
\hline & 3 & 14,7 & 17,8 & 99 & 14,8 & 17,8 & 100 & 14,1 & 17,7 & 99 \\
\hline & 4 & 13,9 & 18,2 & 102 & 14,2 & 17,9 & 100 & 14,0 & 17,8 & 100 \\
\hline & 5 & 15,1 & 17,8 & 99 & 14,8 & 18,1 & 101 & 15,0 & 18,2 & 102 \\
\hline \multirow{6}{*}{ M3 } & Base & 14,3 & 18,2 & 102 & 14,4 & 18,2 & 102 & 14,5 & 18,3 & 102 \\
\hline & 1 & 14,4 & 18,4 & 103 & 14,7 & 18,2 & 102 & 14,5 & 18,0 & 101 \\
\hline & 2 & 13,5 & 18,0 & 100 & 13,9 & 18,2 & 102 & 14,0 & 18,0 & 101 \\
\hline & 3 & 14,6 & 18,1 & 101 & 13,1 & 17,9 & 100 & 13,8 & 17,9 & 100 \\
\hline & 4 & 13,3 & 17,8 & 100 & 12,9 & 18,2 & 102 & 13,1 & 17,9 & 100 \\
\hline & 5 & 16,3 & 17,4 & 97 & 16,6 & 18,0 & 100 & 16,2 & 17,8 & 100 \\
\hline \multirow{6}{*}{ M4 } & Base & 16,2 & 17,6 & 98 & 16,1 & 17,4 & 97 & 16,5 & 17,6 & 98 \\
\hline & 1 & 16,9 & 17,4 & 98 & 17,0 & 16,9 & 95 & 16,8 & 17,3 & 97 \\
\hline & 2 & 17,4 & 17,5 & 98 & 17,5 & 16,9 & 95 & 17,1 & 16,8 & 94 \\
\hline & 3 & 15,7 & 17,5 & 98 & 15,7 & 17,4 & 97 & 14,9 & 17,7 & 99 \\
\hline & 4 & 15,9 & 17,2 & 96 & 15,9 & 16,9 & 95 & 16,3 & 17,1 & 96 \\
\hline & 5 & 18,7 & 17,0 & 95 & 18,8 & 16,9 & 95 & 17,6 & 17,3 & 97 \\
\hline
\end{tabular}


APÊNDICE B: Perfis de infiltração durante os ensaios nos protótipos

(a)

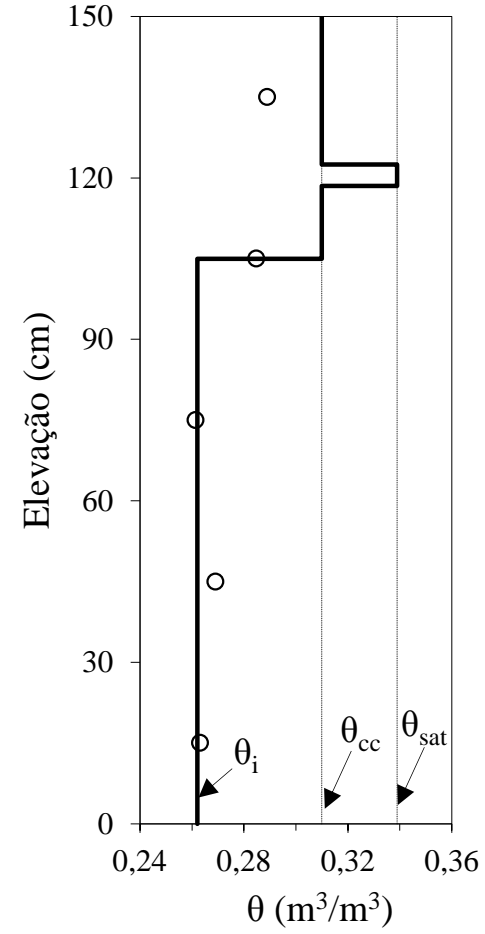

(b)

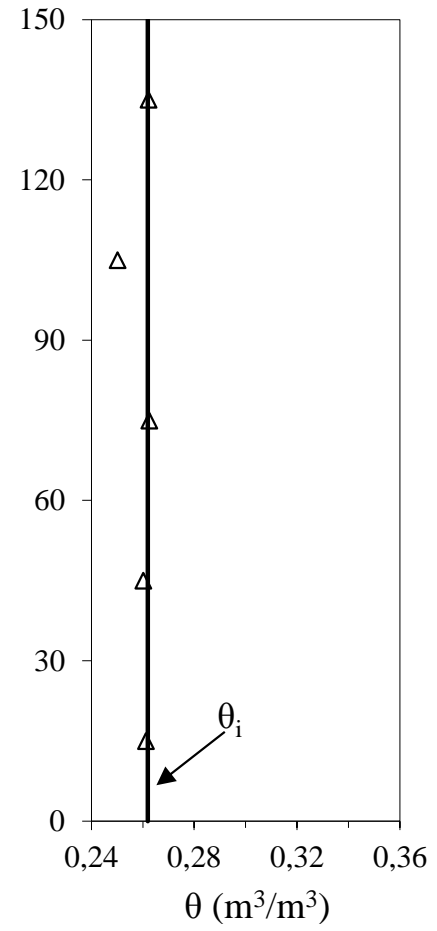

(c)

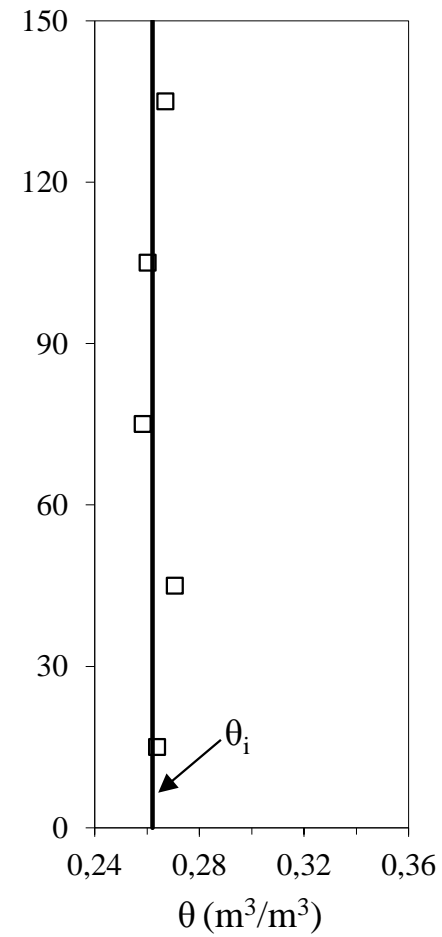

Figura B.1. Perfis de infiltração após 36 dias de ensaio: (a) $10 \mathrm{~cm}$ da face; (b) $80 \mathrm{~cm}$ da face; (c) $130 \mathrm{~cm} \mathrm{da}$ face.

(a)

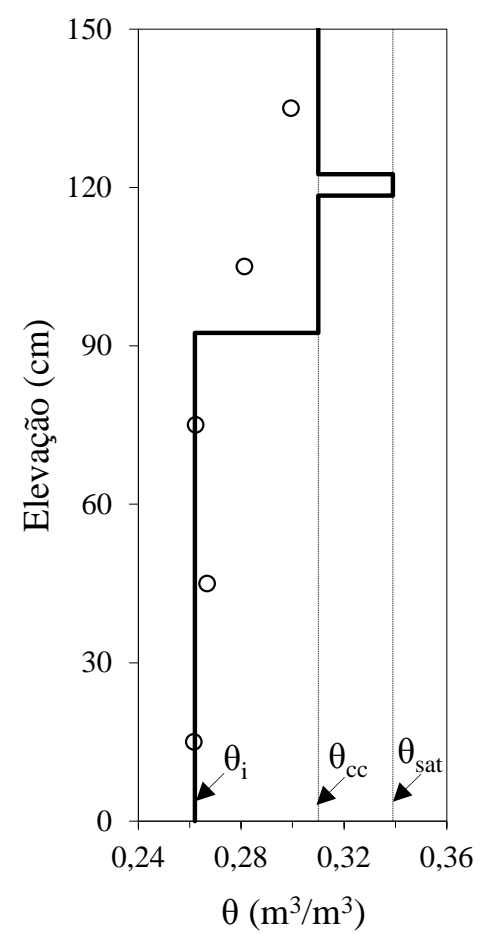

(b)

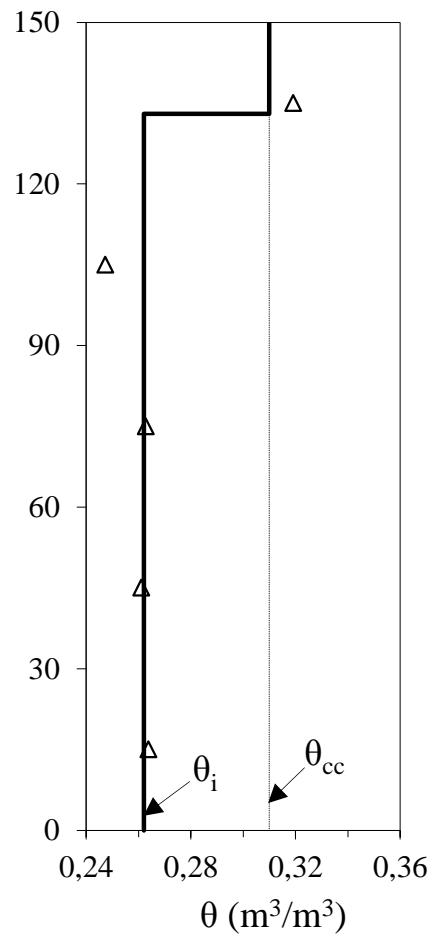

(c)

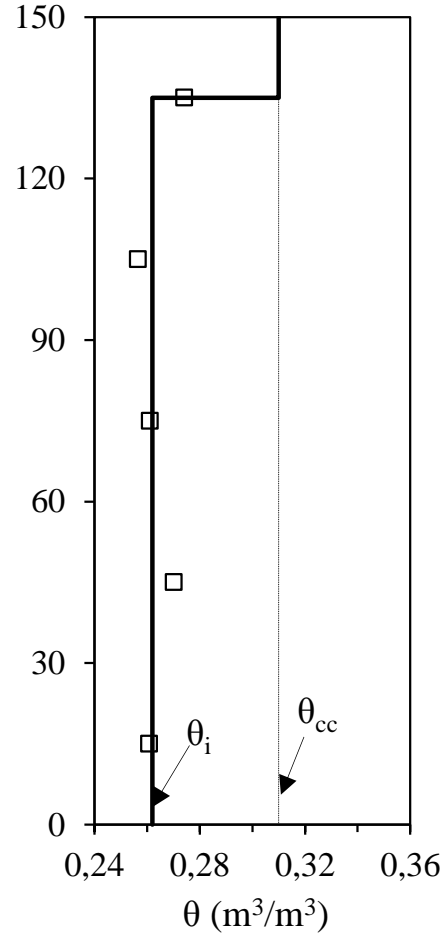

Figura B.2. Perfis de infiltração após 40 dias de ensaio: (a) $10 \mathrm{~cm}$ da face; (b) $80 \mathrm{~cm}$ da face; (c) $130 \mathrm{~cm} \mathrm{da}$ face. 
(a)

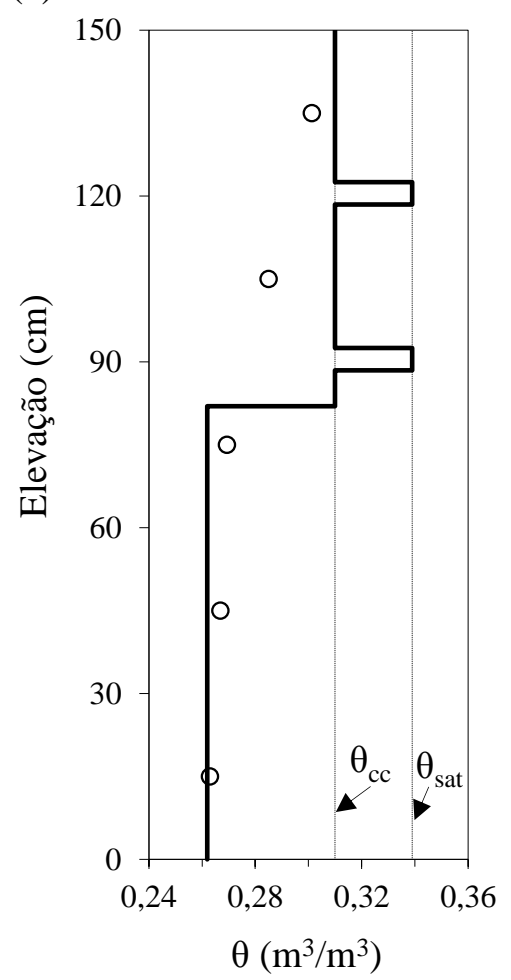

(b)

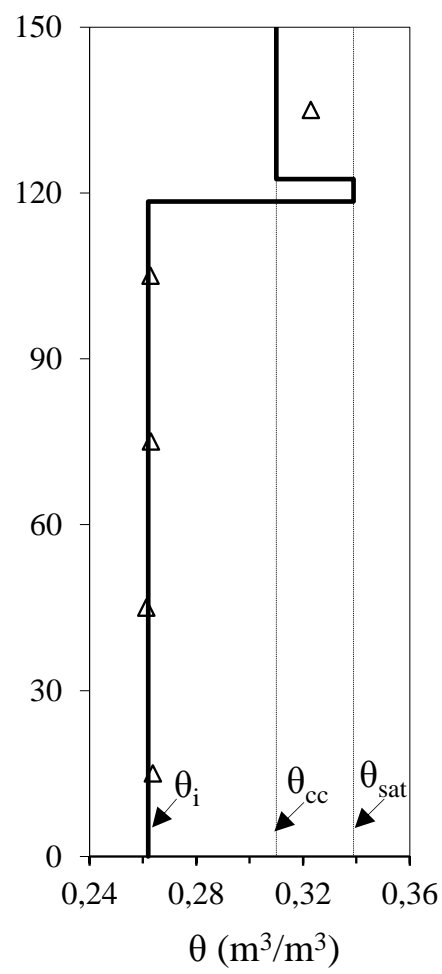

(c)

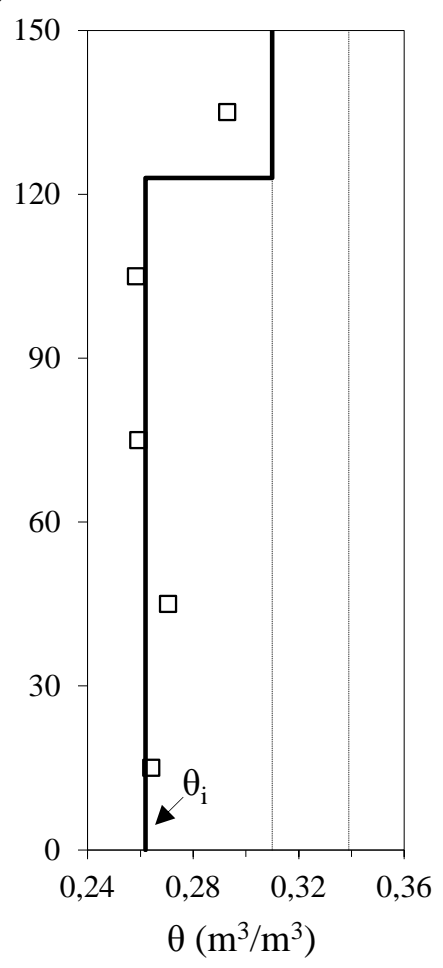

Figura B.3. Perfis de infiltração após 44 dias de ensaio: (a) $10 \mathrm{~cm}$ da face; (b) $80 \mathrm{~cm}$ da face; (c) $130 \mathrm{~cm}$ da face.

(a)

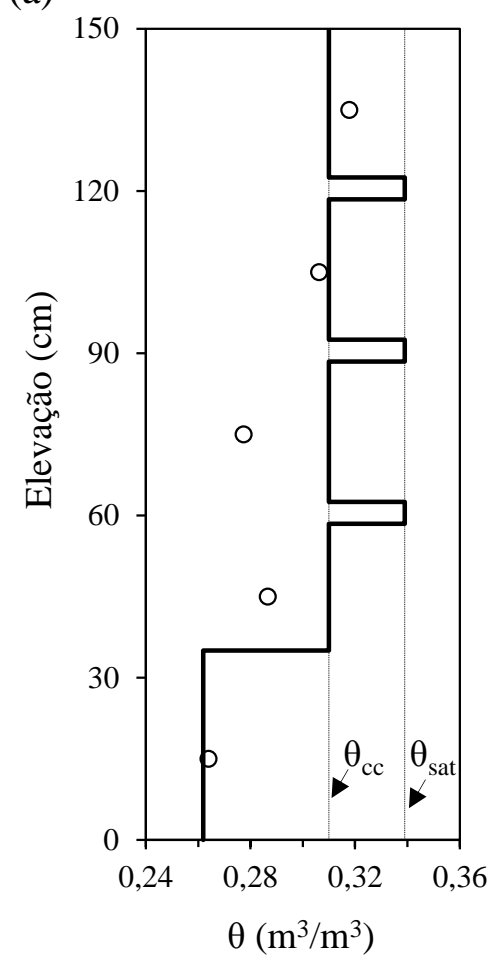

(b)

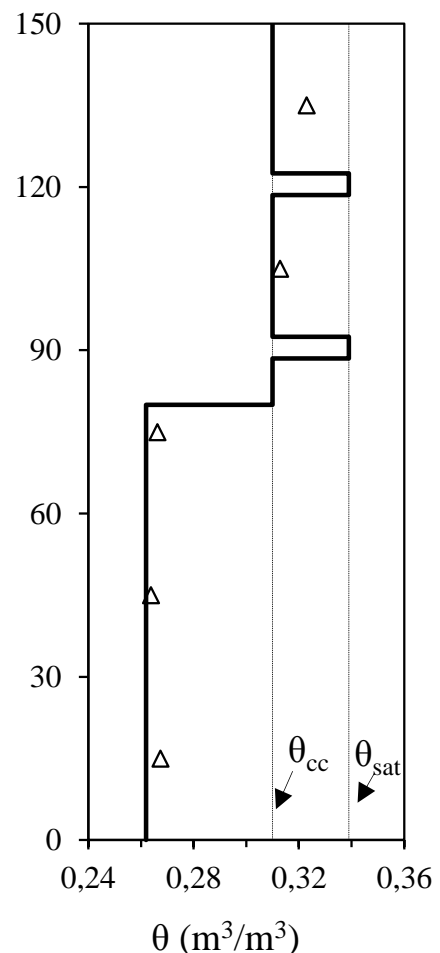

(c)

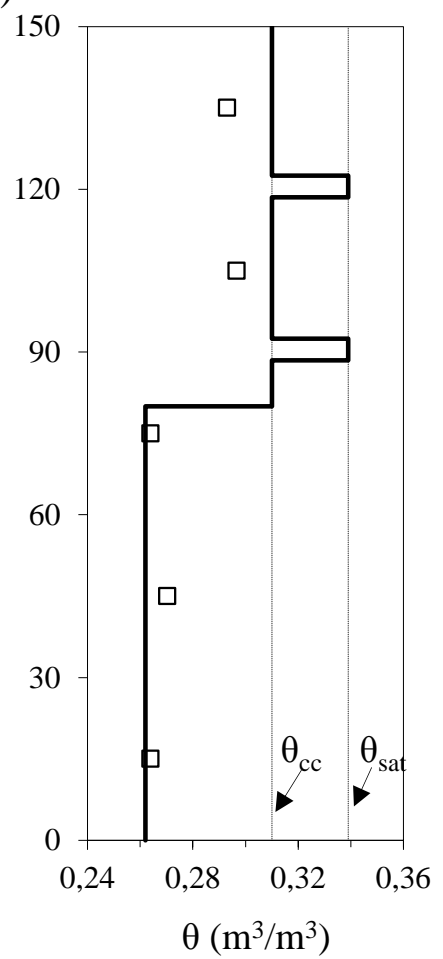

Figura B.4. Perfis de infiltração após 50 dias de ensaio: (a) $10 \mathrm{~cm}$ da face; (b) $80 \mathrm{~cm}$ da face; (c) $130 \mathrm{~cm}$ da face. 
(a)

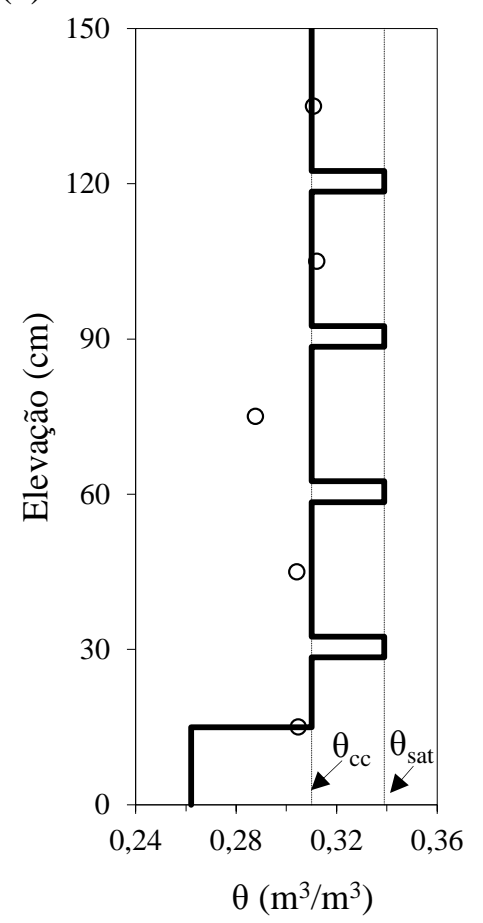

(b)

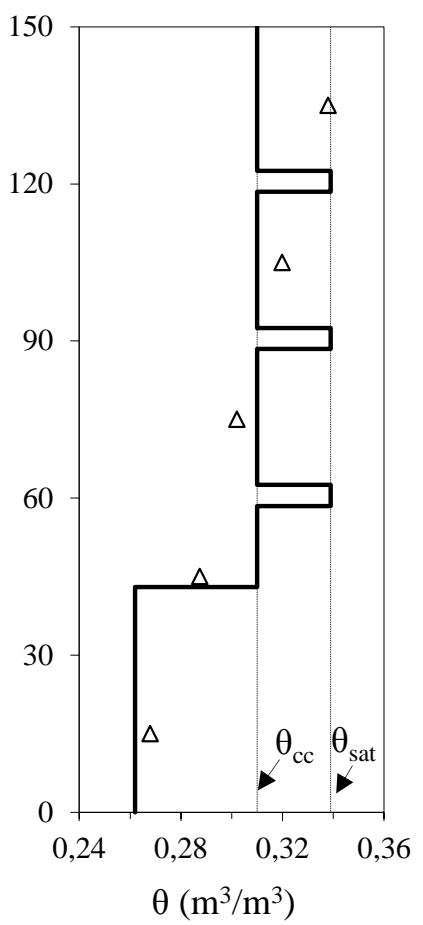

(c)

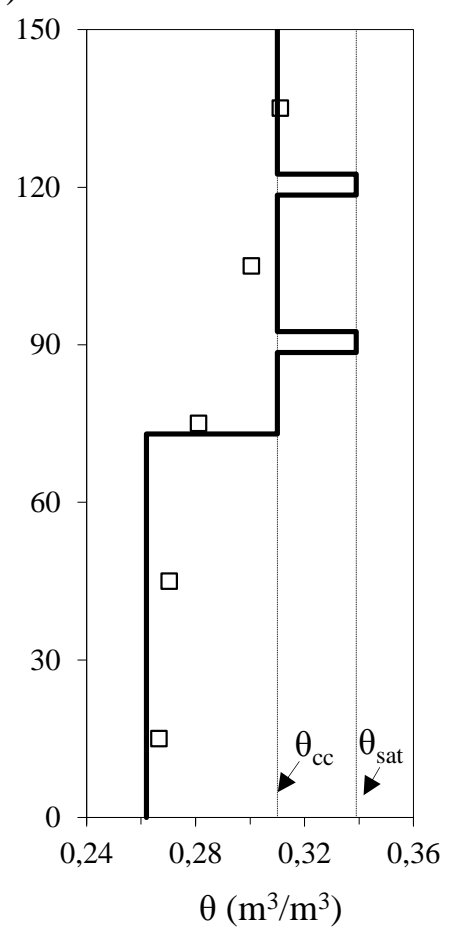

Figura B.5. Perfis de infiltração após 56 dias de ensaio: (a) $10 \mathrm{~cm}$ da face; (b) $80 \mathrm{~cm}$ da face; (c) $130 \mathrm{~cm} \mathrm{da}$ face.

(a)

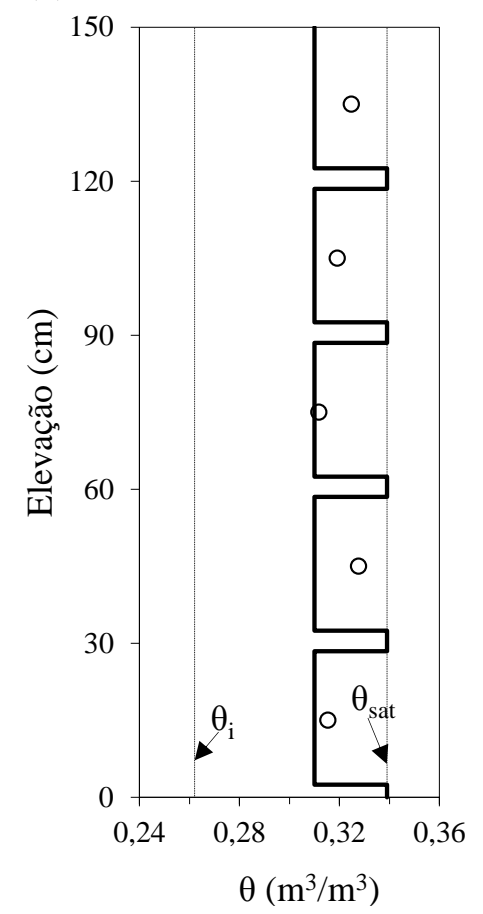

(b)

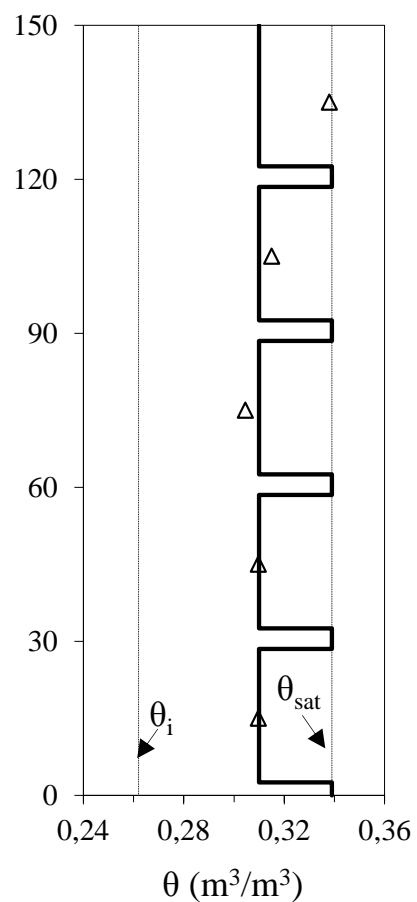

(c)

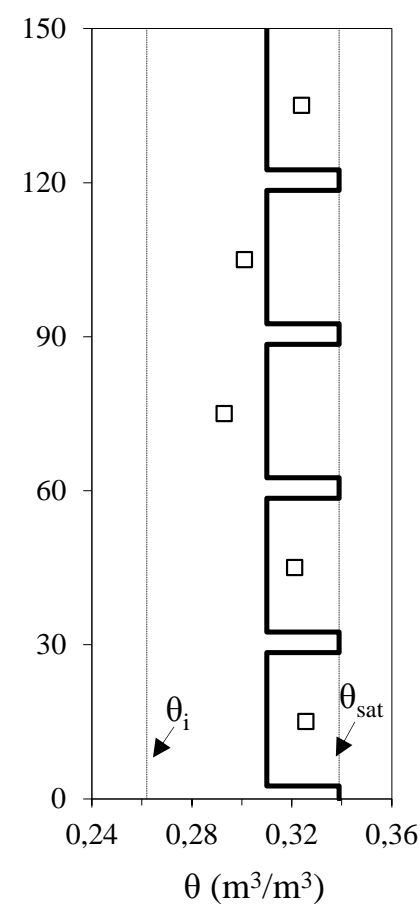

Figura B.6. Perfis de infiltração após 60 dias de ensaio: (a) $10 \mathrm{~cm}$ da face; (b) $80 \mathrm{~cm}$ da face; (c) $130 \mathrm{~cm} \mathrm{da}$ face. 
(a)

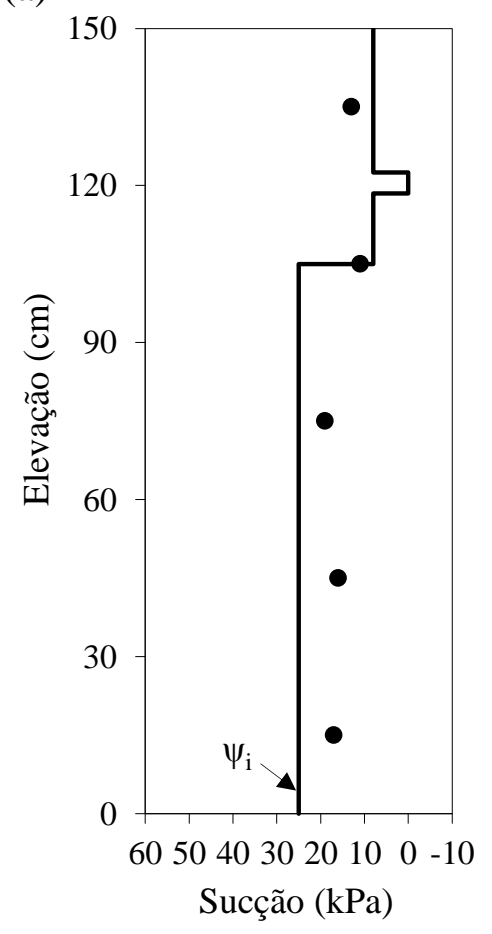

(b)

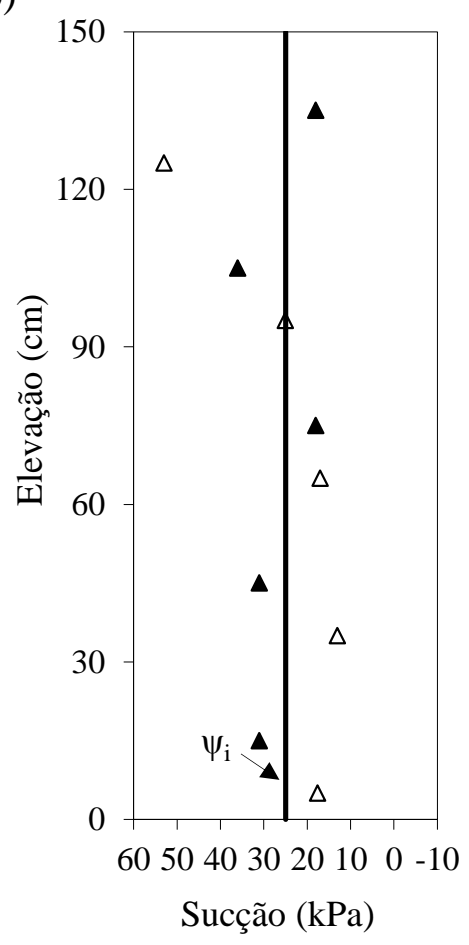

(c)

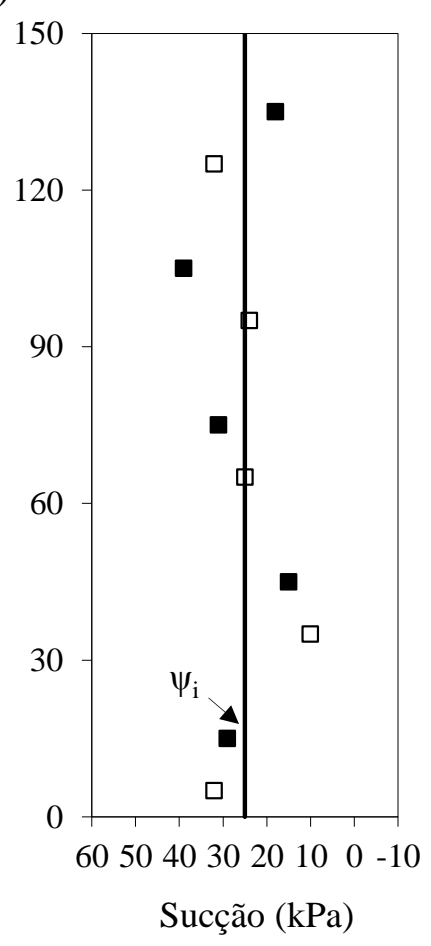

Figura B.7. Perfis de infiltração após 36 dias de ensaio: (a) $10 \mathrm{~cm}$ da face; (b) $80 \mathrm{~cm}$ da face; (c) $130 \mathrm{~cm}$ da face.

(a)

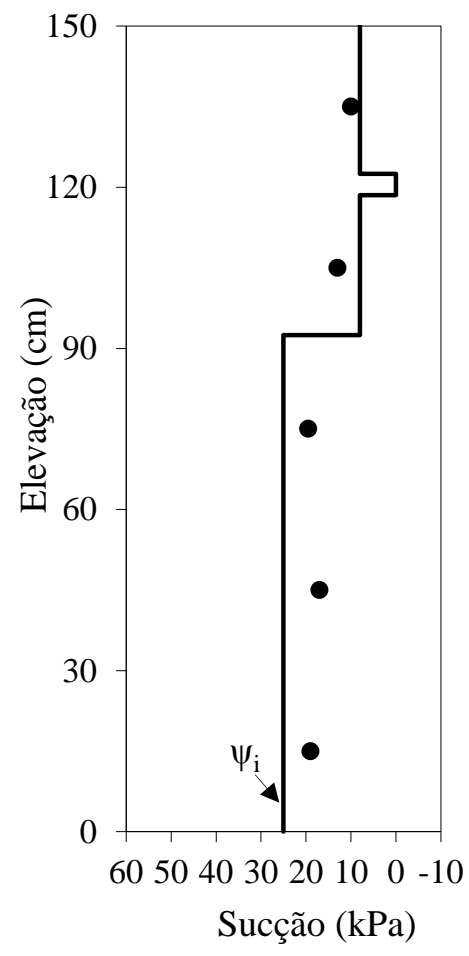

(b)

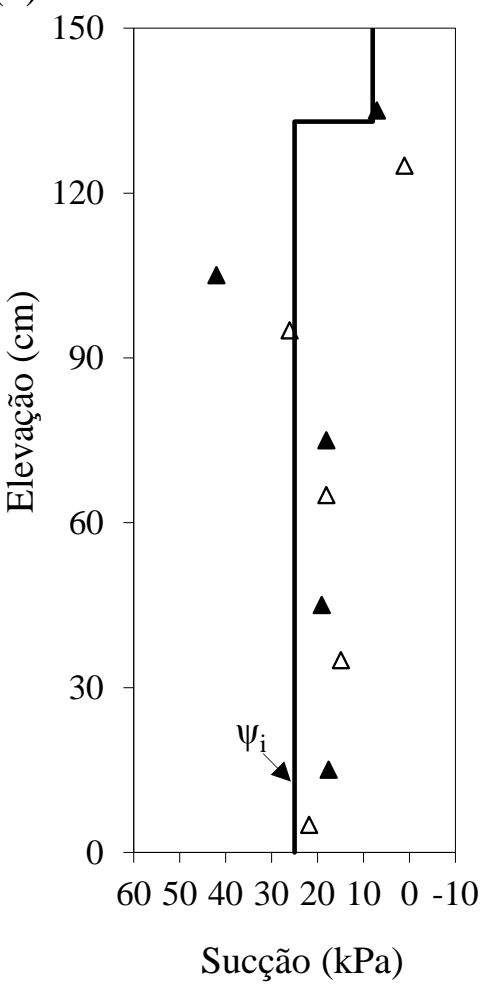

(c)

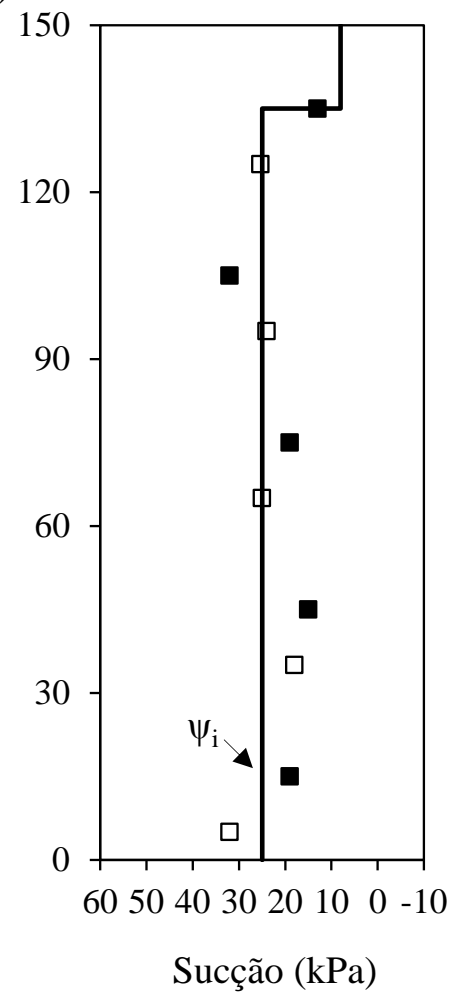

Figura B.8. Perfis de infiltração após 40 dias de ensaio: (a) $10 \mathrm{~cm}$ da face; (b) $80 \mathrm{~cm}$ da face; (c) $130 \mathrm{~cm}$ da face. 
(a)

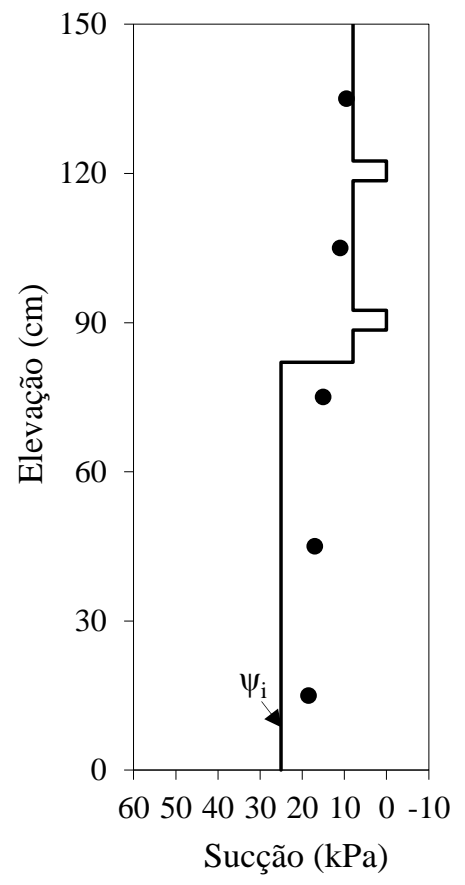

(b)

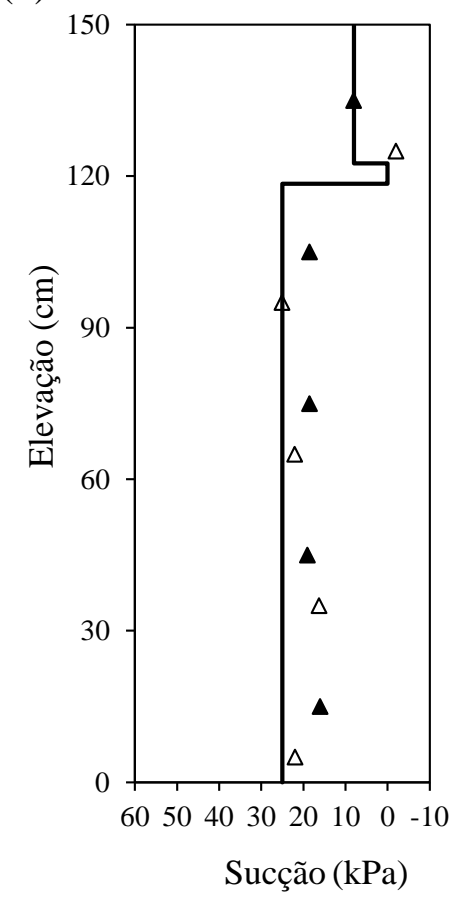

(c)

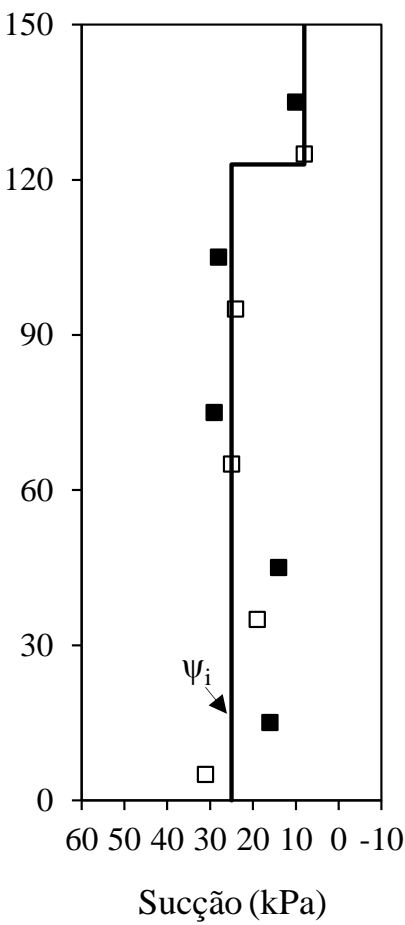

Figura B.9. Perfis de infiltração após 44 dias de ensaio: (a) $10 \mathrm{~cm}$ da face; (b) $80 \mathrm{~cm}$ da face; (c) $130 \mathrm{~cm}$ da face.

(a)

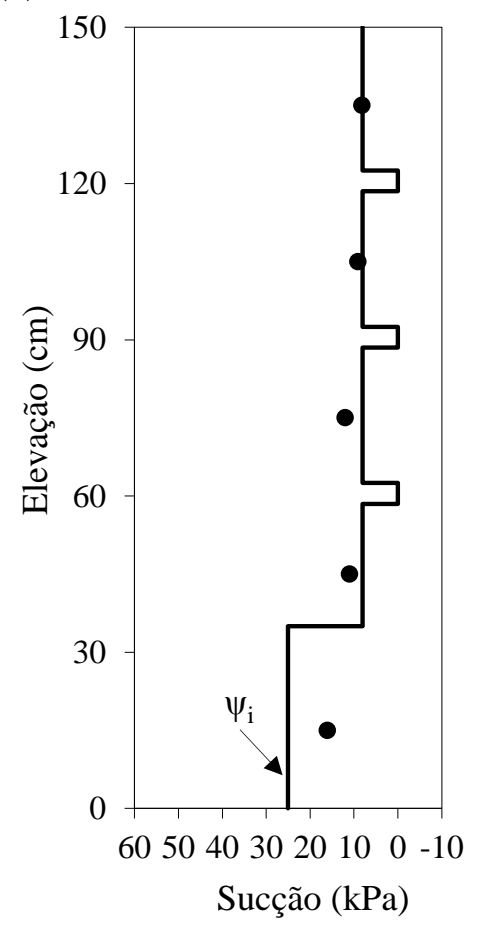

(b)

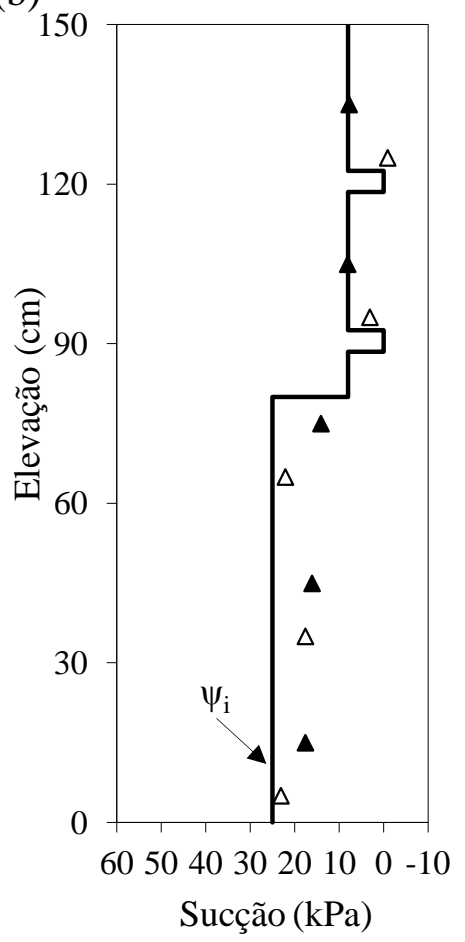

(c)

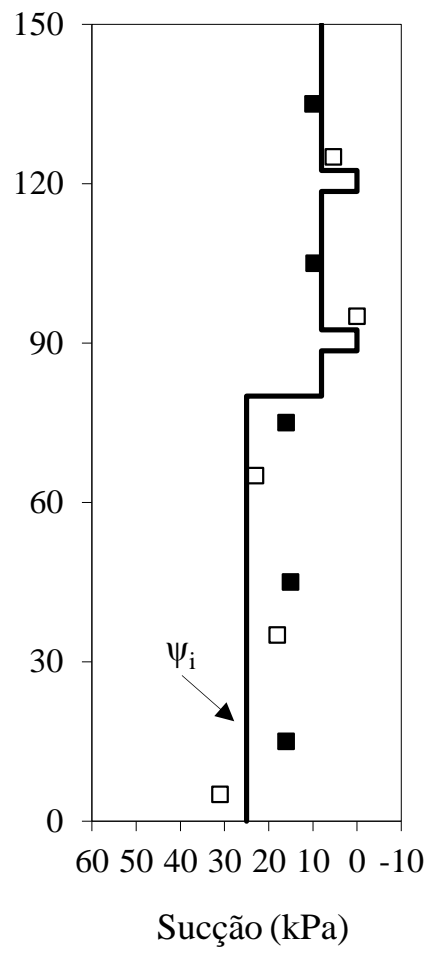

Figura B.10. Perfis de infiltração após 50 dias de ensaio: (a) $10 \mathrm{~cm}$ da face; (b) $80 \mathrm{~cm}$ da face; (c) $130 \mathrm{~cm}$ da face. 
(a)

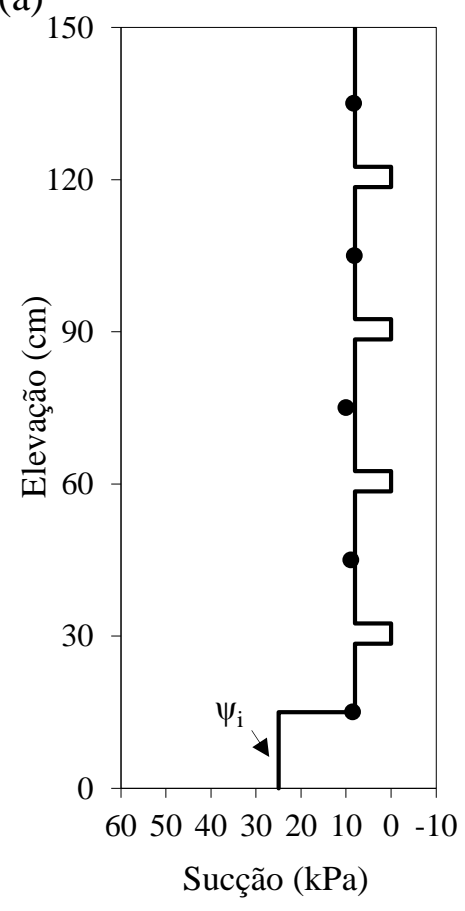

(b)

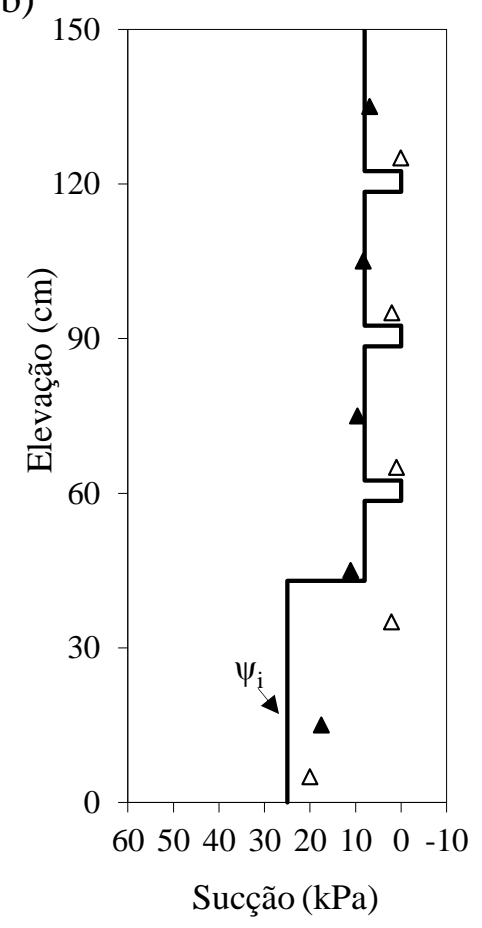

(c)

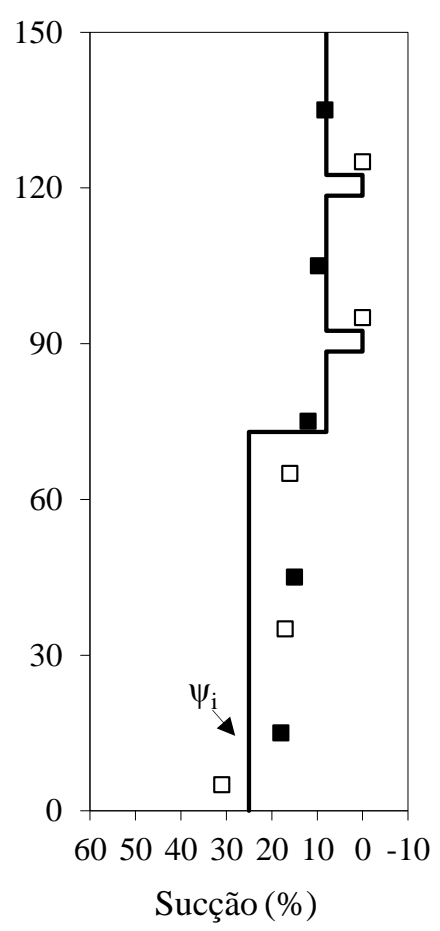

Figura B.11. Perfis de infiltração após 56 dias de ensaio: (a) $10 \mathrm{~cm}$ da face; (b) $80 \mathrm{~cm}$ da face; (c) $130 \mathrm{~cm}$ da face.

(a)

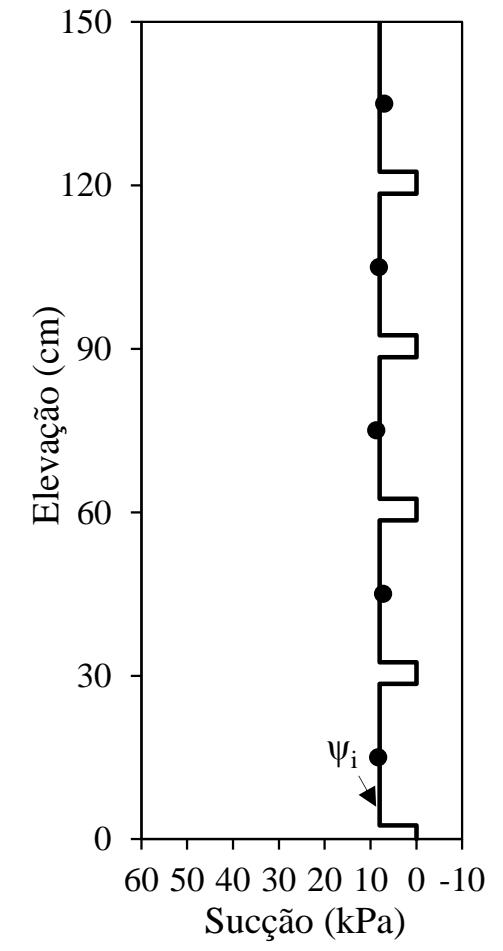

(b)

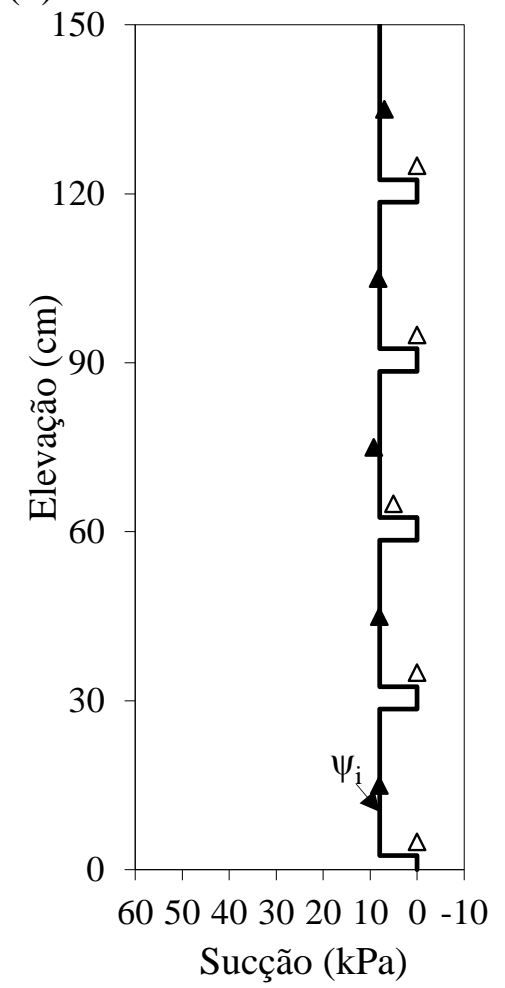

(c)

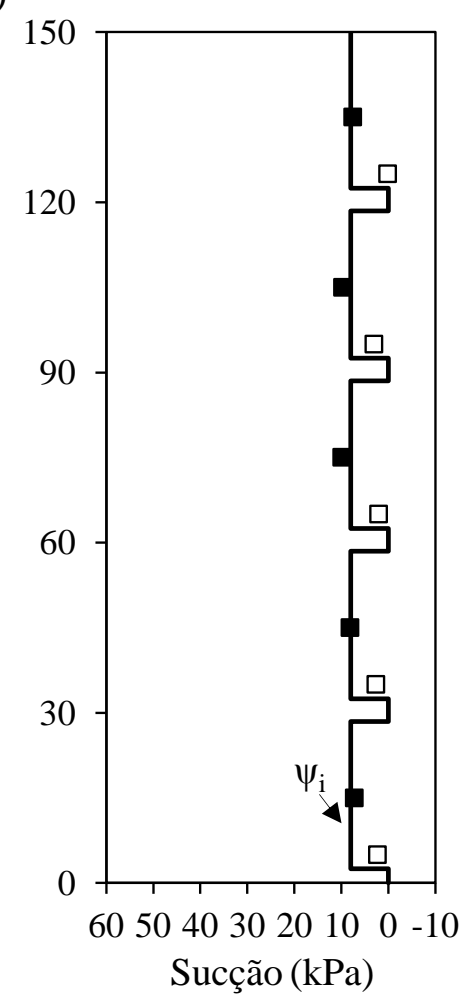

Figura B.12. Perfis de infiltração após 60 dias de ensaio: (a) $10 \mathrm{~cm}$ da face; (b) $80 \mathrm{~cm}$ da face; (c) $130 \mathrm{~cm}$ da face. 
(a)

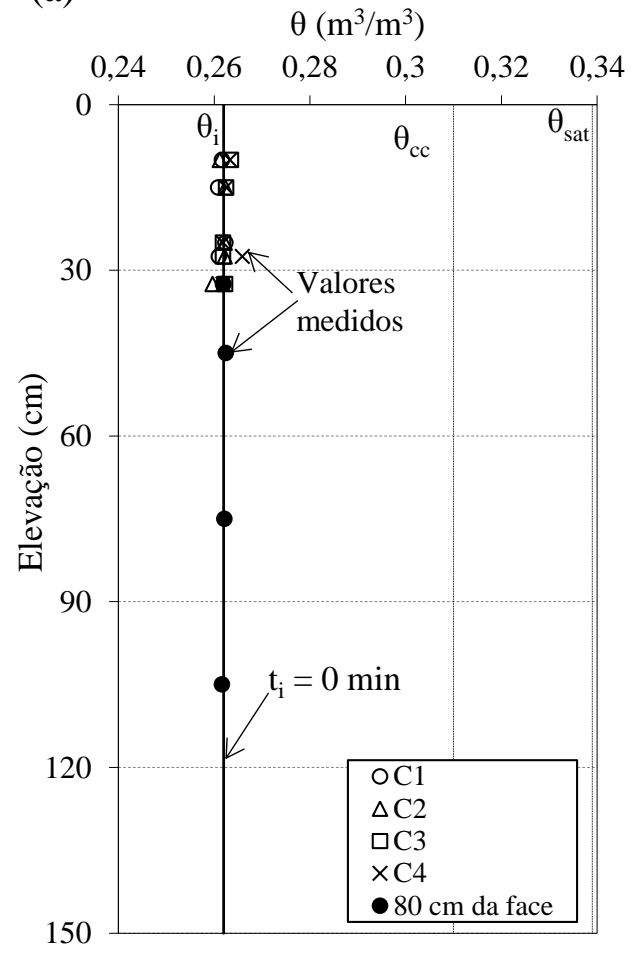

(b)

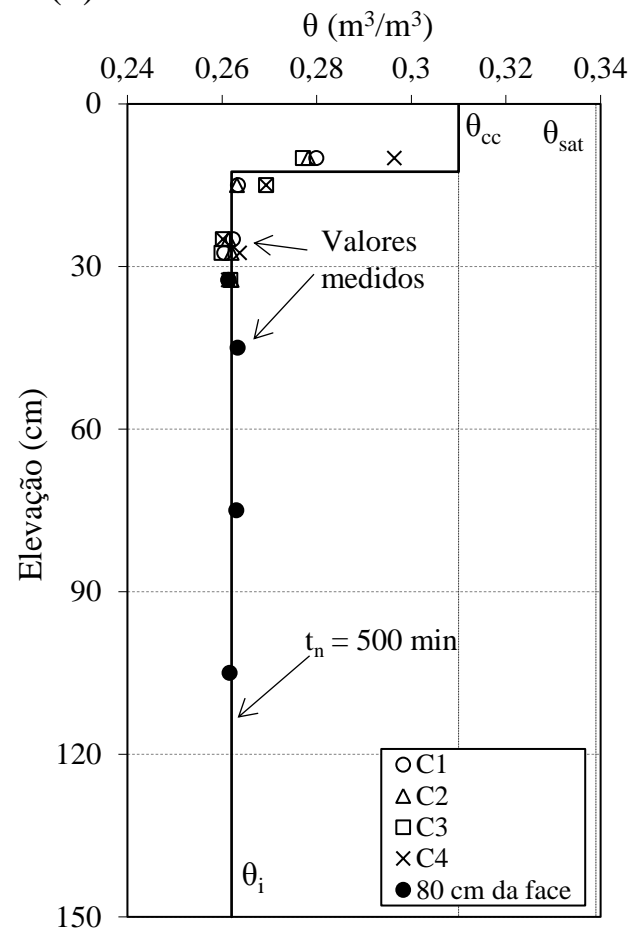

Figura B.13. Perfis de infiltração a $80 \mathrm{~cm}$ da face após (a) 0 min e (b) 500 min.

(a)

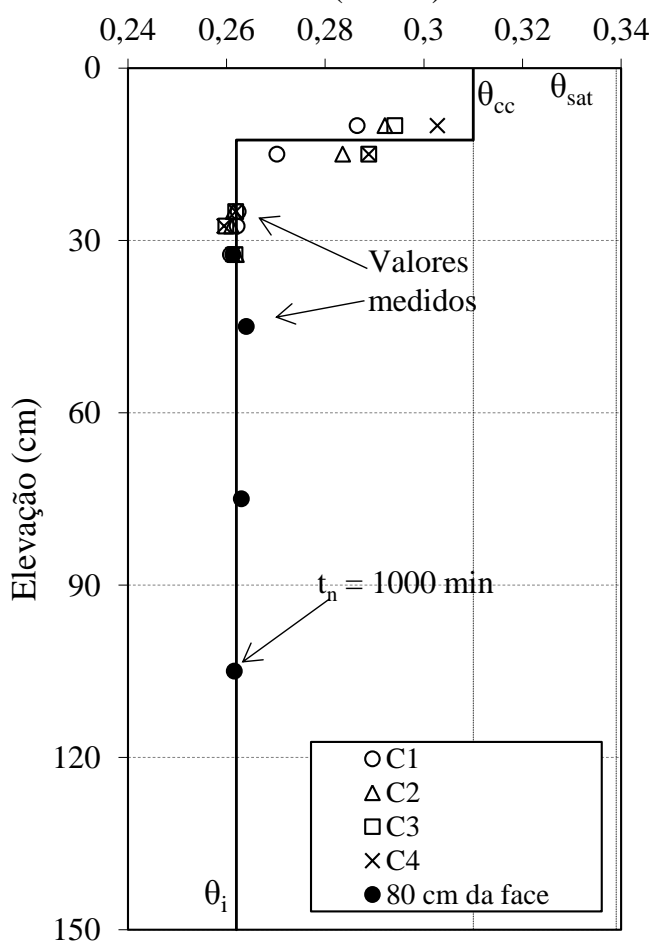

(b) $\theta\left(\mathrm{m}^{3} / \mathrm{m}^{3}\right)$

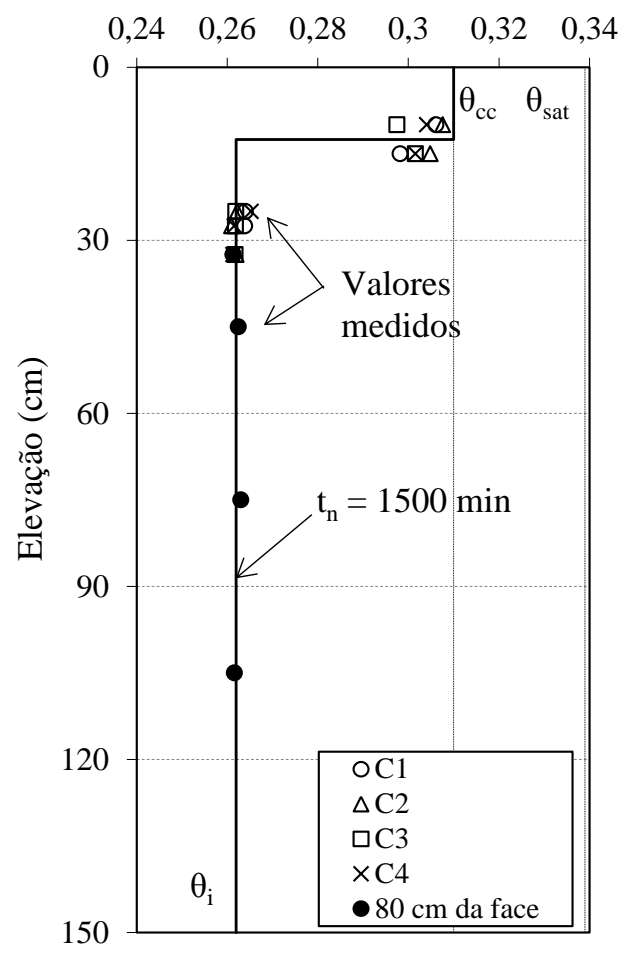

Figura B.14. Perfis de infiltração a 80 cm da face após (a) 1000 min e (b) $1500 \mathrm{~min}$. 
(a)

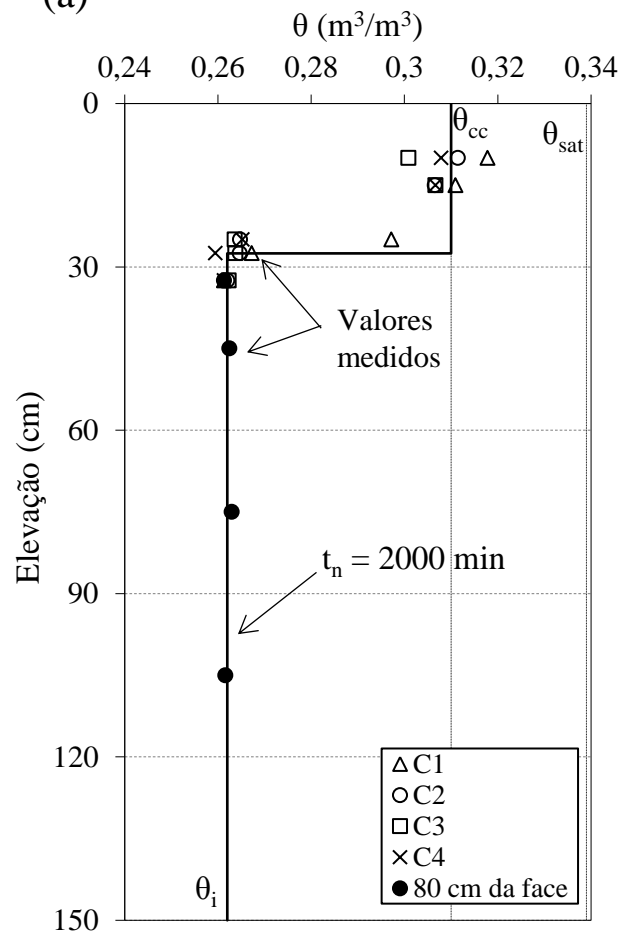

(b)

$$
\theta\left(\mathrm{m}^{3} / \mathrm{m}^{3}\right)
$$

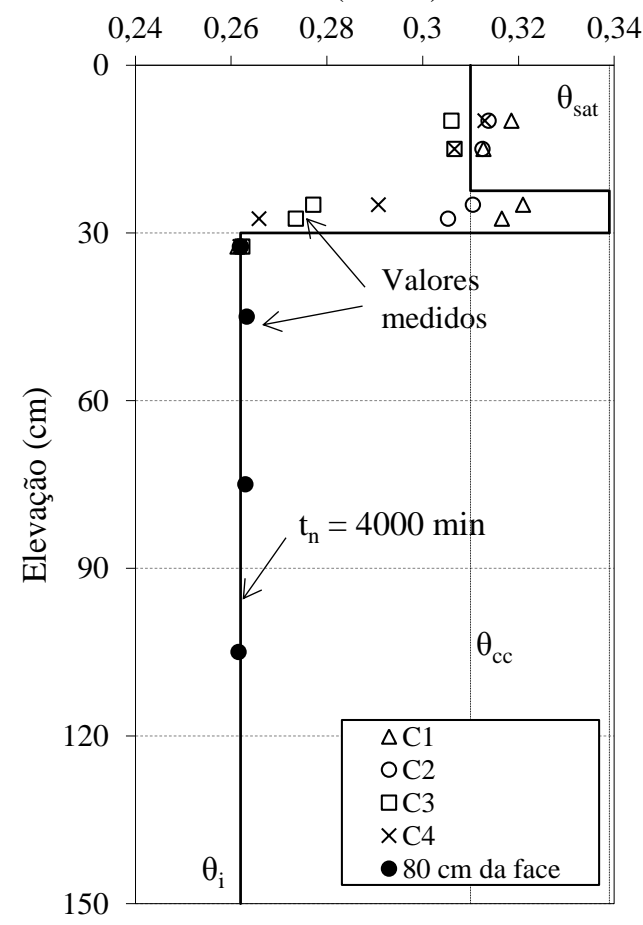

Figura B.15. Perfis de infiltração a $80 \mathrm{~cm}$ da face após (a) 2000 min e (b) $4000 \mathrm{~min}$.

(a)

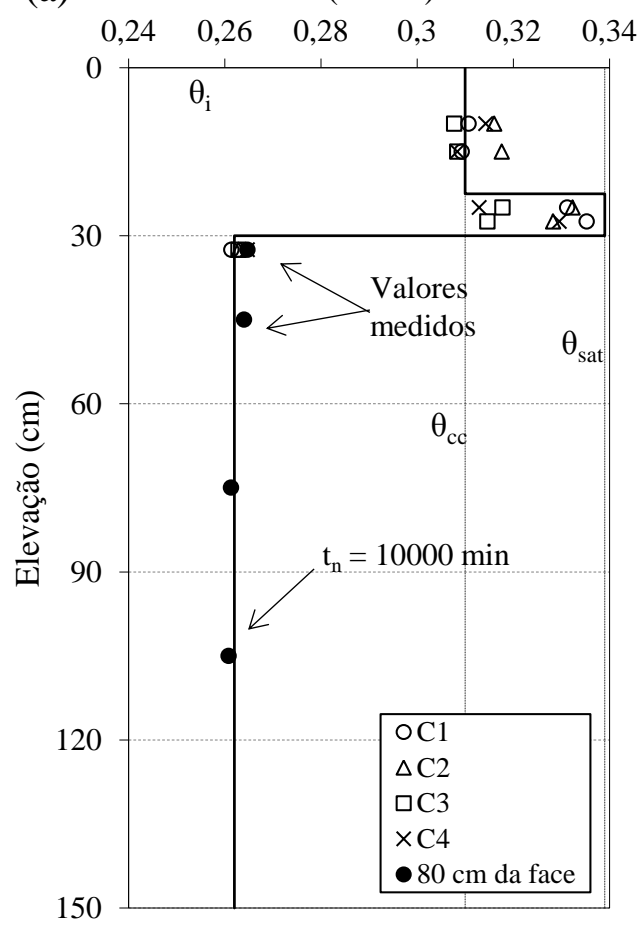

(b)

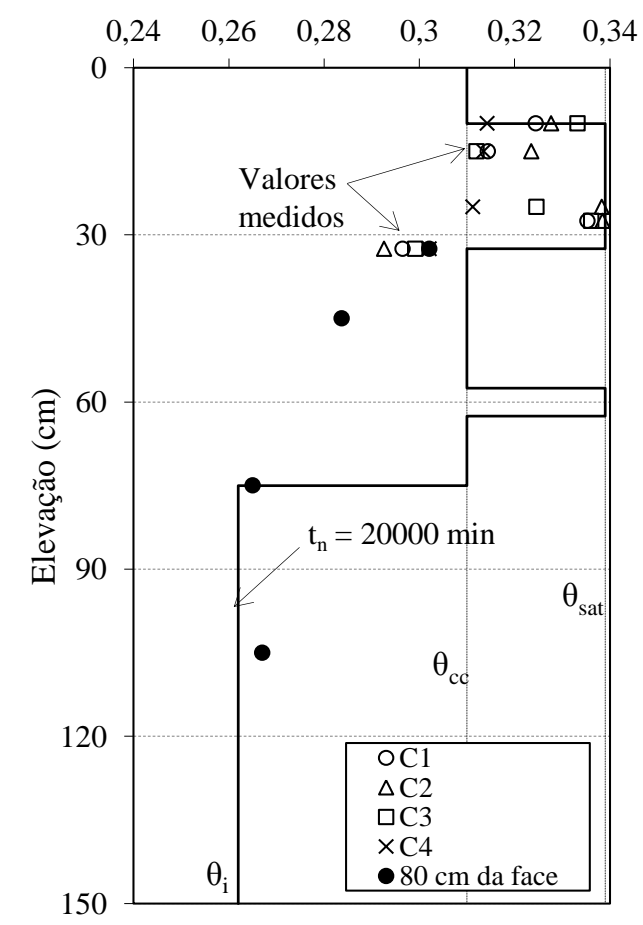

Figura B.16. Perfis de infiltração a 80 cm da face após (a) 10000 min e (b) 20000 min. 

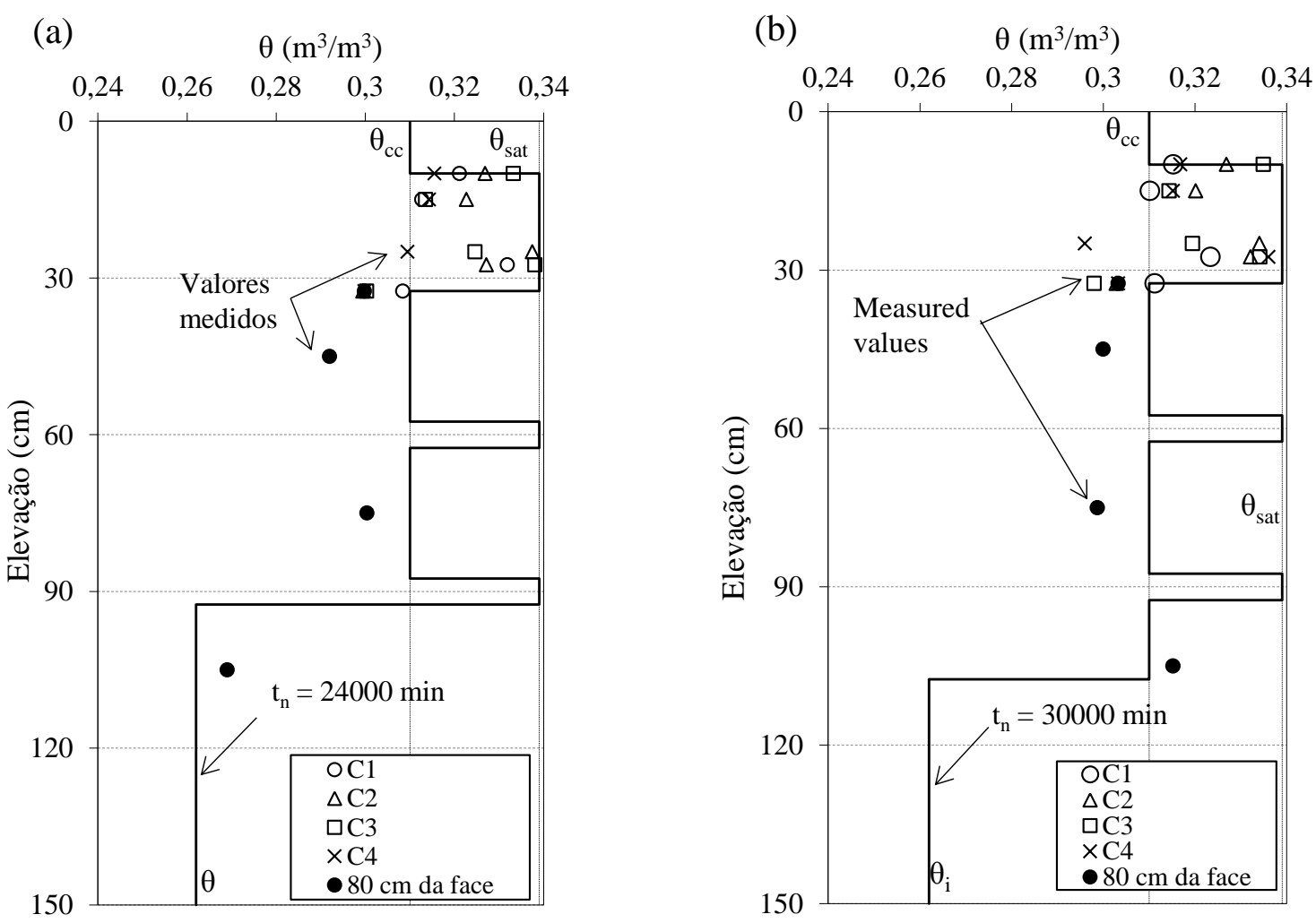

Figura B.17. Perfis de infiltração a $80 \mathrm{~cm}$ da face após (a) $24000 \mathrm{~min}$ e (b) $30000 \mathrm{~min}$. 
a)

APÊNDICE C: Ajustes sigmoidais e distribuições de deformações nos reforços

b)

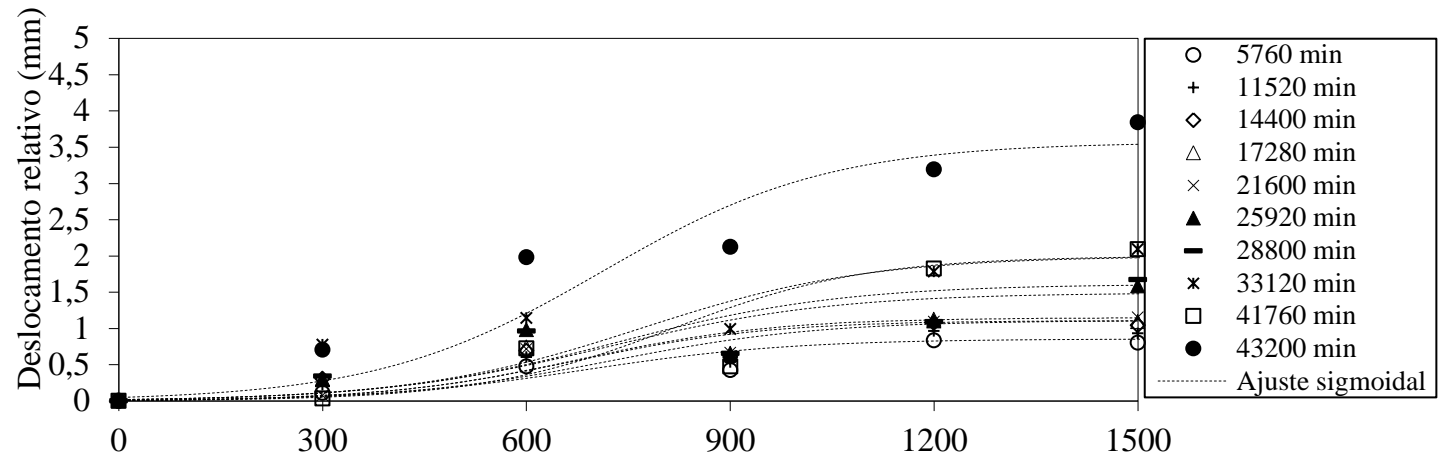

Distância da face (mm)

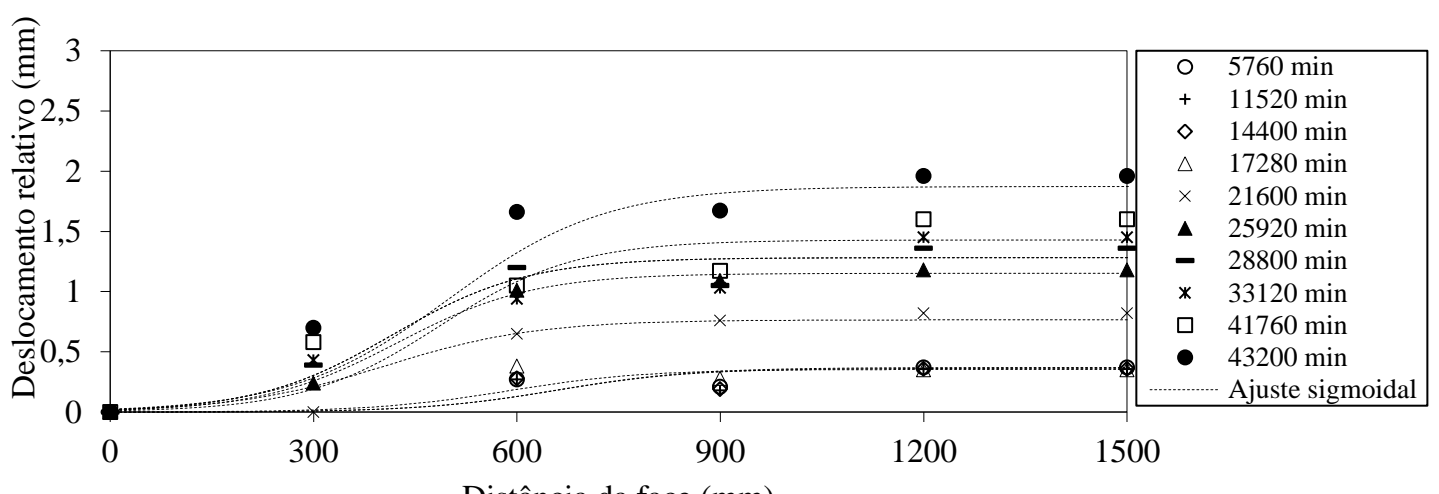

c)

Distância da face (mm)

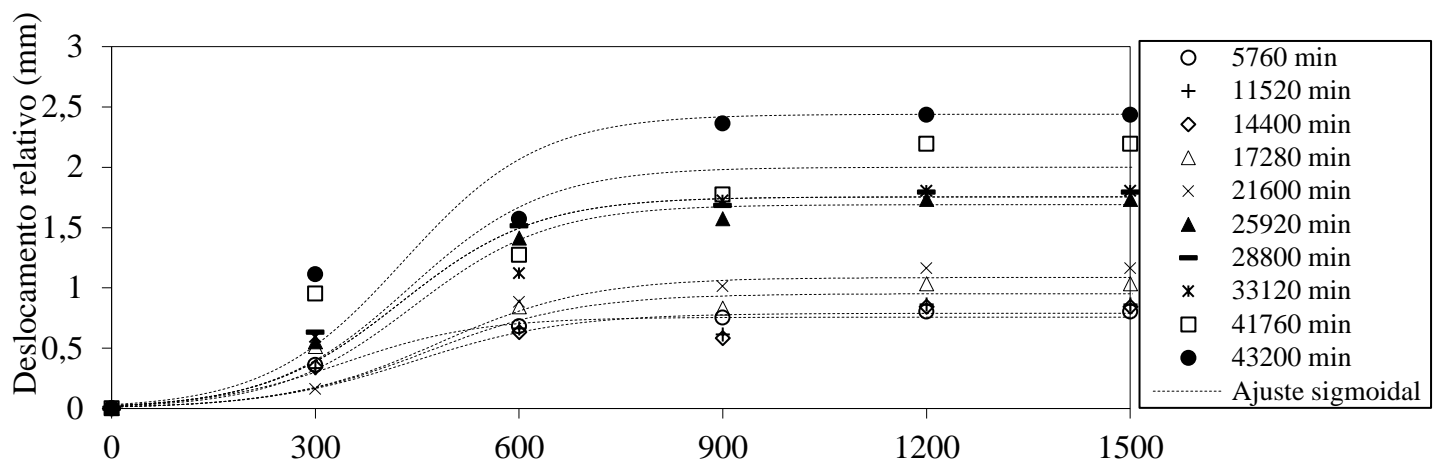

d)

Distância da face (mm)

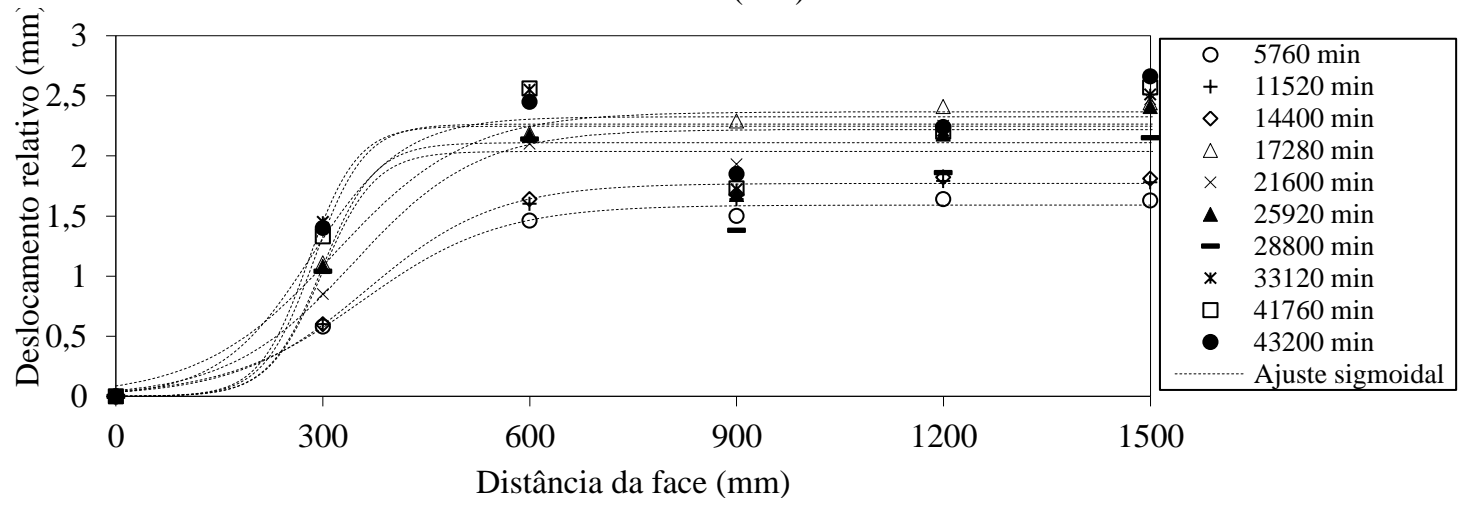

Figura C.1. Distribuição dos deslocamentos internos ao longo do comprimento dos geotêxteis do protótipo M3 nas camadas: (a) 5; (b) 4; (c) 3; (d) 2 . 
a)

b)

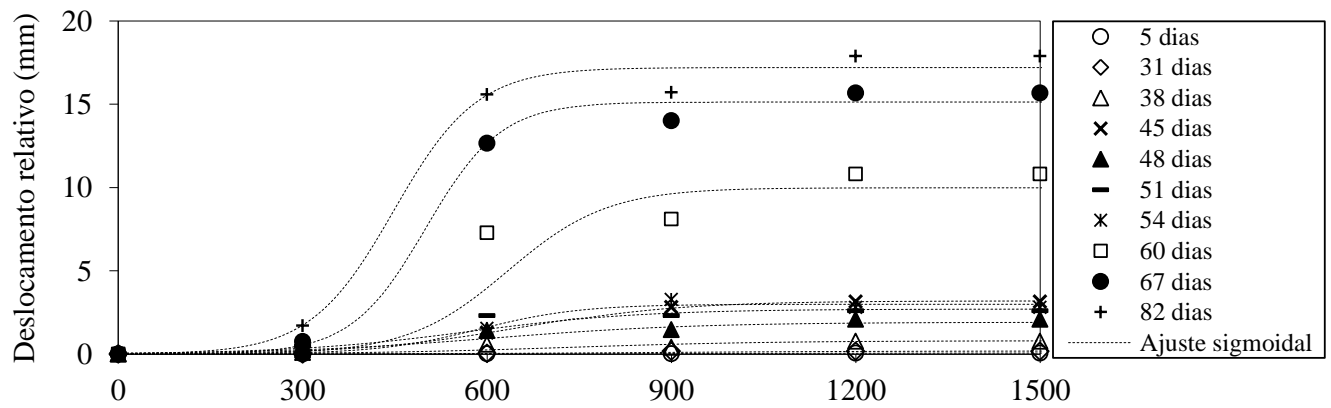

Distância da face (mm)

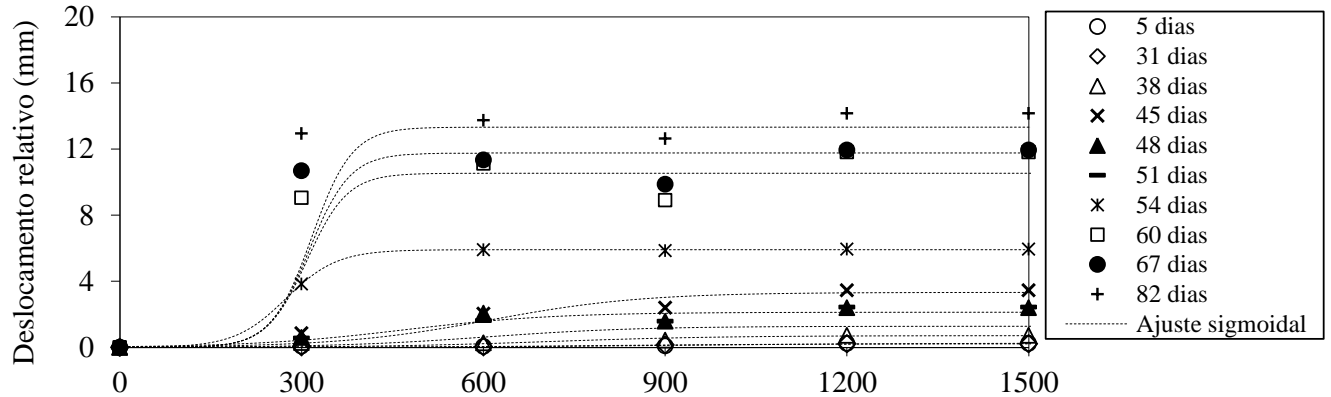

c)

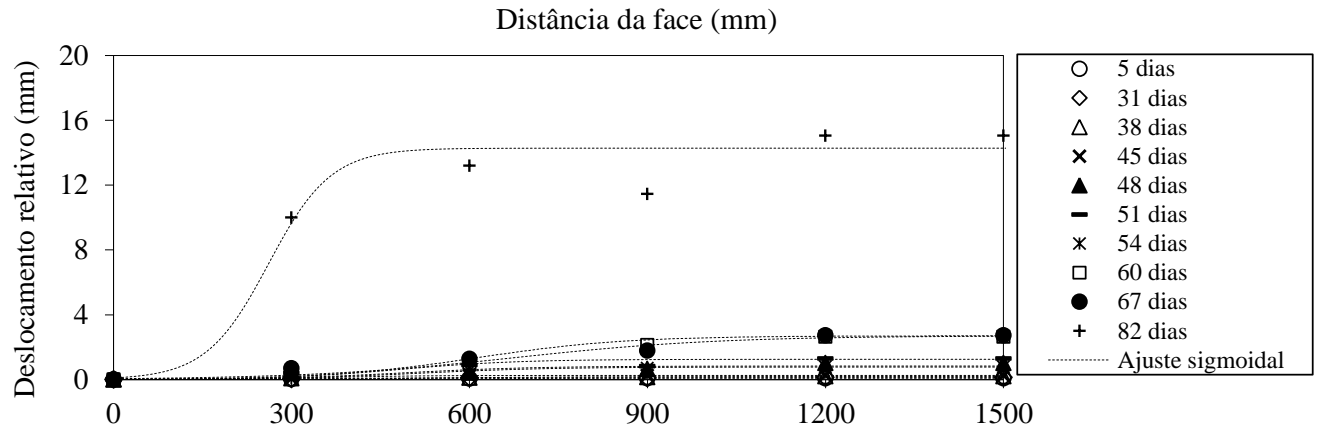

d)

Distância da face (mm)

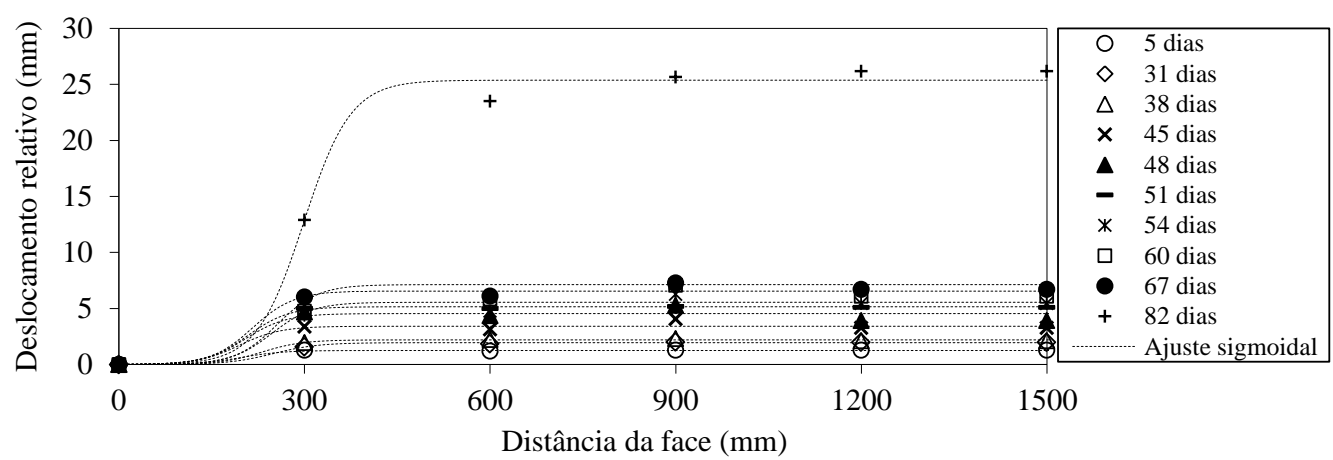

Figura C.2. Distribuição dos deslocamentos internos ao longo do comprimento dos reforços geotêxteis nas camadas (a) 5 (b) 4, (c) 3 e (d) 2 do protótipo M4. 
a)

b)

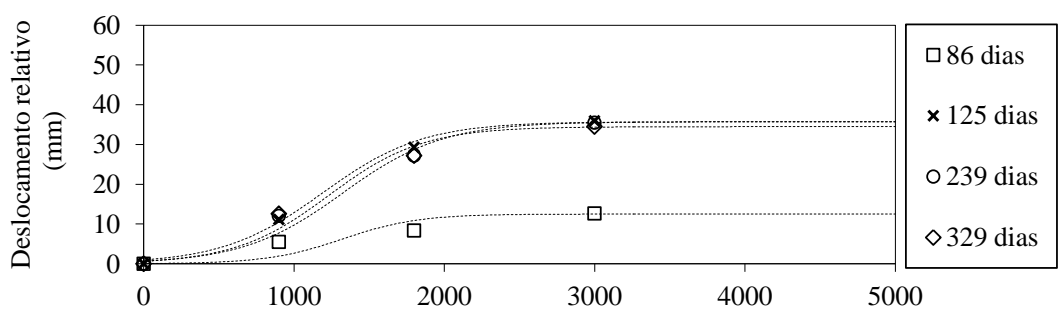

Distância da face (mm)

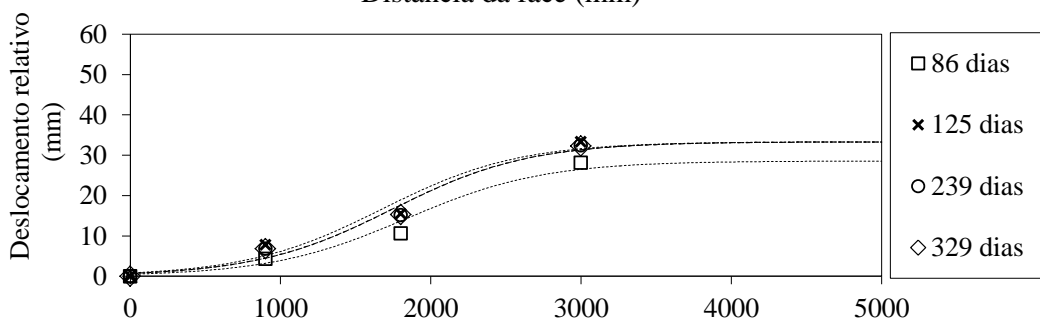

c)

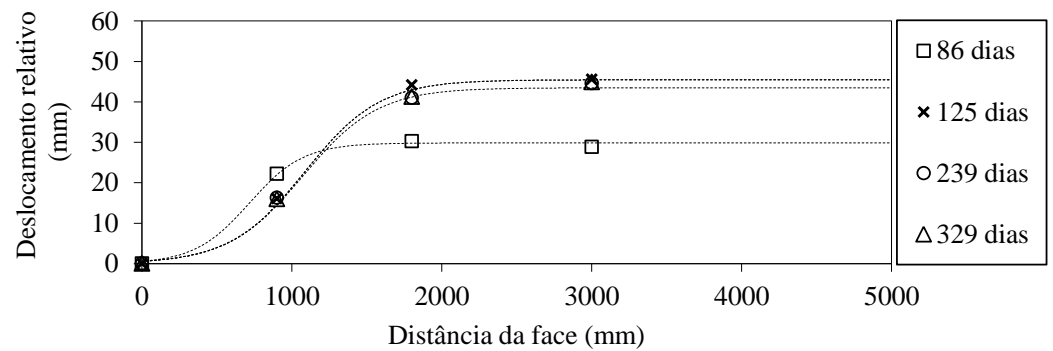

Figura C.3. Distribuição dos deslocamentos internos nos reforços nas camadas (a) E01, (b) E02, (c) E03 da seção de geotêxtil não tecido do muro de Campinas.

a)

b)
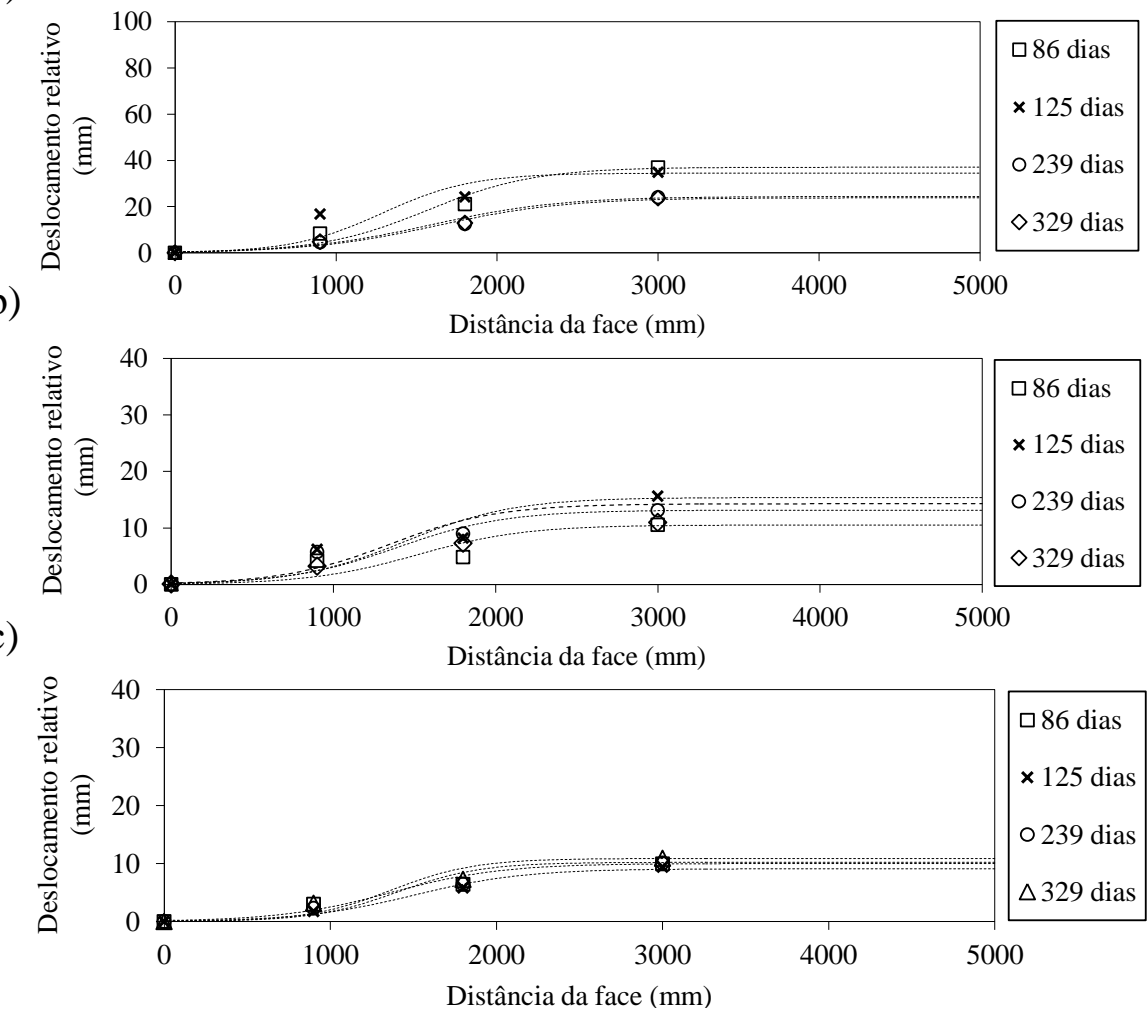

Figura C.4. Distribuição dos deslocamentos internos nos reforços nas camadas (a) E01, (b) E02, (c) E03 da seção de geotêxtil tecido do muro de Campinas. 